JOSÉ WELLINGTON BEZERRA DA COSTA NETO

ACESSO À JUSTIÇA E CARÊNCIA ECONÔMICA

\author{
DisSertaÇão - MeSTRAdo
}

Orientador: Prof. Paulo Henrique dos Santos Lucon

FACULDADE DE DIREITO DA USP

SÃo PAULO

2011 


\section{ACESSO À JUSTIÇA E CARÊNCIA ECONÔMICA}

Dissertação de Mestrado apresentada à Banca Examinadora da Faculdade de Direito da Universidade de São Paulo, como exigência parcial para a obtenção do título de Mestre em Direito, sob orientação do Prof. Paulo Henrique dos Santos Lucon.

\section{FACULDADE DE DIREITO DA USP \\ SÃO PAULO}

2011 
BANCA EXAMINADORA 


\section{DEDICATÓRIA}

A Deus, que em Cristo se fez meu melhor amigo.

À minha querida Erica. Em cada página deste trabalho estão impressas as horas roubadas ao seu convívio; porém as muitas páginas não chegam a representar a ínfima parte de sua capacidade de compreender-me e doar-se para a realização desta minha aspiração.

A meus pais, que ensinaram ao menino o caminho em que deveria andar; e o menino nunca mais se esqueceu. 


\section{AGRADECIMENTOS}

O presente trabalho constitui-se fruto das portas que me foram abertas pelo Prof. Paulo Henrique dos Santos Lucon, admitindo-me ao Curso de Pós-Graduação na Faculdade de Direito da USP, como seu orientando, nos idos de dezembro de 2008. O tema igualmente foi percuciente sugestão por ele oferecida, e por mim prontamente acolhida em razão da relevância do tema, na ordem do dia da militância forense e também no seio acadêmico. Ao longo do trabalho, também seus seguros apontamentos e arguto olhar crítico fizeram toda a diferença, isto sem contar a paciência e prontidão em atender meus chamados. Portanto, ao prof Lucon vai meu sincero agradecimento, no primeiro plano.

Registro também o reconhecimento às frutíferas observações que me foram feitas pelos profs. Flávio Yarshell e Oreste Laspro por ocasião do exame de qualificação, as quais serviram à correção de rumos e acréscimos significativos ao trabalho.

Minha profunda gratidão a meus dois irmãos de armas: Drs Glauco Costa Leite e Gustavo Sampaio Correia. Ao primeiro devo tantas acumulações do Juízo de que sou titular, que nunca poderei retribuir, isto sem contar os proveitosos debates de muitas das idéias agora plasmadas no texto; ao segundo, meu eterno revisor, a generosidade de seus comentários foi um de meus maiores incentivos, e a pertinência de suas sugestões uma tábua de salvação.

Por fim, meu agradecimento ao Dr David Diniz Dantas, magistrado federal, para nós sempre o "Tio David"; exemplo profissional; luminar acadêmico e incentivador incorrigível.

Certamente que o capítulo se tornaria incomodamente grande se fôssemos registrar os agradecimentos a todos que de alguma forma contribuíram para a conclusão desta etapa. Porém concluo registrando o nome de Marli Moraes, que mesmo em meio a problemas de saúde, dispôs-se a revisar o texto, adequando-o aos padrões formais próprios. 


\section{RESUMO}

Inicialmente buscou-se traçar o arcabouço teórico sobre o qual seria analisado o objeto do trabalho, os reflexos da carência econômica sobre as potencialidades de acesso à justiça. Este alicerce consistiu em pontuar a linha evolutiva do caráter da função jurisdicional desde os lindes do Estado Liberal, passando ao Estado do Bem-Estar Social e culminando no Estado Pós-Social, com o principal enfoque no caráter que a garantia de acesso à justiça recebeu em cada um destes contextos. Foram tratados temas paralelos, como a questão do conhecimento acerca dos direitos, bem como a eliminação de custas, solução bastante alvitrada por alguns, intensamente rechaçada por outros.

Depois passou-se à averiguação dos reflexos que a disparidade de condição econômica das partes causa sobre a igualdade destas no processo, e o instrumental conferido ao juiz para a correção das distorções, seguindo-se com o enquadramento da assistência jurídica no quadro de garantias processuais que constitui o que se denomina na doutrina processo justo e équo. Foram realizadas as distinções básicas ente assistência jurídica; assistência judiciária e justiça gratuita. Fez-se ainda uma breve análise de direito comparado, com alguns elementos históricos, concluindo-se com a indicação de pontos que poderiam ser eficazmente aplicados ao sistema brasileiro.

Entra-se então pela segunda parte do trabalho, voltada para a práxis, e que se prende primordialmente na análise do direito positivo brasileiro naquilo que concerne à assistência ao carente no exercício da garantia constitucional de acesso à justiça.

Ao final são apresentadas de forma pontuada as conclusões gerais.

Palavras-Chave: Acesso à justiça - Evolução do conceito - Condição econômica das partes - Repercussões sobre o exercício da função jurisdicional - Instrumental corretivo previsto - Assistência jurídica; assistência judiciária e justiça gratuita - Padrões de confronto e interpretação do direito positivo brasileiro. 


\begin{abstract}
Initially we tried to trace the theoretical framework on which the object of the work would be analyzed, the effects of poverty over the possibilities of access to justice. This foundation was to point the evolution of the character of judicial function from the Liberal State, to the Welfare State and ending in Pos Welfare State, focusing most on the character of access to justice guarantee in each context. Parallel subjects were explored, like the question of knowledge about rights, as also the elimination of judicial fees, solution indeed defended by some, and intensely rejected by others.

Following we searched the effects of economic disparity of the parts over the equality of them in lawsuit, and the instruments given to the judge to correct this distortions, concluding with the contextualization of legal aid in face of procedural guarantees that form what doctrine calls fair and equal trial. There were made the basic distinctions between legal aid in consulting; providing counselors and gratuity from fees. There is a small analysis of comparative law, including some historical elements, concluding with the pointing out of some suggestions that could be profitable in Brazilian system.

We enter the second half of the work, facing the praxis, specially analyzing Brazilian law system concerning legal aid in exercising the constitutional right of access to justice.
\end{abstract}

At the end, the general conclusions are presented in topics.

Keywords: Access to justice - Concept evolution - Parties economic condition Consequences over judicial activity - Corrective instruments provided Legal aid; legal assistance and gratuity - Patterns of confrontation and interpretation of brazilian legal provisions. 


\section{SUMÁRIO}

INTRODUÇÃO: PROPOSTA.

\section{PRIMEIRA PARTE \\ ASPECTOS ESTRUTURAIS E PRINCIPIOLÓGICOS}

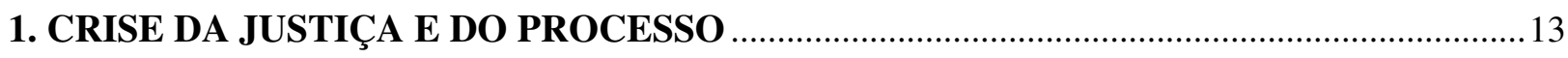

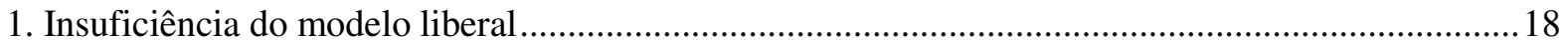

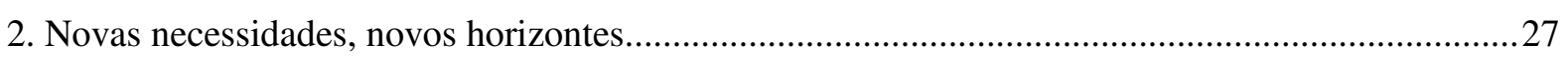

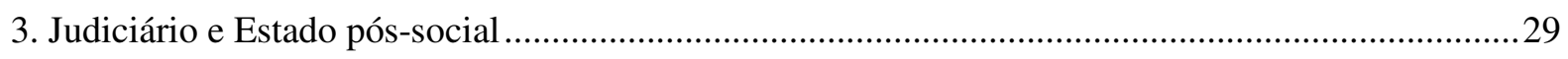

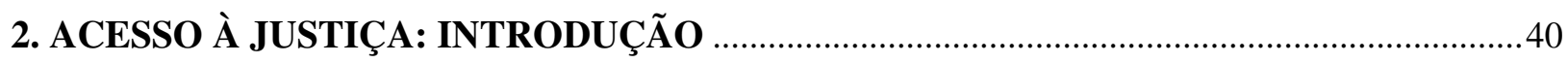

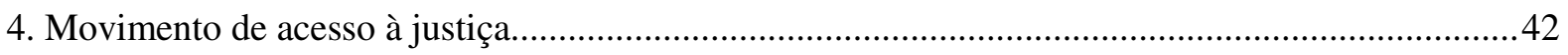

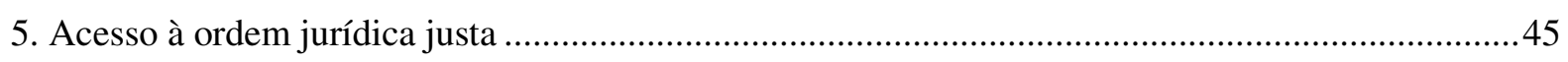

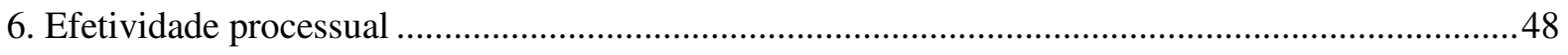

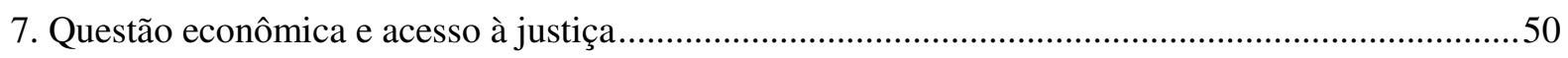

8. Carência econômica; falta de conhecimento dos direitos e acesso à justiça .......................................59

9. Eliminação das custas: uma solução possível? ..............................................................................64

3. IGUALDADE PERANTE A LEI; ISONOMIA MATERIAL E IGUALDADE

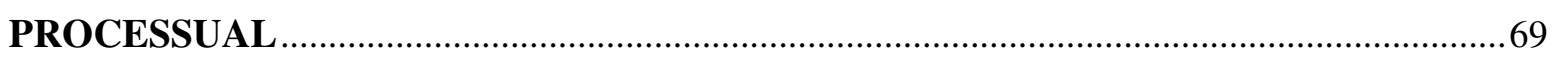

10. Igualdade processual e a condição econômica das partes ..............................................................74

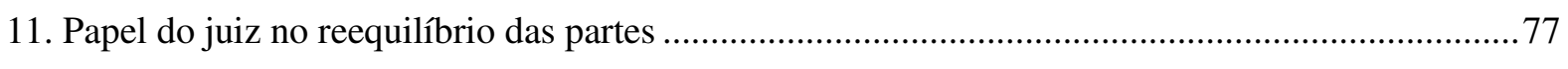

12. Inversão do ônus da prova fundado na disparidade econômica das partes .....................................86

13. Distribuição dinâmica das cargas probatórias ..................................................................................94

4. PROCESSO JUSTO E ÉQUO. ACESSO À JUSTIÇA E ASSISTÊNCIA JUDICIÁRIA ... 106

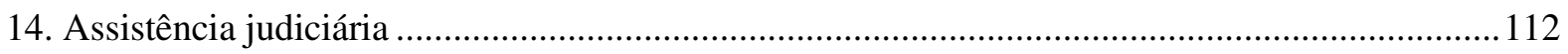

15. Assistência judiciária; assistência jurídica e justiça gratuita........................................................115

16. Assistência jurídica integral e gratuita e as garantias constitucionais do processo........................121

17. Aspectos do regime constitucional garantidor da assistência jurídica integral e gratuita ..............124

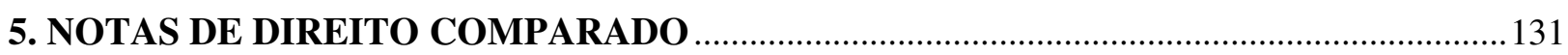

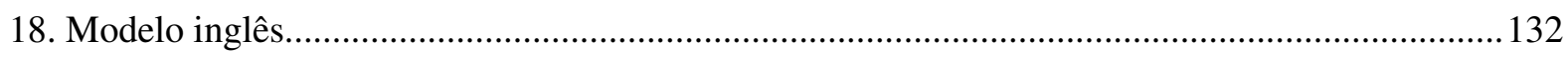

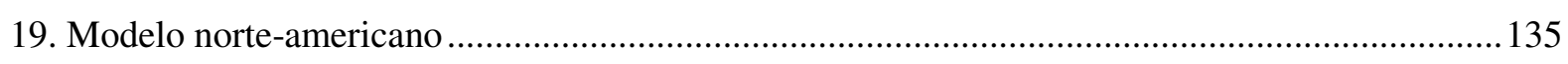

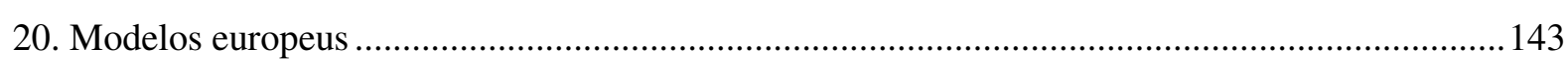

21. Outras disposições do direito constitucional alienígena ...........................................................158

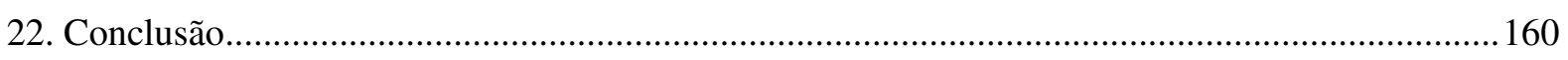




\section{SEGUNDA PARTE \\ ASSISTÊNCIA AO NECESSITADO NO PROCESSO CIVIL BRASILEIRO}

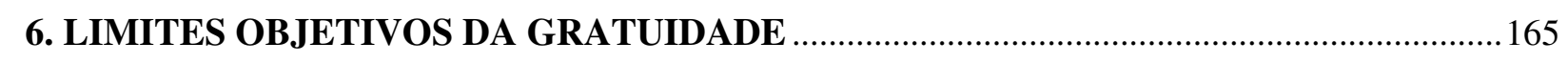

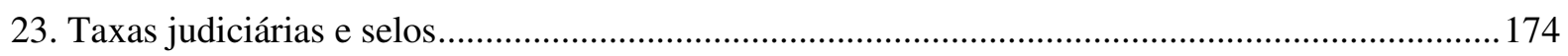

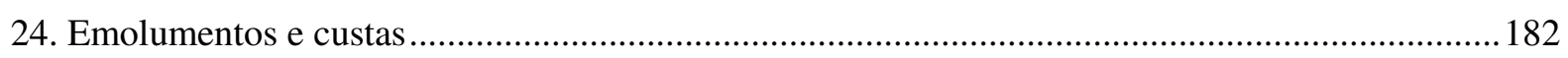

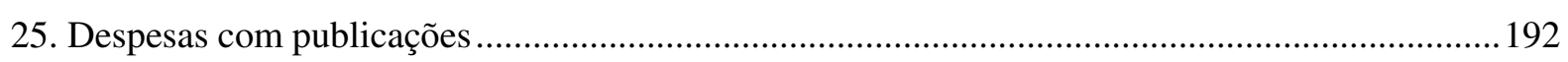

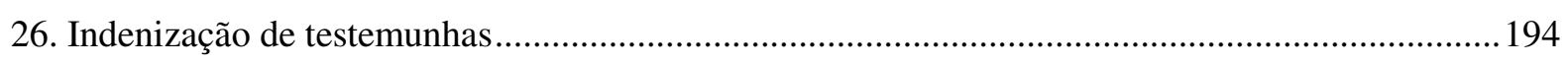

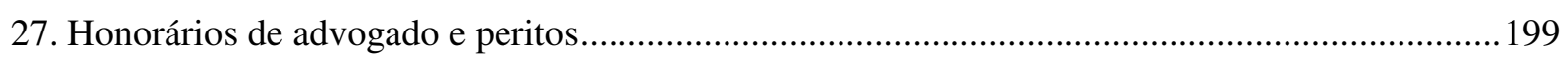

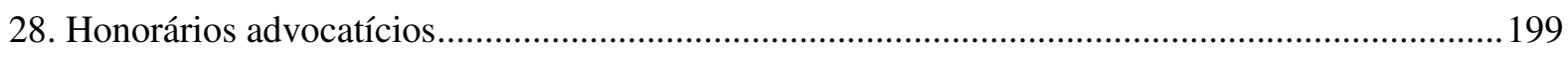

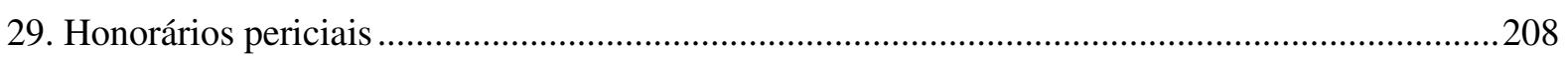

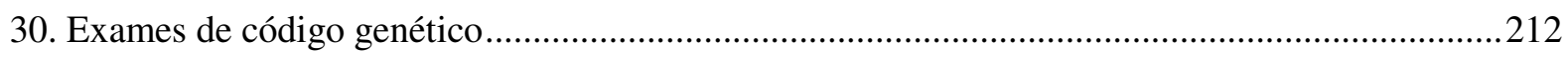

7. LIMITES SUBJETIVOS DA ASSISTÊNCIA JURÍDICA …...............................................214

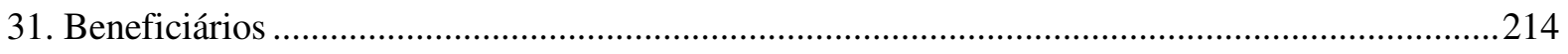

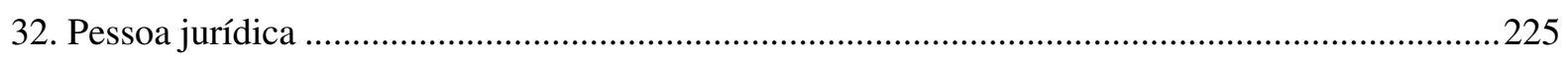

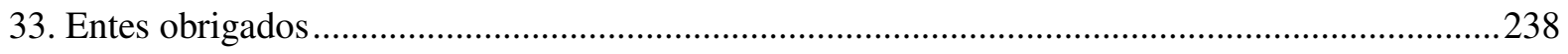

34. Atuação de advogados particulares e entidades privadas ...........................................................242

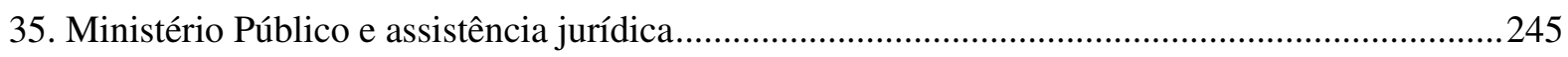

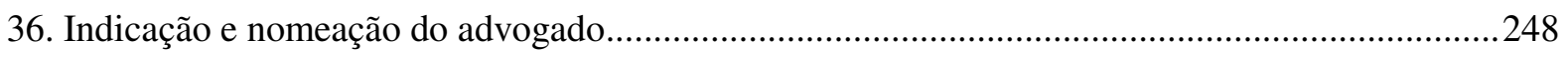

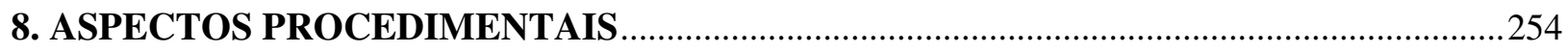

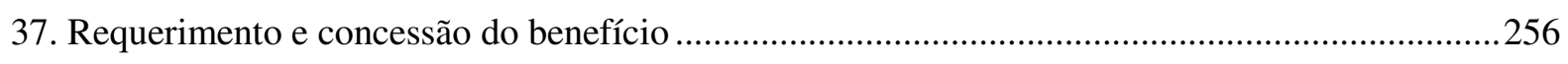

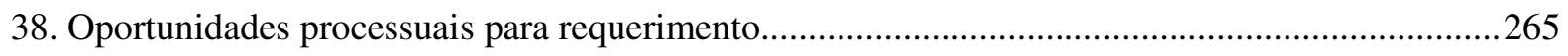

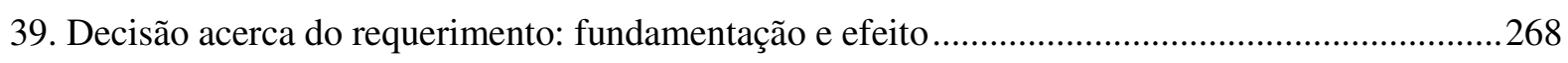

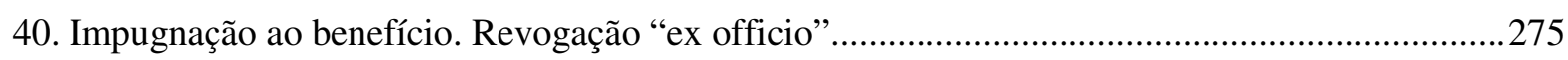

41. Recurso cabível e respectivo regime jurídico .............................................................................28

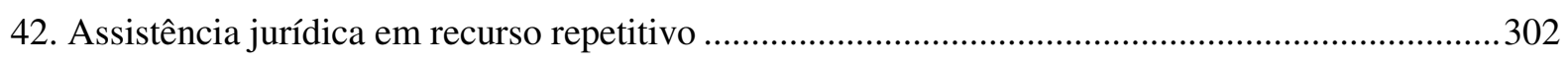

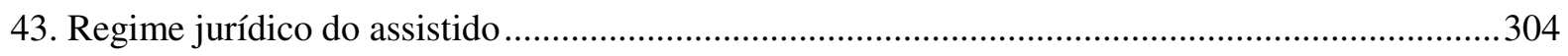

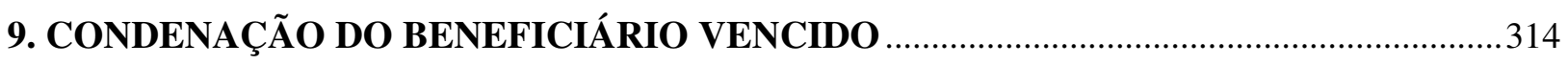

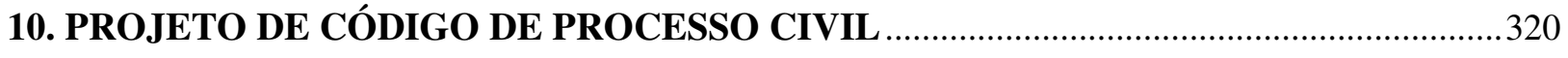

\section{TERCEIRA PARTE \\ CONCLUSÃO}

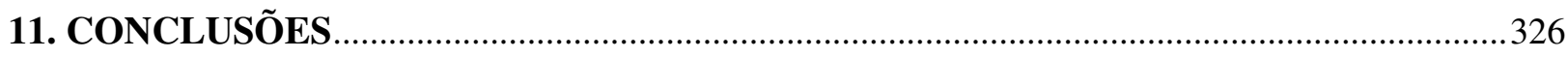

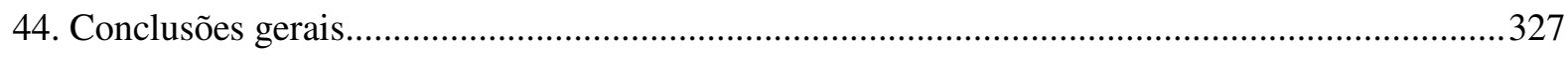

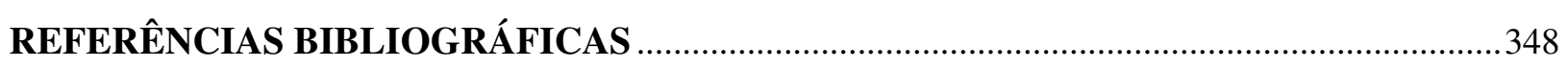




\section{INTRODUÇÃO: PROPOSTA}

A universalização da tutela jurisdicional é idéia expansiva, constituída pelo vetor nuclear da absorção de conflitos antes não jurisdicionalizáveis, na esfera jurisdicional. A idéia de litigiosidade contida é também ínsita ao tema proposto. A "contenção" da litigiosidade é fruto de várias circunstâncias: custo, tempo, falta de cultura, etc.

Há óbices ilegítimos e legítimos ao acesso à tutela ${ }^{1}$. A tendência expansionista representa prestígio ao exercício do direito constitucional de ação (CR, art. $\left.5^{\circ}, \mathrm{XXXV}\right)$, que nada mais é que a promessa de apreciação de todos os litígios, desde que inexistentes óbices legítimos ${ }^{2}$.

E com esta meditação a respeito do direito de acesso à justiça frente aos diversos óbices ilegítimos que iniciaríamos o estudo acerca do presente tema.

O primeiro grande passo nas investigações do direito processual foi mesmo o conjunto de ponderações que se acham agrupadas na fase que se convencionou chamar autonomista. Foi o deslumbramento de reconhecer a distinção entre direito processual e material, direito de ação e direito material invocado, relação jurídica material e relação jurídica processual.

O imanentismo, entretanto, era tão arraigado, que reclamou da fase autonomista um radicalismo que conduziu a excessos tão inconvenientes quanto a fusão do processual ao material, a saber, o abuso do conceptualismo e das abstrações dogmáticas. Se a fusão em questão indevidamente sobrepunha o material e o processual de forma indevida, o autonomismo radical os apartava em distância tão incomensurável que poderia se chegar a pensar que o processo seria um fim em si mesmo.

\footnotetext{
${ }^{1}$ Os exemplos acerca da limitação da tutela versam o aspecto internacional: as exigências de respeito mútuo e de convivência das soberanias dos Estados recomendam que um Estado não jurisdicionalize conflitos relacionados a outro. Também o sistema das condições da ação constitui óbice legítimo à universalização da tutela.

${ }^{2} \mathrm{O}$ tema está bem desenvolvido por Cândido Rangel Dinamarco em sua obra, "Instituições de Direito Processual Civil", nos seguintes termos: "As legítimas limitações ditadas pela Constituição e pela lei ao exercício da jurisdição constituem fator de racionalidade e realismo no sistema. Ao lado delas outras limitações existem, que não são as legítimas e concorrem para impedir que o sistema do processo civil cumpra adequadamente e de modo integral sua função de pacificar pessoas e fazer justiça. Trata-se de fatores vindos das imperfeições da própria lei processual e outros fatores, igualmente perversos, residentes na realidade política, sócio-econômica e cultural da sociedade à qual o processo se destina a servir ... Da atuação conjugada desses ilegítimos fatores limitativos decorre a exclusão de muitas pretensões, que não tem como receber tratamento e solução em via jurisdicional" (DINAMARCO, Cândido Rangel. Instituições de direito processual civil. 6. ed. São Paulo: Malheiros Ed., 2009, v. 1, p. 115-116).
} 
Notou-se que "a doutrina do processo civil, na sua pretensão de construir uma

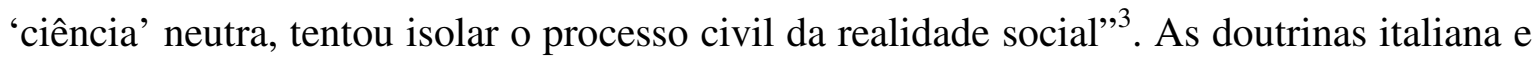
alemã da primeira metade do século XX se centraram no cunhar conceitos como de direito de ação; relação jurídica processual; situação processual; ato processual; pressupostos processuais; sujeitos do processo; objeto do processo e coisa julgada. Ainda a disciplina da prova e sua valoração, repartição de poderes entre as partes e o juiz e formulação de princípios processuais. Após a II Guerra Mundial os estudos se centraram na consideração dos vínculos entre Constituição e processo, com ênfase posta nos direitos processuais das partes, e sobretudo a defesa das noções de acesso ao processo; direito de ser "ouvido em juízo"; à prova; etc ${ }^{4}$.

Percebe-se, então que a correção de rumo foi, sem abrir mão das conquistas da fase autonomista, projetar processo e ordem material no adequado posicionamento recíproco.

É assim que se chega ao terceiro momento metodológico, caracterizado pela consciência da instrumentalidade como viga mestra no estudo de institutos e princípios, bem como na proposta de soluções ${ }^{5}$.

Ocorre que uma nova consciência raia. Mesmo a fase instrumentalista vai dando sinais de exaustão. Da primeira edição do clássico trabalho de Cândido Rangel Dinamarco, retro citado, vão-se mais de vinte anos. A doutrina processual muito se esmerou no descortinamento do papel do processo em searas antes obscurecidas pela ânsia em provarlhe a autonomia.

O próximo passo lógico, que sucede ao reconhecimento da instrumentalidade, é investigar como o processo produz os resultados dele esperados nas esferas jurídica, social e política, eventuais deficiências decorrentes de ineficiência e principalmente a procura de métodos que visem aperfeiçoar a efetividade do processo. É esse o mote atual, a palavra de

\footnotetext{
${ }^{3}$ MARINONI, Luiz Guilherme. Técnica processual e tutela dos direitos. 2. ed. São Paulo: Ed. Revista dos Tribunais, 2008. p. 63.

${ }^{4}$ MONTERO AROCA, Juan. El derecho procesal en el siglo XX. Valencia: Tirant lo Blanch, 2000. p. 60.

${ }^{5}$ DINAMARCO, Cândido Rangel. A instrumentalidade do processo. 7. ed. São Paulo: Malheiros Ed., 1999. p. 21. Ainda no mesmo texto ora citado, acrescenta o ilustre professor das Arcadas: "O processualista sensível aos grandes problemas jurídicos sociais e políticos do seu tempo e interessado em obter soluções adequadas sabe que agora os conceitos inerentes à sua ciência já chegaram a níveis mais do que satisfatórios e não se justifica mais a clássica postura metafísica consistente nas investigações conceituais destituídas de endereçamento teleológico. Insistir na autonomia do direito processual constitui, hoje, como que preocupar-se o físico com a demonstração da divisibilidade do átomo" (A instrumentalidade do processo, cit., p. 21).
} 
ordem na fase pós-instrumentalista ou, como refere Kazuo Watanabe, instrumentalismo substancial ${ }^{6}$.

É este, pois, o contexto no qual propomo-nos a investigar a problemática do acesso à justiça. A lição que segue, de Luiz Guilherme Marinoni, é pertinente:

"Nessa linha, o CPC brasileiro, até a reforma de 1994, desconsiderava totalmente os valores da Constituição Federal. Uma Constituição que se baseia na "dignidade da pessoa humana" (art. $1^{\circ}$, III) e garante a inviolabilidade dos direitos da personalidade (art. $5^{\circ}, \mathrm{X}$ ) e o direito de acesso à justiça diante de "ameaça a direito" (art. $\left.5^{\circ}, \mathrm{XXXV}\right)$, exige a estruturação de uma ação processual capaz de garantir de forma adequada e efetiva a inviolabilidade dos direitos não patrimoniais"7.

Eis o cerne, pois, do tema: o acesso à justiça encarado como o direito à tutela jurisdicional efetiva. Nessa linha, estão abarcados pela proposta pensar: a) a crise da Justiça e do processo; b) acesso à justiça e cidadania; c) acesso à justiça e efetividade processual; d) pontos de estrangulamento; e) movimento de acesso à justiça; f) repercussão prática das concepções adotadas; g) questão econômica e acesso à justiça; h) igualdade processual e a condição econômica das partes; h) papel do juiz no reequilíbrio das partes mediante alteração das regras ordinárias acerca do ônus da prova; i) processo justo e équo, acesso à justiça e assistência judiciária; j) assistência jurídica; assistência judiciária e justiça gratuita; 1) aspectos do regime constitucional garantidor da assistência jurídica integral e gratuita; m) limites objetivos da gratuidade; n) limites subjetivos da assistência jurídica e o) aspectos procedimentais ligados à assistência; o) gratuidade no projeto de Código de Processo Civil.

\footnotetext{
6“'Do conceptualismo e das abstrações dogmáticas que caracterizam a ciência processual e que lhe deram foros de ciência autônoma, partem hoje os processualistas para a busca de um instrumentalismo mais efetivo do processo, dentro de uma ótica mais abrangente e mais penetrante de toda problemática sóciojurídica. Não se trata de negar os resultados alcançados pela ciência processual até esta data. O que se pretende é fazer destas conquistas doutrinárias e de seus melhores resultados um sólido patamar para, com uma visão crítica e mais ampla da utilidade do processo, proceder ao melhor estudo dos institutos processuais - prestigiando ou adaptando ou reformulando os institutos tradicionais, ou concebendo institutos novos - sempre com a preocupação de fazer com que o processo tenha plena e total aderência à realidade sócio-jurídica a que se destina, cumprindo sua primordial vocação que é a de servir de instrumento à efetiva realização dos direitos. É a tendência ao instrumentalismo que se denominaria substancial em contraposição ao instrumentalismo meramente nominal ou formal" (Da cognição no processo civil. São Paulo: Ed. Revista dos Tribunais, 1987. p. 16).

${ }^{7}$ MARINONI, Luiz Guilherme. Técnica processual e tutela dos direitos, cit., p. 64.
} 
PRIMEIRA PARTE

ASPECTOS ESTRUTURAIS E PRINCIPIOLÓGICOS 


\section{CRISE DA JUSTIÇA E DO PROCESSO}

Sabemos que o título em epígrafe constitui jargão, ao qual costuma se seguir a elaboração de longa lista das deficiências do Judiciário. Com o perdão pela repetição, é necessário verificar no que constitui a tal crise, e o ponto de partida há de ser a constatação de que o Poder Judiciário vem fracassando em atender a demanda do tempo atual porque tendo sido concebido no contexto do Estado liberal, não conseguiu transformar-se para acompanhar as novas exigências históricas. Estagnado no espírito individualista, continua um Poder passivo, manietado na inércia que aguarda a provocação do interessado ${ }^{8}{ }^{9}$.

A compreensão do contexto desta crise é fundamental. Em excelente artigo, J.J.Calmon de $\operatorname{Passos}^{10}$ traça um eixo de causalidade entre a sociabilidade do homem, o surgimento das organizações humanas e a hierarquização dos interesses e dos homens que tal organização implica, reclamando a coordenação e submissão das vontades por meio de um poder que se sobreponha à vontade individual, identificando aí a gênese do poder político, conseqüência da escassez dos bens disponíveis para a satisfação das necessidades experimentadas pelos homens.

O instrumento de que se vale o poder político para assegurar a efetividade do modelo adotado é o Direito, conformando e direcionando o corpo social destinatário de sua vetoração. E o meio de que se vale o poder político para formular e realizar o direito é o processo. De um lado, formulando normas jurídicas por categorias, de forma apriorística e genérica, a saber, o processo legislativo e de outro, normas jurídicas concretas, voltadas especificamente para a lide posta em juízo, o processo jurisdicional.

Segue o insigne doutrinador pontuando a origem da democracia liberal, na era moderna, que "defluiu das expectativas econômicas e políticas postas pela burguesia emergente" $" 11$. Em verdade, segundo o autor estudado, uma tríade de fatores conduziu à formação do Estado liberal: igualdade fundamental de todos os homens (a burguesia,

\footnotetext{
${ }^{8}$ SILVA, José Afonso da. Acesso à justiça e cidadania. Revista de Direito Administrativo, Rio de Janeiro, $\mathrm{n}$. 216, p. 18, abr./jun. 1999.

9“'O Judiciário, no período que sucede a Ilustração e a Revolução Francesa, foi concebido como instituição adequada para garantir direitos individuais e enquadrar a sociedade na legislação, especialmente aquela de matriz napoleônica" (CAMPILONGO, Celso Fernandes. Os desafios do Judiciário: um enquadramento teórico. In: FARIA, José Eduardo (Org). Direitos humanos, direitos sociais e justiça. São Paulo: Malheiros Ed., 2002. p. 39).

${ }^{10}$ CALMON DE PASSOS, José Joaquim. Democracia, participação e processo. In: GRINOVER, Ada Pellegrini et al. (Coord.). Participação e processo. São Paulo: Ed. Revista dos Tribunais, 1988. p. 83-97.

${ }^{11}$ CALMON DE PASSOS, José Joaquim. Democracia, participação e processo, cit., p. 87.
} 
embora detentora do poder econômico, via-se alijada do poder político, concentrado nas mãos da nobreza, status vinculado à propriedade da terra, daí porque a afirmação da igualdade originária de todos os homens favorecia o interesse da classe burguesa ascendente); visão antropocêntrica do universo, em substituição à cosmocêntrica clássica, o teocentrismo medieval e a dessacralização do poder.

Esta conjunção de fatores conduziu à "afirmativa de que a soberania tinha sua sede no homem, no indivíduo que, na sua expressão política, é o povo, seu único, exclusivo e absoluto titular,"12.

Bobbio faz uma análise percuciente de um eixo evolutivo que traça, a partir de postulados de filosofia da história, entre a secularização da ética cristã, por ele identificada no jusnaturalismo; a emersão de uma concepção individualista da sociedade; formação do Estado de Direito e da democracia moderna ${ }^{13}$. O grande momento culminante desta evolução está representado na Revolução Francesa, marco na conformação do Estado liberal.

Analisa o autor italiano a inversão do ponto de vista organicista rumo ao individualista, ou seja, da sociedade compreendida a partir do ângulo do corpo social em situação de proeminência em face do indivíduo, este titular precipuamente de deveres para com aquele corpo, apenas um objeto do poder, para o individualista, em que o indivíduo passa a ser a fonte do poder, dotado de primazia sobre a sociedade, partindo-se então da idéia de que toda associação política tenha por fim a conservação dos direitos naturais básicos do indivíduo (segundo a declaração francesa, liberdade, propriedade, segurança e resistência à opressão). "Numa concepção orgânica da sociedade, as partes estão em função do todo; numa concepção individualista, o todo é o resultado da livre vontade das partes"14.

E é esta concepção individualista da sociedade a gênese da democracia moderna, que repousa na soberania não do povo, mas dos cidadãos, reconhecendo-se naquela figura (povo) uma abstração ${ }^{15}{ }^{16}$.

\footnotetext{
${ }^{12}$ CALMON DE PASSOS, José Joaquim. Democracia, participação e processo, cit., p. 89.

${ }^{13}$ BOBBIO, Norberto. A era dos direitos. Trad. port. C.N.Coutinho. Rio de Janeiro: Campus, 1992. p. 49-67; 113-131.

${ }^{14}$ BOBBIO, Norberto. A era dos direitos, cit., p. 119.

${ }^{15}$ BOBBIO, Norberto. A era dos direitos, cit., p. 119. Do mesmo autor são as seguintes palavras: "No Estado despótico, os indivíduos singulares só têm deveres e não direitos. No Estado absoluto, os indivíduos possuem, em relação ao soberano, direitos privados. No Estado de direito, o indivíduo tem, em face do Estado, não só direitos privados, mas também direitos públicos. O Estado de direito é o Estado dos cidadãos" (cit., p. 61).

${ }^{16}$ Obtempera Bobbio que a Declaração Universal, símbolo da Revolução Francesa, foi alvo de críticas as mais diversas, de ordem formal e mesmo substancial, inclusive relacionadas a seu fundamento filosófico (premissa de que existem direitos naturais). Porém sua conclusão é auspiciosa: "apesar da crítica
} 
Seguiu-se, por fim, a desvinculação do econômico e do político, com o reconhecimento de que o primeiro era regido por leis próprias, autoreguladoras e incompatíveis com o regramento estatal. Ao Estado caberia policiar a convivência social de modo a garantir o livre jogo das forças econômicas, regidas exclusivamente pelas leis do mercado, primando-se pela autonomia privada, cuja insígnia maior era o contrato. Conjugados a soberania popular, a dissociação entre o político e econômico, consagrada a relevância do indivíduo, estavam postas as bases da democracia liberal representativa ${ }^{17}$.

Neste contexto, a lei revela-se como o meio mais racional e avançado do povo expressar de modo genérico e abstrato as regras de convívio social, fixando os limites da atuação de todos, inclusive dos órgãos públicos, vinculados tal qual todos os particulares aos ditames regularmente aprovados pelos representantes eleitos da sociedade, emergindo aí a noção de Estado de Direito.

Surge, pois, o problema da fiscalização da exata aplicação da lei, por órgãos independentes em relação aos controlados. Eis aí a semente que culmina com a institucionalização de um Poder Judiciário autônomo.

As Constituições escritas que se sucederam como decorrência da era marcada pela Revolução Francesa tiveram a grande virtude de proclamar o novo ideário políticofilosófico, notadamente a extinção da divisão da sociedade em classes sociais. Entretanto, faltava-lhes tônus no que respeita à efetividade jurídica, isto é, faltava um instrumento eficaz de atuação no confronto do poder político, representado pelos braços legislativo e executivo, “faltava, portanto, um verdadeiro e próprio 'terceiro poder' - uma 'terceira garra' investida do poder de assegurar o respeito à Constituição por parte do grupo 'político","18.

antijusnaturalista, as proclamações dos direitos do homem e do cidadão não só não desapareceram, mesmo na era do positivismo jurídico, como ainda continuaram a se enriquecer com exigências sempre novas, até chegarem a englobar os direitos sociais e a fragmentar o homem abstrato em todas as suas possíveis especificações, de homem e mulher, criança e velho, sadio e doente, dando lugar a uma proliferação de cartas de direitos que fazem parecer estreita e inteiramente inadequada a afirmação dos quatro direitos da Declaração de 1789” (cit., p. 127-128). Os princípios de 1789, conforme leciona, seguiram como fonte ininterrupta de inspiração ideal para os povos que lutaram por sua liberdade. A propósito, convém anotar que o processo que Bobbio chamou de fragmentação do homem abstrato ou especialização, constante na previsão não apenas do homem em sentido genérico como sujeito de direitos, mas também em suas diversas facetas concretas, então como sujeito de direitos especiais, vem bem a calhar no tema centra de nosso estudo, que se foca nas garantias peculiar do "homem pobre" em sentido legal, isto é, desprovido de recursos que permitam acorrer à defesa eficaz de seus direitos.

${ }^{17}$ CALMON DE PASSOS, José Joaquim. Democracia, participação e processo, cit., p. 90.

${ }^{18}$ CAPPELLETTI, Mauro. Constitucionalismo moderno e o papel do Poder Judiciário na sociedade contemporânea. Revista de Processo, Sao Paulo, v. 15, n. 60, p. 110, out./dez. 1990. 
Parece-nos claro, portanto, que um Poder Judiciário assim concebido tem por atividade precípua justamente garantir as regras mínimas do jogo. Isto é, o mote é a preservação da liberdade individual e a proteção da autonomia da vontade, elementos mais caros ao Estado liberal.

Impossível é dizer com precisão se um Poder Judiciário desta forma desenhado é produto de uma ordem jurídica (especialmente processual) com estas prioridades, ou se o contrário. Mais provável é que haja uma interação recíproca de causa e efeito: tanto as características do órgão aplicador da lei influenciam a formulação do método que há de presidir a tal aplicação; como as vicissitudes e peculiaridades do método hão de conformar a feição de seu aplicador.

Para não sobrepairarmos demais no campo teórico, anotamos alguns princípios caríssimos à nossa ciência processual, profundamente arraigados na consciência do processualista desde as primeiras luzes na ciência do Direito, que denotam o que estamos a ponderar.

Vejamos, pois, que o primeiro juiz da causa, ao contrário do que se costuma apregoar, não é o causídico eleito pela parte como digno de sua confiança para patrociná-la, mas sim o próprio interessado. É à parte que cabe, antes de qualquer um, avaliar a conveniência de demandar em juízo a proteção do direito que julga violado, e isto constitui genuína expressão da autonomia da vontade. Mesmo nas chamadas ações constitutivas necessárias ela existe, pois que o que ocorre nestas hipóteses é que querendo a parte obter a alteração da situação jurídicomaterial objeto de seu direito potestativo deverá recorrer às vias jurisdicionais. Porém não se afirma que deva fazê-lo obrigatoriamente. Isto é, o que é obrigatório é o condicionamento da alteração a um pronunciamento jurisdicional, mas não o ingresso em juízo (isto é, pode a parte simplesmente desinteressar-se por levar a cabo a modificação).

Afirma-se, pois, que o princípio da inércia jurisdicional é expressão da feição liberal do desenho processual (nemo iudex sine actore, ne procedat iudex ex officio) ${ }^{19}$.

\footnotetext{
19،[...] o reconhecimento, pela ordem jurídica, de determinados direitos subjetivos, quer privados ou públicos, significa, entre outras coisas, que a satisfação desses direitos, especialmente a satisfação coativa, depende da vontade dos titulares, isto é, da sua livre determinação; eis porque lhes é reconhecido esse exclusivo poder, que é o 'direito de agir em juízo' (o qual, por sua vez, é um direito subjetivo, o direito subjetivo processual por excelência). Nos raros casos em que, ao lado do direito do titular, esteja presente o interesse público pela atuação da lei, permite-se que também o Ministério Público venha agir em juízo" (LIEBMAN, Enrico Tullio. Manuale de diritto processuale civile. 4. ed. Milano: Giuffrè, 1980. Tradução de: LIEBMAN, Enrico Tullio. Manual de direito processual civil. Tradução de Cândido Rangel Dinamarco. 3. ed. São Paulo: Malheiros Ed., 2005. v. 1, p. 195).
} 
No direito pátrio são expressão deste princípio as regras dos arts. $2^{\circ}$ e 262 do Código de Processo Civil (segundo a primeira das normas citadas, "Nenhum juiz prestará a tutela jurisdicional senão quando a parte ou o interessado a requerer, nos casos e forma legais").

Há corolários do princípio da inércia judicial, que constituem, em verdade, expressões deste postulado no curso do processo. Um deles é o princípio da congruência ou correlação. Se cabe à parte dar início à atividade judicial, com muito mais razão cabelhe fixar por meio da demanda os limites da matéria sobre a qual incidirá o pronunciamento do juiz, isto é, o objeto do processo. Não pode o juiz suprir, de ofício, a iniciativa da parte, alterando o objeto do processo, quer para ampliá-lo (o que ocasiona decisão ultra petita) quer para alterá-lo (ao que corresponde a decisão extra petita) ou para reduzi-lo (decisão infra petita). São expressões deste princípio as disposições dos arts. 128 e 460 do Código de Processo Civil ${ }^{20}$.

Expressão da inércia jurisdicional em sede de provas é o princípio dispositivo, que grosso modo, apregoa depender o juiz, na instrução da causa, das provas produzidas por iniciativa das partes. Aliás, a citação que segue é bastante emblemática, especialmente considerando a razão que nos leva a resumidamente mencionar o princípio em questão (qual seja, ressaltar a feição liberal de nosso processo civil):

"O princípio é de inegável sentido liberal, porque a cada um dos sujeitos envolvidos no conflito sub judice é que deve caber o primeiro e mais relevante juízo sobre a conveniência ou inconveniência de demonstrar a veracidade dos fatos alegados"

O esquema de legitimação ordinária é outro ponto chave na feição liberal e individualista de nosso processo civil, com a prescrição sempre lembrada de que ninguém pode pleitear em nome próprio direito alheio, ressalvadas as excepcionais e taxativas previsões legais de legitimação extraordinária por substituição processual $\left(\mathrm{CPC}\right.$, art. $\left.6^{\circ}\right)$.

\footnotetext{
${ }^{20}$ Tratando das expressões do princípio da inércia judicial, Liebman assim se manifesta: "Essa regra não prevalece apenas quanto ao início do processo, mas também para todo o seu curso, porque as partes podem em qualquer momento desistir da ação e impedir o juiz de julgar a causa ... sempre é a parte que indica o objeto do processo, de modo que o juiz não pode pronunciar-se além dos limites da demanda nem sobre exceções que exclusivamente pelas partes possam ser propostas ... Mesmo depois de proferida a sentença, cabe às partes, querendo, interpor eventual recurso" (LIEBMAN, Enrico Tullio. Manual de direito processual civil. Tradução de Cândido Rangel Dinamarco. 3. ed. São Paulo: Malheiros Ed., 2005. v. 1, p. 194).

${ }^{21}$ ARAÚJO CINTRA, Antonio Carlos de; GRINOVER, Ada Pellegrini; DINAMARCO, Cândido Rangel. Teoria geral do processo. 15. ed. São Paulo: Malheiros Ed., 1999. p. 64.
} 


\section{Insuficiência do modelo liberal}

Retomamos, pois, a lição de J.J.Calmon de Passos que vínhamos seguindo como linha mestra, para apontar o malogro do modelo acima traçado. De fato, constatou-se que as leis de mercado, ao contrário do que se esperava, não operaram corretivamente, e a questão social emerge daí em razão da ferocidade incontrolável das forças econômicas. Foi inevitável dar-se vazão ao tão outrora temido intervencionismo estatal, que se revelou, em verdade, como movimento que resultou em hipertrofia do Executivo, único capaz de legislar com a velocidade e requintes técnicos exigidos pelo quadro econômico. É então que se constatam as condições necessárias para a conformação da democracia social. Eis o contexto assim por ele definido com maestria:

"O Estado abandona sua postura liberal, deixando de ser mero guardião das liberdades políticas para se tornar protagonista no cenário econômico. As bases políticas se ampliam, o sufrágio é, agora, universal, novos atores ingressam na cena política e novas demandas se colocam no mercado político. O social se insinua e se expande, em detrimento do individual, e a autonomia privada retrocede sob o impacto do dirigismo contratual, surgindo novas figuras negociais em que o conteúdo dos contratos é quase de todo subtraído ao poder dispositivo dos contratantes. O coletivo se faz presente no processo econômico e no processo político, transformando-se rapidamente a antiga sociedade de vizinhos em sociedade de massa",22.

Esta a feição do Welfare State e da democracia social que lhe corresponde, que também conduziram a situação insustentável. De fato, o eixo de preocupação na atividade estatal passou a ter como centro a competência técnica e o saber científico, conduzindo à opressão, do que são marcas evidentes as manifestações totalitaristas, como o regime nazifascista na Alemanha e Itália, e a ditadura stalinista na Rússia. Forma-se uma casta de tecno-burocratas, distanciados da sociedade civil, pairando acima de qualquer controle social. O Estado que provê torna-se o Estado que oprime ${ }^{23}$.

\footnotetext{
${ }^{22}$ CALMON DE PASSOS, José Joaquim. Democracia, participação e processo, cit., p. 91.

23“Por uma contingência dialética, a democracia liberal transformou-se numa potência opressivamente presente nas mais insignificantes e triviais circunstâncias de nossas vidas". (SILVA, Ovídio A. Baptista da. Democracia moderna e processo civil. In: GRINOVER, Ada Pellegrini et al. (Coord.). Participação $e$ processo. São Paulo: Ed. Revista dos Tribunais, 1988. p. 103).
} 
Retrato desta constatação é a realidade de que o Estado, especialmente no Brasil, é o grande "cliente" do Poder Judiciário, visto que a larga maioria das demandas tem num dos pólos o Estado ou alguma de suas emanações ${ }^{24}$.

Está, assim, posto à calva o cerne da questão: à superação do modelo de Estado liberal não correspondeu, ao menos no nível do direito pátrio, a superação do desenho de processo civil com feições liberais. O descompasso entre as expectativas hoje postas ao instrumento estatal para solução de litígios e canal de participação da sociedade civil nos centros de poder, e aquilo que efetivamente este instrumento (o processo) representa e é capaz de atingir, é a raiz de todos os males que o assolam.

A falta de sintonia mencionada no parágrafo anterior tem sua gênese, indiscutivelmente, no fato de que as concepções jurídicas reinantes no mundo moderno foram concebidas para servir a sociedades menos complexas, não se coadunando com as exigências, estrutura e aspirações das novas organizações sociais típicas à sociedade pósindustrial. Diz-se, então, que não seria o direito processual que estaria padecendo crise aguda, e sim a forma tradicional de processo civil, dependente de conceitos e princípios herdados do Direito Romano ${ }^{25}$.

As disputas a propósito da riqueza socialmente produzida em países subdesenvolvidos e marcados pela desequilibrada distribuição de renda ostentam caráter profundamente antagônico, e a manifestação destes litígios perante o Judiciário possui forte poder de desgaste sobre a estrutura jurídica ${ }^{26}{ }_{-}^{27}$.

\footnotetext{
${ }^{24}$ WATANABE, Kazuo. Acesso à justiça e sociedade moderna. In: GRINOVER, Ada Pellegrini et al. (Coord.). Participação e processo. São Paulo: Ed. Revista dos Tribunais, 1988. p. 130-131.

${ }^{25}$ SILVA, Ovídio A. Baptista da. Democracia moderna e processo civil, cit., p. 99-101.

26“"Os mecanismos tradicionais de regulação dos sistemas de direito estruturados pelo Estado liberal clássico são insuficientes para resolver tais situações conflitivas produzindo forte esclerose nas suas decisões" (RIBEIRO, Paulo de Tarso Ramos. Direito e processo: razão burocrática e acesso à justiça. São Paulo: Max Limonad, 2002. p. 88). Segue adiante o referido autor: "A incapacidade circunstancial do sistema judicial de processar ditos conflitos e, nessa medida, compreendê-los, denuncia os limites da propalada autopoiesis do sistema jurídico enquanto característica particular de auto-regulação suficiente. Ao revés, a alopoiesis do sistema exsurge como o limite que se coloca para o sistema jurídico de regular situações para as quais as normas respectivas não foram previstas aprioristicamente de forma adequada às expectativas sociais de direito da grande maioria da população. Sua aplicação posterior desconsiderando os interesses estratégico desses contingentes populacionais produz contínuos déficits de legitimação do sistema jurídico-decisório" (Direito e processo: razão burocrática e acesso à justiça, cit., p. 89).

${ }^{27}$ “Exceção feita a algumas demandas coletivas (v.g. as chamadas 'ações civis públicas' e ação popular), todas as demais são tratadas como se tivessem configuração interindividual e as técnicas processuais a ela aplicadas são as tradicionais, consistentes em atomização e solução adjudicada dos conflitos ... Sem dúvida alguma, a organização da Justiça em nosso País está, em muitos pontos, dissociada dessa realidade social que nos cerca" (WATANABE, Kazuo. Acesso à justiça e sociedade moderna, cit., p. 151).
} 
José Eduardo Faria apresenta leitura aguda da crise de que vimos falando. Segundo aponta, perante a sociedade é visto o Judiciário cada vez mais como um poder inepto, viciado e moroso. Pelo Executivo, considerada uma instituição perdulária e irresponsável. O Legislativo o acusa de interferir no processo legislativo, e judicializar ou tribunalizar a vida política e administrativa do país, comprometendo o equilíbrio institucional ${ }^{28}$.

A crise do Judiciário decorre da ineficiência com que desempenha suas três básicas funções: instrumental; política e simbólica.

A instrumental representa a idéia de que o Judiciário deveria ser o locus institucional de resolução de conflitos na sociedade contemporânea.

A política, o reconhecimento de que exerce (ou deveria exercer) um papel de mecanismo de controle social, reforçando as estruturas de poder e assegurando a integração da sociedade.

A simbólica é baseada na idéia de que ele dissemina um sentido de justiça na vida social, "socializa as expectativas dos atores na interpretação da ordem jurídica e calibra os padrões vigentes de legitimidade" 29 .

Corrobora o que vimos defendendo, ao anotar que a origem da crise decorre do fato de que o Judiciário foi concebido para exercer estes três papéis no âmbito de uma sociedade estável e de uma economia de mercado, onde os conflitos seriam basicamente interindividuais, surgindo a partir de interesses minimamente unitários. O Judiciário agiria apenas quando acionado, e os juízes jamais poderiam substituir a vontade das partes, atuando sempre numa perspectiva técnica e com horizonte retrospectivo, isto é, versando sobre eventos passados. Ficaria o alcance do julgamento, neste contexto, circunscrito às partes.

O quadro que a seguir traça da realidade com a qual este modelo retrógrado de Judiciário se depara é tão acurado que merece integral transcrição:

"A realidade brasileira, contudo, é incompatível com esse modelo de
Judiciário. Instável, iníqua e contraditória, ela se caracteriza por fortes
desigualdades socais, regionais e setoriais e por uma subseqüente
explosão de litigiosidade; por situações de pobreza absoluta que negam o
princípio da igualdade formal perante a lei, impedem o acesso de parcelas
significativas da população aos tribunais e comprometem a efetividade
dos direitos fundamentais; por uma violência urbana desafiadora da
ordem democrática e oriunda dos setores sociais excluídos da economia
formal, para os quais a transgressão tornou-se a única possibilidade de

\footnotetext{
${ }^{28}$ FARIA, José Eduardo. O Judiciário e seus dilemas. Revista do Advogado, São Paulo, n. 56, p. 64-67, set. 1999.
}

${ }^{29}$ FARIA, José Eduardo. O Judiciário e seus dilemas, cit., p. 64. 
sobrevivência; por uma apropriação perversa dos recursos públicos, submetendo os deserdados de toda sorte a condições hobbesianas de vida; por uma crise fiscal que torna inelástica a prestação de serviços essenciais por parte do setor público, impedindo-o de expandir seu aparato burocrático para atender ao crescimento da demanda; por um sistema legal incoerente e incapaz de gerar um mínimo de previsibilidade de expectativas e segurança nas relações sociais, dada a profusão de regras gerais editadas para dar conta de casos muito específicos e meramente conjunturais e de normas excessivamente singelas para serem aplicadas em situações altamente complexas; e por uma gradativa fragmentação das fontes formais de direito e uma progressiva afirmação das fontes materiais, resultantes dos processos de deslegalização e desconstitucionalização provocados pela transnacionalização dos mercados, pelo policentrismo decisório na economia globalizada, pela relativização das fronteiras geográficas e pelas metamorfoses em andamento nos princípios da soberania e da territorialidade" ${ } 30$ - 31 .

O excesso de formalidades nos procedimentos judiciais é visto como o principal vilão a justificar os pleitos por deslegalização ou desinstitucionalização dos conflitos (sobre o que melhor se discorrerá adiante).

Na obra que linhas atrás citamos, Ovídio A. Baptista da Silva concentra atenção na crise do Direito (e do processo) nos Estados de bem-estar social, apontando como fatores determinantes em sua configuração o aumento populacional formador das grandes cidades e a incontida ascendência das massas, elementos estes caracterizadores da tão propalada civilização de massa.

A ascendência das massas às conquistas materiais da civilização industrial estaria à base de um exacerbado sentido igualitário e uma insaciável sede de justiça social, que

\footnotetext{
${ }^{30}$ FARIA, José Eduardo. O Judiciário e seus dilemas, cit., p. 64-65.

${ }^{31}$ Merecem também transcrição as reflexões de Paulo de Tarso Ramos Ribeiro: "A falta de mecanismos procedimentais específicos que viabilizem uma cognição compreensiva mais intensa das demandas, na sua complexidade integral, gera decisões equivocadas do sistema do ponto de vista da justiça aplicada, nessas ocasiões, em face à informação distorcida que norteia a decisão. A distorção informativa, no âmbito dos procedimentos, constitui-se em primeiro lugar, na apreensão parcial dos conflitos pelas normas de direito material que pautam a produção das decisões. Tais normas são gravadas em sua configuração pelos paradigmas tradicionais de direito do Estado liberal que acentuam a dimensão individual dos conflitos em detrimento do aspecto social que pervade os novos pleitos. Por outro lado, do ponto de vista do processo, o encaminhamento das demandas, a contraposição processual das partes no conflito (contraditório), a produção das provas, etc... são todos realizados em função de um objetivo pré-determinado: a aplicação da jurisdição nos termos individuais comutativos em que foi imaginada. A decisão judicial, assim proferida, vale-se de uma tipificação normativa sem maior efetividade e o sistema perde eficácia. Do ponto de vista estritamente processual, a racionalidade burocrática da decisão - que se pretende correta em termos técnicos e lógico-formais e neutra do ponto de vista político - é contaminada pela inaptidão social dos segmentos excluídos da população em participar dos procedimentos que antecedem a concessão dos provimentos. Seja porque não os conhece nem os vivencia em seu cotidiano, sobretudo aqueles procedimentos que se referem à garantias pessoais da cidadania (due process of law; ampla defesa, contraditório, etc...); seja porque não lhes têm acesso quando da instauração dos conflitos" (RIBEIRO, Paulo de Tarso Ramos. Direito e processo: razão burocrática e acesso à justiça, cit., p. 122-123).
} 
culmina com a explosão de busca pela proteção judiciária com a qual as estruturas concebidas nos moldes tradicionais a que já aludimos, evidentemente não estão preparadas para lidar ${ }^{32}$.

$\mathrm{O}$ incremento do acesso à justiça reflete na mudança qualitativa dos conflitos trazidos a juízo. O processo civil se torna um fenômeno de massa, com a acessibilidade alcançando camadas da população antes excluídas ${ }^{33}$. Esta realidade também tem causado a subversão dos valores do sistema judicial. Os Conselhos de Magistratura e órgãos similares responsáveis pela administração da justiça, têm privilegiado a quantidade em detrimento da qualidade $^{34}$.

Esta busca incontida de justiça se reflete no direito processual no fenômeno da efetividade do processo ou efetividade do Direito ${ }^{35}$ (e aqui lembramos a alusão feita na introdução ao presente trabalho, onde apontou-se a "onda da efetividade" como momento pós-instrumentalista na ciência processual, e que corresponde, como estamos a ver, à insuficiência do modelo de democracia social que está à base do Welfare State). A questão agrava-se na sociedade moderna altamente complexa, pois que desorientada pela perda de referências comportamentais éticas e religiosas, vê-se a "crescente dependência dos esquemas e estruturas jurídicas a que o homem moderno está sujeito"36_37.

E é precisamente neste contexto que emerge a concepção de Direito como instrumento redutor da complexidade e como forma de organização das expectativas congruentemente generalizadas (Niklas Luhmann).

Baseando-se em lição de Norberto Bobbio, segue Ovídio A. Baptista da Silva indicando três promessas descumpridas, feitas em nome da democracia, e que servem à caracterização da configuração atual da "democracia de massas".

\footnotetext{
${ }^{32}$ SILVA, Ovídio A. Baptista da. Democracia moderna e processo civil, cit., p. 102.

${ }^{33}$ MONTERO AROCA, Juan. El derecho procesal en el siglo XX, cit., p. 58-59.

${ }^{34}$ MONTERO AROCA, Juan. El derecho procesal en el siglo XX, cit., p. 84. Conforme defende Montero Aroca, o incremento da litigiosidade tem duas causas principais: a) a amplicação da base social das classes médias e b) o fenômeno social do consumo de massa (El derecho procesal en el siglo XX, cit., p. 81).

${ }^{35}$ SILVA, Ovídio A. Baptista da. Democracia moderna e processo civil, cit., p. 102.

${ }^{36}$ SILVA, Ovídio A. Baptista da. Democracia moderna e processo civil, cit., p. 102.

37"OO Judiciário brasileiro é um exemplo, a confirmar uma tendência que parece mundial, de aumento incessante e desmesurado da demanda social pela prestação jurisdicional. Os juizados de pequenas causas ilustram isso. Há quem defenda a capacidade 'sem limite' do sistema jurídico para o atendimento dessas exigências. Outros advogam, contrariamente, que o ativismo judicial dos novos atores e a variabilidade das estruturas normativas produzem um direito incerto, desprovido de previsibilidade e que provoca um decréscimo na produtividade e na credibilidade do Judiciário. As duas posturas são exageradas, mas demonstram a significância da magistratura para o debate institucional atual" (CAMPILONGO, Celso Fernandes. Os desafios do Judiciário: um enquadramento teórico, cit., p. 44-45).
} 
A primeira promessa descumprida seria a de que nos regimes democráticos o Estado seria o centro exclusivo do poder, e por consequiência, o povo, enquanto unidade ideal, o verdadeiro soberano. O que se verifica, entretanto, é que os grupos, e não os indivíduos, é que são os protagonistas da vida política, constatando-se "a dispersão do poder pelas incontáveis e polifórmicas estruturas parciais da sociedade, fez-se segundo os interesses igualmente parciais de cada uma delas, em detrimento do interesse geral" ${ }^{\text {"38 }}$. Assim é que os instrumentos de controle da legitimidade democrática, forjados no contexto de um sistema representativo do tipo liberal e individualista, nunca guardaram perfeita correspondência com a realidade.

A segunda promessa descumprida foi a de que os mandatos populares conferidos ao representante político seriam essencialmente livres: uma vez eleito, o representante deixa de representar o eleitor e passa a ser legítimo tutor do interesse geral. A temporariedade dos mandatos, entretanto, embora realce a exigência do controle de legitimidade do exercício do cargo, acaba obrigando ao representante, para manter-se na vida pública, a submeter-se de forma servil tanto às diretrizes partidárias, como aos interesses de seus eleitores, e os interesses gerais da nação acabam suprimidos pelos interesses dos grupos.

Isto fez com que "o Estado fosse reduzido ao papel de mero intermediário, ou simples agente de acomodação e transigência entre os inúmeros interesses parciais contrapostos",39.

Por fim, a terceira promessa descumprida está representada pela persistência das oligarquias, indicando o malogro da idéia fundamental de que a liberdade política do cidadão decorreria de sua sujeição exclusivamente à lei, por ele próprio aprovada e consentida.

Os parlamentos, que deveriam ser a essência da tutela dos interesses gerais da nação, estão absorvidos pelos interesses administrativos e preocupados em satisfazer reivindicações de grupos de pressão, e daí se explica o paradoxo do Estado promocional conviver com a insatisfação geral da nação ${ }^{40}$.

Com os olhos mais postos da realidade estrutural do Poder Judiciário e na conformação da atividade judiciária no dia-a-dia forense (isto é, deixando um pouco de lado a realidade macroscópica da inadequação do Judiciário a partir de uma análise calcada

\footnotetext{
${ }^{38}$ SILVA, Ovídio A. Baptista da. Democracia moderna e processo civil, cit., p. 105.

${ }^{39}$ SILVA, Ovídio A. Baptista da. Democracia moderna e processo civil, cit., p. 106.

${ }^{40}$ SILVA, Ovídio A. Baptista da. Democracia moderna e processo civil, cit., p. 108.
} 
na filosofia política), Vittorio Denti apresenta uma visão bastante ampla, retomando questões que já foram aventadas, e acrescendo outras que não poderiam igualmente ser negligenciadas ${ }^{41}$.

Lembra inicialmente que desde finais da década de setenta e ao longo da década de oitenta pede-se uma justiça com "rosto" mais humano, a significar a exigência de maior humanidade, e melhor aderência da justiça civil às garantias constitucionais, reconhecendo-se que a atual postura na administração da justiça não atende aos valores fundamentais afirmados na carta constitucional.

Divide-se então a exposição em quatro frentes: i) análise da explosão de litigiosidade civil, a partir de um complexo de fatores; ii) organização judiciária e sua relação com o fenômeno do incremento de litigiosidade; iii) o papel negativo que também a advocacia desempenha como protagonista do processo; iv) papel que as regras do jogo, isto é, as normas processuais, desempenham na crise da justiça civil.

Sob item "i” estão arrolados elementos bastante variados. Primeiramente um estado perene de incerteza do direito, como consequência não tanto da difusão de legislação setorializada, mas principalmente pelo caráter de tal legislação, destinada a mudanças cíclicas, sob a pressão corporativa e fruto de inadequada técnica legislativa, que produz normas ambíguas, obscuras, de difícil interpretação e cuja aplicação às vezes parece deliberadamente deixada à incerta sorte dos rumos jurisprudenciais. Uma segunda causa de incerteza, na posição do autor estudado, seria o controle de constitucionalidade das leis realizado por uma Corte Constitucional, pois que para definição da norma aplicável devese sempre aguardar o pronunciamento de tal órgão, o que é ainda agravado pela tendência de tais órgãos de não operar simples ab-rogações normativas, mas sim de manipularem o texto da legislação ordinária. Ressalta-se, assim, "gli effetti ché l'instabilità e l'imprevedibilità delle sue decisioni producono sul comportamento dei giudici e, di riflesso, su quello delle parti, introducendo un'altra variabile di rilevante peso nella litigiosità civile" ${ }^{, 42}$.

Em terceiro lugar um dito excesso de garantismo decorrente de uma interpretação "exasperada" do texto constitucional, indo além dos motivos inspiradores dos dispositivos de garantias, causando um alongamento do tempo processual. Em quarto lugar, "l'evoluzione tecnológica e la diffusa aspirazione all'equal protection nei rapporti sociali

\footnotetext{
${ }^{41}$ DENTI, Vittorio. Riflessioni sula crisi della giustizia civile. Sociologia del Diritto, Milano, v. 13, p. 59-79, 1986.

${ }^{42}$ DENTI, Vittorio. Riflessioni sula crisi della giustizia civile, cit., p. 64.
} 
hanno notevolmente complicato i problemi che il giudice si trova quotidianamente ad affrontare",43.

Acerca do item "ii" (organização judiciária), refere-se inicialmente a um problema típico da realidade italiana, qual seja, a concentração de controvérsias perante o "giudice ordinario", relatando-se a sucessiva supressão, ao longo do tempo, de órgãos destinados ao desenlace de específicos tipos de controvérsia, ou meios alternativos de solução de disputas, levando a este inchaço.

O segundo elemento apontado é plenamente aplicável à realidade brasileira: observa-se que a forma de recrutamento de magistrados impõe a formação da primeira instância por juízes mais jovens e em início de carreira. Esta circunstância acaba por ocasionar uma menor autoridade do juízo de primeiro grau em relação aos litigantes, e a mais frágil disposição destes de aceitarem a solução imposta pelo provimento jurisdicional de primeiro grau. A consequência deste estado de coisas é a transferência do "centro de gravidade" da causa às instâncias recursais, quando o desejável seria que estivesse ele concentrado no primeiro grau de jurisdição. Ocorre que, em terceiro lugar, observa-se uma também falta de autoridade das instâncias recursais (referindo-se especificamente, e à luz da organização judiciária italiana, à "giustizia d'appello" e à "giustizia di cassazione", porém com observações que se nos estendem, apenas com as devidas adaptações ao nosso sistema recursal), ponderando-se que o excesso de recursos causa o declínio qualitativo de sua atividade, não por falta de cultura de seus integrantes, porém por falta de uniformidade nas orientações assumidas nos julgados, causando instabilidade.

Uma quarta questão relacionada à administração judiciária realçada por Denti refere-se à forma de ascensão na carreira pelos magistrados, reduzida praticamente quase que exclusivamente à antiguidade (o que também se constata na realidade nacional). Não podendo contar com sua própria capacidade cultural para ascender na carreira, por vezes o magistrado opta pela carreira universitária, abandonando a toga, o que vem causando uma perda de identidade profissional da magistratura no momento atual ${ }^{44}$.

Sobre o item "iii”, discorre ainda o autor acerca de outros quatro componentes. O primeiro deles refere-se à falta de uma séria formação profissional, após a obtenção da

\footnotetext{
${ }^{43}$ DENTI, Vittorio. Riflessioni sula crisi della giustizia civile, cit., p. 65.

${ }^{44}$ Esta realidade igualmente se verifica no Brasil, com o agravamento em Estados como o de São Paulo, onde há grande quantidade de juízes, em que a antiguidade, na verdade, significa eternidade, considerando-se que grande parte dos juízes não chegará aos cargos de cúpula do Tribunal por falta de tempo hábil. Talvez a migração para o magistério só não seja uma realidade em razão de nossa irremediável tradição de remunerar miseravelmente os professores.
} 
láurea, sem ainda uma efetiva especialização, ao que se adiciona a dificuldade do jovem advogado de obter um nível decente de remuneração. Em segundo lugar, a mesma falta de autoridade que vitima o provimento jurisdicional, a que já se aludiu, igualmente molesta a advocacia, verificando-se a falta de consciente estratégia na gestão das controvérsias, bem como de uma percepção do real interesse do cliente, de modo que o zelo na defesa da causa se contém no limite da ética profissional.

Também é a advocacia, em terceiro lugar, carente de governo, isto é, de controle da observância de um mínimo ético. Não existe, segundo o autor italiano e de acordo com sua realidade, um Código de Deontologia Forense, lembrando ainda que por trás do sistema adversarial está como pilar, especialmente no direito anglo-americano, o instituto do contempt of court, como forma de assegurar a correção do julgamento e a execução das decisões judiciais.

Em quarto lugar, retoma-se a questão da formação jurídica, lembrando-se que um mau uso da tutela jurisdicional não poderia ser atribuído ao ensino jurídico, pois que os cursos jurídicos têm estado à altura das necessidades de uma moderna cultura de jurista, e que os reclamos por uma maior profissionalização no ensino jurídico, na verdade, ignoram que a profissão de advogado é apenas uma das possibilidades de utilização da licenciatura em Direito, salientando-se que em países onde a escola de Direito tem um caráter acentuadamente profissional, está caracterizado um ensino universitário de segunda linha, com notas de especialização ${ }^{45}$.

Por fim, a quarta faceta invocada ("iv") refere-se ao papel das normas processuais na crise da justiça civil. A primeira assertiva é a de que as regras processuais não são capazes de impedir que seu aparato garantista seja utilizado de forma anormal, e que em razão desta distorção, o tempo processual se dilate além dos limites de razoabilidade. Ressalta-se ainda que uma das maiores causas de inadequado funcionamento do ofício judicial é a pobre eficiência da sua direção, e do controle dos prazos impostos ao juiz, a fim de propiciar que o processo corresponda aos fins previstos pelo legislador ao discipliná-lo.

\footnotetext{
${ }^{45}$ Se nas bandas italianas a realidade é esta, em solo tupiniquim é aquela referida pelo autor como "ensino universitário de segunda linha". Adiante o tema é novamente abordado, com base em lição de Ovídio Baptista da Silva, que justamente ressalta que as universidades brasileiras tem o ranço de formar exegetas, glosadores do texto legal, revelando-se mais como um curso técnico de rábulas.
} 


\section{Novas necessidades, novos horizontes}

"Marchamos agora para um terceiro tempo - o da democracia participativa. Por ela tenta-se manter a interação entre o econômico e o político e sua formulação jurídica, mas porfia-se por superar o exacerbamento do Estado em detrimento da liberdade" ${ }^{\text {. }}$. Reconhece-se, pois, que todo poder entregue a si mesmo, sem controles, degenera-se, distancia-se das bases que o instituíram. E assim é com o Estado, que se reconhece como ente com fisionomia própria, distinta da sociedade civil, portador de interesses que nem sempre se coadunam com os daquela e freqüentemente com eles conflitam.

Essencial neste contexto a institucionalização de controles do poder econômico e político pela sociedade civil. Três notas características à democracia social são apontadas: participação nas decisões; controle da execução em todas as circunstâncias e acesso às informações.

Ultrapassa-se o sistema representativo-parlamentar, surgem corpos intermediários mais representativos e mais próximos do cidadão e dele mais dependentes; com descentralização da administração ${ }^{47}$.

Como já afiançado, o desenho do método estatal de solução dos conflitos surgidos no seio social (processo) reflete a filosofia política e econômica de seu tempo. Já vimos de ver a feição liberal do processo civil praticado no Brasil, com largo apoio em regras positivadas pelo legislador de 1973.

Também já pensamos ter demonstrado a insuficiência do modelo liberal, assim como os desvios do paradigma do bem-estar social. A questão fundamental é, pois, perquirir qual o modelo de processo que se coaduna com o sistema democráticorepresentativo a que temos nos referido?

A resposta a esta questão (o que, em verdade, podemos apenas esboçar, pois não se apanha debaixo da unha a história em movimento) constitui sem dúvida alguma o nó górdio na compreensão da ciência processual de nosso tempo, especialmente das expectativas que o modelo processual deve estar apto a atender.

A questão, à evidência, não é superar o modelo liberal no sentido de descartá-lo. O processo segue sendo garantia constitucional, e tendo na tutela dos direitos individuais nobre compromisso. O que se está a afirmar é que este não mais é seu único e precípuo

\footnotetext{
${ }^{46}$ CALMON DE PASSOS, José Joaquim. Democracia, participação e processo, cit., p. 92.

${ }^{47}$ CALMON DE PASSOS, José Joaquim. Democracia, participação e processo, cit., p. 93.
} 
alvo, deve ultrapassá-lo, tornando-se instrumento no movimento de democratização da sociedade ${ }^{48}$.

Ainda segundo J.J.Calmon de Passos o desafio deste tempo ao processualista é ser o protagonista na recuperação pelo jurista da condição de cientista político. Arrola, pois, o autor três princípios que hão de reger o novo processo: a) superação do mito da neutralidade do juiz e de seu apolitismo; b) processo alçado ao nível de instrumento político de participação na formulação do direito e de provocação da atuação dos agentes públicos e privados no que concerne à satisfação de interesses transindividuais; c) superação do mito da separação dos poderes, com a solidificação de controles sociais sobre os poderes político e econômico, institucionalizando-se o processo como instrumento de atuação desses controles.

Com a mesma conclusão se alinha Ovídio A. Baptista da Silva: "pensamos que a reforma deva orientar-se decisivamente para o horizonte da participação política, cada vez mais efetiva e abrangente" 49 .

O autor supra citado estabelece como pressuposto a essa mudança a revitalização do modelo do ensino jurídico, que longe de preparar juristas prontos a participar na produção do Direito, prepara exegetas, ou quando muito, inofensivos memorizadores de textos legais. Associa esta característica à matriz romano-germânica de nossa formação ${ }^{50}$.

No item precedente fizemos um apanhado geral das reflexões de Vittorio Denti acerca da crise da justiça civil. E ao lado do que foi dito nos parágrafos precedentes, também merecem referência as conclusões do autor italiano acerca do assunto. Conclui lembrando que a maior exigência de justiça não advém de vetustas fórmulas simplistas e redutoras do litígio, mas da complexidade social hodierna, calcada na complexidade crescente das relações econômicas e sociais ${ }^{51}$.

Eis, no mais, o quanto afiança: i) não se pode mais descurar da íntima correlação entre a reforma do processo, do Judiciário e da atividade da advocacia; ii) a justiça civil representa, ainda, um elemento prevalentemente técnico, ao qual a opinião pública se sente

\footnotetext{
48، Acredito estejamos caminhando para o processo como instrumento político de participação. A democratização do Estado alçou o processo à condição de garantia constitucional; a democratização da sociedade fá-lo-á instrumento de atuação política ... Despe-se o processo de sua condição de meio para a realização de direitos já formulados e transforma-se ele em instrumento de formulação e realização dos direitos. Misto de atividade criadora e aplicadora do direito, ao mesmo tempo" (CALMON DE PASSOS, José Joaquim. Democracia, participação e processo, cit., p. 95).

${ }^{49}$ SILVA, Ovídio A. Baptista da. Democracia moderna e processo civil, cit., p. 109.

${ }^{50}$ SILVA, Ovídio A. Baptista da. Democracia moderna e processo civil, cit., p. 109.

${ }^{51}$ DENTI, Vittorio. Riflessioni sula crisi della giustizia civile, cit., p. 76.
} 
estranha; iii) o sociólogo deve ter voz na projeção de reformas processuais ${ }^{52}$; iv) a abordagem sociológica igualmente se mostra essencial como instrumento de conhecimento de como os institutos processuais são vividos na realidade, como as normas são efetivamente aplicadas, qual o grau de fairness e justiça substancial que o processo civil pode garantir.

Conclui então: "riforme senza sociologia sono soltanto um errore di politici improvvidi o di giuristi timorosi di veder crollare le 'cattedrali nel deserto' del loro astratto concettualismo" $^{, 53}$.

\section{Judiciário e Estado pós-social}

Com base em texto de Celso Fernandes Campilongo destacamos os três principais pólos caracterizadores das feições do Estado alcunhado pós-social: a) surgimento de novos atores sociais; $b$ ) transformação de estruturas normativas e c) ambigüidades das funções judicantes ${ }^{54}$. Vejamos breve e resumidamente cada uma delas.

A concepção individualista típica do Estado liberal restou superada pela democracia social, que transferiu para as classes sociais o eixo de participação e influência nos rumos do corpo social, tendo como expoentes deste momento os partidos e sindicatos. A crise a que vimos nos referindo, da democracia representativa e do Estado social reflete um novo deslocamento do poder, agora do Estado para a sociedade, como uma conseqüência natural da deterioração da credibilidade dos partidos políticos, casas legislativas, do próprio processo eleitoral, e do enfraquecimento dos sindicatos. Os novos movimentos sociais se apresentam como sucedâneos funcionais de partidos e sindicatos. Qual o impacto dessas mudanças no Judiciário ${ }^{55}$

A acurada observação de Paulo de Tarso Ramos Ribeiro a propósito deste deslocamento do eixo decisório do Estado para a sociedade merece menção. Aponta-se que num país como o Brasil, em que é latente a debilidade social das instituições de direito, e que não tenha deveras experimentado a legalidade, há severo risco de ineficácia das

\footnotetext{
52،"nel campo delle riforme processuali l'apporto delle ricerche sociologiche sia stato di gran lunga inferiore a quello di cui si sono giovati altri settori del diritto, suggerendo come possibili line di indagine la rilevazione della realtà sociale rilevante ai fini delle riforme; l'individuazione dei punti deboli del sistema e delle esigenze di riforma; la definizione dei fini e dei contenuti delle riforme; la valutazione della loro effetività" (DENTI, Vittorio. Riflessioni sula crisi della giustizia civile, cit., p. 78).

${ }^{53}$ DENTI, Vittorio. Riflessioni sula crisi della giustizia civile, cit., p. 79.

${ }^{54}$ CAMPILONGO, Celso Fernandes. Os desafios do Judiciário: um enquadramento teórico, cit., p. 30-51.

${ }^{55}$ CAMPILONGO, Celso Fernandes. Os desafios do Judiciário: um enquadramento teórico, cit., p. 32.
} 
delegações normativas. Nos rincões mais remotos do território mais do que debater a cidadania desregulada (conceito chave no contexto destas considerações que estamos a fazer), há "necessidade social de institucionalização da legalidade e seus procedimentos"

Já tivemos também oportunidade de referir que não se trata de superar os momentos do Estado de Direito Liberal e do Estado Social no sentido de desprezar-lhes as conquistas. Os novos atores sociais continuam portadores de direitos chamados "liberais", e os avanços civilizatórios do princípio da legalidade e demais garantias do cidadão hão de ser preservados; também não é pretensão alguma destes novos figurantes dispensar o Estado das obrigações assumidas em sua fase paternalista (cidadania social) ${ }^{57}$.

Cumpre ressaltar, com base ainda na lição de Celso Campilongo (e este citando Luigi Ferrajoli), que neste processo de redefinição de papéis o Judiciário poderá ser visto não como um órgão do Estado, mas sim da sociedade civil, vinculado à soberania popular por dois caminhos: de um lado pela tradicional função de garantia dos direitos fundamentais, de outro, como veículo de crítica popular às disposições ilegítimas ${ }^{58}$. Em conclusão: "os novos atores procuram fazer do juiz parte da sociedade e, conseqüentemente, a partir daí buscam refundar a independência do Judiciário na imagem de um contra-poder da própria sociedade".

Uma manifestação do processo que estamos a abordar é a emergência dos interesses metaindividuais, que se referem a coletividades em larga escala indefinidas, versando objetos indivisíveis e portadores de intensa conflituosidade. Partidos e sindicatos, evidente, nunca foram vocacionados para labor desta envergadura, pois que atuam tradicionalmente na perspectiva classista, lidando com questões específicas e de "recortes demarcados" $"$. A apreensão judicial desta conflituosidade que informa esses "novos atores sociais" exige ampliação do referencial cognitivo do magistrado, o que implica novas exigências quanto à sua formação técnico-profissional ${ }^{60}$.

\footnotetext{
${ }^{56}$ RIBEIRO, Paulo de Tarso Ramos. Direito e processo: razão burocrática e acesso à justiça, cit., p. 95.

${ }^{57}$ "Em outras palavras, sem eliminar os problemas da conflituosidade inter-individual, nem amadurecer o embate político das classes sociais que culminaram no modelo específico de repartição social dos benefícios no welfare state, as sociedades subdesenvolvidas têm de enfrentar, desde logo e em meio a construção vacilante do próprio Estado social, os novos conflitos que destacam o papel dos movimentos sociais em substituição aos partidos e aos sindicatos, por exemplo" (RIBEIRO, Paulo de Tarso Ramos. Direito e processo: razão burocrática e acesso à justiça, cit., p. 92-93).

${ }^{58}$ Precarietá dei valori di riferimento Ed emergenze in Crisi della giurisdizione e crisi della política, S.Mannuzzu e F.Clementi, organizadores, Milano, Franco Angeli, 1988, apud CAMPILONGO, Celso Fernandes. Os desafios do Judiciário: um enquadramento teórico, cit., p. 34.

${ }^{59}$ CAMPILONGO, Celso Fernandes. Os desafios do Judiciário: um enquadramento teórico, cit., p. 34.

${ }^{60}$ CAMPILONGO, Celso Fernandes. Os desafios do Judiciário: um enquadramento teórico, cit., p. 34.
} 
Sindicatos e partidos assumiram conotações cartoriais e corporativas, e embora tenham tido grande participação na construção normativa dos direitos sociais especialmente na década de oitenta e no surgimento de uma nova cidadania social, viram esmaecer no cenário político sua importância como canal de veiculação de demandas ${ }^{61}$.

Não se pode, contudo, descurar que ao Judiciário cabe não só a tradicional função do controle do arbítrio estatal, como ainda, e em novidade, coibir os desvios autocráticos das grandes organizações e mobilizações sociais.

Evidente ainda que o deslocamento de poderes do Estado para a sociedade civil implica a mutabilidade das estruturas normativas, especialmente com o surgimento de centros de produção normativa periférica ou semi-autônoma, por delegação estatal ou afirmação social $^{62}$.

\begin{abstract}
"o Estado liberal formula uma teoria da norma jurídica; o Estado social constrói uma teoria do ordenamento jurídico; e o Estado pós-social enfrenta o desafio da construção de uma teoria do pluralismo jurídico. Que papel desempenha o Judiciário diante da pluralidade de ordens jurídicas? Quais as relações entre a regulação jurídica e a auto-regulação social? A circulação de poderes do Estado para a sociedade é acompanhada pela passagem da unicidade jurisdicional do Estado para a fragmentação da Justiça em diversas instâncias privadas?"63_64
\end{abstract}

A assunção pelo Estado da regulação dos direitos individuais e políticos levou ao fenômeno denominado pela sociologia do direito de institucionalização do conflito e que agora vê-se em franca regressão, com a emergência dos novos atores sociais e a explosão de conflituosidade marcada pela multipolaridade dificilmente enquadrável nas molduras normativistas. Expandem-se assim os instrumentos de autoregulamentação privada, eis a desinstitucionalização do conflito.

A racionalidade jurídica no modelo liberal é de natureza instrumental; no modelo social, teleológica, isto é, de fins (chamado o primeiro de modelo formal, o segundo, material). Ambos têm na hierarquização (estrutural no caso do modelo liberal e funcional

\footnotetext{
${ }^{61}$ RIBEIRO, Paulo de Tarso Ramos. Direito e processo: razão burocrática e acesso à justiça, cit., p. 93.

${ }^{62}$ Seguimos ainda de perto as lições de Celso Campilongo, texto supra citado.

${ }^{63}$ CAMPILONGO, Celso Fernandes. Os desafios do Judiciário: um enquadramento teórico, cit., p. 37.

64،Tudo está a indicar que o pluralismo, princípio inspirador do estado democrático brasileiro, está dando origem a um pluralismo jurídico, reconhecendo as novas fontes normativas e as instâncias pioneiras de negociação desestatizadas, como a mediação, arbitragem, a justiça negociada, a justiça proposta. $\mathrm{O}$ surgimento de explicações para os fenômenos contemporâneos, como o direito alternativo, o ativismo judicial, as associações de juízes democráticos, a semiologia do poder, o direito insurgente, o neomarxismo jurídico, o direito achado na rua e outros, reclama um juiz apto e aberto a uma adequada compreensão da realidade jurídica" (NALINI, José Renato. O juiz e o acesso à justiça. 2. ed. São Paulo: Ed. Revista dos Tribunais, 2000. p. 54-55).
} 
no caso do modelo social), completude e coerência lógica interna, características fundamentais. A racionalidade pós-social supera as matrizes anteriormente citadas, propugnando pelo sistema organizado em forma de redes ou de circularidade, e não mais o modelo piramidal antes referido ${ }^{65}$.

A questão então é distinguir o jurídico do não-jurídico neste novo quadro de complexa pluralidade normativa. Este processo denominado de desestruturação do direito $^{66}$ exige do aplicador e do magistrado em particular saber pragmático acurado ${ }^{67}$, conhecimento das situações concretas, para extrair da regra o máximo que possa oferecer, sem degringolar para o campo da discricionaridade subjetiva do julgador fundada nos caprichos de seu senso pessoal de justiça ${ }^{68}{ }_{-}{ }^{69}$.

\footnotetext{
${ }^{65 ، C}$ Com base nesta sistematicidade, as tramas entre múltiplas cadeias normativas, variadas estruturas basilares e numerosas interrelações jurídicas reforçam o surgimento de infindáveis expansões da complexidade do próprio sistema. Trata-se, sem dúvida, de um discurso abstrato e de difícil percepção para o jurista treinado na tradição da racionalidade formal. Entretanto, ao contrário do que se possa imaginar, os sistemas circulares procuram superar a burocratização e o senso teórico dos sistemas axiomáticos, sempre fazendo referência ao senso prático, à necessidade de reconhecimento da regra do caso particular, da "justiça' do caso concreto" (CAMPILONGO, Celso Fernandes. Os desafios do Judiciário: um enquadramento teórico, cit., p. 39).

${ }^{66}$ Consiste a desestruturação na organização atomizada dos novos centros decisórios e quebra da unidade do ordenamento jurídico (RIBEIRO, Paulo de Tarso Ramos. Direito e processo: razão burocrática e acesso à justiça, cit., p. 113).

${ }^{67 ،}$ 'O caráter pragmático da decisão nos sistemas circulares e estruturados em rede acentua o saber prudencial dos aplicadores da lei em face do caso concreto" (RIBEIRO, Paulo de Tarso Ramos. Direito e processo: razão burocrática e acesso à justiça, cit., p. 114). "A proteção de direitos é antes um exercício de prudência judicial do que labor legislativo, contrariando aqueles que, ao melhor estilo napoleônico, ainda consideram o juiz uma mera bouche de la loi, ou seja, um mero aplicador acorrentado ao silogismo fato-subsunção-Direito" (CARVALHO, André de; RIBEIRO, Marcus Vinicius. Direitos humanos, inclusão jurídica e o papel da assistência jurídica no Brasil do século XXI. Revista Forense, Rio de Janeiro, ano 106, v. 409, p. 49, maio/jun. 2010).

${ }^{68}$ Celso Campilongo segue apontando que a novidade das estruturas normativas estende-se também para o campo da própria normatividade estatal, marcada pela hipertrofia legislativa, inclusive com figuras produzidas fora dos lindes do Parlamento; variabilidade de normas e como resultado da combinação dos dois fatores retro citados, problemas de coerência interna do sistema. Eis a suma: "O que dizer, então, sobre a capacidade destas normas manterem um padrão de logicidade, integração e escalonamento minimamente orgânicos e coerentes? O direito atual rompe com os postulados de harmonia e homogeneidade da 'era das grandes codificações'. A idéia de unicidade do sistema jurídico é substituída por uma visão policêntrica, que admite a convivência de infinitos microssistemas normativos dotados de lógicas próprias mas dificilmente ajustáveis à pretensão de coerência do macrossistema" (Os desafios do Judiciário: um enquadramento teórico, cit., p. 42). Resultado da necessidade de coordenação destes múltiplos pólos irradiadores de preceitos é a proliferação de cláusulas gerais, conceitos jurídicos indeterminados e normas programáticas, isto é, uma redução do grau de precisão das normas, o que exige, por seu turno, do magistrado versatilidade ímpar e formação profissional incompatível com o comumente visto nos bancos das Faculdades de Direito atualmente (a respeito, já tivemos a oportunidade de citar a posição de Ovídio A. Baptista da Silva). A hipertrofia legislativa pode ser atribuída em larga medida ao fenômeno denominado por Kazuo Watanabe de administrativização do Direito, isto é o Direito utilizado como instrumento de governo, o que conduz igualmente a uma ascendência do Executivo sobre os demais poderes, especialmente o Legislativo, que não raro vê sua função típica quando não tolhida, ao menos compartilhada por aquela face do poder estatal (Acesso à justiça e sociedade moderna, cit., p. 131).

69“"A capacidade interna do sistema de absorver, de modo imparcial e em toda sua plenitude, as contradições que opõem as partes no conflito constitui uma espécie de parâmetro de humanização do processo. Um mecanismo adequado à superação da lógica formal que norteia, tantas vezes, a tomada de decisões" (RIBEIRO, Paulo de Tarso Ramos. Direito e processo: razão burocrática e acesso à justiça, cit., p. 105).
} 
O terceiro pólo a ser estudado é a mudança no caráter das funções judicantes, decorrente dos impactos causados por essa nova tessitura sócio-política e jurídica.

Já vimos que a função Judiciária no Estado liberal é marcada pela idéia de fidelidade à lei, prevalecendo no campo da hermenêutica jurídica a chamada interpretação de bloqueio, com o realce ao princípio da legalidade e legalidade estrita e o juiz tendo por precípua atividade demarcar as atividades do Estado e as funções do próprio Judiciário.

A passagem ao Estado Social vê a ascendência da hermenêutica de legitimação das aspirações sociais, e na ciência processual é reflexo disto a recorrente temática da instrumentalidade do processo.

Neste momento pós-social as palavras de ordem são a desformalização, deslegalização e desregulamentação, revelando a insuficiência tanto da norma geral e abstrata utilizada na interpretação de bloqueio, quanto das normas programáticas utilizadas na conformação das políticas públicas e regras promocionais instrumentalizadas para a interpretação de legitimação ${ }^{70}$.

Os desajuste entre a marcha do mecanismo institucional de solução do conflito (processo) e o "tempo" das modernas transações mercantis, o desalinho das regras jurídicas nacionais e a internacionalização do processo produtivo tem conduzido ao fortalecimento dos mecanismos alternativos de resolução dos conflitos jurídicos, o que se costuma chamar de desinstitucionalização do conflito. Alerta-se, entretanto, de que estes sintomas não são reveladores de perda de função por parte da Magistratura, mas sim do reclamo de revisão dos procedimentos; da mudança na formação; do incremento da operacionalidade do Poder Judiciário $^{71}$.

À interpretação de bloqueio e legitimação, combina-se a interpretação reflexiva, "que espelhe a correlação de forças sociais, o momento econômico e a capacidade circunstancial de resposta do sistema político",72.

A tendência dos sistemas jurídicos contemporâneos é criar novas técnicas de garantia de efetividade, defendendo-se que o progresso da democracia mede-se justamente pela expansão dos direitos e pela sua afirmação em juízo.

\footnotetext{
${ }^{70}$ CAMPILONGO, Celso Fernandes. Os desafios do Judiciário: um enquadramento teórico, cit., p. 47.

${ }^{71}$ CAMPILONGO, Celso Fernandes. Os desafios do Judiciário: um enquadramento teórico, cit., p. 44.

${ }^{72}$ CAMPILONGO, Celso Fernandes. Os desafios do Judiciário: um enquadramento teórico, cit., p. 48.
} 
A magistratura assume papel de capital importância na afirmação da cidadania e da justiça substantiva. Reconhece-se, então, que se reclama da atividade jurisdicional neste momento sócio-político a escolha de valores e aplicação de modelos de justiça. Assim, o juiz não aparece mais como "o responsável pela tutela dos direitos e das situações subjetivas, mas também como um dos titulares da distribuição de recursos e da construção de equilíbrios entre interesses supra-individuais"73.

Lapidar e oportuna, neste passo, a crítica de Piero Calamandrei à postura puramente positivista e genuinamente dogmática no exercício da função judicante:

"reducir la función del juez a uma simple actividad de hacer silogismos significa empobrecerla, hacerla estéril, disecarla. La justicia es algo mejor: es la creación que emana de uma conciencia viva, sensible, vigilante, humana. Es precisamente este calor vital, este sentido de continua conquista, de vigilante responsabilidad que es necesario apreciar e incrementar en el juez"74.

Seguindo sua lição, o mesmo autor ressalta que o maior perigo que ameaça os juízes e o funcionalismo público em geral em uma democracia é o hábito, isto é, a indiferença burocrática e a irresponsabilidade anônima. Quando os homens deixam de ser pessoas vivas para se tornarem em números, cédulas, volumes, enfim, "expediente" sobre a mesa.

Esta novidade no exercício da função jurisdicional desperta a preocupação dos demais Poderes, que vêem parte de suas tradicionais atribuições sob encargo da função judicante, e daí vemos tendências ao controle externo da magistratura, recentemente plasmado no ordenamento jurídico brasileiro.

É esta igualmente a constatação de José Eduardo Faria. Em insistindo em enquadrar o Executivo, tentando obrigá-lo a oferecer serviços num contexto de crise fiscal, vê-se o Judiciário diante da inexorável acusação de invasão de áreas que não são de sua competência, inclusive ameaçado de retaliações. Aliás, propostas como a de controle externo da magistratura, imposição de súmula vinculante às instâncias inferiores e extinção das instâncias superiores da Justiça do Trabalho apenas emergiram quando setores da Magistratura (Associação Juízes pela Democracia e Movimento Direito Alternativo)

\footnotetext{
${ }^{73}$ CAMPILONGO, Celso Fernandes. Os desafios do Judiciário: um enquadramento teórico, cit., p. 49.

${ }^{74}$ CALAMANDREI, Piero. Proceso y democracia. Trad. espanhola Hector Fix Zamudio. Buenos Aires: Ediciones Jurídicas Europa-America, 1960. p. 80-81.
} 
passaram a pressionar a Administração Pública com o objetivo de criar condições para a implementação de direitos sociais ${ }^{75}$.

Não mais se concebe o Judiciário disposto a oferecer respostas caracterizadas apenas como compensações por transgressões e atos ocorridos no passado. Demandam-se "respostas prospectivas, flexíveis e abrangentes, com impacto não somente sobre as partes envolvidas, mas, igualmente, sobre terceiros não diretamente participantes do processo" ${ }^{\text {"76 }}$. A questão é como fazê-lo se o arcabouço do nosso sistema jurídico está envelhecido e superado, num contexto de magistrados formalistas e processuais, forjados com base em premissas incompatíveis com a atual realidade socioeconômica brasileira?

A sociedade dita "pós-industrial" é baseada na circulação de informação de forma mais intensa e sofisticada que já se viu, especialmente em razão do avanço da informática. Neste contexto não há mais lugar para grandes fórmulas legitimadoras, ou apoio em verdades fornecidas pela ciência para apresentar soluções prontas e acabadas aos impasses vividos $^{77}$.

Recusam-se, assim, fórmulas preestabelecidas em ideologias para dar solução aos problemas enfrentados, buscando-se soluções advindas no debate amplo, prestigiando-se a contribuição do maior número de posicionamentos possível, "de forma a possibilitar uma opção vinculante a todos os envolvidos no debate" ${ }^{\text {,78. }}$.

Ainda Willis Santiago Guerra Filho segue lembrando que o traço característico marcante do ordenamento jurídico de sociedades assim descritas situa-se na procedimentalização ${ }^{79}$, isto é, a ênfase no aspecto processual do direito. A chamada "fórmula processual" seria o meio mais democrático e compatível com a sociedade cujas características foram declinadas atrás, para dar solução a problemas justamente por ensejar o amplo envolvimento dos interessados, aos quais se abre a oportunidade de oferecer suas contribuições de modo irrestrito em debate dialético.

Superando-se o modelo do direito formal das normas gerais e abstratas, que foram eficazes na proteção às liberdades civis frente ao Estado, exige-se agora que a solução

\footnotetext{
${ }^{75}$ FARIA, José Eduardo. O Judiciário e seus dilemas, cit., p. 64-67.

${ }^{76}$ FARIA, José Eduardo. O Judiciário e seus dilemas, cit., p. 65.

${ }^{77}$ GUERRA FILHO, Willis Santiago. Judiciário e conflitos sociais (na perspectiva da pós-modernidade). Revista de Processo, Sao Paulo, v. 18, n. 70, p. 135, abr./jun. 1993.

${ }^{78}$ GUERRA FILHO, Willis Santiago. Judiciário e conflitos sociais (na perspectiva da pós-modernidade), cit., p. 138.

${ }^{79} \mathrm{~A}$ lição do autor está baseada na doutrina kelseneana e especialmente na famigerada legitimação pelo procedimento de Niklas Luhmann.
} 
brote da confluência das opiniões em um espaço público, com o convencimento dos interessados acerca do acerto ou desacerto dos rumos propostos por cada participante.

A tese, então, conclusivamente sustentada pelo autor citado é a de que neste contexto o Judiciário assume, na atualidade, a posição de maior destaque dentre os Poderes estatais na produção normativa ${ }^{80}$. Para atender a esta expectativa e conformar-se como este espaço público de debates exigido, o procedimento judicial como configurado em nosso ordenamento merece reforma em seus pilares, de modo a possibilitar a maior integração possível de pontos de vista, tornando-se o instrumento de participação política a permitir o exercício da cidadania ativa, participação pluralística, e que a decisão "se torne a um só tempo vinculante para casos futuros semelhantes, e passível de ser modificada, diante da experiência adquirida em sua aplicação" ${ }^{81}$.

Ainda em sua ensinança, Willis Santiago Guerra Filho propõe três posturas judiciais "modelo" para enfrentamento dos desafios postos linhas atrás. A primeira dita do “juiz tradicional”, aferrado às fórmulas clássicas de divisão dos Poderes estatais, aceitando em relação aos demais Poderes posição subalterna, desempenhando sua atividade cercado por uma mitologia, mitos como especialmente o da neutralidade e imparcialidade do Juiz, da apoliticidade da função jurisdicional, além de mitos relacionados ao ordenamento jurídico (sistematicidade, coerência, plenitude, unidade, exclusividade, etc.).

No extremo oposto está o juiz revolucionário, que crê na ruptura do ordenamento jurídico: “O problema com o ‘juiz revolucionário’, por seu turno, reside precisamente em seu ímpeto revolucionário, estimulado por sua crença em uma forma conscientemente articulada de mitologia, que é como proponho se conceba a ideologia" ${ }^{2}$.

A terceira via, defendida como a mais propícia, é a postura do "juiz tolerante", que embora consciente do papel que deve exercer, não propõe a ruptura, senão reformas internas ao sistema jurídico. Compreende então as profundas contradições que grassam na formulação e interpretação do Direito, propondo solução de compromisso para todos os opinantes, o que requer carga de esforço e estudo superiores. Também é capaz de rechaçar a posição de subalternidade em relação aos demais Poderes, reconhecendo que agora o Juiz não há de se limitar a ser apenas a boca da lei, mas sim a boca do Direito ${ }^{83}$.

\footnotetext{
${ }^{80}$ GUERRA FILHO, Willis Santiago. Judiciário e conflitos sociais (na perspectiva da pós-modernidade), cit., p. 141.

${ }^{81}$ GUERRA FILHO, Willis Santiago. Judiciário e conflitos sociais (na perspectiva da pós-modernidade), cit., p. 141.

${ }^{82}$ GUERRA FILHO, Willis Santiago. Judiciário e conflitos sociais (na perspectiva da pós-modernidade), cit., p. 136.

${ }^{83}$ GUERRA FILHO, Willis Santiago. Judiciário e conflitos sociais (na perspectiva da pós-modernidade), cit., p. 138.
} 
O incremento da complexidade da função jurisdicional denota-se pelo enfrentamento do conflito entre "expectativas e demandas fundadas em valores morais e critérios de legitimidade substantiva, por um lado, e os interesses individuais formalmente consagrados pelo Código Civil e pela própria Constituição de outro" ${ }^{\text {"84}}$; pelo enfrentamento de conflitos plurilaterais; conflitos que envolvem políticas públicas de responsabilidade do Executivo; como proceder quando os demais Poderes batem às partes do Judiciário, solicitando decisões que não foram capazes de tomar consensualmente? Indaga-se como se poderia proferir decisões unívocas e coerentes num sistema legal ilógico, fragmentário e inflacionado?

A falta de resposta a estas indagações dá a exata medida da crise do Judiciário. Os mecanismos processuais não permitem uma adequada filtragem e encaminhamento dos conflitos, que acabam chegando em estado bruto, com alta carga de explosividade e passionalidade à apreciação da Magistratura. E como não pode a corporação furtar-se a decidir, não tem outra saída que não exercer uma criatividade decisória que muitas vezes acaba transcendendo os limites da ordem legal. Há nesta criatividade dois problemas. O primeiro, pois acaba atribuindo ao Judiciário funções que não são meramente adjudicatórias, rompendo com a idéia de que o Judiciário é uma atividade reativa, neutra, técnica e programada. Em segundo lugar, "a instituição não dispõe de meios próprios para implementar sentenças que pressupõem decisões dos demais setores da administração pública" ${ }^{\natural 5}$.

O que é importante destacar é que o Estado pós-social "combina elementos de todas as formações anteriores" e nele o Judiciário assume a função de "garante de uma governabilidade ampliadora dos sujeitos e objetos de tutela jurídica" ${ }^{\text {" }}$.

Esta constatação encontra particular ressonância na realidade brasileira, que se diz perplexa com uma crise institucional advinda a partir de "um perfil inteiramente novo no quadro da independência dos Poderes, segundo um modelo que não encontra similar nos demais ordenamentos contemporâneos" $"$.

\footnotetext{
${ }^{84}$ FARIA, José Eduardo. O Judiciário e seus dilemas, cit., p. 66.

${ }^{85}$ FARIA, José Eduardo. O Judiciário e seus dilemas, cit., p. 66.

${ }^{86}$ CAMPILONGO, Celso Fernandes. Os desafios do Judiciário: um enquadramento teórico, cit., p. 51.

${ }^{87}$ GRINOVER, Ada Pellegrini. A crise do Poder Judiciário. Revista de Direito Público, São Paulo, v. 24, n. 98, p. 21, abr./jun. 1991. Neste artigo, a autora faz uma avaliação quadripartite da crise do Poder Judiciário: i) estrutural, caracterizada pelo tão falado inchaço, acarretador de ineficiência crônica, sobrecarga, morosidade, burocratização, etc., que reclamam medidas de política judiciária, seja na vertente jurisdicional, com a deformalização do processo, tratamento coletivo de litígios e reestruturação da organização judiciária, e na vertente extrajudicial, com a deformalização de controvérsias, isto é, prestígio
} 
Esta crise não será necessariamente esboçada negativamente, pois representa o desafio, um novo ponto de partida, para transformações institucionais prementes ${ }^{88}$. A Constituição forjou Poderes Executivo e Legislativo robustos, ambos legitimados pelo voto popular. Ao Executivo facultou-se legislar (ainda que excepcionalmente, como deveria ser), ao Legislativo, reforçou-se o poder de controle e fiscalização.

A questão que exsurge então é a de estabelecer um equilíbrio saudável entre os dois poderes hercúleos ${ }^{89}$, “a quem confiar o controle e a mediação política no embate entre os dois Poderes legitimados pelo voto popular?"90 A resposta que se encontra aponta diretamente para o novo Poder Judiciário, especialmente na figura da Corte Constitucional desenhada pela Lei Maior.

A conclusão de Ada Pellegrini Grinover acerca destes novos desafios é dúbia: de um lado ressalta que o Supremo Tribunal Federal tem assumido a contento esta nova postura de árbitro político, porém “o mesmo otimismo não se pode alimentar em outras

aos equivalentes jurisdicionais, meios alternativos de solução de litígios; ii) institucional, cujas linhas gerais foram referidos no texto, com a assunção pelo Judiciário dessa nova função de árbitro político; iii) crise de mentalidade, assim sintetizada: "O esquema burocrático e verticalizado da magistratura brasileira, a inexistência de controles externos, o próprio método de recrutamento dos juízes, a inocorrência, até pouco tempo atrás, de cursos de aperfeiçoamento e especialização para os membros do Judiciário, o distanciamento dos julgadores, que tem reflexos até mesmo na linguagem, tudo isso tem levado, no curso dos tempos, ao excessivo corporativismo dos juízes, encastelados em posições de gabinete que pouco ou nada têm a ver com a realidade de uma sociedade em transformação" (A crise do Poder Judiciário, cit., p. 22-23); iv) crise dos mecanismos de controle, ressaltando-se, aqui, a necessidade de que às formas de responsabilização tradicional dos juízes (nas esferas penal, administrativa ou civil), dever-se-ia preconizar novas formas de responsabilidade processual, relacionada aos poderes de direção do processo, e política, correspondente à atuação do juiz em relação à sociedade.

${ }^{88}$ Maria Tereza Aina Sadek resume as mudanças no país pós-Constituição de 1988 com a alusão à institucionalização democrática e no Estado de Direito. Porém estas mudanças não se resumiram ao "país legal" (para usarmos a expressão da autora). "O país real também é outro... Para um rápido retrato do país real, bastaria atentar para os seguintes aspectos: o crescimento demográfico e os movimentos migratórios; a aceleração no grau de concentração urbana; o aumento nas taxas de industrialização; a expansão do eleitorado; as modificações nas estruturas econômica e social; a abertura da economia; as transformações nos índices de qualidade de vida e nos indicadores de inclusão social, política e cultural" (Acesso à justiça: visão da sociedade. Justitia, São Paulo, n. 65, n. 198, p. 272, jun.).

${ }^{89}$ Cappelletti fala nos dois perigosos gigantes do moderno "Leviatã", o gigante legislador, "com competência sempre mais vasta, em outras épocas até ignoradas pela lei", e o gigante administrador, "com influência enormemente ampliada" naquilo que se convencionou chamar de "Estado Providência" (Constitucionalismo moderno e o papel do Poder Judiciário na sociedade contemporânea, cit., p. 113). Adiante, no mesmo texto retro citado, fala ainda do "colosso legislativo" e do "mastodonte da burocracia administrativa", que somente podem ser controlados por um terzo gigante, cujos poderes se estendam "além daqueles de mera decisão da controvérsia tradicional". O autor anota que a idéia de um recíproco controle e equilíbrio dos poderes ínsita ao constitucionalismo moderno é a resposta da sociedade à trágica experiência de se saber que o poder político incontrolado está destinado a corromper-se, tornando-se tirânico e abusivo. Situa Cappelletti a Constituição brasileira de 1988 na vanguarda desta grande tendência universal, com um elaborado sistema de controles jurisdicionais, em atenção a esta "nova separação dos poderes".

${ }^{90}$ GRINOVER, Ada Pellegrini. A crise do Poder Judiciário, cit., p. 22. 
questões políticas ... o Judiciário brasileiro não tem evidenciado a mesma sensibilidade"91. A autora fala especificamente da postura tímida em face dos novos instrumentos delineados na Constituição para tratamento de conflitos de massa (v.g. mandado de segurança coletivo e mandado de injunção).

O outro grande desafio deste chamado constitucionalismo moderno é solver o debate acerca da legitimidade democrática deste controle judiciário (ou, como o denominou a profa. Ada Pellegrini Grinover, esta "arbitragem política") seja sobre as leis (jurisdição constitucional) seja sobre a atuação dos demais braços estatais ${ }^{92}$.

\footnotetext{
${ }^{91}$ GRINOVER, Ada Pellegrini. A crise do Poder Judiciário, cit., p. 22.

${ }^{92}$ CAPPELlETTI, Mauro. Constitucionalismo moderno e o papel do Poder Judiciário na sociedade contemporânea, cit., p. 116.
} 


\section{ACESSO À JUSTIÇA: INTRODUÇÃO}

"Não há solução legitimadora para o sistema judicial fora da ampliação da base material de cognição das disputas", seja uma expansão ditada por novos paradigmas de direito, seja orientada para a expansão da estrutura organizacional, para processamento de forma diferenciada das demandas sociais, tanto em termos qualitativos como quantitativos $^{93}$.

Era absolutamente necessária a digressão feita no capítulo anterior, numa breve passagem dos contextos sócio-políticos e jurídicos em que a atividade jurisdicional desempenhou seu mister no evolver dos tempos. Da democracia liberal ao Estado póssocial a mudança dos paradigmas foi sensível, reclamando do cientista processual nova compreensão de seu objeto de estudos.

É inegável, portanto, que a mudança de expectativas com relação ao método estatal de solução de litígios (se é que podemos dizer ser esta ainda sua função primordial) deve ser vista tendo como pano de fundo todo o arcabouço mencionado nos itens anteriores. E é precisamente este contexto que dá à idéia de acesso à justiça inteiramente novo colorido, e é este o principal motivo de termos nos ocupado da evolução do papel da função jurisdicional.

De fato, pensarmos o acesso à justiça no âmbito dos postulados liberais individualistas seria prestigiar sua faceta garantista, especialmente a garantia do direito de ação, como acesso ao Judiciário para preservação das liberdades públicas.

Pensar o tema à luz da democracia social seria enxergar o acesso à jurisdição como a viabilização da prestação de um serviço público de caráter essencial, mais uma dentre as inúmeras prestações sociais que marcam esta configuração.

A análise da evolução do conceito teórico de acesso à justiça em confronto com as características do Estado Liberal e do Welfare State é ressaltada por Mauro Cappelletti e Bryant Garth em obra que se constitui leitura básica e obrigatória a respeito do tema ${ }^{94}$.

A formatação fundada no postulado do laissez-faire compreendia a justiça como qualquer outro bem, acessível aos que pudessem enfrentar seus custos. Cuidava-se, pois,

\footnotetext{
${ }^{93}$ RIBEIRO, Paulo de Tarso Ramos. Direito e processo: razão burocrática e acesso à justiça, cit., p. 128.

${ }^{94}$ CAPPELLETTI, Mauro; GARTH, Bryant. Acesso à justiça. Trad. port. de Northfleet, Ellen Gracie. Porto Alegre: Sérgio Antônio Fabris Editor, 2002.
} 
do acesso formal, porém não efetivo, ao que correspondia a concepção formal de igualdade. Os estudos eram dogmáticos e indiferentes às dificuldades reais de acesso efetivo à justiça.

À emersão dos direitos sociais e superação da concepção individualista, correspondeu a preocupação em assegurar-se ao indivíduo a real possibilidade de acercarse do Judiciário para garantia dos direitos que, à profusão, eram reconhecidos em momento de efervescência do estabelecimento de prestações positivas do Estado como objeto de direitos dos cidadãos.

"Não é surpreendente, portanto, que o direito ao acesso à justiça tenha
ganho particular atenção na medida em que as reformas do welfare state
têm procurado armar os indivíduos de novos direitos substantivos [...] De
fato, o direito ao acesso efetivo tem sido progressivamente reconhecido
como sendo de importância capital entre os novos direitos individuais e
sociais, uma vez que a titularidade de direitos é destituída de sentido, na
ausência de mecanismos para sua efetiva reivindicação" ${ }^{\text {. }}$.

Reconhecem os autores o acesso à justiça como o mais básico dos direitos humanos de um moderno sistema jurídico que tenha a pretensão de não apenas proclamar, mas de fato garanti-los. Isto é, só existe cidadania se houver a possibilidade de reivindicar direitos reconhecidos constitucionalmente, e o primeiro pressuposto para tanto é que esteja assegurado o "direito de reivindicar os direitos" 96.

Analisar a relevância do acesso à justiça no contexto que já traçamos, do Estado pós-social, marcado pela multipolaridade dos conflitos; fragmentação dos centros de decisão e de poder; desestruturação do direito; deslocamento do eixo decisório do Estado para a sociedade; incremento dos movimentos sociais e ascensão de novos atores, compreensão do Judiciário como órgão da sociedade civil; etc., é óbvio que reclama espírito aberto para alçar novos vôos; reler velhos conceitos e engendrar novas concepções.

Natural que passemos por notas das feições garantista e prestacional ${ }^{97}$ do exercício jurisdicional. Seria iníquo e incompleto falar em acesso à justiça e não abordar aspectos do

\footnotetext{
${ }^{95}$ CAPPELLETTI, Mauro; GARTH, Bryant. Acesso à justiça, cit., p. 12.

${ }^{96}$ CARVALHO, André de; RIBEIRO, Marcus Vinicius. Direitos humanos, inclusão jurídica e o papel da assistência jurídica no Brasil do século XXI, cit., p. 32.

97، A implementação do direito à assistência jurídica passa pela reflexão sobre a concretização dos direitos prestacionais, que exigem prestações positivas do Estado. A doutrina comumente denomina tais direitos de direitos humanos sociais, que engloba o conjunto de direitos destinados diretamente à promoção de condições materiais dignas do ser humano. Por isto são chamados de direitos prestacionais, ou seja, aqueles cujo conteúdo exige ações concretas (legislativas e administrativas) do Estado" (CARVALHO, André de; RIBEIRO, Marcus Vinicius. Direitos humanos, inclusão jurídica e o papel da assistência jurídica no Brasil do século XXI, cit., p. 39).
} 
direito de ação ou do princípio da inafastabilidade, ou mesmo sem recordar que a atividade jurisdicional é uma prestação de serviço de relevante cunho social, e até mesmo averiguar seu papel na implementação das políticas públicas típicas à realização dos direitos sociais. Tudo isto deve-se procurar fazer, mas trazendo realce ao quanto mencionado no parágrafo anterior.

A propósito convém ressaltar que em nosso sentir dois são os temas fundamentais da ciência processual na sociedade pós-social contemporânea: acesso à justiça e efetividade processual $^{98}$. Evidente que estão relacionados, entrelaçados por estreita relação de causa e efeito. Procuraremos passar em revista estes temas, ainda que de forma breve, para nos contermos aos objetivos do trabalho.

\section{Movimento de acesso à justiça}

Tratar do tema sem referir, ainda que brevemente, o movimento de acesso à justiça seria verdadeira incipiência, até porque grande parte das concepções atuais a respeito do assunto e os principais avanços legislativos são oriundos da renovação advinda a partir desta corrente de pensamento.

Segundo José Renato Nalini a principal faceta do reclamo de maior facilitação de ingresso no Judiciário concentra-se em seu aspecto cultural, no sentido de representar reação contra o dogmatismo jurídico, forma degenerativa do positivismo jurídico ${ }^{99}$. Na mesma senda, Kazuo Watanabe sentencia: “o problema do acesso à justiça traz à tona não apenas um programa de reforma como também um método de pensamento"100.

Identifica-se como positivismo a exagerada e irrealística simplificação do Direito, reduzindo o jus a lex, isto é, o Direito à norma. A decisão judicial neste quadrante não passaria de um cálculo dedutivo, um silogismo simplório que se recusa a avaliar o direito positivo com base em critérios de justiça, sociais, éticos, políticos e econômicos ${ }^{101}$.

\footnotetext{
${ }^{98}$ Reconhecendo que o enfoque moderno do acesso à justiça envolve a questão da efetividade, mais uma vez lembramos Mauro Cappelletti e Bryant Garth: "O enfoque sobre o acesso - o modo pelo qual os direitos se tornam efetivos - também caracteriza crescentemente o estudo do moderno processo civil ... O 'acesso' não é apenas um direito social fundamental, crescentemente reconhecido; ele é, também, necessariamente, o ponto central da moderna processualística" (Access to justice. Trad. port. de Ellen Gracie Northfleet. Acesso à justiça, cit., p. 12-13).

${ }^{99}$ NALINI, José Renato. O juiz e o acesso à justiça, cit., p. 19-20.

${ }^{100}$ WATANABE, Kazuo. Acesso à justiça e sociedade moderna, cit., p. 128-135.

101“ O movimento do acesso à justiça é uma solução de compromisso. O aspecto normativo do direito não é renegado, mas enfatizado como elemento de extrema importância. É condição necessária ao conhecimento do fenômeno jurídico, mas não suficiente à sua compreensão total. O direito é norma, todavia não se contém todo na positividade" (NALINI, José Renato. O juiz e o acesso à justiça, cit., p. 24).
} 
Reputa o autor em questão este aspecto cultural ${ }^{102}$ como o mais importante deste movimento de acesso à justiça, pois que implica entender que a sociedade já não é a mesma que àquela existente à época das codificações.

O movimento de acesso à justiça constitui uma mudança da perspectiva tradicional, que insistia em ver o Direito sob a ótica de seu produtor em relação ao produto, isto é, o legislador e a lei; a administração pública e o ato administrativo; o juiz e o provimento jurisdicional. O movimento de acesso à justiça inverte o papel de protagonista, que é deslocado ao consumidor do Direito e do serviço judiciário ${ }^{103}$, figura que é assim definida por Mauro Cappelletti:

"all'individuo, ai gruppi, allá società insomma, e cosi ai bisogni alle istanze alle aspirazioni di individui gruppi e società, e soprattutto ogli ostacoli di varia natura - economici, culturali, psicologici, ecc - che si frappongono il diritto come 'prodotto' e il cittafino che a tale 'prodotto' chiede di avere accesso" 104 .

O tema ainda perpassa pelo princípio da isonomia, na medida em que proporcionar o mais amplo e irrestrito acesso ao Judiciário, escancarando suas portas inclusive mediante a compensação de fatores que constituem óbices especialmente aos menos favorecidos, sem dúvida alguma representa prestígio à noção material deste princípio.

É óbvio ainda que não se concebe Direito que não esteja em referência a um corpo social, de modo que seria redundante dizer da relevância social do assunto tratado. Porém não se pode deixar de anotar a especial repercussão que a proliferação das vias de acesso ao Judiciário implica, notadamente porque a obstrução, na medida em que incrementa a insatisfação e descrédito do Judiciário, ainda contribui para o fenômeno da litigiosidade contida.

A repercussão concreta do movimento vê-se na pródiga previsão no direito positivo de dispositivos que permitem inferir sem a mínima sombra de dúvida a intenção de favorecer a todos o acesso à justiça.

\footnotetext{
${ }^{102}$ É reconhecer que reforma legislativa não é o único aspecto que, como num passe de mágica resolveria as agruras do Judiciário inacessível. $\mathrm{O}$ imobilismo e a estrutura mental marcada pelo excessivo conservadorismo, com apego irracional às fórmulas do passado, são também causas que devem ser consideradas se se pretende viabilizar efetivo acesso à justiça. Reclama-se além da estrutura material adequada, que o juiz seja mentalmente preparado para lidar com os novos reclamos, aos quais já temos à saciedade nos referido (cf. WATANABE, Kazuo. Da cognição no processo civil, cit., p. 24).

${ }^{103}$ CAPPELLETTI, Mauro. Dimensioni della giustizia nella società contemporanee. Bologna: Il Mulino, 1994. p. 100.

${ }^{104}$ CAPPELLETTI, Mauro. Dimensioni della giustizia nella società contemporanee, cit., p. 100.
} 
Inicia-se pela previsão no texto constitucional da dignidade da pessoa humana como fundamento da República Federativa do Brasil, e a construção de uma sociedade justa, livre e solidária como um dos objetivos fundamentais da República. É evidente que estas aspirações apenas são atingíveis mediante uma atuação efetiva e independente da função jurisdicional, e que sobretudo seja dotada de permeabilidade às demandas sociais.

Segue-se pela consagração do princípio da isonomia; o direito de petição aos Poderes Públicos em defesa de direitos (art. 5, XXXIV, “a”); princípio da inafastabilidade do controle jurisdicional (art. 5, $\mathrm{XXXV)}$; princípio do juiz natural (art. 5, LIII); contraditório e ampla defesa (art. $5^{\circ}, \mathrm{LV}$ ); garantia da prestação de assistência jurídica e integral aos hipossuficientes (art. $5^{\circ}, \mathrm{LXXIV}$ ), isto sem dizer na mais recente integração ao direito positivo do direito fundamental à "razoável duração do processo e os meios que garantam a celeridade de sua tramitação" (art. 5, LXXVIII), acrescido pela Emenda Constitucional $n^{\circ} 45 / 04$.

No contexto estadual, a Constituição Bandeirante previu que "A lei estabelecerá procedimentos judiciários abreviados e de custos reduzidos para as ações cujo objeto principal seja a salvaguarda dos direitos e liberdades fundamentais" (art. $2^{\circ}$ ).

À opção legislativa pela ampliação do acesso à justiça acorreu a repercussão social, com a inegável explosão de litigiosidade a que já nos referimos (é evidente que a intensificação do demandismo não é conseqüência exclusivamente da ampliação dos instrumentos previstos no direito positivo, mas de uma nova configuração do contexto sócio-político). A população, pois, apercebeu-se da oportunidade de renovação da cidadania e seu exercício ${ }^{105}$.

Ainda José Renato Nalini, após defender que os aspectos práticos da alteração de enfoque que estamos a tratar implicam reformas normativas, institucionais e processuais, passa a formular propostas quanto a esta última, cuja menção é oportuna: a) eliminação das custas; b) simplificação dos atos de comunicação; c) otimização dos instrumentos de informática; d) simplificação procedimental; e) especialização.

\footnotetext{
105“Não é necessário recorrer-se a interpretações sofisticadas para concluir que os responsáveis pela justiça institucionalizada têm compromisso consistente com a multiplicação de portas de acesso à proteção dos direitos lesados. E diante de textos de tamanha abrangência não se pode afirmar que a Constituição tenha deixado de fornecer ao juiz fundamentos positivos para tornar o acesso à justiça uma concreção, uma realidade fenomênica, não mera aspiração doutrinária... Depende, portanto, do juiz converter a opção fundamental vertida para o texto da Constituição em agregação sólida constatável ou em quimera estiolante de expressivos anseios sociais" (NALINI, José Renato. O juiz e o acesso à justiça, cit., p. 43 e 45).
} 
Sua conclusão é dramática: "enfrentar o desafio de ampliar o acesso à justiça é questão de sobrevivência do Judiciário" "106.

Segundo Mauro Cappelletti (cujos trabalhos a respeito do assunto são de conhecimento indispensável) esta renovação de pensamento constitui resposta às duas grandes degenerações da vida política e econômica da sociedade moderna: o capitalismo opressivo de um lado, e o "socialisme concentrationnaire" de outro ${ }^{107}$. É precisamente por isto que apontamos anteriormente que o acesso à justiça constitui, ao lado da efetividade da técnica processual, o grande tema da ciência processual na sociedade contemporânea e no contexto do Estado pós-social.

\section{Acesso à ordem jurídica justa}

É nesta expressão que Kazuo Watanabe resume o direito de acesso à justiça. De plano vê-se que a idéia suplanta a tradicional e formal garantia do direito de ação ou o princípio da inafastabilidade, e vai também além da mera prestação de um serviço público. Constitui prover ao maior número de indivíduos possível a viabilização mais eficiente (e aqui resvalamos na noção de tempo razoável e mínima qualidade aceitável) de acesso à justiça material.

Decompõe o autor que estamos estudando em quatro elementos o direito de acesso à ordem jurídica justa ${ }^{108}$ : a) direito à informação e perfeito conhecimento do direito substancial e à organização de pesquisa permanente a fim de que se afira constantemente a adequação da ordem jurídica à realidade sócio-econômica; b) direito de acesso à Justiça adequadamente organizada e formada por juízes inseridos na realidade social e comprometidos com o objetivo de realização da ordem jurídica justa; c) direito à preordenação dos instrumentos processuais capazes de promover a efetiva tutela dos direitos e d) direito à remoção de todos os obstáculos que se anteponham ao acesso efetivo à Justiça com tais características.

A largueza extrema de todos os itens mencionados reclamaria uma verdadeira biblioteca para que se pudesse tentar esgotá-los.

\footnotetext{
${ }^{106}$ NALINI, José Renato. O juiz e o acesso à justiça, cit., p. 166.

${ }^{107}$ CAPPELLETTI, Mauro. Dimensioni della giustizia nella società contemporanee, cit., p. 101.

${ }^{108}$ WATANABE, Kazuo. Acesso à justiça e sociedade moderna, cit., p. 135.
} 
Os fatores alinhados pelo autor como óbices ao amplo acesso à justiça poderiam ser classificados em exógenos e endógenos, e sua análise bem se comportaria num trabalho de cotejo com os elementos que compõe o acesso à ordem jurídica justa a que acabamos de nos referir.

Quando mencionamos fatores exógenos de óbice à Justiça estamos nos referindo àqueles que antecedem ao processo judicial, e lhe são externos, de natureza econômica (pobreza); social (falta de informação) e cultural (descrédito geral no sistema judiciário e inexistência de arraigada tradição na busca pela solução institucionalizada para o conflito). Fatores endógenos, de sua banda, são os ligados diretamente à técnica processual, entre eles, citam-se a estreiteza do conceito de legitimação para agir, especialmente no âmbito da tutela dos interesses metaindividuais; inexistência de procedimentos simples e céleres, aderentes ao direito material objeto do litígio e ainda a limitação das espécies de provimento jurisdicional.

A ampliação do acesso à Justiça tornou-se objeto de considerações de processualistas ao redor do mundo inteiro, o que originou o chamado movimento de acesso à justiça, que a doutrina costuma separar em três momentos: as três ondas renovatórias ${ }^{109}$. Primeiramente a assistência judiciária aos menos favorecidos, a seguir a representação jurídica para os interesses metaindividuais e se encerra com o chamado novo enfoque do acesso à Justiça ${ }^{110}$.

Esta última onda abarca as anteriores e envolve o conjunto geral de instituições e mecanismos, pessoas e procedimentos utilizados para processar e mesmo prevenir disputas. Reconhece-se ainda a grande influência da natureza do litígio na determinação dos novos mecanismos procedimentais, eis o processo se adaptando ao conflito. "Da

\footnotetext{
${ }^{109}$ André de Carvalho e Marcus Vinicius Ribeiro anotam que no Brasil estas três ondas renovatórias foram influenciadas pela transição política da década de oitenta. Inicialmente, no nascedouro da ditadura militar, a reação foi sobrelevar a fórmulas paraestatais de solução de conflitos, como reação ao cativeiro do sistema de justiça sob o regime militar, sendo característicos então os estudos acerca da produção normativa nãoestatal e do pluralismo jurídico. No agonizar da ditadura, o foco do acesso à justiça retorna à cena judicial, tendo como marco exemplificativo a edição da Lei $n^{\circ} 7.244 / 84$ (juizados de pequenas causas). Editada a Constituição de 1988 a dignidade da pessoa humana assume o papel do vértice axiológico de nossa ordem constitucional, e "retoma-se a juridificação das relações sociais, de modo a tornar o sistema de justiça um espaço a ser apropriado pela sociedade para a implementação de direitos previstos nas normas, mas negados na realidade cotidiana" (CARVALHO, André de; RIBEIRO, Marcus Vinicius. Direitos humanos, inclusão jurídica e o papel da assistência jurídica no Brasil do século XXI, cit., p. 55).

${ }^{110}$ BEDAQUE, José Roberto dos Santos. Direito e processo. 5. ed. São Paulo: Malheiros Ed., 2009. p. 64.
} 
necessidade de outorgar proteção específica a essas novas categorias de direitos advém a questão preliminar da adequação da tutela ao objeto da prestação jurisdicional" ${ }^{, 11}$.

É neste ponto, isto é, na necessidade de conformação do processo ao direito substancial à cuja tutela se presta, que se entrelaçam os dois temas que dissemos fundamentais na ciência processual de nosso tempo: acesso à justiça e efetividade da técnica processual, que será objeto do item subseqüente.

Antes, porém, de a ele passarmos, oportuno referir a sistematização dos obstáculos de acesso à justiça referida por Mauro Cappelleti e Bryant Garth na obra demasiadamente citada até aqui ${ }^{112}$. São apontados como principais obstáculos a serem vencidos as custas judiciais; as possibilidades das partes e os problemas especiais relativos aos interesses difusos.

No que respeita às custas judiciais, refere-se ao elevado custo especialmente dos honorários advocatícios, quer no sistema em que o ônus da sucumbência (incluído o reembolso da verba honorária paga ao patrono pelo vencedor) é carreado ao vencido, quer no sistema em que não há tal reembolso (sistema norte-americano); ainda causas de valor tão ínfimo, que a demanda torna-se uma futilidade, pois que o custo desta há de consumir a totalidade ou boa parte do eventual proveito da vitória. Ainda, e por fim, a demasiada delonga do processo que pressiona os economicamente mais fracos, quer a abandonar o processo, quer a aceitar acordos manifestamente desvantajosos. É o reconhecimento de que “a Justiça que não cumpre suas funções dentro de um 'prazo razoável' é, para muitas pessoas, uma Justiça inacessível"113.

Ao avaliar as possibilidades das partes, pensa-se em situações de vantagens estratégicas em que se encontram determinadas classes de litigantes. O primeiro fator, que já foi referido, diz respeito à posse de recursos financeiros, que possibilitam suportar as delongas do litígio e muitas vezes apresentar de forma mais eficiente seus argumentos. Aponta-se a seguir a capacidade de reconhecer um direito e propor uma ação ou sua defesa, o que se relaciona à falta de conhecimento jurídico básico que alija a maior parte da população do acesso à justiça. Aliás, mesmo aqueles que sabem como encontrar aconselhamento jurídico qualificado podem não o buscar devido à falta de disposição psicológica, como a desconfiança dos advogados, a opressão causada por procedimentos

\footnotetext{
${ }^{111}$ BEDAQUE, José Roberto dos Santos. Direito e processo, cit., p. 65.

${ }^{112}$ CAPPELLETTI, Mauro; GARTH, Bryant. Acesso à justiça, cit., p. 15-29.

${ }^{113}$ CAPPELLETTI, Mauro; GARTH, Bryant. Acesso à justiça, cit., p. 20-21.
} 
complicados, ambientes intimidadores pelo portentoso porte dos tribunais e figuras como magistrados e servidores. Por fim, apontam-se as vantagens que levam os litigantes habituais, que desenvolvem maior experiência que possibilita assumir posição de primazia sobre os litigantes eventuais.

Já no que respeita aos interesses difusos, o problema central é que "ou ninguém tem direito a corrigir a lesão a um interesse coletivo, ou o prêmio para qualquer indivíduo buscar essa correção é pequeno demais para induzi-lo a tentar uma ação"114. Ademais, como na ação individual o agente obterá o ressarcimento do dano causado a si, porém não daqueles efetivamente causados à comunidade, a demanda individual acaba sendo insuficiente para obter o cumprimento da lei.

A conclusão preliminar a que se chega é que os obstáculos criados por nosso sistema são mais pronunciados para as pequenas causas e para os autores individuais, notadamente pobres; de outro lado, há vantagens sobejas aos litigantes organizacionais. Torna-se, pois, difícil transformar os muitos novos direitos emergentes na sociedade de massa em posição de real vantagem concreta. Adiciona-se um fator complicador: os obstáculos são inter-relacionados, de modo que muitas vezes eliminar ou mitigar um, significa exacerbar o outro ${ }^{115}$.

\section{Efetividade processual ${ }^{116}$}

Afirmou-se já no item anterior o intenso liame entre as idéias de acesso à ordem jurídica justa e efetividade processual. Não é necessário acurado conhecimento do tema nem perspicácia incomum para concluir que acesso à ordem jurídica justa pressupõe técnica processual minimamente apta a satisfazer os escopos aos quais se propõe.

Por outras palavras, e clareando a questão: técnica processual ineficaz é obstáculo ao acesso à ordem jurídica justa. Não vai aí nenhuma novidade, eis que esta assertiva é da lavra de doutrina abalizada ${ }^{117}$.

\footnotetext{
${ }^{114}$ CAPPELLETTI, Mauro; GARTH, Bryant. Acesso à justiça, cit., p. 26.

${ }^{115}$ CAPPELLETTI, Mauro; GARTH, Bryant. Acesso à justiça, cit., p. 29.

${ }^{116}$ Cf. BEDAQUE, José Roberto dos Santos. Efetividade do processo e técnica processual. 2. ed. São Paulo: Malheiros Ed., 2007. 605 p. Ainda sempre citado no tema o artigo de BARBOSA MOREIRA, José Carlos. Notas sobre o problema da efetividade do processo. In: GRINOVER, Ada Pellegrini et. al. (Coords.). Estudos de direito processual em homenagem a José Frederico Marques no seu $70^{\circ}$ aniversário. São Paulo: Saraiva, 1982. p. 203-220.

${ }^{117}$ Segundo Kazuo Watanabe, os estudos acerca da efetividade desenvolvem-se em duas perspectivas. A primeira, de direito material, pela qual compreende-se o processo como bem aderente ao direito material,
} 
Para se configurar o processo como instrumento de efetivo acesso à justiça, não é suficiente assegurar o ingresso em juízo. A proteção judicial deve ser efetiva, em cumprimento à ordem constitucional. É disto que se fala com a alusão ao acesso à ordem jurídica justa mediante a tutela jurisdicional $^{118}$.

Entende-se, portanto, que acesso efetivo ao sistema judicial não significa necessariamente acesso à ordem jurídica justa, que somente um sistema eficiente proporciona. A principal missão do processualista é buscar alternativas que favoreçam a resolução dos conflitos de modo tempestivo e seguro, mediante tutelas aptas a afastar a crise de direito material. A técnica processual, portanto, há de ser vista como meios destinados a alcançar escopos, são instrumentos de trabalho, e não fim em si mesmos. Critica-se, por isto, o dogmatismo puro e exagerado, isto é, o formalismo indiferente aos reais problemas a serem resolvidos. "Por isso a idéia de devido processo legal deve ser fundida com a noção de fim - idéia teleológica"119_ ${ }^{120}$.

Oportuna ainda a menção à lição de Paulo de Tarso Ramos Ribeiro:

"O tema do acesso à justiça é, nesse sentido, o primus inter pares do debate acerca da efetividade do processo em prover de justiça a sociedade. A correlação estabelecida funda-se na concepção segundo a qual a efetividade do processo é condição para o acesso à justiça. Por ela habilita-se o processo ao desempenho de suas funções no plano político, jurídico e social. Há mesmo quem diga que o tema do acesso à justiça e, sob certo ângulo, o movimento que o sucedeu, constitui uma profunda alteração paradigmática na abordagem metodológica do processo, assim encarado não mais como apêndice procedimental do direito substantivo, mas como um instrumento de exercício direto da jurisdição pelo Estado"121.

de modo que a pretensão processual estaria perfeitamente ajustada à peculiaridade e à exigência da pretensão material. A outra perspectiva é a de direito processual, na qual as preocupações centram-se na previsão de novos tipos de provimento, procedimentos especiais, aceleração e simplificação do procedimento, facilitação da prova, enfim, viabilização do efetivo acesso à justiça por meio de mecanismos processuais catalisadores. Segundo compreende o ilustre professor, ambas as perspectivas devem fundir-se, tendo como ponto de confluência a pesquisa dos aspectos constitucionais do processo civil, especialmente do acesso à justiça, a seu ver ponto de partida para este empreendimento. "O texto constitucional, em sua essência, assegura 'uma tutela qualificada contra qualquer forma de denegação da justiça', abrangente tanto das situações processuais como das substanciais" (Da cognição no processo civil, cit., p. 18-21).

${ }^{118}$ BEDAQUE, José Roberto dos Santos. Direito e processo, cit., p. 57.

${ }^{119}$ BEDAQUE, José Roberto dos Santos. Direito e processo, cit., p. 58.

${ }^{120}$ “O direito de acesso à Justiça é, portanto, direito de acesso a uma Justiça adequadamente organizada e o acesso a ela deve ser assegurado pelos instrumentos processuais aptos à efetiva realização de direito" (WATANABE, Kazuo. Acesso à justiça e sociedade moderna, cit., p. 134).

${ }^{121}$ RIBEIRO, Paulo de Tarso Ramos. Direito e processo: razão burocrática e acesso à justiça, cit., p. 99. 
Compreende-se, pois, que o direito fundamental de acesso à ordem jurídica justa abarca como uma de suas emanações o direito a um processo efetivo, apto a cumprir os fins a que predeterminado. E é precisamente nestes fins que todo o arcabouço de considerações que fizemos à guisa de caracterizar, ainda que superficialmente, o papel do processo no Estado pós-social, dá ao tema conotação inteiramente diferente do que tradicionalmente posto em doutrina.

A efetividade não toca mais apenas a realização do direito material, a quem ligado o processo por nexo de instrumentalidade. É papel do processo viabilizar a participação do cidadão na vida política, é forma de influenciar os centros de poder e a tomada de decisões. À idéia que já mencionamos, de que a aplicação do direito constitui hoje mero resíduo da atividade judiciária, corresponde o reconhecimento de que realizar o direito material é apenas uma das facetas do processo, que constitui o meio pelo qual desempenha o juiz aquelas novas funções sobre as quais nos detivemos, é a forma pela qual habilitar-se-á o Judiciário à escolha de valores e aplicação de modelos de justiça, novos reclamos da sociedade complexa da contemporaneidade.

Efetividade da técnica processual é, a bem ver, pressuposto para o enfrentamento da conflituosidade multipolar, para cuja solução também se apresenta um sistema normativo organizado em rede e marcado pela normatividade oriunda de centros periféricos, instável e por vezes contraditória. O processo deve ser o instrumento por excelência pelo qual se opera a transferência do eixo decisório do Estado à sociedade civil, característica nuclear da sociedade contemporânea e do Estado pós-social, a que já aludimos.

\section{Questão econômica e acesso à justiça}

Falar de acesso à justiça sem principiar o estudo pela famigerada obra de Mauro Cappelletti e Bryant Garth seria atestar uma pesquisa incompleta. Referência no assunto, a obra dos autores em questão ressalta a correspondência entre a idéia de acesso formal à justiça e o ideal de igualdade formal, noção típica ao Estado Liberal burguês.

Deixados para trás os postulados liberais individualistas no estudo do Direito, e reconhecendo-se os direitos a uma atuação positiva do Estado na efetivação de direitos fundamentais, aquela noção de acesso à justiça também ganha contornos diferenciados. "Não é surpreendente, portanto, que o direito ao acesso efetivo à justiça tenha ganho 
particular atenção na medida em que as reformas do welfare state têm procurado armar os indivíduos de novos direitos substantivos"122.

Reconhecem os autores ora referidos o direito de efetivo acesso à justiça como o mais básico dos direitos fundamentais, pois dele depende a tutela de todos os demais direitos reconhecidos ao indivíduo. Deste modo, a idéia de acesso à justiça assume o papel de "ponto central da moderna processualística" e "seu estudo pressupõe um alargamento e aprofundamento dos objetivos e métodos da moderna ciência jurídica"123.

Parece uma obviedade dizer que a limitação econômica do cidadão constitui, sob a ótica do acesso à justiça, elemento estratificador, isto é, distingue no corpo social aqueles que terão e os que não poderão ter acesso a um processo justo e équo para a defesa de seus interesses.

Não é novidade nenhuma afirmar que, embora o Estado arque com boa parte dos custos gerados pelo sistema judicial (p.ex. salários e estrutura material), fato é que mesmo aquelas despesas deixadas a cargo da parte são fator de alijamento do processo. É comum serem apontados, neste ponto, dois focos: as custas judiciais e os honorários de $\operatorname{advogado}^{124}$.

A propósito, vale anotar a título informativo que a questão do fundamento para a condenação do vencido ao pagamento dos ônus sucumbenciais historicamente tem oscilado entre as conotações penalística e estritamente ressarcitória ${ }^{125}$. Embora as duas idéias sejam apresentadas como antagônicas, a observação percuciente demonstrará que nos pressupostos essenciais, as correntes muito se aproximam.

\footnotetext{
${ }^{122}$ CAPPELLETTI, Mauro; GARTH, Bryant. Acesso à justiça, cit., p. 11.

${ }^{123}$ CAPPELLETTI, Mauro; GARTH, Bryant. Acesso à justiça, cit., p. 13.

${ }^{124}$ Apontam estes elementos Mauro Cappelletti e Bryant Garth, autores que temos utilizado como viga mestra nesta abordagem inicial, além de outros. Ainda Cármen Lúcia Antunes Rocha: "Surge aqui, então, a questão relativa aos custos desta prestação jurisdicional e que têm peneirado, em muitos países e em muitos casos, os cidadãos capazes de exercer, integralmente, o seu direito à jurisdição, do qual dependem, como antes asseverado, todos os demais direitos... Dois pontos sobressaem nesta questão: o primeiro relativo aos custos judiciais e o segundo relativo ao patrocínio das causas e pagamento dos respectivos honorários dos patronos" (ROCHA, Cármen Lucia Antunes. Direito constitucional à jurisdição. In: TEIXEIRA, Sálvio de Figueiredo Teixeira (Coord). As garantias do cidadão na justiça. São Paulo: Saraiva, 1993. p.35).

Luiz Guilherme Marinoni também neste contexto, e reconhecendo implicitamente estes mesmos dois fatores como pontos nevrálgicos na questão, aponta: "vários procedimentos preocupam-se em dispensar o pagamento de custas processuais e dos ônus de sucumbência para estimular o acesso à justiça, como é o caso dos procedimentos relativos à ação popular e à ação destinada a tutelar direitos difusos, coletivos e individuais homogêneos, que configuram instrumentos por meio dos quais o cidadão ou mesmo a entidade que o representa (no caso das ações coletivas) participam da gestão do bem comum" (O custo e o tempo do processo civil brasileiro. Revista Forense, Rio de Janeiro, v. 100, n.375, p. 82, set./out. 2004).

${ }^{125}$ CORDOPATRI, Francesco. La responsabilità processuale: profili storico-dommatici. Roma, La Sapienza Editrice, 1991. 188 p.
} 
A concepção penalística da condenação sucumbencial arvora-se na necessidade de punição ao litigante temerário, tendo por cerne então a má-fé do sucumbente. Já a conotação ressarcitória anota a restauração da diminuição patrimonial sofrida pelo direito do vencedor.

Aponta-se que o problema com a corrente penalística é o fato de relacionar-se à situação do litigante ímprobo, e "sua evoluzione storica ha sempre rifiutato di essere collegata al mero esercizio del diritto di difesa" $" 126$, de modo que "non occorre un lungo discorso per escludere il profilo penalistico dell'attuale condanna alle spese" ${ }^{\text {"127. }}$.

Mesmo a concepção ressarcitória, contudo, não prescinde do pressuposto da culpa, ainda que leve, presumida em desfavor do litigante vencido. Reporta-se, igualmente, a uma concepção "sostanzialistica" do processo, e revela seu limite nos casos de sucumbência oriunda de decisões estritamente processuais ${ }^{128}$.

Outro ponto de contato entre as duas correntes é terem como norte a posição do vencido frente ao direito material ${ }^{129}$.

Diz-se ainda que a conotação ressarcitória da responsabilidade pela sucumbência induz a afirmação da existência de um direito acessório àquele principal, de natureza substancial e que é o debatido na causa, direito acessório este que teria como objeto o ressarcimento em questão. Este direito inclusive portaria uma "azione acessoria". Refere-se também como defeito de ambas as concepções (penalísitca e ressarcitória) o ter o processo em si, e por si só, como pressuposto de danos ${ }^{130}$.

\footnotetext{
${ }^{126}$ CORDOPATRI, Francesco. La responsabilità processuale: profili storico-dommatici, cit., p. 175.

${ }^{127}$ CORDOPATRI, Francesco. La responsabilità processuale: profili storico-dommatici, cit., p. 175.

${ }^{128}$ CORDOPATRI, Francesco. La responsabilità processuale: profili storico-dommatici, cit., p. 176.

${ }^{129} \mathrm{O}$ trecho ora transcito bem sintentiza as duas correntes referidas: "Il punctum dolens delle due teoriche è costituito - come ripetuto - dall'ipoteca sostanzialistica. Infatti, la prima contempla la condanna a guisa di punizione del solo litigante doloso, cioè di colui il quale si induce allá lite pur sapendo che il suo diritto sostanziale non esiste. Ma omette, però, di spiegare la condanna del soccombente mero, nonchè di coordinare la regola victus vicitori con l'esercizio del diritto di difesa del diritto sostanziale. La seconda, del pari, ricollega la condanna nelle spese al dolo o alla colpa, grave o lieve, del soccombente, e, anzi, giunge a identificare la colpa con la soccombenza, tout court" (CORDOPATRI, Francesco. La responsabilità processuale: profili storico-dommatici, cit., p. 177).

${ }^{130}$ CORDOPATRI, Francesco. La responsabilità processuale: profili storico-dommatici, cit., p. 178. Ainda sobre o problema do pressuposto comum a ambas as teorias vincado na violação de deveres/obrigações processuais, Cordopatri assim pontifica: "Intanto, non pare nè logicamente nè giuridicamente corretto inferire la (previa) sussitenza del dovere di agire sine culpa in giudizio dalla (sucessiva) declaratoria di soccombenza. Il tentativo di superare la rilevata impasse mediante il ricorso alla retroatività della 'dichiarazione' giudiziale del diritto o, addirittura, della cosa giudicata, lungi dal riuscire di uma qualche efficacia, testimonia un verso, gli inconvenienti che si parano davanti alla configurazione della responsabilità processuale con conotazioni penalistiche e a quella con conotazioni risarcitorie, e a fornire, dall'altro verso, la coerente soluzione del problema della operatività della compensazione, anche in ipotesi, diverse da quella della oggettiva dubbiezza della lite" (CORDOPATRI, Francesco. La responsabilità processuale: profili storico-dommatici, cit., p. 181-182).
} 
Segundo Cordopatri, outras idéias que buscaram identificar os fundamentos da obrigação de reembolso das despesas processuais não chegaram a resultados significativos, como é o caso das concepções de quase-contrato judicial; escopo da relação jurídica processual de reprimir a lide injusta, afetando o sucumbente por si (ou seja, pelo só fato de ser sucumbente); mera vontade da lei e ainda, razões de eqüidade ou de direito natural $^{131}$.

Uma terceira linha de pensamento merece, ao fim, menção, porque a que mais se achega à configuração atual da responsabilidade pelo reembolso processual. Cuida-se da responsabilidade baseada na sucumbência pura e simples. Basicamente argumenta-se que o direito é imutável no seu império, mesmo antes da declaração judicial, de modo que esta não pode redundar um desvalor deste mesmo direito, mas sim reconhecê-lo na sua exata e originária consistência. $\mathrm{O}$ direito deve ser reconhecido judicialmente como se o fosse no momento da demanda, ou seja, do surgimento da pretensão, de modo que "la condanna nelle spese deve, dunque, essere il complemento necessario della dichiarazione del diritto: tanto nella ipotesi di una sentenza di accoglimento quanto in quella di una sentenza di rigetto" 132

Retomando o estudo de Cappelletti e Garth, temos a comparação entre o que os autores em questão chamam de "sistema americano", que não obriga o vencido a reembolsar ao vencedor os honorários despendidos com seu advogado, e o usual sistema que impõe ao vencido os ônus sucumbenciais.

No primeiro sistema parece evidente que sequer a perspectiva de vitória implica a esperança de obviar os custos que para a parte representou o ingresso em juízo. Entretanto, aponta-se que a conseqüência para o vencido em países que adotam o princípio da sucumbência é aproximadamente duas vezes maior, já que ele pagará os custos de ambas as partes, concluindo-se que "pode-se indagar se a regra da sucumbência não erige barreiras de custo pelo menos tão substanciais, quanto as criadas pelo sistema americano" 133 .

\footnotetext{
${ }^{131}$ CORDOPATRI, Francesco. La responsabilità processuale: profili storico-dommatici, cit., p. 182-183.

${ }^{132}$ CORDOPATRI, Francesco. La responsabilità processuale: profili storico-dommatici, cit., 184. Afirma-se, contudo, que mesmo esta concepção não resta a salvo das críticas apresentadas ao fundamento ressarcitório. A conclusão do autor, entretanto, é que a responsabilidade por reembolso das despesas processuais deve pressupor a violação de deveres/obrigações processuais, seja ela pura e simples, dolosa ou culposa. Distingue, entretanto, entre a responsabilidade simples (sem culpa) da agravada, prevista para o caso de dolo ou culpa grave, de modo que ao fim, sua pesquisa termina sem prescindir da posição subjetiva processual e seu eventual exercício distorcido, a produzir responsabilidade.

${ }^{133}$ CAPPELLETTI, Mauro; GARTH, Bryant. Acesso à justiça, cit., p. 17-18.
} 
O termo comparativo entre os dois sistemas parece claro: o dito "americano" prefere o dispêndio certo ao risco do maior custo (que pode às vezes ser inestimável), isto é, a parte que intenta procurar o sistema judicial sabe já de antemão quanto gastará (ao menos com honorários de advogado), inexistindo risco de que este dispêndio aumente em caso de derrota (repita-se, estamos nos referindo à verba honorária. É óbvio que em termos gerais os gastos em caso de derrota serão maiores, p.ex., com uma condenação, o que não vem ao caso já que tratamos dos custos do processo, e não do impacto econômico decorrente da tutela em si). Já o sistema que adota a regra da atribuição do ônus sucumbencial ao vencido, ao passo que cria para a parte, na perspectiva de ser vencedora, a expectativa de ver-se ressarcida daquilo que despendeu, aumenta-lhe também o risco, na perspectiva de ver-se derrotada, de ter de arcar com maiores dispêndios que os gastos que já teve até então com a própria defesa de seu interesse, já que, como dito arcará também com os custos do adverso.

À vista destas considerações, de interesse situarmos o sistema brasileiro. Embora não seja este o tema central do estudo, algumas considerações parecem pertinentes. De antemão podemos apontar que nosso regime de distribuição dos ônus sucumbenciais pode ser tido como híbrido, isto é, a meio termo entre as possíveis formas retro descritas.

No que concerne às despesas processuais não parece haver, ao menos para o fim de nossas considerações, maiores dificuldades à luz da clara disposição dos arts. 19 e 20 do Código de Processo Civil. O primeiro estatui em seu "caput" que "cabe às partes prover as despesas dos atos que realizam ou requerem no processo, antecipando-lhes o pagamento desde o início até sentença final” (destaque meu).

A segunda regra supra citada prescreve em seu "caput": "A sentença condenará o vencido a pagar ao vencedor as despesas que antecipou e os honorários advocatícios" (destaques meus). Fizemos dois destaques na regra por meio de grifos, vejamos o primeiro.

O vencido deverá, além de arcar com as despesas encetadas para a defesa de seus próprios interesses no processo, reembolsar o vencedor dos gastos que este tiver antecipado (este adiantamento é feito por ocasião de cada ato, e no caso do autor, ainda inclui as despesas com atos determinados de ofício pelo juiz ou requeridos pelo Ministério Público). Por isto é que a doutrina brasileira fala em responsabilidades provisória e definitiva pelo custo do processo ${ }^{134}$. Aquela se refere ao simples adiantamento das

\footnotetext{
${ }^{134}$ DINAMARCO, Cândido Rangel. Instituições de direito processual civil, cit., v. 2, p. 655.
} 
despesas, e é provisória justamente porque dependerá do resultado final da lide; esta, a definitiva, decorre da final condenação.

Portanto, dois são os princípios que regem a sistemática brasileira de custas e despesas processuais, a saber, o da antecipação e o da responsabilidade objetiva do vencido $^{135}$.

Eis até aqui um sistema autenticamente sucumbencial: o vencido é duplamente "penalizado", conforme já expusemos.

Problema surge quando analisamos com algum vagar o regime jurídico da verba honorária, e aqui tem lugar o segundo grifo que fizemos anteriormente à regra do art.20, "caput", do Código de Processo Civil, e se refere precisamente ao emprego da conjunção aditiva "e", deixando claro que o legislador distingue os honorários de advogado das despesas antecipadas pelo vencedor, isto é, os honorários não se compreendem, ao menos à primeira vista do que se depreende da dicção legal, na idéia de reembolso.

Aliás, se os honorários fossem também integrados na idéia de reembolso consequiência lógica inarredável seria a de que deveriam pertencer à parte que os teria "adiantado" ao patrono, e agora lograria com o êxito na demanda, o ressarcimento. Ocorre que o famigerado art. 23 da Lei no 8.906/94 (Estatuto da Ordem dos Advogados do Brasil) prevê que os honorários incluídos na condenação, por arbitramento ou sucumbência, pertencem ao advogado, tendo este direito autônomo para executar a sentença nesta parte $^{136}$. Mais que isto, o art. $24, \S 3^{\circ}$ do mesmo diploma comina de nulidade qualquer disposição, cláusula, regulamento ou convenção individual ou coletiva que retire do advogado o direito ao recebimento dos honorários de sucumbência.

Embora na origem o instituto pudesse ter a finalidade de reembolso, o fato é que sua configuração atual não a denuncia. Honorários incluídos na condenação não se

\footnotetext{
${ }^{135}$ PRUDENTE, Antônio Souza. Custas processuais e acesso à justiça. Cadernos de Direito Constitucional e Ciência Política, São Paulo, v. 6, n. 22, p. 292, jan./mar. 1998.

${ }^{136}$ Entende a jurisprudência haver legitimidade concorrente entre o advogado e a parte para cobrança da verba honorária incluída na condenação. A título exemplificativo, cito: "Possui a parte legitimidade para promover, juntamente com a condenação principal, a execução relativa à verba de sucumbência, a despeito de constituir direito autônomo do advogado, a teor da norma inserta no art. 23 da Lei no 8.906/94 (Estatuto da Advocacia) ... Conferir ao patrono autonomia para executar a verba de sucumbência não implica conferir-lhe exclusividade na propositura da demanda, implicando tão-somente que o direito do patrono independe do direito do cliente" (STJ - REsp no 252.141/DF - Rel. Min. Vicente Leal - 6 ${ }^{\circ}$ Turma - j. 25.09.01).
} 
confundem, pois, com honorários contratados, nem ostentam atualmente a finalidade de ressarci-los à parte vencedora ${ }^{137}$.

Cândido Rangel Dinamarco, a cujas lições já temos recorrido, percebe esta distorção no regime sucumbencial:

"Embora a responsabilidade do vencido pelos honorários do advogado do vencedor esteja inserida no sistema como autêntico reembolso destinado a evitar desfalques no patrimônio daquele que tinha razão (Chiovenda), o Estatuto da Advocacia estabelece que eles pertencem ao advogado (art. 23) e confere a este legitimidade ad causam para promover a execução forçada..."

Justamente para amainar estas possíveis distorções, o ilustre doutrinador propõe as seguintes regras interpretativas para o já citado $\S 3^{\circ}$ do art. 24 da Lei $n^{\circ}$ 8.906/94: a) à falta de estipulação entre o advogado e cliente, os honorários fixados em sucumbência pertencem ao advogado (neste caso não haverá finalidade ressarcitória nenhuma). São nulas nos termos da regra retro citada as cláusulas que não assegurem ao advogado receber pelo menos o equivalente a que vier a ser condenado o vencido a título de honorários sucumbenciais, assim, seguem-se as seguintes proposições: b) se a parte tiver pago ao advogado mais do que o valor dos honorários de sucumbência (como honorários contratados, pro labore ou ad exitum), não será nula a disposição que os destinar à própria parte e não ao causídico; c) quando o valor pago pelo cliente for inferior aos honorários fixados em sucumbência, poderá pertencer ao advogado parte destes suficiente para, somado ao que já fora pago pelo constituinte, atingir o montante da condenação, remanescendo à parte o restante (que em verdade constitui precisamente o que esta já teria

\footnotetext{
137“No tocante aos honorários advocatícios, sequer se concebe como pudesse existir o ônus de adiantá-los. Só na sentença o vencido será condenado a pagá-los ao vencedor. Os honorários contratados, devidos e pagos ou não pagos ao próprio defensor, são objeto de uma pura relação contratual entre as partes e este, não interferindo no processo" (DINAMARCO, Cândido Rangel. Instituições de direito processual civil, cit., v. 2, p. 656).

José Roberto dos Santos Bedaque assim leciona: "Custas constituem espécie de despesa processual, gênero que abrange outras verbas. $\mathrm{O} \S 2^{\circ}$ contém rol exemplificativo de outros gastos gerados pelo processo... Não estão incluídos, todavia, os honorários advocatícios, tratados separadamente no caput do artigo. Por isso, ao relatar recurso de apelação, concluí que a autora da demanda não poderia ser responsável pelos honorários do curador especial nomeado para a defesa de réu citado por edital. Como essa verba não se confunde com despesas, somente ao final se a parte contrária vier a perder, poderá ser responsabilizada pelos ônus da sucumbência. Antes do término do processo impossível fixar verba honorária e muito menos determinar à autora o pagamento. Inaplicável o disposto no art. 19 e $\S 2^{\circ}$, do CPC, pois os honorários advocatícios não se confundem com despesas necessárias à prática de atos processuais. Pelos honorários responde o vencido, devendo a sentença fixá-los (CPC, art. 20)" (in BEDAQUE, José Roberto dos Santos. Arts. 20 e 125. In: MARCATO, Antônio Carlos (Org.). Código de Processo Civil interpretado. 3. ed. São Paulo: Atlas, 2008. p. 74).

${ }^{138}$ DINAMARCO, Cândido Rangel. Instituições de direito processual civil, cit., v. 2, p. 692.
} 
pago ao patrono) e d) se nenhuma remuneração o cliente pagar ao advogado, a integralidade dos honorários sucumbenciais pertencem ao patrono ${ }^{139}$.

No caso do item "b" supra, a parte será parcialmente ressarcida da verba paga ao patrono (não será ressarcida naquilo que o que ela pagou em virtude do contrato profissional, exceder o valor da condenação sucumbencial). No caso do item “c”, a parte será integralmente ressarcida (e ainda repassará ao advogado o saldo excedente entre a condenação sucumbencial e a verba contratada paga, visto ser aquela superior a esta, sob pena de enriquecer-se com o trabalho do advogado); por fim, no item "d", considerando que nenhuma remuneração foi paga pelo cliente, sendo apenas devida a verba sucumbencial, não há falar em ressarcimento.

Nos casos "b" e "c" supra referidos, em que efetivamente há possibilidade ressarcitória, pode-se até pensar que o pagamento dos honorários contratados pelo cliente constitui de certa forma antecipação de despesas com a causa.

A conclusão nos parece clara. O constituinte pode ter a perspicácia (o que não é comum) de fazer inserir no contrato com o advogado, cláusula prevendo possa ressarcir-se dos honorários contratados pagos ao patrono, mediante utilização dos honorários sucumbenciais, desde que respeitadas as proposições trazidas nos parágrafos anteriores.

De outro lado, não inserida disposição alguma neste sentido (o que é mais comum), os honorários sucumbenciais pertencerão integralmente ao advogado, além dos contratados com o cliente ${ }^{140}$. Sob a perspectiva deste, no caso, expectativa alguma haverá de ver-se reembolsado daquilo que despendeu com a contratação do patrono. O mesmo ocorrerá se, mesmo havendo a disposição contratual neste sentido, os honorários sucumbenciais forem inferiores aos pagos pelo cliente em razão da contratação, caso em que o constituinte será ressarcido em parte, e no que toca ao excedente, remanescerá desfalcado. Nestas situações nosso sistema avizinha-se do americano.

\footnotetext{
${ }^{139}$ DINAMARCO, Cândido Rangel. Instituições de direito processual civil, cit., v. 2, p. 693.

${ }^{140}$ Conclusão diametralmente oposta é a de Antônio Souza Prudente: "De concluir-se, pois, que o advogado não tem direito a haver, além dos honorários ajustados, também a verba fixada na sentença, se não houver previsão expressa no contrato de honorários, extra-autos" (Custas processuais e acesso à justiça, cit., p. 296). Em apoio à posição do autor retro citado, temos o seguinte julgado (que igualmente é por ele ressaltado): "PROCESSO CIVIL. HONORÁRIOS DA SUCUMBÊNCIA. INEXISTÊNCIA DE PACTO CONTRATUAL. DIREITO DA PARTE. EXEGESE DO ART. 99, $\S \quad 1^{\circ}$, DA LEI 4.215/63. PRECEDENTES. RECURSO DESPROVIDO. I - Na ausência de convenção em contrário, os honorários da sucumbência constituem direito da parte e se destinam a reparar ou minimizar seus prejuízos em função da causa ajuizada. II - Inexistindo avença, condiciona-se o direito autônomo do advogado, para postular executivamente em seu próprio nome os honorários da sucumbência, ao não recebimento de remuneração do seu constituinte" (STJ, REsp no 16.489/PR, Rel. Sálvio de Figueiredo Teixeira, j. 12.05.92).
} 
Antônio Souza Prudente insurge-se contra esta realidade, afiançando que não seria admissível que a parte vencedora sofra qualquer espécie de prejuízo. Defende, então, que na fase de instrução do processo de conhecimento as partes poderiam juntar aos autos seus contratos de honorários, e então o título executivo judicial advindo deveria impor ao vencido os ônus totais de sucumbência, o que inclui tanto a verba judicialmente arbitrada como a previamente contratada pelo vencedor. Argumenta que em caso de entendimento contrário, a parte vencedora nunca deixaria de sofrer gravames financeiros advindos do processo $^{141}$.

Admite-se a correção lógica do raciocínio que embasa a assertiva contida no anterior parágrafo. Entretanto, a posição em questão é um tanto temerária porque no caso, por exemplo, de sentença condenatória, os parâmetros são aqueles do $\S 3^{\circ}$ do art. 20 do Código de Processo Civil (percentuais sobre o valor da condenação). Ora, se os honorários contratados forem superiores ao montante em questão o vencido arcará com verba honorária sucumbencial superior ao patamar legal. Ademais, é incumbência judicial a fixação da verba honorária estabelecida no bojo do processo; substituí-la ou acrescê-la dos contratados seria fraudar esta atribuição do juiz (o que se admite apenas nas hipóteses expressamente previstas em lei, como ocorre no caso previsto pelo art. 62, II, “d”, da Lei no $8.245 / 91)$.

O problema mais evidente que surge, no que toca especificamente à perspectiva a partir da qual analisamos a questão, é que os custos com o recurso ao processo judicial muitas vezes podem exceder o montante da controvérsia ou consumir o conteúdo do pedido, a ponto, para usar a expressão de Cappelletti e Garth, de tornar a demanda uma futilidade.

Uma interessante solução é a que se verifica na Suécia, em que cerca de $85 \%$ da população tem seguros que cobrem os custos de sucumbência, de modo que o vencedor na

\footnotetext{
${ }^{141}$ PRUDENTE, Antônio Souza. Custas processuais e acesso à justiça, cit., p. 296. Recentemente o C. Superior Tribunal de Justiça adotou posicionamento semelhante no julgamento a seguir especificado: "CIVIL E PROCESSUAL CIVIL. VALORES DESPENDIDOS A TÍTULO DE HONORÁRIOS ADVOCATÍCIOS CONTRATUAIS. PERDAS E DANOS. PRINCÍPIO DA RESTITUIÇÃO INTEGRAL. 1. Aquele que deu causa ao processo deve restituir os valores despendidos pela outra parte com os honorários contratuais, que integram o valor devido a título de perdas e danos, nos termos dos arts. 389, 395 e 404 do CC/02. 2. Recurso especial a que se nega provimento" (STJ, REsp n. 1.134.725/MG, Rel Nancy Andrighi, j. 14/06/2011).
} 
demanda, mesmo que litigando contra um necessitado, pode recuperar seus custos se este é segurado $^{142}$.

Um problema, contudo, assola mesmo os sistemas que prestigiam a regra da sucumbência, em que existe a perspectiva de recomposição do investimento inicial necessário para o ajuizamento da ação, e este é precisamente o da duração do processo.

Embora esta questão não seja objeto de nosso estudo, vale, por ora, anotar que o foco se desloca aqui também para "aqueles que, embora não tenham tão parcos recursos que os faça 'pobres' no sentido dado à expressão pela lei para efeito de obtenção daquela isenção de custas judiciais, não dispõem de folgadas condições econômicas" ${ }^{\text {"143 }}$. A questão para esta camada de cidadãos não é propriamente reunir recursos para ingressar no sistema, mas sim saber quanto tempo suportarão sem a disponibilidade destes mesmos recursos (até o possível ressarcimento com a final vitória desejada). E mais, lidar com um risco, que para eles pode ser trágico, de derrota na demanda e perda completa daquele investimento $^{144}$.

\section{Carência econômica; falta de conhecimento dos direitos e acesso à justiça}

De um outro problema, contudo, queremos tratar nesta sede. Parece-nos bastante patente que a carência de recursos econômicos é normalmente associada ao baixo nível cultural e educacional. Em verdade, embora estejamos no campo sociológico e por ele não pretendamos nos arriscar, estas duas circunstâncias guardam recíproca relação de causa e efeito.

Ao menos em nível médio e fundamental (e em certa medida também no superior, tirante as universidades públicas) uma educação de qualidade depende da disponibilidade de larga capacidade econômica. E é justamente um bom nível cultural e educacional que ensejará maiores possibilidades de êxito profissional. A pouca qualificação manieta o cidadão na base do mercado profissional, quando não na informalidade.

\footnotetext{
${ }^{142}$ SILVA, Marco Antônio Marques da. A efetividade do acesso à justiça. Revista do Instituto dos Advogados de São Paulo, São Paulo, v. 9, n. 17, p. 134, jan./jun. 2006.

${ }^{143}$ ROCHA, Cármen Lucia Antunes. Direito constitucional à jurisdição, cit., p. 36.

${ }^{144}$ É comum que se assista o desenrolar de ações, como a de usucapião, em que a parte investe todos seus recursos à semelhança do que faria para a aquisição da "casa própria" por vias "financeiras", valendo-se de suas economias para arcar com custos, p.ex., de perícias que, a depender da situação (p.ex. necessidade de levantamentos topográficos) são caríssimas. Este "investimento" no sistema judicial é feito pela parte na esperança de que se cuide mesmo de uma forma de "aquisição" da "casa própria". A derrota numa demanda tal importará num grave prejuízo à parte.
} 
Por isto é que os bons estudos acerca do acesso à justiça tratam, ao lado da questão econômica, e interligado a ela, do problema da falta de aptidão para reconhecimento de um direito. A conexão entre os temas é evidente, desde que se observe que os ricos pagam para suprir sua ignorância jurídica ${ }^{145}$.

Carmem Lúcia Antunes Rocha, em estudo que já ressaltamos, defende que o direito à jurisdição se destaca em três fases: a) acesso ao poder estatal prestador da jurisdição; b) a eficiência e prontidão da resposta estatal à demanda de jurisdição; e c) a eficácia da decisão jurisdita. Pois bem, no item "a", a autora em questão faz depender o acesso à jurisdição de dois comportamentos prévios do Estado: declaração normativa expressa (ao menos nos países de tradição jurídica escrita) e dar-se a saber ao povo acerca de seus direitos fundamentais.

"Num país em que o povo não saiba dos direitos e o Poder Público não deseje este conhecimento, o direito nunca passará de mera possibilidade legal a serviço dos poderosos de ocasião" ${ }^{146}$. Aponta-se, aliás, que é justamente em razão do desconhecimento do direito que em muitos rincões, a demanda judicial é tida como um agravo a outrem, e não o regular exercício de um direito fundamental.

A mesma autora ainda defende ser esta uma das raízes do surgimento de uma “jurisdição paraestatal”, significando o retorno à fase da barbárie e da justiça pelas próprias mãos ${ }^{147}$, com graves conseqüências para a sobrevivência do Estado enquanto sociedade política.

Aliás, a incerteza quanto aos direitos é não apenas elemento alijador de acesso à justiça, como ensejador de um acesso despropositado ${ }^{148}$. De fato, a crença na existência de

\footnotetext{
${ }^{145 ،}$ “La realidade es, en efecto, que el rico puede, pagando a su proprio consultor legal, eliminar los efectos de esa ignorância, que en cambio paraliza el pobre em el ejercicio y en la tutela de sus derechos, cuando no lo coloca francamente a la merced de bajas especulaciones profesionales" (CAPPELLETTI, Mauro. La justicia de los pobres. Trad. esp. de Santiago Sentis Mellendo, Tomás A. Banzhaf. In: Proceso, ideologias, sociedad. Buenos Aires: EJEA, 1974. p. 142). Relacionando também a idéia de carência de recursos econômicos; baixo nível cultural e acesso à justiça, cf. MENGER, Anton. El derecho civil y los pobres. Trad. esp. Adolfo Posada, Granada: Editorial Comares, 1998. p. 136. Marco Antônio Marques da Silva vislumbra três ordens de obstáculos que devem ser superados para garantia do direito de acesso à justiça: o primeiro de ordem econômica, quando o cidadão deixa de exercer ou proteger um direito por não ter nenhum acesso ou um acesso mínimo à informação e à assistência jurídica adequada; o segundo de cunho organizacional e o terceiro afeto aos instrumentos técnicos jurídicos, de que se valem os operadores do direito para a efetivação da prestação jurisdicional (SILVA, Marco Antônio Marques da. A efetividade do acesso à justiça, cit., p. 128).

${ }^{146}$ ROCHA, Cármen Lucia Antunes. Direito constitucional à jurisdição, cit., p. 34.

${ }^{147}$ ROCHA, Cármen Lucia Antunes. Direito constitucional à jurisdição, cit., p. 35.

${ }^{148}$ MORELLO, Augusto Mario. El conocimento de los derechos como presupuesto de la participación (el derecho a la información y la realidad social). In: GRINOVER, Ada Pellegrini et al. (Coord.). Participação e processo. São Paulo: Ed. Revista dos Tribunais, 1988. p. 167.
} 
supostos direitos em casos em que inexistem, ou a falsa compreensão da situação jurídica, levam muitas vezes o cidadão às portas do Judiciário. A adequada orientação prévia neste caso atuaria como importante fator de prevenção de litígios inúteis.

Anton Menger aponta a gênese do que se está a afiançar no fato de que os financeiramente desafortunados dirigem sua conduta por um obscuro e ilusório sentido de Direito, estando sua vida jurídica, em verdade, a mercê do acaso ${ }^{149}$.

Paralelamente a este efeito, a carência de informação completa e veraz, conduz igualmente a uma percepção negativa sobre a Justiça, geralmente culpabilizada por todos os males relacionados ao sistema de justiça, figurando entre as instituições com menor índice de confiabilidade ${ }^{150}$

A conformação do devido processo legal e a plena igualdade jurídica dependem fundamentalmente não apenas de um ordenamento igualitário, mas notadamente de que as partes tenham acesso à informação plena sobre o conteúdo das normas que o compõem ${ }^{151}$.

A questão é assim posta por Augusto Mario Morello:

"De qué vale que los operadores jurídicos diversifiquem vocaciones e
estúdios cada vez más complejos em sus técnicas, y generen una
imparable inflación de normas, si, contrariamente, los destinatários
(consumidores) de todo ese arsenal jurídico y de lãs ulteriores tareas de
interpretación, se hallan, vivencialmente, en un vaciamiento o laguna
acerca de la existência, sentido y alcances de unos derechos que elos em
verdad no están en condiciones de alegar, ejercer ni menos tutelar?"

${ }^{149}$ MENGER, Anton. El derecho civil y los pobres, cit., p. 138.

${ }^{150}$ SADEK, Maria Tereza Aina. Acesso à justiça: visão da sociedade, cit., p. 274. Este é um dos elementos que a autora arrola como fator de exclusão da população do Poder Judiciário, os outros três são: i) extrema desigualdade social; ii) altos custos para obtenção de informação e deficiências na localização e existência de varas e iii) heterogeneidade acentuada entre as unidades federadas e regiões.

${ }^{151}$ LUCON, Paulo Henrique dos Santos. Garantia do tratamento paritário das partes. In: CRUZ E TUCCI, José Rogério et al. (Coord.). Garantias constitucionais do processo civil: homenagem aos 10 anos da Constituição Federal de 1988. São Paulo: Ed. Revista dos Tribunais, 1999. 262 p. No mesmo sentido, Kazuo Watanabe: "Ora, não se pode pretender a plenitude da igualdade jurídica, na experiência concreta, sem um ordenamento jurídico efetivamente igualitário e sem que os interessados tenham acesso à informação plena a respeito do conteúdo das normas jurídicas que o compõem... Esse desconhecimento, que é basicamente consequiência do desnivelamento cultural, produto da desigualdade sócio-econômicocultural, é agravado pela complexidade cada vez mais crescente das legislações... Assim, a efetiva igualdade supõe, antes de mais nada, um nivelamento cultural, através de informação e orientação, que permita o pleno conhecimento da existência de um direito" (Assistência judiciária como instrumento de acesso à ordem jurídica justa. Revista da Procuradoria Geral do Estado, São Paulo, n. 22, p. 87-89, jan./dez. 1984).

${ }^{152}$ MORELLO, Augusto Mario. El conocimento de los derechos como presupuesto de la participación (el derecho a la información y la realidad social), cit., p. 167. 
Segue o referido autor lembrando que a presunção de que o destinatário das normas está a par de seu conteúdo é um mal necessário ${ }^{153}$, porém, importa saber se o homem comum é capaz de compreender a razão destas normas.

Passa-se então à análise do direito à informação, não sob a perspectiva clássica de sua compreensão como liberdade de imprensa, mas em dois outros planos de análise. $\mathrm{O}$ primeiro é o reconhecimento de que tal direito compreende a faculdade conferida ao cidadão de exigir acesso em geral à informação que lhe permita situar-se a respeito de quais são seus direitos, bem como quais os direitos e obrigações dos outros com quem se relaciona numa situação particular.

Em verdade é o reconhecimento de que "el libre intercambio de ideas, concepciones y críticas no es bastante para alimentar el proceso democrático de toma de decisiones; ese intercambio y circulación debe ir acompañado de la información acerca de los hechos" $" 154$.

Ressalta-se a previsão no Pacto de São José da Costa Rica (Convenção Americana dos Direitos Humanos), do direito à informação, nos termos em que ora definido, conforme art. 13, item 1: "Toda pessoa tem o direito à liberdade de pensamento e de expressão. Esse direito inclui a liberdade de procurar, receber e difundir informações e idéias de qualquer natureza, sem considerações de fronteiras, verbalmente ou por escrito, ou em forma impressa ou artística, ou por qualquer meio de sua escolha" (destaque nosso).

Aliás, a questão assume especial relevo diante da possibilidade de internalização destas normas com estatura constitucional no direito pátrio, à vista do $\S 3^{\circ}$ do art. $5^{\circ}$ da Constituição da República, incluído pela EC n ${ }^{\circ} 45 / 04^{155}$.

\footnotetext{
${ }^{153}$ No ordenamento pátrio a presunção é plasmada no art. $3^{\circ}$ da Lei de Introdução ao Código Civil, e constitui pressuposto geral de eficácia do ordenamento. A seu respeito são impactantes as palavras de Anton Menger: "la presución de que todo ciudadano conoce todas las leyes es la más ridícula de las invenciones; y los perjuicios que el legislador ocasiona por la ignorância de las leyes, son una injusticia palmaria, injusticia además que, como fácilmente puede demonstrarse, hiere especialmente á las clases inferiores de la sociedad" (MENGER, Anton. El derecho civil y los pobres, cit., p. 138).

${ }^{154}$ MORELLO, Augusto Mario. El conocimento de los derechos como presupuesto de la participación (el derecho a la información y la realidad social), cit., p. 171.

${ }^{155}$ Parece, neste passo, sobejamente oportuno lembrar que analisando a questão da possibilidade de prisão civil do depositário infiel que, diga-se de passagem, consta expressamente do texto constitucional originário (art. $5^{\circ}$, LXVII), o Supremo Tribunal Federal entendeu que a norma constante da Convenção Americana dos Direitos do Homem que implicitamente veda a prisão civil em casos que tais (Decreto ${ }^{\circ}$ 678 de $6^{\circ}$ de novembro de 1992 , art. $7^{\circ}, \mathrm{n}^{\circ} 7$ ), goza hierarquia constitucional (este o entendimento manifestado pelo Min. Celso de Mello, Relator do $\mathrm{HC} \mathrm{n}^{\circ}$ 96.772/SP, julgado em 09.06.09). Há dentro da Corte uma corrente ligeiramente dissidente no que toca aos fundamentos, entendendo que a norma em comento não goza propriamente status constitucional por falta de observância do rito previsto pelo $\S 3^{\circ}$ do art. $5^{\circ}$ da Constituição da República. Entretanto ostenta natureza supralegal (cf. HC no 94.013SP,
} 
Sob outro plano, o direito à informação implica o dever de informação, cometido ao Estado ${ }^{156}$, que no contexto da República moderna, de bases democráticas, há de "abastecer en forma adecuada, permanente, puntual, según las diversificaciones socioeconômicas y culturales"157.

Segue-se lembrando que a ausência deste pressuposto acesso à informação implica numa redução notável e inconstitucional no papel de cidadão e membro ativo de uma sociedade pluralista e dinâmica. Este acesso constitui um prius sem o qual todos os demais direitos têm sua satisfação comprometida, sendo comum o sentimento de que vivemos em meio a um enxame de leis e regulamentos que poucos cumprem e poucos conhecem, e neste sentido, nossa sociedade política é uma sociedade de proclamação de direitos.

O mesmo autor conclui, após ressaltar a importância da efetivação do direito à informação no que concerne aos consumidores, que seria fundamental o incentivo à formação de programas de difusão e esclarecimento, tarefa esta que não deve ser cometida apenas ao Estado, mas também contar com o engajamento das associações de advogados. Apregoa ser esta uma tarefa cultural, de crescimento da liberdade e responsabilidade coletivas, do Estado e da sociedade ${ }^{158}$.

Seria já de grande monta a difusão de mensagens simples e eficazes, que transmitam de forma direta orientações para a solução dos pequenos problemas quotidianos, internalizando nos destinatários a idéia de que são portadores de faculdades e que portam o direito de serem assistidos.

No âmbito do direito brasileiro não se descurou do direito à informação especialmente na esfera das relações de consumo. O art. 6 , II, da Lei nº 8.078/90 (Código de Defesa do Consumidor) previu o direito básico do consumidor à "educação e divulgação sobre o consumo adequado dos produtos e serviços, asseguradas a liberdade de escolha e a igualdade nas contratações". O inciso seguinte também dispôs o direito à: “informação adequada e clara sobre os diferentes produtos e serviços, com especificação

Rel.Min.Carlos Britto, j. 10.02.09), visto que busca fundamento de validade no $\S 2^{\circ}$ do mesmo art. $5^{\circ}$. Isto é, uma figura intermediária entre as normas ordinárias e constitucionais. Ora, a tomar por base esta linha jurisprudencial, e querendo crer na coerência que deve prevalecer no sistema, não haveria razão para justificar diverso entendimento em se tratando da norma que prevê expressamente o direito à informação, que gozaria assim, quando nada, posição hierarquicamente superior às normas ordinárias no sistema pátrio.

${ }^{156}$ MORELLO, Augusto Mario. El conocimento de los derechos como presupuesto de la participación (el derecho a la información y la realidad social), cit., p. 174.

${ }^{157}$ MORELLO, Augusto Mario. El conocimento de los derechos como presupuesto de la participación (el derecho a la información y la realidad social), cit., p. 174.

${ }^{158}$ MORELLO, Augusto Mario. El conocimento de los derechos como presupuesto de la participación (el derecho a la información y la realidad social), cit., p. 179. 
correta de quantidade, características, composição, qualidade e preço, bem como sobre os riscos que apresentem". Ressalta-se ainda a proteção contra a publicidade enganosa e abusiva, que constituem distorções no atendimento daquele direito.

Mesmo a valorização do aspecto preventivo (cf. inciso VI do art. $6^{\circ}$ do CDC) constitui necessário apelo ao atendimento do direito à informação.

Apesar das pungentes declarações normativas acerca do assunto, a realidade segue a passos lentos. No Brasil os direitos individuais e especialmente o direito de acesso à justiça não foram incorporados na consciência do cidadão. Como razão desta realidade, aponta-se a falta de uma cultura de liberdade, existente em países como Estados Unidos e Inglaterra, em que a liberdade é o fundamento da própria nação. "Eles construíram sua identidade nacional de baixo para cima, enquanto que no Brasil, os direitos individuais foram 'concedidos' de cima para baixo, e neste mesmo sentido a nação nasceu e cresceu" $" 159$.

\section{Eliminação das custas: uma solução possível?}

É esta uma das mais correntes propostas quando se analisa a questão dos óbices econômicos de acesso à justiça. Afirma-se que "jurisdição paga é jurisdição aristocrática. A jurisdição é um direito-garantia fundamental e o pagamento de seu exercício nega o princípio democrático, que nele se deve conter, e que a isonomia lhe impõe"160.

Esta também a posição esposada por José Renato Nalini, que ressalta inclusive que mesmo com os auspícios da gratuidade, ainda há muita pobreza excluída, diante da inevitabilidade de algum dispêndio (p.ex. realização de perícias, obtenção de documentos, etc. $)^{161}$.

Tanto Cármen Lúcia Antunes Rocha como José Renato Nalini ressaltam que o montante arrecadado com o exercício da atividade jurisdicional é pífio em termos de

\footnotetext{
${ }^{159}$ SILVA, Marco Antônio Marques da. A efetividade do acesso à justiça, cit., p. 137.

${ }^{160}$ ROCHA, Cármen Lucia Antunes. Direito constitucional à jurisdição, cit., p. 35. Evandro Fernandes de Pontes observa, a respeito das taxas judiciárias, que são "o reflexo de um pensamento conservado em nosso meio jurídico: o de que o exercício jurisdicional é uma função essencial do Estado, mas que infelizmente não deve ser por ele arcado na sua integralidade, já que, politicamente, o exercício jurisdicional não seria uma prioridade política do Estado, e sim da sociedade civil" (PONTES, Evandro Fernandes de. A assistência judiciária na mira do modelo garantista do processo. In: GARCIA LA GUARDIA, Jorge Mario et. al. Acesso à justiça e cidadania. São Paulo: Konrad Adenauer, 2000. p. 67).

${ }^{161}$ NALINI, José Renato. O juiz e o acesso à justiça, cit., p. 61.
} 
receitas públicas, caracterizando-se o sistema judicial como autofágico, isto é, o montante arrecadado não seria suficiente sequer para sustento do próprio aparato.

À idéia de eliminação das custas contrapõe-se, geralmente, o famigerado argumento do estímulo ao demandismo. É mais ou menos neste sentido a ponderação de Cândido Rangel Dinamarco:

\begin{abstract}
"Em tempos passados já se pensou nessa total gratuidade mas prepondera universalmente a onerosidade do processo para as partes, porque a gratuidade generalizada seria incentivo à litigância irresponsável, a dano desse serviço que é a jurisdição. Os casos de gratuidade são excepcionais e específicos, estando tipificados em normas estritas" ${ }^{\text {"162 }}$.
\end{abstract}

A este argumento, Nalini responde: "Os homens não criarão conflitos pelo simples fato de que sua solução judicial será livre de custeio", e metaforicamente, arremata: "da mesma maneira como a imaginária isenção de pagamento por internação hospitalar não é, diretamente ao menos, causa de epidemia"163.

Embora discordando da exatidão da metáfora empregada, concordamos com o segundo autor ${ }^{164}$.

$\mathrm{O}$ argumento que negativamente avalia a questão, afirmando o estímulo ao demandismo em razão da isenção de custas parte de uma concepção que a nosso ver não se justifica. E esta é justamente a que contempla como desvalor o aumento do número de demandas. Esta idéia decorre da crença de que ao aumento do número de demandas atendidas pelo Judiciário corresponde necessariamente o aumento da quantidade de conflitos sociais existentes. Isto é: aumento da beligerância.

Não nos parece que isto seja exatamente assim. $\mathrm{O}$ aumento do número de demandas aforadas nada mais representa que simplesmente isto: aumento de demandas aforadas.

\footnotetext{
${ }^{162}$ DINAMARCO, Cândido Rangel. Instituições de direito processual civil, cit., v. 2, p. 651. Esta também a posição de José Carlos Barbosa Moreira, entendendo que "deban contribuir para costearlo los litigantes que disponen de recursos, aunque no se pueda dejar de tener em cuenta la conveniência de estabelecer limites razonables a las exigências de este gênero" (La igualdad de las partes en el proceso civil. Revista de Processo, São Paulo, v. 11, n. 44, p. 176, out./dez. 1986). No mesmo sentido afirma Marco Antonio Botto Muscari: "É possível afirmar que a demanda por serviços judiciários aumenta quando é menor o custo de processar e maior o benefício esperado" (Justiça no Brasil: barata para os litigantes de má-fé, mas não para os bons cidadãos. Revista de Processo, São Paulo, v. 35, n. 181, p. 311, mar. 2010). Quando refere à expectativa de maior benefício refere-se o autor, principalmente, às esperanças de "lucro fácil" com as famigeradas indenizações por danos morais.

${ }^{163}$ NALINI, José Renato. O juiz e o acesso à justiça, cit., p. 61.

${ }^{164}$ Parece-nos que a isenção do pagamento por internação embora não leve ao aumento na quantidade de doentes, leva (ou pode levar) ao aumento da quantidade de atendimentos (desde que o custo fosse um óbice) realizados, e é justamente do aumento de atendimentos que se fala quando se diz que a isenção de custas pode levar ao incremento na quantidade de demandas.
} 
Pensando hipoteticamente: num espaço amostral de um mil conflitos surgidos na sociedade, antes eram atendidos cem, hoje (com uma suposta isenção de custas) são atendidos quinhentos. Houve aumento do número de demandas, porém a conflituosidade no seio social (isto é, aqueles mil!) permanece intocada.

A verdade é que não há dados empíricos que possam amparar o argumento ora combatido.

E mais, indagamos: porque o aumento do número de demandas aforadas é necessariamente algo ruim e indesejável? Pode esta circunstância representar o aumento da confiança da sociedade no mecanismo de solução institucional, incremento do crédito da Justiça, o que é indiscutivelmente sadio num Estado que se quer democrático, notadamente em que a via judicial é uma das formas de participação do cidadão, de influência sobre os centros de poder.

Ao contrário, a redução na quantidade de demandas em trâmite é que pode ser um perigoso sinal de contenção de litigiosidade, erva daninha na já intrincada teia de pressões sociais.

A bem ver, a elevação na quantidade de processos é circunstância ruim quando vista exclusivamente a partir da ótica do prestador do tal serviço, engessado sob orçamentos mesquinhamente insuficientes, já operando muito aquém da capacidade de absorção dos conflitos apresentados e sem nenhuma perspectiva de proporcional incremento de sua capacidade produtiva.

Não nos parece que seja esta a ótica que deva prevalecer, mas sim a do consumidor da justiça. Que se escancarem os portões do Judiciário a todo cidadão que se sinta lesado, em grande ou em pequena monta! Se a litigância irresponsável é um mal necessário para que se agasalhem sob o sistema dezenas de milhares de outros pleitos legítimos, antes excluídos da órbita da solução estatal, arquemos com ela. Aliás, a bem da realidade, aventureiros há tanto nas camadas mais pobres como nas mais abastadas; e a imposição de custas não parece ser um elemento dissuasivo quando a realidade forense nos indica que atualmente os tais aventureiros no mais das vezes albergam sua vertigem sob o manto da gratuidade.

Obviamente que há conseqüências indesejáveis oriundas da eliminação completa de custas ou mesmo do incremento de concessão do benefício da gratuidade, já que tal situação implica o consumo de verbas públicas para custeio da demanda do necessitado, 
com sensível falta nos setores onde aquela verba seria, ordinariamente, aplicada ${ }^{165}$. Certo é, já se disse, que nosso sistema judiciário sob o prisma financeiro é autofágico (não aufere o suficiente para sustento próprio). Isto não quer dizer que as receitas públicas oriundas de sua atividade não tenham serventia e não causem desfalque acaso faltem. Mesmo insuficientes, fazem diferença num orçamento que conta centavos.

Veja-se o exemplo do Fundo de Assistência Judiciária, que no Estado de São Paulo recebe, entre outros, recursos oriundos dos emolumentos pagos a notários e registradores, dos quais é isento o beneficiário da gratuidade. Os recursos deste Fundo se prestam a custear o serviço de assistência judiciária, e são geridos atualmente pela Defensoria Pública do Estado ${ }^{166}$. Obviamente, então, que a concessão de isenções reflete diretamente no repasse de verbas que custeiam a assistência.

Ponderar estas conseqüências, entretanto, padece do vício já referido linhas atrás, qual seja, a de considerar a situação unicamente sob a perspectiva do prestador do serviço público jurisdicional. Ao privilegiarmos ponto de vista diferente (como já defendido, do consumidor do serviço) perdem força estas assertivas.

Aliás, chega-se a sugerir um maior rigorismo no crivo quanto ao deferimento dos benefícios isentivos da gratuidade não apenas como forma de impedir a sangria de recursos, mas também como uma das vias para solução do crônico problema da morosidade e da sobrecarga da Justiça ${ }^{167}$.

Propostas desta natureza devem ser avaliadas com o devido cuidado porque reduzir a demanda à custa de interpretações que afrontam vetores básicos de nosso sistema judicial, como é o acesso à justiça, parece temerário. Parece mesmo haver uma inversão de valores: pune-se mais uma vez o jurisdicionado carente em razão da falta de estrutura e adequado suprimento de recursos.

Não seria o caso, talvez, de ao invés de enrigecer na análise dos pressupostos necessários para a concessão de assistência, dotar o Judiciário de estrutura e recursos suficientes para atender à demanda? E mais, dotar a própria Defensoria Pública do aporte

\footnotetext{
${ }^{165}$ MUSCARI, Marco Aurélio Botto. Justiça no Brasil: barata para os litigantes de má-fé, mas não para os bons cidadãos, cit., p. 305.

${ }^{166}$ Cf. art. 236 da Lei Complementar Estadual n ${ }^{\circ}$ 988/2006 e art. 20, I, da Lei Estadual n ${ }^{\circ} 11.331 / 02$. V. ainda MUSCARI, Marco Aurélio Botto. Justiça no Brasil: barata para os litigantes de má-fé, mas não para os bons cidadãos, cit., p. 307.

${ }^{167}$ MUSCARI, Marco Aurélio Botto. Justiça no Brasil: barata para os litigantes de má-fé, mas não para os bons cidadãos, cit., p. 309.
} 
financeiro suficiente para o fiel e apropriado desempenho de sua missão constitucional é mais saudável do que reduzir-lhe a demanda.

Uma arguta e desapaixonada observação da realidade ainda implica a adição de mais um argumento. Mesmo com o atual quadro de barreiras econômicas impostas pelas despesas inerentes a um processo judicial, é comumente referido em doutrina e estudos estatísticos o constante aumento de demandas aforadas. Nota-se, entretanto, que esta alta carga de demandas não pode levar ao engano de pensar-se refletir um quadro de ampliação do acesso à justiça. Isto porque a grande maioria do volume de processos tem como autor o Poder Público e suas ramificações, bem como setores minoritários e privilegiados da população $^{168}$.

E estes usuários, sabe-se bem, procuram o Judiciário no mais das vezes para postergar obrigações, fazer rolagem de dívidas e impor moratórias a credores, e para eles tal procedimento escuso é economicamente proveitoso, o que implica não outra conclusão senão a de que "a Justiça estatal brasileira apresenta custos muito baixos ou insignificantes para o litigante de má-fé"169, ao mesmo tempo em que, para o cidadão comum, que procura a prestação jurisdicional com interesses legítimos, embora de parco valor econômico, ela se apresenta cara e inacessível, concluindo-se então por afirmar-se a justiça brasileira como elitista: "alguns poucos setores usam e abusam das facilidades de ingresso na Justiça estatal enquanto a maioria dos cidadãos vê-se distante ou ausente dos serviços judiciais"170.

A partir desta constatação, indaga-se então: será que de fato a ausência de custas é que fomentaria a litigância irresponsável? Ou será que esta já resta fomentada por um inadequado sistema de custas, que é barato para o litigante de má-fé, porém inacessível para a maioria da população de fato necessitada da prestação jurisdicional ? $^{171}$

É inclusive razoável afirmar que estreitar o caminho de acesso à justiça sob a ótica econômica provavelmente agravará unicamente a situação daquele que seja autenticamente carente, alargando o abismo que o separa das figuras referidas dois parágrafos atrás.

Ao Estado incumbe adequar-se a esta realidade.

\footnotetext{
${ }^{168}$ SADEK, Maria Tereza Aina. Acesso à justiça: visão da sociedade, cit., p. 273.

${ }^{169}$ SADEK, Maria Tereza Aina. Acesso à justiça: visão da sociedade, cit., p. 273-274.

${ }^{170}$ SADEK, Maria Tereza Aina. Acesso à justiça: visão da sociedade, cit., p. 274.

${ }^{171}$ As perguntas são retóricas.
} 


\section{IGUALDADE PERANTE A LEI; ISONOMIA MATERIAL E IGUALDADE PROCESSUAL}

Sem maiores dificuldades compreendemos que os enunciados que constituem o título do presente capítulo representam conceitos interligados. A rigor são facetas da mesma realidade. O segundo representa a mais exata compreensão do primeiro; e o terceiro a incidência dos dois primeiros especificamente no direito processual.

É óbvio que não se comportaria nos limites de nosso estudo aprofundamentos quanto aos limites, em geral, do princípio da isonomia, pois que a extensão de seus desdobramentos no fenômeno jurídico vai bem além do que uma única obra poderia conter, que dirá um capítulo. Em verdade traçaremos as linhas daquilo que interessa à ordem de considerações que pretendemos seguir, que se situa precisamente nos efeitos que a disparidade econômica das partes pode causar no fenômeno processual. É este precisamente o corte metodológico.

Algumas idéias de caráter geral são, entretanto, oportunas. Falamos precisamente do escólio de José Souto Maior Borges, que defende a possibilidade de falarmos em hierarquização substancial de princípios constitucionais, assumindo alguns posição de proeminência, indicando-se a isonomia como um destes princípios que constituem viga mestra de toda construção jurídica pátria ${ }^{172}$.

Segue o mesmo autor lecionando que o princípio da isonomia comporta tríplice perfil constitucional, compreendendo: a) igualdade perante a lei; b) igualdade na lei e c) vedação de distinções de qualquer natureza. Alcunha sua configuração na Lei Maior pátria de "estranha vocação constitucional" pois que é simultaneamente norma definidora de um direito; um princípio (mais eminente até do que outros princípios constitucionais) e garantia, no sentido de que "é ela ainda um instrumento constitucional de preservação de si própria", e resume: "a igualdade garante a igualdade"173.

\footnotetext{
${ }^{172}$ BORGES, José Souto Maior. Significação do princípio da isonomia na Constituição de 1988. Revista Trimestral de Direito Público, São Paulo, v. 15, p. 29-34, 1996. O referido autor aponta como fundamentos desta proeminência a insusceptibilidade de reforma e a própria localização topográfica da igualdade, concluindo que "de suas próprias dobras portanto, a CF já impõe ao exegeta o reconhecimento desse privilégio axiológico atribuído à isonomia" (Significação do princípio da isonomia na Constituição de 1988, cit., p. 30).

${ }^{173}$ BORGES, José Souto Maior. Significação do princípio da isonomia na Constituição de 1988, cit., p. 33.
} 
Explica-se então sua assertiva: se todos são iguais formalmente perante a lei, no sentido de que a lei a todos se aplica, porém o conteúdo desta mesma lei a todos aplicável não respeita a isonomia, teríamos a violação da igualdade material (pela aplicação a todos da lei injusta por desigualadora); de outra banda, a lei isonômica que a todos não se aplicasse, seria isonômica apenas em relação àqueles aos quais se aplica, isto é, iguais materialmente serão apenas os beneficiários da aplicação da lei, de modo que haveria violação à igualdade formal.

Conclui com as seguintes palavras:

"Torna-se manifesto por essa via que a $\mathrm{CF}$, no seu art. $5^{\circ}$, estrutura a isonomia de modo refinadamente complexo. Primeiro como um direito à reta aplicação da lei (princípio formal). Segundo, como um princípio cujo conteúdo (não a mera forma de sua aplicação portanto) é inegavelmente amplo e até inexceptuável, pela vedação de distinções de qualquer natureza (princípio material e pessoal). Terceiro porque ela regula também os meios assecuratórios desse direito (a lei e outros atos normativos, como as sentenças judiciais)" ${ }^{\text {"174 }}$.

Ao Judiciário cabe assegurar o primado da Constituição, de modo que não lhe é possível invocar eventual falta de lei expressa como justificativa para omitir-se frente a uma situação de flagrante desigualdade ${ }^{175}$.

Em subitem próprio teceremos algumas considerações justamente sobre a postura ativa exigível do juiz na condução do processo no sentido de restaurar a igualdade entre os litigantes, haja ou não lei passível de no caso promover tal correção.

A tão famigerada questão da isonomia material tem raiz no reconhecimento de que “o próprio enunciado do princípio - 'todos são iguais perante a lei' - nos dá conta de sua inconsistência, visto que a lei é uma abstração, ao passo que as relações sociais são reais" $" 176$.

\footnotetext{
${ }^{174}$ BORGES, José Souto Maior. Significação do princípio da isonomia na Constituição de 1988, cit., p. 33.

${ }^{175}$ BORGES, José Souto Maior. Significação do princípio da isonomia na Constituição de 1988, cit., p. 31.

${ }^{176} \mathrm{GRAU}$, Eros Roberto. O direito posto e o direito pressuposto. 7. ed. São Paulo: Malheiros Ed., 2008. p. 163. As considerações tecidas pelo autor são próprias ao tema que estudamos, visto que baseado na lição de Von Ihering, lembra que o comércio jurídico abstrai das pessoas, só conhece o dinheiro, o que faz deste o "verdadeiro apóstolo da igualdade. Os preconceitos sociais, todas as antíteses sociais, políticas, religiosas, nacionais, são impotentes contra ele". Garante-se a todo homem, "quem quer que ele seja, contanto que saiba pagar, a certeza de poder satisfazer as necessidades de sua existência" ( $O$ direito posto e o direito pressuposto, cit., p. 163). Nosso receio é justamente o de que o fenômeno processual adentre (se é que já não adentrou) esta perigosa e fria seara do comércio jurídico.
} 
Nesta sede tornou-se clássica na literatura jurídica brasileira a obra de Celso Antônio Bandeira de Mello que, embora assaz citada, não pode ser desconsiderada, pena de incompletude do trabalho, além da reconhecida riqueza de suas concepções ${ }^{177}$.

Sintetizaremos apenas alguns pontos, para também não desviarmos por demais do foco. Segundo o referido autor, o discrímen que conviva harmonicamente com o princípio da isonomia depende basicamente de quatro pressupostos: a) que a desequiparação não atinja de modo atual e absoluto um só indivíduo; b) que as situações ou pessoas desequiparadas possuam características, traços nelas residentes, diferençados; c) que haja, abstratamente, correlação lógica entre os fatores diferenciais existentes e a distinção de regime jurídico estabelecida e d) que o vínculo de correlação estabelecido no anterior item seja pertinente à luz dos valores constitucionalmente protegidos ${ }^{178}$. Óbvio é que cada um dos itens em questão é destrinchado pelo doutrinador, o que não se comporta nos propósitos de nosso estudo. Contudo, ressaltar dois destes requisitos nos interessa por razões ligadas ao tema ora em debate.

Ao tratar da necessidade de que a desequiparação tenha por fundamento elemento diferenciador residente na própria pessoa ou situação desigualada (alínea "b") menciona o autor como exemplo de situação em que isto não ocorre o fator "tempo".

Isto nos é particularmente importante pois que um dos focos de nosso estudo é a questão da duração razoável do processo. Normalmente os estudos relacionados à repercussão da condição econômica das partes no processo levam em conta o fator tempo combinado com o elemento carência material.

É afirmação corrente a de que a previsão e efetiva utilização pelo juiz das tutelas de urgência e mecanismos aceleratórios são formas de mais equânime repartição do ônus tempo.

Assevera Celso Antônio Bandeira de Mello, contudo, que “o fator 'tempo' não é jamais um critério diferencial, ainda que em primeiro relanço aparente possuir este caráter" ${ }^{\prime 19}$. À primeira vista esta afirmação poderia aparentar conflituosidade com a contida no parágrafo anterior, levando à indagação acerca da real compatibilidade entre a

\footnotetext{
${ }^{177}$ MELLO, Celso Antônio Bandeira. O conteúdo jurídico do princípio da igualdade. 3. ed. São Paulo: Malheiros Ed., 1997. 48 p.

${ }^{178}$ MELLO, Celso Antônio Bandeira. O conteúdo jurídico do princípio da igualdade, cit., p. 41.

${ }^{179}$ MELLO, Celso Antônio Bandeira. O conteúdo jurídico do princípio da igualdade, cit., p. 30.
} 
idéia nuclear de isonomia material e a previsão dos mecanismos processuais de melhor distribuição do ônus "tempo".

Esta conflituosidade é apenas aparente. O que se defende, em realidade, é que o tempo, por si só, é elemento neutro, e "aquilo que é, em absoluto rigor lógico, necessária e irrefragavelmente igual para todos, não pode ser tomado como fator de diferenciação" ${ }^{180}$. Em outras palavras, o tempo é rigorosamente igual para todos. O que varia é o efeito de seu transcurso, e aí o fator de discrímen não está no tempo em si, mas na situação particular da parte em relação ao fator tempo.

É por isto que é impossível demarcar um período em caráter genérico e abstrato como sendo suficiente para justificar uma tutela de urgência. A situação deverá sempre ser avaliada à luz das peculiaridades concretas ${ }^{181}$.

O que para nós interessa ressaltar é que em razão da carência de recursos econômicos, o decurso do tempo do processo pode acarretar defasagem na posição processual de uma das partes em relação ao adversário ${ }^{182}$.

Aí, precisamente neste caso, uma consciente e vigorosa aplicação de mecanismos aceleratórios e das tutelas de urgência teria o condão de restabelecer a isonomia material, ou ao menos mitigar a disparidade.

Uma questão que daí emerge, e que neste âmbito não ultrapassará os lindes da sugestão, visto que não é nosso tema central, seria pensar na situação de carência econômica da parte frente ao decurso de tempo naturalmente exigido pela marcha processual, como elemento necessariamente a ser considerado como integrante do tão falado periculum in mora, requisito genérico das tutelas urgência ${ }^{183}$, sintetizado na propalada fórmula do risco de dano irreparável ou de difícil reparação (conceito cuja exatidão não nos cumpre avaliar). Numa concepção mais arrojada, quiçá pensar em

\footnotetext{
${ }^{180}$ MELLO, Celso Antônio Bandeira. O conteúdo jurídico do princípio da igualdade, cit., p. 32.

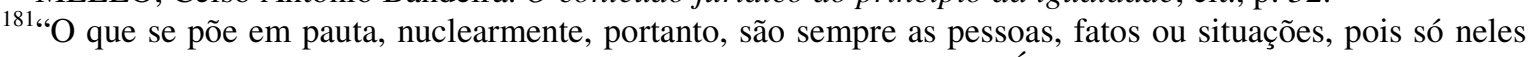
podem residir diferenças. Uma destas diferenças é a reiteração maior. É a sucessão mais dilatada ou menos dilatada; é, em suma, a variação da persistência. Esta variação demarca-se por um período, por uma data, mas o que está sendo objeto de demarcação não é, obviamente, nem o período em abstrato nem a data em abstrato, mas os próprios fatos ou situações contemplados ou demarcados" (MELLO, Celso Antônio Bandeira. O conteúdo jurídico do princípio da igualdade, cit., p. 33).

182،"la parte económicamente menos fuerte se halla en uma situación de menor resistência tanto frente a un proceso excesivamente largo, como frente a un proceso excesivamente costoso" (CAPPELLETTI, Mauro. El proceso como fenomeno social de masa. Trad. esp. de Santiago Sentis Mellendo, Tomás A. Banzhaf. In: Proceso, ideologias, sociedad. Buenos Aires: EJEA, 1974. p. 132).

${ }^{18}$ Óbvio que há previsão que situações em que a tônica é outra, e este requisito dispensado, como ocorre no caso da dita tutela antecipada sancionatória (CPC, art. 273, II). Aqui, contudo, falamos de forma superficial, do que se configura na generalidade dos casos.
} 
reconhecer, mesmo nos casos em que não se constate um anormal decurso de tempo no trâmite processual, na possibilidade de, fundando-se exclusivamente na necessidade de restabelecimento da igualdade material entre as partes, conceder àquela economicamente fragilizada, e por isto impedida de aguardar o tempo normal do trâmite processual, a tutela de urgência ${ }^{184}$.

Outra idéia que sobressai nas lições de Celso Antônio Bandeira de Mello a que temos nos referido, é a de que o vínculo demonstrável entre o traço fático distintivo e a diversidade de regime jurídico deve ser constitucionalmente pertinente. Isto é, não é qualquer distinção que autoriza discriminar, é mister que o discrímen retrate concretamente um bem, e não o desvalor, absorvido no sistema constitucional. Nada melhor que suas próprias palavras para resumir a idéia:

"a lei não pode atribuir efeitos valorativos, ou depreciativos, a critério
especificador, em desconformidade ou contradição com os valores
transfundidos no sistema constitucional ou nos padrões éticos-sociais
acolhidos neste ordenamento"185.

Pensamos não haver dúvida de que tanto a igualdade em sentido material como o acesso à justiça são valores constitucionalmente exaltados. Este último não apenas no sentido formal, limitado à fórmula simplista do princípio da inafastabilidade ou resumido à garantia do direito de ação (CR, art. $\left.5^{\circ}, \mathrm{XXXV}\right)$, mas sim em sentido substancial, como acesso à ordem jurídica justa, mediante a remoção de todos os óbices possíveis de modo a possibilitar um igualitário recurso ao mecanismo institucional para solução de litígios mediante o exercício da jurisdição.

Legitimam-se assim, sob a ótica da idéia de isonomia material, medidas legislativas, políticas públicas e posturas judiciais que, desigualando, igualem. Entenda-se: concorram para um mais equânime e amplo acesso à Justiça.

\footnotetext{
${ }^{184}$ Contrariamente a esta idéia, Elio Fazzalari obtempera que as medidas cautelares ou antecipatórias do provimento de mérito não podem ser dirigidas à tutela da parte mais carente pelo só fato da carência, somente sendo pertinentes quando lograr a parte em questão preencher o pressuposto substancial necessário à medida (La imparzialità del giudice. Rivista di Diritto Processuale, Milano, n. 2, p. 203, 1972). Uma verdade apresentada pelo autor merece transcrição: "la verità è che tutti son deboli in um Stato che non ha somma cura per l'amministrazione della giustizia" (La imparzialità del giudice, cit., p. 203).

${ }^{185}$ MELLO, Celso Antônio Bandeira. O conteúdo jurídico do princípio da igualdade, cit., p. 42.
} 


\section{Igualdade processual e a condição econômica das partes}

Evidente que o princípio da igualdade processual constitui derivação da matriz contida em nível constitucional, a que já nos referimos no item anterior, de modo que todas as considerações que foram feitas se aplicam perfeitamente à seara processual. Notadamente, transpõe-se ao nível processual também a contraposição dos sentidos material e formal da idéia de isonomia.

Por ser tema basilar da ciência processual, o assunto é tratado largamente na doutrina especializada, de modo que seria impossível e até improdutivo aqui reproduzir compilações intermináveis das obras que o mencionam. Abordaremos, por isto, algumas prestigiosas lições, naquilo que seja de mais interesse para o enfoque que pretendemos dar.

Por mais que se proliferem as definições acerca do assunto, há um sentido genérico, lugar comum, de que, se a isonomia na seara Constitucional representa a igualdade perante a lei e igualdade na lei, nos quadrantes da ciência processual representa o paritário tratamento perante o juiz e no processo. Embora desnecessário, há dispositivo no Código de Processo Civil que garante o princípio: art. $125, \mathrm{I}^{186}$.

É curial para considerações que advirão, observar que a imparcialidade do juiz se manifesta fundamentalmente pela garantia de igualdade entre autor e réu no processo, lembrando-se ainda que o contraditório deita raízes no princípio da igualdade, sendo sua expressão no mecanismo dialético do processo ${ }^{187}$.

\footnotetext{
186،Relativamente ao processo civil, verificamos que o princípio da igualdade significa que os litigantes devem receber do juiz tratamento idêntico. Assim, a norma do CPC 125 I teve recepção integral em face do novo texto constitucional. Dar tratamento isonômico às partes significa tratar igualmente os iguais e desigualmente os desiguais, na exata medida de suas desigualdades" (NERY JUNIOR, Nelson. Princípios do processo na Constituição Federal. 9. ed. São Paulo: Ed. Revista dos Tribunais, 2009. p. 97).

${ }^{187}$ COSTA MACHADO, Antonio Cláudio. Código de Processo Civil interpretado. 7. ed. São Paulo: Manole, 2008. p. 122. Ainda no mesmo sentido a lição de José Roberto dos Santos Bedaque: "O princípio constitucional da igualdade reflete-se no contraditório instaurado perante o juiz. A dialética processual implica assegurar às partes, com a maior amplitude possível, a participação em todas as fases do processo, a fim de que sua atividade possa influir na formação do convencimento do julgador. Daí os princípios da ampla defesa e do contraditório, inerentes ao devido processo legal ... Para que se cumpram tais postulados, é imprescindível que ambos os sujeitos parciais tenham assegurada absoluta igualdade de tratamento, não apenas formal, mas também real, competindo ao juiz zelar para que tal ocorra" (in BEDAQUE, José Roberto dos Santos. In: MARCATO, Antônio Carlos (Org.). Código de Processo Civil interpretado, cit., p. 368).
} 
Cintra, Grinover e Dinamarco ressaltam que "a absoluta igualdade jurídica não pode, contudo, eliminar a desigualdade econômica; por isso, do primitivo conceito de igualdade, formal e negativa ... clamou-se pela passagem à igualdade substancial" ${ }^{\prime 88}$.

Geralmente sob os auspícios deste contexto é que são tratadas as ditas prerrogativas processuais, circunstâncias legalmente previstas em que há diferenciação de tratamento das partes processuais justamente sob a justificativa de assim procurar-se reequilibrar uma situação de originário desequilíbrio. É o que ocorre, p.ex., com a atribuição de prazo em quádruplo para a Fazenda Pública contestar e em dobro para recorrer (benefício extensivo ao Ministério Público, cf. art. 188 do Código de Processo Civil).

Há diversos outros regramentos neste sentido, e em torno deles há plêiade imensa de questões controvertidas e debates que não nos convém nesta seara tratar, visto que nosso foco limita-se à disparidade econômica das partes.

O que convém seja demarcado é que no processo civil, também têm vazão formas de compensações jurídicas em favor daqueles que merecem proteção especial ${ }^{189}$.

Em artigo dedicado ao tema ora em estudo, Barbosa Moreira decompõe o princípio da igualdade em algumas facetas relacionadas especificamente ao processo civil ${ }^{190}$. Primeiramente, lembrando que a ambos os litigantes deve ser proporcionado nutrir esperanças pela vitória e mais, nutrir esperanças por obter a vantagem prática da vitória decorrente, identifica que no processo deve preponderar a igualdade de riscos.

Um dos corolários, ainda segundo o autor, desta faceta é a forma de distribuição do ônus da prova, já que seria iníquo que em qualquer hipótese, apenas ao demandante ou ao demandado incumbisse sempre suportar os riscos do eventual fracasso da atividade probatória.

Há, é certo, exceções com as hipóteses de inversão do tal ônus, que inclusive pode ser legal, derivadas em alguns casos de presunções juris tantum, as quais "frecuentemente

\footnotetext{
${ }^{188}$ ARAÚJO CINTRA, Antonio Carlos de; GRINOVER, Ada Pellegrini; DINAMARCO, Cândido Rangel. Teoria geral do processo, cit., p. 54. Prossegue-se a lição nestes termos: "E hoje, na conceituação positiva da isonomia (iguais oportunidades para todos, a serem propiciadas pelo Estado), realça-se o conceito realista, que pugna pela igualdade proporcional, a qual significa, em síntese, tratamento igual aos substancialmente iguais ... A aparente quebra do princípio da isonomia, dentro e fora do processo, obedece exatamente ao princípio da igualdade real e proporcional, que impõe tratamento desigual aos desiguais, justamente para que, supridas as diferenças, se atinja a igualdade substancial" (Teoria geral do processo, cit., p. 54).

${ }^{189}$ GRECO FILHO, Vicente. Direito processual civil brasileiro. 15. ed. São Paulo: Saraiva, 2000. p. 63.

${ }^{190}$ BARBOSA MOREIRA, José Carlos. La igualdad de las partes en el processo civil, cit., p. 176-185.
} 
se inspiram en consideraciones de equidad, y así en definitiva tienden a hacer prevalecer la igualdad material sobre la igualdad formal"191.

Ainda, seguindo Barbosa Moreira, a isonomia processual significa igualdade de oportunidades, isto é, às partes há de se garantir o poder de influir igualmente na marcha processual e no resultado da causa, isto é, as mesmas possibilidades de atuar e as mesmas limitações. É óbvio que algumas diferenças derivam naturalmente da diferença de pólos em que se situam autor e réu, de modo que seja, por exemplo, usual que o encargo de impulsionar o andamento do processo seja mais marcante ao autor ${ }^{192}$.

A igualdade de oportunidades mantém relação de complementaridade com a garantia do contraditório estabelecido entre as partes ${ }^{193}$.

Outrossim aos litigantes é garantida a igualdade de tratamento pelo órgão judicial o que exige, antes de tudo, que a conformação do procedimento não fique sujeita ao arbítrio do magistrado, mas se ajuste ao modelo previamente estabelecido pela lei para os processos em geral.

Parece ser fora de dúvida que o fator econômico, conforme já vimos defendendo, reflete indiscutivelmente sobre a relação jurídica processual como elemento de desestabilização das partes. A rigor tal fator implica efeitos daninhos tanto no que concerne ao acesso à Justiça (e aqui utilizamos a letra maiúscula propositalmente, porque nos referimos ao simples ingresso em juízo), como no que respeita ao acesso à justiça (e aqui o minúsculo é indicativo do acesso à ordem jurídica justa, que compreende o desempenho dos ônus processuais necessários para levar a uma perspectiva de vitória) ${ }^{194}$.

Sobreleva notar que a sorte do processo não deve depender de fatores extrajurídicos, isto é, o processo não se faz para premiar o litigante mais rico ou mais instruído, ou aquele que tenha condições de contratar o melhor advogado, mas sim ao que tenha o

\footnotetext{
${ }^{191}$ BARBOSA MOREIRA, José Carlos. La igualdad de las partes en el processo civil, cit., p. 177.

${ }^{192} \mathrm{O}$ que justifica no ordenamento brasileiro, por exemplo, o regramento do art. 267, III, do Código de Processo Civil.

${ }^{193}$ LUCON, Paulo Henrique dos Santos. Garantia do tratamento paritário das partes, cit., 262 p.

194،"El factor mas frecuente (y quizás el más grave) de disparidad, entre las partes es, sin dudas, el econômico. Cuando no le quita simplesmente a uno la disposición para iniciar un proceso, por el temor de los gastos, la carência de médios significa formidable inferioridad frente a un adversário más acaudalado, en muchíssimas situaciones: piensése, por ejemplo, en la contratación de un abogado, en la necessidad de recurrir a los servicios de un detective particular o a otras fuentes de información para obtener pruebas, en la reprodución de documentos, en las diligencias para contactar testigos residentes en lugar ignorado o de difícil aceso ... La duración - casi siempre demasiado larga - del proceso, ya constituye, de por si, una gravísima desventaja para el litigante más pobre, y no pocas veces lo induce a un acuerdo que, normalmente, él no se inclinaria a aceptar" (BARBOSA MOREIRA, José Carlos. La igualdad de las partes en el processo civil, cit., p. 179).
} 
direito invocado ${ }^{195}$. Ou seja, o processo não deve ser encarado como um jogo, em que o mais capaz se sagre vencedor, mas um instrumento de justiça, em que prevaleça o titular do direito debatido ${ }^{196}$.

Há quem debite esta defasagem na perseguição dos direitos de que padece o desvalido financeiramente à parcialidade dos próprios juristas, que na maioria dos países civilizados sentem-se como servidores e representantes das classes abastadas ${ }^{197}$.

Aponta-se ainda a formação de uma complexa e inchada estrutura de administração da justiça, cercada por "abogados, notários, escribanos y otras personas"198. É óbvio que a formação de tal aparato contribuiu enormemente para a maior eficiência do sistema no atendimento da demanda também crescente. Ressalta-se, contudo, que as instituições custosas e complicadas beneficiam sobretudo aos ricos e cultos.

Ademais, numa sociedade marcada pela supervalorização do ganho, que tem no lucro o móvel da esmagadora maioria de suas empreitadas, não se há de estranhar que as funções gratuitas daquele aparato complicado se desempenhem de forma ruim e vagarosa. Deste modo, a obrigação de prestação gratuita de serviços, embora forjada com o fim de reprimir desigualdades, acaba sendo a mais sensível preterição das classes necessitadas ${ }^{199}$. Tristemente, o que se nota é que "la mediación del abogado a veces producirá más bien el efecto de agravar que el de ablandar el desequilibrio"200 o causídico como intérprete entre o cidadão e o juiz.

\section{Papel do juiz no reequilíbrio das partes}

É imperativo que o juiz, a quem incumbe a direção do processo, se encarregue de conferir às partes o tratamento substancialmente igualitário reclamado pela ordem constitucional. Este é um ponto nevrálgico em nossa exposição: deixar bem vincado este poder-dever de que investido o magistrado ${ }^{201}$.

\footnotetext{
${ }^{195}$ BARBOSA MOREIRA, José Carlos. La igualdad de las partes en el processo civil, cit., p. 180. Ainda no mesmo sentido: "A real igualdade das partes no processo somente se verifica quando a solução encontrada não resultar da superioridade econômica ou da astúcia de uma delas" (BEDAQUE, José Roberto dos Santos. Poderes instrutórios do juiz. 4. ed. São Paulo: Ed. Revista dos Tribunais, 2009. p. 101).

${ }^{196}$ BEDAQUE, José Roberto dos Santos. Poderes instrutórios do juiz, cit., p. 102.

${ }^{197}$ MENGER, Anton. El derecho civil y los pobres, cit., p. 135.

${ }^{198}$ MENGER, Anton. El derecho civil y los pobres, cit., p. 147.

${ }^{199}$ MENGER, Anton. El derecho civil y los pobres, cit., p. 148.

${ }^{200}$ BARBOSA MOREIRA, José Carlos. La igualdad de las partes en el processo civil, cit., p. 181.

201“Ecco dunque che anche nel processo può accadere, come prevede l'art. 3 della Costituzione, Che 'ostacoli di ordine economico e sociale ... 'limitando di fatto la libertà e l'uguaglianza dei cittadini, impediscano 'il
} 
Hão de ser superados velhos mitos, como é o caso da má interpretação do princípio da imparcialidade judicial. Já é de larga difusão o reconhecimento de que imparcialidade não significa indiferença do juiz pelo resultado do processo. O Estado-juiz tem interesse de que a sentença seja justa, e que a atividade processual subministre todos os meios necessários para o bem decidir ${ }^{202}$.

Segue-se ainda o escólio de Barbosa Moreira, observando que não se poderia acusar de parcial o juiz por assumir iniciativas que pareçam indispensáveis ao bom esclarecimento dos fatos objeto do feito, ainda que estas diligências resultem benéficas para uma das partes, até porque a omissão também comprometeria sua imparcialidade na medida em que resultaria vantajosa à outra ${ }^{203}$.

Assume neste ponto especial interesse a atividade judicial na seara probatória (tema, aliás, de largo debate em doutrina). Pode o juiz, atuando nesta seara, indiretamente servir à correção de desequilíbrios, e não se trata aqui de atividade substitutiva à da parte. Disse-se indiretamente porque "el juez no investiga por el litigante ni para el litigante, sino por si mismo y para el proceso, y éso no lo cambia para nada la circunstancia de que el resultado de su actuación pueda ocasionar un beneficio a la parte más veraz"204.

Entende-se, por isto, que esta atividade probatória do julgador não suprime ou interfere na liberdade das partes, inclusive no que concerne aos direitos ditos disponíveis,

pieno sviluppo della persona umana...'. Anche nel processo, dunque, può esservi tra le parti una parità teorica, a cui non corrisponda una parità di fatto: sono 'persone' tutt'e due nello stesso senso, ma i mezzi di cui dispongono per far valere questa uguaglianza sono disuguali. E disuguaglianza di mezzi può significare, anche nel processo, disuguaglianza di personalità" (CALAMANDREI, Piero. Opere giuridiche. Napoli: Morano Editore, 1965. v. 1, p. 692). Também digno de citação é o seguinte excerto de Habscheid: "jamais chegaremos a uma justiça em que as decisões sejam sempre conformes à verdade material. Mas, o que nos é possível é garantir a cada cidadão um tratamento digno e justo, diante dos tribunais, e a igualdade de tratamento às partes. É necessário que tenham elas as mesmas possibilidades, as mesmas chances, que reine o princípio da Waffengleichkeit, da igualdade de armas" (HABSCHEID, Walther J. As bases do direito processual civil. Tradução de Arruda Alvim. Revista de Processo, São Paulo, ano 3, n. 11/12, p. 130, 1978).

${ }^{202}$ BARBOSA MOREIRA, José Carlos. La igualdad de las partes en el processo civil, cit., p. 179.

${ }^{203}$ De certa forma contrariando a tradicional assertiva de que o juiz, ao determinar a realização de certa prova desconhece-lhe o resultado, de modo que não poderia ser assim acusado de parcialidade, Flávio Yarshell pontifica que "se é verdade, por um lado, que o juiz desconhece a quem favorece certa prova, por outro lado, é rigorosamente certo que conhece a quem desfavorece a correspondente falta" (YARSHELL, Flavio Luiz. Antecipação da prova sem o requisito da urgência e direito autônomo à prova. São Paulo: Malheiros Ed., 2009. p. 131). Conclui ainda nesta linha de raciocínio, ser por demais difícil afirmar que a iniciativa probatória do magistrado não gere desigualdade entre as partes, pois que na realidade acaba se prestando a favorecer a parte inerte em desfavor do adversário Reconhece também que a alternativa oposta, a postura puramente liberal do órgão jurisdicional, pode levar à consagração do mais forte, notadamente num cenário sócio-econômico de desigualdades. E arremata: "Então, o problema está aí: é preciso saber quando existe uma desigualdade real a ponto de justificar que o juiz intervenha no equilíbrio da relação jurídica processual que, vista em si mesma, dispensa aos litigantes tratamento igualitário" (Antecipação da prova sem o requisito da urgência e direito autônomo à prova, cit., p. 134).

${ }^{204}$ BARBOSA MOREIRA, José Carlos. La igualdad de las partes en el processo civil, cit., p. 182. 
sobre os quais mantém-se o amplo poder de disposição dos litigantes. Enquanto, contudo, a solução da pendenga permanecer sob a tutela do Estado-juiz não pode este contentar-se com a mera expectativa de um suposto duelo encabeçado pelas partes, postura típica da ultrapassada ideologia liberal clássica ${ }^{205}$.

Ao final de sua exposição, Barbosa Moreira sentencia: "non se logrará jamás suprimir o reducir la desigualdad material de las partes sin que el órgano judicial asuma decididamente un papel más activo en el proceso"206.

O prestigiado processualista não é voz isolada nas idéias que temos ressaltado. No mesmo sentido, Lucon lembra que imparcialidade não se confunde com passividade e neutralidade absoluta, e ao enfocar especificamente a questão econômica, assevera: "ao fazer observar a igualdade das partes no processo, caberá ao juiz compensar de modo adequado desigualdades econômicas de modo a permitir a efetiva, correta e tempestiva defesa dos direitos e interesses em juízo",207_208.

Segundo ainda o escólio abalizado de Bedaque, a cada dia engrossam-se as fileiras dos defensores da idéia de que somente um comportamento ativo do julgador concorre para o real respeito ao princípio da igualdade real entre as partes ${ }^{209}$.

Chega-se a afirmar que dever-se-ia obrigar ao juiz à instrução gratuita de todo cidadão, especialmente o necessitado, e mais, “el Juez debería procurar estabelecer un equilíbrio entre las partes, asumiendo la representación de la parte pobre"210.

Obviamente não chegamos a este extremo de afirmar a possibilidade (ou imposição) de assunção pelo juiz de um dos pólos da lide (evidentemente o pólo composto pela parte economicamente frágil), o que desnaturaria totalmente a dialética em que assentado nosso sistema processual.

Obviamente que o protagonismo judicial ora defendido não é isento a críticas. Fazzalari defende ser falsa esta aparente incumbência do juiz em suprir as deficiências processuais da parte carente, inclusive apotando-se que embora a Constituição imponha o

\footnotetext{
${ }^{205}$ BEDAQUE, José Roberto dos Santos. Poderes instrutórios do juiz, cit., p. 100.

${ }^{206}$ BARBOSA MOREIRA, José Carlos. La igualdad de las partes en el processo civil, cit., p. 183.

${ }^{207}$ LUCON, Paulo Henrique dos Santos. Garantia do tratamento paritário das partes, cit., p. 111.

${ }^{208}$ Especificamente relacionando a questão da iniciativa probatória do magistrado, arremata o autor supra citado: "a iniciativa do juiz no campo probatório é essencial à garantia constitucional da igualdade e à efetivação do processo justo" (LUCON, Paulo Henrique dos Santos. Garantia do tratamento paritário das partes, cit., p. 112).

${ }^{209}$ BEDAQUE, José Roberto dos Santos. Poderes instrutórios do juiz, cit., p. 99.

${ }^{210}$ MENGER, Anton. El derecho civil y los pobres, cit., p. 151.
} 
fornecimento de meios que permitam ao cidadão economicamente fragilizado agir em juízo, não consente que o juiz manifeste qualquer espécie de parcialidade como forma de promovê-1o ${ }^{211}$.

Assim, estaria fora do âmbito do poder do magistrado sustentar ou prover o litigante mais frágil, cabendo-lhe apenas aplicar o direito material. Se a norma substancial não contempla e não compensa dada deficiência, o juiz não pode entregar-se à dúvida e ceder à tentação de escolher como critério de juízo um outro valor, ou simplesmente sua própria vontade, deturpando a norma ${ }^{212}$.

$\mathrm{O}$ autor chega a negar o argumento de que a paridade processual deva ser concreta e efetiva, e que por isso caberia ao juiz suprir a parte mais carente. Ressalta outrossim que deficiência na condução do processo não significa necessariamente debilidade social, com um exemplo bastante interessante: pense-se na parte que contrata advogado caríssimo, porém incompetente. De sua parte, sustenta que paridade processual significa a atribuição de poderes, faculdades, deveres semelhantes às partes, além de iguais possibilidades de agir e reagir.

O ponto nevrálgico de seu posicionamento não é propriamente negar que as fragilidades sócio-econômicas invadem o debate processual, o que em tempo algum Fazzalari defende. O cerne de sua idéia é que mesmo nos casos em que à debilidade social corresponda a debilidade processual, a equalização das partes deve ser buscada antes e fora do processo, ponderando que introduzir no curso do processo regras diversas a favor de litigante supostamente mais débil é tratar mais severamente o adversário, o que também não contaria com respaldo constitucional ${ }^{213}$.

Abstratamente consideradas, ou seja, desconexas a uma situação concreta a um corpo social, as considerações do autor italiano são indiscutivelmente corretas. Os problemas surgem quando cotejadas com a realidade. Primeiramente, o que fazer quando o Estado não promove, antes e fora do processo como se afirma desejável, este balanceamento da parte débil?

\footnotetext{
${ }^{211}$ FAZZALARI, Elio. La imparzialità del giudice, cit., p. 193-203.

${ }^{212}$ FAZZALARI, Elio. La imparzialità del giudice, cit., p. 198. "Del resto, non meno estranei al giudice, e sottratti alla sua responsabilità o iniziativa, sono i problemi che riguardano tutti i cittadini, e che vanno risolti a monte del processo: e così il problema degli oneri patrimoniali e degli oneri fiscali del medesimo" (La imparzialità del giudice, cit., p. 198).

${ }^{213}$ FAZZALARI, Elio. La imparzialità del giudice, cit., p. 200.
} 
A própria assistência jurídica deveria ser atividade de necessidade passageira, porque quer-se que o Estado promova o bem de todos e a redução das desigualdades, a ponto de se tornar desnecessária num futuro que se desejaria o mais próximo possível.

Mas a fria realidade é que os ônus, poderes, deveres e faculdades conferidos às partes em exata proporção de igualdade quando vistas da perspectiva do processo, refletem uma cruel disparidade quando analisadas do ângulo do litigante, porque as condições sócio-econômicas deste permeiam o modo como estas posições jurídicas se lhe pesam. Os setores da vida dos indivíduos não são estanques, e embora em algumas situações peculiares debilidade processual não seja conexa à debilidade social ou econômica, no mais das vezes o será.

Certamente não incumbe ao juiz suprir carências sociais e econômicas enquanto tais, porque seria um desvario completamente alheio a suas funções. Porém corrigir as distorções jurídicas causadas por aquelas situações é sua missão constitucional, especialmente quando tem à mão o instrumental capaz de saná-lo, ou ao menos atenuá-lo no que seja atribuição de seu ofício.

Ainda nesta linha crítica à defesa irrestrita do protagonismo judicial, é interessante perceber que a publicização do processo (aqui identificada com fortalecimento dos poderes de condução e gerência judicial do processo), hoje pensada como grande instrumental na afirmação do processo como forma de garantia dos valores democráticos e meio de participação da sociedade nas tomadas de decisão, tenha origem em linhas autoritárias ${ }^{214}$.

Marco inicial desta linha evolutiva é a ZPO austríaca de 1895 (tendo em Klein seu expoente), produto do autoritarismo próprio do império austro-húngaro. O outro marco é o Código italiano de 1940, que é expressão do Estado fascista ${ }^{215}$.

Provavelmente seja este o motivo pelo qual comumente se associa o incremento dos poderes judiciais com ranços autoritários, concepção combatida pela doutrina mais contemporânea.

\footnotetext{
${ }^{214}$ MONTERO AROCA, Juan. El derecho procesal en el siglo XX, cit., p. 71 e ss.

${ }^{215}$ “El conceder amplios poderes discrecionales al juez, y precisamente a unos jueces como el austríaco o el italiano de sus épocas fuertemente sujetos al Poder Ejecutivo, solo se explica se al mismo tiempo se priva de esos poderes a las partes, poderes que em realidad se resuelven em garantias de las mismas en el inicio y en el desarrollo del proceso civil ... los códigos en que se han concedido mayores facultades a los jueces se han promulgado precisamente en países y momentos en que esos jueces eram menos independientes" (MONTERO AROCA, Juan. El derecho procesal en el siglo XX, cit., p. 74-75).
} 
As considerações que temos feito, no sentido da necessidade de adotar o juiz postura ativa na promoção da igualdade real, notadamente quando o fator de desequilíbrio é econômico, especialmente no campo probatório, nos conduz a um ponto de relevante interesse prático. Passamos a expô-lo sucintamente.

Arraigou-se na doutrina a idéia de que a iniciativa probatória do juiz é tanto mais pronunciada quando se trate de interesse indisponível aquele a respeito do qual se litiga em juízo, e que no campo dos direitos disponíveis prevaleceria a suficiência da verdade formal $^{216}$.

Já tivemos oportunidade de expor, com fundamento no escólio de Barbosa Moreira, que subjaz ao processo, além do interesse material debatido pelas partes, o interesse do próprio Estado em que a sentença seja justa, e que a atividade produtora da tal decisão (processo) seja cercada de garantias mínimas. Estes são dados essenciais no assegurar a legitimidade no próprio exercício do poder jurisdicional.

Não parece ser razoável admitir que em dadas circunstâncias, em razão de determinadas características do direito material debatido, a omissão ou deficiência da atividade probatória das partes possa impor ao órgão estatal encarregado da prestação jurisdicional se contente com uma decisão dissonante em relação à realidade fática, ou mesmo em relação aos valores fundamentais da sociedade a quem a atividade jurisdicional é destinada.

O interesse estatal no correto exercício jurisdicional é público e sempre indisponível $^{217}$. Ele é objeto da relação jurídica processual, não se confundido em tempo algum com o objeto da relação jurídica de direito material, este sim que pode ser alvo de disponibilidade conforme o regime jurídico instituído pelo próprio direito material.

Parece haver na posição que temos criticado uma indevida hibridização entre a natureza e características do direito material, objeto da relação jurídica material debatida, e

\footnotetext{
216“No campo do processo civil, embora o juiz hoje não mais se limite a assistir inerte à produção das provas, pois em princípio pode e deve assumir a iniciativa destas (CPC, arts. 130, 341, etc.), na maioria dos casos (direitos disponíveis) pode satisfazer-se com a verdade formal, limitando-se a acolher o que as partes levam ao processo e eventualmente rejeitando a demanda ou a defesa por falta de elementos probatórios" (ARAÚJO CINTRA, Antonio Carlos de; GRINOVER, Ada Pellegrini; DINAMARCO, Cândido Rangel. Teoria geral do processo, cit., p. 65). Em outra obra (A instrumentalidade do processo), adiante citada, o prof. Cândido Rangel Dinamarco parece melhor refletir esta posição.

217،....sendo o processo instrumento para a consecução de resultado que interessa ao Estado (atuação da vontade concreta do direito objetivo para eliminação da controvérsia e conseqüente pacificação social), é mesmo de se admitir que o magistrado, para esclarecimento dos fatos controvertidos, possa não apenas determinar ou indeferir as provas requeridas pelas partes como, ainda, tomar a iniciativa de medidas de instrução" (YARSHELL, Flavio Luiz. Antecipação da prova sem o requisito da urgência e direito autônomo à prova, cit., p. 113).
} 
direito processual. É indiscutível que este deve moldar-se à luz das características e necessidades daquele, porém por isto não se chega às raias de dizer que passem a partilhar a mesma substância ${ }^{218}$.

Flávio Yarshell anota que pensado o ônus da prova sob enfoque objetivo, apresenta-se irrelevante saber a natureza disponível ou não do direito material controvertido, bem como se há desigualdade entre os litigantes, porque a situação de non liquet, a carência irremediável de provas que causa perplexidade ao julgador, pode suceder seja em processos que debatem direitos disponíveis, seja nos que tratam dos indisponíveis, e independentemente de alguma característica peculiar das partes ${ }^{219}$.

Porém, adiante em suas reflexões admite que as peculiaridades da relação material, em razão do caráter instrumental do processo, acabem penetrando o processo, interferindo na disciplina do ônus das partes, de modo que a disponibilidade do direito material discutido acabe ocasionando maior ênfase para os encargos das partes, e menor intensidade para a iniciativa oficial; e que a indisponibilidade acabe minimizando ou até anulando os ônus das partes, e tornando mais intensa a intervenção estatal, quer via poderes instrutórios do juiz, quer via intervenção do Ministério Público ${ }^{220}$.

Dinamarco aponta como uma das grandes contribuições do processualista ao direito e à justiça nas últimas décadas o reconhecimento do comprometimento axiológico das instituições processuais, levando-se ao repensar da dita "indiferença inicial” a que estaria obrigado o juiz, o qual, ao contrário, não deve descurar dos resultados sócio-econômicos e políticos que sua decisão produzirá, e conclui: "o juiz moderno vai-se libertando do preconceito conservador, 221 .

Aponta-se também como equivocada a concepção que associa reforço de poderes instrutórios do juiz a regimes não democráticos ${ }^{222}$. Isto porque a ativação do juiz em

\footnotetext{
${ }^{218}$ Por mais límpida e fielmente que reflita a face, o espelho não chega a ser carne e osso.

${ }^{219}$ YARSHELL, Flavio Luiz. Antecipação da prova sem o requisito da urgência e direito autônomo à prova, cit., p. 115. Segue o mesmo autor sua reflexão, entretanto, apontando o enfoque do ônus da prova sob o prisma subjetivo, e o faz especialmente na perspectiva do ônus da prova atribuído às partes face ao poder instrutório reconhecido ao juiz, evocando a imagem de que "poder e ônus podem ser vistos como espécies de vasos comunicantes, na medida em que, quanto maior ênfase para o ônus, menor para o poder; e viceversa" (cit., p. 116). E ao fim do item em questão conclui: "Contudo, parece lícito afirmar que o sistema considera elementos da relação de direito material - notadamente alguma forma de indisponibilidade dos interesses discutidos - para tornar relativa a importância ou peso do ônus; o que, ao mesmo tempo, faz crescer a importância e a intensidade do exercício do poder de instrução pelo magistrado" (cit., p. 118).

${ }^{220}$ YARSHELL, Flavio Luiz. Antecipação da prova sem o requisito da urgência e direito autônomo à prova, cit., p. 120-121.

${ }^{221}$ DINAMARCO, Cândido Rangel. A instrumentalidade do processo, cit., p. 36.

${ }^{222}$ BEDAQUE, José Roberto dos Santos. Poderes instrutórios do juiz, cit., p. 102.
} 
atividades instrutórias não exclui a necessária atividade de mesma natureza pelas partes, isto é, o papel do juiz e das partes no caso são complementares, e não reciprocamente excludentes. Deste modo prestigia-se o lema do processo civil moderno, em que a idéia chave não é o da contraposição entre juiz e partes, e muito menos de opressão destas por aquele, mas sim o de colaboração entre um e outras ${ }^{223}$.

Conclui, pois, Bedaque, que "o contraditório efetivo e equilibrado de que fala a doutrina exige que os litigantes combatam com paridade de armas" 224 , e que a omissão da parte pode ser decorrência da inexistência de paridade real. Deste modo, independente da natureza do direito (disponível ou não), deve o juiz participar ativamente da instrução, garantindo deste modo o equilíbrio no exercício do contraditório ${ }^{225}$.

Estas concepções e idéias que temos exposto não se têm limitado ao espectro doutrinário, eis que a jurisprudência as têm prestigiado. Veja-se, por exemplo, o seguinte julgado oriundo do C.Superior Tribunal de Justiça, proferido nos autos do Recurso Especial $n^{\circ}$ 964.649/SP, em que foi Relator o Ministro Napoleão Nunes Maia Filho, julgado em 23 de agosto de 2007: "Em que pese o art. 333, I do CPC determinar que compete ao autor o ônus da prova, quanto ao fato constitutivo do seu direito, o art. 130 do CPC possibilita também ao Juiz a iniciativa probatória, mesmo quando a parte tenha tido a oportunidade de requerer a produção da prova e, no entanto, quedou-se inerte" (destaque nosso). E adiante, na mesma ementa, assim se lê: "De acordo com a prestigiada doutrina processualística contemporânea, admite-se uma atuação protagonista do Julgador, que, ao invés de mero fiscal da aplicação das leis, passa a agir intensivamente para a maior efetividade do processo, especialmente quando se tratar de relação processual desproporcional, a exemplo das demandas previdenciárias" (destaque nosso) ${ }^{226}$.

\footnotetext{
${ }^{223}$ BARBOSA MOREIRA, José Carlos. A função social do processo civil moderno e o papel do juiz e das partes na direção e na instrução do processo. Revista de Processo, São Paulo, ano 10, n. 37, p. 148-149, 1985.

${ }^{224}$ BEDAQUE, José Roberto dos Santos. Poderes instrutórios do juiz, cit., p. 106.

${ }^{225}$ BEDAQUE, José Roberto dos Santos. Poderes instrutórios do juiz, cit., p. 107.

${ }^{226}$ Ainda vale citar: "A iniciativa probatória do magistrado, em busca da verdade real, com realização de provas de ofício, é amplíssima, porque é feita no interesse público de efetividade da Justiça" (STJ - AgRg no REsp n $\mathrm{n}^{\circ}$ 738.576/DF - Rel. Min. Nancy Andrighi - j. 18.08.05). Encampando escólio de Cândido Rangel Dinamarco, eis ainda o seguinte julgado: "A experiência mostra que a imparcialidade não resulta comprometida quando, com serenidade e consciência da necessidade de instruir-se para melhor julgar, o juiz supre com iniciativas próprias as deficiências probatórias das partes. Os males de possíveis e excepcionais comportamentos passionais de algum juiz não devem impressionar o sentido de fechar a todos os juízes, de modo absoluto, as portas de um sadio ativismo" (in DINAMARCO, Cândido Rangel. Instituições de direito processual civil, cit., v. 3, p. 52-54, grifos no original)" (STJ - REsp n ${ }^{\circ}$ 629.312/DF - Rel. Hélio Quaglia Barbosa - j. 27.03.07).
} 
O primeiro destaque aposto indica o reconhecimento da legitimidade da iniciativa probatória do juiz a despeito da letargia da parte. O segundo, de destacada relevância, aponta para a possibilidade de que, em qualquer caso em que se verifique a desproporcionalidade da relação processual, isto é, uma situação de desigualdade real, é legítimo ao magistrado ativar-se no reequilíbrio das partes ${ }^{227}$, restando claro que a citação da demanda de caráter previdenciário é feita a título exemplificativo.

Esta segunda assertiva merece especial atenção, pois que rompe com a idéia já tradicionalmente arraigada em nossa práxis, do suprimento da deficiência probatória da parte limitada aos casos em que se debate relação de consumo.

São profusas a este respeito doutrina e jurisprudência, em razão do expresso reconhecimento pelo diploma consumerista (Lei $\mathrm{n}^{\circ}$ 8.078/90) do consumidor como personagem hipossuficiente técnica e economicamente no cenário jurídico ${ }^{228}$. A facilitação de sua defesa em juízo, notadamente com a inversão do ônus da prova "quando, a critério do juiz, for verossímil a alegação ou quando for ele hipossuficiente, segundo as regras ordinárias de experiências" (CDC, art. $\left.6^{\circ}, \mathrm{VIII}\right)$, tornou-se lugar comum no debate diário dos que militam na área.

Nesta linha, arrojamo-nos por um campo mais arriscado. Queremos ir além do trivialmente debatido, conforme referido no anterior parágrafo. A rigor, acham-se doutrina e jurisprudência consolidadas a respeito da possibilidade deste suprimento da atividade probatória em favor do consumidor hipossuficiente, até em razão das disposições legais que regem a matéria. A verdade é que os debates mais acirrados observam os padrões dos

\footnotetext{
${ }^{227}$ Em posição que nos parece consentânea com a ora defendida, Barbosa Moreira, após reconhecer a dificuldade do litigante mais pobre em munir-se de provas, e lembrando que pode também o Ministério Público atuar no suprimento desta deficiência, em face do disposto no inciso II do art. 83 do Código de Processo Civil, assim se pronuncia: "Também a iniciativa instrutória do próprio juiz órgão judicial pode representar aqui fator importante na correção de desigualdades" (A função social do processo civil moderno e o papel do juiz e das partes na direção e na instrução do processo, cit., p. 142). O autor afirma que a iniciativa probatória do magistrado é o mais valioso instrumento corretivo para o juiz. Lamenta, contudo, que a prática não tem demonstrado fecundo uso deste poder pelos juízes, em razão do que denominou "abulia profissional" e comodismo, além da vetusta mentalidade que vê com reserva a ativação do juiz à busca da verdade, como mácula à imparcialidade. Sua conclusão assim se apresenta: "Confiar ao juiz papel mais ativo na direção e na instrução do feito, ao contrário do que parecem recear alguns, não implica forçosamente instaurar no processo civil o domínio do 'autoritarismo' ou do 'paternalismo'. Não se pretende ignorar nem minimizar a importância do que há de essencialmente dialético no processo contencioso, e menos ainda assimilar-lhe a imagem à da chamada 'jurisdição voluntária'. A ampliação dos poderes do órgão judicial não tem como contrapartida necessária o amesquinhamento do papel das partes, nem a eliminação, ou sequer a redução, das garantias a que fazem jus, e tampouco da responsabilidade que sobre elas pesa" (A função social do processo civil moderno e o papel do juiz e das partes na direção e na instrução do processo, cit., p. 147).

${ }^{228} \mathrm{O}$ reconhecimento da vulnerabilidade do consumidor é princípio básico da política nacional das relações de consumo (art. $4^{\circ}, \mathrm{I}$, do CDC).
} 
casos concretos, isto é, saber se se verificam na hipótese em exame os pressupostos legais para a inversão a que alude o art. $6^{\circ}$, VIII, do CDC, já parcialmente transcrito.

Nossa proposta, vertemos no subitem seguinte.

\section{Inversão do ônus da prova fundado na disparidade econômica das partes}

Algumas conclusões pensamos poder extrair de tudo quanto foi alinhavado até aqui. Principalmente, ressalta-se o reconhecimento de que o prestígio ao princípio da igualdade processual formal implica, a rigor, grave prejuízo às partes, ignorando a realidade de substancial desigualdade entre os litigantes.

Como dos principais motrizes deste desequilíbrio indubitavelmente está o fator econômico, isto é, a carência de recursos financeiros de uma das partes, face à abastança da outra.

É poder-dever do magistrado dar concretude ao princípio constitucional da igualdade material entre as partes, assumindo neste mister postura ativa na condução do processo, especialmente no que respeita à iniciativa probatória, não propriamente com o intento de suprir a deficiência da parte, mas especialmente visando ao atendimento do interesse público e indisponível de correção no exercício jurisdicional e efetividade da tutela daí advinda.

Enfim,

"O melhor que podemos fazer é estar a serviço da comunidade e dos grandes ideais, da liberdade, da justiça social, dos valores supremos. $\mathrm{O}$ que nos pedem hoje é aquilo que a justiça sempre teve: prudência. Desde Aristóteles, prudência é decidir, em situações de incerteza, de uma forma justa. O que exigimos dos juízes e advogados é que contribuam para essa decisão em um mundo com cada vez mais incertezas, mas no qual procuramos ser justos. Penso que isso é um ideal. E esse ideal deve pautar a nossa formação e atividade, e corresponder ao nosso imperativo categórico, para quem é um kantiano como eu",229.

Esta parece ser uma boa introdução para algumas idéias que apresentamos a seguir. Sabemos, de antemão, de sua ousadia, e das inúmeras críticas a que sujeitas, mesmo assim as veicularemos, desde já reconhecendo a necessidade de maior maturação.

\footnotetext{
${ }^{229} \mathrm{O}$ texto é de J.J.GOMES CANOTILHO, em entrevista à revista Diálogos \& Debates, Escola Paulista da Magistratura, ano 8, n. 3, p. 15, mar. 2008.
} 
De tudo quanto exposto, podemos falar sem maiores rebuços numa necessidade de postura caracterizada pela parcialidade positiva do magistrado na configuração do processo contemporâneo. É esta a expressão empregada por Artur César de Souza em monografia dedicada ao tema ${ }^{230}$.

$\mathrm{O}$ autor em questão apresenta alguns pressupostos que devem ser mencionados. $\mathrm{O}$ primeiro deles é a configuração do processo judicial moderno como expressão da soberania democrática popular, isto é, estruturação segundo a pauta de valores democráticos que impregnam a Constituição.

Destarte, o processo deve refletir as bases do regime democrático, isto é, (e aqui o autor em questão se vale das lições de Cândido Rangel Dinamarco, em parte já citadas, em A instrumentalidade do processo) o processo deve ser o microcosmos do Estado Democrático de Direito, com as conotações de liberdade, igualdade e participação (contraditório).

"E para que tenha eficácia essa aplicação integradora entre processo e democracia participativa no âmbito da relação jurídica processual há necessidade de se reconhecer nas sociedades pluralistas e complexas a existência de barreiras externas que podem pôr em risco a participação nesse diálogo público. As desigualdades sociais, econômicas e culturais são exemplos típicos dessas barreiras impeditivas da concretização de um processo público e democrático" ${ }^{, 31}$.

A seguir, associando a idéia do juiz neutro e passivo ao ideário capitalista neoglobalizado, arremata no mesmo sentido das idéias que já vimos defendendo no item precedente: 'Necessita-se de uma 'parcialidade positiva' do juiz, no sentido de que, acima de tudo, ele possa reconhecer as diferenças sociais, culturais, econômicas, psicológicas, etc., bem como essa carga ideológica neoglobalizante que manipula os resultados do próprio processo" ${ }^{\text {232 }}$.

Ressalta-se a necessidade de se redefinir o papel do juiz, que passaria a protagonista das atividades processuais por ele coordenadas e orientadas ${ }^{233}{ }_{-}^{234}$.

\footnotetext{
${ }^{230}$ SOUZA, Artur César. A parcialidade positiva do juiz. São Paulo: Ed. Revista dos Tribunais, 2008. 269 p.

${ }^{231}$ SOUZA, Artur César. A parcialidade positiva do juiz, cit., p. 199.

${ }^{232}$ SOUZA, Artur César. A parcialidade positiva do juiz, cit., p. 202.

233، A alternativa para esse lamentável quadro da natureza humana é realçar a parcialidade positiva do juiz, seja em relação ao réu ou mesmo em relação à vítima do crime e à sociedade como um todo, a fim de que, por meios legítimos conferidos pelo ordenamento jurídico, e que não são poucos, possa promover-se o desenvolvimento da relação jurídica processual penal ou civil com base nos princípios democráticos fundamentais previstos na Constituição Federal brasileira de 1988" (SOUZA, Artur César. A parcialidade positiva do juiz, cit., p. 211).

${ }^{234}$ Flávio Yarshell também dá supedâneo a estas considerações, especificamente no que concerne ao campo probatório, justamente aquele por nós aqui referido. São suas as seguintes palavras: “...também a
} 
A pobreza é tratada, na lição que vimos estudando, como o "tendão de Aquiles" da igualdade processual e do acesso à justiça, isto é, o principal fator de desequilíbrio de forças na relação jurídica processual civil e penal ${ }^{235}$.

Este vetor de parcialidade positiva relaciona-se ainda com a idéia de "processo justo e équo", representada pela dimensão social de um processo caracterizado por um aspecto mais humano e solidário.

Pois bem, com base no arcabouço teórico que pensamos ter esboçado é que sobressai a questão de se saber da possibilidade de encetar o magistrado a inversão do ônus da prova, ao verificar a latente desigualdade econômica dos litigantes.

Percebe-se que mesmo nos casos de relações de consumo, em que há expressa disposição legal autorizativa da inversão do ônus da prova, no caso de verossimilhança da alegação do consumidor ou de hipossuficiência segundo as regras ordinárias de experiência (CDC, art. $\left.6^{\circ}, \mathrm{VIII}\right)$, há uma indisfarçável resistência da jurisprudência em admitir que este procedimento implique efetiva inversão do ônus financeiro na produção da prova.

Veja-se neste sentido, o julgado a seguir, que merece acurada avaliação: “A inversão do ônus probatório não é automática, cabendo ao magistrado a apreciação dos aspectos de verossimilhança da alegação do consumidor ou de sua hipossuficiência o que, se concedida, não acarreta, de qualquer modo, o encargo financeiro de custear as despesas pela parte adversa, mas, apenas, o faz arcar com as conseqüências jurídicas pertinentes" (STJ, AgRg no Ag nº 884.407/SP, Rel. Aldir Passarinho Junior, j. 21.08.07). Ainda: "PROVA - Inversão do ônus - Fato que não implica a alteração do responsável pelo seu custeio - Hipótese em que incumbe à parte que requereu a produção probatória arcar com a despesa - Inteligência do art. 33 do CPC" (1 ${ }^{\circ}$ TACivSP em RT 815/274) ${ }^{236}$.

desigualidade substancial das partes parece justificar maior grau de intervenção estatal e, portanto, um papel mais marcadamente ativo do juiz na instrução como ferramenta para assegurar que a uma delas não se conceda uma vantagem inicial em relação à outra" (YARSHELL, Flavio Luiz. Antecipação da prova sem o requisito da urgência e direito autônomo à prova, cit., p. 126).

${ }^{235}$ SOUZA, Artur César. A parcialidade positiva do juiz, cit., p. 212. Ainda adiante, o mesmo autor assim se manifesta: "Até mesmo as nações do chamado mundo dominante reconhecem que a pobreza é o maior entrave para se conseguir o justo desenvolvimento de um processo jurisdicional ... um aspecto é a possibilidade de se valer do devido processo legal adjetivo para os ricos, e outra para aquele que, de fato, envolvido em sua pobreza, quer usar a vestimenta de litigante" (A parcialidade positiva do juiz, cit., p. 213-214).

${ }^{236}$ No mesmo sentido o seguinte julgado também oriundo de São Paulo: "PROVA - Perícia - Ação declaratória de inexigibilidade de dívida, cumulada com repetição de indébito - Prestação de serviço de fornecimento de energia elétrica - Inversão do ônus da prova que não se confunde com a questão da despesa com a prova pericial - Solução da questão do custeio da prova que não importa em obrigar a outra parte, não enquadrada no artigo 33 do CPC, a custear prova pericial que não é do seu interesse - Decisão que determinou o depósito dos honorários periciais, sob pena de preclusão da prova, reformada - Recurso 
Há de nossa parte certa dificuldade em entender a incoerência que este entendimento proporciona. Transfere-se o efeito negativo decorrente da não produção da prova, porém não se transfere o encargo financeiro de sua produção. Por outras palavras: se com a inversão passa a ser de interesse do fornecedor a produção da prova dispendiosa, como se poderia manter sobre o consumidor o encargo financeiro com sua possível produção $^{237}$ ?

A par desta questão, outra queremos propor, e a respeito desta valem as advertências que fizemos quanto ao reconhecimento de que se trata de ousada sugestão, sujeita a amadurecimento.

Poderia o magistrado, fora do âmbito das relações consumeristas, reconhecendo uma gritante disparidade econômica das partes, a influenciar negativamente a paridade de armas e a possibilidade de igualmente influenciarem o resultado da pendenga, valendo-se da concepção de parcialidade positiva, proceder à inversão do ônus, inclusive financeiro $^{238}$, da prova?

Invocamos tudo quanto vimos expondo até aqui para a discussão desta questão, notadamente a lembrança de que é incumbência do magistrado zelar pela legitimidade da jurisdição, assegurando o justo e équo processo que atenda aos valores fundamentais da sociedade.

Por tudo quanto já citado, parece ser voz corrente na doutrina (e mesmo na jurisprudência) a defesa da ativa postura reclamada do magistrado no processo contemporâneo, combatendo-se a vetusta concepção de que a iniciativa probatória do juiz comprometeria sua imparcialidade e ainda, que seria sinal de autoritarismo do Estado.

Pois bem, não podemos nos contentar, entretanto, com a simples proclamação teórica destas idéias, sem delas extrair efeitos práticos concretos, palpáveis, que no dia-a-

provido" (TJSP - Agravo de Instrumento n. 7.244.150-4 - Barueri - 11 a Câmara de Direito Privado Relator: Gil Coelho - 16.07.08 - V.U.).

${ }^{237}$ Rizzatto Nunes vê com o mesmo inconformismo esta posição: "Se o sistema legal protecionista cria norma que obriga à inversão do ônus da prova, como é que se poderia determinar que o consumidor pagasse as despesas ou honorários?... Uma vez determinada a inversão, o ônus econômico da produção da prova tem de ser da parte sobre a qual recai o ônus processual ... Se assim não fosse, instaurar-se-ia uma incrível contradição: o ônus da prova seria do réu, e o ônus econômico seria do autor (consumidor). Como este não tem poder econômico, não poderia produzir a prova. Nesse caso, sobre qual parte recairia o ônus da nãoprodução da prova?" (Curso de direito do consumidor. 3. ed. São Paulo: Saraiva, 2008. p. 779).

${ }^{238}$ Até porque pensamos ter ficado claro que não concebemos a possibilidade de inverter-se o ônus da prova sem que isto implique consigo a alteração de seu encargo financeiro. 
dia reflitam uma real mudança na forma de litigância quotidianamente desenvolvida no ambiente forense.

Resumir-se à enunciação abstrata da necessidade de redefinição do papel do magistrado, recuando quando propostas de transformações que afetem a práxis são apresentadas, seria assumir ares demagógicos.

Antevemos, é certo, a mais óbvia das objeções: a falta de amparo legal para tal procedimento. A resposta a esta oposição, de relativa simplicidade, vem da pena, até já citada, de José Souto Maior Borges, que tomamos a liberdade de transcrever integralmente a seguir:

\begin{abstract}
“Se há 'espaço' na disciplina legal, que ensejam agressões escancaradas ou subreptícias à legalidade, impõe-se ao Judiciário assegurar o primado da CF ... Não lhe é então lícito alegar que, na ausência de disciplina legal expressa, ser-lhe-ia impossível restaurar a igualdade ... Se, no âmbito da legalidade, há um claro, uma omissão qualquer que viabiliza a instauração da desigualdade, não estará o Judiciário exercendo função legislativa ao reintroduzir a igualdade ... Não estará o Poder Judiciário a usurpar as atribuições do Poder Legislativo ao aplicar a CF, art. $5^{\circ}$, caput e item I, na ausência de provimento legislativo adicional que viesse a dispor sobre situações submetidas a uma desigualdade na lei,"239
\end{abstract}

Também Barbosa Moreira lembra que embora se reconheça que nenhuma revolução puramente processual seja capaz de produzir na estrutura jurídico-social modificações definitivas, não se exonera o processualista de, na sua especialidade, colaborar para a respectiva promoção. E esta colaboração se dá em duas frentes: de lege lata, isto é, analisando o ordenamento vigente, revelando-lhe o perfil, pondo em realce potencialidades mal exploradas e de lege ferenda, mediante apreciação crítica das normas em vigor, ofertando sugestões de reforma ${ }^{240}$.

De mais a mais, não se pode descurar da observação de que, em realidade, carência de amparo legal às inteiras inexiste, já que o dever de conceder às partes tratamento substancialmente igualitário está plasmado no CPC, art. 125, I.

Defender a impossibilidade de proceder o magistrado à inversão ora comentada seria amesquinhar o valor do princípio constitucional de magna grandeza que é a isonomia (sobre o que já dissertamos), admitindo-se que o legislador ordinário, aliado à crueldade da

\footnotetext{
${ }^{239}$ BORGES, José Souto Maior. Significação do princípio da isonomia na Constituição de 1988, cit., p. 31.

${ }^{240}$ BARBOSA MOREIRA, José Carlos. A função social do processo civil moderno e o papel do juiz e das partes na direção e na instrução do processo, cit., p. 140.
} 
realidade concreta em que imerso o fenômeno processual, frustrem a obra do constituinte, no que parece patente haver uma subversão grave e completa do sistema.

Mais que isto, seria também atrofiar a relevância da atuação do Judiciário como instituição precipuamente voltada a dar concretude à Lei fundante do Estado, assegurando a legitimidade do exercício de poder de que a jurisdição é uma das expressões.

Ademais, ao processo, como meio de exercício desta mesma jurisdição, incumbe assegurar a realização do direito material, especialmente da ordem constitucional, que lhe constitui o norte. Para lembrarmos as palavras de Habscheid: o direito material e o processo relacionam-se entre si como o pensamento e a sua expressão ${ }^{241}$. O que se quer dizer é que o processo deve representar a ponte de concretização entre os valores postos no direito material, notadamente na Constituição, e os casos concretos, individualmente considerados, que acorrem ao instrumento estatal de exercício da jurisdição.

Ora, se o exercício do processo na praxe forense constitui tudo, menos a realização dos valores eleitos pelo direito material, ou seja, se a "ponte" a que aludimos no parágrafo anterior é intransitável, então o processo se pode bem definir como uma juridicamente requintada forma de hipocrisia, uma técnica ilusionista de ludibriar a sociedade civil, o que parece ser um retrocesso bem pouco desejável na evolução do Estado Democrático de Direito.

Um outro argumento se nos apresenta. A regra mater em tema de distribuição do ônus da prova segue a idéia geral de que ao autor incumbe a prova do fato que diz fundamento de seu pleito, enquanto ao réu, aquele(s) que aduz em oposição à pretensão do autor, sejam os modificativos, impeditivos ou extintivos do direito invocado. Eis a regra plasmada no art. 333, "caput”, do Código de Processo Civil.

Ocorre que o parágrafo único da mesma regra prevê a possibilidade de que por meio de ato dispositivo bilateral, uma convenção processual, as partes repartam de modo diverso tais encargos. É certo que se cuida de faculdade pouco utilizada na prática, que não encarnou na mentalidade jurídica brasileira. Mas ali está ela, em pleno vigor, com duas únicas limitações: tratar-se a matéria debatida de direito indisponível, ou excessiva dificuldade para uma das partes no exercício do direito (incisos I e II do p.único).

\footnotetext{
${ }^{241}$ HABSCHEID, Walther J. As bases do direito processual civil, cit., p. 117. Vale transcrever: "o processo civil é, não somente um processo de cognição, porém, mais ainda um processo de concretização do direito. Em outros termos, o juiz deve freqüentemente encontrar ou descobrir o direito. O processo civil, é, conseqüentemente, um processo no qual o direito material preexistente se concretiza em cada caso determinado, ou, talvez, se 'fixe," (As bases do direito processual civil, cit., p. 124).
} 
Assim é que a formatação da distribuição do ônus da prova não está empedernida de forma irremediável nos marcos das regras usuais contidas nos incisos I e II da cabeça do art. 333. Ao contrário, podem ser alteradas de acordo com a conveniência e o interesse negocial das próprias partes ${ }^{242}$.

Ora, se assim é, não se vê como a tal alteração não se possa dar por fundamento de muito mais relevo, qual seja, a preservação da igualdade material entre os litigantes.

Aliás, não custa observar que o amparo à restrição contida no art. 333, p.único, II, do Código de Processo Civil visa justamente evitar que por meio da convenção em questão se imponha a uma das partes posição processual excessivamente inferior na comparação com o adverso.

A rigor a sugestão ora veiculada não é assim tão novidadeira. Fala-se hoje de uma teoria dinâmica do ônus da prova, que tem à base, para simplificarmos, a idéia de que deve suportar o ônus da prova aquele que estiver em melhores condições de produzi-la ${ }^{243}$.

Os pressupostos de tal teoria estão plenamente alinhados com as idéias expostas até aqui como fundamento teórico para a inversão do ônus da prova nos termos que a temos proposto. Isto é, há o reconhecimento de que o tratamento da distribuição do ônus da prova apenas pelas regras rígidas, abstratas e estáticas do art. 333 do Código de Processo Civil pode conduzir a situações concretas em que seja impossível a produção da prova por determinada parte (e no caso tratamos desta impossibilidade como decorrência da carência econômica), com o resultado evidente de denegação de acesso à tutela jurisdicional. É por isto que a premissa fundamental no tema é a de que a distribuição do ônus da prova é uma questão constitucional ${ }^{244}$, dada sua íntima correlação com o postulado de acesso à justiça. A proposta, então, é a flexibilização destas regras em razão das peculiaridades do direito material e do caso concreto ${ }^{245}$.

\footnotetext{
${ }^{242}$ No sentido de que a convenção em questão tem natureza de autêntico negócio jurídico processual, à semelhança da eleição de foro: TABOSA, F. Art. 333. In: MARCATO, Antônio Carlos (Org.). Código de Processo Civil interpretado, cit., p. 1.061.

${ }^{243}$ GODINHO, Robson Renault. Prova e acesso à justiça: apontamentos sobre a distribuição do ônus da prova. In: CARVALHO, Fabiano; BARIONI, Rodrigo (Coord.). Aspectos processuais do Código de Defesa do Consumidor. São Paulo: Ed. Revista dos Tribunais, 2008. p. 257.

${ }^{244}$ GODINHO, Robson Renault. Prova e acesso à justiça: apontamentos sobre a distribuição do ônus da prova, cit., p. 245.

${ }^{245}$ Todo o fundamento teórico do autor é aquele por nós defendido: "esse regramento <fala-se do art. 333 do CPC > é insuficiente e não atende às especificidades dos casos concretos e do direito material, tratando estática e uniformemente situações diferenciadas ... O direito de ação compreende a oportunidade de o autor influir no convencimento do julgador, participando efetivamente do processo, existindo um verdadeiro direito à prova, considerando um dos pilares fundamentais do sistema processual
} 
A resposta ofertada por Robson Renault Godinho acerca da possível objeção acerca da inexistência de fundamento legal para a inversão do ônus da prova em casos que tais, é a mesma por nós anteriormente ofertada: "a necessidade de inversão do ônus da prova decorrente diretamente da Constituição, não há necessidade de integração legislativa"246.

Mesmo sem falar textualmente numa "doutrina" de distribuição dinâmica dos ônus probatórios, Flávio Yarshell admite-lhe os pressupostos, notadamente no que especificamente toca o tema ora em estudo, obtemperando que as desigualdades existentes na relação substancial penetram o processo, e que afora as relações de consumo, "há outras hipóteses relevantes, que dizem respeito à Fazenda Pública, à parte economicamente mais fraca (ainda que fora das relações de consumo) e até mesmo ao incapaz"247 (sublinhamos), e que a disciplina das posições da relação processual devem levar em conta esta diferença inicial.

É óbvio que toda a estrutura garantística contida na Constituição, e conformadora do devido processo legal, há de informar a providência em tela. Assim é que tal inversão há de ser devidamente fundamentada, procedendo-a o magistrado em respeito ao contraditório, isto é, em momento processual que permita à parte agravada pela inversão adaptar-se à mudança, produzindo então as provas que passaram a ser de seu encargo. Este momento poderá ser ao despachar a própria inicial ou mais adiante, por exemplo, quando da decisão saneadora. Seja como for, mesmo que procedida após o curso da instrução, há de ser autorizada à parte mais onerada com a inversão a oportunidade de produzir suas provas amplamente (daí porque se a inversão, por algum motivo, se der após o

contemporâneo ... o legislador infraconstitucional não é livre para a ampla restrição da inversão do ônus da prova, podendo-se falar em limites constitucionais materiais no caso de a distribuição do ônus probatório frustrar a fruição de um direito fundamental" (GODINHO, Robson Renault. Prova e acesso à justiça: apontamentos sobre a distribuição do ônus da prova, cit., p. 249-250).

${ }^{246}$ GODINHO, Robson Renault. Prova e acesso à justiça: apontamentos sobre a distribuição do ônus da prova, cit., p. 256.

${ }^{247}$ YARSHELL, Flavio Luiz. Antecipação da prova sem o requisito da urgência e direito autônomo à prova, cit., p. 126-127. O autor, contudo, aponta as dificuldades sobrevindas nesta empreitada em nivelar os contendores em tema de acesso às oportunidades probatórias. Refere especificamente três espinhos: i) nem sempre é fácil estabelecer a premissa da desigualdade quando ela não vem diretamente reconhecida no ordenamento jurídico, além do que, a desigualdade ainda que admitida no âmbito substancial, pode não justificar tratamento diferenciado em tema de direito probatório, porque não haja, propriamente, prejuízo à produção dos elementos de instrução pelo interessado (na verdade o que diz o autor é que além do reconhecimento das desigualdades, devem existir elementos de conexão entre a tal disparidade e o tratamento diferenciado); ii) necessidade de identificar se o restabelecimento da igualdade é tema afeto à lei, ou reservada ao juiz em cada caso concreto, anotando-se o perigo de incidirem ambos os mecanismos, que podem reforçar em demasia a posição de uma das partes, ou anularem-se reciprocamente; e iii) problemas relacionados à possibilidade de que, ao tentar reequilibrar a balança, o magistrado permita-lhe pender para o outro lado, agora prejudicando a parte tida inicialmente como mais forte (Antecipação da prova sem o requisito da urgência e direito autônomo à prova, cit., p. 127-129). 
encerramento da instrução, está deverá ser reaberta se a parte agravada manifestar interesse em produzir outras provas diante da nova configuração de distribuição do ônus da prova).

Não custa mais uma vez relembrar, na linha do que já exposto no item precedente, a crítica efusiva de Fazzalari à atuação judicial pronunciada como ora defendida, postulando que o juiz não pode tomar iniciativas processuais para suprir a omissão de uma das partes que seja socialmente carente, salientando que seria abusivo o uso dos poderes de instrução do juiz em favor de uma das partes, mesmo que seja a considerada mais frágil ${ }^{248}$.

É preciso lutar contra a "máquina de impedir", assim alcunhada por Jorge Walter Peyrano, precursor de uma mais clara sistematização da doutrina das cargas probatórias dinâmicas (fundamento teórico da posição ora exposta e melhor analisada no item seguinte). Assim denomina o autor a "engrenagem" que sempre aparece quando uma nova corrente doutrinária ou jurisprudencial surge em antagonismo ao estado de coisas vigente $^{249}$.

A idéia está aí posta, sujeita a todas as críticas e censuras. De nossa parte contentamo-nos em fomentar o debate, do qual possam florescer bons frutos.

\section{Distribuição dinâmica das cargas probatórias}

Faz-se nesta oportunidade breve apanhado da doutrina difundida no cenário jurídico processual com a denominação em epígrafe. Embora brevemente já se tenha aludido a ela no anterior item, convém minuciá-la pouco mais, pois que constitui o alicerce teórico da

\footnotetext{
${ }^{248}$ FAZZALARI, Elio. La imparzialità del giudice, cit., p. 201-202.

${ }^{249}$ PEYRANO, Jorge Walter. La doctrina de las cargas probatorias dinámicas y la máquina de impedir en materia jurídica. In: PEYRANO, Jorge Walter (Dir.); WHITE, Inês Lépori (Coord.). Cargas probatorias dinámicas. Buenos Aires: Rubinzal-Culzoni, 2008. p. 81. O autor em questão arrola as principais críticas à doutrina das cargas probatórias dinâmicas, e como seria de esperar, são aquelas mesmas oponíveis ao que foi defendido no texto (inversão fundada na disparidade econômica das partes), até porque o que se defendeu no texto é nada mais que uma ramificação da doutrina da distribuição dinâmica dos ônus probatórios. À menção da falta de texto legal a amparar a medida, Jorge Peyrano responde obtemperando que "desde mediados del siglo pasado dicha línea de pensamiento es absolutamente descartable" (Cargas probatorias dinámicas, cit., p. 88), ponderando que há diversos institutos que somente mereceram consagração legal após repetidas decisões judiciais que os reconheciam, e largo apoio doutrinário. De mais a mais, a crítica perde propósito quando se anota que a teoria em questão tem sido contada como "doutrina recebida", conforme se melhor verá no item seguinte, dedicado apenas à doutrina da distribuição dinâmica das cargas probatórias. Quanto à possível surpresa causada à parte onerada, há resposta adequada no item seguinte, porém por ora convém anotar que, segundo Jorge Peyrano, tal argüição caberia em face de qualquer nova concepção ou teoria no cenário jurídico, e perde sentido justamente quando se pensa na doutrina analisada como "já recebida". Além disto, sua aplicação igualmente se justifica pela faculdade que tem o órgão judicial de apreciar a conduta processual da parte, de um lado, e de outro, pelo dever de apreciar todos os elementos coletados mediante a regra da "sana crítica" (Cargas probatorias dinámicas, cit., p. 91). Para outras considerações, v. item seguinte.
} 
posição retro defendida, acerca da possibilidade do juiz, fora do âmbito das relações de consumo e baseado unicamente na disparidade econômica das partes no que concerne ao acesso ao acervo probatório, proceder à inversão do ônus da prova, carreando-o à parte que revele melhores condições econômicas de produzi-la.

A regra do art. 333 do Código de Processo Civil é baseada em dois critérios: i) a posição da parte em juízo e ii) a natureza do fato que se quer provar, para com base neles efetuar a distribuição do ônus da prova. Reconhece-se, contudo, que tais critérios são falhos. Exemplifica-se: na ação movida pelo devedor para ver declarada a inexigibilidade da duplicata protestada porque já paga, o fato "constitutivo" de seu direito é, na verdadem um fato extintitivo do direito do credor. Este mesmo fato (pagamento), contudo, será extintivo do direito do autor na ação de cobrança desta duplicata ajuizada pelo credor. Ou seja, o mesmo fato será "constitutivo" ou "extintivo" conforme a posição processual da parte que o invoca. Daí porque a distribuição do ônus probatório com base apenas na posição da parte apresenta-se incongruente.

Apesar disto uma regra matriz de distribuição do ônus da prova apresenta-se como um mal necessário, porque permite que, em qualquer conjuntura, o juiz se pronuncie sobre o mérito da causa, mesmo quando persista a incerteza acerca da matéria fática, o que se faz mediante a distribuição do risco processual diante da falta ou insuficiência probatória. Dizse, por isto, que as fórmulas de distribuição do ônus da prova são mais normas de decisão que de direito probatório propriamente dito ${ }^{250}$.

A fórmula de distribuição do art. 333 é abstrata, prévia e estática, sem levar em conta o caso concreto ${ }^{251}$. A distribuição em questão é feita com base no que se denomina teoria das normas porque consagrada conforme a sintaxe da lei ${ }^{252}$.

\footnotetext{
${ }^{250}$ PEYRANO, Jorge Walter. La regla de la carga de la prueba enfocada como norma de clausula del sistema. Revista de Processo, São Paulo, v.35, n.185, p. 107, jul. 2010. O autor em questão reconhece, contudo, a má consciência que pende em relação a demandas que acabem solucionadas de acordo exclusivamente com regras de distribuição do ônus da prova, porque representam o fracasso da atividade probatória desenvolvida no curso do processo, o que, a seu ver, explica "la proliferación de modernas instituciones probatórias que contribuyen a tener por acreditados hechos que normalmente no podrían considerarse demostrados. Así, pueden citarse a la doctrina de la prueba difícil y a las llamadas pruebas leviores, como ejemplos de lo que venimos señalando" (La regla de la carga de la prueba enfocada como norma de clausula del sistema, cit., p. 113).

${ }^{251}$ DALL'AGNOL JUNIOR, Antonio Janyr. Distribuição dinâmica dos ônus probatórios. Revista dos Tribunais, São Paulo, v. 90, n. 788, p. 95, jun. 2001.

${ }^{252}$ KNIJNIK, Danilo. As (perigosíssimas) doutrinas do "ônus dinâmico da prova" e da "situação de senso comum" como instrumentos para assegurar o acesso à justiça e superar a "probatio diabolica". In: FUX, L.; NERY JR., N.; WAMBIER, T. A. A. (Coord.). Processo e Constituição: estudos em homenagem ao professor José Carlos Barbosa Moreira. São Paulo: Ed. Revista dos Tribunais, 2006. p. 943.
} 
Associa-se a regra do art. 333 a um processo civil liberal, havendo "clara sintonia entre a fixidez da distribuição do ônus probatório e a idéia de que o escopo da jurisdição é apenas pacificar",253.

Adverte-se, entretanto, que a idéia de distribuição estátiva do ônus probatório não corresponde sequer à concepção originária de James Goldschmidt, mentor da teoria das situações jurídicas processuais e cargas processuais ${ }^{254}$.

Justamente porque fixada a distribuição de forma estática, pode ocorrer no caso concreto que acarrete iniqüidade, causando situação de sensível desequilíbrio às partes, porque para uma delas, aquela que inicialmente onerada pela repartição na forma do art. 333, seria extremamente difícil, senão impossível, colher a prova, e para outra, aquela que a princípio não-onerada, não o seja, porque tem maior proximidade e familiaridade com o acervo probatório.

Neste contexto impõe-se ao órgão judiciário um dever de conformação constitucional do processo ${ }^{255}$, pena de incorrer em inconstitucional aplicação das normas processuais por causarem a inutilidade da ação judiciária, violação oculta à garantia de acesso útil à justiça $a^{256}$.

$\mathrm{Na}$ verdade o reconhecimento da insuficiência da regra estática do art. 333 do Código de Processo Civil não é novidade no direito brasileiro. O Código de Defesa do Consumidor, diploma vigente desde 1990, já reconhecia que uma situação de latente desigualdade das partes no que concerne ao acesso ao material probatório poderia ensejar a dinamização da distribuição estática, conforme a famigerada regra do art. $6^{\circ}$, VIII, da Lei $\mathrm{n}^{\circ} 8.078 / 90$.

\footnotetext{
${ }^{253}$ KNIJNIK, Danilo. As (perigosíssimas) doutrinas do "ônus dinâmico da prova" e da "situação de senso comum" como instrumentos para assegurar o acesso à justiça e superar a "probatio diabolica", cit., p. 944.

${ }^{254}$ PEYRANO, Jorge Walter; CHIAPPINI, Julio O. Lineamientos de las cargas probatorias “dinámicas". In: PEYRANO, Jorge Walter (Dir.); WHITE, Inês Lépori (Coord.). Cargas probatorias dinámicas. Buenos Aires, Rubinzal-Culzoni, 2008. p. 15.

${ }^{255}$ CARPES, Arthur Thompsen. A distribuição dinâmica do ônus da prova no formalismo-valorativo. Revista da AJURIS, Porto Alegre, v.3 3, n. 104, p. 12, dez. 2006.

${ }^{256}$ KNIJNIK, Danilo. As (perigosíssimas) doutrinas do "ônus dinâmico da prova" e da "situação de senso comum" como instrumentos para assegurar o acesso à justiça e superar a "probatio diabolica", cit., p. 943. "Importa destacar que el esquema legal de distribución del onus probandi que constituye el armazón que remata con La recordada regla de la carga de la prueba (se debe resolver contra quien corria el riesgo procesal de no probar), establece a priori un tanto rígidamente el referido reparto de esfuerzos probatorios. De ahí la aparición de doctrinas que han procurado dotar de mayor flexibilidad a dicho esquema. Sin embargo, cabe acotar, que algunos códigos procesales civiles ni siquiera mencionan cómo debe prorratearse el esfuerzo probatório y otros lo aluden pero de modo escueto y que genera vacilaciones" (PEYRANO, Jorge Walter. La regla de la carga de la prueba enfocada como norma de clausula del sistema, cit., p. 111112).
} 
A doutrina reconhece no CDC, art. $6^{\circ}$, VIII, uma concessão expressa e positivada no direito brasileiro a uma forma de dinamização do ônus probatório. O fundamento do referido art. $6^{\circ}$, VIII, é o mesmo da teoria das cargas dinâmicas, apenas que a previsão positivada no direito pátrio foi restrita às relações de consumo ${ }^{257}$. Diz-se a distribuição dinâmica por não se ater a preceitos rígidos e pré-concebidos, mas sim depender das circunstâncias do caso concreto ${ }^{258}$.

A pergunta que se faz é se esta solução comporta generalização? A proposta defendida no item anterior responde positivamente.

Outra perspectiva que se põe acerca do problema é o raciocínio de que os contratos ou convenções probatórios são nulos quando tornem excessivamente difícil para uma das partes o exercício do direito, conforme art. 333, p.único, II, do Código de Processo Civil. Danilo Knijnik questiona, então, a possibilidade de aplicar-se esta mesma regra de mitigação do p.único, inciso II, do art. 333, ao "caput" do mesmo dispositivo, no sentido de mitigação do ônus que implique probatio diabolica ${ }^{259}$.

Do p.único, II, do art. 333 se depreende um postulado geral de que a repartição do ônus probatório nunca deve tornar impossível ou excessivamente difícil a uma parte o exercício do direito.

Em resumo a distribuição dinâmica do ônus da prova compreende incumbir o encargo probatório a quem, pelas circunstâncias particulares do caso concreto, e sem que interesse se desempenha o papel processual de autor ou réu, se encontre em melhores condições de produzir a prova respectiva.

É bom anotar o que, pela própria conotação das afirmações até aqui feitas já deve ter ficado claro. Ou seja, a doutrina em questão comporta aplicação excepcional e subsidiária. A regra geral é a incidência das cargas probatórias na forma de repartição prevista na regra do art. 333 do Código de Processo Civil.

O que se propõe é uma solução para situações-limite problemáticas em que estas regras, a prevalecer sua incidência, implicam afronta a princípios constitucionais caros, a seguir arrolados.

\footnotetext{
${ }^{257}$ DALL'AGNOL JUNIOR, Antonio Janyr. Distribuição dinâmica dos ônus probatórios, cit., p. 92; CARPES, Arthur Thompsen. A distribuição dinâmica do ônus da prova no formalismo-valorativo, cit., p. 12-13.

${ }^{258}$ PEYRANO, Jorge Walter; CHIAPPINI, Julio O. Lineamientos de las cargas probatorias “dinámicas”, cit., p. 17.

${ }^{259}$ KNIJNIK, Danilo. As (perigosíssimas) doutrinas do "ônus dinâmico da prova" e da "situação de senso comum" como instrumentos para assegurar o acesso à justiça e superar a "probatio diabolica", cit., p. 944.
} 
Embora contando com precedentes antigos, conforme se verá oportunamente, a doutrina em questão ganhou corpo da Argentina, especialmente nos casos de responsabilidade civil profissional, principalmente na área médica. Expoente acerca do assunto é o jurista argentino Jorge Walter Peyrano ${ }^{260}$.

Dall'Agnol Junior arrola uma tríade de postulados que identificam a doutrina da repartição dinâmica das cargas probatórias ${ }^{261}$ : i) inaceitável o estabelecimento prévio e abstrato do encargo probatório; ii) ignorável é a posição da parte no processo; e iii) desconsiderável a distinção entre fatos constitutivos, extintivos, modificativos e impeditivos.

Arremata o mesmo autor: "o que ocorre, pelo visto, é uma flexibilização da doutrina tradicional, em homenagem ao princípio da efetividade da tutela jurisdicional, na medida em que essa objetiva, sem dúvida, garantir o direito a quem realmente o titule"262.

A teoria sob exame tem pelo menos quatro ordens de fundamentação: i) princípio da igualdade das partes em termos materiais, já que visa corrigir uma desigualdade real verificada no que respeita ao acesso ao acervo probatório; ii) respeito aos deveres de lealdade e colaboração das partes, os quais têm raiz em princípios como a probidade e boa-fé processuais ${ }^{263}$; iii) princípio do acesso à justiça ${ }^{264}$, especialmente sob a ótica de que simplesmente ensejar o ingresso no sistema judiciário não significa possibilitar o acesso à ordem jurídica justa, se não se assegura o pleno desenvolvimento de atividades processuais, notadamente a exposição da pretensão e das provas que lhe sustém; iv) fundamento mais remoto é identificado quando a doutrina ora exposta é analisada à luz da concepção de formalismo-valorativo, que tem em Carlos Alberto Álvaro de Oliveira seu principal expoente no cenário nacional. Basicamente cuida-se de lembrarmos que o processo, mais do que ferramente técnica, é intrumento ético destinado à concretização de valores que a sociedade, ao pô-los na Constituição, afirmou ter na mais alta conta ${ }^{265}$.

A idéia de repartição dinâmica do ônus da prova não é propriamente nova. Dall'Agnol identifica seu gérmen em Bentham, segundo quem a carga da prova deve ser

\footnotetext{
${ }^{260}$ Jorge W Peyrano, por sua vez, refere a origem espanhola da doutrina (La regla de la carga de la prueba enfocada como norma de clausula del sistema, cit., p. 112).

${ }^{261}$ DALL'AGNOL JUNIOR, Antonio Janyr. Distribuição dinâmica dos ônus probatórios, cit., p. 98.

${ }^{262}$ DALL'AGNOL JUNIOR, Antonio Janyr. Distribuição dinâmica dos ônus probatórios, cit., p. 98.

${ }^{263}$ Essas duas ordens de fundamentação são referidas por Knijnik (As (perigosíssimas) doutrinas do "ônus dinâmico da prova" e da "situação de senso comum" como instrumentos para assegurar o acesso à justiça e superar a "probatio diabolica", cit., p. 945).

${ }^{264}$ CARPES, Arthur Thompsen. A distribuição dinâmica do ônus da prova no formalismo-valorativo, cit., p. 15.

${ }^{265}$ CARPES, Arthur Thompsen. A distribuição dinâmica do ônus da prova no formalismo-valorativo, cit., p. 9.
} 
imposta àquela das partes que a possa produzir com menos inconvenientes. Também recorda Moacyr Amaral Santos, que citando Demogue, já anotava que o ônus da prova incumbe àquela das partes que a possa produzir com menos incômodo, vexame ou despesas $^{266}$. Também Augusto Mario Morello, propondo uma visão solidarista da repartição do ônus da prova, já havia referido o encargo probatório sobre quem esteja em melhores condições. Essa visão solidarista igualmente prestigia o princípio da cooperação. Há inclusive quem encontre no próprio Direito Romano o embrião deste pensamento.

Baseando-se nas conclusões do XVII Congreso Nacional de Derecho Procesal (Argentina) Peyrano refere as principais "novidades" acerca da doutrina em questão: i) em matéria de "desplazamiento de la carga de la prueba" a doutrina estudada é o capítulo mais atual e com mais consequiências práticas, anotando-se que acolhem-na também com denominação diversa, como é o caso de Augusto Mario Morello que fala em princópio da solidariedade probatória; ii) a doutrina das cargas probatórias dinâmicas é considerada "doutrina recebida". Ademais, deve haver um especial cuidado na valoração da prova produzida pela parte em melhores condições porque esta também terá maiores possibilidades para desvirtuar tal prova em seu próprio benefício; iii) é recomendável a regulamentação legal do assunto, porém não em disposições taxativas ou demasiado casuísticas, que possam ser interpretadas de maneira inflexível, dificultando-se o ajuste ao caso concreto; iv) há um certo risco de que a invocação da doutrina em questão de ofício e no momento de sentenciar possa implicar afronta à garantia da defesa em juízo, por acarretar surpresa $^{267}$.

Acerca desta última questão, Jorge W. Peyrano assevera que a tendência é afastar os receios do "fantasma" do cerceamento de defesa. Primeiramente que a se considerar esta doutrina como concepção recebida, tratar-se-ia de um argumento de direito e como tal invocácel de ofício pelo Tribunal. Demais disto a previsão, por exemplo, de uma audiência preliminar na qual o juiz possa advertir às partes sobre a possibilidade de inversão, eliminaria o risco apregoado ${ }^{268}$. A aplicação da teoria seria também chancelada pelo dever

\footnotetext{
${ }^{266}$ DALL'AGNOL JUNIOR, Antonio Janyr. Distribuição dinâmica dos ônus probatórios, cit., p. 99.

${ }^{267}$ PEYRANO, Jorge Walter; CHIAPPINI, Julio O. Lineamientos de las cargas probatorias "dinámicas", cit., p. 21-22.

${ }^{268}$ No Brasil audiência tal é prevista pelo art. 331 do Código de Processo Civil, embora a opinião prevalente atualmente indique sua não-obrigatoriedade.
} 
do órgão judicial de apreciar todos os elementos de prova coletados "mediante la aplicación de la regla de la sana crítica" ${ }^{, 69}$.

Segundo ainda a lição de Knijnik, há limites materiais e formais à aplicação da doutrina $^{270}$. Os primeiros estariam assim elencados: i) não pode a idéia de distribuição dinâmica ser aplicada simplesmente para compensar a inércia ou a inatividade processual do litigante inicialmente onerado; ii) não é suficiente igualmente que uma das partes esteja em melhores condições para produção da prova se, quem invoca a dinamização, não prove estar impossibilitada de produzir a prova; iii) a dinamização não pode conduzir à probatio diabolica reversa (isto é impor ao adversário uma prova impossível ou extremamente difícil), assim como não implica o estabelecimento de presunções de circunstâncias ou fatos; iv) por fim, a aplicação de tal doutrina não pode conduzir a parte onerada em razão da dinamização a produzir prova contra si, em ofensa ao conhecido princípio constitucional nesta seara.

A respeito desta última questão, contudo, rebate Jorge W. Peyrano que o princípio referido é mais "folclórico" no mundo jurídico do que real, afirmando ser um preceito de origem desconhecida e sem expressão no direito positivado histórico. Cita Mercader para observar que o princípio em exame tem origem na jurisprudência germânica bárbara, quando o pleito se resolvia numa luta perante a assembléia popular, e que depois foi assimilado ao processo penal. Lembra também que todas as leis processuais civis do mundo consagram institutos que, analisados rigorosamente, comportam a produção de prova em favor do adversário (o autor fala na “absolución de posiciones”) ${ }^{271}$.

Os limites formais são assim arrolados: i) a dinamização após o encerramento da instrução sem dar às partes a oportunidade de produção ou complementação da prova afronta o contraditório, pois as partes não podem ser surpreendidas com a decisão de dinamização; ii) deve o juiz, antes de proceder à referida dinamização, intimar as partes e fundamentar sua decisão pena de caracterizar-se retroatividade oculta.

Outrossim, a aplicação da doutrina das cargas probatórias dinâmicas diz respeito a apenas determinados fatos e circunstâncias, e não a todo o material probatório. Não

\footnotetext{
${ }^{269}$ PEYRANO, Jorge Walter; CHIAPPINI, Julio O. Lineamientos de las cargas probatorias "dinámicas”, cit., p. 23.

${ }^{270}$ KNIJNIK, Danilo. As (perigosíssimas) doutrinas do "ônus dinâmico da prova" e da "situação de senso comum" como instrumentos para assegurar o acesso à justiça e superar a "probatio diabolica", cit., p. 947-948.

${ }^{271}$ PEYRANO, Jorge Walter. La doctrina de las cargas probatorias dinámicas y la máquina de impedir en materia jurídica, cit., p. 93-94.
} 
acarreta um "desplazamiento" completo da carga probatória, senão parcial, mantendo-se sobre a parte "beneficiada" certos esforços probatórios ${ }^{272}$.

Pode também suceder que quem prima facie se encontre em melhores condições de prova, na realidade não o esteja. Nestes casos não há falar em ingerência da doutrina examinada. Quando as dificuldades atingem tanto ao autor como ao réu não há justificativa para diversa distribuição do onus probandi, o que até acarretaria quebra de basilares princípios processuais $^{273}$.

A doutrina admite sem maiores rebuços a compatibilidade da teoria da dinamização do ônus probatório com o direito brasileiro ${ }^{274}$. Arthur Carpes refere expressamente acerca da dinamização no caso da parte que está em melhores condições econômicas de produzir a prova, no que a doutrina da carga dinâmica e o tema central do presente estudo acerca do acesso à justiça sob a ótica da condição econômica das partes se entrelaçam.

É bom anotar também que o tema já tem perpassado a jurisprudência. É sempre citado, a este respeito, o Recurso Especial n 69.309/SC, de Relatoria do Ministro Ruy Rosado de Aguiar, julgado em 18 de junho de 1996 (já se vão quase quinze anos). A ementa, no que interessa ao assunto em observação, está assim redigido: "Não viola regra sobre a prova o acórdão que, além de aceitar implicitamente o principio da carga dinâmica da prova, examina o conjunto probatório e conclui pela comprovação da culpa dos réus (...)". Vale anotar que na espécie cuidava-se de caso de responsabilização civil profissional na área médica.

No universo do Tribunal de Justiça do Estado de São Paulo merecem referência alguns precedentes, como aquele a seguir ressaltado:

“AGRAVO DE INSTRUMENTO - Ação civil pública ambiental - Ônus da prova a cargo do requerido - Teoria das Cargas Processuais Dinâmicas que está lastrada na simples idéia de que se pode incumbir a carga probatória a quem, pelas circunstâncias do caso e sem interessar se é autor ou réu na ação, se encontre em melhor condição para produzi-la Valor dos honorários periciais mantido - Necessidade de suspensão do processo até cumprimento de cartas precatórias - Artigo 338 do CPC -

\footnotetext{
${ }^{272}$ PEYRANO, Jorge Walter. La doctrina de las cargas probatorias dinámicas y la máquina de impedir en materia jurídica, cit., p. 95.

${ }^{273}$ PEYRANO, Jorge Walter. La doctrina de las cargas probatorias dinámicas y la máquina de impedir en materia jurídica, cit., p. 96.

${ }^{274}$ KNIJNIK, Danilo. As (perigosíssimas) doutrinas do "ônus dinâmico da prova" e da "situação de senso comum" como instrumentos para assegurar o acesso à justiça e superar a "probatio diabolica", cit., p. 950; CARPES, Arthur Thompsen. A distribuição dinâmica do ônus da prova no formalismo-valorativo, cit., p. 17; DALL'AGNOL JUNIOR, Antonio Janyr. Distribuição dinâmica dos ônus probatórios, cit., p. 104-105.
} 
Agravo de instrumento parcialmente provido" (Agravo de Instrumento $\mathrm{n}^{\circ}$ 759.433.5/4, São Sebastião, Rel. Samuel Junior, julgado em 10/07/08).

No voto condutor lê-se acerca do já citado art. 333 do Código de Processo Civil:

"esta regra foi erigida à luz de um processo concebido sob a ótica dos direitos privados e da igualdade formal, que não condiz com a realidade de relações de massa e assimétricas, como é o caso das relações de consumo e também das ações civis ambientais.

Assim, em princípio, há necessidade de flexibilização das regras, para que possa ser encontrada a verdade real e para que questões formais não superem as de fundo. Por isso, a luz de moderna orientação doutrinária, que como se verá mais adiante já vem sendo encampada pela jurisprudência, em casos como o presente a produção da prova deve ser carreada à parte que apresente melhores condições de produzi-la, à luz da chamada Teoria das Cargas Probatórias Dinâmicas".

Há inúmeros outros precedentes da mesma Corte. Vale ressaltar, contudo, o posicionamento no que respeita à famigerada questão de se saber se a aplicação da teoria pode chegar a causar a inversão do custeio da prova.

Em sentido negativo responde-se:

"A teoria da distribuição dinâmica da carga das provas, oriunda da Argentina e do Uruguai, visa a uma nova interpretação do art. 333 do CPC; tem aplicação restrita a casos especiais e cuida de quem deve produzir determinada prova. Cuida da produção, não do pagamento da prova. A teoria não altera a aplicação do art. 33 ; pois custeia a prova quem tem o ônus de produzi-la. Inexistente demonstração de que a ré tenha melhor condição para produzir a prova, a teoria não tem aplicação. Cabe ao autor custear a prova que requereu" (TJSP, Agravo de Instrumento ${ }^{\circ}$ 990.10.037925-9, Rel. Torres de Carvalho, julgado em 29 de julho de 2010).

Vê-se que a doutrina em questão tem logrado boa inserção no âmbito das lides versando questões ambientais e versando direitos do consumidor em geral, além daqueles conflitos nos quais originou-se sua aplicação (responsabilidade do profissional médico).

Cito ainda dois precedentes em que a aplicação da doutrina em estudo teve por fundamento evitar estivesse uma das partes (por sinal consumidor) sujeito à prova de "fato" negativo:

"PROCESSO CIVIL - FATO NEGATIVO - PROVA DIABÓLICA TEORIA DA DISTRIBUIÇÃO DINÂMICA DO ÓNUS DA PROVA CABIMENTO. Em atenção ao princípio da igualdade, aplica-se a teoria da distribuição dinâmica do ónus da prova por ser impossível a demonstração do fato negativo pelo consumidor" (TJSP, Apelação $\mathrm{n}^{\circ}$ 
9203036-40.1005.8.26.0000, Rel Gilberto Leme, julgado em 05/04/2011).

"Agravo de instrumento. Inscrição indevida do nome da autora no rol de inadimplentes. Alegação de que não possui o original do contrato para a realização de eventual realização de perícia grafotécnica. Impossibilidade de onerar a autora à produção de prova diabólica. Teoria da distribuição dinâmica do ônus da prova, segundo a qual, a parte que possuir melhores condições, deverá produzir a prova - Aplicação do art. 389, II, do CPC Provimento" (TJSP, Agravo de Instrumento $\mathrm{n}^{\circ}$ 994.10.377570-8, Rel Enio Zuliani, julgado em 25/11/2010).

É importante ressaltar, juntamente com Dall'Agnol Jr, que é "notável o liame que se faz, no caso, entre a teoria da carga dinâmica e o ativismo judicial, segundo sua expressão positivada"275. O mesmo autor destaca que a doutrina da distribuição dinâmica não implica propriamente inversão do ônus probatório, mas sim de atribuição, concluindo que o processo civil brasileiro está impregnado de princípios que se ajustam perfeitamente à doutrina da carga dinâmica, notadamente os princípios da probidade processual e do dever de colaboração para com o julgador (cf. art. 14 do Código de Processo Civil); e o princípio da solidariedade, que segundo defende, emerge dos arts. 125, I e III; 131 e 130, in fine, todos do Código de Processo Civil. Não custa recordar também a disposição do art. 339 do Código de Processo Civil, que estabelece um dever de colaboração do qual ninguém (o que inclui as partes) se exime.

Cuida-se, na verdade, de uma nova atribuição distinta dos parâmetros legais estáticos, e feita de acordo com as peculiaridades do caso concreto, em que uma das partes está em posição privilegiada em relação à outra no que respeita a potencialidades probatórias.

Numa circunstância ainda a aplicação da dinamização viria a calhar. Cuida-se da inviabilização da prova por ato culposo do adverso processual, em afronta ao dever de cooperação (p.ex. destruição de documento relevante para a lide pelo adversário que tem consigo o documento). A rigor alterações relacionadas à repartição do ônus da prova para enfrentar situações deste jaez são pontuadas na legislação positiva.

Embora com restrição à exibição de coisa ou documento, o art. 359, I e II, do Código de Processo Civil, prescreve que o juiz admita como verdadeiros fatos que por meio de exibição de documentos ou coisa pretendia uma parte provar, quando haja recusa ilegítima da outra em apresentá-los em juízo (ou mesmo quando o adversário que os tenha

${ }^{275}$ DALL'AGNOL JUNIOR, Antonio Janyr. Distribuição dinâmica dos ônus probatórios, cit., p. 102. 
consigo mantenha-se silente e não efetue a exibição no prazo legal). Verifica-se ainda hipótese de mesma natureza no caso da recusa à realização de exame médico ordenado por juiz (art. 232 do Código Civil) ${ }^{276}$.

Uma última distinção merece ser feita, e diz ela respeito à chamada doutrina do senso comum, facilmente confundível com a teoria da distribuição dinâmica, porém com traços distintos marcantes ${ }^{277}$.

Segundo a doutrina do senso comum, a existência de determinadas circunstâncias provadas nos autos autorizariam o julgador a, conforme as máximas da experiência, considerar demonstrada outra, sem a necessidade de realizar perícia, e a despeito da natureza técnica da matéria.

Talvez o que gere certa confusão, por vezes, com a idéia de dinamização do ônus da prova, é a larga incidência desta doutrina também em sede de culpa profissional. É bom de ver, contudo, que ela não opera nova atribuição do ônus da prova nem implica sua inversão, remetendo, na verdade, ao campo da valoração probatória, na forma dos arts. 131 e 335 do Código de Processo Civil.

Seriam dois os pressupostos que autorizariam a incidência desta ordem de idéias: a) dano causado em razão de algo que está sob o controle exclusivo do réu e b) superveniência de danos incompatíveis com uma operação cuidadosa da coisa sob controle deste $^{278}$.

Em arremate, anota-se que a doutrina da carga dinâmica tende a enraizar-se em outros quadrantes do direito positivo brasileiro, como se vê do Anteprojeto de Código de

\footnotetext{
${ }^{276}$ Danilo Knijnik distingue, na verdade, esta hipótese em duas: a) inviabilização da prova por ato culposo da parte contrária e b) inviabilização da prova por violação dos deveres de cooperação por um dos litigantes, salientando nesta segunda hipótese que se a violação implica apenas dificuldade à produção da prova pelo adversário, então a solução estaria na aplicação das sanções previstas para a litigância de má-fé; porém se efetivamente impossibilitam a prova, então o caso seria de dinamizar o ônus probatório (KNIJNIK, Danilo. As (perigosíssimas) doutrinas do "ônus dinâmico da prova" e da "situação de senso comum" como instrumentos para assegurar o acesso à justiça e superar a "probatio diabolica", cit., p. 947). De nossa parte cremos que a distinção é desnecessária, porque redutível a uma única situação. Falar-se em violação do dever de cooperação implica necessariamente pensar-se num ilícito processual que, segundo pensamos, para configurar-se depende pelo menos de culpa. Se a prova inviabilizou-se por caso fortuito ou força maior não há como falar nem em ato culposo da parte que tinha acesso à prova, nem em violação de dever processual algum por parte dela.

${ }^{277}$ KNIJNIK, Danilo. As (perigosíssimas) doutrinas do "ônus dinâmico da prova" e da "situação de senso comum" como instrumentos para assegurar o acesso à justiça e superar a "probatio diabolica", cit., p. 948-949.

${ }^{278}$ KNIJNIK, Danilo. As (perigosíssimas) doutrinas do "ônus dinâmico da prova" e da "situação de senso comum" como instrumentos para assegurar o acesso à justiça e superar a "probatio diabolica", cit., p. 950. $\mathrm{O}$ autor em questão assim classifica a referida teoria: "trata-se de perigosíssima doutrina, a exigir enorme cautela e uma fundamentação apurada" (cit., p. 950), daí porque restringe sua aplicação a situações excepcionalíssimas.
} 
Processo Coletivo Brasileiro, em que dois dispositivos merecem destaque, a saber, os $\S \S 1^{\circ}$ e $3^{\circ}$ do art. 11 :

"Sem prejuízo do disposto no artigo 333 do Código de Processo Civil, o ônus da prova incumbe à parte que detiver conhecimentos técnicos ou informações específicas sobre os fatos, ou maior facilidade em sua demonstração.

Durante a fase instrutória, surgindo modificação de fato ou de direito relevante para o julgamento da causa (parágrafo único do artigo $5^{\circ}$ deste Código), o juiz poderá rever, em decisão motivada, a distribuição do ônus da prova, concedendo à parte a quem for atribuída a incumbência prazo razoável para sua produção, observado o contraditório em relação à parte contrária (artigo 25 , parágrafo $5^{\circ}$, inciso IV)".

Ainda merece destaque o art. 358, "caput” e parágrafos do Projeto de Código de Processo Civil, que expressamente acolhe a doutrina da distribuição dinâmica das cargas probatórias, inclusive ressaltando os limites formais já apontados:

"Art. 358. Considerando as circunstâncias da causa e as peculiaridades do fato a ser provado, o juiz poderá, em decisão fundamentada, observado o contraditório, distribuir de modo diverso o ônus da prova, impondo-o à parte que estiver em melhores condições de produzi-la.

$\S 1^{\circ}$ Sempre que o juiz distribuir o ônus da prova de modo diverso do disposto no art. 357 , deverá dar à parte oportunidade para o desempenho adequado do ônus que lhe foi atribuído.

$\S 2^{\circ}$ A inversão do ônus da prova, determinada expressamente por decisão judicial, não implica alteração das regras referentes aos encargos da respectiva produção". 


\section{PROCESSO JUSTO E ÉQUO ${ }^{279}$. ACESSO À JUSTIÇA E ASSISTÊNCIA JUDICIÁRIA}

Buscar relacionar os três temas supra apontados é tarefa fundamental em qualquer estudo sério acerca da relevância da condição econômica das partes na efetivação de um processo justo, que reflita um Estado Democrático de Direito e os anseios da sociedade. Dizer que o princípio da inafastabilidade ou o direito de ação são garantias constitucionais de primeira grandeza não acresce muito à fórmula já bastante dita e repetida em doutrina e jurisprudência (e que nem por isto pode-se dizer tenham sido concretizadas na experiência brasileira, mais acostumada às solenes declarações e promessas que com reais efetivações de direitos).

Também não representaria grande novidade lembrar que a assistência jurídica integral e gratuita aos economicamente menos favorecidos é igualmente assegurada em nível constitucional.

O que cumpre fique registrado com ênfase é que o conceito já vergastado de devido processo legal tem experimentado uma evolução especialmente na última década, rumo a um moderno garantismo que induz novas exigências à fórmula difundida de due processo of $l a w^{280}$. Tais exigências são sintetizadas por Luigi Paolo Comoglio em três perguntas:

\footnotetext{
${ }^{279}$ Merecem ser transcritas as palavras de Federico Carpi acerca da importância, no contexto europeu, da garantia do justo processo ofertada pela Corte de Estrasburgo: "A ben vedere la vera, e forse única, rivoluzione copernicana in matéria processuale nella sconda meta Del XX secolo sta próprio in tale convenzione e nella previsione, in essa contenuta, della tutela giurisdizionale offerta dalla Corte europea per i diritti dell'uomo di Strasburgo in caso di violazione, normativa e/o di fatto, dei diritti fondamentali, e fra esi di quelli garantistici Del processo, nell'otica soggettiva, cioè indipendenza e imparzialità del giudice, ed oggettiva, e cioè contraddittorio, eguaglianza delle armi, efficienza ed effettività, durata ragionevole, pubblicità mediata (free press - fair trial, con equo bilanciamento) e immediata (controllo del pubblico e partecipazione popolare, secondo il nostro art. 102, comma $3^{\circ}$, cost.)" (A proposito di giusto processo. Rivista Trimestrale di Diritto e Procedura Civile, Milano, ano LXI, n. 1, p. 293, 2007).

${ }^{280} \mathrm{~A}$ doutrina reconhece esta evolução, mesmo que não intencionalmente, quando propõe releituras evolutivas de velhos conceitos e princípios atrelados ao acesso à justiça, como é da inafastabilidade, não visto mais como simples garantia de apreciação pelo Judiciário de qualquer lesão ou ameaça de lesão a direito, mas como garantia de tutela adequada, efetiva e rápida: "O princípio da inafastabilidade garante uma tutela jurisdicional adequada à realidade da situação jurídico-substancial que lhe é trazida para solução. Ou seja, garante o procedimento, a espécie de cognição, a natureza do provimento e os meios executórios adequados às peculiaridades da situação de direito material. É de onde se extrai, também, a garantia do devido processo legal. E daí se retira o princípio da adequação do procedimento, que nada mais é do que um subproduto do princípio da adequação da tutela jurisdicional" (DIDIER JR, Fredie. Notas sobre a garantia constitucional do acesso à justiça: o princípio do direito de ação ou da inafastabilidade do Poder Judiciário. Revista de Processo, São Paulo, v. 27, n. 108, p. 28, out./dez. 2002).
} 
a) Como se poderia prestar uma Justiça concretamente acessível a todos?

b) Como se pode garantir aos litigantes um direito de ação que não seja puramente teórico, mas sim efetivo, concorrendo para reforçar o direito a um processo justo e équo?

c) Como se pode assegurar a efetividade da tutela jurisdicional, como requisito essencial de Justiça em qualquer ordenamento jurídico socialmente avançado? ${ }^{281}$

Segue Comoglio observando que respostas satisfatórias a estas questões somente podem advir a partir de uma superação ou revisão de algumas idéias que são por ele assim alinhavadas: i) uma concepção puramente formal de acesso ao Poder Judiciário; ii) uma paridade de armas que assegure aos litigantes que a decisão final de mérito dependa mais da consistência ou inconsistência da pretensão, que da diferença de habilidade ou capacidade econômica de uma das partes em confronto com o adversário; iii) a carga intolerável com os custos e despesas processuais, que em casos mais complexos, podem se estender por anos; iv) o tempo excessivamente longo da atividade judicial, como fator primário de gênese e proliferação de denegação de justiça em sentido substancial; v) as gritantes insuficiências e deficiências do sistema de proteção judiciária aos necessitados, fundado tradicionalmente no munus honorificum dos profissionais do foro e vi) inadequada forma de tutela dos interesses difusos, coletivos e fragmentários ${ }^{282}$.

Ademais, o direito de invocar a jurisdição de uma corte, tribunal ou magistrado traduz-se na impossibilidade de privar-se qualquer um não apenas do ato inicial de impulso do procedimento, mas também dos atos processuais subseqüentes, que são necessários à obtenção da tutela pretendida ${ }^{283}$.

Destas poucas e preliminares afirmações já emerge claro que a idéia de acesso à justiça em sentido substancial (isto é, compreendendo não apenas o ingresso em juízo, mas o direito a um procedimento justo, no qual se assegure a participação em paridade de armas com o adverso e ao final, uma tutela efetiva) constitui o núcleo do conceito de processo justo e équo, que por sua vez representa uma evolução, um aprimoramento, do princípio de due processo of law.

\footnotetext{
${ }^{281}$ Tradução livre do seguinte texto: "a. come si possa render ela giustizia concretamente accessibile a tutti; b. come si riesca a garantire alle parti in lite um diritto di azione, che non sia puramente teórico, ma sia effetivo, concorrendo a rafforzare il diritto ad un processo 'equo' e 'giusto'; c. come sia consentito assicurare l'effettività della tutela giurisdizionale, quale requisito essenziale della giustizia in qualsiasi ordinamento giuridico socialmente avanzato" (COMOGLIO, Luigi Paolo. Garanzie costituzionali e "giusto processo" (modelli a confronto). Revista de Processo, São Paulo, v. 23, n. 90, p. 111, abr./jun. 1998).

${ }^{282}$ COMOGLIO, Luigi Paolo. Garanzie costituzionali e "giusto processo" (modelli a confronto), cit., p. 111.

${ }^{283}$ COMOGLIO, Luigi Paolo. Garanzie costituzionali e "giusto processo" (modelli a confronto), cit., p. 112.
} 
Comoglio segue apresentando modelos de processo justo e équo conforme as perspectivas de autor e réu respectivamente. Sob a ótica do primeiro, constitui-se a ação em sentido estrito, compreendendo o acesso efetivo à corte, isto é, o poder de promover o procedimento civil, levando a cabo a demanda em face daquele que se julga o violador de seu direito; em sentido mais largo, ação abarca o direito de ser ouvido pelo juiz, o poder de agir no curso do processo, alegando os fatos relevantes, produzindo as provas necessárias, enfim, debatendo em geral a causa.

Na perspectiva do réu, o caráter dialético do processo incorpora o direito da parte demandada a um procedimento leal e correto, que se apresenta sob diferentes manifestações: i) direito a uma citação regular, mediante adequada forma de notificação do ato inicial do processo; ii) direito, conexo e derivado do primeiro, de ser constantemente informado de todos os eventos processuais ulteriores, que afetem sua possibilidade de defesa efetiva no curso do processo; iii) o direito de se fazer representar e defender por profissional legalmente habilitado; iv) o direito à prova, incluindo o direito de reagir e de se defender das alegações de fato e da atividade probatória contrária, seja produzindo prova em seu favor, seja impugnando a prova do adversário; v) direito de assistir pessoalmente à colheita de prova oral; vi) direito de não ser vinculado a decisões de juízo formado inter alios, sobre o qual não tenha tido a oportunidade de se manifestar e vii) o direito de ser ouvido e julgado por um magistrado imune à "ciência privada", isto é, que decida a causa unicamente com fundamento na prova e demais elementos colhidos no contraditório processual ${ }^{284}$.

A seguir o autor que vimos estudando toca ponto de nosso máximo interesse, a saber, a análise do desenho brasileiro de devido processo legal, esboçado a partir da Constituição da República de 1988, à luz dos contornos já apresentados de processo justo e équo. Comoglio reputa a Constituição brasileira como na vanguarda dos ordenamentos modernos, em palavras que merecem transcrição:

"Sviluppando con coerenza alcune bazilari opzioni ideologiche, peraltro
ben evidenziate nel Preambolo, la Costituzione federale Del 1988 - pure
caratterizzata dal requisito della rigidità - configura un sistema di
garanzie processuali, che, per l'analicità e per la precisione delle sue
espressioni primarie, può ben dirsi progredito ed, in certi punti,
addiruttura all'avanguardia, nel panorama delle Costituzioni moderne"285

${ }^{284}$ COMOGLIO, Luigi Paolo. Garanzie costituzionali e "giusto processo" (modelli a confronto), cit., p. 113-114.

${ }^{285}$ COMOGLIO, Luigi Paolo. Garanzie costituzionali e "giusto processo" (modelli a confronto), cit., p. 138-139. 
A partir daí, faz-se um detalhado estudo acerca do catálogo de liberdades e direitos subjetivos objeto de importantes declarações normativas contidas na Constituição, como componentes deste direito ao processo (mais que um simples direito à ação judicial). No rol, o autor italiano arrola desde a garantia da inafastabilidade, transitando pelo contraditório e ampla defesa, necessidade de motivação das decisões judiciais, até a imperiosa assistência jurídica integral e gratuita aos necessitados (CR, art. 5, LXXIV).

Os reflexos deste novo modelo constitucional surgem mais tanto maior seja a abertura da ciência processual a um objetivo comum de política judiciária, a saber, o contínuo melhoramento da efetividade processual, emergindo como instrumento de progresso evolutivo do ordenamento jurídico. Estes reflexos operam, na opinião do autor, em duas direções.

De um lado, rumo a um devido processo legal ressuscitado, capaz de em si sintetizar a plenitude garantística, atuando como catalisador dos valores fundamentais que informam o sistema judiciário. Releva o aspecto ético e a conotação deontológica do processo. Neste contexto está a ênfase ao papel diretivo do juiz, voltado à realização destes valores fundamentais, além do que, a legitimação do processo ainda deriva da circunstância de não estar subordinado a uma rígida e pré-constituída legalidade formal, mas sim perfeitamente compatível com um sistema de forma flexível e elástica, no qual o poder discricionário do juiz não corra o risco de converter-se em arbítrio, pois que encontra limite técnico intransponível naqueles próprios valores constitucionais que constituem pressupostos a um processo équo e justo.

O outro vetor para o qual aponta o modelo constitucional de devido processo legal a que temos nos referido diz respeito à efetividade do processo, a ser assegurada no plano técnico-prático, ofertando-se forma de tutela adequada à vista da relação jurídica controvertida $^{286}$.

À guisa de síntese conclusiva, as palavras que seguem são significativas:

"Ciò conferma e ribadisce, ancora una volta, perchè emerga daí nuovi modelli costituzionalli - attraverso il riferimento, ache testuale, al devido processo (o al proceso debido) - la più attenta apertura cuturale verso quei valori, da considerarsi ormai come le mete permanenti del diritto processuale costituzionale. Ma cio, soprattutto, spiega e giustifica perchè mai, in quei medesimi modelli, sai forte l'incidenza dei profili eticomoralli e deontologici, che nobilitano il processoi, facendone uno strumento efficiente di progresso evolutivo dell'ordinamento

\footnotetext{
${ }^{286}$ COMOGLIO, Luigi Paolo. Garanzie costituzionali e "giusto processo" (modelli a confronto), cit., p. 146.
} 
costituzionale e giuridico, non più dominato da un rigido formalismo fine a se stesso o da garanzie puramente astratte di legalità procedurale" ${ }^{\text {287 }}$.

Fala-se então no surgimento de um novo e moderno jusnaturalismo processual, como uma síntese terminológica do movimento que vimos descrevendo.

Esta evolução de que temos tratado corresponde àquela a que a doutrina também se refere como superação da idéia de procedural due process (devido processo legal processual), entendido simplesmente como processo ordenado, com enfoque estritamente processualístico (orderly proceeding) ${ }^{288}$.

Fala-se então em devido processo legal substancial, que neste sentido diz respeito à limitação do poder estatal, à preocupação com a igual proteção dos direitos do homem e dos interesses da comunidade quando confrontados, ressaltando-se o processo como instrumento que deveria ser apto a produzir decisões justas, razoáveis e proporcionais com a realidade ${ }^{289}$.

\begin{abstract}
"Respeitar as garantias mínimas de meios e de resultados significa efetivar o devido processo legal substancial e ao mesmo tempo fazer cumprir o objetivo central de todo o processo civil, que é justamente o acesso à ordem jurídica justa. Eis o princípio-síntese a ser atingido mediante o devido processo legal; com ele atinge-se o processo justo que é aquele portador de tutela jurisdicional a quem efetivamente tem razão meios justos, resultados justos.

Em relação ao devido processo legal substancial e o acesso à ordem jurídica justa, há uma verdadeira identidade, já que, de um lado representa verdadeira justiça substancial e, de outro, constitui arrimo das liberdades e dos direitos fundamentais e projeta-se no processo como um
\end{abstract}

\footnotetext{
${ }^{287}$ COMOGLIO, Luigi Paolo. Garanzie costituzionali e "giusto processo" (modelli a confronto), cit., p. 148.

${ }^{288}$ LUCON, Paulo Henrique dos Santos. Devido processo legal substancial e efetividade do processo. In: MARTINS, Ives Gandra da Silva; JOBIM, Eduardo (Coords.). O processo na Constituição. São Paulo: Quartier Latin do Brasil, 2008. Em suas conclusões, o autor em questão arremata: "O modelo internacionalmente aceito do processo justo e équo está presente no sistema jurídico brasileiro e funda-se na cláusula geral do devido processo legal" (Devido processo legal substancial e efetividade do processo, cit., p. 296). Humberto Theodoro Junior tratanto desta idéia de processo justo e équo fala em "nova roupagem do devido processo legal", que conserva as conquistas procedimentais clássicas, porém as incrementa com a "otimização dos resultados alcançados no plano do direito de fundo", ressaltando, ao fim, que o compromisso do processo justo é o de proporcionar a efetividade (THEODORO JUNIOR, Humberto. Estrutura e função no campo do direito processual: visão estática e visão dinâmica do fenômeno jurídico. In: THEODORO JR, Humberto; LAUAR, Maira Terra (Coords). Tutelas diferenciadas como meio de incrementar a efetividade da prestação jurisdicional. Rio de Janeiro: GZ, 2010. p. 12).

${ }^{289}$ LUCON, Paulo Henrique dos Santos. Devido processo legal substancial e efetividade do processo, cit., $p$. 275-277. Vale ainda transcrever o seguinte excerto, extraído da mesma obra supra citada: "O devido processo legal processual e substancial representa, por todo o exposto, o núcleo central não da relativização (Kazuo Watanabe), mas da integração do binômio direito e processo e procura dar o máximo de eficácia às normas constitucionais para a efetivação do controle dos atos de poder e da igualdade substancial das partes no processo" (LUCON, Paulo Henrique dos Santos. Devido processo legal substancial e efetividade do processo, cit., p. 279).
} 
sistema legítimo de limitações ao poder do juiz e, por conseqüência, de limites ao exercício da jurisdição na correta aplicação do direito dotado de indispensável razoabilidade (fair and reasonable). Em síntese, a essência do devido processo legal substancial é: proteção a toda e qualquer ação arbitrária e não razoável” ${ }^{, 290}$.

A busca por instrumentos de garantia do efetivo acesso à justiça somente sobreveio como reação dos indivíduos às estruturas políticas, então habituadas a assegurar apenas formalmente direitos e garantias. O Direito é sempre impregnado de conteúdo ideológico e significação política, e o processo, embora seja sempre mostrado como instrumento técnico e aparentemente neutro, sofre e se modifica como todo o resto do Direito de acordo com as guinadas políticas, culturais e econômicas da sociedade ${ }^{291}$.

O componente ideológico é indissociável do processo civil, como o é de toda regulação positiva do agir humano em sociedade. Porém estudos estritamente técnicos são sempre necessários em torno do direito processual. Atualmente o principal condicionamento do processo é a realidade em si mesma, no qual o vertiginoso aumento de litigiosidade é dado marcante. É justamente este quadro que conduz à mudança de foco da doutrina, dos grandes temas técnicos para os problemas práticos causados pela defasagem entre demanda versus solução ${ }^{292}$. Aí a explicação para que o tema da efetividade seja indiscutivelmente o principal alvo das considerações da doutrina processual de nosso tempo.

Há uma nítida linha evolutiva do processo em correspondência ao caráter da relação Estado/súdito. Ao modelo de liberdades públicas, corresponde o processo voltado a assegurar ao cidadão aquele espaço mínimo protegido nas declarações de direito típicas daquilo que se convencionou chamar de "primeira geração" de direitos fundamentais. O processo nesta ótica passa de mera praxe a direito público subjetivo a recorrer ao poder jurisdicional, e sua função é assegurar a incolumidade desta esfera de direitos garantidos aos cidadãos. "Com a democratização do Estado o processo passa a ser tido como um instrumento posto ao cidadão com status de garantia constitucional. Em uma sociedade democrática o processo é visto como um dos modos de atuação política"293.

\footnotetext{
${ }^{290}$ LUCON, Paulo Henrique dos Santos. Devido processo legal substancial e efetividade do processo, cit., p. 297. ${ }^{291}$ SILVA, Marco Antônio Marques da. A efetividade do acesso à justiça, cit., p. 126.

${ }^{292}$ MONTERO AROCA, Juan. El derecho procesal en el siglo XX, cit., p. 76.

${ }^{293}$ SILVA, Marco Antônio Marques da. A efetividade do acesso à justiça, cit., p. 127.
} 
O direito processual reflete as idéias éticas, ideológicas e políticas que caracterizam uma dada sociedade. "Os sistemas políticos se refletem na norma constitucional e têm um efeito direto sobre as bases do direito processual civil"294.

\section{Assistência judiciária}

As noções trazidas no item anterior eram de capital importância, pois buscamos demonstrar o papel de proeminência, e mesmo de centralidade, da idéia de acesso à justiça no contexto do devido processo legal substancial, modelo de processo justo e équo. Há verdadeira identidade entre a idéia de devido processo legal substancial e acesso à ordem jurídica justa.

A partir das noções ora postas não é necessário grande esforço argumentativo para se perceber que um sistema eficaz e adequado à realidade de assistência jurídica aos menos favorecidos, como um dos principais fios condutores (senão o principal) da garantia de acesso à justiça, há de constituir a viga mestra, o alicerce, de qualquer sistema que se pretenda alinhado com um desenho de processo justo e équo. Propositalmente, falamos aqui em assistência jurídica (não apenas judiciária), bem como aludimos genericamente aos menos favorecidos (não apenas aos pobres), por razões que serão exploradas adiante.

O que por ora queremos deixar demarcado é o protagonismo que um sistema de

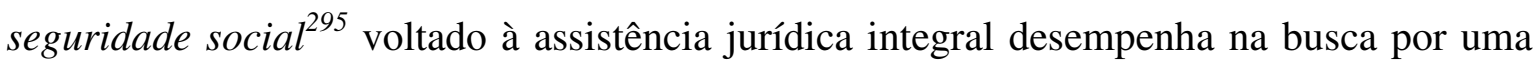
adequada prestação do serviço jurisdicional, que deveras represente bastião da liberdade, locus para exercício da cidadania, instrumento para a ruptura do confinamento dos mais carentes na sedimentada estratificação do corpo social.

Sobretudo deve-se pensar uma rede voltada à assistência jurídica integral e gratuita sob a ótica teleológica como uma instituição cujo êxito implicaria sua própria extinção, por desnecessidade ${ }^{296}$.

Em linhas precedentes tratamos da diversidade de condições econômicas das partes e seus efeitos sobre a almejada igualdade processual. Por isto é importante que fique registrado que o sistema de assistência jurídica integral tem dois desideratos que podem ser

\footnotetext{
${ }^{294}$ HABSCHEID, Walther J. As bases do direito processual civil, cit., p. 117.

${ }^{295}$ A expressão é de Paulo Henrique dos Santos Lucon, em artigo já citado (Devido processo legal substancial e efetividade do processo, cit., p. 292).

${ }^{296}$ LOPES, Maurício Antônio Ribeiro. Garantia de acesso à justiça: assistência judiciária e seu perfil constitucional. In: CRUZ E TUCCI, José Rogério et. al. Garantias constitucionais do processo civil: homenagem aos 10 anos da Constituição Federal de 1988. São Paulo: Ed. Revista dos Tribunais, 1999. p. 68.
} 
resumidos num jogo de palavras: assegurar igual acesso a uma Justiça igualitária, isto é, imparcial. Ou seja, espera-se que uma tal estrutura seja capaz romper o paradigma de acesso à Justiça apenas à parcela da sociedade que ostente determinadas características, tidas mesmo como vantagens em relação aos demais (p.ex. determinado grau de instrução e nível de informação; determinado nível de condições financeiras; etc. $)^{297}$.

Mas não apenas isto, pois que nada adiantaria assegurar ao menos favorecido o ingresso num sistema de resolução de conflitos (que não é necessariamente apenas o formal, representado pelo Poder Judiciário), se a originária desigualdade repercute no desenrolar do processo (isto é, processo de resolução de controvérsias, não se resumindo ao processo judicial, perante o Estado-juiz, nossas considerações nesta sede são mais amplas).

Fala-se então da obrigação do Estado também de "propiciar a todos iguais condições para, dentro do processo, superar as desigualdades de fato ... que lhes possibilitem, concretamente, sustentarem suas razões, produzirem suas provas, influírem sobre a formação do convencimento do juiz" ${ }^{298}$.

Há um ranço na praxe forense que costuma vincular assistência jurídica (especialmente a judiciária) à carência econômica. Embora este seja o principal enfoque de nosso estudo, não se pode deixar de registrar que esta conexão não é necessária. O ranço é compreensível, dada a alusão tradicional no ordenamento pátrio, especialmente em nível constitucional, da prestação de assistência aos que comprovem insuficiência de recursos, o que é observado também em nível infraconstitucional, com o vetusto diploma regente da matéria, segundo o qual, considera-se necessitado "para os fins legais, todo aquele cuja situação econômica não lhe permita pagar as custas do processo e os honorários de advogado, sem prejuízo do sustento próprio ou da família” (art. $2^{\circ}$, p.único, da Lei ${ }^{\circ}$ $1.060 / 50)$.

Veja-se, entretanto, que embora seja este o campo mais fecundo de incidência da assistência, pode ela ser prestada sem vinculação a esta circunstância de carência

\footnotetext{
297،Não há democracia, não há justiça social, não há respeito à dignidade humana onde não exista, concretamente assegurada pelo Estado, a igualdade de oportunidades diante da lei" (MORAES, Humberto Peña de. Assistência judiciária pública e os mecanismos de acesso à justiça, no Estado democrático. In: GRINOVER, Ada Pellegrini et al. (Coord.). Participação e processo. São Paulo: Ed. Revista dos Tribunais, 1988. p. 242). Ainda vale transcrever: "o princípio da isonomia exige, portanto, para sua existência efetiva, a assistência judiciária” (LOPES, Maurício Antônio Ribeiro. Garantia de acesso à justiça: assistência judiciária e seu perfil constitucional, cit., p. 69).

${ }^{298}$ GRINOVER, Ada Pellgrini. Assistência judiciária e acesso à justiça. Revista da Procuradoria Geral do Estado, São Paulo, n. 22, p. 18-19, jan./dez. 1984.
} 
econômica. É o que ocorre em sede processual penal, em que a necessidade de concreto e efetivo exercício do direito de defesa impõe nomeação de defensor ao acusado, seja ele economicamente necessitado ou não ${ }^{299}$.

Oportuna, por outro lado, uma constatação. Nota-se no cenário brasileiro que a chamada "classe média" encontra-se sob o enfoque do acesso à justiça em situação mais delicada que propriamente as classes menos favorecidas. É que normalmente não preenchem os pressupostos necessários para obter isenções de custas e taxas judiciárias, bem como para se servirem de serviços de defensoria e convênios (assistência judiciária em geral), porém não detém poder econômico suficiente que permita custear uma demanda ou obter o acompanhamento de profissionais qualificados ${ }^{300}$.

O panorama atual do ordenamento pátrio apresenta os dois luminares normativos em tema de assistência jurídica integral aos menos favorecidos. De um lado o inciso LXXIV do art. $5^{\circ}$ da Constituição da República, inserindo no rol dos direito e deveres individuais e coletivos a "assistência jurídica integral e gratuita aos que comprovarem insuficiência de recursos". De outro lado a regulamentação infraconstitucional, a famigerada Lei $n^{\circ} 1.060 / 50$. É de pasmar que a legislação em questão remonte a mais de cinqüenta anos, especialmente porque nunca se viveu período em que as mutações no corpo social sejam tão drásticas quanto rápidas.

De toda forma, saliente-se que o diploma contém alterações, porém a larga maioria remontando à década de 80 . A mais recente data de 2001 (Lei $n^{\circ} 10.317$ ), que inseriu entre as isenções albergadas pelo benefício, as despesas com a realização do exame de código genético - DNA que for requisitado pela autoridade judiciária nas ações de investigação de paternidade ou maternidade (art. $\left.1^{\circ}, \mathrm{VI}\right)$.

É preciso dizer que a norma constitucional retro salientada, segundo se entende, consubstancia direito público subjetivo, e é self executing ${ }^{301}$.

\footnotetext{
${ }^{299}$ GRINOVER, Ada Pellegrini. Assistência judiciária e acesso à justiça, cit., p. 20.0 art. 261 do Código de Processo Penal estipula: "Nenhum acusado, ainda que ausente ou foragido, será processado ou julgado sem defensor". E o parágrafo único arremata: "A defesa técnica, quando realizada por defensor público ou dativo, será sempre exercida através de manifestação fundamentada".

${ }^{300}$ SILVA, Marco Antônio Marques da. A efetividade do acesso à justiça, cit., p. 137. No mesmo sentido: CARVALHO, André de; RIBEIRO, Marcus Vinicius. Direitos humanos, inclusão jurídica e o papel da assistência jurídica no Brasil do século XXI, cit., p. 61.

${ }^{301}$ É o entendimento de Ada P.Grinover, fundado em Pontes de Miranda, e que embora se refira à previsão do anterior diploma constitucional, vale para o presente, já que similares as previsões constitucionais acerca do assunto (cf. Assistência judiciária e acesso à justiça, cit., p. 22).
} 


\section{Assistência judiciária; assistência jurídica e justiça gratuita}

Ada Pellegrini Grinover, com amparo em lição de Pontes de Miranda, distingue os conceitos de assistência judiciária e justiça gratuita. Este seria "um direito pré-processual exercível perante o juiz que deve prestar a jurisdição"; aquele estabeleceria em desfavor dos entes federativos um dever de organização, isto é, de se prover estruturas capazes de fornecer o serviço público em questão ${ }^{302}$.

A propósito do tal dever de organização, não custa ressaltar que o art. 134 da Constituição da República previu a Defensoria Pública como instituição essencial à função jurisdicional do Estado, "incumbindo-lhe a orientação jurídica e a defesa, em todos os graus, dos necessitados". É ainda sintomático que a norma constitucional contenha referência ao inciso LXXIV do art. $5^{\circ}$ da Constituição, indicando claramente que seria incumbência deste órgão a prestação do serviço público referido na norma núcleo dos direitos e garantias individuais e coletivos.

Outra distinção bastante propagada em doutrina é feita entre os conceitos de assistência jurídica e judiciária. A distinção é de relevo, porque a própria Constituição alude à assistência jurídica, não apenas à judiciária.

Entende-se que assistência judiciária é prestação de serviço restrita ao processo judicial, desde o ingresso em juízo e durante seu desenrolar. As principais formas por meio das quais o Estado se desincumbe desta tarefa são disponibilizando advogados para patrocínio das causas dos menos afortunados, e arcando com custos de atos processuais (como ocorre com as perícias).

A assistência jurídica, de sua banda, contém conceito mais largo, abrangendo atividades extra e pré-processuais, das quais a mais relevante é o aconselhamento jurídico. Já tivemos oportunidade de ressaltar a relevância da capacitação da sociedade para conhecimento dos direitos e reconhecimento de seus problemas como “jurídicos”.

Em verdade a doutrina anterior ao atual texto constitucional, ou contemporânea à sua elaboração, já defendia esta perspectiva ampliativa do conceito de assistência judiciária, que assim compreenderia "atividades técnico-jurídicas no campo da prevenção, da consultoria, do aconselhamento e da informação",303.

\footnotetext{
${ }^{302}$ GRINOVER, Ada Pellegrini. Assistência judiciária e acesso à justiça, cit., p. 22.

${ }^{303}$ MORAES, Humberto Peña de. Assistência judiciária pública e os mecanismos de acesso à justiça, no Estado democrático, cit., p. 240.
} 
"Claro que, nesse enfoque, amplia-se a concepção de 'assistência judiciária'. A ponto de tornar a expressão inadequada.

E se amplia, primeiro, com relação aos economicamente fracos, para estender-se à informação, da qual nasce a conscientização, e à orientação extraprocessual que, corretamente conduzida pelos canais institucionalizados da mediação, pode propiciar a solução pacífica de conflitos, constituindo-se em instrumento alternativo ao processo. Da 'assistência judiciária' passa-se, assim, à 'assistência jurídica'.

Em segundo lugar, amplia-se o conceito, para abranger os necessitados no plano jurídico, conquanto não o sejam no plano econômico"304.

Nota-se por este excerto que o vetor ampliativo vai no sentido objetivo, isto é, de alargar a qualidade de utilidades prestadas pelo serviço público de assistência judiciária (ou melhor, jurídica) e também no subjetivo, no sentido de compreender em expressões como necessitados, carentes, menos favorecidos, titulares de recursos insuficientes, não apenas os que assim sejam por razões econômicas, mas os que por quaisquer motivos sejam carentes de tutela jurídica ${ }^{305}$.

Oportuno neste passo observar a lacuna existente no ordenamento pátrio no que concerne à assistência pré ou extra-processual. A Lei $\mathrm{n}^{\circ} 1.060 / 50$, sobre não dispor de qualquer regra a respeito, é peremptória em estipular que os benefícios da assistência judiciária compreendem todos os atos do processo até decisão final do litígio, em todas as instâncias $\left(\operatorname{art} .9^{\circ}\right)$.

No Estado de São Paulo, no convênio firmado entre a Ordem dos Advogados do Brasil e a Defensoria Pública, acerca da atuação de advogados em suprimento à função deste órgão, cuja estrutura ainda é manifestamente insuficiente para atender à demanda,

\footnotetext{
${ }^{304}$ MORAES, Humberto Peña de. Assistência judiciária pública e os mecanismos de acesso à justiça, no Estado democrático, cit., p. 241.

305“(...) parece necessário rever o antigo conceito de assistência judiciária aos necessitados, porque, de um lado, assistência judiciária não significa apenas assistência processual, e porque, de outro lado, necessitados não são apenas os economicamente pobres, mas todos aqueles que necessitam de tutela jurídica" (GRINOVER, Ada Pellegrini. Assistência judiciária e acesso à justiça, cit., p. 21). No mesmo sentido da distinção entre assistência jurídica e judiciária, dela extraindo importantes conseqüências no que concerne à comprovação de insuficiência de recursos, tema que merecerá oportuna abordagem: RIZZATTO NUNES, Luiz Antônio. A assistência judiciária e a assistência jurídica: uma confusão a ser solvida. Revista do Instituto dos Advogados, São Paulo, v. 7, n. 14, p. 85, jul./dez. 2004.

Ainda: "Podemos conceituar o instituto da assistência jurídica gratuita como o direito público subjetivo da pessoa de ter acesso ao ordenamento jurídico de forma justa, assim entendido como a viabilização da consultoria jurídica, assistência postulatória judicial e administrativa, além da gratuidade processual e extraprocessual, a serem prestadas pelos poderes constituídos, uma vez comprovada a insuficiência de recursos ou ocorrida determinada situação jurídica de impotência individual ou coletiva de salvaguarda de direitos ou interesses, que seja de relevância à sociedade" (PRIETO ALVAREZ, Anselmo. O Estado social democrático de direito no Brasil e a assistência jurídica integral e gratuita. Revista dos Tribunais, São Paulo, v. 95, n. 848, p. 36-59, jun. 2006).
} 
também se constata patente omissão no que concerne aos serviços de orientação, consultoria ou aconselhamento.

A famigerada tabela que prevê os índices remuneratórios dos advogados que atuem na assistência não contém campo algum destinado à assistência extra-processual, logo, não há previsão de remuneração para quem a esta seara se dedique (que se o fizer, será por mera liberalidade). Quem milita no foro cotidianamente sabe das minúcias com que se avalia o tal "código remuneratório" das certidões necessárias ao pagamento dos honorários pelo Estado, e que ao mínimo sinal de qualquer incongruência, o pagamento é peremptoriamente sustado (o que, ressalte-se, é legítimo, já que são os recursos públicos).

Ora, por mais que se queira crer no espírito altruísta da nobre classe dos advogados, não se há de cerrar os olhos para a realidade de que a falta de remuneração é desestímulo capital para que qualquer um se dedique a este mister, ainda mais considerando-se o sucateamento das carreiras jurídicas, causado especialmente pelo inchaço da quantidade de profissionais que ano a ano encharcam o mercado.

O prejuízo de uma tal omissão mostra-se patente, por exemplo, em Estados onde se admite a conciliação pré-processual ${ }^{306}$, a ser levada a cabo por setores próprios, estruturados geralmente junto aos foros de primeiro e segundo graus, nos quais atuem conciliadores cadastrados junto aos juízos.

A existência de tais setores e sua atuação nos processos em curso é prática corriqueira, especialmente no Estado de São Paulo, em que várias Comarcas são dotadas de profícuas iniciativas neste sentido.

Falamos particularmente desta atuação antes mesmo do ajuizamento da ação, possibilitando-se a resolução do conflito antes de invadir as vias formais do Judiciário.

\footnotetext{
${ }^{306}$ No Estado de São Paulo, o art. $4^{\text {o do Provimento n }}$ 953/2005, do Conselho Superior da Magistratura prevê: "Artigo $4^{\circ}$ - A tentativa de conciliação poderá ocorrer antes do ajuizamento da ação.

$\S 1^{\circ}$ - Comparecendo o interessado diretamente, encaminhado através do Juizado Especial Cível ou pelo Ministério Público na atividade de atendimento ao público, o funcionário ou voluntário do Setor de Conciliação colherá sua reclamação, sem reduzi-la a termo, emitindo, no ato, carta-convite à parte contrária, informativa da data, horário e local da sessão de conciliação, facultada, ainda, a solicitação por meio de representante legal;

$\S 2^{\circ}$ - A carta será encaminhada ao destinatário, pelo próprio reclamante, ou pelo correio, podendo esse convite ser feito, ainda, por telefone, fax, ou meio eletrônico. A única anotação que se fará sobre o litígio refere-se aos nomes dos litigantes, na pauta de sessões do Setor;

$\S 3^{\circ}$ - Será feito o registro dos acordos, na íntegra, em livro próprio do Setor, sem distribuição;

$\S 4^{\circ}$ - Não obtida a conciliação, as partes serão orientadas quanto à possibilidade de buscar a satisfação de eventual direito perante a Justiça Comum ou Juizado Especial;

$\S 5^{\circ}$ - Descumprido o acordo, o interessado poderá ajuizar a execução do título judicial, a ser distribuída livremente a uma das Varas competentes, conforme a matéria versada no título executivo".
} 
O apoio dos advogados em iniciativas que tais é de fundamental importância, pois normalmente são eles que se habilitam à função de conciliadores, e sua atuação consciente junto ao assistido pode levar a resultados extremamente frutíferos.

Ocorre que por inexistir perspectiva alguma de contraprestação financeira nesta atuação pré-processual os advogados resistem à instalação de setores de conciliação abrangendo tais atividades, e naturalmente, mesmo que instalados, estimularão as partes a relegarem para o processo judicial eventual tentativa de composição amigável, caso em que poderiam haurir alguma retribuição.

Portanto, urge que os entes federativos, por meio dos órgãos competentes, e mesmo o próprio Poder Judiciário e a Ordem dos Advogados do Brasil, se mobilizem no sentido de assegurar aos patronos dedicados à assistência jurídica, a justa contraprestação também nos casos de assistência pré e extra-processual, de caráter consultivo e de aconselhamento. Afinal, na forma como a situação hoje se apresenta, indubitavelmente está a ocorrer ilícito enriquecimento do Estado em detrimento daqueles advogados que se dispõem a prestar um tal serviço sem a devida contraprestação.

É importante neste passo observar que o mesmo art. 134 da Constituição da República, a que já aludimos, que previu a Defensoria Pública como instituição essencial à função jurisdicional do Estado, previu o seguinte em seu $\S 1^{\text {o: }}$ "Lei complementar organizará a Defensoria Pública da União e do Distrito Federal e dos Territórios e prescreverá normas gerais para sua organização nos Estados, em cargos de carreira, providos, na classe inicial, mediante concurso público de provas e títulos, assegurada a seus integrantes a garantia da inamovibilidade e vedado o exercício da advocacia fora das atribuições institucionais".

A tal Lei Complementar foi editada em janeiro de 1994, sob nº 80, e previu entre as funções institucionais da Defensoria Pública, as seguintes: i) prestar orientação jurídica e exercer a defesa dos necessitados, em todos os graus; ii) promover, prioritariamente, a solução extrajudicial dos litígios, visando à composição entre as pessoas em conflito de interesses, por meio de mediação, conciliação, arbitragem e demais técnicas de composição e administração de conflitos; iii) promover a difusão e a conscientização dos direitos humanos, da cidadania e do ordenamento jurídico; iv) prestar atendimento interdisciplinar, por meio de órgãos ou de servidores de suas Carreiras de apoio para o exercício de suas atribuições (art. $4^{\circ}$, I a IV, os incisos seguintes referem-se a atividade propriamente processual). 
O legislador não descurou, como se vê, da relevância da atividade extrajudicial abarcada pela idéia de assistência jurídica, dando-lhe sobeja ênfase no rol das atividades institucionais cometidas à Defensoria Pública. Não custa lembrar que a norma retro citada tem a qualidade de norma geral, vinculativa não apenas à Defensoria Pública da União, Distrito Federal e Territórios, como também às Defensorias Estaduais.

Resta patente, portanto, que a atuação de advogados nesta seara constitui, tanto quanto a atuação judiciária, forma de suprimento da deficiência estatal, afigurando-se indiscutivelmente legítima a reivindicação de previsão de remuneração.

Porém não é este o único fator limitador do serviço público de assistência judiciária. Infelizmente reconhece-se que, a despeito dos esforços e da boa vontade tanto de defensores públicos como de advogados de ofício, ainda é grande a defasagem entre a demanda da sociedade, especialmente da população mais carente de recursos econômicos e intelectuais, e os serviços disponibilizados. Já em texto anterior à atual ordem constitucional Barbosa Moreira constatava ${ }^{307}$ : "Em nosso país, não é ousadia rotular de quimérica toda e qualquer iniciativa de avanço ponderável, ao menos a curto prazo, no particular" 308 .

Marco Antônio Marques da Silva, embora com os olhos mais voltados para a justiça penal, arrola o que entende por serem os pontos nevrálgicos nesta constatada ineficiência estatal: i) a insuficiência de defensores públicos e a baixa remuneração de defensores providos por convênios, o que acarreta a precariedade técnica, no mais das vezes quase nula, em desfavor do assistido; ii) aparelhamento material e pessoal do Poder Judiciário obsoleto e insuficiente e iii) necessidade de adequação de institutos processuais às demandas que a atual sociedade põe à apreciação dos juízes. O mesmo autor aponta que a organização da Justiça no Brasil ainda ostenta o estigma liberal, pensada para a solução de conflitos individuais ${ }^{309}$ (sobre este assunto, já dissertamos).

Outro ponto problemático diz respeito à atuação junto às instâncias administrativas. Diversas expressões empregadas pela Lei $\mathrm{n}^{\circ}$ 1.060/50 indicariam a sua incidência exclusivamente nos processos judiciais. Assim é a referência à atuação do juiz no art. $5^{\circ}(\mathrm{e}$

\footnotetext{
${ }^{307}$ Sabe-se que a atual Constituição foi um marco no que respeita à busca pelo Judiciário para salvaguarda da enorme plêiade de direitos individuais e coletivos que nela restaram albergados, não é à toa que é alcunhada "Constituição cidadã". Ora, se já sob a égide de um regime ditatorial se via a insuficiência do serviço prestado, que dirá agora, em que tal prestação assume ares típicos de Welfare State.

${ }^{308}$ BARBOSA MOREIRA, José Carlos. A função social do processo civil moderno e o papel do juiz e das partes na direção e na instrução do processo, cit., p. 142.

${ }^{309}$ SILVA, Marco Antônio Marques da. A efetividade do acesso à justiça, cit., p. 130-132.
} 
outros dispositivos); a alusão no art. $6^{\circ}$ ao curso da ação; no art. $7^{\circ}$ fala-se também em parte contrária; e no art. $9^{\circ}$, em decisão final do litígio, etc.

Já se tem dito à saciedade que a Lei $\mathrm{n}^{\circ}$ 1.060/50 abarca parte da garantia constitucional prevista no também já citado inciso LXXIV do art. $5^{\circ}$. O que a Constituição prevê é a assistência jurídica, o que denota a extensão da garantia a todos os recônditos da vida do cidadão onde problemas jurídicos possam surgir, e sabe-se bem que questões desta natureza não exsurgem apenas nos processo judiciais.

A idéia de assistência extrajudicial não pode permanecer restrita à seara consultiva, mas deve abarcar também a assessoria para a prática de atos jurídicos (p.ex. lavratura de escrituras; registro de títulos e documentos; etc.) e o patrocínio em processos $\operatorname{administrativos}^{310}$. Neste último campo haveria fecunda seara para iniciativas onde a assistência é plenamente necessária, bastando pensar nos expedientes formados a partir de infrações de trânsito/suspensão de habilitação; expedientes relacionados ao Poder Público, mormente o municipal, e o exercício do poder de polícia sobre o desempenho de atividade empresarial (p.ex. expedição e cassação de alvarás de funcionamento de estabelecimento; aplicação de penalidades; etc.); expedientes administrativos afetos ao Registro de Imóveis; autuações administrativas em geral; etc.

Um dos principais campos de atuação da assistência neste aspecto seria o dos processos administrativos disciplinares. Há normas, como o Estatuto dos Funcionários Públicos Civis do Estado de São Paulo, que presumem a hipossuficiência do indiciado e determinam a nomeação de defensor mesmo no caso de inércia do interessado. É neste sentido o art. 281 da Lei Estadual paulista $\mathrm{n}^{\circ}$ 10.261/68, segundo o qual ao acusado revel será nomeado defensor dativo, norma complementada pelo $\S 3^{\circ}$ do art. 282 do mesmo diploma: "Não tendo o acusado recursos financeiros ou negando-se a constituir advogado, o presidente nomeará advogado dativo" (grifo nosso, que sublinha a intensidade desta presunção de hipossuficiência, abarcando até situações extremas de voluntária recusa à nomeação de defesa técnica).

\footnotetext{
${ }^{310}$ Maurício Antônio Ribeiro Lopes, abordando a questão da menção pela Lei ${ }^{\circ} 1.060 / 50$ de expressões que remetem apenas ao processo judicial assim se manifesta: "No entanto, quer nos parecer que essas expressões nunca excluíram a possibilidade de concessão de assistência judiciária aos casos administrativos. A aplicação da lei, concedendo assistência, somente quando ocorresse contenda, implicaria, obviamente, na restrição imposta a magnitude do instituto, cerceando aos pobres direito de tanta relevância quanto os demais. Saliente-se ainda que o legislador ao elaborar a lei visou a justa distribuição do Direito e esta não somente se faz presente em processos contenciosos" (LOPES, Maurício Antônio Ribeiro. Garantia de acesso à justiça: assistência judiciária e seu perfil constitucional, cit., p. 85).
} 
Recentemente o C.Supremo Tribunal Federal, no entanto, editou a súmula vinculante $\mathrm{n}^{\circ} 5$ no seguinte sentido: "A falta de defesa técnica por advogado no processo administrativo disciplinar não ofende a Constituição".

Obviamente que o entendimento em questão não está a alijar do campo da assistência os processos administrativos disciplinares, apenas arrosta a obrigatória nomeação de defensor para o indiciado inerte. Porém para o indiciado que deseja ver-se defendido por profissional advogado, dever ser assegurada a nomeação de defensor público ou de advogado vinculado à atividade de assistência.

A propósito, não custa anotar que entre as funções institucionais da Defensoria Pública, está a seguinte: "exercer, mediante recebimento dos autos com vista, a ampla defesa e o contraditório em favor de pessoas naturais ou jurídicas, em processos administrativos e judiciais, perante todos os órgãos e em todas as instâncias, ordinárias ou extraordinárias, utilizando todas as medidas capazes de propiciar a adequada e efetiva defesa de seus interesses" (art. $4^{\circ}, \mathrm{V}$, da Lei Complementar $\mathrm{n}^{\circ}$ 80/1994, grifo nosso).

A Lei $n^{\circ}$ 9.784/99 que rege o processo administrativo no âmbito federal prevê que este será regido, entre outros, por um critério que merece destaque: "proibição de cobrança de despesas processuais, ressalvadas as previstas em lei" (inciso XI). Ainda o art. $3^{\circ}$ assegura ao administrado, entre outros, o direito de "fazer-se assistir, facultativamente, por advogado, salvo quando obrigatória a representação, por força de lei” (grifamos).

\section{Assistência jurídica integral e gratuita e as garantias constitucionais do processo}

Michele Taruffo define a Constituição Brasileira como emblema da fase madura do fenômeno que denominou de constitucionalização das garantias fundamentais do processo, fenômeno iniciado a partir da segunda metade do século XX na evolução da justiça civil ${ }^{311}$. Após ressaltar a diversidade dos níveis com que Constituições de diversos países e mesmo Declarações internacionais, detalham as garantias fundamentais do processo, o autor ressalta que esta diversidade de minúcias reflete o momento histórico e o grau de sensibilidade ética e política acerca da garantia do processo.

Esta constatação é bastante significativa no contexto brasileiro, em que uma Constituição nitidamente garantística sucede uma traumática fase ditatorial da República, e

\footnotetext{
${ }^{311}$ TARUFFO, Michele, Le garanzie fondamentali della giustizia civile nel mondo globalizzato. RTDC: revista trimestral de direito civil, Rio de Janeiro, v. 5, n. 17, p. 117, jan./mar. 2004.
} 
daí o enorme elenco de direitos que consta especialmente dos arts. $5^{\circ}$ a $7^{\circ}$ da Constituição além de outros espalhados por todo o texto ${ }^{312}$.

Ainda o mesmo autor segue sua lição, esclarecendo que apesar destas diferenças entre os ordenamentos, há um núcleo essencial em princípio irrenunciável, que governa a administração da justiça, e que se refere à independência e imparcialidade do juiz; à parte, a quem deve ser assegurado o acesso à tutela jurisdicional e ao direito de defender-se; e ao procedimento, que deve ser rápido, simples, acessível e eficiente ${ }^{313}$.

A efetividade da garantia do processo pode ser abordada por dois vieses possíveis, o primeiro, denominado por Taruffo como "effettività istituzionale"; o segundo, "effettività concreta". A primeira é representada pela previsão abstrata num ordenamento de todos os mecanismos institucionais e processuais necessários para dar um conteúdo efetivo à garantia. São diversos os exemplos dos mecanismos que atendem a esta faceta, entre eles, indiscutivelmente está a previsão de eficaz forma de assistência jurídica ao necessitado, além de outros, como a existência de remédios cautelares adequados, amplo direito à prova, sem limitações injustificadas, procedimentos rápidos e simples, etc.

Já a efetividade denominada concreta consubstancia "l'applicazione diretta e specifica, nella realtà dei singoli processi, delle garanzie fondamentali e dei meccanismi istituzionali che sono finalizzati allá loro attuazione" ${ }^{, 314}$. Isto é, a necessidade de correspondência entre a previsão normativa abstrata e o que na vida corrente do foro, na praxe do dia-a-dia, nos processos individualmente considerados, ocorre, isto é, perquirir se estes mesmos instrumentos institucionais funcionam de forma adequada.

Conclui Taruffo que uma das maiores dificuldades que se tem verificado ao redor do mundo é justamente a adaptação das previsões normativas infraconstitucionais e da praxe quotidiana ao modelo constitucional de processo civil.

Não se reclama larga militância nos foros brasileiros para se notar também em solo tupiniquim este drama, particularmente na sede do tema que estamos abordando (assistência jurídica integral e gratuita). As afirmações de cunho teórico, as previsões

\footnotetext{
${ }^{312}$ Falando acerca de países que passaram pos experiências ditatoriais, Habscheid anota: "A experiência comum de tais países, de um período de injustiça e de ditadura, levou aos 'pais' de tais constituições a reforçar a competência do terceiro poder do Estado e conferir-se, aí, um livre acesso (à justiça)" (As bases do direito processual civil, cit., p. 137). A própria Lei de Assistência Judiciária, conforme observa Evandro Fernandes de Pontes, "foi o resultado da primeira hora democrática pós-fascismo varguista" (A assistência judiciária na mira do modelo garantista do processo, cit., p. 68).

${ }^{313}$ TARUFFO, Michele, Le garanzie fondamentali della giustizia civile nel mondo globalizzato, cit., p. 119.

${ }^{314}$ TARUFFO, Michele, Le garanzie fondamentali della giustizia civile nel mondo globalizzato, cit., p. 123.
} 
normativas e as interpretações que se lhes dão sempre tendem em benefício do amplo acesso à justiça e da busca do pleno amparo ao mais carente.

Porém o que o quotidiano revela é uma realidade cruelmente diversa. Veja-se o exemplo de um problema que será melhor explorado adiante, mas que ao ensejo do assunto ora abordado, merece breve pincelada.

Doutrina e jurisprudência de peso reconhecem o direito do necessitado à prova pericial à custa do Estado, sempre lembrando que o acesso à justiça compreende esta benesse, já que seria de hipocrisia risível assegurar-lhe o ingresso no sistema judicial sem permitir-lhe a produção das provas necessárias ao acolhimento de sua pretensão, com farta invocação a princípios constitucionais a amparar tal entendimento.

Porém a triste realidade que se verifica na praxe forense (ao menos no Estado de São Paulo) é a da existência de um Fundo destinado a custear tais perícias, em que os valores previstos para cada modalidade de prova técnica são amesquinhados, e em que determinadas áreas sequer contam com previsão (p.ex. perícia contábil); não se prevê cobertura para as despesas que o perito terá para a colheita do material necessário para a realização do exame, de modo que não raras vezes o vistor se vê na contingência de renunciar à nomeação.

Neste impasse é comum que o processo sofra retardos descomunais, isto na melhor das hipóteses, pois que além de ver eternizar-se o processo, pode findar a parte por ter a produção da prova irremediavelmente perdida.

A conclusão, embora batida, é a de que a reforma de mentalidade é indispensável para promover a combinação entre a efetividade em nível institucional, e em nível concreto, reclamando-se ainda uma corajosa atuação do juiz que deve dispor-se, em cada processo que individualmente transita por suas mãos, reproduzir em nível microscópico a realidade macroscopicamente prevista nas normas superiores de regência do Estado.

É das garantias constitucionais do processo que este ramo do conhecimento jurídico "traggono la loro linfa vitale" "315. E no estudo dos institutos processuais infelizmente tem sido negligenciado o papel destes na efetivação das garantias constitucionais, sendo sempre oportuno instar o reconhecimento de que o ordenamento processual outra coisa não é senão a lei que regulamenta a garantia de justiça contida na Constituição ${ }^{316}$.

\footnotetext{
${ }^{315}$ LIEBMAN, Enrico Tullio. Problemi del processo civile. Napoli: Morano Ed., 1962. p. 149.

${ }^{316}$ LIEBMAN, Enrico Tullio. Problemi del processo civile, cit., p. 150.
} 
A viga mestra que deve permear o espírito do processualista ao interpretar o objeto de sua ciência é o de que os institutos processuais devem dar vida às garantias postas em nível abstrato na Constituição. Transcrevendo Liebman:

"Questa è la strada che dovrà permettere di riconoscere nel processo non solo uno strumento di giustizia, ma anche uno strumento o - se si preferisce - uma garanzia di liberta" ${ }^{, 317}$.

O modelo de acesso à justiça não se cinge à idéia de facilitar ao homem comum o ingresso no sistema judicial. Devemos buscar a eliminação de todos os obstáculos interiores ao processo, isto é, as excentricidades teóricas, o ritualismo, males que conduzem a um consumo desmedido de tempo e à onerosidade excessiva do fenômeno processual. A esta linha outras se ajuntam, para em convergência fornecer esta nova mentalidade de que vimos falando: um eficaz sistema de assistência jurídica, acesso à informação antes do processo e durante seu tramitar, eliminação de barreiras econômicas e supressão de todas as formas de discriminação ${ }^{318}{ }_{-}^{319}$.

E tendo estas noções como pano de fundo que se buscará abordar as principais controvérsias que envolvem o tema de nosso estudo.

\section{Aspectos do regime constitucional garantidor da assistência jurídica integral e gratuita}

Já tivemos oportunidade de ressaltar a distinção entre os conceitos de assistência jurídica, assistência judiciária e benefício da gratuidade. O principal diploma que em nível infranconstitucional trata dos institutos é a Lei $\mathrm{n}^{\circ}$ 1.060, que remonta à década de 1950, com alterações posteriores que, como já também ressaltamos, concentram-se na década de 1980.

\footnotetext{
${ }^{317}$ LIEBMAN, Enrico Tullio. Problemi del processo civile, cit., p. 151.

${ }^{318}$ MORELLO, Augusto Mario. La justicia, de frente a la realidad. Buenos Aires: Rubinzal-Culzoni Editores, 2002. p. 28.

319،La silueta del Modelo del Acceso a la Justicia importa una alternativa cultural abarcadora (y no solo jurídica), dispuesta a que los derechos o libertades fundamentales (y qué duda cabe que uno de ellos es el derecho a la Justicia), como los que conciernen a la educación, a la salud, a la vida, a preservar el medio ambiente, a la calidad y dignidad de vida, dejen de constituir para la mayoria de los ciudadanos y las personas un mero propósito de mejoramiento que, sin embargo, cuando carece de su expansión útil al no disponerse de los médios que aseguran en tiempo próprio su defensa" (MORELLO, Augusto Mario. La justicia, de frente a la realidad, cit., p. 29).
} 
O diploma em questão contém disposições híbridas, pois que tratam simultaneamente de preceitos que se enquadram no âmbito da assistência judiciária, bem como outros referentes à gratuidade.

Fato é que diversas são as divergências e inconsistências doutrinárias e jurisprudenciais na aplicação da lei em questão.

Em sede constitucional a assistência jurídica é prevista pelo inciso LXXIV do art. $5^{\circ}$, entre os direitos e garantias fundamentais, precisamente no âmbito dos direitos e deveres individuais e coletivos: "o Estado prestará assistência jurídica integral e gratuita aos que comprovarem insuficiência de recursos".

Consequiência direta da natureza do direito em questão é sua inclusão entre as cláusulas pétreas, conforme previsão do art. $60, \S 4^{\circ}$, IV, da Constituição da República, de modo que não sujeita ao poder constituinte derivado, sequer por proposta meramente tendente a abolir-lhe a incidência.

A rigor há diversas outras disposições que se referem de modo mediato ao acesso à justiça, como é o caso da garantia do direito de petição, direito de obtenção de certidões em repartições públicas, e mesmo outras destinadas à tutela em geral de direitos de natureza diversificada, como o caso do mandado de segurança coletivo, mandado de injunção, habeas data, habeas corpus, ação penal privada subsidiária da pública, e a consignação da justiça social como fundamento da ordem $\operatorname{social}^{320}$. Em suma, poderíamos dizer da conformação de um sistema cuja vetoração primordial é possibilitar o mais amplo acesso à justiça.

A assistência jurídica como um dos principais instrumentos de efetivação do acesso à justiça tem fundamento no princípio da solidariedade social, e representa o desempenho da função protetiva do Estado, compreendida esta nas finalidades políticas estatais. Pondera-se que ou se reconhece o direito à assistência ou o direito de mendicidade ${ }^{321}$.

É famigerada a tripartite classificação das normas constitucionais, proposta pelos mais renomados autores, dividindo-as em normas de eficácia plena; eficácia contida ou restringível e eficácia limitada ${ }^{322}$, conforme independam para sua plena eficácia de atuação

\footnotetext{
${ }^{320}$ CARVALHO, André de; RIBEIRO, Marcus Vinicius. Direitos humanos, inclusão jurídica e o papel da assistência jurídica no Brasil do século XXI, cit., p. 27.

${ }^{321}$ LOPES, Maurício Antônio Ribeiro. Garantia de acesso à justiça: assistência judiciária e seu perfil constitucional, cit., p. 68-72. Funda o autor parte de suas observações nas lições de Carlos Babo.

${ }^{322}$ A terminologia eventualmente varia de autor para autor, mas os conceitos são basicamente os mesmos.
} 
do legislador ordinário (normas de eficácia plena); admitam atividade ordinária, embora dela não dependam para plena operatividade do comando constitucional (eficácia contida ou restringível) e dependam de atuação do legislador infraconstitucional para eficácia da norma (normas de eficácia limitada).

Baseado na lição de Michel Temer, José Marcelo Menezes Vigliar lembra que todas as normas constitucionais são dotadas de eficácia, já que, no mínimo, resultam na revogação de todas as normas anteriores que com elas conflitem, ou seja, uma eficácia negativa. Tratando especificamente do direito fundamental previsto no já citado inciso LXXIV do art. $5^{\circ}$ conclui que a assistência jurídica integral e gratuita classifica-se como norma constitucional de eficácia contida, ou de eficácia redutível ou restringível, na terminologia de Temer $^{323}$.

Assim é que segundo o entendimento em questão, a norma que prevê a assistência jurídica integral e gratuita é dotada de eficácia redutível, contida ou restringível. Aliás, entendimento diverso seria incompatível com o $\S 1^{\circ}$ do art. $5^{\circ}$ da Constituição da República, segundo o qual, as normas definidoras dos direitos e garantias fundamentais têm aplicação imediata.

Em verdade o fundamento da posição defendida pelo autor citado é a idéia de que o já dito inciso LXXIV do art. $5^{\circ}$ "estaria a restringir o alcance do dispositivo, já que não indicou a forma de comprovação da insuficiência de recursos, sequer expressamente remetendo a complementação à atividade ordinária do legislador, mas que será necessária"324.

Há, é certo, uma imprecisão terminológica no trecho transcrito, pois que se fosse efetivamente necessária esta atividade legislativa ordinária, então estaríamos diante de norma constitucional de eficácia limitada.

A nosso ver a atividade legislativa ordinária em matéria de assistência jurídica integral e gratuita é admissível, porém não necessária ${ }^{325}$. Recomendável, porém dela não

\footnotetext{
${ }^{323}$ VIGLIAR, José Marcelo Menezes, Assistência jurídica integral e gratuita. Tutela constitucional e concessão do benefício. Justitia, São Paulo, v. 57, n. 171, p. 65, jul./set. 1995.

${ }^{324}$ VIGLIAR, José Marcelo Menezes, Assistência jurídica integral e gratuita. Tutela constitucional e concessão do benefício, cit., p. 63.

${ }^{325}$ No mesmo sentido de ser a norma do inciso LXXIV do art. $5^{\circ}$ qualificada como de eficácia contida e cláusula pétrea: RAMOS, Glauco Gumerato. Assistência jurídica integral ao necessitado. Revista dos Tribunais, São Paulo, v. 88, n. 765, p. 48, jul. 1999.
} 
depende a eficácia da norma constitucional ${ }^{326}$. Aliás, parece-nos que sequer tal atividade seja essencial no que concerne especificamente à regulamentação da forma de comprovação da insuficiência de recursos.

A falta de menção à forma de comprovação é irrelevante, pois plenamente suprível por normas já existentes no direito pátrio, e falamos precisamente de norma fundamental em matéria probatória, o art. 332 do Código de Processo Civil, segundo o qual "todos os meios legais, bem como os moralmente legítimos, ainda que não especificados neste Código, são hábeis para provar a verdade dos fatos, em que se funda a ação ou a defesa".

A atividade infraconstitucional seria oportuna para detalhar conceitos enunciados na Constituição da República. Não custa recordar que a Lei $\mathrm{n}^{\circ} 1.060 / 50$, anterior ao atual diploma constitucional, abrange apenas em parte a noção de assistência jurídica integral e gratuita por ela trazida. Reconhece-se que há um campo sobre o qual verte a Constituição da República sua luz, e que não é abarcado pela Lei n ${ }^{\circ}$ 1.060/50.

Norma que, p. ex., estrutura órgão destinado a prestar o serviço público em questão, seria extremamente bem vinda, mas sua falta não impede que a garantia espraie sua proteção. Neste passo, lembra-se que o órgão constitucionalmente destinado a tal mister é a Defensoria Pública, regida pela Lei Complementar $n^{\circ} 80$ de 12 de janeiro de 1994, que cumprindo o prescrito pelo $\S 1^{\circ}$ do art. 134, organizou a Defensoria Pública da União e do Distrito Federal e dos Territórios e prescreveu normas gerais para sua organização nos Estados.

Tanto é exato o que estamos a afirmar que no Estado de São Paulo, até recentemente, a Defensoria Pública não fora instituída, e a garantia da assistência jurídica integral e gratuita foi prestada pela Procuradoria de Assistência Judiciária, vinculada à Procuradoria Geral do Estado, e pela Ordem dos Advogados do Brasil, mediante convênio firmado com aquele órgão.

\footnotetext{
${ }^{326}$ Maurício Antônio Ribeiro Lopes, após empreender percuciente estudo voltado a distinguir as noções de normas e princípios constitucionais; direitos fundamentais e garantias individuais, especialmente com base nas lições de Canotilho, assim conclui por qualificar a assistência jurídica integral no contexto da Teoria da Constituição: "A assistência jurídica integral se não tem força própria para se constituir em princípio constitucional em termos absolutos ou clássicos não pode deixar de ser classificada, na doutrina de Canotilho, como princípio-garantia, ou como norma constitucional eletiva de princípio-garantia, que bem sintetiza nossa conclusão axiológica do objeto" (Garantia de acesso à justiça: assistência judiciária e seu perfil constitucional, cit., p. 67).
} 
Certo é que o nível desejável de excelência não foi atingido, apesar dos heróicos esforços destes órgãos, porém não se pode dizer que a norma constitucional remanesceu inteiramente obstaculizada em sua eficácia pela ausência da atividade legislativa ordinária.

O caráter fundamental do direito plasmado no citado inciso LXXIV do art. $5^{\circ}$ ainda decorre de sua íntima relação com os princípios da isonomia e do devido processo legal.

\begin{abstract}
"A assistência judiciária é um direito assegurado por configurar um dos momentos do Due Processo of Law. Sem ela não se pode cogitar de 'igualdade de todos perante a lei'. Impossibilitando-a, impedir-se-á que se materialize o 'devido processo legal', em todas as suas dimensões (...) Enquanto não se proporcionar aos 'mais carentes' aos 'economicamente fracos', aos 'necessitados', 'assistência judiciária', digna e decente, a lei nunca será igual para todos. Nem todos serão iguais perante a lei’327.
\end{abstract}

A assistência jurídica integral e gratuita é prestação positiva a cargo do Poder Público que se insere no contexto do Estado Social de Direito, em que a preocupação é proporcionar melhorias substanciais à sociedade civil ${ }^{328}$.

Uma importante conseqüência do fato de emanar o direito à assistência jurídica integral e gratuita diretamente de norma constitucional de eficácia plena (conquanto restringível), é que a efetivação do direito em questão comporta a utilização de instrumentos postos na própria Lei Maior para hipóteses de omissão do Poder Público.

José Marcelo Menezes Vigliar, a quem já temos citado, lembra a possibilidade de utilização do mandado de injunção, a ação de inconstitucionalidade por omissão, além da iniciativa popular $^{329}$. Maurício Antônio Ribeiro Lopes pontua que a negativa de assistência a quem tenha comprovado a situação de necessidade implica infração a direito líquido e certo, abrindo a via do mandado de segurança ou, se o caso de ameaça ou efetiva violação ao direito de liberdade, do habeas corpus ${ }^{330}$.

\footnotetext{
${ }^{327}$ TREVISAN, Oswaldo, A assistência judiciária: fundamentos constitucionais. Revista da Procuradoria Geral do Estado, São Paulo, n. 22, p. 180-183, jan./dez. 1984.

${ }^{328}$ RAMOS, Glauco Gumerato. Assistência jurídica integral ao necessitado, cit., p. 49. Neste mesmo norte Marcelo Malizia Cabral: "disciplinado em nível constitucional, no título II da Carta Política, que estatui os 'direitos e garantias fundamentais', o acesso à justiça, assegurado a toda humanidade, reclamando ação positiva do Estado, constitui-se em direito humano prestacional, atributo, aliás, reconhecido pelos estudiosos do tema" (Concretização do direito humano de acesso à justiça: imperativo ético do Estado Democrático de Direito. In COLETÂNEA de trabalhos de conclusão de curso apresentados ao Programa de Capacitação em Poder Judiciário - FGV Direito Rio. Porto Alegre: Tribunal de Justiça do Estado do Rio Grande do Sul, 2009. p. 48).

${ }^{329}$ VIGLIAR, José Marcelo Menezes, Assistência jurídica integral e gratuita. Tutela constitucional e concessão do benefício, cit., p. 69-70.

${ }^{330}$ LOPES, Maurício Antônio Ribeiro. Garantia de acesso à justiça: assistência judiciária e seu perfil constitucional, cit., p. 71.
} 
Entende ainda o referido autor que de todos estes mecanismos, o mais eficaz seria mesmo a iniciativa popular, devido ao potencial alcance, já que medidas judiciais tendem a limitar-se aos litigantes. Cogita-se também da ação civil pública, "embora tenha-se que proceder a uma minuciosa delimitação do objeto de sua causa petendi, e quem seriam os beneficiários, para não torná-la uma ação de inconstitucionalidade por omissão disfarçada" 331 .

No que concerne à ação de inconstitucionalidade por omissão parece-nos incongruente sua aplicabilidade. É que tende a doutrina por reconhecer seu cabimento no caso em que normas constitucionais de eficácia limitada remanescem absolutamente impedidas em sua eficácia em razão do descumprimento pelo Estado-legislador de um dever de legislar imposto pelo legislador constituinte ${ }^{332}$.

Conforme em linhas precedentes defendemos, não é este o caso da norma inserta no inciso LXXIV do art. $5^{\circ}$.

Ademais, com a procedência da ação direta "será dada ciência ao Poder competente para a adoção das providências necessárias e, em se tratando de órgão administrativo, para fazê-lo em trinta dias" (CR, art. 103, $\S 2^{\circ}$ ). Entende-se que o Poder Legislativo, mesmo comunicado do reconhecimento da omissão, não poderá ser compelido a legislar, remanescendo ainda a oportunidade e conveniência para fazê-lo, por respeito ao princípio da separação dos poderes, de modo que apenas quanto a órgãos administrativos a imposição de prazo representa tutela mais intensa em face da omissão do Poder Público ${ }^{333}$.

Deste modo, mesmo que se entendesse pela possibilidade de aplicar-se ao caso o referido remédio, seu alcance prático seria deveras limitado.

Em relação ao mandado de injunção, a mesma crítica inicial referida quanto à ação direta de inconstitucionalidade por omissão aqui se aplica. É remédio voltado para as normas constitucionais de eficácia limitada que definam direitos e liberdades

\footnotetext{
${ }^{331}$ VIGLIAR, José Marcelo Menezes, Assistência jurídica integral e gratuita. Tutela constitucional e concessão do benefício, cit., p. 70. A seguir conclui: "O que se vislumbra é o ajuizamento de ação civil pública, cujo objeto veicule obrigação de fazer, quer para se efetivar a Assistência Jurídica Integral e Gratuita, postulando-se a criação de órgãos para tal fim, quer para determinar que, no mínimo, se observe a concessão do benefício menor da justiça gratuita, nos termos da lei" (Tutela constitucional e concessão do benefício, cit., p. 70).

${ }^{332}$ MORAES, Alexandre de. Direito constitucional. 25. ed. São Paulo: Atlas, 2010. p. 775.

${ }^{333}$ MORAES, Alexandre de. Direito constitucional, cit., p. 777. Cf. ainda a respeito o art. $12-\mathrm{H}$ da Lei ${ }^{\circ}$ 12.063/09, que inseriu na Lei ${ }^{\circ}$ 9.868/99 disposições específicas à ação direta de inconstitucionalidade por omissão.
} 
constitucionais, ou prerrogativas inerentes à nacionalidade, soberania e cidadania (art. $5^{\circ}$, LXXI), e que dependam, para sua eficácia, da atuação do legislador ordinário.

Sobre os efeitos da decisão, paira antiga divergência, entre concretistas e não concretistas. Os primeiros subdivididos em concretistas geral e individual, e estes, em concretistas individual direto e intermediário. Por óbvio não é esta a sede própria para tratar deste assunto, convindo apenas lembrar que na composição atual do Colendo Supremo Tribunal Federal vigoram as posições concretista geral e individual concomitantemente ${ }^{334}$. Pela primeira, ao reconhecer a omissão, o Poder Judiciário poderia, por meio do mandamus, suprir a lacuna legislativa em caráter genérico, isto é, erga omnes, fixando os parâmetros para o exercício do direito por qualquer interessado. Pela segunda, este suprimento estaria restrito ao caso concreto, isto é, limitado ao prejudicado que recorreu à tutela constitucional ${ }^{335}$.

Quando, contudo, tratamos da efetivação da garantia de acesso à justiça por meio de instrumentos judiciais, não podemos escapar à tautologia: para garantia do acesso à justiça por vias judiciais, é preciso que haja acesso à justiça.

Por outras palavras, um sistema de assistência judiciária falho, incapaz de prover ao necessitado um patrono com qualificação adequada para, p.ex., buscar a reparação de um dano de que tenha sido vítima o carente, poderá prover-lhe um patrono para buscar em juízo o direito a uma assistência judiciária de qualidade? Isto é, faz-se necessário um patrono para obter em juízo o reconhecimento do "direito a ter um patrono nomeado".

Assim, um sistema inacessível assim o será também para a garantia do direito de acesso à justiça.

\footnotetext{
${ }^{334}$ MORAES, Alexandre de. Direito constitucional, cit., p. 181-182.

${ }^{335}$ Os concretistas diretos defendem que ao proclamar a omissão o C.Supremo Tribunal Federal deveria, desde logo, suprir a omissão para o caso concreto. Para os intermediários, dever-se-ia conferir ao legislativo prazo razoável para suprimento da lacuna, e então, ultrapassado este, por meio de reclamação, suprir-se a falta da norma regulamentadora.
} 


\section{NOTAS DE DIREITO COMPARADO}

Tratemos de forma breve, e apenas à guisa de informação, de alguns rudimentos da configuração da assistência jurídica ao necessitado nas principais culturas jurídicas do mundo contemporâneo.

Antes, porém, convém anotar, na esteira da lição de Vittorio Denti, a percepção de três tendências de fundo no que se refere à configuração da assistência jurídica no contexto complexo dos Estados contemporâneos ${ }^{336}$. Na verdade quando se fala aí em Estados contemporâneos deve-se dar o desconto de que o texto utilizado como base para a presente exposição data de 1979, portanto a realidade retratada já é diversa em alguns aspectos, o que também se tomará o cuidado de referir. Fato é que estas tendências contêm importante interesse histórico, até porque identificam as raízes dos principais modelos de assistência que ainda vemos na órbita alienígena.

A primeira tendência é considerar a questão da assistência como um problema de igualdade perante a administração da justiça, e assim, como uma questão de simples concessão de gratuidade da prestação jurisdicional, o que pode ser resolvido de diversas formas igualmente eficazes, entre elas, a remuneração dos serviços profissionais prestados ao carente pelo Estado, ou com uso de fundos públicos; ou a atuação de um sistema de serviços legais pré-pagos (prepaid legal services), com formas de seguros privados; e gratuidade da prestação profissional advocatícia, que percebem compensação em vantagens de natureza variada, conexas contudo ao status profissional ${ }^{337}$.

A segunda tendência considera a prestação dos profissionais liberais (advogados) como um serviço de interesse público e social, integrando-se assim a um sistema de assistência regulado e programado por órgão público, ou pelo menos sujeito ao controle público, sem, entretanto, excluir formas de assistência de caráter privado, como aquela prestada por sindicatos de operários a seus associados ${ }^{338}$.

A terceira a última tendência considera a assistência como parte de um serviço social mais amplo, e acredita que essa atividade de promoção social seja coerentemente

\footnotetext{
${ }^{336}$ DENTI, Vittorio. L'evoluzione del legal aid nel mondo contemporaneo. In: STUDI in onore di Enrico Tullio Liebman. Milano: Giuffrè, 1979. v. 2, p. 1159 e ss.

${ }^{337}$ DENTI, Vittorio. L'evoluzione del legal aid nel mondo contemporaneo, cit., v. 2, p. 1169.

${ }^{338}$ DENTI, Vittorio. L'evoluzione del legal aid nel mondo contemporaneo, cit., v. 2, p. 1169.
} 
desempenhada por um ofício público, inserto num programa de atuação de uma mais avançada forma de justiça social ${ }^{339}$.

Retendo estas tendências em mente, vejamos alguns exemplos concretos, tendo-as como pano de fundo.

\section{Modelo inglês}

Ao lado da reforma canadense da província de Quebec, levada a efeito em 1972, e da reforma sueca de 1973, o modelo instituído na Inglaterra a partir de 1949 é considerado um dos expoentes da segunda tendência referida anteriormente, em que a assistência legal compreende-se como uma de várias competências da assistência pelo Estado, segundo a ideologia de Welfare State.

Segundo Denti, o modelo mais importante desta tendência é o advindo do Legal Aid and Advice Act inglês de $1949^{340}$. Entre outras falhas, a este modelo faltava um plano geral de instituição de um ofício público de assistência, relegando-se a administração do sistema de assistência à Law Society, a corporação de advogados inglesa, que observa em sua gestão prevalentemente o interesse dos profissionais liberais, daí a proposta surgida de se atribuir a administração da assistência a um órgão público independente, que não seja parte de órgão de governo, mas não esteja tão vinculado aos interesses privados da Law Society. A virtude, de outro lado, deste diploma foi unificar um esquema de assistência legal, até 1949 inexistente.

Em finais da década de 60 e início da de 70 do século passado já se via o esgotamento do modelo advindo da legislação de 1949 e a necessidade de expansão do esquema assistencial, com o surgimento de importantes modelos alternativos norteamericanos, no contexto, naquele país, das lutas pelos direitos civis.

Fato é que até 1988 o esquema de assistência legal permaneceu sob a administração da Law Society, somente com o Legal Aid Act de 1988 formou-se a Legal Aid Board, responsável pelo financiamento do serviço público em questão com recursos públicos.

\footnotetext{
${ }^{339}$ DENTI, Vittorio. L'evoluzione del legal aid nel mondo contemporaneo, cit., v. 2, p. 1169.

${ }^{340}$ DENTI, Vittorio. L'evoluzione del legal aid nel mondo contemporaneo, cit., v. 2, p. 1172.
} 
Em 1999 editou-se o Access to Justice Act, que aboliu o Legal Aid Board, estabelecendo em seu lugar o Legal Services Comission (LSC), remodelando radicalmente o modelo até então observado ${ }^{341}$.

A Legal Service Comission é o órgão gestor da assistência jurídica, estando hierarquicamente vinculada ao Lord Chancellor, e composta por não menos que sete membros e não mais que doze (limites, entretanto, que podem ser alterados pelo Lord Chancellor de acordo com o que lhe pareça apropriado). Os membros igualmente são nomeados pelo Lord Chancellor, o qual também indicará o presidente da Comissão.

Tais membros, segundo regulamenta o diploma de 1999, é desejável que tenham experiência e conhecimento na provisão de serviços que a Comissão pode financiar como parte do serviço do Community Legal Service ou do Criminal Defence Service; no trabalho das cortes; assuntos relacionados aos consumidores; condições sociais e gestão.

A assistência legal é prestada, de modo geral, por duas grandes frentes: Community Legal Service (CLS), destinado ao auxílio cível; e Criminal Defence Service (CDS), destinado ao trabalho na área criminal. Qualquer firma ou agência que intente assumir a prestação de serviços de assistência legal deverá manter um contrato com a $C L S$ ou com a $C D S$.

O Community Legal Service (CLS), que será referido daqui por diante como serviço legal comunitário, numa tradução livre, consiste nos seguintes componentes: i) prover informações gerais sobre a lei e o sistema legal e a disponibilidade de serviços legais; ii) provisão de ajuda por meio do aconselhamento legal, a exemplo de identificar como a lei se aplica em um circunstância particular; iii) a provisão de ajuda na prevenção, na composição ou outro modo de solução de disputas acerca de direitos e deveres legais; iv) provisão de ajuda no cumprimento das decisões por meio das quais estas disputas são resolvidas e v) provisão de ajuda no que concerne aos procedimentos legais não relacionados a disputas ${ }^{342}$.

Já o Criminal Defence Service (CDS), facilmente traduzível como serviço de defesa criminal, inclui: i) procedimentos perante qualquer corte com relação a um indivíduo

\footnotetext{
${ }^{341}$ Esta evolução histórica está descrita no texto disponibilizado no seguinte endereço eletrônico: LEGAL AID. Disponível em: <http://www.lawcentres.org.uk/uploads/Legal_Aid.pdf>. Acesso em: mar. 2011.

${ }^{342}$ Tradução livre do seguinte excerto do Access of Justice Act 1999: "The description of services referred to in subsection (1) are - (a) the provision of general information about the Law and legal system and the availability of legal services; (b) the provision of help by the giving of advice as to how the law applies in particular circumstances; (c) the provision of help in preventing, or settling or otherwise resolving, disputes about legal rights and duties; (d) the provision of help in enforcing decisions by which such disputes are resolved, and (e) the provision of help in relation to legal proceedings not relating to disputes".
} 
acusado de uma infração; ii) procedimentos perante qualquer corte concernente a um indivíduo condenado pela prática de uma infração (incluindo procedimento em respeito a uma sentença ou ordem); iii) procedimentos relacionados a indivíduo sob o Extradiction Act 2003; iv) procedimentos para obrigar um indivíduo a manter a paz ou se comportar bem sob a seção 115 do Magistrates Courts Act 1980 e para lidar com um indivíduo que falhe em obedecer a uma ordem sob a égide desta seção; v) procedimentos de apelação ofertada por um indivíduo sob a seção 44A do Criminal Appeal Act 1968; vi) procedimentos por atentado cometido, ou dito com tendo sido cometido, por um indivíduo contra uma corte e vii) outros procedimentos concernentes a um indivíduo, perante qualquer outra corte ou outra instituição, como seja prescrito ${ }^{343}$.

Podem também ser incluídos no âmbito no $C D S$ o serviço de aconselhamento legal para indivíduos detidos ou envolvidos em processos que possam levar à detenção.

Importante frisar também que incumbe ao $L S C$ o credenciamento de pessoas ou equipes para a prestação dos serviços de assistência legal, podendo inclusive autorizar terceiros a promover tal credenciamento. Uma das fontes de receita da entidade é justamente a possibilidade de cobrança de taxa pelas atividades de credenciamento; monitoramento dos serviços prestados pelas entidades e pessoas credenciadas e autorização de credenciamento por terceiros.

Por fim, cumpre anotar que o diploma de 1999 criou o Funding Code, que é o conjunto de regras que norteia a concessão da assistência, estabelecendo os critérios e requisitos que qualificam o postulante como possível beneficiário ${ }^{344}$.

Os critérios são complexos e variam de acordo com a natureza da causa, bem como são diversos em extensão. Os pretensos assistidos igualmente devem qualificar-se financeiramente para percepção do benefício, para tanto devem providenciar prova adequada de sua condição financeira, mediante apresentação de extratos bancários e

\footnotetext{
${ }^{343}$ Mais uma tradução livre do seguinte excerto do Access of Justice Act 1999: "In this Part "criminal proceedings' means - (a) proceedings before any court for dealing with an individual accused of an offence; (b) proceedings before any court for dealing with an individual convicted of an offence (including proceedings in respect of a sentence or order); (c) proceedings for dealing with an individual under the Extradition Act 2003; (d) proceedings for binding an individual over to keep the peace or to be of good behavior under section 115 of the Magistrates Courts Act 1980 and for dealing with an individual who fails to comply with an order under that section; (e) proceedings on an appeal brought by an individual under section 44A of the Criminal Appeal Act 1968; (f) proceedings for contempt committed, or alleged to have been committed, by an individual in the face of a court and $(\mathrm{g})$ such other proceedings concerning an individual, before any such court or other body, as may be prescribed".

${ }^{344}$ Com uma boa descrição, inclusive histórica, acerca do sistema de assistência legal inglês conferir o texto disponibilizado no sítio eletrônico: LEGAL AID. Disponível em: <http://www.lawcentres.org.uk/uploads/Legal_Aid.pdf>. Acesso em: mar. 2011.
} 
documentos assemelhados ${ }^{345}$. Aliás, de acordo com as condições financeiras, podem os pretendentes até mesmo ser compelidos ao pagamento de uma contribuição.

Segundo anota mais uma vez Denti, o problema deste modo de prestar assistência concentra-se em proporcionar o serviço em caráter singular, ou seja, como forma de solução particularizada dos problemas legais dos indivíduos, sem atentar para as necessidades legais dos grupos marginalizados enquanto categoria social, carecendo-se então de uma reforma legal que considere a pobreza em caráter mais geral ${ }^{346}$.

\section{Modelo norte-americano}

Para Vittorio Denti o modelo norte-americano, ao menos aquele posto em prática na década de sessenta, enquadra-se na terceira tendência retro referida no que concerne à evolução da assistência legal no mundo contemporâneo e que, recapitulando, vê a assistência como parte de um amplo serviço social, desenvolvido por um uffici pubblici ${ }^{347}$.

$\mathrm{Na}$ verdade, desde finais do século XIX até meados do século $\mathrm{XX}$, a assistência legal nos Estados Unidos da América remanesceu sub-subsidiada e pouco desenvolvida. Apenas na década de sessenta é que um novo modelo surge, como parte de uma política geral de combate à pobreza. O Legal Service Program que esteve em atuação nos EUA no período de 1964 a 1974, vinculado ao Office of Economic Opportunity (O.E.O.), é classificado por Denti como "Il programma più avanzato di Legal Aid nei paesi di tipo capitalistico",348.

\footnotetext{
${ }^{345}$ No caso do $C L S$, os critérios são definidos de acordo com os fatores assim descritos: "In settling the criteria to be set out in the code the Commission shall consider the extent to which they ought to reflect the following factors- (a) the likely cost of funding the services and the benefit which may be obtained by their being provided, (b) the availability of sums in the Community Legal Service Fund for funding the services and (having regard to present and likely future demands on that Fund) the appropriateness of applying them to fund the services, (c) the importance of the matters in relation to which the services would be provided for the individual,

(d) the availability to the individual of services not funded by the Commission and the likelihood of his being able to avail himself of them, (e) if the services are sought by the individual in relation to a dispute, the prospects of his success in the dispute, (f) the conduct of the individual in connection with services funded as part of the Community Legal Service (or an application for funding) or in, or in connection with, any proceedings,

(g) the public interest, and (h) such other factors as the Lord Chancellor may by order require the Commission to consider".

${ }^{346}$ DENTI, Vittorio. L'evoluzione del legal aid nel mondo contemporaneo, cit., v. 2, p. 1174.

${ }^{347}$ DENTI, Vittorio. L'evoluzione del legal aid nel mondo contemporaneo, cit., v. 2, p. 1169.

${ }^{348}$ DENTI, Vittorio. L'evoluzione del legal aid nel mondo contemporaneo, cit., v. 2, p. 1174.
} 
As tão famigeradas três "ondas renovatórias" de acesso à justiça, referidas por Cappelletti e Garth, são associadas às reformas legais e movimentos correlatos ocorridos nos Estados Unidos da América a partir da década de sessenta ${ }^{349}$.

A primeira onda é associada à primeira reforma de peso, ocorrida em 1965 com o citado Legal Service Program of the Office of Economic Opportunity. O núcleo do sistema em questão eram os Neighbourhood Law Firms, espalhados nas áreas carentes das grandes cidades e alguns centros rurais, onde atuavam advogados estipendiados pelo Estado, em tempo integral ou parcial.

São apontadas três linhas que plasmam a filosofia deste programa: i) difusão das atividades dos centros de assistência legal por diversos meios, como o debate público, distribuição de volantes pelas ruas das cidades, comunicação através de rádio e televisões locais, inclusive política esta que causou não pequeno confronto com a tradicional regra de "riservatezza della professione legale"; ii) atividades voltadas para reformas legislativas em favor das classes menos favorecidas, principalmente pela condução de test cases em matérias interessantes a toda classe carente, o que se viabilizou principalmente por meio de class actions, sem prejuízo dos meios tradicionais, por meio das mudanças de jurisprudência de cortes superiores, além de inovações legislativas e administrativas; iii) participação direta dos representantes da categoria assistida na gestão do escritório de assistência, o que se coaduna com a exigência de participação que caracteriza a evolução da ação administrativa no estado contemporâneo ${ }^{350}$.

O Legal Service Program estava, entretanto, por demais vinculado aos humores políticos do partido no poder, daí porque ter sido alvo de diversas críticas no contexto do jogo político então vigente, que conduziram ao seu gradual desmantelamento. A grande luta dos responsáveis pelo programa junto ao OEO era desvinculá-lo deste plano, tornando-o sujeito a órgão independente ${ }^{351}$. Este órgão veio em 1974, de caráter privado

\footnotetext{
${ }^{349} \mathrm{~A}$ associação das ondas renovatórias às reformas legais norte-americanas é referida no texto O acesso ao direito e à justiça: um direito fundamental em questão. Dir. Científico: Boaventura de Sousa Santos. Coordenadores: João Pedroso, Catarina Trincão; João Paulo Dias, no âmbito do Observatório Permanente da Justiça Portuguesa, Centro de Estudos Sociais, da Universidade de Coimbra - Faculdade de Economia, publicação de julho de 2002. O texto é encontrável na rede mundial de computadores: SOUSA SANTOS, Boaventura de (Dir. Científico). O acesso ao direito e à justiça: um direito fundamental em questão. Coordenadores: João Pedroso, Catarina Trincão; João Paulo Dias. DHNet. Disponível em: <www.dhnet.org.br/dados/lex/a_pdf/01_boaventura_acesso_jud_pt.pdf>. Acesso em: 29 mar. 2011.

${ }^{350}$ DENTI, Vittorio. L'evoluzione del legal aid nel mondo contemporaneo, cit., v. 2, p. 1175.

${ }^{351}$ DENTI, Vittorio. L'evoluzione del legal aid nel mondo contemporaneo, cit., v. 2, p. 1176. SOUSA SANTOS, Boaventura de (Dir. Científico). O acesso ao direito e à justiça: um direito fundamental em questão. Coordenadores: João Pedroso, Catarina Trincão; João Paulo Dias, cit.
} 
porém financiado por recursos públicos, o Legal Services Corporation (LSC), sistema atualmente em vigor.

Apenas para completar a explanação antes iniciada, anotemos superficialmente que a segunda onda renovatória do acesso à justiça é representada pela proteção aos interesses difusos, coletivos e fragmentados, por meio de incentivos ao particular para demandar acerca de tais objetos, atuando como uma espécie de private attorney general $^{352}$. A terceira e última onda renovatória refere-se às $A D R$ 's (Alternative Disputes Resolution), meios que podem constituir alternativas aos tribunais judiciais (resolvendo litígios que os tribunais também estão aptos a resolver); complemento (litígios que nunca chegariam aos tribunais) e substitutos aos tribunais (transferindo-se a competência para a resolução de determinados conflitos dos tribunais judiciais a estes órgãos especializados na resolução alternativa de litígios). É o cenário que se denomina pluralismo jurídico e judicial ${ }^{353}$.

Esta evolução em ondas renovatórias não ocorre simetricamente na Europa, onde são verificados fenômenos mais ou menos autônomos que se enquadram numa ou noutra faceta destas tendências.

A LSC - Legal Services Corporation constitui entidade privada, sem fins lucrativos, atualmente maior provedor de assistência jurídica nos Estados Unidos da América. A entidade distribui cerca de $95 \%$ de seu orçamento a pelo menos 136 programas de assistência legal sem fins lucrativos, com mais de 900 escritórios promovendo assistência jurídica a famílias e indivíduos de baixa renda ${ }^{354}$.

É bom informar que a entidade em questão tem suas atividades limitadas à esfera civil, atuando precipuamente nas áreas de família (violência doméstica; guarda de filhos; destinação de órfãos; etc.); habitação (renegociação de empréstimos e financiamentos habitacionais; litígios entre proprietários e inquilinos; etc., assuntos relacionados à política de defesa do consumidor, especialmente empréstimos inescrupulosos que vitimizam os

\footnotetext{
${ }^{352}$ SOUSA SANTOS, Boaventura de (Dir. Científico). O acesso ao direito e à justiça: um direito fundamental em questão. Coordenadores: João Pedroso, Catarina Trincão; João Paulo Dias, cit. Segundo o texto a defesa dos interesses transindividuais assumiu tripla forma: gabinetes especializados na defesa de interesses coletivos, criados antes de 1960, sustentados por fundações e contribuições privadas; gabinetes de advogados não especializados no tema e juristas do Estado (governmental advocates), último e mais importante passo (cit., p. 9).

${ }^{353}$ SOUSA SANTOS, Boaventura de (Dir. Científico). O acesso ao direito e à justiça: um direito fundamental em questão. Coordenadores: João Pedroso, Catarina Trincão; João Paulo Dias, cit., p. 12.

${ }^{354}$ Informações facilmente encontráveis no sítio eletrônico da entidade: LSC - LEGAL SERVICE CORPORATION. Disponível em: <www.lsc.gov/about:lsc.php>.
} 
mais vulneráveis, principalmente idosos, inclusive prestando-se assistência para que indivíduos possam gerenciar seus débitos).

A declaração de propósitos contida no Legal Service Corporation Act deveria constituir carta de princípios de qualquer serviço de assistência legal: i) há uma necessidade de prover igualitário acesso ao sistema de justiça em nossa nação, para indivíduos que procuram reparação por ilícitos; ii) há uma necessidade de prover serviço de assistência legal de alta qualidade para aqueles que, de outro modo, não seriam capazes de se prover de adequado conselho legal; iii) prover assistência legal para aqueles que encaram uma barreira econômica para receber adequada orientação legal servirá melhor aos fins da justiça e assistirá ao aumento de oportunidades para pessoas de baixa renda; iv) para muitos de nossos cidadãos, a disponibilidade de serviços legais representa reafirmação da fé no nosso Estado de Direito (government of laws); v) para preservar sua força, o programa de assistência legal deve ser resguardado da influência ou uso relacionado a pressões políticas e vi) advogados prestando assistência legal devem ter inteira liberdade para patrocinar o melhor interesse de seus clientes em manter o Código de Responsabilidade Profissional, os Cânons da Ética, e os altos padrões da profissão legal ${ }^{355}$.

A Corporação é composta por um quadro de diretores integrado por onze membros votantes, indicados pelo Presidente com o consentimento e aprovação do Senado, e não mais que seis poderão pertencer ao mesmo partido político. A maioria deverá compor a bar (associação de advogados naquele país) da Corte mais elevada de qualquer Estado, e nenhum poderá ser empregado a tempo integral do governo. Interessante notar que para indicações ocorridas após 28 de dezembro de 1977, ou no máximo a partir de 31 de julho de 1978, a composição do quadro deverá incluir representante dos assistidos. Os diretores desempenham o ofício conforme mandato temporalmente limitado (três anos). A estrutura da Corporação também inclui Conselhos Estaduais compostos por nove membros indicados por cada Governador, e as indicações a este devem partir da bar association do Estado correspondente ${ }^{356}$.

O parágrafo 2996e do Legal Services Corporation Act prevê os poderes, deveres e limitações da Corporação. A entidade está autorizada, segundo a disposição em questão, a: i) prover auxílio financeiro a programas qualificados de promoção de assistência legal a

\footnotetext{
${ }^{355}$ Tradução livre do parágrafo 2996 do Legal Services Corportation Act, composto por seis itens que espelham os princípios enunciados no texto.

${ }^{356}$ Tradução livre do parágrafo $2996 \mathrm{c}$ do Legal Services Corportation Act, itens (a), (b) e (f).
} 
clientes elegíveis, subvencionando ou firmando contratos com indivíduos, parcerias, firmas, corporações e organizações sem fins lucrativos, e o próprio Estado e governos locais, desde que demonstrado que os serviços que serão promovidos por estes últimos não seriam providos adequadamente por entidades não governamentais; ii) aceitar em nome da Corporação, e empregar ou dispor, qualquer dinheiro ou propriedade, real ou pessoal, tangível ou intangível, recebida por doação, herança ou outro modo; iii) assumir a responsabilidade, por subvenção ou contrato, das seguintes atividades desde que relacionadas à prestação de assistência legal: (a) pesquisa, exceto quando relacionadas a aspectos legais ou políticos muito genéricos sem relação com a representação de clientes elegíveis; (b) treinamento e assistência técnica e (c) servir como pólo de informações.

O parágrafo $\mathrm{n}^{\circ} 2996 \mathrm{f}$ estabelece os requisitos e limitações para subvenções e contratos. Entre outras coisas, a disposição em questão observa que a Corporação, após consulta ao Director of the Office of Management and Budget e aos Governadores de diversos Estados, deve estabelecer o limite máximo de receita para que indivíduos se tornem aptos a receberem o serviço de assistência provido pela Corporação. Ainda a entidade deve estabelecer as linhas mestras para assegurar que na fixação destes limites sejam anotados fatores como o patrimônio líquido e nível de receita do cliente; débitos fixos, despesas médicas e outros fatores que afetem a disponibilidade de pagamento do cliente; o custo de vida da localidade e outros elementos relacionados à situação financeira do potencial beneficiário, inclusive observando-se se a falta de receitas decorre de recusa ou falta de disposição voluntária ao trabalho.

Há série enorme de requisitos e proibições que delineiam a atividade da Corporação, e que aqui não comportariam avaliação mais detalhada. Anote-se, entretanto, que diversas disposições procuram impedir que a atividade de assistência legal se imiscua na seara da atividade política, no sentido de militância partidária ou adoção de ideologias que sejam vinculadas a esta ou aquela corrente política.

Os programas resumidamente expostos neste subitem e no anterior indicam a institucionalização da atividade de assistência legal, evoluindo então do modelo primário do munus honorificum, atualmente em franca decadência. Surgem filões nesta órbita da advocacia subsidiada ou organizada pelo Estado, de advocacia social e política. No 
primeiro caso os problemas dos pobres ainda são tratados de forma individual, no segundo, como problemas de uma classe menos favorecida (public interest advocacy) ${ }^{357}$.

Neste contexto de advocacias social e polícia desenvolvem-se dois modelos alternativos, que correspondem justamente aos dois sistemas aqui expostos até agora: advocacia convencionada e advocacia pública.

A primeira corresponde ao modelo inglês criado em 1949 e aperfeiçoado por legislação posterior, em que ao cidadão incumbe escolher de uma lista de inscritos, seu patrono, o qual é remunerado pelo Estado porém a título privado, de acordo com valores de mercado. É o chamado judicare system, que também foi prestigiado na década de 70 na França e Alemanha ${ }^{358}$.

Já o regime de advocacia pública tem seu modelo plasmado no sistema de Public Salaried Attorney ou Salaried Staff Attorney com origem em 1965, no já citado Legal Service Program da OEO americano, com objetivos e características diferenciados em relação ao judicare system. De fato, os profissionais atuantes nos neighbourhood law offices são assalariados pelo Estado, e tem-se aí como mote dar conhecimento aos menos favorecidos acerca de seus novos direitos, e à necessidade de fazê-los valer por meio da atuação em juízo patrocinada por advogados. Os escritórios eram pequenos e estrategicamente posicionados em vizinhanças mais carentes, de modo a obter maior eficácia em vencer as barreiras sociais, culturais e econômicas obstativas do pleno acesso à justiça. O sistema em questão é definido como a "vanguarda da guerra contra a pobreza"359.

Os modelos retro referidos de advocacia convencionada (judicare system) e advocacia pública (Salaried Staff Attorney) não remanesceram estanques. Encontramos sistemas em que se combinam as vantagens das duas formas, como na Suécia e parte do Canadá. Na própria Grã-Bretanha foram estabelecidos trinta neighbourhood law centres em Londres, em complementação ao judicare system. Nos Estados Unidos, de outra banda, igualmente foram realizadas trinta e oito experiências com juristas independentes, à moda

\footnotetext{
${ }^{357}$ SOUSA SANTOS, Boaventura de (Dir. Científico). O acesso ao direito e à justiça: um direito fundamental em questão. Coordenadores: João Pedroso, Catarina Trincão; João Paulo Dias, cit., p. 18.

${ }^{358} \mathrm{O}$ sistema judicare foi alvo de críticas justamente por atender unicamente os interesses dos necessitados como indivíduos, não como classe, não servindo adequadamente à tutela de interesses emergentes dos chamados novos direitos, como aqueles oriundos de relações de consumo (SOUSA SANTOS, Boaventura de (Dir. Científico). O acesso ao direito e à justiça: um direito fundamental em questão. Coordenadores: João Pedroso, Catarina Trincão; João Paulo Dias, cit., p. 19).

${ }^{359}$ SOUSA SANTOS, Boaventura de (Dir. Científico). O acesso ao direito e à justiça: um direito fundamental em questão. Coordenadores: João Pedroso, Catarina Trincão; João Paulo Dias, cit., p. 19.
} 
do judicare. Afirma-se que a tendência em ascensão é justamente combinar as duas alternativas $^{360}$.

Conforme dito alhures, o Legal Service Corporation tem sua atuação restrita à esfera civil. Reconhece-se, contudo, no sistema norte-americano, o direito à assistência legal também na seara criminal, onde há fecunda atuação de defensores públicos.

Neste tema, na verdade, o mais conhecido marco é o famigerado caso Gideon vs. Wainwright, julgado pela Suprema Corte Americana em 18 de março de $1963^{361}$. Clarence Earl Gideon fora acusado de invasão numa sala de jogos em Panama City, Florida, onde findou condenado. Remeteu uma missiva à Suprema Corte argüindo a invalidade do julgamento, no qual the foi negado o acompanhamento por um advogado, embora tenha solicitado assistência em razão de carência econômica (informe-se que Gideon não tinha formação jurídica alguma).

A discussão envolvida no julgamento da causa abrangia, basicamente, a superação de precedentes anteriores, notadamente o caso Betts vs. Brady, em que se afirmara que a indicação de um advogado não seria um direito fundamental essencial a um julgamento justo $^{362}$; a extensão aos Estados do direito garantido pela sexta emenda da Constituição Americana, bem como a integração deste direito no conceito de devido processo legal, garantido pela décima quarta emenda ${ }^{363}$.

\footnotetext{
${ }^{360}$ SOUSA SANTOS, Boaventura de (Dir. Científico). O acesso ao direito e à justiça: um direito fundamental em questão. Coordenadores: João Pedroso, Catarina Trincão; João Paulo Dias, cit., p. 19. A respeito vale citar a diretriz contida no próprio Legal Services Corporation Act, no item (g) do parágrafo 2996f: "The Corporation shall provide for comprehensive, independent study of the existing staff-attorney program under this chapter and, through the use of appropriate demonstration projects, of alternative and supplemental methods of delivery of legal services to eligible clients, including judicare, vouchers, prepaid legal insurance, and contracts with law firms; and, based upon the results of such study, shall make recommendations to the President and the Congress, not later than two years after the first meeting of the Board, concerning improvements, changes, or alternative methods for the economical and effective delivery of such services".

${ }^{361}$ Gideon vs. Wainwright, 372 US 335 (1963). Para Berizonce, o caso em questão constituiu a mola propulsora do desenvolvimento da assistência legal não apenas na seara criminal, mas também na civil no Estados Unidos da América (La organización de la asistencia jurídica (un estúdio sintético de la legislación comparada). Revista de Processo, São Paulo, ano 14, n. 54, p. 170, abr./jun. 1989).

${ }^{362}$ LEWIS, Anthony. Gideon's trumpet. New York: Vintage Books, 1989. p. 8-9.

363، In all criminal prosecutions, the accused shall enjoy the right to a speedy and public trial, by an impartial jury of the State and district wherein the crime shall have been committed, which district shall have been previously ascertained by law, and to be informed of the nature and cause of the accusation; to be confronted with the witnesses against him; to have compulsory process for obtaining witnesses in his favor, and to have the Assistance of Counsel for his" (Sixth Amendment).

"All persons born or naturalized in the United States, and subject to the jurisdiction thereof, are citizens of the United States and of the State wherein they reside. No State shall make or enforce any law which shall abridge the privileges or immunities of citizens of the United States; nor shall any State deprive any person of life, liberty, or property, without due process of law; nor deny to any person within its jurisdiction the equal protection of the laws" (Fourteenth Amendment).
} 
Argumentos interessantíssimos emergiram durante as discussões, como o que segue:

\begin{abstract}
"That government hires lawyers to prosecute and defendants who have the money hire lawyers to defend are the strongest indications of the widespread belief that lawyers in criminal courts are necessities, not luxuries" 364
\end{abstract}

Até então o entendimento prevalente era o de que nos julgamentos estaduais, a garantia da assistência técnica de advogado limitava-se às acusações de crimes capitais (ou seja, sujeitos à pena capital). Ao concluir o julgamento, e superando o precedente retro citado (Betts vs. Brady), o entendimento da Suprema Corte pode ser resumido no seguinte trecho de Mr. Justice Clark:

“... the Constitution makes no distinction between capital and noncapital cases. The Fourteenth Amendment requires due process of law for deprival of 'liberty' just as for deprival of 'life', and there cannot constitutionally be a difference in the quality of the process based merely upon a supposed difference in the sanction involved"365

A inovação no caso foi o reconhecimento de que a carência econômica a impossibilitar a contratação de um advogado era circunstância especial o suficiente para ensejar o direito da parte acusada à indicação, pela Corte, de um patrono para assistir-lhe tecnicamente nos procedimentos, e isto não apenas nos casos de ofensas capitais, como também naqueles em que pudesse resultar gravame à liberdade do acusado.

Anote-se, entretanto, que por ocasião deste julgamento não se chegou a reconhecer um direito amplo e genérico à assistência por advogado em todas as causas de natureza criminal independentemente da circunstância do acusado ${ }^{366}$.

Atualmente a assistência legal em matéria criminal é prestada predominantemente por defensores públicos ${ }^{367}$.

\footnotetext{
${ }^{364}$ Gideon vs. Wainwright, 372 US 335 (1963).

${ }^{365}$ Gideon vs. Wainwright, 372 US 335 (1963).

${ }^{366}$ Para uma detalhada explanação acerca do caso Gideon: LEWIS, Anthony. Gideon's trumpet, cit., 277 p.

${ }^{367}$ CASTRO, José Roberto de. Manual de assistência judiciária: teoria, prática e jurisprudência. 1. ed. Rio de Janeiro: Aide Ed., 1987. p. 51.
} 


\section{Modelos europeus}

Neste subitem, à guisa de notícia, traçaremos breve paralelo entre alguns modelos europeus de assistência jurídica ao necessitado.

No sistema alemão, o fundamento de validade da assistência legal advém do art. 103 da Constituição Alemã $\tilde{a}^{368}$, item 1, que, a rigor, veicula o que entre nós se qualifica como princípio da inafastabilidade. Dois são os marcos em sede de assistência na legislação tedesca, a saber, duas leis de 1980, as quais reformularam o regime até então regulado pelos arts. 114 e seguintes do ZPO. A primeira, de 18 de junho de 1980, sobre Assistência Extrajudicial, e a segunda, de 13 de agosto de 1980, Lei sobre Ajuda para Custas Processuais.

Basicamente dois são os requisitos para o gozo do benefício Armenrecht (assistência legal), um chamado intrínseco, perspectiva de êxito da causa (fumus boni juris), e outro extrínseco, a carência econômica do cidadão a impedir que sem prejuízo do próprio sustento faça frente às despesas relacionadas à causa ${ }^{369}$.

A doutrina alemã (bem como a italiana, sistema no qual, como se verá, vige requisito parecido) chega a questionar a constitucionalidade deste primeiro requisito (a plausibilidade do direito invocado), argumentando-se que enquanto o não-carente é livre para instaurar um processo ou de resistir à demanda sem realizar qualquer prévia valoração do fundamento apresentado, para o carente o acesso à justiça estaria irremediavelmente limitado a esta espécie de "umiliazione",370, ou seja, haveria uma prévia suspeita de que o necessitado se valeria de demanda arbitrária ou temerária.

Indiscutível é que o carente acaba sujeito a um regime mais severo para acesso ao sistema de justiça que o não-necessitado. Mas parece que esta cautela até se justifica porque se por um lado pesa o direito fundamental de acesso à justiça, de outro, os recursos empregados são públicos, pois é o Estado (e a sociedade, em última instância) que financia esse ingresso em juízo.

\footnotetext{
${ }^{368}$ SOUSA SANTOS, Boaventura de (Dir. Científico). O acesso ao direito e à justiça: um direito fundamental em questão. Coordenadores: João Pedroso, Catarina Trincão; João Paulo Dias, cit., p. 119. O texto da Constituição Alemã está assim posto: "Vor Gericht hat jedermann Anspruch auf rechtliches Gehör".

${ }^{369}$ GIANNAKOS, Ângelo Maraninchi. Assistência judiciária no direito brasileiro. Porto Alegre, Livr. do Advogado, 2008. p. 47-48.

${ }^{370}$ TROCKER, Nicolo. Processo civile e Costituzione: problemi di diritto tedesco e italiano. Milano: Giuffrè, 1974. p. 321.
} 
O pedido é dirigido ao mesmo órgão encarregado de julgamento da causa, procedendo-se inclusive à oitiva da parte contrária. $\mathrm{O}$ requerente expõe neste pleito os termos da controvérsia, ou seja, os fundamentos da pretensão, inclusive com indicação dos meios de prova de que dispõe. O pleito é apresentado perante o "cancellière della corte",371, que literalmente traduzido significaria chanceler do tribunal ${ }^{372}$, e apesar dos elementos que o compõe, não depende de maiores formalidades, podendo ser apresentado verbalmente.

Nesta fase preliminar há já um relevante debate da causa, de seus aspectos de fato e de direito, embora o objeto do litígio seja, então, apenas a assistência legal. Contudo, nesta fase o carente não goza assistência alguma, o que é um grave defeito pouco denunciado. Por isto mesmo alguns tribunais chegaram a considerar a possibilidade de conceder a assistência de um advogado para o Armenrechtsverfahren (procedimento legal de gratuidade) $)^{373}$.

A gratuidade abrange as custas processuais bem como os honorários do advogado nomeado ou indicado pelo próprio beneficiário, isenção esta que, obviamente, é personalíssima. Na verdade a partir de 18 de dezembro de 1919 foi introduzido o sistema judicare, sinteticamente já exposto em linhas precedentes ${ }^{374}$. Para o advogado constitui-se em obrigação legal aceitar o encargo, individualmente ou em "Oficinas de Consulta", podendo exonerar-se apenas por motivos relevantes, entre os quais não se enquadra o excesso de serviço ${ }^{375}$.

A concessão do benefício pode observar amplitude total ou parcial. Para esta segunda hipótese há previsão interessante na legislação tedesca. Cuida-se do poder atribuído ao magistrado de fixar para a causa um valor inferior ao real (Prozessverbilligung), correspondente à condição patrimonial do interessado, e que constituirá a base de cálculo para as contribuições incidentes, que então restarão reflexamente reduzidas ("spese ridotte").

Esta redução, contudo, vale apenas para a parte carente, para o adversário segue-se o trâmite processual de acordo com o valor real da controvérsia. Nas palavras de Trocker,

\footnotetext{
${ }^{371}$ TROCKER, Nicolo. Processo civile e Costituzione: problemi di diritto tedesco e italiano, cit., p. 329.

372 “A decisão final de aceitar o pedido é tomada pelo funcionário de categoria superior que presta assistência aos magistrados" (SOUSA SANTOS, Boaventura de (Dir. Científico). O acesso ao direito e à justiça: um direito fundamental em questão. Coordenadores: João Pedroso, Catarina Trincão; João Paulo Dias, cit., p. 119 ).

${ }^{373}$ TROCKER, Nicolo. Processo civile e Costituzione: problemi di diritto tedesco e italiano, cit., p. $330-331$.

${ }^{374}$ GIANNAKOS, Ângelo Maraninchi. Assistência judiciária no direito brasileiro, cit., p. 49.

${ }^{375}$ BERIZONCE, Roberto Omar. La organización de la asistencia jurídica (un estúdio sintético de la legislación comparada), cit., p. 169-170.
} 
"si tratta di un típico modo di stabilire l'egualianza creando delle diseguaglianze; ovvero, introducendo dei trattamenti differenziati si cerca di raggiungere un'egualianza effetiva" ${ }^{376}$. Critica-se, contudo, o fato da redução abranger unicamente a taxa judiciária e os honorários do advogado, e não também as despesas periciais ${ }^{377}$.

Lembra ainda a doutrina a possibilidade para o caso da dita concessão parcial da benesse, de proceder-se ao pagamento parcelado das despesas processuais ${ }^{378}$. Na verdade promove-se a análise da declaração de rendimentos do pretendente ao benefício, buscando averiguar se parte deles pode ser destinada ao custeio do processo. É o que se chama rendimento contributivo ${ }^{379}$, se este rendimento, feitas as deduções referentes às despesas básicas com o sustento próprio e da família, for inferior a 15 euros por mês, confere-se a gratuidade integralmente. Se for superior, o requerente tem a possibilidade de pagar uma mensalidade, fixada em proporção com seus rendimentos.

Estas mensalidades podem perdurar pelo prazo máximo de quatro anos, ou seja, quarenta e oito meses, findos os quais se a totalidade dos custos do processo não foram liquidados, dar-se-á o remanescente como perdido.

Outra interessantíssima previsão, que seria cá no Brasil por demais útil, é a de, além de remunerar o serviço extrajudicial do advogado, estabelecer um bônus financeiro para o caso de alcançar a solução extrajudicial do litígio ${ }^{380}$.

Em princípio a assistência não abrange matéria penal. Porém pode ocorrer a designação de defensor independentemente dos rendimentos sempre que considerado necessário pelo Tribunal, em função da gravidade do fato ou da detenção preventiva superior a três meses ${ }^{381}$.

\footnotetext{
${ }^{376}$ TROCKER, Nicolo. Processo civile e Costituzione: problemi di diritto tedesco e italiano, cit., p. 317. Acerca deste poder judicial, também: GIANNAKOS, Ângelo Maraninchi. Assistência judiciária no direito brasileiro, cit., p. 50.

${ }^{377}$ TROCKER, Nicolo. Processo civile e Costituzione: problemi di diritto tedesco e italiano, cit., p. 319.

${ }^{378}$ BERIZONCE, Roberto Omar. La organización de la asistencia jurídica (un estúdio sintético de la legislación comparada), cit., p. 168; GIANNAKOS, Ângelo Maraninchi. Assistência judiciária no direito brasileiro, cit., p. 50.

${ }^{379}$ SOUSA SANTOS, Boaventura de (Dir. Científico). O acesso ao direito e à justiça: um direito fundamental em questão. Coordenadores: João Pedroso, Catarina Trincão; João Paulo Dias, cit., p. 119-120.

${ }^{380}$ BERIZONCE, Roberto Omar. La organización de la asistencia jurídica (un estúdio sintético de la legislación comparada), cit., p. 170. Segundo o autor retro citado, este bônus seria de 100 DM, segundo valores da época em que editado o texto em questão, 1989.

${ }^{381}$ SOUSA SANTOS, Boaventura de (Dir. Científico). O acesso ao direito e à justiça: um direito fundamental em questão. Coordenadores: João Pedroso, Catarina Trincão; João Paulo Dias, cit., p. 121.
} 
Bom de ver ainda que são considerados nulos contratos de honorários advocatícios entre beneficiário da assistência e seu defensor ${ }^{382}$.

Em texto anterior à reforma levada a cabo no início da década de oitenta, Trocker apontava a insatisfação da doutrina alemã com o aspecto extrajudicial do serviço de assistência legal ${ }^{383}$. Segundo se dizia, os ofícios ou escritórios de consulta extrajudicial (Rechtsberatungsstellen) não funcionavam de maneira satisfatória, basicamente porque eram poucos e operantes quase que exclusivamente nas grandes cidades; a assistência era prestada por um advogado em caráter singular e em sistema de rodízio, de modo que muitas vezes quando do retorno após uma consulta inicial, o beneficiário deparava-se com outro profissional, de modo que o elemento de confiança entre advogado e cliente restava inteiramente desatendido. Acresça-se que havia uma regra de localização topográfica e estrutura organizativa inteiramente inadequada ${ }^{384}$.

Este sistema foi objeto de reforma, como dito, tanto no início da década de oitenta como em 1994, e diz-se que após esta última reforma, abrange todos os domínios da ciência do Direito $^{385}$. É de ser ressaltada a atividade de aconselhamento legal que pode ser prestada pelo próprio "cancellière della corte", alto funcionário vinculado à Corte, que tem atribuição da receber o pleito de assistência. Obviamente que esta consulta é prestada de forma direta, simples e rápida, mais a título de prestação de informações. Não lhe cabe assumir a representação do necessitado. No caso desta mera atividade informativa não ser suficiente, emitirá uma licença ou autorização para que o necessitado recorra a advogado de sua escolha, o qual, ao depois, formulará o pedido de apoio judiciário ${ }^{386}$.

\footnotetext{
${ }^{382}$ GIANNAKOS, Ângelo Maraninchi. Assistência judiciária no direito brasileiro, cit., p. 51; BERIZONCE, Roberto Omar. La organización de la asistencia jurídica (un estúdio sintético de la legislación comparada), cit., p. 170.

${ }^{383}$ TROCKER, Nicolo. Processo civile e Costituzione: problemi di diritto tedesco e italiano, cit., p. 357-358. O texto já tem sido assaz citado anteriormente, e remonta, como se vê, a 1974. Por isto tivemos o cuidado de recorrermos a ele apenas no que se manteve homogêneo mesmo após as reformas da década de oitenta e noventa (1994).

${ }^{384}$ Eis a conclusão de Trocker: "Nell' ambito della consulenza stragiudiziale ci si è accontentati invece di uma realizzazione più apparente che effettiva e per di più sopravvive in essa quella concezione deprecabilmente caritativa che in passato era stata oggetto di giustificate critiche" (TROCKER, Nicolo. Processo civile e Costituzione: problemi di diritto tedesco e italiano, cit., p. 359).

${ }^{385}$ SOUSA SANTOS, Boaventura de (Dir. Científico). O acesso ao direito e à justiça: um direito fundamental em questão. Coordenadores: João Pedroso, Catarina Trincão; João Paulo Dias, cit., p. 121.

${ }^{386}$ SOUSA SANTOS, Boaventura de (Dir. Científico). O acesso ao direito e à justiça: um direito fundamental em questão. Coordenadores: João Pedroso, Catarina Trincão; João Paulo Dias, cit., p. 121-122; BERIZONCE, Roberto Omar. La organización de la asistencia jurídica (un estúdio sintético de la legislación comparada), cit., p. 169.
} 
Evidente também que o necessitado pode procurar diretamente o advogado de sua escolha para consultar-se, o qual, repita-se, oportunamente formulará se o caso o pedido de assistência.

Um último dado consiste no importante papel que seguros privados tem desempenhado na cobertura de gastos judiciais dos necessitados (Rechtsschutzversicherung). Ainda na década de setenta, Trocker no texto já citado, observava a tendência que se difundia no sistema alemão de se estipularem seguros contra o risco patrimonial do processo ${ }^{387}$. Obviamente que a solução recebia críticas, como por exemplo o fato de nada operar no que concerne à questão da ignorância acerca de direitos, ou seja, o famigerado problema da desinformação jurídica que acomete e manieta as classes mais baixas da população.

Passemos em revista, a seguir, o sistema italiano. É preciso dizer que embora matriz histórica de grande parte dos princípios estruturais do direito processual brasileiro, a Itália fez-se retrógrada em tema de assistência legal, perdurando uma organização arcaica e altamente criticada.

Bom que seja dito que o amparo assistencial ao necessitado conta com fundamento constitucional expresso, conforme se vê do art. 24 da Constituição Italiana: "Sono assicurati ai non abbienti, con appositi istituti, i mezzi per agire e difendersi davanti ad ogni giurisdizione".

A questão é que a forma como configurada a organização da assistência legal em nível infraconstitucional quedou-se incongruente com as exigências do mundo contemporâneo, especialmente quando se apregoa como mote a eficácia de direitos humanos fundamentais, chegando a ser classificada como arbitrária ${ }^{388}$.

Retomando mais uma vez aquelas três tendências em tema de assistência referidas por Vittorio Denti, fio condutor do início da presente exposição, enquadra-se o sistema italiano naquilo que se definiu como primeira tendência. Segundo o referido autor a legislação italiana (assim como, segundo ele, a espanhola e a belga) mantiveram caracteres

\footnotetext{
${ }^{387}$ TROCKER, Nicolo. Processo civile e Costituzione: problemi di diritto tedesco e italiano, cit., p. 361 . "Por último, además de los mecanismos que hemos analizado, no puede dejar de mencionarse la cobertura que en matéria assistencial se integra con los seguros privados sobre gastos judiciales y procesales" (BERIZONCE, Roberto Omar. La organización de la asistencia jurídica (un estúdio sintético de la legislación comparada), cit., p. 170).

388،Enfim, é um sistema arbitrário, na mais singela das expressões, já que não permite o acesso dos pobres ao judiciário, o que acaba por deixar a Justiça desacreditada aos homens e levando os mesmos à solução pela autotutela" (SOUZA, Silvana Cristina Bonifácio. Assistência jurídica integral e gratuita. São Paulo: Ed. Método, 2003. p. 109).
} 
tipicamente liberais, remontando ao contexto oitocentista, sustendo legislação que advém da segunda metade do século XIX $^{389}$. Na contramão das demais nações, que bem ou mal passaram a reconhecer a necessidade de remuneração aos profissionais que atendem aos necessitados, direta ou indireta, e mesmo que de acordo com tarifas mais baixas, Itália manteve-se fiel ao combalido sistema de dever honorífico do advogado ${ }^{390}$.

Outras características do sistema em questão, ressaltadas por Denti, são a grande autonomia deixada às associações profissionais na regulação dos modos da assistência judiciária e no controle da efetividade da prestação pelos advogados, além da ausência de um difuso instrumento de consulta legal, que mesmo onde disponibilizado, não o é por um escritório ou ofício público, ostentando caráter limitado e casual ${ }^{391}$.

O patrono, então, neste regime, apenas logra remuneração se vencedor na pendenga pois que na concepção então prestigiada, "o patrocínio da causa dos pobres seria um dever honorífico e obrigatório da classe dos advogados, e não do Estado" ${ }^{\text {392 }}$.

Na Itália o regime legal da assistência ao necessitado está contido no Decreto régio $\mathrm{n}^{\circ} 3.282$ de dezembro de 1923. O diploma é classificado por Cappelletti como um "decreto lei fascita", e o sistema adotado igualmente qualificado como "hipócrita" porquanto baseado naquela idéia já mencionada de dever honorífico ${ }^{393}$.

É bom deixar anotado que não apenas o advogado, mas todos os intervenientes no processo em que figura o beneficiário, prestarão sua atividade a título de dever honorífico, assim ocorre em relação a peritos, assistentes técnicos, agentes públicos em geral chamados a atuar de alguma forma no feito, etc.

Trocker enumera quatro principais diferenças entre o sistema alemão, já estudado, e o italiano, ora em exame: a) possibilidade de apresentação do pedido de admissão ao

\footnotetext{
${ }^{389}$ Apesar do Decreto régio que organiza a assistência na Itália ser datado de 1923, substancialmente mantémse um sistema instaurado em 1865 (GIANNAKOS, Ângelo Maraninchi. Assistência judiciária no direito brasileiro, cit., p. 65).

${ }^{390}$ DENTI, Vittorio. L'evoluzione del legal aid nel mondo contemporaneo, cit., v. 2, p. 1170 . Eis o artigo $1^{\circ}$ do Decreto $\mathrm{n}^{\circ} 3.282 / 1923$ : "Il patrocinio gratuito dei poveri è un ufficio onorifico ed obbligatorio della classe degli avvocati e dei procuratori".

${ }^{391}$ DENTI, Vittorio. L'evoluzione del legal aid nel mondo contemporaneo, cit., v. 2, p. 1171.

${ }^{392}$ GIANNAKOS, Ângelo Maraninchi. Assistência judiciária no direito brasileiro, cit., p. 64.

${ }^{393}$ Obviamente que seu raciocínio é de lucidez irretorquível: "Es obvio, empero, que, en una economia de mercado, las más de las veces, y ciertamente con alguna noble excepción, esa solución se reduce necesariamente a una verdadera y propria farsa, o a una tragedia, según los puntos de vista" (CAPPELLETTI, Mauro. El proceso como fenomeno social de masa, cit., p. 134). Em outro texto da mesma obra, Cappelletti classifica o já citado art. $1^{\circ}$ do Decreto régio que trata da assistência como "retórica farsesca" (La justicia de los pobres. Trad. esp. de Santiago Sentis Mellendo, Tomás A. Banzhaf. Proceso, ideologias, sociedad, cit., p. 139).
} 
regime de assistência pela via verbal, e em geral, mais informal (enquanto o sistema italiano, como se verá, é marcadamente mais rígido); b) competência do mesmo juízo que decidirá o mérito da causa para examinar também o pleito de assistência, além da maior celeridade do procedimento preliminar voltado a decidir acerca do direito à assistência; c) retribuição, ainda que parcial, do Estado ao advogado dedicado à defesa do necessitado e d) possibilidade de um concurso parcial do necessitado nas despesas do processo ${ }^{394}$. Conclui o autor, então, sua comparação afirmando ser ela inteiramente favorável ao sistema tedesco.

Conforme estas notas diferenciadoras já apontadas fica fácil apontarmos as principais características do regime vigente na Itália, a par do quanto já explicitado anteriormente.

Primeiramente anota-se que o pedido de assistência legal não é formulado perante o mesmo órgão jurisdicional que tem competência para decidir a causa que será o objeto do benefício. Ao contrário, o pleito se apresenta perante uma Comissão, formada, segundo Silvana Cristina Bonifácio Souza, por um magistrado, dois membros do Ministério Público e um membro da Ordem dos Advogados ${ }^{395}$. Parece, contudo, que segundo o art. $5^{\circ}$ do Decreto $\mathrm{n}^{\circ} 3.282 / 1923$ a Comissão é, na verdade, formada por um magistrado, um membro do Ministério Público e um membro da Ordem dos Advogados ${ }^{396}$.

\footnotetext{
${ }^{394}$ TROCKER, Nicolo. Processo civile e Costituzione: problemi di diritto tedesco e italiano, cit., p. 355.

${ }^{395}$ SOUZA, Silvana Cristina Bonifácio. Assistência jurídica integral e gratuita, cit., p. 109.

396، Art. 5. Presso ogni tribunale, ogni corte di appello o sezione distaccata di corte di appello e la Corte di cassazione è istituita una Commissione per il gratuito patrocinio, composta:

1) di un membro del corpo giudicante del tribunale o della corte, ovvero d'un ex magistrato di pari grado, che è designato ogni anno dal primo presidente della Corte di cassazione o della corte di appello o dal presidente della sezione staccata di corte di appello, e tiene la presidenza della Commissione. Egli non può intervenire nei giudizi riguardanti gli affari da lui esaminati in qualità di membro della Commissione;

2) di un funzionario del ministero pubblico, addetto alla corte od al tribunale, che è designato ogni anno dal procuratore generale, o dall'avvocato generale della sezione distaccata, ed esercita le funzioni di relatore. Queste possono, invece, essere affidate dal procuratore generale o dal detto avvocato generale ad un giudice $\mathrm{o}$ ad un giudice aggiunto, ovvero anche ad un uditore, il quale ultimo, però, non avrà voto deliberativo;

3) del presidente del Consiglio dell'Ordine degli avvocati, o, in assenza o mancanza, di un avvocato patrocinante da lui delegato, o nominato dal primo presidente della Corte o dal presidente della sezione distaccata di corte di appello.

Un cancelliere o primo cancelliere della corte o del tribunale esercita le funzioni di segretario.

L'ammissione al gratuito patrocinio per le cause di competenza dei conciliatori, le quali abbiano un valore superiore a lire 50, vien fatta dalla Commissione presso il tribunale nel cui circondario deve aver luogo il giudizio".

Nel procedimento fallimentare il giudice delegato, mediante decreto da emanarsi di volta in volta, dispone l'anticipazione delle spese giudiziarie occorrenti per la procedura, dalla sentenza dichiarativa di fallimento a quella che ne ordina la cessazione per mancanza di attivo.
} 
Em geral os requisitos para a admissão ao benefício legal são análogos àqueles já referidos e vigentes na Alemanha: estado de pobreza e a plausibilidade do direito invocado. Aponta-se, entretanto, quanto a este segundo requisito, que a legislação italiana acaba sendo por demais severa, ao expressar a exigência em termos de "probabilità dell'esito favorevole nella causa di affare" 397 .

A Comissão perante a qual apresentado o pedido de assistência não ostenta natureza jurisdicional. Aliás, é este um dos pontos de crítica a esta sistemática, porquanto a matéria em questão acaba sujeita a um órgão não dotado das garantias e atributos (como por exemplo a independência e imparcialidade) próprios dos órgãos do Poder Judiciário ${ }^{398}$.

Outro ponto fraco, comum ao sistema alemão, é a possibilidade de manifestação do adversário, a quem se dá a vantagem de conhecer previamente os elementos em que se baseará a causa do pretendente ao benefício, visto que este contraditório preliminar ter por único objeto a questão da assistência legal.

Uma das mais latentes críticas feitas ao modelo italiano é o exacerbado formalismo aplicado ao pedido inicial, apresentado perante a dita Comissão ${ }^{399}$. Cappelletti assevera que dá-se a impressão de que tais requisitos foram pensados justamente a fim de desencorajar ao carente de buscar a estrutura de assistência ${ }^{400}$.

O pedido deve ser apresentado por escrito, em "papel sellado" 401 , com a indicação clara e precisa dos elementos de fato e de direito que constituirão a causa do pedido, além dos meios de prova pretendidos.

Refere-se, então, que nesta conjuntura obviamente que os elementos mais simplórios da sociedade não terão a mínima condição de redigir um pedido nestes termos para o que, certamente, terão de recorrer a um advogado que, no contexto de uma economia de mercado, não emprestariam graciosamente sua pena a este mister. É por isto que se questiona em doutrina a compatibilidade do regime assim estabelecido com o art. 24 já transcrito da Constituição daquele país.

\footnotetext{
${ }^{397}$ Art. 15, 2, do Decreto régio 3.282/1923.

${ }^{398}$ TROCKER, Nicolo. Processo civile e Costituzione: problemi di diritto tedesco e italiano, cit., p. 325.

${ }^{399}$ SOUZA, Silvana Cristina Bonifácio. Assistência jurídica integral e gratuita, cit., p. 109.

${ }^{400}$ CAPPELLETTI, Mauro. El proceso como fenomeno social de masa. Trad. esp. de Santiago Sentis Mellendo, Tomás A. Banzhaf. Proceso, ideologias, sociedad, cit., p. 135.

${ }^{401}$ CAPPELlETTI, Mauro. El proceso como fenomeno social de masa. Trad. esp. de Santiago Sentis Mellendo, Tomás A. Banzhaf. Proceso, ideologias, sociedad, cit., p. 135.
} 
As estatísticas apresentadas por Cappelletti há mais de trinta anos já refletiam os nefastos efeitos deste vetusto sistema. Enquanto na Inglaterra, França e Alemanha o patrocínio gratuito foi responsável por percentuais variantes de $20 \%$ a $30 \%$ das causas, conforme períodos apurados na década de sessenta, na Itália este percentual era de $1 \%$ em 1960, 0,61\% em 1964 e 0,54\% em 1965 ${ }^{402}$. Estes dados levam o autor em questão a concluir: "La violación del precepto constitucional expresado en el art. 24 y sintetizado en la fórmula del 'Estado social de derecho' no podría ser más macroscópica”403.

Outro problema verificado é que os necessitados acabam defendidos por advogados mais jovens e inexperientes, ou mesmo "abogados fracasados" 404 , de modo que ao carente até mesmo o nível qualitativo da defesa de sua causa seria inferior, perpetuando-se ao longo de todo o trâmite do processo aquela desigualdade que já se verifica no procedimento preliminar destinado à obtenção da assistência.

A rigor o Estado parece renunciar à prestação do serviço jurisdicional ao necessitado, transferindo este encargo segundo o modelo analisado à classe dos profissionais liberais advogados.

Como se não bastassem os defeitos já referidos, a lei italiana "no prevê ni en lo más mínimo la institución de oficinas legales de consultoria gratuita extrajudicial, estabelecidas en cualquier parte del território nacional” ${ }^{\star 405}$. Ainda outra inadequação referida diz respeito ao fato de que a legislação italiana preveja apenas os pólos extremos possíveis: de um lado a impossibilidade de arcar com o custo da demanda, e de outro a capacidade plena de custear-lhe. Não se prevê a solução intermédia, de admissão parcial daquele que tenha condições de arcar com parte do custo do processo.

Interessante ainda anotar que a parte carente beneficiária da assistência, acaso vencida, deverá submeter-se a novo juízo de delibação pela Comissão para que possa apresentar sua “impugnação", conforme se extrai do art. 13 do diploma já citado ${ }^{406}$.

\footnotetext{
${ }^{402}$ CAPPELLETTI, Mauro. El proceso como fenomeno social de masa. Trad. esp. de Santiago Sentis Mellendo, Tomás A. Banzhaf. Proceso, ideologias, sociedad, cit., p. 136.

${ }^{403}$ CAPPELLETTI, Mauro. El proceso como fenomeno social de masa. Trad. esp. de Santiago Sentis Mellendo, Tomás A. Banzhaf. Proceso, ideologias, sociedad, cit., p. 137.

${ }^{404}$ CAPPELlETTI, Mauro. La justicia de los pobres. Trad. esp. de Santiago Sentis Mellendo, Tomás A. Banzhaf. Proceso, ideologias, sociedad, cit., p. 140.

${ }^{405}$ CAPPELlETTI, Mauro. La justicia de los pobres. Trad. esp. de Santiago Sentis Mellendo, Tomás A. Banzhaf. Proceso, ideologias, sociedad, cit., p. 142.

${ }^{406}$ Art. 13 "L'ammissione al gratuito patrocinio giova per tutti i gradi di giurisdizione.

Tuttavia la parte che l'ottenne, quando sia rimasta soccombente, non può giovarsene per proporre impugnazione, senza aver ottenuta nuova ammissione dalla Commissione competente per il collegio, cui deve deferirsi l'esame dell'impugnazione".
} 
Passa-se então a breve estudo do regime vigente em França. O sistema francês ostenta particular importância em tema de assistência legal por ter sido, conforme afirmase em doutrina, o primeiro a organizar em legislação um sistema de apoio judiciário, muito embora silente a respeito a Constituição. A pioneira lei francesa remonta a 22 de janeiro de 1851 (Code de l'Assistance Judiciaire) ${ }^{407}$.

A característica geral do sistema francês é a adaptação da estrutura judicial às novas formas de litígio que advêm das reformas legislativas, privilegiando-se assim a especialização dos órgãos judiciais ${ }^{408}$.

Após a lei de 1851, o grande marco na legislação francesa foi o diploma advindo em 1972, a Lei $n^{\circ} 72-11$ de $3^{\circ}$ de janeiro de 1972 , que deu ao sistema de acesso ao direito um caráter avançado de seguridade social, implicando o grande mérito de prever o custeio dos honorários advocatícios pelo Estado, inovando o anterior regime baseado na caridade e no favor ${ }^{409}$.

Características básicas do esquema implantado em 1972 eram a possibilidade de benefício a qualquer cidadão francês ou estrangeiro residente, além de associações sem fins lucrativos. Previa-se também uma tabela de valores como parâmetros de rendimentos para que se concedesse o benefício, prevendo-se elevações em cotas para cada dependente a cargo do requerente. A tabela em questão não excluía casos específicos, em que à luz das características do litígio, poderia ser concedido o benefício mesmo afora os limites monetários.

O pedido de assistência era dirigido ao Departamento de Apoio Judiciário, e a concessão poderia ser total ou parcial, conforme o caso.

Algumas manifestações doutrinárias são contraditórias acerca do sistema vigente em 1972. Por um lado afirmava-se o profundo descontentamento da classe dos advogados, que contestavam o regime em questão dado que os limites financeiros estabelecidos para o requerimento da benesse compreendiam nada menos que quase $75 \%$ da população

\footnotetext{
${ }^{407}$ SOUZA, Silvana Cristina Bonifácio. Assistência jurídica integral e gratuita, cit., p. 110; GIANNAKOS, Ângelo Maraninchi. Assistência judiciária no direito brasileiro, cit., p. 51. CASTRO, José Roberto de. Manual de assistência judiciária: teoria, prática e jurisprudência, cit., p. 43-44. Afirma-se que foi tal diploma que legou ao instituto a denominação "Assistência Judiciária", que foi seguida posteriormente pelos diversos Estados que adotaram regime de tal porte (PINTO, Robson Flores. A garantia constitucional da assistência jurídica estatal aos hipossuficientes. Cadernos de Direito Constitucional e Ciência Política, São Paulo, v. 1, n. 3, p. 101, abr./jun. 1993).

${ }^{408}$ SOUSA SANTOS, Boaventura de (Dir. Científico). O acesso ao direito e à justiça: um direito fundamental em questão. Coordenadores: João Pedroso, Catarina Trincão; João Paulo Dias, cit., p. 42.

${ }^{409}$ GIANNAKOS, Ângelo Maraninchi. Assistência judiciária no direito brasileiro, cit., p. 52.
} 
francesa. Daí porque acusava-se tal sistema de ser solidarista, complexo e intervencionista, seguindo tendência de socialização da advocacia ${ }^{410}$.

Contraditoriamente, entretanto, um dos defeitos do sistema em questão era que, apesar da enorme proporção referida no parágrafo anterior, apenas um pequeno número de requerentes acabavam efetivamente beneficiando-se do apoio judiciário. Outros problemas indicados eram a baixa remuneração dos profissionais dedicados à assistência, com gritante desigualdade especialmente na área penal, além de desigualdade na própria distribuição geográfica do benefício, implicando que alguns advogados fossem agraciados com diversas nomeações, e outros, poucas ou nenhuma. Também era limitado o orçamento destinado pelo Ministério da Justiça. Além disto, aquele limite de renda exigido para recurso ao apoio judiciário não era atualizado de acordo com o salário mínimo, o que causava gradual defasagem e redução dos elegíveis. Não havia ainda estrutura organizada voltada às consultas extrajudiciais, cujos serviços eram dispersos e descentralizados ${ }^{411}$.

Relatório do Conselho de Estado apontando estas e outras inadequações do sistema implantado em 1972 serviu de base à edição de novel legislação, de 10 de julho de 1991, Lei $\mathrm{n}^{\circ}$ 91-647, que posteriormente contou com o aprimoramento pela Lei $\mathrm{n}^{\circ} 98-1163$, de 18 de dezembro de 1998.

A lei de 1991 alargou o âmbito subjetivo do benefício. O rendimento mínimo para acesso passou a estar atrelado aos mínimos reajustes previstos para a remuneração ${ }^{412}$, e instituiu-se a possibilidade de revisão judicial da decisão dos gabinetes de apoio judiciário.

\footnotetext{
${ }^{410}$ As pessoas físicas poderiam requerer o benefício "siempre que justifiquen que sus ingresos mensuales son inferiores a 900 francos, en cuyo caso reciben la ayuda judicial total; o al menos, a una suma que fija la reglamentación, variable según las jurisdiciones y la índole de los asuntos, hasta un limite de 1.500 francos, en cuyo supuesto, se benefician con la ayuda judicial parcial ... De acuerdo a estudios realizados por el Ministério de Economia y Finanzas, el 45,2\% de los hogares franceses tenían por entoces una renta neta global inferior a 800 fr. mensuales y el 29,3\% una renta neta global comprendida entre 800 y 1.500 fr." (BERIZONCE, Roberto Omar. La organización de la asistencia jurídica (un estúdio sintético de la legislación comparada), cit., 166-167). Esta mesma proporção é confirmada no texto igualmente já referido de SOUSA SANTOS, Boaventura de (Dir. Científico). O acesso ao direito e à justiça: um direito fundamental em questão. Coordenadores: João Pedroso, Catarina Trincão; João Paulo Dias, cit.

${ }^{411}$ SOUSA SANTOS, Boaventura de (Dir. Científico). O acesso ao direito e à justiça: um direito fundamental em questão. Coordenadores: João Pedroso, Catarina Trincão; João Paulo Dias, cit., p. 47 e 53.

${ }^{412}$ Diz o vigente art. $4^{\circ}$ da Lei 91-647: "Le demandeur à l'aide juridictionnelle doit justifier, pour l'année 2001, que ses ressources mensuelles sont inférieures à $5175 \mathrm{~F}$ [*francs*] pour l'aide juridictionnelle totale et à $7764 \mathrm{~F}$ pour l'aide juridictionnelle partielle.

Ces plafonds sont affectés de correctifs pour charges de famille.

Ils sont revalorisés, au 1er janvier de chaque année, comme la tranche la plus basse du barème de l'impôt sur le revenu.

Les personnes bénéficiaires de l'allocation supplémentaire du Fonds national de solidarité ou du revenu minimum d'insertion sont dispensées de justifier de l'insuffisance de leurs ressources.
} 
O serviço também passou a ser prestado em nível de consulta jurídica, além do que as partes passaram a ter acesso, por meio de um anuário, às especialidades de cada profissional $^{413}$.

O sistema inaugurado em 1991 prevê a assistência legal em duas vertentes: i) apoio jurisdicional e ii) apoio no acesso ao direito. Esta última mediante a consulta preventiva de litígios, com a prestação de informações e conselhos sobre direitos e deveres, além de assessoramento para a prática de atos jurídicos; ou ainda assistência perante comissões de caráter não-jurisdicional, ou perante os vários serviços administrativos, incentivando formas extrajudiciais de solução dos litígios ${ }^{414}$.

A Lei de Acesso ao Direito e à Resolução Amigável de Conflitos de 1998 trouxe proposta de modernização. Na verdade o contexto em que se põe no cenário francês é o da "estratégia de reformas no sector da justiça, numa perspectiva global e abrangente" Como da própria alcunha dada ao diploma se pode aferir, privilegia-se a prevenção do recurso aos tribunais, com prestígio aos meios alternativos de resolução das disputas. Em resumo:

\begin{abstract}
"A anterior Lei de 1991 definia o acesso ao direito e à justiça apenas em duas vertentes, em regra dependentes de juristas: a consulta jurídica e a assistência no âmbito dos procedimentos não jurisdicionais. A nova definição de apoio ao direito e à justiça concebe o apoio em vários níveis e com o envolvimento de múltiplos actores no terreno: associações, trabalhadores sociais, agentes de acesso ao direito, instituições, emprego para jovens, profissionais da justiça e do direito" ${ }^{416}$.
\end{abstract}

Segundo a regulamentação atualmente em vigor, o benefício pode ser concedido aos cidadãos franceses ou aos nacionais de Estados membros da Comunidade Européia; além disto, estrangeiros com residência habitual e regularizada em França são também

Pour les Français établis hors de France, les plafonds prévus par le premier alinéa sont établis par décret en Conseil d'Etat après avis de la commission permanente pour la protection sociale des Français de l'étranger".

${ }^{413}$ SOUSA SANTOS, Boaventura de (Dir. Científico). O acesso ao direito e à justiça: um direito fundamental em questão. Coordenadores: João Pedroso, Catarina Trincão; João Paulo Dias, cit., p. 47 e 58.

${ }^{414}$ SOUSA SANTOS, Boaventura de (Dir. Científico). O acesso ao direito e à justiça: um direito fundamental em questão, cit., p. 67. Na verdade a assistência jurídica (aide juridique) está assim prevista pelo art. $1^{\circ}$ da Lei $\mathrm{n}^{\circ}$ 91-647: "L'aide juridique comprend l'aide juridictionnelle, l'aide à l'accès au droit et l'aide à l'intervention de l'avocat au cours de la garde à vue et en matière de médiation pénale et de la composition pénale".

${ }^{415}$ SOUSA SANTOS, Boaventura de (Dir. Científico). O acesso ao direito e à justiça: um direito fundamental em questão, cit., p. 64.

${ }^{416}$ SOUSA SANTOS, Boaventura de (Dir. Científico). O acesso ao direito e à justiça: um direito fundamental em questão. Coordenadores: João Pedroso, Catarina Trincão; João Paulo Dias, cit., p. 68-69. 
elegíveis. Mesmo esta condição pode ser dispensada em determinados casos (p.ex. menores; testemunhas assistidas; etc.). Fora destes casos o benefício pode ser concedido nos casos em que houver particular interesse no litígio (art. $6^{\circ}$ da Lei $n^{\circ}$ 91-647).

Os pedidos são formulados mediante preenchimento de formulário próprio e declaração de rendimentos, documentos remetidos aos gabinetes de apoio judiciário estabelecidos na sede de cada Tribunal de Grande Instância ${ }^{417}$. No caso de concessão de apoio total, o Estado arca com todos as custas judiciais que ficariam a cargo do litigante; se o apoio é parcial o Estado paga apenas parte dos honorários advocatícios, cabendo o restante a ser pago pelo beneficiário, mediante contratação com o patrono com base naquilo que regularmente se contrata afora do benefício. Também aos agentes públicos envolvidos no processo pode o beneficiário parcial ter de pagar alguma retribuição ${ }^{418}$.

O beneficiário, se perder, pode ser condenado a reembolsar à outra parte as custas, exceto honorários. Se o beneficiário vencer o advogado pode reclamar o pagamento de seus honorários, desde que haja autorização do Bastonário, e desde que a indenização recebida pelo beneficiário atinja determinado montante. O patamar dos honorários no caso também segue o que se exigiria num caso não alcançado pelo apoio judiciário ${ }^{419}$.

Por fim, vale observar o largo espectro da atividade de consultoria extrajudicial formatado na França, dentro do contexto de uma política que se denominou "justiça de proximidade", com a previsão de importantes entidades destinadas a saciar este filão de carência.

Os principais órgãos neste quadrante são os CDAD's (Conseils Departamentaux d'Accès au Droit), sucessores dos Conseils Departamentaux de l'Aide Juridique, criados em 1991 e que não alçaram grandes vôos.

Estes órgãos podem ser bem conceituados como verdadeiros pólos aglutinadores de diversos ramos e espécies de conhecimentos jurídicos e que se destinam a atender diversificadas necessidades dos cidadãos.

\footnotetext{
${ }^{417}$ GIANNAKOS, Ângelo Maraninchi. Assistência judiciária no direito brasileiro, cit., p. 54.

${ }^{418}$ Art. 24: "Les dépenses qui incomberaient au bénéficiaire de l'aide juridictionnelle s'il n'avait pas cette aide sont à la charge de l'Etat.

Toutefois, l'aide juridictionnelle partielle laisse à son bénéficiaire la charge d'un honoraire fixé par convention avec l'avocat conformément à l'article 35 ou d'un émolument au profit des officiers publics et ministériels qui prêtent leur concours".

${ }^{419}$ SOUSA SANTOS, Boaventura de (Dir. Científico). O acesso ao direito e à justiça: um direito fundamental em questão. Coordenadores: João Pedroso, Catarina Trincão; João Paulo Dias, cit., p. 72.
} 
Nas palavras da doutrina portuguesa que temos assaz citado,

"é uma entidade de interesse público dotada de personalidade jurídica, sob a presidência do Presidente do Tribunal de Grande Instância na sede de cada Departamento ... A principal missão do CDAD é definir uma política de acesso ao direito no Departamento em que está inserido e coordenar acções em matéria de apoio ao acesso ao direito" ${ }^{420}$

Neste esforço, entre outras linhas de atuação, tal entidade promove a difusão do conhecimento acerca dos direitos, mediante distribuição de brochuras, campanhas informativas nos meios de comunicação, sistema de informação itinerante, e no âmbito específico da consulta jurídica, a emissão de "vales". Segundo esclarece Giannakos, em tais pólos atuam profissionais diversos, como autoridades judiciárias, conselho geral, advogados, notários, associações, etc ${ }^{421}$.

Internamente os CDAD's são compostos por Assembléia Geral e Conselho de Administração. A composição geral da entidade envolve além do Presidente do Tribunal de Grande Instância, os profissionais da área do direito, acima já referidos; as coletividades locais a cargo das políticas sociais; as associações especializadas em áreas como auxílio a vítimas e mediação, consumidores, carentes, direito da habitação e direito de estrangeiros; e o Estado, representado pelo préfet de département ${ }^{422}$.

Merece também menção a atuação das Maisons de Justice et du Droit (MJD’s), criação do governo francês nesta empreitada de aproximar a justiça dos cidadãos. Basicamente, as maisons têm por atribuição a prevenção da delinqüência, o apoio às vítimas e acesso ao direito, além do desenvolvimento da cidadania, apoio aos meios alternativos de resolução de disputas ${ }^{423}$.

As Casas são compostas por uma equipe polivalente, composta basicamente pelo Presidente do Tribunal de Grande Instância, o Procurador da República da zona; magistrados que colaboram em diversas tarefas; funcionário que desempenhe atividade de secretaria; servidores que efetuam entrevistas rápidas, mediações e controle judicial

\footnotetext{
${ }^{420}$ SOUSA SANTOS, Boaventura de (Dir. Científico). O acesso ao direito e à justiça: um direito fundamental em questão. Coordenadores: João Pedroso, Catarina Trincão; João Paulo Dias, cit., p. 73.

${ }^{421}$ GIANNAKOS, Ângelo Maraninchi. Assistência judiciária no direito brasileiro, cit., p. 56.

${ }^{422}$ SOUSA SANTOS, Boaventura de (Dir. Científico). O acesso ao direito e à justiça: um direito fundamental em questão. Coordenadores: João Pedroso, Catarina Trincão; João Paulo Dias, cit., p. 75; e texto localizado no sítio eletrônico a seguir declinado, INCLUSION EUROPE. CONSEILS DEPARTEMENTAUX D'ACCES AU DROIT (CDAD). Disponível em: <http://www.inclusioneurope.org/FFOR/FR/FR_CDAD.pdf>. Acesso em: 04 maio 2011.

${ }^{423}$ Cf. o sítio eletrônico: MINISTĖRE DE LA JUSTICE. Tribunal de Grande Instance de Bordeaux. Disponível em: <http://www.maisondejustice.fr>. Acesso em: 05 maio 2011.
} 
quando requerido pelas autoridades judiciárias; um educador da Proteção Judiciária de Menores para acompanhamento dos casos envolvendo menores; um agente de probation para acompanhamento do cumprimento de penas e auxílio a ex-reclusos; conciliador para conflitos cíveis; um representante de associação de apoio às vítimas; e advogados que atuem no âmbito das consultas extrajudiciais ${ }^{424}$.

A avaliação das atividades destes órgãos junto aos cidadãos tem sido profundamente positiva, e a quantidade de maisons instaladas é crescente. Em 2002 eram 85 Casas de Justiça e de Direito nos 46 Departamentos Regionais em que dividida a nação ${ }^{425}$.

Outra iniciativa que merece referência são as PAD's (Points d'Accès au Droit), local de acolhimento gratuito e permanente, atuando precipuamente na prestação de informações sobre direito e deveres dos cidadãos.

Cuida-se, na verdade, de uma espécie de posto avançado dos CDAD's em regiões não adequadamente servidas. Sua criação é promovida pelos CDAD's e atuam sob dependência destes, podendo alojar-se em locais onde se prestam outras informações, preferencialmente jurídicas ${ }^{426}$.

Há igualmente uma fecunda atuação de conciliadores, distribuídos por locais diversos de acesso ao público, como as já referidas MJD's, no próprio Tribunal de Instância, escolas e zonas rurais. O acesso é gratuito e os acordos firmados contam com força executiva, podendo a atividade desempenhar-se em caráter pré-processual ou endoprocessual $^{427}$.

Por fim deve ser lembrada também a atuação do Médiateur de la Republique (Provedor de Justiça), que exerce a função de mediador administrativo. Atua tal figura no campo do contencioso administrativo, por meio dos Delegados de Mediador espalhados pelo país, sob a ótica da prevenção à judicialização do conflito. Interessante notar que além da tentativa de resolução do conflito propriamente dita, tais figuras exercem pressão institucional sobre a própria Administração Pública, e especialmente em queixas

\footnotetext{
${ }^{424}$ SOUSA SANTOS, Boaventura de (Dir. Científico). O acesso ao direito e à justiça: um direito fundamental em questão. Coordenadores: João Pedroso, Catarina Trincão; João Paulo Dias, cit., p. 76-77.

${ }^{425}$ SOUSA SANTOS, Boaventura de (Dir. Científico). O acesso ao direito e à justiça: um direito fundamental em questão. Coordenadores: João Pedroso, Catarina Trincão; João Paulo Dias, cit., p. 77.

${ }^{426}$ SOUSA SANTOS, Boaventura de (Dir. Científico). O acesso ao direito e à justiça: um direito fundamental em questão. Coordenadores: João Pedroso, Catarina Trincão; João Paulo Dias, cit., p. 78-79.

${ }^{427}$ SOUSA SANTOS, Boaventura de (Dir. Científico). O acesso ao direito e à justiça: um direito fundamental em questão. Coordenadores: João Pedroso, Catarina Trincão; João Paulo Dias, cit., p. 80-81.
} 
envolvendo concessionárias de serviço público, exigindo a resposta às demandas populares com qualidade e eficiência. Exercem o que se denomina uma magistratura de influência ${ }^{428}$, inclusive propondo a alteração de rotinas faltosas.

Os Delegados de Mediador tem exercido profícuo trabalho no cenário francês, e a tendência é de aumento de profissionais dedicados a esta atividade, que é voluntária e exercida por período de um ano renovável. Os Delegados são nomeados pelo próprio Médiateur e em geral são ex-funcionários, executivos aposentados, jovens estudantes, todos com uma boa formação jurídica e experiência no setor público ${ }^{429}$. Tornaram-se verdadeiros interlocutores diretos dos cidadãos.

\section{Outras disposições do direito constitucional alienígena}

Nas linhas precedentes procuramos analisar com algum vagar alguns sistemas estrangeiros de assistência legal. Obviamente que isto não significa desprezo aos demais ou que estes não contenham elementos que mereçam referência. Ocorre que mencioná-los seria refugir ao escopo do presente trabalho.

De toda forma, e apenas a título informativo, apontamos algumas disposições encontráveis em Constituições estrangeiras que asseguraram ao economicamente carente o direito de amplo acesso à justiça, inclusive mediante assistência jurídica.

No âmbito da América do Sul, a Constituição Chilena garantiu no art. 19, § $3^{\circ}$, o seguinte: "La ley arbitrará los medios para otorgar asesoramiento y defensa jurídica a quienes no puedan procurárselos por sí mismos”. Igualmente a Constituição Paraguaia prevê no art. 17 os direitos processuais assegurados aos cidadãos sob sua égide, os quais se estendem ao processo penal ou de outra natureza, quando puder advir pena ou sanção. $\mathrm{O}$ item 6 dispõe: "que el Estado le provea de un defensor gratuito, en caso de no disponer de medios económicos para solventarlo".

A Constituição do Peru prevê no art. 139 os direitos e princípios que regem a função jurisdicional, e está consignado no item 16: "El principio de la gratuidad de la administración de justicia y de la defensa gratuita para las personas de escasos recursos; y, para todos, en los casos que la ley señala”. O art. 254 da Constituição uruguaia também

\footnotetext{
${ }^{428}$ SOUSA SANTOS, Boaventura de (Dir. Científico). O acesso ao direito e à justiça: um direito fundamental em questão. Coordenadores: João Pedroso, Catarina Trincão; João Paulo Dias, cit., p. 85-87.

${ }^{429}$ LE MÉDIATEUR DE LA RÉPUBLIQUE. Disponível em: <http://www.mediateur-republique.fr/frcitoyen-03-01-01>. Acesso em: 06 maio 2011.
} 
garante: "La justicia será gratuita para los declarados pobres con arreglo a la ley. En los pleitos en que tal declaración se hubiere hecho a favor del demandante, el demandado gozará del mismo beneficio hasta la sentencia definitiva, la cual lo consolidará si declara la ligereza culpable del demandante en el ejercicio de su acción”.

$\mathrm{O}$ art. 26 da Constituição Venezuelana estipula: "El Estado garantizará una justicia gratuita, accesible, imparcial, idónea, transparente, autónoma, independiente, responsable, equitativa y expedita, sin dilaciones indebidas, sin formalismos o reposiciones inútiles". Igualmente o art. 27 estabelece: "El procedimiento de la acción de amparo constitucional será oral, público, breve, gratuito y no sujeto a formalidad, y la autoridad judicial competente tendrá potestad para restablecer inmediatamente la situación jurídica infringida o la situación que más se asemeje a ella. Todo tiempo será hábil y el tribunal lo tramitará con preferencia a cualquier otro asunto".

Em Argentina a função da assistência jurídica ao carente se desempenha em duas frentes, primeiro o "Defensor del pueblo de La Nación", figura que segue modelo de Ombudsman de origem sueca e que se disseminou ao redor do mundo com as mais diversas denominações (a figura do Mediador francês, alhures referida, é uma destas derivações $)^{430}$.

As funções do Defensor estão previstas no art. 86 da Constituição Argentina, segundo o qual incumbe-lhe "defensa y protección de los derechos humanos y demás derechos, garantías e intereses tutelados en esta Constitución y las leyes, ante hechos, actos $\mathrm{u}$ omisiones de la Administración; y el control del ejercicio de las funciones administrativas públicas".

Para o desempenho desta atividade é-lhe assegurada autonomia funcional e legitimação processual (extraordinária, por substituição processual), gozando também "de las inmunidades y privilegios de los legisladores" (art. 86). É nomeado e removido por decisão da terça parte do Congresso (quorum exigido em cada um das Cámaras), contando com mandato de cinco anos uma vez renovável.

\footnotetext{
${ }^{430}$ BRAUNER, Daniela Jacques. Acesso à justiça no MERCOSUL. Revista Brasileira de Direito Constitucional, São Paulo, v. 15, p. 67, jan./jun. 2010. Disponível em: $<$ http://www.esdc.com.br/RBDC/RBDC-15/RBDC-15-067-

Daniela_Jacques_Brauner_(Acesso_a_Justica_no_Mercosul).pdf $>$.
} 
Já o "Ministério Público de La Defensa" assemelha-se ao que no Brasil temos em termos de Defensoria Pública. O órgão em questão é chefiado pelo "Defensor General de La Nación", e composto por defensores, tutores e curadores públicos.

Em matéria penal exercem sua atividade em favor daquele que não tenha constituído advogado; e em matéria não-penal, daqueles que não tenham condições financeiras de fazê-lo, além de exercerem curadoria de ausentes, menores e incapazes em geral $^{431}$. Igualmente prestam serviço de consultoria e orientação extrajudicial.

Anote-se, por fim, que os defensores públicos são nomeados por concurso e gozam a mesma estatura e mesmas garantias que os membros do Ministério Público Fiscal e magistrados, com inamovibilidade, irredutibilidade de vencimentos e imunidade funcional, além de perceberem vencimentos similares.

Onde não haja defensores públicos suficientes para atender à demanda, cabe ao Defensor General nomear advogados e defensores $a d$ hoc que supram a deficiência ${ }^{432}$.

A Constituição espanhola prevê no art. 119: "La justicia será gratuita cuando así lo dispogna da ley y, en todo caso, respecto de quienes acreditem insuficiência de recursos para litigar".

$\mathrm{O}$ art. 20 da Constituição portuguesa prevê respectivamente nas alíneas 1 e 2: “A todos é assegurado o acesso ao direito e aos tribunais para defesa dos seus direitos e interesses legalmente protegidos, não podendo a justiça ser denegada por insuficiência de meios econômicos" e "Todos têm direito, nos termos da lei, à informação e consulta jurídicas, ao patrocínio judiciário e a fazer-se acompanhar por advogado perante qualquer autoridade.

\section{Conclusão}

No capítulo destinado às conclusões gerais apresentamos um apanhado geral do que constituiu o breve panorama sobre alguns sistemas estrangeiros de assistência jurídica ao necessitado.

\footnotetext{
${ }^{431}$ BRAUNER, Daniela Jacques. Acesso à justiça no MERCOSUL, cit., p. 74.

${ }^{432}$ BRAUNER, Daniela Jacques. Acesso à justiça no MERCOSUL, cit., p. 75.
} 
Como conclusão específica deste capítulo ressaltamos algumas das iniciativas estudadas, e que seriam oportunas no sistema brasileiro, à guisa de sugestão para reformas e inovações.

A primeira idéia que deriva dos programas norte-americanos (Legal Service Program e Legal Service Corporation) é o da participação dos assistidos na gestão do órgão prestador do serviço de assistência, o que possibilita a melhor aderência às reais carências dos beneficiários.

No Brasil seria plenamente viável, por exemplo, a integração nas Comissões de Assistência Judiciária das subseções da Ordem dos Advogados do Brasil, de um ou mais representantes da sociedade, além da previsão junto às Defensorias Públicas, da integração de seus órgãos diretivos por representante dos assistidos.

Serviços alternativos àquilo que propriamente se define como assistência jurídica, porém versando assuntos que constituem o foco de grande parte dos conflitos trazidos a juízo, seria frutífera forma de prevenção de litígios. Exemplo disto é o assessoramento ao gerenciamento de débitos prestado aos consumidores pelo Legal Service Corporation. Outra sugestão nesta seara seria o aconselhamento familiar.

Iniciativas deste porte atuariam ainda antes da eclosão da crise financeira ou familiar, e poderia ser facilmente enquadrada no âmbito do serviço de atendimento extrajudicial (que, lamentavelmente, ainda não é prestado no Brasil de forma expressiva).

Destaque ainda deve ser dado para o investimento por parte da Legal Service Corporation na atividade de pesquisa de seus integrantes, desde que relacionada ao objeto do serviço prestado (assistência).

Iniciativa como esta seria absolutamente factível no Brasil, e bastante auspiciosa. Adiante chegamos a sugerir, por exemplo, o escalonamento de honorários de acordo com a graduação do profissional (item 33).

Uma outra idéia interessante seria a previsão de descontos parciais ou totais para participação em cursos de especialização ou pós-graduação em sentido estrito, além de bolsas de estudo, especificamente voltados para os profissionais integrados no serviço de assistência.

Como forma de acesso a estes benefícios poder-se-ia exigir do pretendente a comprovação de um número mínimo de atendimentos pelo regime de assistência no último 
ano (ou período superior), de modo a comprovar uma atuação expressiva (evitando a inscrição fugaz puramente para obter o benefício). Ainda exigir-se-ia do beneficiário dos descontos e bolsas uma carência após a conclusão do curso, um período pelo qual obrigatoriamente permanecerá vinculado à assistência (evitando também a debandada geral após lograr obter o grau pretendido mediante o benefício).

É bom também anotar que no Brasil vige o que poderíamos denominar sistema misto (à luz da contraposição exposta no corpo do texto entre os regimes de salaried staff attorney e judicare system), onde os defensores públicos equivalem à figura dos advogados assalariados pelo Estado, e os advogados que atuem em razão de convênio firmado entre a Ordem dos Advogados do Brasil local e a Defensoria Pública atuam em regime privado, remunerados, pelo menos em tese, de acordo com os valores de mercado.

Outra idéia profundamente importante seria o incentivo financeiro para a solução extrajudicial do litígio. Vimos que na Alemanha prevê-se ao advogado, além da remuneração pela consulta extrajudicial, um bônus financeiro para o caso de alcançar alternativa resolução da disputa. Mediante alteração das tabelas próprias, com previsão de códigos específicos para a espécie, tal realidade seria facilmente factível entre nós.

Aliás este incentivo poderia também ser previsto mesmo para os casos em que se obtém, em juízo (ou seja já com o trâmite processual) uma solução alternativa ao provimento jurisdicional.

Sugere-se uma gradação de incentivos: havendo a solução extrajudicial do conflito, o advogado seria remunerado pela consultoria extrajudicial, acrescendo-se o bônus pela solução alcançada sem necessidade de recurso às vias jurisdicionais. Se mesmo após este recurso, os advogados lograrem mediante profícua atuação obterem uma solução conciliada, outro bônus lhes seria previsto (agora um pouco reduzido em relação ao primeiro porque, afinal, chegou a haver a necessidade de trâmite processual). Mesmo para a solução ocorrida no trâmite do processo este bônus seria gradativamente menor à medida que a marcha processual se aproximasse da sentença, evitando aquela prática comum de se aguardar a solução de primeira instância, para então buscar-se o acordo.

Por fim, um modelo a ser copiado é o da larga rede de atendimento extrajudicial forjada na França, composta principalmente pelas entidades já referidas no corpo do capítulo (CDAD's; PAD's e MJD’s). A tônica é a criação de pólos multifacetados que congregam diversas qualidades de informações e assistência, facilmente acessíveis aos 
cidadãos. O modelo no Brasil encontra eco em algumas iniciativas pontuais no Estado de São Paulo, com “Poupa-tempos" e CIC's (Centros de Integração da Cidadania).

Providências desta ordem devem ser encorajadas, especialmente quando tendentes a levar o conhecimento acerca dos direitos básicos dos cidadãos às periferias e interiores dos Estados da Federação. 
SEGUNDA PARTE

ASSISTÊNCIA AO NECESSITADO NO PROCESSO CIVIL BRASILEIRO 


\section{LIMITES OBJETIVOS DA GRATUIDADE}

A Lei $n^{\circ} 1.060 / 50$ contém, como já ressaltamos, disposições híbridas, atinentes à assistência judiciária e à gratuidade. É sobre estas últimas que nos concentraremos. Disposições chaves neste contexto são os arts. $3^{\circ}$ e $9^{\circ}$ do diploma em questão, que estipulam os fios condutores na análise deste aspecto do problema. É óbvio que a análise de outros dispositivos e a menção a outras regras será natural, tanto da mesma Lei $\mathrm{n}^{\mathrm{o}}$ 1.060/50, como de outros diplomas normativos. O que salientamos é que o ponto de partida de nossa exposição será a interpretação conjunta destas regras.

Segundo o art. $3^{\circ}$ a assistência judiciária compreende as seguintes isenções: i) das taxas judiciárias e dos selos; ii) dos emolumentos e custas devidos aos Juízes, órgãos do Ministério Público e serventuários da justiça; iii) das despesas com as publicações indispensáveis no jornal encarregado da divulgação dos atos oficiais; iv) das indenizações devidas às testemunhas que, quando empregados, receberão do empregador salário integral, como se em serviço estivessem, ressalvado o direito regressivo contra o poder público federal, no Distrito Federal e nos Territórios; ou contra o poder público estadual, nos Estados; v) dos honorários de advogado e peritos; vi) das despesas com a realização do exame de código genético - DNA que for requisitado pela autoridade judiciária nas ações de investigação de paternidade ou maternidade.

O último item foi incluído no rol de isenções pela Lei $\mathrm{n}^{\circ} 10.317$, em vigor desde $6^{\circ}$ de dezembro de 2001.

Ainda, o art. $9^{\circ}$ assegura: "Os benefícios da assistência judiciária compreendem todos os atos do processo até decisão final do litígio, em todas as instâncias".

Temos então nas duas regras a extensão material da gratuidade, compreendendo quais as despesas albergadas pela isenção; e a extensão procedimental, indicando quais fases do procedimento serão atingidas (que no caso são todas, até às instâncias recursais).

O primeiro ponto de análise oportuna que surge é o de se saber do caráter deste rol apresentado pelo art. $3^{\circ}$. Artêmio Zanon, nesta quadra, assim se pronuncia: "O que a LAJ menciona no parágrafo único do art. $2^{\circ}$ dá-lhe taxatividade nas isenções do art. $3^{\circ}{ }^{\circ 433}$. O parágrafo único do art. $2^{\circ}$ é que define necessitado para fins legais como "aquele cuja

\footnotetext{
${ }^{433}$ ZANON, Artêmio. Assistência Judiciária gratuita: comentários à Lei da Assistência Judiciária (Lei ${ }^{\circ}$
} 1.060, de 5-2-1950). São Paulo: Saraiva, 1985. p. 27. 
situação econômica não lhe permita pagar as custas do processo e os honorários de advogado, sem prejuízo do sustento próprio ou da família”.

Se a idéia do autor em questão era afirmar que as isenções são taxativas no sentido de que abarcam apenas os necessitados para fins legais (e daí porque alude ao p.único do art. $2^{\circ}$ ), então somos compelidos a concordar com sua posição.

Por outro lado, se sua idéia era de afirmar que o elenco do art. $3^{\circ}$ já transcrito é taxativo, então não nos parece haver coerência com o postulado de acesso à justiça. De fato, em sentido contrário, Augusto Tavares Rosa Marcacini leciona que toda referência legal acerca das isenções abrangidas pela gratuidade só pode ser interpretada como sendo uma enumeração exemplificativa, valendo tal interpretação para $o$ art. $3^{\circ}$ da Lei $n^{\circ}$ $1.060 / 50^{434}$.

Também afirmam que o rol é meramente exemplificativo Fredie Didier Jr. e Rafael Oliveira, em monografia dedicada ao benefício da gratuidade ${ }^{435}$. Também afiança que o "catálogo legal tem feitio exemplificativo", Araken de Assis, que, aliás, apresenta pertinente crítica à técnica legislativa empregada observando que seria muito mais proveitosa uma isenção genérica, envolvendo despesas e honorários, que o citado art. $3^{\circ}$ da Lei $n^{\circ} 1.060 / 50$. Melhor seria omitir o elenco legal justamente porque o benefício "não tolera limitações", observando que bastaria aplicar o art. $9^{\circ}$, que já compreende todos os atos do processo até decisão final do litígio, em todas as instâncias ${ }^{436}$.

Compreende-se o debate que esteja à raiz desta pequena divergência de opiniões. Parece fora de dúvida que a concessão de gratuidade para o litígio constitui forma elementar de proceder à equalização dos mais carentes, meio de atender ao postulado da isonomia material.

\footnotetext{
${ }^{434}$ MARCACINI, Augusto Tavares Rosa. Assistência jurídica, assistência judiciária e justiça gratuita. Rio de Janeiro: Forense, 1996. p. 36.

${ }^{435}$ DIDIER JR, Fredie; OLIVEIRA, Rafael. Benefício da justiça gratuita. 3. ed. Salvador, Jus Podivm, 2008. p. 14. Embora sem menção clara, Maurício Vidigal também sugere compreender pela não exaustividade do rol encetado pelo referido art. $3^{\circ}$ da LAJ: "O exame do art. $3^{\circ}$ demonstra que não somente o valor das custas e dos honorários advocatícios devem ser considerados, mas todas as despesas necessárias ao exercício efetivo da defesa" (Lei da Assistência Judiciária interpretada. São Paulo: Juarez de Oliveira, 2000. p. 24).

${ }^{436}$ ASSIS, Araken de. Benefício da gratuidade. Ajuris: revista da Associação dos Juízes do Rio Grande do Sul, Porto Alegre, v. 25, n. 73, p. 165, jul. 1998. Cândido Rangel Dinamarco embora não se posicione especificamente sobre esta questão, apresenta interpretação até surpreendentemente restritiva com relação aos itens componentes do rol de isenções, como oportunamente se verá.
} 
Por isto é que as benesses concedidas justificam-se na medida em que se prestem ao atendimento desta finalidade. Aí não vai novidade nenhuma, e dispensamos nesta oportunidade considerações mais detidas sobre este evidente propósito do benefício.

Havendo um indevido alargamento das isenções, de modo a perder a correspondência com as necessidades advindas da isonomia processual e do princípio do acesso substancial à justiça, passa-se ao extremo oposto: o beneficiário deixa de ser indivíduo devidamente alçado ao pé de igualdade com aqueles que detêm recursos suficientes para litigar, para ser pessoa injustificadamente albergada por privilégios odiosos, que lhe asseguram indevida posição de superioridade em relação ao adversário.

Com um exemplo ilustramos a questão, ao ensejo em que já aproveitamos para tratar de outro tema de relevo na seara do que temos abordado.

Vê-se às claras que o art. $3^{\circ}$ da Lei $n^{\circ} 1.060 / 50$ não menciona isenção extensiva às eventuais multas processuais impostas à parte, no mais das vezes por litigância de má-fé (CPC, arts. 17 e 18) ou por ato atentatório à dignidade da justiça (CPC, arts. 600 e 601). Compreendendo tratar-se o rol de mera exemplificação dos valores abrangidos seria legítimo concluir, então, que o beneficiário também de tais verbas estaria isento?

A resposta negativa poderia saltar aos olhos como óbvia, porém assim não é, especialmente porque segundo o art. 35 do Código de Processo Civil, as sanções impostas às partes em conseqüência de má-fé serão contadas como custas e reverterão em benefício da parte contrária.

Ora, gozando as sanções processuais, na forma do dispositivo supra citado, o mesmo regime jurídico das custas, e estando estas abarcadas pela isenção decorrente do benefício da gratuidade, consequiência lógica inarredável é que as multas também o estejam.

A aparente juridicidade deste argumento é tão convincente, que há até julgado do Colendo Superior Tribunal de Justiça que, embora não negue a possibilidade de impor-se ao beneficiário litigante de má-fé multa processual, afirma a suspensão da exigibilidade nos mesmos termos que as demais verbas processuais (custas e despesas): "A circunstância de ser o recorrente beneficiário da gratuidade de justiça não impossibilita a imposição das multas em razão da interposição dos recursos manifestamente improcedentes e protelatórios. A Corte, assim, impõe a multa na hipótese referida, porém, tem determinado 
a suspensão do pagamento em razão da concessão de gratuidade de justiça" (STJ, AgRg nos EDcl no AgRg no Ag 563.492/GO, Rel.Carlos Alberto Menezes Direito, j. 28.10.04).

Cuidava-se na espécie de multa aplicada com fundamento no p.único do art. 538 do Código de Processo Civil, para o caso de interposição de embargos de declaração manifestamente protelatórios, multa esta que reverte em favor do adverso. Aliás, no voto condutor do julgamento retro citado há menção a precedente no mesmo sentido (isto é com aplicação de multa nos termos do art. 538, p.único, do CPC, e suspensão de exigibilidade em razão da gratuidade deferida): EDclREsp n 264.661/MG, Relator o Ministro Ruy Rosado de Aguiar, DJ de 10/11/03.

Com a devida vênia, ousamos divergir do Colendo Sodalício. Sanções processuais não podem gozar o mesmo regime jurídico de custas e despesas porque ostentam natureza jurídica manifestamente diversa. As segundas representam o ônus oriundo do regular exercício de um direito; para o autor, do regular exercício do direito de ação, para o réu, do regular exercício do constitucional direito de defesa. Tanto assim é que a imposição do pagamento das custas e despesas processuais, no atual sistema que tem como regra nuclear o art. 20 do Código de Processo Civil, independe da postura processual da parte ${ }^{437}$, importando apenas que saia derrotada. Por outras palavras: mesmo a parte que se portou de forma altaneira no curso do processo, se derrotada, ver-se-á na contingência de ressarcir o adversário das despesas por ele antecipadas, e ainda pagar-lhe-á a verba honorária. $\mathrm{O}$ fundamento da imposição na espécie é o princípio da causalidade, e não a prática de qualquer ilícito processual. Repudiamos, por isto, qualquer idéia que assemelhe ônus da sucumbência com sanção processual.

Sanções processuais, como parece intuitivo, são conseqüências de comportamentos ilícitos praticados pela(s) parte(s) no curso do processo. A falta de correspondência ou relação com custas e despesas é tão evidente, que pode a parte sagrar-se vencedora e mesmo assim ter de arcar com multas, p.ex., por litigância de má-fé ${ }^{438}$.

\footnotetext{
${ }^{437}$ Excepciona-se no caso a regra do art. 22 do Código de Processo Civil, prevendo que a negligência do réu em argüir fato modificativo, impeditivo ou extintivo do direito do autor, ensejando o prolongamento da lide, levá-lo-á a arcar com custas a partir do saneamento e à perda do direito de haver honorários, mesmo que vencedor. Nesta hipótese, contudo, a natureza da verba sucumbencial é desnaturada, pois que deixa de representar normal decorrência do exercício de um direito, para tornar-se em sanção por uma negligência processual. É o legislador que no caso a utiliza como forma de punição.

438“"Por sua vez, multas, creio que até o leigo tem exata noção do que sejam: penalidades, punições. Embora se contem como custas não são despesas processuais" (ZANON, Artêmio. Assistência Judiciária gratuita: comentários à Lei da Assistência Judiciária (Lei no 1.060, de 5-2-1950), cit., p. 29). O mesmo autor nega caráter punitivo à condenação ao pagamento de custas.
} 
A afirmação do legislador de que as multas serão contadas como custas não significa qualquer espécie de homogeinização da natureza jurídica dos institutos. Significa apenas que as multas processuais serão apuradas, calculadas e pagas na mesma oportunidade processual em que as custas processuais ${ }^{439}$.

Pelo visto não se pode estender às multas processuais qualquer das benesses inerentes ao benefício da gratuidade, seja a isenção, seja a suspensão de exigibilidade. Neste sentido é a abalizada posição de Fredie Didier Jr. e Rafael Oliveira, cuja transcrição é propícia face à contundência e correção dos argumentos invocados, com os quais nos alinhamos inteiramente:

“A gratuidade judiciária não abrange, nem poderia abranger, as multas processuais. Se assim não fosse, estar-se-ia admitindo um acesso irresponsável e inconseqüente à justiça, consubstanciado no fato de o beneficiário poder, impunemente, abusar do direito de demandar, sem que nenhuma sanção the pudesse ser aplicada (nos casos de multa com caráter punitivo) ou sem que fosse possível impor-lhe medidas coercitivas para efetivação da tutela jurisdicional (nos casos de multas com caráter coercitivo). Deve-se lembrar que o escopo da norma é beneficiar a pessoa carente de recursos, jamais municiá-la com um escudo legal para defendê-la da própria torpeza" ${ }^{440}$.

É também neste mesmo sentido a opinião de Barbosa Moreira (que também é citado pelos autores supra referidos), para quem a pobreza não pode amparar um bill de indenidade quanto a comportamentos antijurídicos ${ }^{441}$.

É bom que se diga que a jurisprudência não é insensível à posição que ora defendemos, valendo citar o precedente oriundo do julgamento pelo Colendo Superior Tribunal de Justiça do Recurso Ordinário em Mandado de Segurança ${ }^{\circ} 15.600$, oriundo de São Paulo, em que foi relator o Ministro Aldir Passarinho Junior, e julgado em 20 de maio de 2008: “A concessão do benefício da assistência judiciária não tem o condão de tornar o assistido infenso às penalidades processuais legais por atos de litigância de má-fé por ele praticados no curso da lide" 442 .

\footnotetext{
${ }^{439}$ No mesmo sentido: COSTA MACHADO, Antonio Cláudio. Código de Processo Civil interpretado, cit., p. 42.

${ }^{440}$ ZANON, Artêmio. Assistência Judiciária gratuita: comentários à Lei da Assistência Judiciária (Lei no 1.060, de 5-2-1950), cit., p. 14.

${ }^{441}$ BARBOSA MOREIRA, José Carlos. O direito a assistência jurídica - evolução no ordenamento brasileiro de nosso tempo. Revista de Processo, São Paulo, v. 17, n. 67, p. 124, jul./set. 1992.

${ }^{442} \mathrm{E}$ interessante ressaltar que o mesmo relator que figurou nos autos do AgRg nos EDcl no AgRg no Ag 563.492/GO, por nós citado anteriormente, Ministro Carlos Alberto Menezes Direito, havia proferido anteriormente, em 23.09.03 (portanto cerca de um ano antes do julgamento por nós invocado), entendimento contrário, no sentido de que "A parte beneficiária de justiça gratuita não pode se utilizar
} 
A rigor não podemos afirmar que o julgado retro referido seja inteiramente contrário ao inicialmente trazido, de relatoria do eminente Ministro Carlos Alberto Menezes Direito, já que naquele não se negou a aplicação da multa, mas sim afirmou-se a suspensão de sua exigibilidade. Fato é, contudo, que neste segundo julgado nenhuma menção se faz a tal suspensão de exigibilidade, o que se vê não só pela simples leitura da ementa, mas pela análise do próprio voto condutor, que nada refere. Daí se concluir que neste caso entendeu-se aplicável a multa e plenamente exigível ${ }^{443}$.

Parece-nos equivocado valer-se do caráter exemplificativo do rol inscrito no art. $3^{\circ}$ da Lei $n^{\circ} 1.060 / 50$ para estender a isenção e a suspensão de exigibilidade quanto às custas e demais despesas processuais, deferidas ao beneficiário da gratuidade, também às multas processuais.

De outro lado não é razoável afirmar o caráter taxativo do rol do art. $3^{\circ}$ do diploma supra citado, em razão dos abusos e excessos que ocasionalmente possam ocorrer. A solução é corrigirem-se tais desvios.

Não é preciso maior digressão nem elaborado raciocínio jurídico para concluir que as isenções e benesses deferidas ao carente de recursos econômicos têm como única finalidade propiciar-lhe o acesso à ordem jurídica justa em pé de igualdade com o adverso economicamente abastado. A isenção que à luz destes propósitos é justificada é aquela que atinja as despesas decorrentes naturalmente do regular exercício do direito de ação ou de defesa.

\footnotetext{
dessa circunstância para ingressar com pedidos sabidamente teratológicos e protelatórios, devendo ser penalizada com multa" (EDcl no AgRg nos EmbDev no REsp 94.648/SP). A rigor não se pode dizer que este julgado seja manifestamente contrário ao anterior, pois que naquele não se negou a possibilidade de imposição da multa, apenas que afirmou-se a suspensão de sua exigibilidade, o que é diverso. De toda forma, como naquele primeiro julgamento, de setembro de 2003, não se menciona possível suspensão de exigibilidade, crê-se que a isto não se procedeu.

${ }^{443}$ No âmbito do Eg.Tribunal de Justiça do Estado de São Paulo, encontramos julgados assim ementados: "LITIGÂNCIA DE MÁ FÉ - Multa - Alteração deliberada da verdade dos fatos - Hipótese em que a mera condição de beneficiário da assistência judiciária gratuita não pode servir de óbice à imposição da pena por litigância de má-fé, uma vez evidenciado que o autor alterou deliberadamente a verdade dos fatos, omitindo a notícia de que as contas postuladas já haviam sido prestadas pela ré perante o PROCON, conquanto discordasse o autor sobre o critério das informações fornecidas - Sentença reformada - Recurso provido, em parte" (TJSP, apelação cível n 991.01.036355-7, Rel. João Camillo de Almeida Prado Costa, j. 09.02.10). Ainda: "EMBARGOS À EXECUÇÃO - Cerceamento de defesa não caracterizado - Depoimento pessoal e prova testemunhal que não tem o condão de se sobrepor a prova documental - Beneficiário da Assistência Judiciária - Execução da multa e indenização por litigância de má-fé - Hipótese em que a execução deve prosseguir, mesmo sendo o executado beneficiário da assistência judiciária - Não pode o beneficiário da assistência judiciária se eximir do pagamento da indenização por litigância de má-fé, sob pena de desvirtuamento do referido beneficio - Recurso improvido" (TJSP, apelação cível n ${ }^{\circ}$ 7.083.859-6, Rel. Heraldo de Oliveira Silva, j. 20.09.06).
} 
Parece evidente que os valores oriundos de sanções processuais não se podem enquadrar nesta categoria, visto que representam conseqüência do abuso do direito de ação ou de defesa, isto é, exercício irregular de tais direitos, o que constitui modalidade de ato ilícito. Aí se vê com clareza porque parece absolutamente impossível a equiparação de regimes jurídicos.

Para pôr pá de cal sobre a questão é bastante que se perceba que as sanções processuais de ordem econômica sob nenhuma perspectiva representam óbice de acesso à justiça, pois que não há previsão de que seu pagamento seja condicionante à prática de atos processuais ou mesmo ao ajuizamento de ação (exceto na hipótese do art. 268, "caput", do Código de Processo Civil, em que parece-nos que havendo imposição de pena na demanda anterior, extinta sem resolução do mérito, a repropositura dependeria também do pagamento da sanção).

Em verdade estender a isenção às sanções processuais representaria dar à parte beneficiária uma vantagem desconexa à sua condição de economicamente carente. E conceder tratamento desigual sem correspondência com o fator de desequiparação significa albergar privilégio indevido, o que afronta a mais comezinha idéia de isonomia material.

Conclusão: isentar o beneficiário da gratuidade das sanções processuais pecuniárias, ou mesmo suspender-lhes a exigibilidade, sobre não favorecer o acesso à justiça, assegura ao beneficiário uma posição de vantagem injustificada sobre o adversário, além de deixar impune eventual comportamento ilícito processual, o que é sobejamente convidativo ao deslize.

Foi por isto que optamos por tratar da questão da extensão ou não da gratuidade às sanções ao ensejo da análise do caráter exemplificativo ou exaustivo do rol do art. $3^{\circ}$ da Lei $\mathrm{n}^{\mathrm{o}} 1.060 / 50$, e o receio de que se possa conceder ao beneficiário tratamento injustificadamente benéfico em demasia, a afrontar a isonomia.

A este propósito, uma segunda conclusão pode ser alinhavada: o rol do art. $3^{\circ}$ da Lei $\mathrm{n}^{\mathrm{o}} 1.060 / 50$ é exemplificativo ${ }^{444}$, para o fim de acolher eventuais despesas ali não enumeradas, porém que decorram naturalmente do regular exercício do direito de ação ou de defesa.

\footnotetext{
${ }^{444} \mathrm{Na}$ jurisprudência, neste sentido: TJSP, Agravo de Instrumento n ${ }^{\circ}$ 7.287.970-0, da Comarca de Araçatuba, Rel. Rubens Cury, j. 08.09.08. Ainda no sentido da interpretação extensiva do rol do art. $3^{\circ}$ já citado: TJSP, Agravo de Instrumento $n^{\circ}$ 1.254.877-0/9, Rel. Norival Oliva, j. 14.04.09.
} 
Uma última questão cumpre seja analisada, qual seja, a de se saber se as multas coercitivas acham-se albergadas pelo benefício da gratuidade. Na lição transcrita parágrafos atrás, da lavra de Fredie Didier Jr. e Rafael Oliveira já tivemos oportunidade de anotar a posição dos referidos autores, no sentido negativo.

Concordamos com este posicionamento, contudo algumas ponderações devem ser feitas porque o fundamento de tal posicionamento é no caso completamente diverso daquele que ilustra nossa posição referente às multas processuais sancionatórias.

Não nos seria propício aqui destrinchar com detalhes a tipificação das tutelas jurisdicionais à luz da forma de sua efetivação, o que necessariamente passaria pela polêmica das classificações ternária e quinária.

Vale entretanto observar que Marinoni vê na multa, forma de execução ou coerção indireta, o traço distintivo entre as tutelas mandamental e executiva, visto que esta estaria sujeita à execução direta, isto é, realização prática independente da vontade do devedor ${ }^{445}$. São do mesmo autor as assertivas que merecem transcrição: “A multa limita-se a forçar o réu a adimplir, mas não garante a realização do direito independentemente da sua vontade ... não há cabimento em pensar que o juiz, ao impor a multa, condena o demandado"446 . É claro, prossegue Marinoni, que como toda a multa, também a processual coercitiva transmuda-se em sancionatória assim que haja o descumprimento do preceito.

Devemos tomar aquele critério que temos defendido para a avaliação de quais verbas podem ser consideradas abarcadas pelo rol exemplificativo do art. $3^{\circ}$ da Lei $n^{\circ}$ 1.060/50, qual seja, a consideração da relevância da verba para fins de possibilitar ou obstar o acesso à justiça, bem como o risco de permitir ao beneficiário posição de injustificada vantagem sobre o adversário (quando aludimos a injustificada, queremos dizer sem correspondência com sua situação de carência econômica, que é o fator que justificaria o tratamento desigual).

Ora, as astreintes, como parece ter ficado demonstrado, têm caráter intimidatório, e não se erige o seu pagamento em pressuposto para o ingresso em juízo, para o exercício do direito de defesa, ou mesmo para a prática de atos processuais. Não se vê como possa a sua isenção alargar para o beneficiário as portas à ordem jurídica justa.

\footnotetext{
445، A diversidade em termos de efetividade, bem como de repercussão e de impacto sobre a esfera jurídica do réu, entre os meios de execução direta e de execução indireta, previstos nos arts. 461 e 461-A do CPC, e 84 do CDC, conduz a duas maneiras distintas de se prestar tutela dos direitos e, desse modo, a duas sentenças diferentes, a executiva e a mandamental" (Técnica processual e tutela dos direitos, cit., p. 96).

${ }^{446}$ MARINONI, Luiz Guilherme. Técnica processual e tutela dos direitos, cit., p. 95 e 97.
} 
Ao contrário, estar-se-ia privando o juiz de uma das técnicas previstas pelo sistema processual para assegurar a tutela específica, o que redundaria em última análise em prejuízo do credor da obrigação. Haveria indiscutível ruptura da paridade de armas, e especialmente enfraquecimento da possibilidade de franquear-se ao titular do direito exatamente a utilidade que este lhe enseja. A este prejuízo do credor não corresponde a dilatação do acesso à justiça para o devedor, única circunstância que poderia eventualmente justificar o parcial sacrifício daquele.

Uma observação entretanto é útil: dado o caráter da multa, há de ser ela suficiente para efetivamente influir no ânimo do obrigado, adverte Cássio Scarpinella Bueno: “daí ela deve ser suficientemente adequada e proporcional para este mister. Não pode ser insuficiente a ponto de não criar no obrigado qualquer receio quanto às conseqüências de seu não-acatamento" 447 .

Imagina-se, pois, que aquele que definitivamente não detenha recursos financeiros não se sentirá assim compelido pela multa coercitiva, exceto por algum apelo moral que o avolumar da dívida possa lhe impingir, mas nada além do incômodo de saber-se devedor (incômodo que no mais das vezes não se mostra tão marcante).

Mais frustrante será tentar cobrar tais valores, já que não há de causar espanto a inexistência de patrimônio suficiente para saldar a dívida.

O que se quer dizer, em conclusão, é que o benefício da gratuidade não abarca as multas coercitivas, porém a aplicação desta técnica de efetivação do comando judicial muito provavelmente terá pouco poder persuasivo em face de obrigado pobre em termos jurídicos, mas aí estamos fora do âmbito específico do regime legal do benefício da justiça gratuita.

Passemos agora a uma análise particular das principais características de cada item referido pelo art. $3^{\circ}$ da Lei $n^{\circ} 1.060 / 50$.

\footnotetext{
${ }^{447}$ BUENO, Cássio Scarpinella. Art. 461. In: MARCATO, Antônio Carlos (Org.). Código de Processo Civil interpretado, cit., p. 1474.
} 


\section{Taxas judiciárias e selos}

As taxas judiciárias são espécies do gênero tributo, especificamente de modalidade vinculada a uma contraprestação estatal direta na forma de utilidade, que no caso consubstancia a prestação do serviço judiciário $^{448}$.

Decorre daí a lógica conclusão de que credor de tal verba é o ente público prestador do serviço, a saber, Fazendas Estadual ou Federal, estando o regimento de custas plasmado em normas específicas editadas em cada esfera federativa.

$\mathrm{Na}$ verdade a questão da natureza jurídica das custas processuais como taxas ou preços públicos é tema de longa divergência doutrinária. Porém ressalta-se que a maioria da doutrina nacional e estrangeira as enquadra como tributo. Mesmo em jurisprudência o tema é discutido desde início da década de 70, oscilando-se posições num e noutro sentido. A partir de 1990 o Supremo Tribunal Federal passou a entender reiteradamente que os emolumentos relacionados aos serviços notariais tinham natureza jurídica de taxa remuneratória de serviço público. Com relação às taxas judiciárias o entendimento consolidou-se mais recentemente igualmente no sentido da natureza tributária ${ }^{449}{ }_{-}^{450}$.

Afirma-se em doutrina que o modo como é realizada a cobrança das custas no Brasil viola a proporcionalidade. A aplicação às custas processuais do regime jurídico das

\footnotetext{
${ }^{448}$ Vale lembrar as duas modalidades de taxas indicadas pelo art. 77 do Código Tributário Nacional: "As taxas cobradas pela União, pelos Estados, pelo Distrito Federal ou pelos Municípios, no âmbito de suas respectivas atribuições, têm como fato gerador o exercício regular do poder de polícia, ou a utilização, efetiva ou potencial, de serviço público específico e divisível, prestado ao contribuinte ou posto à sua disposição".

${ }^{449}$ Veja-se a respeito a edição da súmula n ${ }^{\circ} 667$ ("Viola a garantia constitucional de acesso à jurisdição a taxa judiciária calculada sem limite sobre o valor da causa"). Ainda neste sentido: "AÇÃO DIRETA DE INCONSTITUCIONALIDADE. TAXA JUDICIÁRIA. NATUREZA JURÍDICA: TRIBUTO DA ESPÉCIE TAXA. PRECEDENTE DO STF. VALOR PROPORCIONAL AO CUSTO DA ATIVIDADE DO ESTADO. Sobre o tema da natureza jurídica dessa exação, o Supremo Tribunal Federal firmou jurisprudência no sentido de se tratar de tributo da espécie taxa (Representação 1.077). Ela resulta da prestação de serviço público específico e divisível, cuja base de cálculo é o valor da atividade estatal deferida diretamente ao contribuinte. A taxa judiciária deve, pois, ser proporcional ao custo da atividade do Estado a que se vincula. E há de ter um limite, sob pena de inviabilizar, à vista do valor cobrado, o acesso de muitos à Justiça. Ação direta julgada parcialmente procedente, para declarar a inconstitucionalidade dos $\S \S 2^{\circ}$ e $5^{\circ}$ do artigo 114 do Código Tributário de Goiás" (STF, ADI n 948/GO, Rel Min Francisco Rezek, j. 09/11/95).

${ }^{450}$ SACCHIS, Bianca Rocha; CEZNE, Andréa Nárriman. A inconstitucionalidade da cobrança das custas processuais sobre o valor da causa perante a natureza jurídica tributária. In: TELLINI, Denise Estrela; JOBIM, Geraldo Cordeiro; JOBIM, Marco Félix (Orgs.). Tempestividade e efetividade processual: novos rumos do processo civil brasileiro: estudos em homenagem à professora Elaine Harzheim Macedo. 1. ed. Caxias do Sul: Plenum, 2010. p. 39-42. Segundo as autoras, diversos critérios podem ser eleitos para mensurar o valor do tributo a ser pago: custo global do serviço; custo parcial da atividade; vantagem auferida do serviço e capacidade contributiva. Segundo se ensina, atualmente adota-se o critério da razoável equivalência, afirmando-se então que não há limitação da taxa ao exato custo do serviço remunerado. "A teoria da razoável equivalência exige uma proporção razoável entre o produto da taxa e o seu custo total" (cit., p. 43).
} 
taxas implica como consequiência inarredável o fim do cálculo sobre o valor da causa. Isto porque a base de cálculo das taxas de serviço devem efetivamente mensurar a intensidade da atividade estatal de que constitui a contraprestação. A proporcionalidade entre o valor a ser pago e o serviço prestado é no caso concretização da estrutura do tributo.

Assim é que se defende que o valor da causa não é medida da atividade estatal desenvolvida no exercício da função jurisdicional. Intrometendo-se então elementos estranhos que nada têm com a relação "custo/benefício", resta descaracterizada a exação como taxa. Inexistindo correspondência entre a taxa e o custo da atividade estatal são violadas as limitações constitucionais ao poder de $\operatorname{tributar}^{451}$.

Em suma, conforme a posição noticiada, o cálculo como encetado, por si só afronta a Constituição da República por ferir a própria natureza do tributo (taxa). O defeito mais ganha realce quando o sacrifício atinge princípio constitucional de primeira grandeza como é o acesso à justiça.

Apesar do posicionamento doutrinário posto em destaque, cumpre informar que o Supremo Tribunal Federal em mais de uma ocasião já negou procedência à tese em questão ${ }^{452}$.

\footnotetext{
${ }^{451}$ SACCHIS, Bianca Rocha; CEZNE, Andréa Nárriman. A inconstitucionalidade da cobrança das custas processuais sobre o valor da causa perante a natureza jurídica tributária, cit., p. 44-45. "Portanto, a cobrança das custas vinculadas ao valor da causa deve ser vista como inconstitucional, visto que não há o dimensionamento necessário relativo ao serviço prestado, afrontando-se estruturalmente a conceituação das custas como taxas" (cit., p. 50).

452، A jurisprudência da Corte é tranqüila no sentido de que é constitucional a cobrança da taxa judiciária que toma por base de cálculo o valor da causa ou da condenação, observando-se o princípio da razoabilidade" (STF, ADI n 2040/PR, Rel Min Maurício Corrêa, j. 15/12/99).

"I. Taxa Judiciária: sua legitimidade constitucional, admitindo-se que tome por base de cálculo o valor da causa ou da condenação, o que não basta para subtrair-lhe a natureza de taxa e convertê-la em imposto: precedentes (ADIn 948-GO, 9.11.95, Rezek; ADIn MC 1.772-MG, 15.4.98, Velloso). II. Legítimas em princípio a taxa judiciária e as custas ad valorem afrontam, contudo, a garantia constitucional de acesso à jurisdição $\left(\mathrm{CF}\right.$, art. $\left.5^{\circ}, \mathrm{XXXV}\right)$ se a alíquota excessiva ou a omissão de um limite absoluto as tornam desproporcionadas ao custo do serviço que remuneraram: precedentes (Rp 1.077-RJ, 28.3.84, Moreira, RTJ 112/34; Rp 1.074- , 15.8.84, Falcão, RTJ 112/499; ADIn 948-GO, 9.11.95, Rezek; ADIn MC 1.378-5, 30.11.95, Celso, DJ 30.5.97; ADIn MC 1.651-PB, Sanches, DJ 11.9.98; ADIn MC 1.772-MG, 15.4.98, Velloso). III. ADIn: medida cautelar: não se defere, embora plausível a argüição, quando - dado o conseqüentes restabelecimento da eficácia da legislação anterior - agravaria a inconstitucionalidade denunciada: é o caso em que, se se suspende, por aparentemente desarrazoada, a limitação das custas judiciais a $5 \%$ do valor da causa, seria restabelecida a lei anterior que as tolerava até $20 \%$. IV. Custas dos serviços forenses: matéria de competência concorrente da União e dos Estados (CF 24, IV), donde restringir-se o âmbito da legislação federal ao estabelecimento de normas gerais, cuja omissão não inibe os Estados, enquanto perdure, de exercer competência plena a respeito $\left(\mathrm{CF}\right.$, art. $24, \S \S 3^{\circ}$ e $\left.4^{\circ}\right)$. V. Custas judiciais são taxas, do que resulta - ao contrário do que sucede aos impostos (CF, art. 167, IV) - a alocação do produto de sua arrecadação ao Poder Judiciário, cuja atividade remunera; e nada impede a afetação dos recursos correspondentes a determinado tipo de despesas - no caso, as de capital, investimento e treinamento de pessoal da Justiça - cuja finalidade tem inequívoco liame instrumental com o serviço judiciário" (STF, ADI 1926/PR, Rel Min Sepúlveda Pertence, j. 19/04/99).
} 
No caso da União, as custas devidas na Justiça Federal (justiça dita comum) de primeiro e segundo graus são reguladas pela Lei Federal n ${ }^{\circ}$ 9.289/96. No caso de exercício de competência delegada pelas Justiças Estaduais, na forma do permissivo contido no art. $109, \S 3^{\circ}$, da Constituição da República, as custas serão regidas pela legislação estadual pertinente. O próprio art. $4^{\circ}$, II, do diploma retro citado isenta do pagamento "os que provarem insuficiência de recursos e os beneficiários da assistência judiciária gratuita”.

Em síntese, a forma de pagamento das taxas judiciárias é feita de acordo com as seguintes regras: i) o autor ou requerente pagará metade das custas e contribuições tabeladas, por ocasião da distribuição do feito, ou, não havendo distribuição, logo após o despacho da inicial; ii) aquele que recorrer da sentença pagará a outra metade das custas, dentro do prazo de cinco dias, sob pena de deserção; iii) não havendo recurso, e cumprindo o vencido desde logo a sentença, reembolsará ao vencedor as custas e contribuições por este adiantadas, ficando obrigado ao pagamento previsto no item precedente (ou seja, a outra metade da taxa) e iv) se o vencido, embora não recorrendo da sentença, oferecer defesa à sua execução, ou embaraçar seu cumprimento, deverá pagar a outra metade, no prazo marcado pelo juiz, não excedente de três dias, sob pena de não ter apreciada sua defesa ou impugnação (art. 14).

Anexa à lei está a tabela de custas. Prevê-se, por exemplo, que para as ações cíveis em geral a taxa será de um por cento sobre o valor da causa, com o mínimo de dez UFIR e o máximo de mil e oitocentos UFIR.

No âmbito do Estado de São Paulo a matéria é regulada pela Lei Estadual no 11.608 de 29 de dezembro de 2003, que discrimina inclusive os atos que se consideram excluídos do conceito de taxa judiciária $\left(\operatorname{art.} 2^{\circ}\right)$.

As regras básicas no Estado de São Paulo são: i) recolhimento de 1\% (um por cento) sobre o valor da causa no momento da distribuição ou, na falta desta, antes do despacho inicial; essa mesma regra se aplica às hipóteses de reconvenção e de oposição (vale observar que na esfera federal a reconvenção não se sujeita à cobrança de custas); ii) 2\% (dois por cento) sobre o valor da causa, nos termos do artigo 511 do Código de Processo Civil, como preparo da apelação e do recurso adesivo, ou, nos processos de competência originária do Tribunal, como preparo dos embargos infringentes; iii) $1 \%$ (um

\footnotetext{
“A jurisprudência desta Corte vem admitindo o cálculo das custas judiciais com base no valor da causa, desde que mantida razoável correlação com o custo da atividade prestada" (STF, ADI n ${ }^{\circ} 2.655 / \mathrm{MT}$, Rel Min Ellen Gracie, j. 09/10/03).
} 
por cento) ao ser satisfeita a execução. Também há aí limites mínimo e máximo: “Os valores mínimo e máximo a recolher-se, em cada uma das hipóteses previstas nos incisos anteriores, equivalerão a 5 (cinco) e a 3.000 (três mil) UFESPs - Unidades Fiscais do Estado de São Paulo, respectivamente, segundo o valor de cada UFESP vigente no primeiro dia do mês em que deva ser feito o recolhimento" (art. $4^{\circ}$, I a III e $\S 1^{\circ}$ ).

Há normas específicas (p.ex. para ação penal), cuja menção aqui se torna desnecessária, pois não se trata do foco do estudo.

Não custa consignar posicionamento doutrinário segundo o qual a taxa judiciária estaria abarcada pela imunidade tributária referida pelo art. 5, XXXIV, alínea "a", da Constituição da República, partindo-se do pressuposto de que a ação civil seria uma forma qualificada de exercício do direito de petição, com a específica destinação ao Poder Judiciário $^{453}$.

Em geral o beneficiário estará isento destas verbas cujo regime jurídico foi superficialmente elencado nas linhas precedentes. Convém a propósito lembrar que a legislação paulista prevê uma forma intermediária de gratuidade, isto porque não representa a completa isenção, porém não obsta o acesso à justiça do carente de recursos. Cuida-se do diferimento do recolhimento das custas.

De fato, o art. $5^{\circ}$ da lei bandeirante refere que o recolhimento da taxa judiciária será diferido para depois da satisfação da execução quando comprovada, por meio idôneo, a momentânea impossibilidade financeira do seu recolhimento, ainda que parcial, aplicandose tal regime nas ações de alimentos e revisionais de alimentos; nas ações de reparação de dano por ato ilícito extracontratual, quando promovidas pela própria vítima ou seus herdeiros; na ação declaratória incidental e nos embargos à execução. Indo além e evitando debates estéreis, o legislador paulista expressamente estendeu esta benesse do diferimento às pessoas jurídicas, nos termos do p.único do mesmo art. $5^{\text {o454 }}$.

Este interessante regime atende de forma plena e criativa ao postulado contido no art. 13 da Lei $n^{\circ}$ 1.060/50 que prevê a possibilidade do juiz determinar o parcial pagamento

\footnotetext{
${ }^{453}$ PRUDENTE, Antônio Souza. Custas processuais e acesso à justiça, cit., p. 292.

${ }^{454}$ Concede-se o diferimento, por exemplo, para pessoas jurídicas em recuperação judicial ou em vias de adentrarem tal regime. Neste sentido: TJSP, Agravo de Instrumento no 7.161.137-3, São Paulo, $14^{\mathrm{a}}$ Câmara de Direito Privado, Relator Thiago de Siqueira, j. 30.01.08. Ainda: TJSP, Agravo de instrumento $\mathrm{n}^{\circ}$ 437.660-4/8-00, São Paulo, Câmara Especial de Falências e Recuperações Judiciais de Direito Privado, Relator Elliot Akel, j. 15.03.06.
} 
das custas, que serão rateadas entre os credores, para os assistidos que puderem em parte atender às despesas do litígio. Isto é, o parcial deferimento da gratuidade.

Vimos já que está compreendido no conceito de taxa judiciária o preparo recursal, fixado conforme o regimento de custas aplicável à causa, valor devido pela prestação do serviço judiciário em instância recursal.

Com o preparo não se confunde a verba destinada a custear a despesa com traslado dos autos ao órgão incumbido de apreciar o recurso, e a devolução dos mesmos, o chamado porte de remessa e retorno ${ }^{455}$.

O Código de Processo Civil deixa nítida a distinção entre as figuras, embora as equipare no que tange à falta de seu recolhimento: assim como a falta do preparo, o não pagamento do porte de remessa e retorno dos autos há de implicar a deserção. Eis a redação do art. 511 do diploma supra citado: "No ato de interposição do recurso, o recorrente comprovará, quando exigido pela legislação pertinente, o respectivo preparo, inclusive porte de remessa e de retorno, sob pena de deserção".

A questão que emerge diretamente desta equiparação de regimes jurídicos é a de se saber se a isenção deferida ao beneficiário da gratuidade abrange apenas o preparo recursal, ou estende-se ao porte de remessa e retorno.

Como já se disse alhures, equiparação de regimes jurídicos não significa em hipótese alguma coincidência de conceitos. Taxa judiciária (preparo recursal) e porte de remessa não contam com definições coincidentes. Estabelecer que a falta de recolhimento de uma ou outro destes valores implicará a mesma conseqüência processual não significa estabelecer que o conceito de um abarque o do outro. Daí porque a interpretação rigorosamente gramatical implicaria concluir que a isenção do preparo (ou da taxa judiciária) sem nenhuma alusão às despesas de traslado dos autos impõe o recolhimento destas.

A aparente correção deste argumento foi tão intensa que chegou a amparar a formação de sólida corrente jurisprudencial. Convém ressaltar, neste contexto, que o regimento paulista de custas, a já citada Lei Estadual $n^{\circ} 11.608 / 03$ de forma clara e peremptória estabeleceu que na taxa judiciária não se incluem "as despesas com o porte de remessa e de retorno dos autos, no caso de recurso, cujo valor será estabelecido por ato do Conselho Superior da Magistratura" (art. $2^{\circ}$, p.único, II).

\footnotetext{
${ }^{455} \mathrm{O}$ art. $8^{\circ}$ da Lei $\mathrm{n}^{\circ} 9.289 / 96$ refere-se ao porte de remessa e retorno como despesas de traslado, sujeitando a elas apenas os recursos dependentes de instrumento.
} 
O art. 511, $\S 1^{\circ}$, do Código de Processo Civil ao dispensar do preparo os recursos interpostos pelas pessoas jurídicas de direito público, pelo Ministério Público e pelos que gozam isenção legal (como é o caso dos beneficiários de gratuidade) não esclarece em nada a questão, pois que, como já dito, no conceito de preparo não se inclui, no rigor gramatical, o porte de remessa e retorno.

Ora, o art. $6^{\circ}$ da Lei Estadual $n^{\circ} 11.608 / 03$ estabeleceu a já tradicional isenção da taxa judiciária em favor da União, do Estado, do Município e respectivas autarquias e fundações, assim como do Ministério Público. A conclusão jurisprudencial não foi outra: a falta de alusão ao porte de remessa e retorno implica a exigibilidade de tal verba ${ }^{456}$.

O assunto adquiriu expressão tal, especialmente em demandas envolvendo o Instituto Nacional do Seguro Social, que chegou a ser objeto de súmula editada pelo C.Superior Tribunal de Justiça. Baseando-se no entendimento que nos traslados a ocorrerem dentro do próprio Estado compete à unidade federativa legislar a respeito (logo, se da isenção está excluído o porte de remessa e retorno, a exclusão há de prevalecer), a Corte assim editou o verbete $\mathrm{n}^{\circ}$ 178: "O INSS não goza de isenção do pagamento de custas e emolumentos, nas ações acidentárias e de benefícios, propostas na justiça estadual”.

Fato é que inexistindo norma estadual em sentido contrário, ou sendo caso em que inaplicável legislação estadual, entende-se que a isenção do preparo abrangeria o porte de remessa e retorno no que tange aos entes públicos isentos ${ }^{457}$.

\footnotetext{
${ }^{456}$ A título exemplificativo, cito julgados do Eg.Tribunal Paulista neste sentido: "RECURSO - Deserção Apelação interposta pelo Instituto Nacional do Seguro Social em ação acidentária - Hipótese - Ausência de recolhimento das despesas com porte de remessa e retorno - Ocorrência - Isenção da taxa judiciária porém não de tais custas (Lei Estadual no 11.608/03, artigo 2 $2^{\circ}$, II, e $6^{\circ}$ ) - Observância - Não preenchimento do requisito de admissibilidade - Vedação - Conhecimento do reclamo - Impossibilidade" (TJSP, Apelação n ${ }^{\circ}$ 601.439-5/3, Pitangueiras, 16 $6^{\mathrm{a}}$ Câmara de Direito Público, Relator Francisco Olavo, j. 27.2.07, V.U.); "ACIDENTE DO TRABALHO - Benefício - Marceneiro - Redução da acuidade auditiva - Concessão de auxilio-acidente de 50\% - Insurgência autárquica - Não conhecimento - A Lei Estadual no 11.608/2003, no seu artigo $6^{\circ}$, dispõe sobre a isenção do pagamento da taxa judiciária às autarquias da União, porém o inciso II, do artigo $2^{\circ}$, do mesmo diploma legal, dispõe que na taxa judiciária não se incluem as despesas com o porte de remessa e de retorno dos autos - Não tendo, a apelante, comprovado, no ato da interposição da apelação, o recolhimento do porte de remessa e retorno, é de se julgar deserto o presente apelo - Não conheceram do recurso autárquico" (TJSP, Apelação Cível n. 713.430-5/4, São Caetano do Sul, $16^{\mathrm{a}}$ Câmara de Direito Público, Relator: Oswaldo Cecara, 08.07 .08 - V.U.). Por fim: "RECURSO - Preparo Apelação interposta por autarquia estadual - Recebimento condicionado ao recolhimento do porte de remessa e retorno dos autos - Inteligência da Lei Estadual no 11.608/03 - Isenção das pessoas jurídicas de direito público apenas da taxa judiciária, que, por sua vez, excluiu de seu conceito o porte de remessa e retorno - Recurso improvido" (TJSP, Agravo de Instrumento no 429.901-5/9-00, Ribeirão Preto, $7^{\text {a }}$ Câmara de Direito Público, Relator Walter Swensson, j. 19.12.05, V.U.).

457، Os municípios, pessoas jurídicas de direito público, não estão sujeitos ao recolhimento do preparo e do porte de remessa e retorno quando da interposição de recursos, a teor do disposto no $\S 1^{\circ}$ do art. 511 do CPC” (STJ, EDcl no REsp no 371.188/DF, Rel. Min. Francisco Peçanha Martins, j. 21.02.06).
} 
A questão é saber se o mesmo entendimento pode ser transposto aos beneficiários da gratuidade, até porque o art. 511, § 1º do Código de Processo Civil alude na mesma regra aos entes públicos e aos que gozam isenção legal, como é o caso dos beneficiários da gratuidade.

O critério que propusemos no início deste capítulo calha na solução da questão: o caráter exemplificativo do rol do art. $3^{\circ}$ da Lei $n^{\circ} 1.060 / 50$ permite abarcar outras verbas ali não referidas, desde que decorram do normal exercício do direito de ação ou de defesa. É óbvio sob este prisma que o porte de remessa e retorno não pode ser cobrado do juridicamente pobre, pois que se trata de verba decorrente tão só do ato de interposição do recurso, e devida independente da procedência do reclamo recursal.

Um outro argumento se alinha: não há muito sentido em isentar-se a parte da contraprestação principal, que no caso é a devida em razão da prestação do serviço judiciário em instância recursal, e cobrá-la pelo acessório, representado no caso pela despesa com a simples remessa dos autos à Corte competente para apreciá-los e devolvêlos após julgados à origem. A questão aqui é de pura razoabilidade e bom senso na interpretação do campo de incidência da isenção legal.

Certo é, contrariar-se-á, que as isenções fiscais são regidas por princípio de legalidade estrita, isto é, dependentes sempre de lei que especifique as condições e requisitos exigidos para sua concessão, os tributos a que se aplica e, sendo o caso, o prazo de sua duração (CTN, art. 176). Deste modo, razoabilidade e bom senso não serviriam para determinar isenção da verba em debate.

Entretanto tal contrariedade é falaciosa. Primeiro porque o porte de remessa e retorno não se enquadra na noção de taxa de serviço, portanto, não se the aplica o regime jurídico tributário. Cuida-se de simples repasse de despesas. Segundo, mesmo que se aplicasse no caso o princípio da legalidade estrita típico ao regime de isenções fiscais, princípios constitucionais de superior grandeza militariam em favor da isenção, como os já tão falados postulados do amplo acesso à ordem jurídica justa, devido processo legal e isonomia material.

Desnecessário afirmar que facultar à parte acesso à justiça e efetiva participação no processo é também possibilitar-lhe levar às instâncias recursais seu pleito, até porque o duplo grau de jurisdição é também prestigiado em nível constitucional. 
Ademais, também não se há de descurar que a assistência jurídica a que já temos aludido à saciedade, igualmente contida na Lei Maior, é prevista com o predicativo da integralidade (CR, art. $5^{\circ}$, LXXIV) $)^{458}$.

Válido informar que o C.Supremo Tribunal Federal, no julgamento do Agravo de Instrumento $\mathrm{n}^{\circ}$ 351.360/PA, em que figurou como Relator o Ministro Sepúlveda Pertence, julgamento este proferido em 25.04.02, entendeu que cuidando-se de recurso da competência de órgão da Justiça da União, a isenção do $\S 1^{\circ}$ do art. 511 do Código de Processo Civil há de compreender o porte de remessa e retorno ${ }^{459}$.

Concluímos, pois, que a interpretação meramente gramatical do art. $511, \S 1^{\circ}$, do Código de Processo Civil (e ainda, no caso do Estado de São Paulo, do art. art. $2^{\circ}$, p.único, II, da Lei Estadual $n^{\circ} 11.608 / 03$, c.c. art. $6^{\circ}$ do mesmo diploma) é pobre, terminando por mostrar-se afrontosa aos princípios constitucionais a que já nos referimos. Imperioso é considerar abarcado pela isenção do preparo recursal também o porte de remessa e retorno. Alertamos, contudo, que este posicionamento não é pacífico, embora conte com respaldo jurisprudencial $^{460}$ doutrinário $^{461}$.

\footnotetext{
${ }^{458}$ Neste sentido: "ASSISTÊNCIA JUDICIÁRIA - Custas - Recurso - Despesas de porte de remessa e retorno - Isenção - Cabimento - Gratuidade que é integral, nos termos do art. $5^{\circ}$, inciso LXXIV, da Constituição Federal de 1988 - Harmonia com o art. $3^{\circ}$, inciso I, da Lei ${ }^{\circ} 1.060 / 50$, cuja isenção compreende as taxas judiciárias e dos selos postais - Ônus do Estado, no qual inclui o Judiciário como Poder, de prover os recursos para a condução de peças de processos por meios próprios ou por empresa prestadora de serviços postais - Reconhecimento - Recurso provido" (TJSP, Agravo de Instrumento $\mathrm{n}^{\circ}$ 7.097.655-7, Comarca de Sorocaba, Rel. Cerqueira Leite, j. 06.12.06).

${ }^{459} \mathrm{O}$ destaque que lançamos é justificado porque frisa que o C.STF no caso não se posicionou acerca de eventuais legislações estaduais que prevejam a restrição da isenção apenas ao preparo propriamente dito.

${ }^{460} \mathrm{Na}$ jurisprudência paulista encontramos, em sentido contrário, e aplicando aos beneficiários da gratuidade o mesmo regime a que sujeitos os demais entes beneficiários das isenções legais: "JUSTIÇA GRATUITA Despesas processuais - Isenção apenas da taxa judiciária - Obrigatoriedade do pagamento das despesas com o porte de remessa e de retorno dos autos, uma vez que estas não estão inseridas no conceito de taxa judiciária - Inteligência do art. $2^{\circ}$, parágrafo único, II, da Lei $\mathrm{n}^{\circ} 11.608 / 03$ - Infringência ao disposto no art. $525, \S 1^{\circ}$, do CPC evidenciada - Agravo não conhecido, restando revogada a concessão do efeito suspensivo" (TJSP, Agravo de Instrumento no 433.012-4/2, Comarca do Guarujá, Rel. Álvaro Passos, j. 07.06.06). Neste mesmo sentido: TJSP, Ap.Cível $n^{\circ}$ 7.164.733-7, Rel. Jurandir de Sousa Oliveira, j. 13.11.07. De outro lado, dando pela isenção do beneficiário da gratuidade: "Estão dispensados do recolhimento do porte de remessa e retorno os recorrentes que litigam sob os benefícios da justiça gratuita" (STJ, REsp nº 429.216/RS, Rel. Min. Teori Albino Zavascki, j. 25.05.04). No mesmo sentido já havia decidido o C.Superior Tribunal de Justiça no julgamento do Recurso Especial ${ }^{\circ}$ 445.904/PI, Rel. Min. Aldir Passarinho Junior, julgado em 21.10.03, publicado no Diário da Justiça de 1\%12/03. Mais antigo, temos neste sentido também o julgamento ainda do Recurso Especial no 257.292/MG, Rel.Min. Ruy Rosado de Aguiar, julgado em 22.08.00. No Estado de São Paulo também há julgados neste sentido, como o a seguir ementado: "Agravo de Instrumento - Decisão que deixou de receber o recurso de apelação em razão da ausência de recolhimento da taxa de porte de remessa e retorno - Inadmissibilidade - Apelante beneficiário de Assistência Judiciária - Isenção legal que alcança todas as custas e despesas processuais Despesas com porte de remessa e retorno que estão incluídas no preparo - Decisão reformada - Recurso provido" (Agravo de Instrumento $\mathrm{n}^{\mathrm{o}}$ 706.906.5/0-00, Rel. Leme de Campos, j. 22.10.07).

${ }^{461}$ Entendem que no conceito de preparo referido pelo $\S 1^{\circ}$ do art. 511 do CPC está incluído o porte de remessa e retorno Fredie Didier Jr. e Rafael Oliveira (Benefício da justiça gratuita, cit., p. 14). No mesmo
} 
Ainda o inciso I do art. $3^{\circ}$ da Lei $n^{\circ}$ 1.060/50 alude aos vetustos "selos". "Às vezes a taxa deve ser paga por meio de selos anexados aos papéis e inutilizados. Trata-se de meio arcaico de recolhimento, mas que, eventualmente, ainda pode ser previsto por leis estaduais" 462 .

No Estado de São Paulo, a Lei Estadual n 10.394/70, que reorganiza a Carteira de Previdência dos Advogados de São Paulo, estabeleceu em seu art. 48 uma contribuição de 1,5\% do salário mínimo vigente na Capital do Estado para o instrumento de mandato ser anexado ao processo, contribuição esta devida por mandante. Igualmente pela juntada de substabelecimento será paga a contribuição fixa de 1,5\% sobre o salário-mínimo vigente na Capital, qualquer seja o número de mandatos substabelecidos ( $\$ 2^{\circ}$ do art. 48).

O próprio art. 49 do diploma supra citado isenta de tal contribuição o beneficiário da gratuidade. Entretanto, sagrando-se o beneficiário vencedor na causa, a contribuição será cobrada ao vencido na proporção em que for, devendo ser incluída, pelo contador, na conta de liquidação.

Estão ainda abrangidas pela gratuidade as despesas postais, seja para remessa de cientificações em geral, tal como citações (exceto nas hipóteses especificadas no art. 222 do Código de Processo Civil) e intimações, seja para remessa de cartas precatórias ${ }^{463}$.

\section{Emolumentos e custas}

A redação do inciso II do art. $3^{\circ}$ da Lei $n^{\circ}$ 1.060/50 está assim cunhada: "emolumentos e custas devidos aos juízes, órgãos do Ministério Público e serventuários da Justiça”. Não parece pairar dúvida acerca da recepção apenas parcial da referida estipulação pela Constituição da República de 1988, diante da expressa vedação imposta tanto a magistrados como a membros do Ministério Público, a que percebam, a qualquer

sentido: PINHEIRO, Eduardo Bezerra de Medeiros. Breves observações acerca da Lei ${ }^{\circ}$ 1.060/50. Revista dos Tribunais, São Paulo, v. 85, n. 733, p. 94, nov. 1996 e MIRANDA, Gilson Delgado. Art. 511. In: MARCATO, Antônio Carlos (Org.). Código de Processo Civil interpretado, cit., p. 1.751.

${ }^{462}$ VIDIGAL, Mauricio. Lei da Assistência Judiciária interpretada, cit., p. 28.

${ }^{463}$ MARCACINI, Augusto Tavares Rosa. Assistência jurídica, assistência judiciária e justiça gratuita, cit., p. 39. Na jurisprudência, ressaltamos decisão por nós já citada quando tratamos do caráter do rol trazido pelo art. $3^{\circ}$ da Lei $\mathrm{n}^{\circ} 1.060 / 50$, e que foi proferida pelo Eg. Tribunal de Justiça de São Paulo, nos autos do Agravo de Instrumento $\mathrm{n}^{\circ}$ 7.287.970-0, da Comarca de Araçatuba, Rel. Rubens Cury, j. 08.09.08. Vale ainda transcrição a posição de Dinamarco: "As despesas postais consideram-se incluídas nas taxas judiciárias e portanto não são exigidas aos beneficiários da assistência judiciária" (DINAMARCO, Cândido Rangel. Instituições de direito processual civil, cit., v. 2, p. 700). Também neste sentido: VIDIGAL, Mauricio. Lei da Assistência Judiciária interpretada, cit., p. 34. 
título, custas ou participação em processos, honorários ou percentagens (CR, arts. 95, parágrafo único, II e $128, \S 5^{\circ}$, II, “a”).

No que respeita aos emolumentos devidos a serventuários, entretanto, a norma remanesce vigente. Entende-se por emolumento, segundo Maurício Vidigal, a contraprestação pecuniária recebida por delegados do poder público, os escrivães ${ }^{464}$. É o mesmo autor quem lembra que o art. 31 do Ato das Disposições Constitucionais Transitórias previu a estatização das serventias do foro judicial. Como a norma expressamente ressalvou os direitos dos então atuais titulares, não se descarta a possibilidade de que perdurem ainda nos rincões do país serventias judiciais não estatizadas, ou seja, nas palavras ainda de Maurício Vidigal: "escrivães não funcionários públicos"465. Por óbvio estão abarcadas as verbas devidas às serventias extrajudiciais, o que será objeto de análise linhas adiante.

A doutrina chega a inserir sob o manto do mencionado inciso II verbas que são, também, objeto de outros incisos, havendo certa sobreposição ${ }^{466}$. Limitaremos nossas assertivas às verbas que somente aqui se comportariam.

Reponta, assim, a isenção quanto ao pagamento das despesas de locomoção dos oficiais de justiça, a chamada "condução" "467. Obviamente que o servidor não arcará por si com a despesa que é inerente à sua atividade, o que será incumbência do Estado ${ }^{468}$.

Outra despesa que se acha albergada pela regra em comento é aquela decorrente de extração de cópias dos autos, bem como eventual autenticação destas. Deve o juiz determinar que as cópias necessárias sejam feitas gratuitamente, e na impossibilidade, "que o escrivão providencie o traslado das peças, transcrevendo o seu conteúdo e certificando sua conformidade com os originais" 469 . Considerando o atual estágio dos recursos de

\footnotetext{
${ }^{464}$ VIDIGAL, Mauricio. Lei da Assistência Judiciária interpretada, cit., p. 28.

${ }^{465}$ VIDIGAL, Mauricio. Lei da Assistência Judiciária interpretada, cit., p. 28.

${ }^{466} \mathrm{Com}$ base na lição de Alcides de Mendonça Lima, por exemplo, Araken de Assis observa que emolumentos se referem à remuneração de serviços prestados no processo em caráter eventual, como a remuneração do perito, que comportará análise do inciso próprio. Ainda refere às despesas postais, que já foi por nós relacionada, bem como indenizações a testemunhas, que serão também objeto de oportuna análise. (ASSIS, Araken de. Benefício da gratuidade, cit., p. 166).

${ }^{467}$ MARCACINI, Augusto Tavares Rosa. Assistência jurídica, assistência judiciária e justiça gratuita, cit., p. 38. Na jurisprudência, e invocando o art. $9^{\circ}$ da LAJ: $1^{\circ}$ TAcSP, Agravo de Instrumento $\mathrm{n}^{\circ}$ 1.240.269-6, da Comarca da Capital, relatado pelo Juiz Jurandir de Sousa Oliveira, em 10 de agosto de 2004. Ainda das anotações de Theotonio Negrão temos precedente inserido na RJTJESP 90/368 (Código de Processo Civil e legislação processual em vigor. 33. ed. São Paulo: Saraiva, 2002. p. 1.148).

${ }^{468} \mathrm{Em}$ São Paulo há fundo próprio para tanto, efetuando os Oficiais de Justiça um "mapeamento" das diligências realizadas sob regime de gratuidade.

${ }^{469}$ MARCACINI, Augusto Tavares Rosa. Assistência jurídica, assistência judiciária e justiça gratuita, cit., p. 43. No mesmo sentido: DIDIER JR, Fredie; OLIVEIRA, Rafael. Benefício da justiça gratuita, cit., p. 15.
} 
informática e sua progressiva inserção do âmbito forense, certamente esta última alternativa ficará reservada a casos extremos.

É de se anotar que a extração de cópias que é albergada pela gratuidade não é apenas aquela que tenha como objeto os próprios autos nos quais deferido o benefício, como, p.ex., para a formação de instrumento, mas mesmo cópias de outros processos, desde que necessárias para instrução daquele no qual a benesse tenha sido concedida ${ }^{470}$.

No que concerne à autenticação de cópias, invoca-se o disposto no art. 385, "caput", do Código de Processo Civil, para amparar a possibilidade de que se determine ao escrivão que a proceda. Eis a redação do dispositivo: “A cópia de documento particular tem o mesmo valor probante que o original, cabendo ao escrivão, intimadas as partes, proceder à conferência e certificar a conformidade entre a cópia e o original”, ${ }^{\wedge 71}$.

Em sentido oposto, defende-se também que a regra da autenticação pelo escrivão na forma do dispositivo sob análise somente comporta incidência em caso de impugnação na forma do art. 372 do Código de Processo Civil (que remete a parte contra quem produzido o documento ao prazo do art. 390 para a admissão ou não da autenticidade da assinatura e da veracidade do contexto). Ou seja, não veicularia a regra apenas mais uma via de autenticação posta à disposição, no caso, dos beneficiários da gratuidade ${ }^{472}$.

De nossa parte embora creiamos na correção da assertiva contida no parágrafo anterior, isto é, a restrição da autenticação pelo escrivão aos casos em que houver impugnação à autenticidade documental, não nos parece inviável a interpretação extensiva, para abrangência da hipótese em que a parte, por ser beneficiária da gratuidade, estaria isenta de eventuais emolumentos devidos pelo serviço de autenticação de cópias.

É certo que, considerando a realidade do quotidiano forense, em que as demandas em que ao menos uma das partes é beneficiária é ampla maioria, e ainda em que as atribuições dos escrivães são já sobejas, atuando tais servidores no limite do humanamente possível, temos que concluir que implementar tal atividade seria dificílimo. De outro lado

\footnotetext{
${ }^{470}$ TJSP, Agravo de Instrumento no 1.254.731-0, relator Des. Norival Oliva, j. 09.06.09.

${ }^{471}$ É esta a posição de Fredie Didier Jr. e Rafael Oliveira (Benefício da justiça gratuita, cit., p. 15).

${ }^{472}$ Transcrevamos as palavras de Antônio Cláudio da Costa Machado: "Só em caso de impugnação é que cabe a intimação das partes para a conferência e posterior certificação via lavratura de termo; a regra não se presta, observe-se, a simplesmente colocar à disposição do litigante mais um meio de autenticação" (Código de Processo Civil interpretado, cit., p. 394). Também no sentido de que a autenticação somente é exigível quando surgir controvérsia sobre a autenticidade do documento: DINAMARCO, Cândido Rangel. Instituições de direito processual civil, cit., v. 3, p. 606.
} 
o direito da parte não pode ser suprimido pela deficiência estrutural do serviço público, além do que, nossa ordem de considerações é teórica.

Certamente os problemas advindos da inviabilidade prática de se exigir do escrivão que autentique cópias das partes beneficiárias da gratuidade sempre que estas o requeiram foram amplamente mitigados em razão do acréscimo do inciso IV ao art. 365 do Código de Processo Civil pela Lei $n^{\circ} 11.382 / 06$, declarando fazerem a mesma prova que o original "as cópias reprográficas de peças do próprio processo judicial declaradas autênticas pelo próprio advogado sob sua responsabilidade pessoal, se não lhes for impugnada a autenticidade".

Dois problemas são de plano constatáveis: primeiro a limitação da declaração às cópias do próprio processo (no nosso entender injustificável); segundo, a pouca valia da tal autenticação que não resiste à impugnação pelo interessado (e neste ponto, a autenticação procedida pelo escrivão, como forma de solucionar a impugnação, assumiria inclusive maior grau de confiabilidade que a do advogado, gradação que nos parece pouco justificável).

Como já dito alhures, a isenção de emolumentos refere-se ao quantum devido em contraprestação por serviços prestados por delegatários do poder público, e entre eles assumem especial relevo os detentores de delegação de serventias extrajudiciais.

Barbosa Moreira empreende raciocínio a partir do qualificativo inserido no inciso LXXIV do art. $5^{\circ}$ da Constituição da República à assistência, que passou a ser jurídica e ainda integral. A mudança na adjetivação representa notável ampliação no universo atingido pela benesse, daí sua conclusão de que tanto os atos notariais, como quaisquer outros de natureza jurídica praticados extrajudicialmente são albergados pela isenção ${ }^{473}$.

Segue o mesmo autor observando que o inciso LXXVI do art. $5^{\circ}$ da Constituição (que estabelece serem gratuitos para os reconhecidamente pobres o registro civil de nascimento e a certidão de óbito) é meramente explicitante da garantia genérica contida no inciso LXXIV. E a seguir responde à possível objeção de que os serviços notariais e de registro são prestados em caráter privado, lembrando que também o são por delegação do Poder Público (CR, art. 236, "caput”), o que implica a seguinte consequiência:

\footnotetext{
${ }^{473}$ BARBOSA MOREIRA, José Carlos. O direito a assistência jurídica - evolução no ordenamento brasileiro de nosso tempo, cit., p. 124.
} 
"O que se deve entender é que o delegado assume, nos mesmos termos, o dever, que corria ao delegante, de prestar a assistência. Isso vale para o registro de nascimento e para a certidão de óbito, como para quaisquer outros atos congêneres. A lei que, de acordo com o art. 236, $\S 2^{\circ}$, "estabelecerá normas gerais para a fixação de emolumentos relativos aos atos praticados pelos serviços notariais e de registro", terá de preservar a gratuidade devida aos carentes de meios, sob pena de tornar-se inconstitucional" ${ }^{, 474}$.

Não custa ressaltar que a lei referida pelo $\S 2^{\circ}$ do art. 236 da Constituição foi editada em 2000, sob o número 10.169, e não referiu em seu texto qualquer alusão à isenção de que gozassem beneficiários da gratuidade, a não ser aquela decorrente do inciso LXXVI do art. $5^{\circ}$ da Constituição (referente ao assento de nascimento e à certidão de óbito) ${ }^{475}$.

A Lei $n^{\circ}$ 8.935/94, chamada "Lei dos Cartórios", que regulamentou a atividade de notários e registradores, também foi tímida em tratar da gratuidade, limitando-se no "caput" do art. 45 a reiterar a garantia já contida na Constituição quanto ao assento de nascimento e certidão de óbito: "São gratuitos os assentos do registro civil de nascimento e o de óbito, bem como a primeira certidão respectiva" (destaquei, conforme redação dada pela Lei $\mathrm{n}^{\circ}$ 9.534/97). Dois parágrafos incluídos pela Lei $\mathrm{n}^{\circ} 11.789 / 08$ vieram a ampliar também de forma quase irrisória a garantia, prevendo-se no $\S 1^{\circ}$ que para os reconhecidamente pobres não seriam cobradas certidões de nascimento ou óbito (ou seja, estendendo a isenção para além da primeira certidão) ${ }^{476}$. O $\S 2^{\circ}$ aludiu à vedação de que nas certidões de nascimento ou óbito expedidas gratuitamente haja qualquer alusão à condição de pobreza ou semelhante.

Em geral tem-se entendido que a gratuidade se estende aos atos extrajudiciais que sejam desdobramento necessário e imediato do direito subjetivo reconhecido no processo no qual a benesse tenha sido concedida, o que é até imperativo lógico. Não teria sentido algum garantir à parte a gratuidade para o curso processual, e depois denegá-la no ato

\footnotetext{
${ }^{474}$ BARBOSA MOREIRA, José Carlos. O direito a assistência jurídica - evolução no ordenamento brasileiro de nosso tempo, cit., p. 131.

${ }^{475}$ Art. $8^{\circ}$. Os Estados e o Distrito Federal, no âmbito de sua competência, respeitado o prazo estabelecido no art. $9^{\circ}$ desta Lei, estabelecerão forma de compensação aos registradores civis das pessoas naturais pelos atos gratuitos, por eles praticados, conforme estabelecido em lei federal.

Parágrafo único. O disposto no caput não poderá gerar ônus para o Poder Público.

${ }^{476} \mathrm{Na}$ verdade a Lei $\mathrm{n}^{\circ} 11.789 / 08$ acresceu o $\S 2^{\circ}$, pois que o primeiro parágrafo era antes o único, e foi apenas renumerado, de modo que a garantia referente à gratuidade das certidões de óbito e nascimento em geral já era prevista anteriormente no diploma normativo por redação trazida pela Lei $\mathrm{n}^{\circ}$ 9.534/97. Ampliação houve em relação ao mínimo constitucionalmente previsto.
} 
culminante de inscrição no registro público do qual dependa a eficácia do direito reconhecido $^{477}$.

Mas não apenas isto. Há de se ter em conta situações em que atos notariais ou de registro são necessários não para a completa eficácia do direito já reconhecido no processo, mas para viabilizar a cognição da matéria pelo juízo, isto é, para instrução do feito. A amplitude da garantia do acesso à justiça em sentido substancial impõe também se reconheça a gratuidade para tal conjuntura ${ }^{478}$.

Assim, por exemplo, será gratuita não apenas a inscrição no fólio registral da sentença que reconhece a usucapião, mas também há de se reconhecer a gratuidade para ato anterior, a expedição de certidão da matrícula do imóvel usucapiendo, necessária para a instrução do processo que posteriormente poderá culminar no reconhecimento da prescrição aquisitiva. Muito provavelmente tal expediente será absolutamente necessário para que se possa, por exemplo, identificar quem seja o proprietário constante do registro, bem como quem sejam os confrontantes, já que o primeiro ostenta a rigor a posição de réu no processo, e os segundos, de intervenientes obrigatórios (CPC, art. 942).

Neste norte, já se reconheceu, por exemplo, a gratuidade da inscrição no Registro de Imóveis de penhoras realizadas no bojo de processo executivo em que a parte seja beneficiária da gratuidade ${ }^{479}$, ato absolutamente necessário à efetividade da cobrança do crédito. Outros casos em que se tem considerado extensiva a gratuidade concedida no processo a atos notariais e de registro são a inscrição da sentença que reconhece a

\footnotetext{
477،É inadmissível, em síntese, que a parte pobre, recorrendo ao Poder Judiciário, tenha a eficácia de provimento jurisdicional favorável obtido cerceada pela insubmissão do titular de uma serventia extrajudicial. Como se diria no linguajar comum, não se pode condescender em que o hipossuficiente 'ganhe, mas não leve"' (LIMA, Rogério Medeiros Garcia de. Serventias extrajudiciais e justiça gratuita. Revista de Processo, Sao Paulo, v. 21, n. 83, p. 234, jul./set. 1996).

${ }^{478}$ No mesmo sentido: MARCACINI, Augusto Tavares Rosa. Assistência jurídica, assistência judiciária e justiça gratuita, cit., p. 44.

${ }^{479}$ TJSP, Agravo de Instrumento $\mathrm{n}^{\circ}$ 86.683-4/0, Rel. Rebouças de Carvalho, j. 10.02.99. Há um precedente entendendo que no caso de protesto, aquele que, intimado, pagou o título, ou seja, reconhecidamente devedor, não faz jus à inexigibilidade dos emolumentos devidos ao Tabelião mesmo em caso de carência econômica: "Serviços notariais Protesto. Cancelamento do Registro Emolumentos 1. A natureza tributária dos emolumentos, devidos ao delegado do cartório por ato de sua atribuição, não permite a aplicação analógica ou extensiva de norma que exclua a sua exigibilidade salvo nos casos expressamente previstos na lei. 2. A deficiência econômica, temporária ou permanente, de quem teve titulo protestado e efetivou o seu pagamento, não gera direito subjetivo líquido e certo à inexigibilidade da exação Recurso improvido" (TJSP, Apelação Cível nº 752.240-5/2-00, Rel. Laerte Sampaio, j. 18.03.08).
} 
usucapião $^{480}$; averbação de sentença de separação judicial e averbação de nomes em registro nascimento ${ }^{481}$.

Eduardo Bezerra de Medeiros Pinheiro relata precedente oriundo do Tribunal de Justiça do Estado do Rio de Janeiro em que se deferiu a expedição de alvará para isenção de custas extrajudiciais relativas a escrituras e registro de imóvel ${ }^{482}$.

Ressalta ainda Marcacini que a necessidade do autor da ação de usucapião de instruir a inicial com planta do imóvel não poderia representar óbice de acesso à justiça por falta de condições econômicas de prover tal documento (CPC, art. 942). Defende o autor em questão que em casos que tais, admita-se que a inicial venha instruída com mero desenho, requerendo a parte ao juiz a nomeação de um perito para providenciar o memorial descritivo e a planta do bem usucapiendo ${ }^{483}$.

Vale ainda anotar que no Estado de São Paulo, os emolumentos devidos a notários e registradores foram regulamentados pela Lei Estadual $\mathrm{n}^{\circ} 11.331 / 02$, que em seu art. $9^{\circ}$, II, previu que serão gratuitos "os atos praticados em cumprimento de mandados judiciais expedidos em favor da parte beneficiária da justiça gratuita, sempre que assim for expressamente determinado pelo Juízo". Por isto é que se pode sem receios sustentar que a renitência do delegatário em atender ao comando judicial o sujeitará às sanções administrativas e até penais pertinentes ${ }^{484}$

Araken de Assis propugna por interpretação restrita da gratuidade no que toca às despesas extraprocessuais. Refere que as despesas que apenas indiretamente sejam relacionadas à prestação jurisdicional, apenas por norma específica seriam albergadas pela

\footnotetext{
${ }^{480}$ Cumpre ressaltar que no concernente à usucapião especial há expressa disposição legal concedente da gratuidade, conforme se vê do art. 60 "caput", da Lei no 6.969/81: "O autor da ação de usucapião especial terá, se o pedir, o benefício da assistência judiciária gratuita, inclusive para o Registro de Imóveis".

${ }^{481}$ Cf. precedentes citados por Maurício Vidigal (Lei da Assistência Judiciária interpretada, cit., p. 28-29) bem como por Marcacini (Assistência jurídica, assistência judiciária e justiça gratuita, cit., p. 44-45).

${ }^{482}$ PINHEIRO, Eduardo Bezerra de Medeiros. Breves observações acerca da Lei no 1.060/50, cit., p. 733.

${ }^{483}$ MARCACINI, Augusto Tavares Rosa. Assistência jurídica, assistência judiciária e justiça gratuita, cit., p. 45-46. Na jurisprudência encontramos o seguinte precedente: "Usucapião - Ausência de planta ou croqui do imóvel objeto do usucapião - Intimação dos autores para emendarem a inicial com a juntada do croqui Ausência da juntada ou manifestação - Indeferimento da petição inicial - Extinção do processo sem julgamento do mérito - Apesar do artigo 942, do Código de Processo Civil, mencionar a necessidade de se juntar o laudo do imóvel na petição inicial, há de se mitigar tal norma, por excesso de formalismo e possibilidade da realização de perícia ou juntada posterior - No caso, os autores são beneficiários da justiça gratuita, o que confirma a necessidade de requerimento da planta diretamente da Prefeitura - O usucapião é uma ação de caráter social - Provimento com determinação" (TJSP, Apelação cível n 278.95S.4/4-00, Rel. Enio Zuliani, j. 10.08.06).

${ }^{484}$ LIMA, Rogério Medeiros Garcia de. Serventias extrajudiciais e justiça gratuita, cit., p. 237.
} 
benesse, ressaltando a título exemplificativo, o caso da averbação de sentença de separação consensual $^{485}$.

Recentemente a questão da isenção ao reconhecidamente pobre no que concerne a despesas extrajudiciais assumiu ainda mais relevo com a edição da Lei ${ }^{\circ}$ 11.441/07. Mediante alterações introduzidas no Código de Processo Civil, o diploma em questão criou em nosso sistema o inventário, separação e divórcio consensuais, mediante escritura pública, isto é, extrajudiciais (CPC, arts. 982 e 1.124-A).

No que respeita às separações e divórcios extrajudiciais, maiores dúvidas não poderia haver, diante da expressa previsão do $\S 3^{\circ}$ do art. 1.124-A: "A escritura e demais atos notariais serão gratuitos àqueles que se declararem pobres sob as penas da lei”.

Dúvida poderia haver em razão da inexistência de previsão semelhante no que concerne aos inventários e partilhas. Contudo, seria ela logo espancada pelo recurso à amplitude que se tem dado à garantia constitucional prevista no já citado inciso LXXIV do art. $5^{\circ}$, que ao inserir sob sua égide a assistência jurídica e integral foi além dos atos judiciários. Indiscutivelmente, por isto, os procedimentos extrajudiciais em questão achamse albergados pela gratuidade em caso de pobreza. É óbvio também que a gratuidade abrange todos os atos inseridos no contexto da escritura seja de inventário/partilha, seja de separação/divórcio, isto é, não apenas a lavratura, mas eventual averbação de seu conteúdo em outras serventias ${ }^{486}$.

Defende-se a inaplicabilidade no caso do art. $4^{\circ}$ da Lei $n^{\circ} 1.060 / 50$ (segundo o qual bastaria à parte afirmar na inicial a falta de condições de pagar custas e honorários), pois que o diploma em questão não abrangeria a atividade notarial. Aplicável à espécie seria a Lei $\mathrm{n}^{\circ} 7.115 / 83$ cujo art. $1^{\circ}$ prevê: "A declaração destinada a fazer prova de vida, residência, pobreza, dependência econômica, homonímia ou bons antecedentes, quando firmada pelo próprio interessado ou por procurador bastante, e sob as penas da Lei, presume-se verdadeira" 487 .

\footnotetext{
${ }^{485}$ ASSIS, Araken de. Benefício da gratuidade, cit., p. 169-170.

${ }^{486}$ TARTUCE, Fernanda. Assistência judiciária, gratuidade e a Lei 11.441/2007. In: MATHIAS COLTRO, Antônio Carlos; DELGADO, Mario Luiz (Coord.). Separação, divórcio, partilhas e inventários: questionamentos sobre a Lei n ${ }^{\circ}$ 11.441/2007. São Paulo: Método, 2007. p. 104-105.

${ }^{487}$ TARTUCE, Fernanda. Assistência judiciária, gratuidade e a Lei 11.441/2007, cit., p. 106. Diverge a jurisprudência acerca da necessidade de que o procurador que firme a declaração seja munido de poderes especiais. Ressaltamos adiante trecho do voto condutor do julgamento pelo extinto $1^{\circ}$ TACivSP do Agravo de Instrumento $\mathrm{n}^{\circ}$ 1.284.661-8, Relator Álvaro Torres Junior: "O douto Juiz Relator indeferiu o benefício da gratuidade judiciária pleiteado pela recorrente por entender inviável seu acolhimento à falta de declaração subscrita pela própria parte, insuficiente o requerimento feito por advogado regularmente
} 
No caso de recusa do Tabelião, três são os possíveis recursos a serem manejados pelo interessado: impetração de mandado de segurança; requerimento de procedimento administrativo de dúvida (inclusive a dúvida inversa, requerida pelo interessado, admitida jurisprudencialmente) e reclamação funcional à Corregedoria Geral da Justiça ${ }^{488}$.

Nota-se que não abordamos de forma destacada a precisão das "custas" no inciso sob exame. Justificamos. Adotando a distinção proposta por Artêmio Zanon, temos que do conceito genérico de despesas processuais, distinguem-se as modalidades custas e honorários. As primeiras são por ele definidas como os encargos resultantes do processo contencioso ou não, exigidas desde a distribuição, objeto de condenação acessória pela sentença (e que não depende de pedido), sem caráter punitivo. Têm sentido mais restrito que as despesas, portanto, compreendendo a parte destas destinadas à expedição $e$ movimentação dos feitos, conforme Regimento de Custas de cada Estado ${ }^{489}$.

Os honorários, como parece óbvio, representam a remuneração de peritos e advogados, e vêm referidos pelo inciso $\mathrm{V}$ do art. $3^{\circ}$ da Lei $\mathrm{n}^{\circ} 1.060 / 50$.

Por este conceito, as custas em sentido estrito consistiriam na taxa judiciária, que por nós já foi abordada no item anterior, daí porque desnecessária repetição daquelas considerações.

Uma rubrica cumpre seja analisada neste subitem, qual seja, a caução exigida para a propositura de ação rescisória. Prevista pelo inciso II do art. 488 do Código de Processo Civil, a garantia em questão é fixada em $5 \%$ sobre o valor da causa, e segundo o texto

constituído sem poderes especiais. Isso porque entende o digno Relator que a Lei ${ }^{\circ}$ 7.115, de 29.08.93, em seu art. $1^{\circ}$, estabeleceu a presunção de veracidade da declaração de pobreza desde que feita por procurador bastante (texto expresso do dispositivo). Esse 'bastante' da lei seria o advogado com poderes especiais para fazer tal declaração. Não se entende, no entanto, que a lei pretendeu dar essa conotação à qualificadora 'bastante' dada ao procurador. Tendo em mente o intuito da própria lei em facilitar a concessão do dito benefício, que se presumia verdadeiro desde que lançada a declaração aludida, não se há de considerar o "procurador bastante" mencionado no texto da lei como sendo o que exige poderes especiais outorgados ao advogado para requerer os benefícios da gratuidade judiciária. Acrescente-se, em favor dessa definição, o que dispõe o art. $4^{\circ}$, 'caput', da Lei n 1.060/50, ao afirmar que 'A parte gozará dos benefícios da assistência judiciária, mediante simples afirmação, na própria petição inicial, de que não está em condições de pagar as custas do processo e os honorários de advogado, sem prejuízo próprio ou de sua família'. Ao aludir à possibilidade de requerer-se o benefício mediante declaração posta na própria petição inicial, esta por óbvio subscrita por advogado, sem mencionar a necessidade de poderes especiais para tanto, está a lei facultando o requerimento feito por procurador com poderes de representação geral para o foro, sem a outorga de poderes específicos para se fazer o aludido requerimento. Nesse ponto, pois, entende-se desnecessária a exigência formulada pelo douto juiz Relator, com o respeito devido à sua posição bem fundamentada". Em sentido contrário, isto é, exigindo a declaração de pobreza subscrita por procurador com poderes especiais, extinto $2^{\circ}$ TACivSP, Agravo de Instrumento n 771.323-0/1, Rel. Veira de Moraes, j. 17.12.02.

${ }^{488}$ TARTUCE, Fernanda. Assistência judiciária, gratuidade e a Lei 11.441/2007, cit., p. 107/108.

${ }^{489}$ ZANON, Artêmio. Assistência Judiciária gratuita: comentários à Lei da Assistência Judiciária (Lei $\mathrm{n}^{\circ}$ 1.060, de 5-2-1950), cit., p. 28-29. 
legal, estabelecida "a título de multa, caso a ação seja, por unanimidade de votos, declarada inadmissível, ou improcedente".

Parece de meridiana clareza que o depósito em questão serve à garantia de uma possível sanção, cominada à parte que promove ação rescisória infundada. A lei assim considera a demanda se for declarada inadmissível ou improcedente por unanimidade de votos. É óbvio que se a ação for assim declarada por maioria, à parte caberá restituir-se do valor depositado previamente.

Se fôssemos seguir de forma rigorosamente lógica o que já alhures defendemos acerca do benefício da gratuidade e sua não aplicabilidade às multas processuais, seríamos compelidos a negar a isenção ${ }^{490}$. Fato é, contudo, que doutrina de peso e jurisprudência caudalosa têm dado pela abrangência de tal verba pela isenção oriunda da gratuidade ${ }^{491}$. Na doutrina é esta a posição de Fredie Didier Jr e Rafael Oliveira ${ }^{492}$; Augusto Tavares Rosa Marcacini ${ }^{493}$; Paulo Henrique dos Santos Lucon $^{494}$; Eduardo Bezerra de Medeiros Pinheiro $^{495}$; Barbosa Moreira ${ }^{496}$ e Araken de Assis ${ }^{497}$.

A hesitação aqui quanto à possibilidade de conceder-se ou a não a isenção decorre da peculiaridade da previsão legal: cuida-se de uma sanção (e daí porque a tendência é negar o beneplácito legal), porém exigida em caráter prévio, isto é, como requisito de admissibilidade da ação rescisória, logo, como condicionante do acesso à justiça (e daí a tentação de conceder-se a isenção).

\footnotetext{
${ }^{490} \mathrm{Na}$ doutrina, é esta a posição de Nelson Nery Jr e Rosa Maria de Andrade Nery: "O certo é que o depósito tem nítido caráter cominatório para quem promover ação infundada. Não é esse o sentido da assistência judiciária, que pretende livrar a parte dos ônus decorrentes do processo e não das indenizações devidas em virtude de atos de sua responsabilidade" (NERY JUNIOR, Nelson; NERY, Rosa Maria Andrade. Código de Processo Civil comentado e legislação extravagante. 7. ed. São Paulo: Ed. Revista dos Tribunais, 2003. p. 839). Na jurisprudência, igualmente neste sentido: “A gratuidade judiciária concedida em favor do autor não abrange o recolhimento do depósito prévio, porque ele tem natureza de sanção e a lei específica, que estabelece critérios para a concessão da gratuidade, não engloba a isenção do depósito prévio" (TJSP, Embargos de Declaração n 904.026-5/0-01 e Ação Rescisória n 904.026-5/8-00, Rel. Israel Góes dos Anjos, j. 29.03.10).

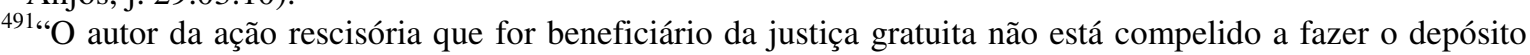
prévio previsto no art. 488, inciso II, do Código de Processo Civil. Precedentes" (STJ, AR n ${ }^{\circ}$ 1.423/SP, Rel. Min. Laurita Vaz, j. 12.12.07); "Com a outorga do benefício, fica o autor dispensado, por ora, do depósito aludido no art. 488, inciso II, do CPC, conforme reconhecimento doutrinário e jurisprudencial" (TJSP, AR nº 1.160.030-0/5, Rel. Adílson de Araújo, j. 18.03.08).

${ }^{492}$ DIDIER JR, Fredie; OLIVEIRA, Rafael. Benefício da justiça gratuita cit., p. 15.

${ }^{493}$ MARCACINI, Augusto Tavares Rosa. Assistência jurídica, assistência judiciária e justiça gratuita, cit., p. 39-40.

${ }^{494}$ LUCON, Paulo Henrique dos Santos. Garantia do tratamento paritário das partes, cit., p. 113.

${ }^{495}$ PINHEIRO, Eduardo Bezerra de Medeiros. Breves observações acerca da Lei no 1.060/50, cit., p. 102.

${ }^{496}$ BARBOSA MOREIRA, José Carlos. O direito a assistência jurídica - evolução no ordenamento brasileiro de nosso tempo, cit., p. 126.

${ }^{497}$ ASSIS, Araken de. Benefício da gratuidade, cit., p. 167.
} 
Em atenção a este quê híbrido que há na figura deste depósito prévio é que alvitramos $^{498}$, a posição intermédia: a multa não é de ser exigida em caráter prévio, de modo a impedir o acesso do menos favorecido à justiça; porém não se há de prestigiar a impunidade para a litigância irresponsável (e já tivemos oportunidade de rechaçar a extensão da isenção às sanções processuais), destarte, ocorrente a hipótese prevista pelo inciso II do art. 488 do Código de Processo Civil (inadmissibilidade ou improcedência proclamadas por unanimidade) o beneficiário deverá ser apenado nos termos da regra em questão, mesmo que não se lhe tenha exigido tal multa de forma prévia, como específico pressuposto processual $^{499}$.

Não há maiores dúvidas acerca de a isenção abranger a caução a que alude o art. 835 do Código de Processo Civil (autor nacional ou estrangeiro que residir fora do Brasil ou daqui se ausentar no curso da demanda). É que aqui a garantia não se refere à sanção alguma (como ocorre no caso analisado nos parágrafos anteriores), mas se presta à segurança do pagamento de custas processuais e honorários do advogado do adversário. Ora, como o beneficiário, enquanto mantida a condição de pobreza em termos jurídicos, não seria compelido a arcar com estas verbas, não teria sentido exigir que as garantisse (de quem não se exige o plus não se poderia exigir o minus).

\section{Despesas com publicações}

A isenção estabelecida pelo inciso III do art. $3^{\circ}$ da Lei $n^{\circ} 1.060 / 50$ está assim redigida: "das despesas com as publicações indispensáveis no jornal encarregado da divulgação dos atos oficiais".

As publicações que se consideram indispensáveis são atos de comunicação que consubstanciam citações e intimações. No que concerne a estas, é de se lembrar que havendo na Comarca órgão oficial de publicação dos atos judiciais, as intimações consideram-se feitas "pela só publicação" dos atos no órgão em questão (CPC, arts. 236, “caput" e 237, “caput”). É este o método largamente difundido, inclusive por meio de

\footnotetext{
${ }^{498}$ Para uma ampla discussão acerca do caráter deste depósito (se multa "em antecipação", mera garantia do juízo ou forma de rechaçar a litigância temerária) veja-se a íntegra do julgamento da Ação Rescisória ${ }^{\circ}$ 1.376-1/PR, de Relatoria do Min. Gilmar Mendes, julgamento de 9.11.05.

499،A exoneração do depósito não implica afastamento da multa, tal como se entende, de forma não pacífica, em ações movidas pelas Fazendas Públicas e Ministério Público (JTJ, 113/448, relator Carlos Ortiz). Quanto se aplica a pena, não se está impedindo o acesso à Justiça, mas se impondo sanção processual que tem por objetivo evitar a proliferação de ações semelhantes" (VIDIGAL, Mauricio. Lei da Assistência Judiciária interpretada, cit., p. 33).
} 
órgão oficial eletrônico (diário da justiça eletrônico), salvo rincões onde ainda haja necessidade de recurso às regras dos incisos do art. 237 (intimação pessoal ou postal pelo escrivão).

Os encargos cobrados com publicação de editais para qualquer uma das finalidades enunciadas no parágrafo anterior (citação ou intimação) são objeto de regulamentação própria na esfera de cada Estado da Federação. Aqui aludiremos até em caráter exemplificativo às regras vigentes no Estado de São Paulo, sem prejuízo de extensão das assertivas de caráter geral ao quanto regulamentado em outras unidades federativas.

Estipula a Lei Estadual $n^{\circ} 11.608 / 03$ que na taxa judiciária não se incluem as publicações de editais (art. $2^{\circ}$, p.único, I). Com base nesta disposição, o Provimento $\mathrm{n}^{\circ}$ 1.668 de 28 de julho de 2009, do Eg.Conselho Superior da Magistratura Bandeirante, dando nova redação ao art. $5^{\circ}$ do Provimento $n^{\circ}$ 1.321/2007, assim estipulou: "Ressalvadas as hipóteses de concessão dos benefícios da assistência judiciária gratuita, as partes suportarão os custos de publicação de editais no Diário de Justiça Eletrônico, os quais serão fixados periodicamente pelo Conselho Superior da Magistratura e publicados por meio de Comunicado no Diário de Justiça Eletrônico, para fins de recolhimento prévio em Guia do Fundo de Despesas”.

Em princípio, pois, com base no referido dispositivo da Lei $\mathrm{n}^{\circ}$ 1.060/50 estaria a parte beneficiária da gratuidade isenta desta despesa no caso de necessidade de publicação de edital, seja para citação, seja para intimação, seja ainda da parte adversa, ou mesmo de terceiros potencialmente interessados no processo ou que devam dele tomar ciência.

Problema surgiu em dias há muito passados, pois que em alguns casos a lei comete à parte o encargo de promover a publicação de editais não apenas no órgão oficial, como também em jornal particular, inclusive em alguns casos demandando que seja de ampla circulação local. Referimo-nos aos arts. 232 e 687 do Código de Processo Civil. A primeira destas regras estabelece como requisito para a citação editalícia "a publicação do edital no prazo máximo de 15 (quinze) dias, uma vez no órgão oficial e pelo menos duas vezes em jornal local, onde houver" (destacamos). A segunda prescrição refere-se ao edital de hasta pública, estipulando que "será afixado no local do costume e publicado, em resumo, com antecedência mínima de 5 (cinco) dias, pelo menos uma vez em jornal de ampla circulação local". 
A polêmica do cotejo destas disposições com a contida no inciso III do art. $3^{\circ}$ da Lei no 1.060/50 seria previsível, já que a isenção referia-se apenas a uma parte do encargo, e a dúvida ensejava três soluções possíveis: manter à parte a imposição da publicação em jornal particular, à sua custa, restringida a gratuidade à publicação no órgão oficial; manter à parte o encargo de publicação em jornal particular, porém impor a este a gratuidade $\mathrm{e}$ isentar a parte beneficiária da gratuidade do encargo de publicação em jornal particular (e por consequiência isentar o particular de ser atingido por publicações gratuitas) ${ }^{500}$.

Disse-se que a polêmica em questão era antiga, pois que desde a década de oitenta restou espancada pela expressa a clara opção legislativa que veio plasmada pelo acréscimo de um parágrafo ao art. $3^{\circ}$ da Lei $n^{\circ} 1.060 / 50$ pela Lei $n^{\circ} 7.288 / 84$ : “A publicação de edital em jornal encarregado da divulgação de atos oficiais, na forma do inciso III, dispensa a publicação em outro jornal” (destaque nosso). Parece de solar clareza a escolha da terceira solução supra especulada.

\section{Indenização de testemunhas}

A quarta isenção prevista na regra contida no inciso IV do art. $3^{\circ}$ da Lei $n^{\circ} 1.060 / 50$ refere-se às "indenizações devidas às testemunhas que, quando empregados, receberão do empregador salário integral, como se em serviço estivessem, ressalvado o direito regressivo contra o poder público federal, no Distrito Federal e nos Territórios; ou contra o poder público estadual nos Estados".

O dispositivo é de clareza patente. No caso de gratuidade o impacto imediato da despesa decorrente do afastamento da testemunha de seu labor recairá sobre o próprio empregador, que não lhe poderá descontar o período de afastamento. Mediatamente tal impacto deveria ser repassado ao Estado, por via do direito de regresso que é assegurado ao empregador.

Dois problemas são de pronto constatáveis. O primeiro deles é que aguardar do Estado o cumprimento de obrigação pecuniária nunca foi atividade das mais aprazíveis. Imagine-se a necessidade de recurso à via judicial e notadamente a inserção em regime de pagamento de precatórios (ou mesmo requisições de pequeno valor). É bem plausível em

\footnotetext{
${ }^{500}$ Tratando desta polêmica, e defendendo a terceira solução alvitrada, cf. ZANON, Artêmio. Assistência Judiciária gratuita: comentários à Lei da Assistência Judiciária (Lei no 1.060, de 5-2-1950), cit., p. 30-32.
} 
casos assim que o apequenado valor a que faria jus o empregador, talvez bem inferior ao custo do próprio processo, implicaria a renúncia ao direito de reembolso.

Neste passo, é difícil deixar de apontar que a solução ofertada pelo Código de Processo Civil é bem mais prática, e prevalece sobre o referido inciso IV do art. $3^{\circ}$ da Lei n $1.060 / 50$. Deveras, assim dispõe o p.único do art. 419 do Código de Processo Civil: “O depoimento prestado em juízo é considerado serviço público. A testemunha, quando sujeita ao regime da legislação trabalhista, não sofre, por comparecer à audiência, perda de salário nem desconto no tempo de serviço". É notório que a regra em questão não estipula em favor do empregador direito de regresso de ordem alguma contra quem quer que seja.

Explicamos porque entendemos que o referido p.único do art. 419 prevalece sobre a norma do diploma específico que disciplina a gratuidade: a norma em questão tornou regra geral em nosso sistema que parcela do custo pelo comparecimento da testemunha, qual seja, aquela que se refere ao possível desconto do período de afastamento do serviço, seja arcada pelo empregador, e isto independente de ser a parte beneficiária da gratuidade. Por outras palavras, a regra do CPC, art. 419, p.único, aplica-se a todos os processos em que seja produzida a prova oral testemunhal, mesmo em que as partes não sejam beneficiárias da gratuidade.

Ora, não teria o mínimo sentido que, no caso de serem as partes beneficiárias da gratuidade (ou de o ser a parte que requereu a produção da prova testemunhal) o empregador pudesse voltar-se contra o Estado para ressarcir-se daquilo que pagou à testemunha durante o afastamento. A diferença de tratamento em desfavor do Estado aí não se justificaria por alguma diferença na posição do empregador em uma ou outra circunstância (isto é, a despesa que o empregador tem no caso da testemunha desempenhar seu mister em favor de parte beneficiária, e no caso de fazê-lo em favor de parte não beneficiária, é exatamente a mesma: impedimento de desconto de salário, daí porque não se justificaria o auxílio estatal ao empregador num caso, e sua ausência em outro) ${ }^{501}$.

O segundo problema refere-se à omissão do dispositivo quanto às verbas gastas pela própria testemunha para prover a seu comparecimento em juízo (p.ex. custos com transporte, e até mesmo, dependendo de sua condição social, trajes condizentes; despesa

\footnotetext{
${ }^{501} \mathrm{O}$ descompasso entre a regra do já citado inciso IV do art. $3^{\circ}$ e o art. 419, p.único, do Código de Processo Civil também foi notado por Maurício Vidigal: "A estipulação do inciso IV, ficou parcialmente sem sentido, porque, ao contrário do que sucedia no regime do Código de 1939, cujo art. 249 outorgava à testemunha o direito de exigir do interessado o salário que deixasse de receber, hoje a parte não está nunca obrigada a pagar à testemunha o dia de serviço, porque o empregador não o pode deixar de fazer" (Lei da Assistência Judiciária interpretada, cit., p. 29-30).
} 
com alimentação; hospedagem; etc., tudo a depender do caso concreto) ${ }^{502}$. Neste caso, o dispositivo limita-se a isentar o beneficiário da gratuidade de tais despesas, e certamente que não poderiam estas ser imputadas ao empregador. Para este basta a impossibilidade de descontos no salário do empregado-testemunha.

Duas são as possíveis soluções: arcar a própria testemunha com estes dispêndios ou impor ao Estado tal encargo. É intuitiva a segunda solução, já que é ao Estado (em sentido amplo) que incumbe a prestação da assistência jurídica integral e gratuita ${ }^{503}$.

O Código de Processo Civil regula a questão no art. 419, “caput”, obviamente para o caso da parte incumbida de arcar com os custos da prova não ser beneficiária da gratuidade: "A testemunha pode requerer ao juiz o pagamento da despesa que efetuou para comparecimento à audiência, devendo a parte pagá-la logo que arbitrada, ou depositá-la em cartório dentro de 3 (três) dias".

Nada impede a aplicação analógica do mesmo procedimento no caso de incumbir ao Estado ressarcir a testemunha, com a peculiaridade que no caso certamente o juízo deverá oficiar ao órgão público com atribuição para promover tal reembolso.

Um outro problema deve ser aventado. A impossibilidade de que a testemunha seja prejudicada em seus rendimentos (salário) por ausentar-se do serviço para comparecer em juízo limita-se às hipóteses em que sujeita a testemunha ao regime trabalhista (note-se a menção do art. $3^{\circ}, \mathrm{IV}$, da Lei $\mathrm{n}^{\circ} 1.060 / 50$, à figura do "empregador", e a do art. 419, p.único, à sujeição à "legislação trabalhista").

Indaga-se então: e no caso de testemunha que desempenha atividade autônoma, com rendimentos diários e variáveis?

No julgamento da Apelação Cível no 957.470-3, da Comarca de Sorocaba, relatada pelo Desembargador Antônio Pinto, o Egrégio Tribunal de Justiça do Estado de São Paulo entendeu incabível o ressarcimento da testemunha. Na hipótese, pelo que se compreende pela leitura do v.acórdão, a parte vencedora apresentou nos autos um recibo de pagamento que fizera à testemunha, no importe de $\mathrm{R} \$ 300,00$, e que se referiria ao dia de trabalho

\footnotetext{
${ }^{502}$ Infelizmente há relatos de episódios em que testemunhas são obstadas de depor por usarem tal ou qual roupa ou acessórios tidos como não adequados à respeitabilidade do ambiente forense. Se tal se dá por acinte, é aceitável o óbice à oitiva; se tal se dá por absoluta carência de recursos financeiros, aí a questão muda de figura.

${ }^{503}$ No mesmo sentido: GIANNAKOS, Ângelo Maraninchi. Assistência judiciária no direito brasileiro, cit., p. 25. Também na mesma senda: VIDIGAL, Mauricio. Lei da Assistência Judiciária interpretada, cit., p. 30.
} 
perdido (vendas), e requereu que o vencido fosse condenado ao reembolso ao vencedor (que houvera antecipado o pagamento à testemunha).

No caso entendeu-se que "o depoimento prestado em juízo é considerado serviço público, não comportando remuneração, ou seja, é obrigatório e sem contraprestação pecuniária”. A assertiva é absolutamente correta. Entendeu-se também que a forma como se queria proceder ao reembolso era incabível, pois que caberia ao juízo arbitrá-la, na forma do já citado art. 419 do Código de Processo Civil.

Com todas as vênias, discordamos em parte do respeitável entendimento. Parecenos que no caso não se tratava de buscar a testemunha remuneração ou contraprestação pecuniária pelo depoimento prestado, mas de ressarcimento pelo lucro cessante, idéia que integra a noção mais ampla de dano patrimonial.

Ademais, haveria aí injustificável tratamento díspare: à testemunha que trabalha sob regime celetista, nenhum desconto é imposto pela ausência ao serviço; à testemunha que trabalha em regime autônomo e com ganhos diários, é-lhe impingida a perda da renda que teria naquele período de ausência. Será que seria a diversidade de regime laboral justificativa bastante para a desigualdade de tratamento? Quer-nos parecer que não.

Assim é que segundo nos parece, no caso da testemunha que trabalha com rendimentos diários, incumbirá a ela requerer em juízo, na forma do art. 419 “caput”, do Código de Processo Civil, o reembolso do dia de trabalho perdido. Ao juiz incumbirá, de sua banda, prudentemente arbitrar o valor devido, com base inclusive nos valores médios que a testemunha comprove ter obtido nos períodos imediatamente anteriores ao comparecimento em juízo.

Não sendo a parte beneficiária da gratuidade, à ela incumbirá tal ressarcimento, na forma prescrita pelo já citado art. 419, "caput". Em sendo o caso de gratuidade, como dito, é ao Estado que incumbirá tal ressarcimento.

Concordamos com o julgado ora comentado no que aponta a impropriedade do procedimento da parte que junta aos autos recibo de valor pago à testemunha como reembolso pela ausência desta ao dia de trabalho, e pretende ver-se ressarcida do vencido. De fato, com plena razão o v.acórdão ao apontar que o arbitramento do valor devido caberá ao juízo. Efetuado o pagamento na solenidade de instrução ou em cartório, então poderá a parte vencedora que tenha arcado com o encargo pretender o ressarcimento do vencido (e se for este beneficiário da gratuidade, é contra o Estado que a pretensão ao ressarcimento 
será dirigida). É óbvio que se a parte a quem caberia desde logo ressarcir a testemunha for beneficiária da gratuidade, é contra o Estado que a testemunha deverá se voltar, em razão do inciso ora estudado.

Convém também lembrar que a testemunha faz jus ao ressarcimento pelo simples fato do comparecimento ${ }^{504}$. A não realização de sua oitiva é irrelevante (p.ex. em razão de acolhimento de contradita; desistência da prova; redesignação da audiência de instrução; etc.).

Devemos ainda deixar registrada a propósito deste tema a posição de Augusto Tavares Rosa Marcacini, que da mesma forma aponta a possibilidade de que o juiz arbitre o valor devido à testemunha à guisa de indenização e, reconhecendo a isenção no caso da parte a quem caberia pagar indenização ser beneficiária da gratuidade, arremata que "a final, a testemunha poderá receber tal valor, conforme veremos adiante" (destaque nosso) ${ }^{505}$.

Segue então o autor ponderando que ao final do processo em que ao menos uma das partes foi beneficiária da gratuidade, teremos diversos possíveis credores, entre eles, particulares que foram chamados a atuar no feito, e entre estes, as testemunhas. Segundo o autor, em sendo o beneficiário vencedor na liça, então caberá à parte contrária reembolsar a testemunha; se o beneficiário for o vencido, contudo, ao Estado caberá arcar com os créditos devidos a particulares, reembolsando-se então a testemunha.

Não podemos concordar com esta posição. Não parece haver alguma razoabilidade em obrigar a testemunha a aguardar o fim do processo para ver-se ressarcida, quer do Estado (no caso do beneficiário ser vencido) quer do adversário do beneficiário (no caso de ser a parte não beneficiária vencida), ainda mais se considerarmos o lamurioso problema de lentidão que assola o sistema judiciário brasileiro.

Sobre não ser razoável, esta posição não parece se compadecer com o regramento imposto pelo art. 419 do Código de Processo Civil, segundo o qual a parte deve reembolsar a testemunha "logo que arbitrada" (a indenização é claro) ou "deposita-la em cartório dentro de 3 (três) dias". Parece evidente, por isto, a impossibilidade de se aguardar o desfecho do processo para se providenciar o reembolso da testemunha. A "parte" a que alude a regra não é a "parte vencida", mas sim a parte a quem incumbirá custear a prova conforme a regra matriz nesta matéria dos arts. 19 "caput" e 33 ambos do Código de Processo Civil (adiantamento de despesas pela parte que requer ou realiza o ato).

\footnotetext{
${ }^{504}$ COSTA MACHADO, Antonio Cláudio. Código de Processo Civil interpretado, cit., p. 430.

${ }^{505}$ MARCACINI, Augusto Tavares Rosa. Assistência jurídica, assistência judiciária e justiça gratuita, cit., p. 44.
} 
Se a parte a quem incumbia adiantar a despesa da testemunha for beneficiária da gratuidade, então o Estado providenciará o tal adiantamento, ressarcindo-se desde logo a testemunha. Se o beneficiário for vencido na causa, o Estado absorverá o prejuízo; se for vencedor, poderá o ente público ressarcir-se junto ao vencido nos termos do art. $20, \S 2^{\circ}$ do Código de Processo Civil, que inclusive alude de forma expressa à indenização de viagem e diária da testemunha (houve sub-rogação pelo Estado na posição do vencedor relativamente a este crédito).

Uma última constatação: a praxe forense tem denotado o pouco uso das regras comentadas neste subitem, sabe-se lá se por desconhecimento ou se em razão do apequenado valor das verbas normalmente envolvidas na hipótese $\mathrm{e}^{506}$.

\section{Honorários de advogado e peritos}

A primeira impressão pode ser que estejamos diante de regra de induvidosa interpretação, afinal, não há maiores controvérsias em afiançar que honorários dos profissionais referidos no inciso $\mathrm{V}$ do art. $3^{\circ}$ ora analisado representam suas verbas remuneratórias, decorrentes do serviço prestado no processo.

Esta primeira impressão, entretanto, é sobejamente enganosa. Aqui se aninham os mais dificultosos problemas que a praxe forense tem revelado, em algumas circunstâncias, verdadeiramente insolúveis. Mais que isto, a interpretação rasa da isenção referente aos honorários de advogado, feita em consonância com o que dispõe o art. 11 da Lei $n^{\circ}$ 1.060/50 e com cotejo com as regras atuais do art. 20 do Código de Processo Civil, conduz a becos jurídicos intransponíveis. Sigamos a ordem proposta pelo inciso, tratando dos honorários advocatícios.

\section{Honorários advocatícios}

Como já adiantado no anterior parágrafo, a simplória comparação entre as regras do art. $3^{\circ}, \mathrm{V}$, e art. 11, ambos da Lei $\mathrm{n}^{\circ} 1.060 / 50$ no contexto das regras de sucumbência fixadas no Código de Processo Civil, conduz a dúvidas que merecem esclarecimento.

\footnotetext{
${ }^{506} \mathrm{O}$ testemunho, de muito mais valia dada a largueza da experiência, é de Maurício Vidigal: "nunca ouvi relato de exigência semelhante (reembolso pedido por testemunha), tanto perante órgãos públicos, como diante de particulares não necessitados. As testemunhas, carentes ou não, ignoram a possibilidade desta cobrança e, mesmo que soubessem dela, dificilmente exerceriam seus direitos em virtude do nosso hábito nacional de desprezar o gozo de pequenos direitos" (Lei da Assistência Judiciária interpretada, cit., p. 30).
} 
A primeira dúvida que surge é saber se a regra ora posta refere isenção ao beneficiário de arcar com os honorários de seu patrono ou do patrono do adverso. Poderíamos ser levados a uma interpretação que torna a regra inteiramente inócua: suponhamos se entenda que os honorários aí referidos são os devidos ao próprio patrono. $\mathrm{O}$ art. 20 do Código de Processo Civil estabelece como ônus sucumbencial o pagamento de verba honorária ao advogado do adversário, isto é, o vencido nunca é condenado em razão da sucumbência a pagar honorários ao próprio advogado. A conclusão a partir da interpretação ora cogitada não poderia ser outra: a isenção se refere a uma condenação que na prática nunca ocorrerá (o vencido, repita-se, não é condenado a pagar honorários ao próprio patrono).

Quando vamos ao art. 11, que deve ser analisado juntamente com este inciso V, teríamos a mesma perplexidade. Diz a cabeça do dispositivo: "Os honorários de advogados e peritos, as custas do processo, as taxas e selos judiciários serão pagos pelo vencido, quando o beneficiário de assistência for vencedor na causa" (destaque nosso).

Ora, segundo estabelece o art. 20, "caput”, do Código de Processo Civil, viga mestra em tema de princípio da sucumbência, a sentença condenará o vencido ao pagamento das despesas antecipadas pelo vencedor e os honorários de advogado, isto sempre, ou seja, independentemente do vencedor ser ou não beneficiário da gratuidade.

E a perplexidade maior vem em face do $\S 2^{\circ}$ do mesmo art. 11: "A parte vencida poderá acionar a vencedora para reaver as despesas do processo, inclusive honorários do advogado, desde que prove ter a última perdido a condição legal de necessitada". Ora, se é a regra geral a de que o vencido arque com as despesas do processo e os honorários do advogado que patrocinou o adversário, independentemente de gratuidade, como se poderia entender esta inversão da regra da sucumbência: se o vencedor perder a condição de necessitado, o vencido poderá reaver as despesas do processo e honorários de advogado. Ora, se o vencedor não fosse beneficiário da gratuidade, nunca poderia ser compelido a reembolsar o vencido pelas despesas sucumbenciais (em razão das normas do Código de Processo Civil); porém o sendo, desde que perdida esta condição, estará sujeito a este gravame. A incongruência é invencível.

Estas perplexidades são plenamente explicáveis. Estamos, na verdade, de forma até ilustrativa, cotejando normas de um diploma que remonta a meados do século passado com um sistema que lhe é bem posterior. Ou seja, há um descompasso temporal, cronológico, neste procedimento. 
As normas do art. $3^{\circ}, \mathrm{V}$, art. 11 e art. 12 da Lei $\mathrm{n}^{\circ}$ 1.060/50 reclamam interpretação histórica, isto é, em consonância com o sistema vigente quando de sua edição. Aí sim a compreensão será ajustada. Façamos isto, com base na excelente lição de Augusto Marcacini $^{507}$.

Devemos ter em conta que no sistema sucumbencial originariamente previsto pelo Código de Processo Civil de 1939 a condenação ao pagamento de verba honorária pelo vencido era excepcional. Por regra os advogados eram remunerados pelos seus próprios clientes. As hipóteses em que isto era possível eram de litigância de má-fé; ação resultante de dolo ou culpa contratual ou extracontratual e absolvição da instância (o que seria equivalente à atual extinção do processo sem resolução do mérito). Vejamos as redações dos arts. 63, 64 e 205 daquele vetusto diploma: "Sem prejuízo do disposto no art. 3ª parte vencida, que tiver alterado, intencionalmente, a verdade, ou se houver conduzido de modo temerário no curso da lide, provocando incidentes manifestamente infundados, será condenada a reembolsar à vencedora as custas do processo e os honorários do advogado" (art. 63); "Quando a ação resultar de dolo ou culpa, contratual ou extra-contratual, a sentença que a julgar procedente condenará o réu ao pagamento dos honorários do advogado da parte contrária" (art. 64); e "No caso de absolvição da instância, o autor será condenado ao pagamento das despesas feitas pelo réu com o preparo da defesa, inclusive honorários de advogado, que o juiz arbitrará” (art. 205).

Afora estas hipóteses, caberia ao vencedor remunerar seu próprio advogado, ou seja, o que hoje se denomina honorários de sucumbência eram absolutamente excepcionais. Por esta razão é que houve necessidade de que por disposição expressa se acrescentasse àquele rol (onde já constavam os casos de litigância da má-fé, ação resultante de dolo ou culpa e absolvição da instância) mais uma hipótese: o caso de ser o vencedor beneficiário da gratuidade. E foi isto que o art. 11 da Lei $n^{\circ} 1.060 / 50$ fez ao dispor que os honorários de advogado e perito, as custas do processo, taxas e selos judiciários, seriam pagos pelo vencido quando o beneficiário da assistência fosse vencedor. Se assim não fosse, o próprio beneficiário vencedor é que se encarregaria destas verbas, de acordo com a regra geral vigente.

A conclusão se põe de forma mais clara nas palavras do próprio Augusto Marcacini:

\footnotetext{
${ }^{507}$ MARCACINI, Augusto Tavares Rosa. Assistência jurídica, assistência judiciária e justiça gratuita, cit., p. 49 e ss.
} 
"Tal artigo, na verdade, estabelecia uma exceção ao sistema, em favor do beneficiário, que sempre recebia honorários quando vencedor, e não somente nos casos de má-fé, dolo ou culpa" ${ }^{~}{ }^{08}$.

A rigor o art. 11 "caput" não trouxe inovação, pois que o art. 76 do próprio Código de Processo Civil de 1939 já previa regra semelhante ("Vencedor na causa o beneficiado, os honorários de seu advogado, as custas contadas em favor dos serventuários da justiça, bem como taxas e selos judiciários, serão pagos pelo vencido").

Entendida a sistemática então vigente, adquire sentido o já citado $§ 2^{\circ}$ do art. 11 da Lei $n^{\circ} 1.060 / 50$. A parte vencida em litígio contra beneficiário da gratuidade era condenada ao pagamento das custas processuais e honorários de advogado de forma excepcional, em razão da condição de necessitado reconhecida ao adverso vencedor. Não fosse esta condição de hipossuficiente daquele, e o vencido não teria sobre si tais encargos. Por isto é que fazia sentido estipular que se o vencedor perdesse a condição de miserabilidade jurídica nada mais justificaria a forma mais gravosa com que tratado o vencido, a quem imposto o ônus sucumbencial, o que justificaria que o tal vencido demandasse do vencedor agora em condições econômicas mais favoráveis, o reembolso daquelas verbas. Ou seja, era uma medida de isonomia.

A partir de 1965, com a Lei n 4.632 , que alterou a redação do art. 64 do Código de Processo Civil de 1939, passou a viger o regime de sucumbência tal como atualmente o temos: a sentença condenaria o vencido ao pagamento dos honorários da parte vencedora, fixando-os de forma moderada e motivada.

Daí a conclusão de Marcacini: "Na medida em que, desde a Lei no 4.632/65, a condenação em honorários passou a ser imposta a todos em função da sucumbência, o art. 11 foi revogado tacitamente; com o novo Código, então, que melhor regulamentou a matéria, não há como entendê-lo em vigor" ${ }^{\text {"509 }}$. Igualmente, acerca do $\S 2^{\circ}$ do art. 11 arremata: "está igualmente revogado pelo novo sistema, posto que hoje a condenação em honorários foi generalizada a todos, não havendo sentido na restituição ali determinada"

É esta a mesma conclusão do autor com relação aos parágrafos do art. 11, ou seja, todos estariam tacitamente revogados. A propósito, ainda não chegamos a dizer, mas o $§ 1^{\circ}$

\footnotetext{
${ }^{508}$ MARCACINI, Augusto Tavares Rosa. Assistência jurídica, assistência judiciária e justiça gratuita, cit., p. 50. ${ }^{509}$ MARCACINI, Augusto Tavares Rosa. Assistência jurídica, assistência judiciária e justiça gratuita, cit., p. 50. ${ }^{510}$ MARCACINI, Augusto Tavares Rosa. Assistência jurídica, assistência judiciária e justiça gratuita, cit., p. 51.
} 
fixava parâmetros para a verba honorária que seria arbitrada em favor do advogado do beneficiário vencedor: até $15 \%$ sobre o líquido apurado na execução da sentença.

Podemos agora compreender qual a dimensão da isenção referida pelo inciso $\mathrm{V}$ ora analisado. Originalmente, a regra se destinava a isentar o beneficiário do pagamento dos honorários do próprio patrono, já que era este o encargo a que normalmente estaria sujeito no regime original do Código de Processo Civil de 1939. Contudo, face à falta de especificação pela regra, não se pode negar que a norma estendia-se também às hipóteses em que poderia a parte ser condenada ao pagamento de honorários ao advogado adversário (e tais eram os casos taxativamente enumerados de litigância de má-fé, ação fundada em dolo ou culpa contratual ou extracontratual e absolvição da instância) ${ }^{511}$.

Presentemente, como dito à saciedade, tornou-se regra o pagamento pelo vencido dos honorários de sucumbência devidos ao adversário. Não há previsão de condenação sucumbencial da parte ao pagamento de honorários ao próprio patrono. A regra isentiva, contudo, remanesce em vigor para o fim de isentar o beneficiário, regra geral, do pagamento de honorários ao advogado adversário, acaso seja o tal beneficiário sucumbente. Porém é inegável também que esta regra se presta a isentar o beneficiário da gratuidade de honorários devidos ao próprio patrono, e terá tal regra aplicação na remota hipótese de o patrono voltar-se inusitadamente contra o assistido para o fim de cobrar-lhe honorários. Os honorários do advogado que patrocina o necessitado serão pagos pelo Estado.

Na prática o que se tem verificado é que nos casos em que a parte não é somente alvo de gratuidade, mas também do serviço público de assistência, os advogados ou são servidores do Estado, e daí recebem seus vencimentos para o fim de prestar o serviço ao necessitado, ou os advogados, mesmo particulares, mediante convênio com o Poder Público, percebem dos cofres públicos sua remuneração pelo patrocínio do necessitado, normalmente de acordo com tabelas próprias $^{512}$. Por isto não poderia voltar-se contra o próprio assistido (e daí o inciso $\mathrm{V}$ incidiria também, já que, repita-se, não especifica a quais "honorários" se refere).

\footnotetext{
${ }^{511}$ Havia aí a inconveniência de isentar-se o beneficiário da verba honorária no caso de litigância de má-fé que tinha caráter nitidamente sancionatório, e já defendemos anteriormente no texto a incongruência de dar-se ao benefício esta dimensão. Seja como for, no caso a isenção decorria impositivamente da lei e do sistema então vigente de sucumbência.

${ }^{512}$ Neste sentido prescreve o $\S 1^{\circ}$ do art. 22 da Lei $n^{\circ} 8.906 / 94$ (Estatuto da OAB): "O advogado, quando indicado para patrocinar causa de juridicamente necessitado, no caso de impossibilidade da Defensoria Pública no local da prestação de serviço, tem direito aos honorários fixados pelo juiz, segundo tabela organizada pelo Conselho Seccional da OAB, e pagos pelo Estado”.
} 
De outro lado, a parte que comparece a juízo com advogado de sua confiança, apenas requerendo o benefício da gratuidade, poderá ter contratado com o patrono verba honorária (normalmente neste caso, dada a situação de pobreza da parte, os honorários são contratados ad exitum $)^{513}$.

Convém deixar registrada na espécie a posição restritiva do prof. Cândido Dinamarco acerca do tema, aliás, não apenas no que respeita aos honorários advocatícios, como também periciais. Segundo entende o renomado mestre, o benefício "não inclui isenção à obrigação final por honorários advocatícios em caso de sucumbir o beneficiário. Nem inclui dispensa de adiantar honorários a perito e outros auxiliares eventuais de encargo judicial" $" 514$. Adiante o autor melhor explica seu posicionamento no que concerne à não-isenção de pagamento dos honorários advocatícios de sucumbência, esclarecendo que o beneficiário que saiu vencido já exauriu os objetivos pelos quais a gratuidade lhe foi deferida, e que incumbe ao juiz em casos que tais condená-lo normalmente, porém observa que nos termos do art. 12 da Lei $\mathrm{n}^{\circ}$ 1.060/50, apenas tal valor se tornará exigível se vier o beneficiário a ostentar condições econômicas no qüinqüênio referido pelo dispositivo ${ }^{515}{ }_{-}^{516}$.

No que concerne à questão da revogação do art. 11 da Lei $n^{\circ} 1.060 / 50$, temos que paira divergência doutrinária, especialmente no que concerne ao $\S 1^{\circ}$. Veja-se que com relação ao "caput" e ao $\S 2^{\circ}$ a longa exposição de cunho histórico que já fizemos denota que tais regras perderam sua eficácia. Isto é, mesmo que entendêssemos que revogação tácita não houve (porque, por exemplo, são regras especiais e que prevalecem sobre as disposições gerais trazidas pelo Código acerca da sucumbência, numa aplicação do $\S 2^{\circ}$ do art. $2^{\circ}$ da Lei de Introdução ao Código Civil) teríamos regras que perderam seu propósito porque forjadas para um sistema assentado sobre premissas inteiramente diferentes.

\footnotetext{
513، Também está dispensado de pagar honorários de advogado, seja ao seu próprio patrono (a menos que, por exemplo, pactue que a remuneração dependerá do êxito na demanda, quando ela tiver conteúdo patrimonial), seja ao advogado da parte contrária, enquanto persistir a situação de carência financeira" (DIDIER JR, Fredie; OLIVEIRA, Rafael. Benefício da justiça gratuita, cit., p. 15).

${ }^{514}$ DINAMARCO, Cândido Rangel. Instituições de direito processual civil, cit., v. 2, p. 700.

${ }^{515}$ DINAMARCO, Cândido Rangel. Instituições de direito processual civil, cit., v. 2, p. 702.

${ }^{516}$ Neste ponto, em particular, o posicionamento do prof. Dinamarco não discrepa daquele sustentado pelos autores que defendem a isenção mesmo da verba honorária sucumbencial, pois também a doutrina que defende que a isenção abrange tal verba, aponta a necessidade de que haja condenação, perdurando a isenção se inocorrente a hipótese referida pelo art. 12 da Lei no 1.060/50. Ou seja: dizer que por não estar isenta de tal verba a parte deve ser condenada embora com a suspensão da exigibilidade (Dinamarco) e dizer que em razão da isenção, a condenação permanecerá com a exigibilidade suspensa é, a rigor, dizer a mesma coisa. No que concerne aos honorários periciais, Cândido Dinamarco não faz a ressalva do art. 12, e refere-se de forma clara ao adiantamento.
} 
Dizer que o vencido pagará honorários ao patrono do vencedor quando este for beneficiário da gratuidade, é nada dizer, porque o vencido está jungido a esta obrigação em qualquer hipótese $^{517}$. Entender, por outro lado, que o vencido possa em algum tempo reaver do vencedor a verba sucumbencial porque este era beneficiário da gratuidade seria afrontar de forma impetuosa o princípio da isonomia, já que não se justificaria que o beneficiário, depois de perdida a condição de pobreza, ficasse sujeito a um encargo que o não-beneficiário exatamente na mesma posição, isto é, de vencedor na causa, nunca ficará. Não há fator de discrímen que legitime uma tal aberração.

Com isto o que queremos dizer é que as normas do art. 11 "caput" e $\S 2^{\circ}$ tornaramse absolutamente obsoletas sistematicamente (isto é afrontam os princípios básicos que regem o regime sucumbencial e o próprio direito processual, como é o caso da isonomia conforme ilustrado no anterior parágrafo).

Esta mesma constatação não existe em relação ao $\S 1^{\circ}$. À primeira vista não haveria incompatibilidade sistemática na fixação de limites para o estabelecimento de verba honorária em favor do patrono de beneficiário. Aqui a definição da manutenção em vigor da regra requer mais refinado pensamento.

Devemos recorrer ao que na realidade do dia-a-dia se verifica. Como dito anteriormente, via de regra duas possíveis situações se verificam no patrocínio de causas de necessitados: ou os patronos são indicados por serviço de assistência, e aí percebem dos cofres públicos sua remuneração, conforme tabelamento próprio; ou, quando contratados pela parte economicamente desfavorecida, acordam honorários módicos, sendo na maioria dos casos contratados ad exitum, ou seja, a depender do resultado da causa.

O que se percebe em geral, a partir desta realidade, é que os patronos que se dispõem a prestarem seus serviços aos carentes o fazem em condições significativamente

\footnotetext{
517، A disposição do 'caput' (do art. 11) é mera aplicação das regras de sucumbência expressas hoje no Código de Processo Civil. A redação de todo este artigo fazia mais sentido no regime do Código de 1939 em que, durante muito tempo até a alteração de seu art. 64 pela Lei no 4.632, de 18 de maio de 1965, a condenação ao pagamento de honorários não dependia apenas da derrota na causa, sendo necessário dolo ou culpa, contratual ou extracontratual" (VIDIGAL, Mauricio. Lei da Assistência Judiciária interpretada, cit., p. 69). É o mesmo autor quem lembra que no caso de necessitado defendido por órgão oficial, os honorários de sucumbência beneficiarão a entidade. Este entendimento aparentemente conflitaria com o art. 21 "caput" da Lei n ${ }^{\circ} 8.906 / 94$, que prescreve em casos que tais pertencerem ao advogado empregado os honorários. Porém o C.Supremo Tribunal Federal, no julgamento da ADI no 1.194/DF, Rel.Maurício Corrêa, julgado em 20.05.09, declarou acerca desta regra: "O art. 21 e seu parágrafo único da Lei n. 8.906/1994 deve ser interpretado no sentido da preservação da liberdade contratual quanto à destinação dos honorários de sucumbência fixados judicialmente". Deste modo, se por contrato ou mesmo no estatuto de regência da carreira (no caso de advogados integrantes de carreiras públicas, como procuradores) estabelece-se que os honorários sucumbenciais são devidos à entidade empregadora, ou se se traz forma de rateio entre empregado (servidor) e empregadora, tal deverá ser observado.
} 
mais prejudiciais que os demais. As tabelas de honorários pagos pelo Estado (em sentido amplo, não federativo) são defasadas e prevêem quantias módicas quando comparadas ao grau do labor exigido do advogado no acompanhamento de causa muitas vezes complexa, bem como se pensarmos no que normalmente se estabelece como retribuição ao causídido em causas semelhantes fora do universo da assistência judiciária.

Quando os honorários são contratados, o regime ad exitum é extremamente ingrato, pois que obriga o advogado a praticamente custear todo o trâmite processual, arcando com gastos para o acompanhamento de todo o processo, para só ao final ver-se remunerado, isto se obtiver vitória, ou seja, há o risco de que se veja derrotado e na contingência de arcar com o prejuízo do quantum gasto no acompanhamento da causa. Nesta conjuntura o processo acaba se tornando para o causídico um "investimento de retorno incerto".

Ora, se fôssemos com alguma coerência levar em conta esta situação de maior penúria do advogado que atua em regime de assistência judiciária ou que presta serviços mesmo que contratados, porém à parte juridicamente pobre, teríamos de concluir que talvez se lhe fosse mais próprio permitir a fixação dos honorários de sucumbência em quantia até mais elevada que a devida pelo regime geral do art. 20, $\S 3^{\circ}$, do Código de Processo Civil, pois aí se compensaria a modicidade dos honorários pagos pelo Estado (no caso de assistência judiciária, cf. $\S 1^{\circ}$ do art. 22 do EOAB) ou o risco assumido com fixação de honorários ad exitum (no caso de patronos "particulares").

De toda forma, vê-se aí claramente que a desequiparação introduzida pela regra, sobre vetusta, atualmente não se compadece com o regime estabelecido em geral para os advogados que não atuam sob o manto da gratuidade ou em regime de assistência judiciária $^{518}$.

Curial deixar registrada a posição em sentido contrário de Araken de Assis, que tomamos a liberdade de transcrever:

“...razões obscuras sustentam a hipotética desarmonia entre o art. $11, \S 1^{\circ}$, da Lei n ${ }^{\circ}$ 1.060/50 e o sistema comum de sucumbência.

Ele prevê, à semelhança do art. $20, \S 3^{\circ}$, do CPC, a fixação dos honorários em percentual, calculados sobre o valor da condenação, e regula uma situação particular: honorários para os advogados de

\footnotetext{
${ }^{518}$ Também Maurício Vidigal entende pela revogação do referido $§ 1^{\circ}$ do art. 11 da Lei no $1.060 / 50$ (cf. Lei da Assistência Judiciária interpretada, cit., p. 71). Na jurisprudência encontramos também pronunciamento sobre a questão: "Com o advento do Código de Processo Civil de 1973, não mais se justifica a limitação da verba honorária, nos casos em que vencedora parte beneficiária de assistência judiciária gratuita, ao teto de $15 \%$ previsto no art. 11 da lei 1060/50. Aplicável, em casos tais, a norma geral do parágrafo $3^{\circ}$ do art. 20 do diploma instrumental” (STJ, REsp nº 28.662/SP, Rel. Sálvio de Figueiredo Teixeira, j. 24.08.93).
} 
necessitados. Está de pleno acordo, portanto, quer com a regra da condenação do vencido, em virtude do fato objetivo da sua derrota, quer com o critério da base de cálculo da verba nas ações condenatórias.

É verdade que fixa percentual abaixo do máximo admitido na lei geral. Em que residiria então a incompatibilidade? A regra especial se baseia, como a geral, em critérios de conveniência, e a diferença de percentuais máximos, dado acidental e contingente, nenhum relevo ostenta no assunto, tão arbitrário é o percentual escolhido, na lei da gratuidade, como qualquer outro.

Por tais razões, o art. $11, \S 1^{\circ}$, da Lei $\mathrm{n}^{\circ} 1.060 / 50$, consagrando o percentual médio, largamente adotado na aplicação do art. $20, \S 3^{\circ}$, do $\mathrm{CPC}$, se acomoda às diretivas deste último" ${ }^{\circ 19}$.

Com a devida vênia, concordamos com o apontamento de que em linhas gerais o dispositivo segue os mesmos parâmetros do art. 20 do Código de Processo Civil, buscando uma proporcionalidade em relação ao valor da condenação, igualmente impondo ao vencido tal encargo, como conseqüência da derrota. Também estamos de acordo com a afirmação de que a eleição do valor de tal proporcionalidade é feito de acordo com opção legislativa sem maiores conteúdos lógicos. E não nos insurgimos que a escolha do valor seja feita de acordo com este "arbítrio" legislativo. O que não se pode admitir é que a fixação de limites distintos para situações idênticas (isto é, idênticas sob o ponto de vista daquilo que poderia ser considerado relevante para conduzir a um tratamento desigual) transforme esta opção legislativa em odioso tratamento prejudicial ao patrono que presta ao necessitado seus serviços. Não nos parece haja obscuridade nesta ordem de idéias.

Aliás, de lege ferenda, deve-se ressaltar que aí está, na modulação dos parâmetros dos honorários de sucumbência, um instrumento que se poderia utilizar para o fim de atrair a atenção dos advogados e seu interesse pelo patrocínio da causa do necessitado.

A realidade do foro é de que à assistência judiciária, em especial, se dedicam os advogados neófitos, que ainda estão a formar sua carteira de clientes, que necessitam angariar experiência. Tão logo ascenda o profissional, deixa as "águas rasas" do patrocínio do necessitado, e não se pode negar que a retribuição financeira é aí o principal móvel para a debandada. Estipular mais polpudos honorários de sucumbência não apenas como forma de compensar a humildade dos honorários pagos pelo Estado, mas especialmente de buscar a atenção do profissional que já debandou ou está a ponto de debandar do serviço de assistência é ponto a ser considerado.

\footnotetext{
${ }^{519}$ ASSIS, Araken de. Benefício da gratuidade, cit., p. 196.
} 


\section{Honorários periciais}

É a segunda classe de isenções referidas no mesmo dispositivo. Em termos teóricos não teríamos muita dificuldade em interpretar a regra, pois que, como até já foi dito, estáse aqui a prever a isenção do beneficiário relativamente à verba remuneratória devida ao vistor. Aqui é imperioso adotar visão bastante complacente, o que de resto se alinha com a idéia já difundida de que acesso substancial à justiça é mais que abrir as portas do Judiciário, é permitir que a parte "transite pelos corredores" livremente, isto é, se lhe permita a utilização de todos os meios disponíveis para fazer valer sua pretensão, e daí decorrência lógica é assegurar o amplo direito à prova, evitando restrições que sejam fundadas simplesmente na carência econômica do interessado.

A questão aqui deveras mais complicada é saber se a isenção compreende não apenas as verbas propriamente remuneratórias, mas também as despesas geralmente implicadas na produção da prova técnica.

Em geral a própria realização do exame e a produção do parecer técnico demandam despesas, tal como com a extração de cópias, deslocamentos, exames prévios, etc. Que o perito aqui não perceberá da parte remuneração (incumbirá ao Estado remunerá-lo), não há dúvida, a questão é: terá o perito de trabalhar, em prejuízo próprio, arcando com os custos ou chamadas despesas indiretas atreladas à produção da prova?

A questão ainda mais se complica quando se observa que conforme o art. 14, "caput", da Lei $\mathrm{n}^{\mathrm{o}} 1.060 / 50$ prescreve, os profissionais liberais designados para o desempenho da função de perito são obrigados ao respectivo cumprimento, sob pena de multa, sem prejuízo da sanção disciplinar cabível. Ainda é oportuno lembrar o disposto no art. 339 do Código de Processo Civil: "Ninguém se exime do dever de colaborar com o Poder Judiciário para o descobrimento da verdade".

Neste ponto a questão não se mostra tão pacífica. Araken de Assis, por exemplo, afiança: "o perito, particular colaborando com o Poder Público, apesar de auxiliar do juízo (art. 139), não é obrigado a trabalhar de graça, nem a suportar as despesas inerentes à prova (v.g. cópias e transporte) ${ }^{, 520}$. É bem observado pelo referido autor que a cominação de multa ou pena disciplinar não resolvem de forma direta a eventual resistência do perito que, ao ver-se às voltas com a necessidade de despender altas quantias para desempenho do encargo, resiste à nomeação. A conclusão do autor é: "responderão pelos honorários do

\footnotetext{
${ }^{520}$ ASSIS, Araken de. Benefício da gratuidade, cit., p. 168.
} 
perito 'o não beneficiário, se vencido, ou o Estado, ao qual incumbe a prestação da

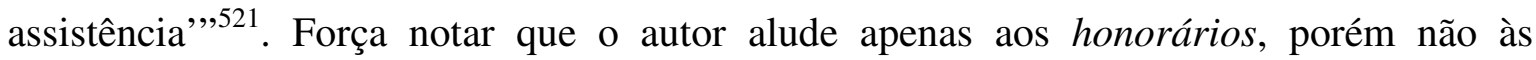
despesas decorrentes da perícia.

Na mesma trilha, Fredie Didier Jr e Rafael Oliveira, ressaltando o munus público que é cometido ao perito nomeado, defendem que "deverá aguardar pelo fim do processo para que possa receber seus honorários, que serão pagos pelo não-beneficiário, se vencido, ou pelo Estado, se vencido for o beneficiário" ${ }^{22}$.

Augusto Marcacini igualmente lembra que é dever do perito colaborar com a Justiça, ponderando também que por ser profissional da confiança do juízo, comumente nomeado, o que percebe em outros trabalhos acabaria por compensar a prestação gratuita no caso de atender a beneficiário da gratuidade, de modo que incumbiria ao perito prestar gratuitamente seu serviço. A isenção, segundo o mesmo autor, abrange também as despesas com a produção da prova ${ }^{523}$ : "O que não se pode é simplesmente deixar de realizar a perícia, ou exigir o adiantamento da parte contrária, que não requereu a perícia, e, portanto, não tem o ônus de antecipação das despesas" ${ }^{524}$.

Maurício Vidigal da mesma forma reconhece a amplitude da isenção, porém não deixa de reconhecer os problemas de ordem prática que são enfrentados pela impossibilidade de se impor ao perito que trabalhe arcando com as despesas oriundas da prova. Reconhece dificuldade enfrentada por magistrados para angariarem recursos dos órgãos públicos para custeio de provas em casos que tais: “Quando necessariamente há grandes despesas para realização da prova, o juiz fica sem ter como conseguir que ela seja feita, mas impor o pagamento ao necessitado é desprezar os comandos constitucionais e legais" 525 .

Barbosa Moreira entende excelentemente inspirado o entendimento de que todas as despesas indiretas decorrentes da perícia se achem albergadas pela isenção, porém admite:

\footnotetext{
${ }^{521}$ ASSIS, Araken de. Benefício da gratuidade, cit., p. 168.

${ }^{522}$ DIDIER JR, Fredie; OLIVEIRA, Rafael. Benefício da justiça gratuita cit., p. 17.

${ }^{523}$ Entendendo que a isenção abrange as despesas com a perícia, também Ângelo Maraninchi Giannakos (GIANNAKOS, Ângelo Maraninchi. Assistência judiciária no direito brasileiro, cit., p. 126-127) e Eduardo Bezerra da Medeiros Pinheiro (Breves observações acerca da Lei $\mathrm{n}^{\circ}$ 1.060/50, cit., p. 103). Em sentido contrário, já nos referimos alhures à posição de Cândido Dinamarco, entendendo que o beneficiário da gratuidade não está isento de adiantar honorários a peritos e outros auxiliares eventuais.

${ }^{524}$ MARCACINI, Augusto Tavares Rosa. Assistência jurídica, assistência judiciária e justiça gratuita, cit., p. 42.

${ }^{525}$ VIDIGAL, Mauricio. Lei da Assistência Judiciária interpretada, cit., p. 31.
} 
"mas parece ao menos problemático que se possa sempre levar a tese às últimas consequiências" 526 .

Na jurisprudência as vozes da mesma forma pontificam: “A gratuidade judiciária abrange os honorários periciais, sob pena de inefetividade ... Necessidade, todavia, de ressarcir o perito com os gastos que houver com a confecção material do laudo, sob pena de enriquecimento ilícito" (TJSP, AI no 107.163.4/8, Rel. Linneu Carvalho, julgado em 16.03.99). E não apenas na esfera do Sodalício Estadual encontramos pronunciamentos assim: "A gratuidade de que goza o assistido não significa deva o perito arcar com os custos necessários à realização da prova. Nem mesmo razoável exigir-se que, habitualmente, preste serviços que só serão remunerados caso vencida a parte contrária à que goza do benefício..." (STJ, REsp no 141.770/MS, Rel. Eduardo Ribeiro, julgado em $27.04 .99)^{527}$.

De nossa parte concordamos com todas as assertivas feitas. Deveras admitir a isenção no que concerne à remuneração do perito, porém imaginar que a parte possa ser compelida a arcar com as despesas por este despendidas para a realização do exame, seria prestigiar uma miragem de direito, isto é, conceder uma benesse ilusória, uma hipocrisia, fora que haveria clara afronta ao princípio do amplo acesso à ordem jurídica justa e ao direito à prova.

De outro lado, impor ao perito o trabalho gratuito não se compadece com idéias basilares de nossa República, como a da dignidade da pessoa humana e o valor social do trabalho (art. $1^{\circ}$ da Constituição da República).

É ao Estado que incumbe prestar a assistência jurídica integral e gratuita, e não há grande mistério em afirmar que ao Estado caberá arcar com o custo integral decorrente da produção da prova: honorários e despesas indiretas. Ocorre que a forma de regulamentação desta questão pelo Estado pode (e na prática tem) inviabilizar tanto o direito à prova de que titular o beneficiário, como o direito à remuneração assegurado ao perito.

\footnotetext{
${ }^{526}$ BARBOSA MOREIRA, José Carlos. O direito a assistência jurídica - evolução no ordenamento brasileiro de nosso tempo, cit., p. 128.

${ }^{527}$ Ainda do mesmo Tribunal: “As despesas pessoais e materiais necessárias para a realização da perícia e confecção do respectivo laudo estão abrangidas pela isenção legal de que goza o beneficiário da justiça gratuita. Como não se pode exigir do perito que assuma o ônus financeiro para execução desses atos, é evidente que essa obrigação deve ser desincumbida pelo Estado, a quem foi conferido o dever constitucional e legal de prestar assistência judiciária aos necessitados.

Não fosse assim, a garantia democrática de acesso à Justiça restaria prejudicada, frustrando a expectativa daqueles privados da sorte de poderem custear, com seus próprios meios, a defesa de seus direitos" (STJ, REsp no 131.815/SP, Rel. César Asfor Rocha, julgado 16.06.98).
} 
Citamos um caso de nossa vida profissional que ilustra a questão. Cuidava-se de ação de usucapião, em que os autores eram, como sói, beneficiários da gratuidade. O julgamento o mérito dependia da perfeita identificação do imóvel usucapiendo, para o que deferiu-se a produção da prova pericial de engenharia. $\mathrm{O}$ vistor aceitou o encargo sem rebuços, inclusive a percepção dos honorários de acordo com convênio próprio destinado a tal fim.

Ocorre que a produção da prova dependia da realização de um levantamento topográfico. O custo: R \$11.000,00. A parte, é óbvio, não dispunha de tal numerário. Não há dúvidas de que era ao Estado que incumbia arcar com esta despesa, contudo, por esta não se achar prevista na tabela própria, caberia ao perito eventualmente ajuizar contra a Fazenda Pública a competente ação de cobrança, que se sujeitaria ao regime de pagamento via precatório. Até lá, entretanto, como viabilizar a produção da prova? Uma coisa é ponderar que o vistor arque com custos decorrentes de transporte, que por vezes não são tão expressivos (um ou dois tanques de combustível) ou cópias. Outra é exigir-lhe um montante de tal vulto, inclusive em prejuízo do próprio sustento. Irrazoável pareceria tal postura, e legítima a recusa do perito.

Ainda há determinadas espécies de perícias não contempladas nas tabelas próprias destinadas a remunerar os casos de gratuidade (p.ex., no Estado de São Paulo, perícia contábil). Repita-se: entender que é dever do perito prestar o serviço gratuitamente é cabível quando aquilo que deixou de receber ou as despesas indiretas não assumem vulto considerável, sendo facilmente compensáveis com o quanto recebido pelo vistor em outras perícias. Agora a situação se inviabiliza quando tal valor assume monta que pode inclusive causar a desestabilização financeira do profissional.

Uma solução alvitrada pela jurisprudência, e lembrada por Theotonio Negrão seria, em casos como o acima citado, determinar o juiz a suspensão do processo e o oficiamento ao Estado para que este pague as despesas necessárias à produção da prova técnica ${ }^{528}$.

Parece ser o menos pior dos caminhos, embora conte-se com a desvantagem imensa de atravancar por demais o andamento do processo, pois bem se sabe os entraves burocráticos que envolvem dispêndios como tais do Poder Público. E mais, havendo negativa do Estado, que se poderá fazer (p.ex. sob a alegação de ausência de dotação orçamentária)? Difícil parece sustentar que neste caso possa o juiz determinar medidas

\footnotetext{
${ }^{528}$ STJ in RF 342/334 apud NEGRÃO, Theotonio; GOUVÊA, José Roberto. Código de Processo Civil e legislação processual em vigor, cit., p. 1.149.
} 
coercitivas, tais como bloqueios de contas ou apreensão de numerários, afinal, não é o Estado parte no processo.

\section{Exames de código genético}

O inciso em questão é obra de inclusão feita pela Lei ${ }^{\circ} 10.317 / 01$, e bem poderia comportar-se na rubrica anterior, já que se trata de modalidade de prova pericial. A virtude do inciso em questão foi referir-se expressamente não apenas a honorários, mas sim às despesas com a realização do exame, expressão mais abrangente (o que evita celeumas quanto à abrangência das chamadas "despesas indiretas" com a realização da prova, assaz referida anteriormente).

Por isto é que se entende que estão abarcadas pela isenção as despesas necessárias ao transporte dos interessados até o local do laboratório responsável pela realização da prova. No Estado de São Paulo tais exames são realizados pelo IMESC (Instituto de Medicina Social e Criminologia do Estado de São Paulo), órgão público que o faz gratuitamente aos beneficiários da benesse legal. Em casos assim não exsurgem maiores dificuldades pois que sendo os responsáveis pela realização do exame servidores públicos, já recebem regularmente sua remuneração pela forma de vencimentos.

De todo modo, em sendo o caso de requisitar-se a realização do exame a laboratório particular, há de se tentar observar o máximo quanto possível regime de rodízio, a fim de não se onerar sempre a mesma entidade ${ }^{529}$.

Outro problema é ainda suscitado por Barbosa Moreira. É que são poucas as localidades onde se encontram laboratórios aptos à realização de exames em questão, geralmente os grandes centros comerciais (o autor refere-se que à época da redação do texto citado na nota de rodapé, apenas São Paulo e Belo Horizonte dispunham de laboratórios assim). A realização do exame deve ser feita com pequeno intervalo de tempo da coleta do material, de modo que o portador do material coletado deverá deslocar-se rapidamente até o laboratório, o que reclamará dependendo do caso, a emissão de passagens aéreas. E daí a indagação do autor: serão as empresas aéreas obrigadas a tanto, mesmo sem norma jurídica específica que lho imponha? $?^{530}$

\footnotetext{
${ }^{529}$ DIDIER JR, Fredie; OLIVEIRA, Rafael. Benefício da justiça gratuita, cit., p. 19.

${ }^{530}$ BARBOSA MOREIRA, José Carlos. O direito a assistência jurídica - evolução no ordenamento brasileiro de nosso tempo, cit., p. 129.
} 
Parece-nos que na espécie a melhor solução seria carrear ao Poder Público o custeio do transporte, o que implica aquel'outro problema referente à celeridade processual, que será certamente comprometida diante da necessidade de aguardar-se a disponibilização orçamentária do Estado (e por vezes a renitência baseada na alegação de falta de previsão orçamentária, e a impossibilidade de proceder-se ao pagamento sem esta previsão legal, será irrebatível). 


\section{LIMITES SUBJETIVOS DA ASSISTÊNCIA JURÍDICA}

Por limites subjetivos queremos nos referir às pessoas relacionadas ao instituto objeto do estudo. Isto é, tanto os potenciais beneficiários, integrantes do pólo passivo da relação em questão, como os legalmente obrigados, que compõem o pólo ativo.

\section{Beneficiários ${ }^{531}$}

A questão é tratada pelo art. $2^{\circ}$ "caput" e parágrafo único da Lei $\mathrm{n}^{\circ}$ 1.060/50, em dispositivo que suscita algumas discussões: “Gozarão dos benefícios desta Lei os nacionais ou estrangeiros residentes no País, que necessitarem recorrer à justiça penal, civil, militar ou do trabalho" e "Considera-se necessitado, para os fins legais, todo aquele suja situação econômica não lhe permita pagar as custas do processo e os honorários de advogado, sem prejuízo do sustento próprio ou da família”.

Parece óbvio que os nacionais são suscetíveis de receber o benefício, seja da assistência, seja da gratuidade (e a assistência jurídica em geral) residam ou não em território nacional. Quanto aos estrangeiros, entretanto, estabeleceu-se restrição, condicionando-se a prestação do serviço de assistência ou mesmo a isenção legal apenas àqueles que comprovem residência no País.

Em verdade o dispositivo, embora analisado na perspectiva do ordenamento hoje em vigor e das concepções atuais de acesso à justiça, na época representou em favor do estrangeiro até maior complacência, já que a correspondente regra contida no Código de Processo Civil de 1939 era ainda mais restritiva: "O benefício de gratuidade será concedido a estrangeiro quando este residir no Brasil e tiver filho brasileiro, ou quando a sua lei nacional estabelecer reciprocidade de tratamento" (art. 70). Ou seja, do estrangeiro exigia-se, então, não apenas a residência em solo nacional, mas ainda possuir filho brasileiro, apenas acrescendo o caso de haver reciprocidade em favor de brasileiros na lei nacional do pretendente ao benefício.

\footnotetext{
${ }^{531}$ A expressão não é isenta de críticas da doutrina: "Há de considerar, por conseqüência, como imprópria a expressão beneficiário da assistência judiciária, de vez que os que se encontram nas condições não são destinatários de um benefício, e sim titulares de um direito exercitável" (LOPES, Maurício Antônio Ribeiro. Garantia de acesso à justiça: assistência judiciária e seu perfil constitucional, cit., p. 72).
} 
Já desde antes da vigência da atual ordem constitucional a regra era alvo de críticas, por ser antidemocrática e restringir de forma injustificável o acesso à justiça no que respeita aos estrangeiros ${ }^{532}$. Mais do que isto, não se pode negar que se estabelece uma distinção de tratamento que parece claramente odiosa, por não haver nenhuma justificativa razoável para se eleger o elemento nacionalidade ou mesmo domicílio como fatores de diferenciação no acesso a benefícios facilitadores do ingresso em juízo, já que pobreza e "problemas jurídicos" atingem indiscriminadamente brasileiros e estrangeiros, residentes ou em trânsito pelo território nacional.

Aliás, a hediondez de tal disparatada regra fica mais evidente quando se percebe que ao brasileiro, mesmo que não residente no País, os benefícios eram assegurados, o que fazia com que o único elemento distintivo fosse mesmo a nacionalidade, o que dava à regra tons xenofóbicos inaceitáveis.

Sob a égide da atual Constituição da República estas incoerências (e porque não, inconstitucionalidades) estão definitivamente amainadas. É que considerando a constitucionalização do direito à assistência jurídica integral e gratuita, elevado à categoria de direito fundamental (CR, art. 5, LXXIV), seu alcance subjetivo passou a ser aquele que informa todos os demais direitos que neste patamar se inserem, conforme a redação ao art. $5^{\circ}$, "caput”, da Constituição.

Poder-se-ia então pensar que evolução na verdade não houve, visto que a norma em questão alude como seus destinatários aos brasileiros e estrangeiros residentes no País, no que nenhuma alteração houve em relação ao atual art. 2, "caput", da Lei no 1.060/50. Ledo engano.

Doutrina basilar do Direito Constitucional, acompanhada de jurisprudência de peso, atestam que a correta interpretação da norma-matriz supra citada é no sentido de que a Constituição da República somente pode assegurar a validade e gozo dos direitos fundamentais dentro do território nacional, mas não tem o sentido de excluir o estrangeiro em trânsito ${ }^{533}$.

\footnotetext{
${ }^{532}$ CASTRO, José Roberto de. Manual de assistência judiciária: teoria, prática e jurisprudência, cit., p. 90.

${ }^{533}$ MORAES, Alexandre de. Direito constitucional. 13. ed. São Paulo: Atlas, 2003. p. 63. É esta também a posição do Ministro Celso de Mello, citada e adotada no julgamento pelo C. Supremo Tribunal Federal do $\mathrm{HC} \mathrm{n}^{\circ}$ 74.051-1/SC, cujo relator foi o Ministro Marco Aurélio, julgamento este datado de 18.06.96. Posição ligeiramente mais restritiva é a de José Afonso da Silva, para quem os estrangeiros são tutelados por outras normas, notadamente de Direito Internacional, além do que, normas que tratam do regime jurídico do estrangeiro não-residente (Curso de direito constitucional positivo. 20. ed. São Paulo: Malheiros Ed., 2001. p. 192). Lembra o mesmo autor que o Brasil é signatário das Declarações Universal e Americana dos
} 
Sem maiores hesitações, portanto, afirma-se que aos estrangeiros em trânsito também se estendem os benefícios inerentes à assistência jurídica integral e gratuita estabelecida tanto no nível constitucional, como no legal (Lei n ${ }^{\circ} 1.060 / 50$ ). Aliás, não apenas aos estrangeiros em trânsito, como também às pessoas jurídicas, tais garantias e direitos fundamentais se estendem no que lhes sejam compatíveis, conforme oportunamente será analisado dada a profusão de posicionamentos e ensinanças a respeito do ponto. Por fim, fique vincado que igualmente aos apátridas se estendem as benesses estudadas $^{534}$.

É de ver, ainda, que a regra do citado art. $2^{\circ}$, "caput", não condiciona a extensão do benefício à existência de reciprocidade em favor de brasileiros, na legislação nacional do estrangeiro, como fazia o antigo art. 70 do Código de Processo Civil de 1939, de modo que presentemente tal questão se torna irrelevante, ou seja, mesmo que na legislação a que submetido o estrangeiro que requer o benefício não se conceda ao brasileiro a mesma benesse, mesmo assim, a ele se estenderão os benefícios previstos na legislação brasileira.

Dois são os pontos nodais de delicado tratamento quando procuramos avaliar a extensão subjetiva da assistência jurídica, mais precisamente no que respeita aos beneficiários: fixar um adequado conceito de necessitado e analisar a extensão dos benefícios às pessoas jurídicas.

No que respeita ao primeiro destes pontos, as dificuldades decorrem do uso pela lei de cláusulas genéricas, como "situação econômica"; "sustento próprio" e "família". Divagações são inevitáveis: saber se situação econômica equivale à situação patrimonial; se implica avaliar apenas as receitas do requerente, ou também suas despesas; saber se

Direitos do Homem, além do que a República tem como um de seus fundamentos a dignidade da pessoa humana, proclamada como valor universal dedicado ao ser humano. Não parece haver maiores dúvidas em que, alijar do acesso à ordem jurídica justa e à reparação de lesões a seus direitos, o estrangeiro, em razão de sua singela condição econômica atenta contra esta mais comezinha noção. Ainda o Pacto de São José da Costa Rica assegura no art. $8^{\circ}$, item 1: "Toda pessoa terá o direito de ser ouvida, com as devidas garantias e dentro de um prazo razoável, por um juiz ou Tribunal competente, independente e imparcial, estabelecido anteriormente por lei, na apuração de qualquer acusação penal formulada contra ela, ou na determinação de seus direitos e obrigações de caráter civil, trabalhista, fiscal ou de qualquer outra natureza" e ainda o art. 25, item 1: "Toda pessoa tem direito a um recurso simples e rápido ou a qualquer outro recurso efetivo, perante os juizes ou tribunais competentes, que a proteja contra atos que violem seus direitos fundamentais reconhecidos pela Constituição, pela lei ou pela presente Convenção, mesmo quando tal violação seja cometida por pessoas que estejam atuando no exercício de suas funções oficiais". Não é preciso maior digressão para reconhecermos que muitas vezes somente assegurados benefícios inerentes à assistência jurídica integral e gratuidade é que o direito de ser ouvido se há de tornar efetivo.

534،O art. $2^{\circ}$, caput, menciona os nacionais e os estrangeiros residentes no País como beneficiários. Não menciona o estrangeiro não-residente e de passagem no Brasil, tampouco o apátrida. Entretanto, a estes também se estende o benefício, por força do art. $5^{\circ}$,caput, CD/88, independente de convênios de reciprocidade de assistência judiciária gratuita: lex dixit minus quam voluit" (DEMO, Roberto Luis Luchi. Assistência judiciária gratuita. Revista da AJURIS, Porto Alegre, v. 27, n. 83, p. 348, set. 2001). 
valor destinado a "sustento próprio" significa tão somente aquele necessário para as despesas básicas de subsistência, ou se abarca todas as demais que advenham do próprio padrão de vida do requerente ${ }^{535}$; e mais, saber se se devem computar como "família" todos aqueles que efetivamente dependam da receita haurida pelo requerente, incluindo agregados, ou apenas aqueles a quem o requerente deva alimentos (isto é, em relação aos quais tenha a obrigação de amparo material $)^{536}$.

Como se vê, a plêiade de questões suscitáveis é grande. Contudo, em razão do longo período de vigência de tais conceitos (já no Código de Processo Civil de 1939 a noção nuclear de necessitado era a mesma $)^{537}$, as noções foram se assentando e hoje acham-se de forma até uniforme bastante sedimentadas em sede doutrinária e jurisprudencial.

Vejamos então alguns parâmetros invocados. Já de plano se ressalta que "pobre" em termos jurídicos não é necessariamente miserável ou indigente, não se postula estado de mendicância ${ }^{538}$.

Entende-se também que situação econômica não diz respeito à situação patrimonial, ou seja, o que se avalia é a liquidez financeira do requerente, a posse de recursos, para ser mais claro, dinheiro. Mesmo que proprietário de bens, até mesmo imóveis, o requerente pode ser agraciado com o benefício se não dispõe de quantia líquida para arcar com os custos da demanda. Não se justifica exigir-se a alienação de patrimônio para custeio do processo. E mais, por vezes as quantias hauridas de tal patrimônio, a título de frutos civis, são empregadas no próprio sustento do titular (p.ex.complementação de salário ou aposentadoria).

Outrossim, não se exige também que o requerente esteja vivendo à míngua de qualquer rendimento. Mesmo aquele que detenha salário regular e razoável, poderá ver-se agraciado desde que suas entradas sejam severamente comprometidas pelas

\footnotetext{
${ }^{535} \mathrm{Em}$ sede de Direito de Família é bastante conhecida a distinção entre os alimentos civis e os naturais, inclusive acolhida pela Lei. Vê-se que o art. 1.694, "caput", refere-se à verba necessária para que o alimentando possa viver de modo compatível com sua condição social, inclusive para atender às necessidades de sua educação. Já o $\S 2^{\circ}$ da mesma regra estipula que quando a situação de necessidade resultar de culpa de quem os pede os alimentos serão apenas os indispensáveis à subsistência.

${ }^{536}$ É esta, por exemplo, a posição de Carlos S. de Barros Jr: "Pensamos também que, para os fins da assistência judiciária, o conceito de família deve abranger até onde alcança a efetiva obrigação alimentar, em face das leis civis" (Justiça gratuita. Revista Forense, Rio de Janeiro, n. 101, p. 43, jan. 1945).

${ }^{537}$ Dizia o art. 68: "A parte que não estiver em condições de pagar as custas do processo, sem prejuizo do sustento próprio ou da família...”.

${ }^{538}$ CASTRO, José Roberto de. Manual de assistência judiciária: teoria, prática e jurisprudência, cit., p. 91; VIDIGAL, Mauricio. Lei da Assistência Judiciária interpretada, cit., p. 14; BARROS JR, Carlos S. de. Justiça gratuita, cit., p. 43.
} 
responsabilidades com as quais tem de $\operatorname{arcar}^{539}$. E mais, tais responsabilidades não são aquelas circunscritas àqueles a quem o requerente deva alimentos. O conceito de família a ser abarcado pelo art. $2^{\circ}$ em comento é o mais amplo possível, ou seja, abrange agregados, familiares ou não, que dependam economicamente do requerente. E para tal fim não se exige sequer residência sob o mesmo teto (p.ex. imagine-se o genitor que sustente o filho que estude em outra cidade, o que é bastante usual quando do ingresso em Universidades).

Não se pode censurar o legislador pelo emprego de expressões genéricas ou conceitos imprecisos, pois estamos de fato num daqueles pontos em que a flexibilidade na aferição da matéria é fundamental para se permitir que o ordenamento acompanhe a evolução do corpo social, adaptando-se às mutações e evoluções que neste se verificam.

É o que costumeiramente se afirma em casos análogos: a necessidade financeira não se afere com regras aritméticas, precisão matemática. A sensibilidade pessoal do magistrado, as características e peculiaridades da Comarca e mesmo da região, o momento socioeconômico pelo qual passa o País, as condições pessoais do requerente, tudo isto é de ser considerado 540 .

Quando se pensa na questão da consideração ou não dos dispêndios necessários à manutenção da condição social do pretendente ao benefício, como verbas destinadas ao próprio "sustento", mais parcimônia se exige. De um lado não se há de exigir da parte que, à custa do processo, experimente sacrifício de seu usual padrão de vida; de outro, entretanto, considerar que parte restará com seu sustento comprometido porque deixará de patrocinar supérfluos hábitos de luxo, é um acinte à dignidade da Justiça num país de carentes $^{541}$.

\footnotetext{
${ }^{539}$ Curioso é um antigo precedente citado por José Roberto de Castro, oriundo do Tribunal de Justiça de Pernambuco: "É de conceder-se o benefício da assistência judiciária ao magistrado, por isso que não pode custear despesas judiciais sem se privar dos recursos indispensáveis ao próprio sustento" (Ac. das Câmaras Reunidas do TJ-PE, em 12.06.50, no Ag.nº 38.323, Rel. Des.Genaro Freire, AF, 27:191).

540 ،... a condição de necessitado não pode ser medida com instrumento de precisão, considerando-se que o fato de a parte ser proprietária de poucos bens não constitui óbice, importando, na verdade, não se confundir necessidade com dificuldade" (PINHEIRO, Eduardo Bezerra de Medeiros. Breves observações acerca da Lei $\mathrm{n}^{\circ} 1.060 / 50$, cit., p. 100).

${ }^{541} \mathrm{O}$ seguinte precedente bem ilustra a questão: "O simples fato de fazer um indivíduo muitas despesas, as quais consumam quase todo ou a totalidade de seus ganhos, não se presta, por si só, a configurar o estado de miserabilidade exigido, pois, se elevados esses ganhos, nem todas as despesas estarão dirigidas ao essencial para seu sustento ou de sua família, muitas certamente havendo que não são imprescindíveis a isso. Mesmo os detentores de elevadíssimos ganhos, na casa das dezenas de milhares de reais, podem-se achar em condição de comprometimento de todos eles, segundo o padrão de vida que mantenham, o que não os faz miseráveis para o fim de obter a gratuidade judiciária. Assistência Judiciária confere-se aos efetivamente necessitados, segundo prescrito pelo artigo $1^{\circ}$ da Lei $n^{\circ} 1.060 / 50$, não àqueles que apenas não se dispõem a reduzir, um pouco, seus gastos com coisas não essenciais e vivam, momentaneamente, sem margem de ganho não comprometido"(TJSP, AI n 990.10.029914-0,Rel.Vieira de Moraes, j. 17.06.10).
} 
Neste ponto não podemos firmar assertivas padronizadas e precisas acerca dos critérios que hão de presidir a decisão acerca da questão. Aqui valerão aqueles elementos declinados parágrafos atrás.

Afirma-se que "a natureza da ação ou o tipo de pedido formulado não podem também ser utilizados como critério para a concessão da gratuidade. Não há qualquer relação entre o bem da vida pleiteado e a possibilidade, no presente, de arcar com as despesas e honorários" $" 542$.

Deveras esta assertiva é, a priori, escorreitamente correta. Contudo quando se avalia a prática quotidiana do instituto, algumas ressalvas e observações são pertinentes. Uma das maiores dificuldades que se constata na praxe do foro é aferir a real condição econômica das partes. Comum é que busquem estas dissimular sua real situação financeira/patrimonial, valendo-se então da gratuidade como forma de impulsionarem o processo sem riscos.

Infelizmente, no mais das vezes este desiderato é alcançado, e dizer que não, seria partir de uma ilusória constatação da realidade. Justificativas as mais variadas se põe: o esmagador volume de serviço e a necessidade de que os processos sejam postos em marcha impede que os magistrados avaliem com a calma necessária, artesanalmente, a situação econômica em particular de cada parte; a falta de meios para que a parte contrária colha elementos probatórios a demonstrar que seu adverso mente quando afirma pobreza, mormente porque os dados mais relevantes são protegidos por sigilo (p.ex. declarações de imposto de renda; informações bancárias; etc.), entre outros elementos, contribuem para que, na prática, a mera declaração de pobreza acabe bastando, e mais, que diante da impugnação do adversário (que normalmente não vem instruída adequadamente, ou sequer conta com requerimentos para expedição de ofícios a órgãos pertinentes para aferir a situação econômica do impugnado), acabe prevalecendo sempre a famigerada presunção de veracidade da declaração (art. $4^{\circ}, \S 1^{\circ}$, da Lei $\left.\mathrm{n}^{\circ} 1.060 / 50\right)$.

Neste contexto, às vezes as características da demanda, especialmente a natureza do direito material debatido ou a matéria fática alegada, acabam traindo o desiderato da parte e denunciando sua real condição financeira.

\footnotetext{
${ }^{542}$ MARCACINI, Augusto Tavares Rosa. Assistência jurídica, assistência judiciária e justiça gratuita, cit., p. 86, adiante, ainda arremata o mesmo autor: "Não há, porém, algum tipo de ação ou de direito material que possa, por si só, impedir a concessão do benefício" (Assistência jurídica, assistência judiciária e justiça gratuita, cit., p. 87).
} 
Apontamos para dois casos de nossa experiência profissional em que isto ficou demarcado: num caso, por motivos não recordados, era necessário ao autor declinar na matéria fática debatida, seus rendimentos (inclusive sendo-lhe até mais proveitoso, em razão do objeto do litígio, declarar rendimento de monta), e de fato a parte o fez, declarando perceber renda mensal de aproximadamente $\mathrm{R} \$ 8.000,00$. O benefício havia sido deferido (talvez até por deficiência no exame da inicial, e atentando-se apenas para a declaração de pobreza), e em sede de impugnação, aquela informação declinada na inicial acabou sendo o ponto fundamental que ensejou a revogação da benesse, até porque o beneficiário não apontou que tal renda fosse completamente consumida por seu sustento.

Noutro caso a parte litigava acerca da existência de vícios em móveis planejados que havia adquirido junto à ré, com custo aproximado de $\mathrm{R} \$ 30.000,00$. Para instruir a inicial fez juntar aos autos fotografias da residência, e especialmente dos móveis objeto da pendenga. Foi aí que se viu que tais móveis eram destinados a ornamentar uma enorme e portentosa churrasqueira, numa casa amplíssima e requintada por adereços invejáveis, como, além da dita churrasqueira, uma enorme piscina. Na espécie, houve impugnação à gratuidade (que mais uma vez, fora deferida inadvertidamente com simples declaração de pobreza), e diante dos retratos em questão, o juízo exigiu do autor a juntada das últimas declarações de rendimentos à Receita Federal. A parte, entretanto, prontamente recolheu as custas iniciais devidas, renunciando assim tacitamente ao benefício (e patenteando que de fato tinha condição de arcar com o custo da demanda).

Com estes exemplos, até simplórios, queremos defender que embora em princípio não se possa vincular a natureza do direito material ou a grandeza econômica do bem da vida debatido, à condição econômica da parte, em casos limítrofes, especialmente quando há certo desvio ético na postura adotada de dissimulação da real situação, tais elementos acabam sendo poderosos instrumentos para aferir a verdade ${ }^{543}$.

Outra questão assaz suscitada nos meios forenses acerca do tema, diz respeito à caracterização da contratação de advogado particular para patrocínio da causa, como sinal indicativo de abastança, a justificar a revogação ou o indeferimento da isenção (referimo-

\footnotetext{
${ }^{543}$ Eis precedente desta estirpe: “ASSISTÊNCIA JUDICIÁRIA - Pedido - Agravante que se qualifica como empresária, contrata advogado às suas expensas, titulariza a propriedade de diversos bens móveis e imóveis, litiga sobre contrato de valor milionário e não acosta qualquer documento que denote situação ruinosa - Mercê negada - Pedido de prazo para recolhimento das custas e demais despesas processuais Deferido, excepcionalmente - Recurso parcialmente provido" (TJSP, AI nº 661.09.054451-0, Rel. Maia da Rocha, j.10.05.10). No sentido contrário: FORNACIARI JR, Clito. Provas para a concessão de justiça gratuita. Tribuna do Direito, São Paulo, n. 191, mar. 2011.
} 
nos apenas à isenção porque parece que a contratação de profissional de própria confiança não se coaduna com a indicação pelo serviço de assistência, modo que a assistência jurídica por esta modalidade ficaria, no caso, impossibilitada. De todo modo, adiante tratamos da questão com mais vagar).

No mais das vezes não são conhecidos no processo os termos da contratação firmada com o advogado. Quando são conhecidos, também é comum constatar-se a contratação de honorários ad exitum (acerca dos quais já referimos), isto é, ao patrono seria devida uma parcela do benefício econômico advindo ao constituinte em razão de êxito, total ou parcial, no litígio. É evidente que esta forma de estipulação não denota riqueza alguma por parte daquele que contrata o patrono.

Por isto é que a afirmação corrente na jurisprudência é que o simples fato da parte comparecer acompanhada de patrono por si contratada para acompanhamento da causa, não constitui per si causa para revogação ou indeferimento do benefício da gratuidade, não sendo legítimo presumir-se a partir desta circunstância, sua higidez econômica. Esta posição é de fato irretorquível ${ }^{544}$.

Note-se, entretanto, que se os termos em que contratado o patrono emergirem nos autos, e deles se perceber o pagamento de polpudos honorários, independentemente do resultado da demanda, tudo a denotar sinal exterior de riqueza por parte do constituinte, pode sim o juiz valer-se de tal circunstância como um indicativo do descabimento da gratuidade.

A verdade é que um enorme conjunto de variantes poderá influir na convicção do magistrado e permitir que avalie adequadamente se a presunção de veracidade da declaração de pobreza (art. $4^{\circ}, \S 1^{\circ}$, da Lei $\left.n^{\circ} 1.060 / 50\right)$ está na verdade aninhando uma fraude, alguns são estes por nós referidos (limitamo-nos a tratar daqueles mais

\footnotetext{
${ }^{544}$ A título exemplificativo, cito: "Não é suficiente para afastar a assistência judiciária a existência de advogado contratado. O que a lei especial de regência exige é a presença do estado de pobreza, ou seja, da necessidade da assistência judiciária por impossibilidade de responder pelas custas, que poderá ser enfrentada com prova que a desfaça. Não serve para medir isso a qualidade do defensor, se público ou particular" (STJ, REsp n ${ }^{\circ}$ 679.198/PR, Rel. Carlos Alberto Menezes Direito, j. 21.11.06).

"A presunção de veracidade da declaração de pobreza, firmada nos termos do § Io do artigo 4o da Lei 1060/50, pode ser afastada por elementos indicativos em sentido contrário e, em tal caso, cabe à parte demonstrar sua efetiva pobreza. No caso dos autos, a contratação de advogado particular para patrocinar a causa e o fato de o autor ter profissão não constituem elementos que, por si só, são capazes de elidir a presunção que emana da declaração, até porque ausentes nos autos quaisquer outras circunstâncias indicativas de que não se trata de pessoa pobre na acepção jurídica do termo. Trata-se de ajudante geral, pessoa cuja simplicidade pode deduzir-se até pelas assinaturas por ele lançadas" (TJSP, AI $n^{\circ}$ 1.265.2270/7, Rel. Manoel Justino Bezerra Filho, j.04.05.09). Ainda no mesmo sentido: TJSP, AI n ${ }^{\circ}$ 7.045.548-4, Rel. Rizzatto Nunes, j.14.12.05; TJSP, Ap. $\mathrm{n}^{\circ}$ 521.543-4/1-00, Rel. Elcio Trujillo, j. 17.10.07; $2^{\circ}$ TAcSP, Ap. $n^{\circ}$ 546099-0/2, Rel. Soares Levada, j. 05.05.99.
} 
correntemente encontrados na praxe). Valor da causa; características da matéria fática alegada no processo; termos de contratação de advogado particular; até mesmo o tipo de roupas e acessórios usados pela parte (com o que o magistrado se depara em audiências); modelo de carro conduzido; etc.

De acordo com as peculiaridades do caso, tais elementos poderão ou não contar com peso para a dedução da realidade da pobreza afirmada. O que não se pode é estabelecer regras a priori, excluindo algum destes elementos ou afirmando-o absolutamente decisivo e imprescindível.

Distinguem-se também as noções de necessitado jurídico e econômico ${ }^{545}$. Casos há em que o processo é meio indispensável para a obtenção do resultado prático visado por uma das partes, que não pode obtê-lo extrajudicialmente (p.ex. ações constitutivas necessárias). E mais, em alguns destes casos o legislador estabelece não apenas a indispensabilidade da mera oportunização do contraditório, mas exige-o com feições efetivas. O exemplo mais gritante é o do processo penal, em que ao acusado será nomeado defensor, queira ou não, seja rico ou pobre ${ }^{546}$. Considera-se neste caso que a parte é necessitada da assistência técnico-jurídica de um advogado para exercer sua defesa, sem nenhuma consideração à sua condição econômica.

Há quem identifique as noções de necessitado jurídico e acusado no processo penal. Mas a realidade é que também na esfera do processo civil tal figura se acha com clareza na pessoa do interditando, que será defendido pelo órgão do Ministério Público, ou quando este for o autor da ação, pelo "curador à lide" (CPC, art. 1.182, § $1^{\circ}$ ). Veja-se que a representação jurídica do interditando neste caso independe de sua condição financeira, presumindo o legislador em caráter absoluto, que necessite ele da assistência jurídica, mesmo que abastado. O mesmo se verifica em relação ao incapaz que não tenha representante legal ou cujo representante tenha com ele interesses colidentes, assim como o réu revel citado fictamente, por edital ou hora certa $\left(\mathrm{CPC} \text {, art. } 9^{\circ}\right)^{547}$.

Afirma-se em doutrina que restringir o conceito de necessitado ao hipossuficiente econômico é prestigiar visão míope e obsoleta, baseado na anterior ordem constitucional e

\footnotetext{
${ }^{545}$ MARCACINI, Augusto Tavares Rosa. Assistência jurídica, assistência judiciária e justiça gratuita, cit., p. 83-84.

${ }^{546}$ Cf. art. 261, "caput" e p.único, do Código de Processo Penal.

${ }^{547}$ DEMO, Roberto Luis Luchi. Assistência judiciária gratuita, cit., p. 351.
} 
"no modelo praticado pela advocacia""548. Aliás, distingue-se o caráter das funções desempenhadas pela Defensoria Pública em razão da natureza de carência suprida. Diz-se, então, que o atendimento ao necessitado econômico significa exercício de função típica da Defensoria. O atendimento ao necessitado jurídico, exercício de função atípica. Sob o prisma da função atípica o conceito de necessitado é indeterminado, cabendo à lei ordinária estabelecê-lo sem perder, entretanto, correspondência com o art. $1^{\circ}$, "caput", da Lei Complementar $n^{\circ} 80 / 94^{549}$.

Podemos dizer que a assistência jurídica nos termos em que referida pelo inciso LXXIV do art. $5^{\circ}$ da Constituição abarca tanto o atendimento ao que nos parágrafos anteriores denominamos necessitado jurídico como o econômico. É certo que a norma constitucional fala naqueles que comprovarem "insuficiência de recursos" (embora sem especificar que os recursos assim faltantes sejam os econômicos, isto parece subentendido). De toda forma não vai disparate algum em ponderar que a Constituição garante a assistência jurídica integral e gratuita, pelo menos, ao hipossuficiente econômico, o que não exclui outras classes de necessitados reconhecidos pela atividade legiferante infraconstitucional com caráter ampliativo da garantia ${ }^{550}$.

Fato é, entretanto, que a Lei $\mathrm{n}^{\mathrm{o}}$ 1.060/50 restringe-se à figura do carente econômico. Ao necessitado jurídico são dispensadas disposições específicas em cada diploma regente da situação cuja peculiaridade inspire o legislador a presumir a necessidade do atendimento técnico por advogado ou Defensor Público.

A propósito, convém observar que o caráter personalíssimo do benefício é referido pelo art. 10 da Lei $n^{\circ}$ 1.060/50 nos seguintes termos: "São individuais e concedidos em cada caso ocorrente os benefícios de assistência judiciária, que se não transmitem ao cessionário de direito e se extinguem pela morte do beneficiário, podendo, entretanto, ser concedidos aos herdeiros que continuarem a demanda e que necessitarem de tais favores, na forma estabelecida nesta Lei”.

\footnotetext{
${ }^{548}$ A crítica aguda é de Leandro Coelho de Carvalho, no artigo As atribuições da Defensoria Pública sob a ótica do acesso à ordem jurídica justa. Revista de Processo, São Paulo, v. 33, n. 156, p. 205, fev. 2008.

${ }^{549}$ CARVALHO, Leandro Coelho. As atribuições da Defensoria Pública sob a ótica do acesso à ordem jurídica justa, cit., p. 216-218.

550“'Ao referir-se aos 'necessitados', o constituinte não limitou a exegese aos financeiramente carentes, embora seja esta a finalidade precípia da Defensoria Pública. Em determinados casos, previstos no ordenamento, a instituição pode (deve) atuar mesmo sem aferição do estado de carência. É o que ocorre na curadoria especial, atribuição constitucional exclusiva (art. 4, VI, da LC 80/94), e na hipótese do art. 306 do CPP, alterado pela Lei n 11.449/2007" (CARVALHO, Leandro Coelho. As atribuições da Defensoria Pública sob a ótica do acesso à ordem jurídica justa, cit., p. 208).
} 
Segundo leciona José Roberto de Castro, se "a parte" (esta é a expressão utilizada pelo autor) for composta por mais de uma pessoa, como no caso do inventário, todos deverão pleitear o benefício ${ }^{551}$.

A nós parece que seria mais próprio falarmos em pluralidade de pessoas componentes do mesmo pólo do processo (cada pessoa ou ente componente do pólo será uma parte). Não parece igualmente necessário que todos os herdeiros pleiteiem o benefício, bastando que o inventariante, a quem incumbe representar o espólio (CPC, art. 991, I), o faça. Porém é necessário que ao avaliar o pedido feito pelo inventariante o juiz leve em conta não apenas a situação pessoal deste, porém de todos os herdeiros bem como o patrimônio inventariado (ou objeto do arrolamento) ${ }^{552}$. Já no caso de litisconsórcio, o benefício apenas abrangerá o co-litigante que o requerer e obtiver deferimento.

Afirma-se ainda que aquele que pleiteia o benefício pode fazê-lo em nome próprio ou dos que lhe sejam dependentes, exemplificando-se com o caso da mulher que pede alimentos para si e para os filhos que tem em comum com o réu ${ }^{553}$. Esta assertiva, entretanto, deve ser bem entendida. $\mathrm{O}$ que ocorre no caso é que a genitora pede para si, em nome próprio, e na qualidade de representante legal ou assistente dos filhos menores (conforme o caso de incapacidade absoluta ou relativa). Como ela aglutina sobre si a atuação processual dela própria e de outras partes, então se lhe pode autorizar o pedido único.

Ainda Artêmio Zanon aconselha, como medida de boa política judiciária, não se aceite pedido de gratuidade de um dos cônjuges (na verdade o autor refere apenas à virago) no caso de pleitos amigáveis de ruptura da sociedade ou do vínculo conjugais ${ }^{554}$. Não se vislumbra, entretanto, a necessidade de tal cautela, aplicando-se ao caso o disposto no art. 24 do Código de Processo Civil, apenas que o interessado que for beneficiário da

\footnotetext{
${ }^{551}$ CASTRO, José Roberto de. Manual de assistência judiciária: teoria, prática e jurisprudência, cit., p. 124.

552،“Assistência judiciária - Indeferimento - Possibilidade da concessão do benefício de assistência judiciária a espólio que demonstre a impossibilidade de atender ao pagamento das despesas do processo Precedentes jurisprudenciais - Espólio representa em juízo a comunidade de herdeiros - Análise da miserabilidade, apta a autorizar o deferimento do pedido, deve se dar em duas frentes: situação dos herdeiros e patrimônio do espólio - Inventariante pobre na acepção jurídica do termo - Concessão do benefício da justiça gratuita - Recurso provido" (TJSP, AI n. 5.704.144.700/SP, Rel. Francisco Loureiro, j. 07/08/08).

${ }^{553}$ ZANON, Artêmio. Assistência Judiciária gratuita: comentários à Lei da Assistência Judiciária (Lei ${ }^{\circ}$ 1.060, de 5-2-1950), cit., p. 77.

${ }^{554}$ ZANON, Artêmio. Assistência Judiciária gratuita: comentários à Lei da Assistência Judiciária (Lei ${ }^{\circ}$ 1.060, de 5-2-1950), cit., p. 77.
} 
gratuidade restará isento dos recolhimentos devidos, seja em adiantamento, seja em rateio final $^{555}$.

Segundo defende Maurício Vidigal, se o benefício não for concedido a quem suceder o beneficiário por transmissão entre vivos ou por morte, as custas e despesas já verificadas poderiam ser exigidas, como se tivesse se operado a revogação ${ }^{556}$.

Da mesma forma a posição em questão não parece, com a devida vênia, a mais acertada. Primeiro que a revogação do benefício nem sempre opera retroativamente. Conforme adiante se defende, os efeitos da decisão revocatória dos benefícios da gratuidade dependerão dos fundamentos que a amparam. Se reconhecida a inexistência do pressuposto da miserabilidade, haverá retroação ao início da atuação processual da parte; acaso reconhecido o desaparecimento o benefício se considera revogado desde a alteração em questão.

No caso de sucessão de partes no processo, em que o sucedido gozava os benefícios e o sucessor não os goze, não há falar em reconhecimento de que a situação de pobreza inexistisse desde o início do processo. A situação de pobreza do sucedido existia e era legítima a concessão da benesse; esta situação deixou de existir com a assunção do pólo pelo sucessor, este sim não caracterizado como pobre (ou, ao menos, inerte quanto ao requerimento). É legítimo, então, que as custas e despesas passem a ser contadas a partir da sucessão processual.

Convém observar que o benefício se refere à parte processual. Assim é que figurando no feito um substituto processual por legitimação extraordinária, é a sua condição financeira que será levada em conta, e não a do substituído.

\section{Pessoa jurídica}

Eis o segundo ponto, daqueles dois por nós referidos, e que representam os pontos nevrálgicos na análise do alcance subjetivo passivo da assistência jurídica integral e gratuita. Certo é que a questão ora posta é de antiqüíssimo debate em doutrina e

\footnotetext{
${ }^{555} \mathrm{O}$ próprio autor em questão cita um antiquíssimo julgado em amparo a esta tese: “(...) O benefício da justiça gratuita abrangeu, somente, a desquitanda. Imprescindível, portanto, o recolhimento de $50 \%$ da taxa judiciária e das custas processuais, no que concerne ao cônjuge varão, tendo em vista o caráter daquela medida" (TJSC, Ap. no 3.980, Rel. Rid Silva, Jurisprudência Catarinense 3/4:234-5, 1974) (o julgado está citado na obra supra descrita, p. 80).

${ }^{556}$ VIDIGAL, Mauricio. Lei da Assistência Judiciária interpretada, cit., p. 69.
} 
jurisprudência, e objeto da análise de praticamente a totalidade dos doutrinadores que, com alguma consistência, se debruçaram sobre o instituto.

A verdade é que a origem de tais divergências remonta à omissão do legislador, que se tivesse de pronto espancado as dúvidas, afirmando ou negando de forma peremptória a extensão benefício aos entes morais, teria prevenido a insegurança. Ainda hoje esta previsão normativa se faria bem-vinda, já que, como se verá, ainda pairam correntes as mais diversas quanto a diversos pontos (p.ex. requisitos a serem observados pela pessoa jurídica para o gozo do benefício, espécies de pessoas jurídicas alcançáveis, etc.).

É de ver que originariamente a realidade visada pelo legislador ao idealizar a assistência jurídica (e aqui usamos o termo em questão para abrangermos tanto a assistência judiciária como a simples gratuidade) tinha como alvo a pessoa natural. Isto parece patente a partir da própria redação da cabeça do art. $2^{\circ}$ e do seu parágrafo único, ambos da Lei $\mathrm{n}^{\mathrm{o}}$ 1.060/50. A alusão a nacionais e estrangeiros residentes (e não também sediados) bem como a referência a sustento próprio e da família, por exemplo, permitem deduzir facilmente esta constatação.

Aliás, tanto assim é que o Decreto $\mathrm{n}^{\mathrm{o}} 2.457$, de $8^{\circ}$ de fevereiro de $1897^{557}$, destinado a organizar a assistência judiciária no Distrito Federal, expressamente vedou a extensão da benesse às pessoas jurídicas: "Não poderão gosar do beneficio da Assistencia Judiciaria as corporações e associações de qualquer especie, nem tampouco o estrangeiro no civel, salvo quando houver reciprocidade de beneficio no paiz a que pertencer" (art. $3^{\circ}$ ).

Esta restrição foi perdendo espaço, sob o influxo das tendências ampliativas do acesso à justiça que desde o tempo de antanho vêm influindo na ciência processual ${ }^{558}$, o que pensamos já ter sido à saciedade explorado em outros capítulos.

E fato é que apesar dos indícios de que o alvo objetivado pelo legislador nos diplomas mais antigos que regularam a questão fosse a pessoa natural (dita física), não se pode deixar de reconhecer que uma clara restrição da benesse em favor somente destas pessoas não houve.

\footnotetext{
${ }^{557}$ Cuida-se do primeiro diploma brasileiro a traçar normas consistentes acerca da assistência judiciária.

${ }^{558} \mathrm{Em}$ artigo de 1945, por nós já citado, Carlos S. de Barros Jr já afirmava: "Esta restrição [do benefício às pessoas naturais] tem sido considerada injusta, podendo ferir de modo irreparável direitos legítimos de litigantes pobres" (Justiça gratuita, cit., p. 44). Segundo Marcacini, também continham vedações de concessão do benefício à pessoa jurídica os Códigos de Processo dos Estados de São Paulo e da Bahia (Assistência jurídica, assistência judiciária e justiça gratuita, cit., p. 88).
} 
Com o advento da Constituição da República de 1988 a questão sedimentou-se no sentido de que a falta de distinção pelo art. $5^{\circ}$, LXXIV, implica necessariamente a aplicação da regra tanto a pessoas físicas como jurídicas, com base naquele comezinho princípio hermenêutico tão difundido de que onde o legislador não diferençou, não o há de fazer o intérprete. Por isto é que não se constatam maiores rebuços na doutrina específica em afirmar tal extensão do benefício ${ }^{559}$, bem como em jurisprudência ${ }^{560}$.

Seria até difícil de sustentar a compatibilidade com a Constituição, de diploma legal que estabelecesse restrição desta natureza.

As discussões mais recentes neste tema não têm foco propriamente na possibilidade ou não de concessão do benefício às pessoas jurídicas, como parece ter ficado demonstrado nos parágrafos anteriores. O que se nota é que as mais intrincadas divergências surgem noutro horizonte: em se aferir os requisitos que presidem esta concessão, isto é, se são os mesmos ou não em comparação ao que impera em relação à pessoa natural.

\footnotetext{
559،Hoje, admite-se, de forma pacífica, que a pessoa jurídica pode valer-se da assistência judiciária, bastando, para tanto, que se enquadre como "necessitado" (CASTRO, José Roberto de. Manual de assistência judiciária: teoria, prática e jurisprudência, cit., p. 92, é curioso ressaltar que a obra citada data de 1987, ou seja, há mais de vinte anos é pacífico o entendimento da extensão do benefício às pessoas jurídicas). "Ora, o art. $5^{\circ}$, LXXIV, da CF/88 não distingue entre pessoas físicas e jurídicas, no âmbito da assistência jurídica, que é mais abrangente do que a gratuidade. E a circunstância de o dispositivo se situar dentre os direitos e garantias individuais nada significa, porque o art. $5^{\circ}$ se aplica a ambas, indiferentemente, inclusive protegendo as pessoas jurídicas da interferência estatal (inc. XVIII) e da dissolução compulsória (inc. XIX)" (ASSIS, Araken de. Benefício da gratuidade, cit., p. 174). Ainda Artêmio Zanon: "Entendo que o Poder Legislador, quase sempre minucioso entre nós, não assentando isenções e não restringindo, oportunizou ao aplicador da norma legal estender os benefícios da assistência judiciária às entidades de direito privado" (Assistência Judiciária gratuita: comentários à Lei da Assistência Judiciária (Lei n 1.060 , de 5-2-1950), cit., p. 19). Luís Alberto Thompson Flores Lenz em artigo assaz citado acerca do assunto também leciona: "Logo, atualmente, a abordagem da matéria objeto deste estudo deve partir do próprio texto da Lei Maior, uma vez que o inc. LXXIV do art. $5^{\circ}$ daquele diploma legal não discrimina, para os efeitos de assistência jurídica, as associações e os entes coletivos. Além disso, tal preceito deve ser interpretado de forma harmônica com o inc. XXXV do mesmo artigo, o qual veda a exclusão da apreciação pelo Poder Judiciário de qualquer ameaça ou lesão de direito, sem que precise ser, como na Constituição passada, individual" (Da concessão da assistência judiciária gratuita às pessoas jurídicas e aos entes beneficentes. Revista dos Tribunais, São Paulo, v. 80, n. 674, p.63, dez. 1991).

${ }^{560}$ Há uma infinidade de decisões, inclusive dos Tribunais Superiores, neste sentido. Para não sermos cansativos, limitamo-nos a ressaltar o seguinte julgado, dada a relevância do órgão prolator, e mais, dos fundamentos invocados: "O benefício da gratuidade - que se qualifica como prerrogativa destinada a viabilizar, dentre outras finalidades, o acesso à tutela jurisdicional do Estado - constitui direito público subjetivo reconhecido tanto à pessoa física quanto à pessoa jurídica de direito privado, independentemente de esta possuir, ou não, fins lucrativos. Precedentes. - Tratando-se de entidade de direito privado - com ou sem fins lucrativos -, impõe-se-lhe, para efeito de acesso ao benefício da gratuidade, o ônus de comprovar a sua alegada incapacidade financeira (RT 787/359 - RT 806/129 - RT 833/264 - RF 343/364), não sendo suficiente, portanto, ao contrário do que sucede com a pessoa física ou natural (RTJ 158/963-964 - RT 828/388 - RT 834/296), a mera afirmação de que não está em condições de pagar as custas do processo e os honorários advocatícios. Precedentes" (STF, RE nº 192.715 AgR/SP, 2º Turma, Rel. Min. Celso de Mello, j. 21.11.06).
} 
Fredie Didier Jr e Rafael Oliveira reconhecem na evolução da jurisprudência do C.Superior Tribunal de Justiça duas correntes principais, com variantes: uma mais antiga, no sentido de que apenas pessoas jurídicas filantrópicas, pias, beneficentes ou sem fins lucrativos poderiam receber o benefício; e outra mais recente, estendendo a qualquer pessoa jurídica tal possibilidade, desde que efetivamente comprovada a situação de necessidade, salientando-se nesta senda, que as pessoas jurídicas com finalidades beneficentes, pias e filantrópicas, estariam dispensadas da prova da necessidade, valendo para elas a presunção de veracidade da declaração a que alude o art. $4^{\circ}, \S 1^{\circ}$, da Lei $n^{\circ}$ 1.060/50, apenas sujeitando-se as pessoas com fins lucrativos à real comprovação da penúria financeira $^{561}$.

Também não se pode negar voz à corrente que sustenta o descabimento do benefício às pessoas jurídicas, embora se reconheça minoritária ${ }^{562}$.

É imperativo do Estado Democrático de Direito, em que o acesso à ordem jurídica justa é pedra fundamental, especialmente na construção de um Judiciário robusto, que não se estabeleçam restrições despropositadas, como seria o empeço a que pessoas jurídicas gozem da benesse legal.

Curial é ver-se que à base da garantia/direito fundamental de acesso à Justiça aos economicamente desfavorecidos está o reconhecimento de que problemas jurídicos atingem indiscriminadamente ricos e pobres (como de resto, também se acerca de doutos e indoutos, nacionais e estrangeiros, homens e mulheres, adultos e crianças, etc.). E mais, que por vezes a realidade pessoal de carência financeira implica restrição de acesso à potencial solução deste problema.

Ora, esta mesma conjuntura é verificável no universo das pessoas morais, que também são atingidas por problemas jurídicos e que também sofrem agruras financeiras que podem obstaculizar o acesso à solução almejada. Se tal obstáculo é considerado injusto

\footnotetext{
${ }^{561}$ DIDIER JR, Fredie; OLIVEIRA, Rafael. Benefício da justiça gratuita cit., p. 31-33, inclusive com citação de julgados.

${ }^{562}$ Há julgados citados por Maurício Vidigal (Lei da Assistência Judiciária interpretada, cit., p. 22), com o argumento de que a alusão a "sustento" só pode ser entendida como provisão de alimento, vestuário, educação, saúde, etc., necessidades básicas do ser humano. Na doutrina, é interessante observar que adota este posicionamento Artêmio Zanon no trecho que se transcreve a seguir, muito embora em linhas precedentes tenhamos apontado outro trecho da mesma obra, em que o autor adota posicionamento diametralmente oposto: "Venia concessa, apesar de haver decisões após a LAJ que concedem os benefícios da justiça gratuita também a algumas espécies de 'pessoa jurídica', tenho para mim que tal não se deveria admitir ainda que se trate de sociedade de fins não lucrativos e que tenha ou não patrimônio e rendas próprias" (ZANON, Artêmio. Assistência Judiciária gratuita: comentários à Lei da Assistência Judiciária (Lei n ${ }^{\circ}$ 1.060, de 5-2-1950), cit., p. 77).
} 
no que respeita à pessoa natural, porque se há de considerá-lo justo, ou ao menos aceitável, no que concerne à pessoa jurídica?

Definitivamente não há fator de discrímen a justificar uma diferença de tratamento tão gritante. É presumível da linha argumentativa até então seguida que estabelecer uma restrição de tal ordem, seria equivalente a negar-se, por exemplo, à mulher, o acesso ao benefício, em razão do sexo, ou fazê-lo em relação a crianças, em razão da idade. A iniqüidade presente é a mesma.

Obviamente que é irrelevante o fato do legislador infraconstitucional ter atinado apenas para a necessidade da pessoa natural. "A lei não pode instituir formas que tornem ilusórios os princípios constitucionais e as garantias que a Constituição assegura aos indivíduos" $" 563$.

Se alguma impertinente dúvida havia sob o império da anterior ordem constitucional, certamente não poderá ter sobrevivido à Constituição Cidadã. Se não quisermos recorrer aos princípios fundamentais de nosso Estado Democrático, os quais seriam mais que suficientes para ensejar a extensão do benefício às pessoas jurídicas, e nos mantivermos rentes à simplória interpretação gramatical, já teríamos arsenal suficiente para proclamar que também as pessoas jurídicas fazem jus à assistência jurídica.

É que o constituinte aludiu apenas "aos que comprovarem" e "insuficiência de recursos". Não há alusão a "residência", "sustento próprio" ou "família". Evidente que "insuficiência de recursos" é cláusula muito mais ampla, e pode sem receios abranger a condição financeira da pessoa jurídica.

Parece-nos que mesmo a antiga menção a "sustento próprio" era plenamente aplicável às pessoas jurídicas. Embora estas não ostentem família, estão sob o pálio de diversas responsabilidades indispensáveis à continuidade de sua atividade. A sociedade empresarial deve estar em dias com seus tributos; deve pagar seus empregados; quitar seus fornecedores; etc. O desajuste com relação a estas obrigações implicará irremediavelmente a interrupção de suas atividades (p.ex. a falta de pagamento da taxa para renovação de licenças poderá implicar a lacração do estabelecimento; sem salários, empregados não haverá; ante a inadimplência, novos fornecimentos de matéria-prima não serão feitos). Por isto pode-se facilmente dizer que estas obrigações básicas estão relacionadas ao "sustento

\footnotetext{
${ }^{563}$ ROSAS, Roberto. Processo civil e justiça social. Revista dos Tribunais, São Paulo, ano 71, v. 564, p. 9, out. 1982.
} 
próprio" das pessoas jurídicas, pois correspondem ao que, em relação à pessoa natural, se despende com a própria subsistência.

A pessoa jurídica que esteja sob risco de não conseguir arcar com estas despesas básicas não poderá arcar com os custos do processo sem prejuízo do próprio sustento, estando indiscutivelmente abarcada pelo conceito do p.único do art. $2^{\circ}$ da Lei $n^{\circ}$ $1.060 / 50^{564}$.

Parece claro do que foi exposto que o comprometimento de verba superavitária destinada, por exemplo, ao reinvestimento, incremento da atividade ou sua ampliação, não significa risco ao sustento próprio.

Do que expusemos alhures restou claro que uma sólida corrente de pensamento acerca do assunto invoca a finalidade da pessoa jurídica para fins de definir a possibilidade de incidência do benefício da assistência jurídica, ou pelo menos para definir-lhe os pressupostos exigíveis para gozo da benesse ${ }^{565}$.

Vale menção específica um julgado referido por Luís Thompson Flores, oriundo do Eg.Tribunal de Justiça do Estado do Rio de Janeiro, Ap.cível $n^{\circ}$ 7.888/RJ, em que se afirmou a respeito das entidades filantrópicas, de caridade ou pias, e que em geral não visem o lucro: "Nem precisa estar tal instituição em situação de insolvência, ou desaparelhada", argumentando-se que "empregar recursos na condução de uma demanda equivale a subtraí-los à consecução dos generosos fins sociais, razão de ser da sociedade apelada"566.

\footnotetext{
${ }^{564}$ É desse pensamento também Barbosa Moreira: “...conquanto pessoa jurídica não tenha família, perfeitamente se concebe que the faltem meios de prover às despesas do processo sem sacrificar sua própria manutenção" $(\mathrm{O}$ direito a assistência jurídica - evolução no ordenamento brasileiro de nosso tempo, cit., p. 128.

${ }^{565}$ É esta, por exemplo, a posição de Luís Alberto Thompson Flores Lenz: "Tal benefício, como é óbvio, só se aplica às entidades pias e beneficentes e nunca a associações civis e comerciais de fins lucrativos" (Da concessão da assistência judiciária gratuita às pessoas jurídicas e aos entes beneficentes, cit., p. 68). Citamos a seguir duas decisões que exemplificam as duas ramificações jurisprudenciais neste ponto: de um lado os que defendem que apenas às pessoas jurídicas sem fins lucrativos se estendem os benefícios da gratuidade, inclusive com presunção juris tantum de miserabilidade; e de outro os que admitem tal extensão aos entes que contam com finalidade lucrativa, mas sujeitam tais entidades à cabal prova de sua carência financeira: "O Superior Tribunal de Justiça firmou compreensão no sentido de que as pessoas jurídicas sem fins lucrativos (entidades filantrópicas, de assistência social e sindicatos) gozam de presunção juris tantum de miserabilidade, razão pela qual, para a concessão do benefício da gratuidade de justiça, é prescindível a comprovação de sua condição" (STJ, AgRg no REsp no 1.103.391/RS, Rel. Min. Arnaldo Esteves Lima, j. 20.04.10); e "A egrégia Corte Especial decidiu, no julgamento dos Embargos de Divergência no Recurso Especial $n^{\circ} 388.045 / R S$, em 22/09/2003, que as pessoas jurídicas com finalidade lucrativa podem gozar dos benefícios da justiça gratuita, desde que comprovem, de modo satisfatório, a impossibilidade de arcarem com os encargos processuais, sem comprometer a existência da entidade" (STJ, REsp n 604.259/SP, Rel. Min. Castro Filho, j. 13.12.05).

${ }^{566}$ LENZ, Luís Alberto Thompson Flores. Da concessão da assistência judiciária gratuita às pessoas jurídicas e aos entes beneficentes, cit., p. 67.
} 
Com todas as vênias, parece haver aí uma distorção de foco na apreciação da questão. O critério eleito pelo legislador já por antiqüíssima tradição, e sufragado na atual Constituição da República, como norte na apreciação do cabimento da assistência jurídica integral e gratuita é a singeleza financeira, a miserabilidade jurídica, pobreza legal, insuficiência de recursos. Imiscuir na avaliação acerca do cabimento do benefício a finalidade da pessoa jurídica que o requer parece destoar dos limites traçados pela Constituição e pela legislação infraconstitucional para o instituto.

É por isto também que não parece haver possibilidade de dispensar-se a situação de dificuldade econômica, mesmo que para entidades sem fins lucrativos ${ }^{567}$.

Quer-se dizer que a finalidade da pessoa jurídica pretendente ao benefício é irrelevante para fins de considerá-la abarcável pela benesse, que não é destinada aos que busquem lucro ou aos que visem o bem-estar do próximo, mas aos pobres ou economicamente desvalidos. Afastar do benefício as pessoas jurídicas com fins lucrativos é presumir que tal finalidade esteja a ser atingida com êxito pelo ente, isto é, de que esteja ela efetivamente a gozar lucros suficientes para fazer frente a esta despesa, e tal presunção, sobre não conter respaldo na lei, não encontra eco sequer na realidade sócio-econômica do país.

Não pode haver dúvidas, então, de que o benefício se estende às pessoas jurídicas independentemente de ostentarem finalidade exclusivamente lucrativa ou benemérita.

A questão que se segue é a de saber se possível distinguir entre uma e outra no que concerne à exigência de comprovação do estado de "pobreza"568.

Dizer que para a pessoa jurídica sem fins lucrativos é suficiente o requerimento do benefício, dispensando-a da comprovação do estado de miserabilidade, ou agraciando-a com a mesma presunção a que alude o art. $4^{\circ}, \S 1^{\circ}$, da Lei $n^{\circ} 1.060 / 50$, significa estabelecer

\footnotetext{
${ }^{567} \mathrm{O}$ critério invocado por Marcacini para aferir o cabimento do benefício às pessoas jurídicas é distinto do apresentado no texto, embora conduza à mesma conclusão acerca do cabimento, que, entretanto, entende o autor restrito às pessoas sem fins lucrativos: "A solução para o problema deve ser encontrada mediante o seguinte raciocínio: se houver um caso concreto em que a não-concessão da gratuidade implique inevitavelmente lesão aos princípios processuais constitucionais, a gratuidade deve ser concedida, ainda que o conceito legal de necessitado não se coadune com aquele que postula o benefício, pois a definição legal não se superpõe àqueles princípios superiores ... O que não se pode admitir é a concessão do benefício a entidades que tenham finalidade lucrativa, ainda que deficitárias" (Assistência jurídica, assistência judiciária e justiça gratuita, cit., p. 89).

568“ $\mathrm{O}$ benefício da assistência judiciária gratuita pode ser deferido às pessoas jurídicas, sendo mister, contudo, distinguir duas situações: (i) em se tratando de pessoa jurídica sem fins lucrativos (entidades filantrópicas ou de assistência social, sindicatos, etc.), basta o mero requerimento, cuja negativa condiciona-se à comprovação da ausência de estado de miserabilidade jurídica pelo ex adverso; (ii) no caso de pessoa jurídica com fins lucrativos, incumbe-lhe o onus probandi da impossibilidade de arcar com os encargos financeiros do processo (EREsp 388.045/RS, Rel. Ministro Gilson Dipp, Corte Especial, julgado em 01.08.2003, DJ 22.09.2003)" (STJ, AgRg no Ag n 1.297.627/RS, Rel. Luiz Fux, j. 01.06.2010).
} 
uma presunção de que, em razão de não ostentar finalidade de ganho, não ostentaria também liquidez patrimonial suficiente para arcar com os custos da demanda; de outro lado, negar o mesmo regime para a pessoa jurídica com fins lucrativos, a quem incumbiria a prova do estado de necessidade, significaria estabelecer uma presunção contrária, qual seja, a de que esta qualidade de ente ostentaria, via de regra, liquidez financeira suficiente para arcar com os custos do processo.

Este entendimento é, com o devido acatamento, tão equivocado, que tem acarretado na praxe forense distorções verdadeiramente insuportáveis. Fundações portentosas, proprietárias de patrimônio milionário, de todos conhecido (p.ex. porque proprietárias de Universidades; Hospitais; e serviços públicos desta natureza; etc.), vêm a juízo pretendendo, com o simples requerimento do benefício da gratuidade, a isenção legal; de outro lado, sociedades empresariais com fins lucrativos, às beiras da extrema unção, vêemse às voltas com a necessidade de arcar com os custos decorrentes da demanda.

Não há mesmo como estabelecer alguma relação necessária entre a condição financeira da pessoa jurídica e sua finalidade. $\mathrm{O}$ que se quer dizer é que entidades pias, filantrópicas e beneméritas poderão ostentar respeitável capacidade financeira (como sói ocorrer), caso em que seria completamente injustificável beneficiá-las seja com a isenção legal, seja com a própria assistência judiciária (e é comum que tais entes venham defendidos em juízo por bons profissionais advogados, contratados mediante boa remuneração). De outro lado, pessoas jurídicas empresariais poderão estar às voltas com a bancarrota, e daí fazerem jus ao benefício legal.

Não se está a defender que as pessoas jurídicas com fins lucrativos devem ser dispensadas da comprovação do estado de carência financeira, nem que as pessoas jurídicas sem fins lucrativos devem necessariamente comprová-la. Defende-se, neste quadrante, que o critério para concessão do benefício deve ser o mesmo para ambas as categorias de entes, não operando aí a finalidade como causa de distinção neste ponto.

Vejamos agora a questão da possibilidade ou não de extensão às pessoas jurídicas da presunção a que se refere o $\S 1^{\circ}$ do art. $4^{\circ}$ da Lei $n^{\circ} 1.060 / 50$.

Duas são as vertentes que serão propostas. A primeira delas é a de se buscar qual o fundamento para que tal presunção seja estabelecida em favor da pessoa natural, e tal não parece ser outro que não a idéia de que a boa-fé sempre se presume, antigo princípio geral 
de direito tão difundido, de modo que não seria correto presumir a falsidade da declaração de pobreza exigida.

Indaga-se então: ao exigir que a declaração de "pobreza" (seria melhor dizer de insuficiência financeira) apresentada pela pessoa jurídica venha acompanhada da efetiva comprovação do desfavor econômico não se estaria a, de plano, presumir sua falsidade? Esta presunção é legítima diante daquele princípio geral de que é a boa-fé que sempre se presume?

Segunda vertente: o principal argumento para afirmar a extensão do benefício da assistência jurídica às pessoas jurídicas é afirmar que quer o art. $5^{\circ}$, LXXXIV, da Constituição da República, quer o art. $2^{\circ}$, "caput" e p.único, da Lei n ${ }^{\circ} 1.060 / 50$, não estabeleceram distinção entre classes de pessoas, de modo que o regime jurídico da assistência jurídica seria aplicável tanto às pessoas naturais, como às jurídicas, indistintamente.

Ora, ao encetarmos esta afirmação estamos estendendo em sua inteireza o regime jurídico da assistência jurídica às pessoas jurídicas, tal como previsto para as pessoas físicas. Assim é que as verbas abarcadas pela benesse (art. $3^{\circ}$ ) serão as mesmas; o procedimento para concessão, impugnação e revogação será o mesmo (arts. $5^{\circ}$ a $8^{\circ}$ ); a extensão temporal será a mesma (art. $\left.9^{\circ}\right)$; etc.

Qual a justificativa para decotarmos, deste regime jurídico, apenas a questão atinente à comprovação da necessidade, que ao contrário de todos os demais elementos, não se dará na forma prevista pelo art. $4^{\circ}$ da Lei $n^{\circ} 1.060 / 50$ ?

A resposta à primeira questão é evidentemente negativa (se ao se exigir comprovação estar-se-ia presumindo a falsidade da declaração?). É tradicionalíssima a regra de que o ônus da prova de determinada afirmação incumbe a quem a formula. Aliás, é tal princípio que está à base do art. 333, I e II, do Código de Processo Civil. Ao autor incumbe a prova do fato constitutivo de seu direito, e nem por isto se afirma que há uma inicial presunção de que sejam falsas suas alegações.

Assim, em se exigir no caso de pessoa jurídica que acompanhe à sua alegação de insuficiência de recursos as provas pertinentes, nada mais se está fazendo que dando aplicação à regra do citado art. 333, I, do Código de Processo Civil, pois que seria injustificada a incidência da inversão do ônus da prova que o art. $4^{\circ}, \S 1^{\circ}$, da Lei $n^{o}$ $1.060 / 50$ enseja. 
E aí é que surge a segunda questão: o que justificaria no caso o afastamento da regra do art. $4^{\circ}, \S 1^{\circ}$, da Lei $n^{\circ} 1.060 / 50$, quando todas as demais regras que formam o regime jurídico da assistência judiciária/gratuidade, são aplicáveis à pessoa jurídica?

Não vemos resposta justificável, senão o preconceito de que as pessoas jurídicas dificilmente passariam por reveses econômicos e que seriam, normalmente, abastadas, e assim não se lhes poderia aceitar qualquer declaração de miserabilidade com presunção de veracidade. Mudanças no regime jurídico da assistência jurídica em relação à pessoa jurídica apenas seriam aceitáveis quando relacionadas à natureza destas, diversa da das pessoas físicas, o que não é o caso quando se afasta a presunção de veracidade da declaração de pobreza (porque seria que o representante legal quando apresentasse declaração em próprio nome, litigando como pessoa natural, seria agraciado com a presunção; e quando apresentasse a mesma declaração, agora em nome da sociedade que compõe, não o seria?).

Ao que parece, então, a declaração de insuficiência econômica apresentada pelo representante legal da pessoa jurídica goza a mesma credibilidade que aquela apresentada pela pessoa natural, pois não há fator de discrímen que legitime uma tal distinção, quando todos os demais compostos do regime jurídico da assistência judiciária e gratuidade são aplicados de forma indistinta em favor da pessoa jurídica. Mas isto não quer significar a desconstrução de todo arcabouço jurisprudencial e doutrinário formado em torno do assunto (e que em parte foi já por nós destacado, especialmente nas notas anteriores).

A peculiaridade quando o caso é de concessão à pessoa jurídica é a necessidade de maior cautela do órgão judicial, com especial atenção para indícios de abuso ${ }^{569}$, e isto se justifica porque o qualificativo de "necessitado" e a noção de "prejuízo ao sustento próprio" quando se referem à pessoa jurídica, são diversos do que se verifica em relação à pessoa natural, o que decorre naturalmente da diferença da natureza de ambas.

Veja-se, por exemplo, que no caso de sociedades empresariais, será documento que necessariamente instruirá a inicial, por indispensável à propositura da ação, o contrato social $^{570}$. Nele estarão declinados importantes elementos, como o valor do capital social e a quantidade de sócios, a localização do estabelecimento e eventualmente, até indicação de filiais; o ramo de atividade; etc.

\footnotetext{
${ }^{569}$ BARBOSA MOREIRA, José Carlos. O direito a assistência jurídica - evolução no ordenamento brasileiro de nosso tempo, cit., p. 128.

${ }^{570}$ Devemos lembrar que há sólida jurisprudência no sentido de que tal documento não constitui indispensável componente do ajuizamento.
} 
Estes elementos deverão ser atentamente avaliados pelo juízo para o caso de, havendo suspeita de abuso, exigir, mesmo de ofício, comprovação do estado de miserabilidade alegado ${ }^{571}$. Até mesmo fato de conhecimento público, notório, poderá ensejar a exigência de prova pelo magistrado, bastando imaginar-se que compareça a juízo conhecida multinacional e requeira o benefício; ou o conhecido supermercado da pequena cidade do interior; filial de conhecida rede de lojas; sociedade empresarial que constitui o carro chefe da atividade econômica da região; etc. Os exemplos se multiplicariam às escâncaras.

O que é importante ficar vincado é que nestes casos a exigência de comprovação do estado de pobreza não advém dum imaginário menor valor atribuído à declaração a que se refere o art. $4^{\circ}$ da Lei $n^{\circ} 1.060 / 50$, ou mesmo do só fato de ostentar o requerente a qualidade de pessoa jurídica, mas sim da existência nos autos de dados que justifiquem a suspeita. E tal se daria mesmo em relação à pessoa natural que tenha ajuntado à inicial sua declaração de pobreza.

É fora de dúvida que suspeitando o órgão judicial da declaração porque, por exemplo, a pessoa natural requerente se qualifique como empresário; servidor público de alto escalão; etc., ou porque as próprias características da matéria fática debatida induzam a desconfiança (sobre alhures já falamos), poderá da mesmíssima forma exigir também da pessoa física a comprovação do estado de pobreza anunciado ${ }^{572}$.

Arrolemos nossas conclusões: a) a pessoa jurídica pode ser abarcada pela assistência jurídica integral e gratuita; b) tal extensão independe da finalidade ou natureza da pessoa jurídica, mas apenas de sua saúde financeira; c) os pressupostos para a concessão da benesse não se hão de distinguir em razão da finalidade ou natureza da pessoa jurídica que o requer, de modo que pessoas dotadas de finalidades beneméritas ou lucrativas, estarão sob as mesmas exigências; d) a forma de comprovação do estado de pobreza aplicável às pessoas jurídicas é o mesmo que o previsto para as pessoas naturais; e) apenas que com relação às pessoas jurídicas recomenda-se ao órgão judicial maior cautela, porque

571،"PROCESSO CIVIL - GRATUIDADE DA JUSTIÇA (LEI 1.060/50). 1. A presunção contida no art. $4^{\circ}$ da Lei 1.060/50, quanto à declaração de pobreza, dispensa o requerente de comprovação. 2. Possibilidade de exigir-se prova quando assim o entender o magistrado, ou quando houver impugnação da parte contrária. 3. O juiz pode, de ofício, exigir comprovação, se não se satisfez com a mera afirmação. 4. Recurso especial provido”. (STJ, REsp no 465.966/RS, Rel. Min. Eliana Calmon, j. 09.12.03).

572“"A miserabilidade processual deve ser vista no contexto do processo, seja em relação à presunção ou demonstração de necessidade, seja em relação aos ônus que o interessado suportará. A autora é funcionária pública, exerceu ou exerce função de direção, tem vencimentos razoáveis e não se enquadra 'prima facie' no perfil da lei; as despesas processuais não são elevadas e não justificam a isenção pretendida" (TJSP, Agravo Interno, $\mathrm{n}^{\circ}$ 611.244.5/3-01, Rel. Torres de Carvalho, j. 29.01.07). 
a natureza destas, entes morais que são, implica diversa qualificação do estado de necessidade e do requisito de "prejuízo ao próprio sustento".

Tragamos a título informativo alguns entendimentos acerca do assunto. Há quem defenda que pessoas jurídicas que, embora sem finalidade lucrativa, sejam destinadas a servir a seus sócios, como é o caso de clubes e associações, não poderiam receber o benefício, cabendo nestes casos aos próprios sócios suprir a deficiência econômica da entidade. Pela mesma razão, também as cooperativas não fariam jus à benesse, pois caberia aos cooperados o socorro, apenas cabendo o benefício se todos os cooperados se subsumirem ao conceito de necessitado segundo o p.único do art. $2^{\circ}$ da Lei $n^{\circ} 1.060 / 50^{573}$.

Com relação aos sindicatos, há de se observar que são pessoas jurídicas sem fins lucrativos, de modo que remetemos a tudo quanto já dissemos acerca desta classe de entidades. Apenas há de se observar que por vezes tais entidades atuam como substitutos processuais de seus associados. Nesta hipótese há de ser considerada a condição econômica do substituto processual e não do substituído, pois é quem efetivamente atua em juízo ou fora dele. Não teria sentido conceder ao sindicato riquíssimo isenção da custas e despesas processuais porque atua defendendo direito de associado necessitado.

A jurisprudência é vacilante no que concerne a sociedades empresariais em regime de recuperação judicial. Afirma-se, de um lado, que a "circunstância de a empresa agravante ser beneficiária do favor legal da recuperação judicial não faz inferir, por si só, que também faz jus à benesse da gratuidade da justiça” (TJSP, AI n 7.277.321-4, Rel. Castro Figliolia, j. 08.10.09) ${ }^{574}$. De outro também já se decidiu que "demonstrada a insuficiência econômica pelo deferimento do pedido de recuperação judicial, é possível a concessão da gratuidade" (TJSP, AI n 7.350.853-9, Rel. Miguel Petroni Neto, j. 31.08.09).

No que respeita à massa falida, há decisões no sentido de que "não há como presumir miserabilidade na falência, porquanto, a despeito da preferência legal de determinados créditos, subsistem, apenas, interesses de credores na preservação do montante patrimonial a ser rateado. Frise-se que a massa falida, quando demandante ou

\footnotetext{
${ }^{573}$ DEMO, Roberto Luis Luchi. Assistência judiciária gratuita, cit., p. 349-350.

574،“Assistência Judiciária - Pessoa Jurídica - Empresa em Recuperação Judicial - Ausência de prova da impossibilidade de a agravante arcar com as despesas do processo - Situação de desequilíbrio financeiro que não comprova, por si só, a necessidade do benefício - Recurso improvido" (TJSP, AI n ${ }^{\circ}$ 990.10.030595-6, Rel. Elliot Akel, j. 06.07.10); ainda: "ASSISTÊNCIA JUDICIÁRIA - Benesse Processual - Pessoa Jurídica em recuperação judicial - Prova da incapacidade financeira - Ausência Inexistência da prova de balanço negativo e dificuldade para honrar pro labore do sócio - Hipossuficiência não demonstrada - Decisão mantida - Recurso improvido" (TJSP, AI nº 7.413.110-1, Rel. Mario de Oliveira, j. 02.10.09).
} 
demanda, se sujeita aos ônus sucumbenciais" (STJ, EREsp n ${ }^{\circ}$ 855.020/PR, Rel. Benedito Gonçalves, 28.10.09) ${ }^{575}$.

É óbvio que não se pode deduzir que a pessoa jurídica apenas fará jus ao benefício da gratuidade quando estiver às portas da falência ou de recuperação judicial. Apenas exemplificamos com estas situações porque casos de extremada dificuldade financeira. Basta que haja potencial prejuízo àquelas despesas básicas a que já aludimos.

Note-se ainda que em algumas situações embora o requerente seja pessoa jurídica de fins empresariais, e portanto lucrativos, sua singeleza denuncia tratar-se de mero apanágio da pessoa natural, que constitui o núcleo e força motriz da atividade. Isto é, são casos em que "predomina a presença e a participação pessoal de um profissional, que usa da microempresa ou da firma em nome individual para o exercício da sua atividade" ${ }^{, 576}$. Nestes casos deverá haver especial atenção do órgão judicial para as condições econômicas daquela pessoa natural que constitui o arrimo da atividade, pois é quem, na realidade, está demandando.

Lembre-se, contudo, que no caso de empresa individual, embora para fins fiscais possa até existir alguma equiparação à pessoa jurídica, a rigor processualmente quem comparece em juízo para defender os interesses relacionados à atividade é o próprio empresário pessoa natural, visto que não há distinção de personalidades jurídicas e patrimônio.

Ressalte-se também que a assistência jurídica é extensível aos entes que, embora não dotados de personalidade jurídica, o são de personalidade judiciária, isto é, gozam

\footnotetext{
${ }^{575}$ No mesmo sentido: "PROCESSUAL CIVIL E TRIBUTÁRIO. JUSTIÇA GRATUITA. MASSA FALIDA. HIPOSSUFICIÊNCIA PRESUMIDA INEXISTÊNCIA. 1. Não é presumível a existência de dificuldade financeira da empresa em face de sua insolvabilidade pela decretação da falência para justificar a concessão dos benefícios da justiça gratuita. 2. Nos termos da jurisprudência do STJ e do STF, a massa falida, quando demandante ou demandada, sujeita-se ao princípio da sucumbência (Precedentes: Ag 1031939/MG, Rel. Min. Mauro Campbell, DJe 01.09.08; REsp 148.296/SP, Rel. Min. Adhemar Maciel, Segunda Turma, DJ 07.12.1998; REsp 8.353/SP, Rel. Min. Humberto Gomes de Barros, Primeira Turma, DJ 17.05.1993; STF RE 95.146/RS, Rel. Min. Sydney Sanches, Primeira Turma, DJ 03-05-1985) 3. Recurso especial não provido" (STJ, REsp n ${ }^{\circ}$ 1.075.767/MG, Rel. Castro Meira, j. 25.11.08). E ainda: "Tratando-se de massa falida, não se pode presumir pela simples quebra o estado de miserabilidade jurídica, tanto mais que os benefícios de que pode gozar a 'massa falida' já estão legal e expressamente previstos, dado que a massa falida é decorrência exatamente não da 'precária' saúde financeira (passivo superior ao ativo), mas da própria 'falta' ou 'perda' dessa saúde financeira" (STJ, REsp nº 833.353/MG, Rel. Francisco Falcão, j. 15.05.07).

${ }^{576}$ DEMO, Roberto Luis Luchi. Assistência judiciária gratuita, cit., p. 349.
} 
capacidade de estar em juízo. É o caso do condomínio, espólio, massa falida, nascituro, heranças jacente e vacante ${ }^{577}$.

Convém, por fim, registrar que o projeto de Código de Processo Civil em vias de aprovação contempla de forma expressa a possibilidade de extensão do benefício às pessoas jurídicas, conforme o "caput” do art. 99: “A pessoa natural ou jurídica, brasileira ou estrangeira, com insuficiência de recursos para pagar as custas e as despesas processuais e os honorários de advogado gozará dos benefícios da gratuidade de justiça, na forma da lei”.

\section{Entes obrigados}

Passa-se agora à análise do alcance subjetivo de ordem ativa relacionado à assistência jurídica integral e gratuita. Como já dito alhures, cuida-se aqui de analisar quem são os possíveis obrigados à prestação. Fixar esta idéia é de suma importância porque definirá, a rigor, quem poderá figurar no pólo passivo de possíveis demandas que versem a questão da assistência jurídica, seja para postular que o Estado-Juiz torne efetiva a missão constitucionalmente cometida, impondo a obrigação de fazer, seja para postular a compensação financeira correspondente à sua falta ou defeituosa prestação.

O inciso LXXIV do art. $5^{\circ}$ da Constituição estabelece que o Estado prestará assistência jurídica integral e gratuita, obviamente utilizando a expressão em sentido amplo, não federativo. $\mathrm{O}$ art. $1^{\circ}$ da Lei $\mathrm{n}^{\circ} 1.060 / 50$ na sua original redação previa que a assistência judiciária seria incumbência dos poderes públicos federal e estadual. A redação trazida pela Lei no 7.510/86 precisou tal redação: “Os poderes públicos federal e estadual, independente da colaboração que possam receber dos municípios e da Ordem dos Advogados do Brasil, - OAB, concederão assistência judiciária aos necessitados nos termos da presente Lei”.

Com isto parece claro que a obrigação de prestação do serviço público de assistência jurídica integral e gratuita, ou ao menos da assistência judiciária, é incumbência

\footnotetext{
${ }^{577}$ DIDIER JR, Fredie; OLIVEIRA, Rafael. Benefício da justiça gratuita, cit., p. 34. Exemplificativamente, veja-se o seguinte julgado: "Despesas de condomínio. Ação de cobrança. Gratuidade judiciária. Condomínio, sob forte quadro de inadimplência. Excepcionalidade. Princípio do livre acesso à jurisdição. Benefício concedido. Recurso provido. Excepcionalidade, interesse coletivo submetido a risco, sobrevida de Condomínio, sob forte conjuntura de inadimplência de consortes, recurso a empréstimo bancário para fazer frente aos suprimentos de rotina, custas processuais, valores que somam expressivos, extensa a lista de cobranças a ajuizar, justifica-se, constitui adequado apreço ao princípio do livre acesso à jurisdição, conceder, nessa intercorrência, beneficio de gratuidade judiciária” (2 TAcSP, AI n ${ }^{\circ}$ 731255-0/8, Rel. Carlos Russo, j. 09.04.02).
} 
precípua da União e dos Estados. Isto não quer dizer que a tais entes cabe exclusividade nesta atividade, como se verá adiante. No que respeita precisamente ao benefício da gratuidade, que de forma específica se refere exclusivamente à dispensa provisória das custas e despesas processuais, parece óbvio que acabará arcando com os encargos advindos da isenção o ente situado na esfera de atuação da atividade jurisdicional que for acionada.

Assim, no âmbito da Justiça Estadual (que pode ser a dita "comum" ou mesmo a especializada, que no caso da Justiça Estadual é a Militar), incumbirá ao Estado-membro financiar a causa, seja por meio da isenção, seja arcando com os custos que seriam atribuíveis ao beneficiário, como honorários de advogado, peritos, indenização de testemunhas, etc., como já abordado anteriormente. Na órbita federal, à União caberá custear tais encargos, abrangendo seu suporte tanto a Justiça Federal (que é a "comum") como as especiais (Justiça do Trabalho; Justiça Eleitoral e Justiça Militar).

Vale lembrar nesta quadra que o art. $2^{\circ}$, "caput", da Lei $n^{\circ} 1.060 / 50$ refere-se de forma expressa ao gozo do benefício na "Justiça penal, civil, militar ou do trabalho".

Poder-se-ia imaginar que por não dispormos em nossa organização políticoadministrativa de justiças municipais, o município estaria isento de obrigações nesta esfera de atividade estatal. Não é assim contudo.

Primeiro que uma simples interpretação gramatical de cotejo do art. $5^{\circ}$, LXXIV, da Constituição da República em relação ao art. $1^{\circ}$ da Lei $n^{\circ} 1.060 / 50$ já não permite esta conclusão. De fato, o inciso constitucional alude a uma cominação em relação ao Estado que é assim referido sem conotações federativas, de modo a abranger todas as pessoas políticas, União, Estados-membros e Municípios; e o inciso em questão refere-se à assistência jurídica integral e gratuita.

Ora, já restou delineada a distinção entre assistência jurídica; assistência judiciária e gratuidade. A Lei $\mathrm{n}^{\mathrm{o}}$ 1.060/50 refere-se exclusivamente à assistência judiciária e à gratuidade, partes integrantes do todo mais amplo que compreende a assistência jurídica. Logo, apenas as atividades na modalidade assistência judiciária e gratuidade é que são da restrita alçada dos Estados e da União, ao menos em caráter de imposição legal. As demais atividades relacionadas à assistência jurídica, e aqui nos referimos à atividade consultiva e extrajudicial, que também integra aquele conceito, são cometidas a todas as pessoas políticas conforme a dicção constitucional. 
Em segundo lugar deve-se ter em mente que a Lei $\mathrm{n}^{\circ} 1.060 / 50$ e a própria Constituição da República, estabelecem um mínimo a ser assegurado ao necessitado. Por outras palavras, a interpretação que o art. $1^{\circ}$ da Lei $n^{\circ} 1.060 / 50$ deve receber é a de que a assistência judiciária será prestada pelo menos pelos poderes públicos federal e estadual, o que é confirmado pela cláusula "independente da colaboração que possam receber dos municípios e da Ordem dos Advogados do Brasil, - OAB”, e não no sentido de que apenas os poderes públicos federal e estadual a prestarão.

Certo é, contudo, que deverá haver lei municipal institucionalizando o serviço. Maurício Vidigal inclusive faz uma distinção: se a lei municipal estipular o dever geral de prestação da assistência judiciária pelo Município, poderá este ser obrigado inclusive a ressarcir terceiros que suprirem sua falha (p.ex. advogados particulares atuando em regime de assistência, como dativos); de outro lado se há a simples manutenção de serviço municipal de assistência judiciária, sem a previsão de caráter geral retro citada, então não se lhe poderá atribuir responsabilidade por remunerar terceiros que supram a possível deficiência deste serviço ${ }^{578}$.

A posição, contudo, não é pacífica. Afirma-se que qualquer lei municipal que institua órgão de assistência jurídica para atendimento aos munícipes seria inconstitucional, por afronta à atribuição constitucionalmente assegurada à Defensoria Pública que comporta apenas repartição nas esferas estadual e federal. Chega-se, aliás, ao extremo de afirmar que os profissionais que eventualmente atuem nestas "assistências municipais" incorreriam em crime de usurpação de função pública, tipificado pelo art. 328 do Código Penal ${ }^{579}$.

\footnotetext{
${ }^{578}$ VIDIGAL, Mauricio. Lei da Assistência Judiciária interpretada, cit., p. 13.

${ }^{579}$ CARVALHO, Leandro Coelho. As atribuições da Defensoria Pública sob a ótica do acesso à ordem jurídica justa, cit., p. 209-210. Eis os argumentos veiculados pelo autor em questão: "Por melhores que sejam os profissionais contratados, não possuem as prerrogativas dos defensores públicos (prazo em dobro, poder de requisição de documentos de órgãos públicos e inexigibilidade de mandato, dentro outros) e baseiam-se num modelo proveniente da advocacia, sem a busca constante da efetividade, nem adoção das práticas de Justiça Restaurativa. Em outras palavras, propiciam meramente acesso formal ao Judiciário, e não à ordem jurídica justa, como seria desejável. Tampouco atuam na esfera administrativa. Nada impede haja cobrança pelo serviço, que necessariamente deve ser gratuito. A inexistência de concurso para ingresso e de corregedoria na maioria dos casos, igualmente contribui para a prestação do serviço de qualidade duvidosa. Por fim, muitas vezes estas 'Defensorias' atendem precipuamente a interesses eleitoreiros de Prefeitos ou ao próprio Município, contra quem dificilmente litigam, menosprezando os direitos das pessoas carentes" (cit., p. 209-210). Parece que os argumentos em questão não convencem, porque não se referem propriamente à análise da situação em tese, senão aos defeitos na forma de concretização das iniciativas municipais. Bastaria que encontrássemos um determinado Município em que os profissionais engajados no serviço fossem concursados (p.ex. procuradores municipais), que recebam unicamente dos cofres municipais seus vencimentos (ou seja, atuem gratuitamente), sob uma corregedoria eficiente e em esferas múltiplas, inclusive extrajudicial, que os argumentos esvanecem. O que queremos dizer é que uma
} 
A doutrina refere três sistemas possíveis no que respeita à forma pela qual o Estado se desincumbe do serviço público de assistência jurídica. O primeiro deles, chamado judicare, preconiza a atuação de advogados particulares, profissionais liberais, que são remunerados pelo Estado pela atuação em questão, mas sem por isto passarem a pertencer ao quadro administrativo do Poder Público; o segundo sistema constitui-se naquele formado por advogados servidores públicos, integrantes do aparato do Estado, remunerados por vencimentos; e por fim, o terceiro sistema chamado misto, formado pela combinação dos outros dois: atuação em assistência jurídica tanto de advogados particulares como de servidores públicos ${ }^{580}$.

No Brasil podemos afirmar a existência de um quadro peculiar: a prevalência do sistema de prestação combinada ou mista, não por opção legislativa, mas por incompetência do Estado. Como dito alhures, a Constituição da República idealizou o órgão para a prestação da assistência jurídica, a Defensoria Pública, deixando nítido que assegurou, pelo menos, a prestação em questão por meio de membros de uma carreira institucionalizada.

Fato é, contudo, que a implementação de tal carreira não se efetivou senão recentemente, seja em nível federal (Defensoria Pública da União) seja estadual (Defensorias Públicas dos Estados) e mesmo assim ainda de forma incompleta e insuficiente para atender à demanda, o que vem impondo a necessidade da atividade supletiva de advogados particulares ou mesmo de procuradores do Estado, como ocorre em São Paulo ${ }^{581}$.

coisa é sustentar a afronta a atribuições constitucionais exclusivamente cometidas à Defensoria Pública (argumento válido); outra bem diversa é defender que a forma como prestado o serviço, por ser inadequada ao ideal delineado na Constituição, seria inconstitucional. Já no texto ficou registrado nosso entendimento diverso, no sentido de que a Constituição assegura o mínimo a ser ofertado ao carente.

${ }^{580}$ MARCACINI, Augusto Tavares Rosa. Assistência jurídica, assistência judiciária e justiça gratuita, cit., p. 62-63; GIANNAKOS, Ângelo Maraninchi. Assistência judiciária no direito brasileiro, cit., p. 23-24. O primeiro dos autores citados refere as possíveis vantagens e desvantagens de cada um dos sistemas, e conclui que o sistema combinado ou misto seria, segundo seu ponto de vista, o mais proveitoso ao carente. Segundo Giannakos, o sistema judicare é o adotado na Alemanha; Áustria; França; Holanda e Inglaterra. A forma mista é a adotada na Suécia.

${ }^{581}$ Ainda é de se notar que a principal vantagem apontada para o sistema judicare, qual seja, a de possibilitar ao assistido a escolha do profissional de sua confiança para atuar remunerado pelo Estado, é ignorada pela forma como, na prática, tal sistema tem operado, ao menos no Estado de São Paulo. É que apesar do que consta do $\S 4^{\circ}$ do art. $5^{\circ}$ da Lei ${ }^{\circ} 1.060 / 50$, temos que a parte necessitada será assistida pelo advogado indicado pela Subseção local da Ordem dos Advogados do Brasil, não tendo havido notícia em nossa vida profissional de que alguém tenha indicado advogado de sua confiança, e que este tenha logrado remunerarse pelo Estado, nos termos do convênio mantido entre a Defensoria Pública e a OAB. 


\section{Atuação de advogados particulares e entidades privadas}

Conforme afiança Barbosa Moreira, "nada autoriza supor que a Constituição haja reservado ao Poder Público o monopólio da assistência. Se ele tem o dever de assistir, nem por isso se concluirá que o tenha em caráter exclusivo" ${ }^{\text {"582 }}$. É bem por isto que já referimos a possibilidade do Município reforçar a atuação estatal nesta seara.

E não apenas isto. O fato de a Constituição da República ter idealizado um órgão destinado ao desempenho da atividade prevista pelo art. $5^{\circ}$, LXXIV, a saber, a Defensoria Pública (art. 134) não significa que tenha atribuído exclusivamente a este órgão tal desiderato. Disse-se já, e repete-se agora, a Constituição assegura o mínimo a fim de não remanescer a sua norma como mero ornamento à ordem constitucional; porém todo auxílio será bem vindo.

Assim é que não apenas o Município, mas também a sociedade civil poderá vir em apoio (ou seria melhor dizer em socorro) do Estado na atuação da assistência jurídica. Por isto é que entidades civis sem fins lucrativos, como fundações e organizações nãogovernamentais; escritórios-escolas vinculados a Universidades; sindicatos; etc., são figuras comumente vistas prestando serviço desta índole. O próprio apoio supletivo da Ordem dos Advogados do Brasil seria oportuno.

A concorrência de advogados particulares é deveras proveitosa mesmo que se verificasse suficiência da atuação da Defensoria Pública para atendimento à demanda, o que poria à disposição do necessitado mais uma opção para satisfação de sua necessidade, e mais, não se pode negar que a atuação exclusiva nesta seara de órgãos vinculados ao Estado pode causar certo desconforto, visto que possivelmente em muitos casos as pretensões dos necessitados se voltam contra o próprio Estado, sendo saudável que haja possibilidade de recurso a um profissional desvinculado ao aparato estatal.

Sugestiona-se que a Defensoria Pública, a par de sua atuação concreta voltada à assistência jurídica, igualmente atue como órgão gestor; fiscalizador e arregimentador das entidades privadas, e especialmente dos advogados particulares, que atuem em auxílio ao Poder Público 583 .

\footnotetext{
${ }^{582}$ BARBOSA MOREIRA, José Carlos. O direito a assistência jurídica - evolução no ordenamento brasileiro de nosso tempo, cit., p. 130.

${ }^{583}$ RAMOS, Glauco Gumerato. Assistência jurídica integral ao necessitado, cit., p. 54-55. Na verdade o autor dá a impressão de sugerir a atuação da Defensoria exclusivamente nesta frente fiscalizatória e gestora, propondo então a conformação desta como órgão "enxuto". Parece-nos, entretanto, que uma atuação não prescinda da outra. Resumir a atividade da Defensoria aos lindes propostos seria descumprir sua missão constitucional, que é prestar a assistência jurídica. A par disto seria salutar sua atuação nas áreas supra referidas, como forma até de suprir suas próprias limitações no desempenho de sua função constitucional.
} 
Na qualidade de gestora, à Defensoria Pública incumbiria gerir e administrar os convênios firmados entre entidades privadas ou a Ordem dos Advogados do Brasil e o Estado (em sentido amplo), compondo as tabelas remuneratórias, definindo-lhes as rubricas e mesmo o patamar de honorária devido.

Presentemente um dos grandes entraves à atuação do advogado particular em regime de assistência jurídica é a forma lacunosa com que confeccionadas as tabelas de honorários pagos pelo Estado, sem contar a modicidade dos valores e sua constante defasagem em relação ao advogado que atua na forma particular (isto é contratos privados firmados com clientes para prestação do serviço em caráter particular).

Uma atuação perspicaz da Defensoria levaria à previsão de verbas para as consultas preventivas, e toda sorte de atividade extrajudicial (p.ex. elaboração de contratos; acompanhamentos a ofícios extrajudiciais; atuação em sessões de mediações e tentativas de composição pré-processuais; ou até a singela atividade de contatar a parte contrária e tentar, mediante negociações informais, chegar a um acordo). Atualmente a omissão em questão opera como estímulo ao demandismo, já que entre realizar um acordo no curso do processo, em audiência preliminar, e lograr receber honorários do Estado, e realizar o mesmo acordo pré-processualmente, sem ajuizamento de ação, e nada receber por falta de precisão na tabela própria, há o advogado de legitimamente realizar a primeira opção.

Na qualidade de fiscalizadora, a Defensoria Pública seria incumbida de realizar constantes avaliações da qualidade do serviço prestado pelo advogado dativo, analisando o conteúdo de peças apresentadas; desempenho em audiência; ou mesmo de atendimentos prestados; combatividade; sem prejuízo de também fiscalizar o pagamento dos honorários mediante comprovação de realização da atividade remunerada.

E por fim, como arregimentador, à Defensoria caberia selecionar os advogados aptos à prestação do serviço público de assistência jurídica, e aqui há de ter-se todo o cuidado. É óbvio que não se pode pretender uma duplicação do concurso público para Defensores Públicos, mas isto não quer dizer que o patrono possa inscrever-se sem maiores indicações ao órgão gestor de sua capacidade técnica e conhecimento jurídico.

Para isto a aplicação de singelas provas tanto para inscrição como à guisa de reciclagem para os que já estão inscritos não constituiria pecado algum, além da análise de currículos, motivando-se o profissional a realizar cursos de especialização, pós-graduação, e, enfim, de aprimoramento de seu conhecimento. Tais provas se prestariam a avaliar a 
presença do conhecimento básico na área para a qual pretende inscrever-se o patrono. Infelizmente a proliferação de cursos jurídicos de baixíssima qualidade tem depauperado a classe dos advogados, que por vezes não revelam condições mínimas para o exercício de seu ministério privado, por mais esforços que, reconhecidamente, se empreendam nos exames de Ordem. A praxe do dia-a-dia forense o mostra. Não parece justo impor ao necessitado pagar a conta por este desvirtuamento.

Outra proposta que motivaria o aprimoramento seria a fixação de honorários escalonados de acordo com o nível de maestria do advogado, apurando-se conforme critérios objetivos (p.ex. uma gradação: advogados com nível de especialização; nível de mestrado; nível de doutorado; nível de livre docência; advogados com cursos de aperfeiçoamento ou sem nenhum destes predicados).

O que não se permite sem afronta à Constituição é um modelo de assistência baseado na inexistência de Defensoria Pública, admitindo-se a concorrência de outras figuras em caráter complementar ${ }^{584}$.

Aliás, nota-se um virogoso ranço entre Defensores Públicos em serem de qualquer forma vinculados à atividade própria do advogado, questionando-se até mesmo a localização topográfica do art. 134 da Constituição da República ${ }^{585}$. Afirma-se a inconstitucionalidade do $\S 1^{\circ}$ do art. $3^{\circ}$ da Lei $\mathrm{n}^{\circ}$ 8.906/94 (a norma prescreve que os Defensores Públicos exercem atividade de advocacia). O argumento é um tanto convincente: o art. 134, $\S 1^{\circ}$, da Constituição estipula em relação aos Defensores Públicos ser-lhes "vedado o exercício da advocacia fora das atribuições institucionais".

Daí a conclusão de que a Defensoria Pública seria atividade incompatível com a advocacia, e que ao empossar-se no cargo deveria o advogado, agora Defensor, licenciar-se nos termos em que estipula o art. 12, II, da Lei $\mathrm{n}^{\circ}$ 8.906/94 (Estatuto da Ordem dos Advogados do Brasil); e, se aplicado o dito $\S 1^{\circ}$ do art. $3^{\circ}$ (que prevê a atividade funcional

\footnotetext{
${ }^{584}$ CARVALHO, André de; RIBEIRO, Marcus Vinicius. Direitos humanos, inclusão jurídica e o papel da assistência jurídica no Brasil do século XXI, cit., p. 53.

585،Defensor Público não é advogado... A afirmação, tão simples quanto direta, reflete um dos maiores entraves à verdadeira consolidação da Defensoria Pública no Brasil e revela a fonte de inúmeros equívocos na praxe forense. A paradoxal correlação entre a Defensoria Pública e a Advocacia encontra óbices de natureza prática, jurídica e ética" (CARVALHO, Leandro Coelho. As atribuições da Defensoria Pública sob a ótica do acesso à ordem jurídica justa, cit., p. 218). Afirma o autor que a manutenção dos Defensores nos quadros da Ordem dos Advogados, aliás, questão de polêmica atual, é tisnada por razões políticas de ambos os lados. De um lado Defensores seriam ávidos pela possibilidade de paralelamente à atividade funcional desempenharem o ministério privado, até como forma de compensar a baixa remuneração; e do lado da Ordem, o interesse seria em preservar a arrecadação (contribuições pagas pelos Defensores filiados) além de manter certo controle sobre atuação de tanto relevo para o interesse público (cit., p. 220).
} 
de Defensoria como espécie do gênero advocacia), o Defensor assim licenciado perderia sua capacidade postulatória. Ou seja, as regras seriam contraditórias.

De mais a mais, afirma-se ainda a inconstitucionalidade formal, já que apenas Lei Complementar poderia definir as normas gerais acerca da carreira, sendo para tanto incabível o Estatuto da Advocacia, lei ordinária que é ${ }^{586}$.

O fato é que para se estabelecer que a Defensoria Pública exerça supervisão da assistência desempenhada por profissionais privados ou mesmo outros órgãos públicos não há necessidade de vinculá-la à atividade de advocacia em termos de gênero da mesma espécie.

\section{Ministério Público e assistência jurídica}

$\mathrm{Na}$ antiga Lei Complementar $\mathrm{n}^{\circ} 40 / 81$, que veiculava normas gerais para a organização do Ministério Público dos Estados, constava como dever dos membros do Ministério Público Estadual "prestar assistência judiciária aos necessitados, onde não houver órgãos próprios" (art. 22, XIII) ${ }^{587}$.

Ainda na década de oitenta, e antes da vigência da atual Constituição da República, a disposição era criticada por doutrina de respeito, afirmando-se que era anticientífico atribuir ao órgão do Ministério Público este tipo de atividade. Justificava-se então apontando que os membros do Ministério Público são destituídos de capacidade postulatória, e somente aqueles que gozem as garantias institucionais do advogado poderiam desempenhar a contento a atividade de assistência, que é típica da advocacia; por fim, argumentava-se ainda que os membros do Ministério Público não estariam sujeitos à atividade censória da Ordem dos Advogados do Brasil ${ }^{588}$.

Com a inauguração da ordem constitucional de 1988 o Ministério Público adquiriu perfil completamente diverso, assumindo renovadas atribuições que ressaltam sua

\footnotetext{
${ }^{586}$ CARVALHO, Leandro Coelho. As atribuições da Defensoria Pública sob a ótica do acesso à ordem jurídica justa, cit., p. 219-220. O mesmo autor defende a inconstitucionalidade em estipular-se a obrigatória filiação de Defensores à Ordem dos Advogados do Brasil, além do que, a prática implicaria infração funcional e ato de improbidade administrativa.

${ }^{587}$ No Estado de São Paulo o Decreto $n^{\circ}$ 5.042/1931 previa que na inexistência de advogado que pudesse arcar com o encargo na nomeação de defesa do necessitado, incumbia este ao membro do Ministério Público designado pelo juiz. Esta mesma atribuição remanesceu na vigência da Lei Estadual $\mathrm{n}^{\circ}$ 10.000/1939, especialmente no caso de falta de advogado que pudesse desincumbir-se do encargo (LOPES, Maurício Antônio Ribeiro. Garantia de acesso à justiça: assistência judiciária e seu perfil constitucional, cit., p. 77-78).

${ }^{588}$ GRINOVER, Ada Pellegrini. Assistência judiciária e acesso à justiça, cit., p. 17-26.
} 
independência como órgão voltado à defesa da ordem jurídica, do regime democrático, dos interesses sociais e individuais indisponíveis (art. 127 da Constituição da República).

Fora de dúvida que a vedação ao exercício da advocacia (CR, art.128, § 5, II, "b") constitui duro golpe contra a atribuição mesmo que subsidiária de prestação de assistência jurídica. Ademais é ínsita a algumas disposições de seu regime jurídico, como por exemplo a tríplice garantia da inamovibilidade, vitaliciedade e irredutibilidade de subsídios (art. $128, \S 5^{\circ}$, I) e a vedação à representação judicial e a consultoria jurídica de entidades públicas (art. 129, IX), a idéia de firmá-lo como órgão independente, com feições bastante assemelhadas ao que se poderia definir como um quarto Poder da República, desvinculando-o inteiramente de funções típicas de Poder Executivo, como é o caso da assistência jurídica integral e gratuita, que se insere num dos programas de governo, política pública, a cargo deste filão do poder estatal.

A Lei no 8.625/93 (Institui a Lei Orgânica Nacional do Ministério Público, dispõe sobre normas gerais para a organização do Ministério Público dos Estados e dá outras providências), sendo posterior à Constituição da República de 1988 não incluiu entre as funções gerais ou deveres do membro do Ministério Público prestar assistência jurídica (cf. arts. 25 e 43$)$.

Há de se notar a existência de resquícios normativos de atribuições assistenciais ao Ministério Público. É possível que isto ocorra sobretudo na esfera das legislações estaduais de regência. Em São Paulo, por exemplo, a Lei Orgânica Estadual do Ministério Público, Lei $\mathrm{n}^{\mathrm{o}}$ 734/93, estabelece no art. 169, XVI, como dever funcional do membro do Ministério Público "dar atendimento e orientação jurídica aos necessitados".

No próprio Código de Processo Civil vemos, como já citado alhures, a atribuição ao órgão do Ministério Público, da representação judicial do interditando, quando não for o autor da ação (CPC, art. 1.182, $\S 1^{\circ}$ ). Defende-se a derrogação dessa norma, incompatível com o atual perfil constitucional do Ministério Público ${ }^{589}$.

\footnotetext{
${ }^{589}$ NERY JUNIOR, Nelson; NERY, Rosa Maria Andrade. Código de Processo Civil comentado e legislação extravagant, cit., p. 1.243. Outros casos de assistência a necessitado jurídico, como já mencionamos, são os de nomeação de curador especial às figuras referidas pelo art. $9^{\circ}$ do Código de Processo Civil. Acerca deste mesmo assunto os autores retro citados assim se pronunciam: "O MP defende direitos sociais e individuais indisponíveis (CF 127). Atuar como curador especial no processo civil era e é função atípica do MP. No Estado de SP, a LCE-SP 667/91 16 retirou do MP a função de curador de ausentes, de sorte que a nomeação deveria recair, normalmente, na pessoa de um advogado, vedado ao MP paulista exercê-la. Nos Estados onde remanescia norma atribuindo ao MP a função, exercia ele função não típica da instituição, porque atuava na defesa de direitos privados de particular. A discussão revela apenas interesse histórico porque tal atribuição hoje é função institucional da defensoria pública (LDP, 4 VI)” (Id., p. 352).
} 
Outra hipótese em que persiste um viés assistencial na atuação do Ministério Público refere-se à ação civil ex delicto ou mera execução da sentença condenatória, cuja legitimidade ativa é atribuída ao órgão ministerial no caso de ser pobre o titular do direito à reparação (art. 68 do Código de Processo Penal). A propósito desta regra, o C.Supremo Tribunal Federal acolheu a tese da dita "inconstitucionalidade progressiva", dando pela legitimidade do Ministério Público onde ainda não instalada a Defensoria Pública ${ }^{590}$.

É fora de dúvida, portanto, que todas as vezes que o Ministério Público se imiscuir em função de assistência judiciária, o fará em caráter excepcional e atípico ${ }^{591}$. Certo é que deverá inclusive justificar nos autos sua atuação, que apenas será aceitável se inexistir na Comarca órgão da Defensoria Pública ou mesmo a possibilidade de que advogados particulares, indicados pela Ordem dos Advogados do Brasil ou nomeados diretamente pelo magistrado o façam.

Não justifica a atuação ministerial a simples deficiência da Defensoria Pública ou do órgão com esta conveniado para prestação da assistência jurídica, assim como não se hão de invocar os entraves burocráticos impostos ao requerente seja para a nomeação de Defensor Público, seja para a indicação de advogado por convênios públicos. A má prestação de um serviço público não pode implicar sua transferência a outrem, que inclusive não é constitucionalmente vocacionado para tanto.

\footnotetext{
${ }^{590}$ DEMO, Roberto Luis Luchi. Assistência judiciária gratuita, cit., p. 337. O julgado referido pelo autor está assim ementado: "Ministério Público: legitimação para promoção, no juízo cível, do ressarcimento do dano resultante de crime, pobre o titular do direito à reparação: C. Pr. Pen., art. 68, ainda constitucional (cf. RE 135328): processo de inconstitucionalização das leis. 1. A alternativa radical da jurisdição constitucional ortodoxa entre a constitucionalidade plena e a declaração de inconstitucionalidade ou revogação por inconstitucionalidade da lei com fulminante eficácia ex tunc faz abstração da evidência de que a implementação de uma nova ordem constitucional não é um fato instantâneo, mas um processo, no qual a possibilidade de realização da norma da Constituição - ainda quando teoricamente não se cuide de preceito de eficácia limitada - subordina-se muitas vezes a alterações da realidade fáctica que a viabilizem. 2 . No contexto da Constituição de 1988, a atribuição anteriormente dada ao Ministério Público pelo art. 68 C. Pr. Penal - constituindo modalidade de assistência judiciária - deve reputar-se transferida para a Defensoria Pública: essa, porém, para esse fim, só se pode considerar existente, onde e quando organizada, de direito e de fato, nos moldes do art. 134 da própria Constituição e da lei complementar por ela ordenada: até que - na União ou em cada Estado considerado -, se implemente essa condição de viabilização da cogitada transferência constitucional de atribuições, o art. 68 C. Pr. Pen. será considerado ainda vigente: é o caso do Estado de São Paulo, como decidiu o plenário no RE 135328" (STF, RE nº 147.776/SP, Rel. Sepúlveda Pertence, j. 19.05.98).

${ }^{591} \mathrm{Na}$ jurisprudência encontramos alguns julgados controvertidos, conforme exemplificamos: "Acidente de trabalho - Ação promovida pelo Ministério Público - Inadmissibilidade - Ausência de legitimidade Recurso parcialmente provido, para que se determine a regularização da representação processual do autor (art. 13, CPC) - O MP, em face da atual legislação acidentaria, não tem legitimidade à propositura de ação acidentária" ( $2^{\circ}$ TAcSP, Ap. 764.397-0/0, Rel. Romeu Ricupero, j. 20.02.03). No sentido contrário: "PROCESSUAL CIVIL - ACIDENTE DO TRABALHO - AÇÃO PROPOSTA PELO MINISTÉRIO PÚBLICO ASSISTINDO O OBREIRO - LEGITIMIDADE - RECONHECIMENTO. É de se reconhecer a possibilidade do obreiro propor a ação com a assistência do Ministério Público. Vencido o relator" $\left(2^{\circ}\right.$ TAcSP, Ap. 818.022-0/0, Rel. Paulo Ayrosa, j. 16.11.04).
} 
Incumbe neste caso inclusive ao próprio Ministério Público, por meio dos instrumentos postos à sua disposição pela mesma Constituição da República, pugnar pela implementação adequada do serviço público de assistência jurídica integral e gratuita (p.ex. ajuizando ações civis públicas; instaurando inquéritos civis; firmando termos de ajustamento de conduta; etc.).

\section{Indicação e nomeação do advogado}

Os $\S \S 1^{\circ}$ a $4^{\circ}$ do art. $5^{\circ}$ da Lei $n^{\circ} 1.060 / 50$ estabelecem uma ordem de preferência na nomeação de patrono à parte beneficiária. Lembre-se apenas que a nomeação de advogado é serviço afeto à assistência judiciária (não à gratuidade, que, como dito à saciedade, refere isenção provisória de custas).

Conforme se depreende dos dispositivos retro citados, será sempre preferido para a defesa da causa o advogado que o interessado indicar, e que declare aceitar o encargo ( $\S$ $4^{\circ}$ ), esta é a prioridade, ao menos conforme a letra da lei, assegurar-se ao beneficiário a possibilidade de eleger profissional que lhe tenha conquistado a confiança ${ }^{592}$.

Acaso a parte não indique o profissional que lhe patrocinará a causa o juiz determina que o serviço de assistência judiciária, organizado e mantido pelo Estado indique o profissional que o fará, no prazo de dois dias úteis $\left(\S 1^{\circ}\right)$. A este serviço corresponde a Defensoria Pública, onde instalada, ou outro órgão pelo Estado (em sentido amplo) incumbido de prestar o serviço de assistência jurídica.

Se no Estado ou no foro da causa não houver serviço da natureza daquele referido no parágrafo anterior, é à Ordem dos Advogados do Brasil que incumbirá a indicação de advogado, seja por suas seções estaduais, seja por suas subseções municipais $\left(\S 2^{\circ}\right)$.

Por fim, nos Municípios desprovidos de subseções da Ordem dos Advogados do Brasil o próprio juiz fará a nomeação do advogado que patrocinará a causa $\left(\S 3^{\circ}\right)$.

Sustenta-se que a preferência a que alude o $\S 4^{\circ}$ (advogado indicado pela parte) refere-se apenas às situações em que caberia à Ordem dos Advogados do Brasil ou ao próprio magistrado a nomeação (ou seja, às situações dos $\S \S 2^{\circ}$ e $3^{\circ}$ ), de modo que

\footnotetext{
592“"Razão não há porque não se conceda ao beneficiário o direito de escolher advogado de sua confiança, condição de grande valor na advocacia" (BARROS JR, Carlos S. de. Justiça gratuita, cit., p. 43). Mauro Cappelletti refere que "en Italia no le corresponde a la parte pobre el derecho de elegirse libremente un abogado de su confianza" (La justicia de los pobres. Trad. esp. de Santiago Sentis Mellendo, Tomás A. Banzhaf. Proceso, ideologias, sociedad, cit., p. 144).
} 
havendo serviço de assistência organizado e mantido pelo Estado, sua indicação prevaleceria sobre a preferência do assistido ${ }^{593}$.

$\mathrm{Na}$ verdade a situação deve ser bem compreendida. Em sendo o local onde tramitará o feito abarcado por Defensoria Pública não faria sentido permitir que o assistido indique patrono, para ser remunerado pelos cofres públicos, a fim de patrocinar-lhe a causa. Aí o interesse do necessitado deve ser conjugado com o do Erário: desatende a mínima idéia de economicidade remunerar advogado para realizar serviço pelo qual já se pagam vencimentos aos Defensores Públicos.

Pode sim a parte carente comparecer a juízo com advogado de sua confiança, e que pugne unicamente pela isenção de custas e despesas (mera gratuidade), caso em que, na verdade, vigora entre advogado e cliente relação de natureza particular e contratual.

O máximo que se poderia permitir ao assistido seria, dentre o corpo de Defensores Públicos, manifestar preferência por algum que lhe tenha angariado a confiança.

Já no caso de não ser a Comarca atendida por Defensoria Pública, a nomeação se faria pela Ordem dos Advogados do Brasil, que normalmente conta com corpo de advogados inscritos para o serviço de assistência. A preferência do assistido, neste caso, dar-se-á dentre os membros deste corpo.

Já no caso de indicação e nomeação pelo próprio juiz, nenhuma restrição haverá à parte para que indique advogado de sua confiança, já que entre a livre escolha pelo magistrado e a livre escolha pela parte, esta últim obviamente deve prevalecer.

Há quem defenda que o advogado não é obrigado a aceitar a nomeação feita diretamente pelo juiz, e o art. 14 da Lei $\mathrm{n}^{\mathrm{o}} 1.060 / 50$ teria sido derrogado pelo art. $6^{\circ}$, “caput”, da Lei no 8.906/94, de modo que somente a Ordem dos Advogados do Brasil poderia nomear ${ }^{594}$. A posição é altamente inconsistente.

Primeiro que a nomeação do advogado que patrocinará a causa do assistido é feita com referência a determinado processo, devidamente individualizado, e não em caráter genérico, para que o tal patrono assista àquele beneficiário em todos os atos da vida. Ora, o presidente do processo é o magistrado, de modo que ao incluir-se em seu poder de direção

\footnotetext{
${ }^{593}$ LOPES, Maurício Antônio Ribeiro. Garantia de acesso à justiça: assistência judiciária e seu perfil constitucional, cit., p. 84.

${ }^{594}$ DEMO, Roberto Luis Luchi. Assistência judiciária gratuita, cit., p. 340.
} 
a nomeação de patrono não vai vilipêndio algum à nobreza da função desempenhada pelo causídico.

A levar às últimas consequiências o raciocínio em questão, então teria o juiz perdido a atribuição de direção do processo porque, afinal, não há hierarquia entre magistrados, advogados e membros do Ministério Público (art. 6" "caput”, do EOAB).

Há aí um patente equívoco na extensão que se pretende dar ao referido dispositivo do Estatuto da Advocacia. Interpreta-se-o corretamente entendendo-se que veda ele que o magistrado exerça regência sobre a pessoa do advogado, mas não impede que o juiz exerça poder de direção sobre a atuação processual do patrono, poder-dever este ínsito à função do magistrado. Nada mais houve aí que a repartição legal de atribuições, sem nenhuma opção valorativa em favor do juiz e em demérito do advogado.

Em segundo lugar, a nomeação pelo juiz (que na verdade é a indicação, porque nomeação para atuação no processo pelo magistrado ocorrerá mesmo com a indicação pelo serviço de assistência ou pela Ordem dos Advogados do Brasil) se dá em caráter duplamente subsidiário. Isto é, depende da inexistência de serviço de assistência, de seção ou subseção da Ordem dos Advogados do Brasil, ou seja, é o último recurso de que se socorrerá a parte, que se não o fizer verá à míngua seu direito à assistência jurídica integral e gratuita.

Não parece haver alguma razoabilidade em preferir-se o achaque a um direito fundamental constitucionalmente assegurado, tornado miragem por melindres de nenhuma importância.

O que se tem verificado na praxe forense é uma praticamente inocorrente aplicação do $\S 4^{\circ}$ do art. $5^{\circ}$ da Lei $n^{\circ} 1.060 / 50$ (preferência ao advogado indicado pela parte). De fato, a parte que deseja o patrocínio de advogado dativo, remunerado pelos cofres públicos de acordo com as tabelas próprias (em São Paulo em razão de convênio com a Defensoria Pública), deve contentar-se com o profissional indicado pelo serviço de assistência ou pela Ordem dos Advogados do Brasil.

Apesar da letra do referido $\S 4^{\circ}$ e da afirmação corrente em doutrina acerca da necessidade de permitir-se ao assistido a eleição do advogado que lhe tenha conquistado a fidúcia, a verdade é que apenas se viabiliza tal escolha nos casos em que a parte limita sua 
pretensão à gratuidade. Isto é, comparece em juízo com o advogado já constituído, e pede apenas a gratuidade ${ }^{595}$.

A propósito não se há de pensar que o pretendente ao benefício apenas possa requerê-lo em bloco, isto é, "tudo ou nada". Como já dito e repetido cansativas vezes, assistência jurídica compreende, entre outros serviços, a assistência judiciária e a gratuidade. Se em razão de suas particulares circunstâncias a parte pretende apenas o segundo destes benefícios, preferindo escolher por si o advogado que melhor lhe apeteça, não há porque exigir que se valha do serviço de assistência. Inclusive em hipóteses que tais poderá até mesmo ajustar com o patrono remuneração (o que normalmente ocorre é fixá-la ad exitum $)^{596}$.

Outro ponto assaz debatido diz respeito à possibilidade ou não de substabelecimento (ou outra forma de cessão do serviço) por parte do advogado indicado ao assistido. É óbvio que se se trata da situação narrada no parágrafo anterior, ou seja, de patrono constituído e que se limita a pleitear em nome da parte a isenção de custas e despesas (gratuidade), há normal outorga de mandato e o substabelecimento há de observar as regras civis comuns para os mandatos judiciais. A questão se põe na hipótese de

\footnotetext{
${ }^{595} \mathrm{Um}$ antigo julgado citado por José Roberto de Castro, oriundo do Eg.Tribunal de Justiça do Estado do Rio de Janeiro faz uma interessante distinção entre a constituição do advogado pela parte, caso em que seria incabível a assistência, isto é, a remuneração pelos cofres públicos; e a mera sugestão ou indicação pela parte, sem outorga de mandato, caso em que seria necessário o ato judicial complementar de nomeação pelo juiz, abrindo-se a possibilidade de remuneração pelo Estado na qualidade de defensor dativo: "O defensor judicial, investido por ato do juiz dos poderes necessários à defesa dos direitos de quem por sua miserabilidade jurídica invoca a proteção do Estado, exerce um munus público e não pode delegar tais poderes ou transferir tais encargos, como se fora procurador judicial normalmente constituído pela parte. A concessão da justiça gratuita não é incompatível com a outorga, pela parte favorecida, do mandato judicial regularmente conferido ao advogado por ela escolhido. Se ela o elege e lhe outorga procuração, não há que ser tal escolha homologada pelo juiz, ao conceder os benefícios da gratuidade, nem o escolhido assim investido é simples defensor dativo, mas seu procurador constituído. A simples sugestão ou indicação de defensor, no pedido de justiça gratuita, não vale, todavia, outorga de mandato, já que tal ato tem que ser completado pelo juiz, que, em tal caso, só ele o nomeia, ainda que homologue a escolha do suplicante" (TJRJ, Acórdão das Câmaras Reunidas, Ap. 720, Rel. Agenor Rabelo, j. 29.11.1953, RT 222:493).

596،"Se o beneficiário da Assistência Judiciária Gratuita opta por um determinado profissional em detrimento daqueles postos à sua disposição gratuitamente pelo Estado, deverá ele arcar com os ônus decorrentes desta escolha ... Esta solução busca harmonizar o direito de o advogado de receber o valor referente aos serviços prestados com a faculdade de o beneficiário, caso assim deseje, poder escolher aquele advogado que considera ideal para a defesa de seus interesses. Recurso especial provido para, reformando o acórdão recorrido, julgar procedente o pedido formulado na inicial" (STJ, REsp n ${ }^{\circ}$ 965.350/RS, Rel. Nancy Andrighi, j. 09.12.08). Na órbita do Estado de São Paulo temos exemplificativamente: "Assistência judiciária - Concessão do beneficio a quem tem advogado constituído - Possibilidade - Restrição que importaria em violação ao artigo $5^{\circ}$, LXXIX, da Constituição Federal - Para a concessão dos benefícios da justiça gratuita basta que a parte afirme não estar em condições de pagar as custas do processo e os honorários de advogado, sem prejuízo próprio ou de sua família, não impedindo a outorga do favor legal o fato de ter advogado constituído, tudo sob pena de violação ao artigo $5^{\circ}$, LXXIV, da Constituição Federal e à Lei n. ${ }^{\circ} 1.060 / 50$, que não contemplam tais restrições - Favor, ademais, que não se restringe às despesas processuais, que não seriam de vulto, abrangendo, também, os honorários de advogado - Agravo de instrumento provido" (2 $2^{\circ} \mathrm{TAcSP}, \mathrm{AI} \mathrm{n}^{\circ}$ 747.411-0/1, Rel. Romeu Ricupero, j. 25.07.02).
} 
indicação e nomeação do patrono, seja por serviço de assistência, seja pela Ordem dos Advogados do Brasil ou pelo próprio magistrado, conforme o já referido permissivo do $\S$ $3^{\circ}$ do art. $5^{\circ}$ da Lei $n^{\circ} 1.060 / 50$.

A doutrina acerca do assunto inclina-se pela negativa, lembrando que a defensoria dativa é munus intransferível, sendo o principal argumento o de que no caso de assistência judiciária não há outorga de mandato, de modo que não haveria o que substabelecer ${ }^{597}$.

Convém lembrar, a propósito, que segundo o art. 16, p.único, da Lei $\mathrm{n}^{\circ}$ 1.060/50 o mandato não se há de exigir "quando a parte for representada em juízo por advogado integrante de entidade de direito público incumbido, na forma da lei, de prestação de assistência judiciária gratuita", apenas constando certas ressalvas quanto aos atos previstos no art. 38 do Código de Processo Civil e ainda o requerimento de abertura de inquérito policial por crime de ação privada, ou mesmo a propositura da ação penal em casos que tais, bem como a oferta de representação no caso de crimes apurados por ação penal condicionada (alíneas "a" e "b" do p.único do art. 16).

Uma outra questão se põe: poderia o assistido recusar o advogado indicado pelo serviço de assistência? A resposta indiscutivelmente há de ser positiva, porém com uma condicionante: desde que haja motivo bastante para tanto. Ora, se o sistema visa privilegiar a indicação de advogado que seja da confiança da parte, ou ao menos alguém em relação a quem a parte não tenha restrições pré-concebidas, não seria de alguma congruência obrigála a ser assistida por alguém em relação a quem a priori já detém desconfiança.

Frise-se mais uma vez que esta recusa há de ser motivada, e mais, com justificativa plausível e razoável. Seria aconselhável que esta recusa seja apreciada por órgão superior da Defensoria Pública ou da própria Ordem dos Advogados do Brasil (p.ex. pela Comissão de Assistência Judiciária), preferencialmente pelo mesmo órgão que fez a indicação.

\footnotetext{
${ }^{597}$ Roberto Luis Luchi Demo apresenta uma distinção que, com sinceridade, mostra-se incompreensível, porém a reproduzimos para conhecimento do leitor: "Recusando a nomeação, ainda que por motivo justificado, não pode o advogado nomeado indicar outro colega, mesmo com a aceitação deste, pois somente o Juiz e a OAB têm poderes para nomear defensor (art. $5^{\circ}, \S \S 2^{\circ}$ e $3^{\circ}$ da Lei $n^{\circ} 1.060 / 50$ ). A defensoria dativa é munus intransferível, não se concedendo ao defensor o poder de substabelecer ... Diversa é a situação em que o interessado procura diretamente o serviço de assistência judiciária, submetendo-se a triagem e obtendo a assistência judiciária. Neste caso, é possível o substabelecimento desquê limitado a advogado também pertencente à própria entidade" (Assistência judiciária gratuita, cit., p. 340). Também são negativas ao substabelecimento as lições de José Roberto de Castro (Manual de assistência judiciária: teoria, prática e jurisprudência, cit., p. 111) e Artêmio Zanon (Assistência Judiciária gratuita: comentários à Lei da Assistência Judiciária (Lei no 1.060, de 5-2-1950), cit., p. 54). No Estado de São Paulo o $§ 11^{\circ}$ da cláusula $4^{\circ}$ do Convênio firmado entre a Defensoria Pública Estadual e a Ordem dos Advogados do Brasil disciplina: "Tendo em vista o caráter personalíssimo do múnus assumido pelo advogado conveniado, é vedado o substabelecimento dos poderes recebidos nos termos deste Convênio. O substabelecimento sujeita o advogado às sanções previstas no presente convênio".
} 
Um último ponto merecerá atenção. O vetusto Decreto Federal $n^{\circ} 2.457$ de $8^{\circ}$ de fevereiro de 1897, a que já nos referimos, previa a existência de uma comissão de assistência judiciária, que apreciaria os pleitos dos necessitados, emitindo um parecer a respeito. Tal parecer, segundo o art. 17 do Decreto, seria assim composto: "O parecer da commissão se occupará, explicita e distinctamente, da pobreza do supplicante e da apparente justiça da causa. A concessão do patrocinio gratuito só terá logar no caso de conclusão favoravel sobre ambos os pontos, mas o despacho de admissão pelo juiz nenhum valor terá para o julgamento final da acção quanto ao segundo ponto" (destaque nosso).

Prendemo-nos ao ponto destacado: aparente justiça da causa. Indaga-se se não seria o caso de ressuscitarmos este expediente? É que um dos argumentos comumente aventados contra institutos facilitadores do ingresso em juízo é a proliferação de lides temerárias. Ora, se se permitisse ao órgão que procede à triagem fazê-lo não apenas tendo por objeto a condição econômica da parte, mas especialmente a viabilidade jurídica de sua pretensão, muitas demandas absolutamente infundadas estariam alijadas do acesso irresponsável a juízo.

Aliás, expediente nesta natureza é fecundamente difundido nos sistemas vigentes em outros países, como Itália e Alemanha, inclusive com a previsão de prévio contraditório (ou seja, manifestação do adverso), contando com exame sumário da causa, em que o único objeto a ser decidido é a concessão do benefício ${ }^{598}$.

Dir-se-á que ao advogado responsável pela causa já caberá proceder a esta atividade catalisadora. Sabe-se, entretanto, que na prática isto não ocorre com tanta efetividade, até porque os honorários pagos pelo Estado independem do resultado do processo.

Evidente que não se há de proceder a um estudo profundo da causa, mas apenas a uma avaliação perfunctória, de modo a se certificar que não se trata de pretensão manifestamente infundada ou maliciosa ${ }^{599}$. Seria a avaliação da presença do fumus boni juris, para lembrarmos conceito que hoje repercute pelos vários quadrantes da disciplina processual.

\footnotetext{
${ }^{598}$ Confira-se a respeito o capítulo 5 do presente estudo.

${ }^{599}$ BARROS JR, Carlos S. de. Justiça gratuita, cit., p. 44. O autor em questão defendia este controle, criticando sua abolição pelo Código de Processo Civil de 1939. Ainda em doutrina, defendendo a subsistência no atual sistema de tal pressuposto, Maurício Antônio Ribeiro Lopes leciona que a exigência "remanesce íntegra, pois deriva da própria finalidade do instituto. $\mathrm{O}$ crivo por que deve passar a pretensão do interessado não significa exame aprofundado da hipótese jurídica, pois não visa decidir a demanda, mas sim apenas impedir o desvrituamento da assistência judiciária, não permitindo sejam objetos de demanda interesses inoportunos ou injustos, os quais, não raro, são pretendidos por má-fé" (LOPES, Maurício Antônio Ribeiro. Garantia de acesso à justiça: assistência judiciária e seu perfil constitucional, cit., p. 82).
} 


\section{ASPECTOS PROCEDIMENTAIS}

Neste item cumpre avaliar os aspectos procedimentais relacionados à aplicação da Lei $\mathrm{n}^{\mathrm{o}} 1.060 / 50$. Vale salientar que por aspectos procedimentais aludimos principalmente à forma de requerimento, concessão, indeferimento e revogação dos benefícios legais, e mais, as possíveis repercussões sobre o procedimento principal no qual as benesses incidirão.

É imperioso ainda proceder a uma distinção. Vê-se que a Lei ${ }^{\circ} 1.060 / 50$, no que concerne aos ditos aspectos procedimentais, alude repetidamente ao benefício da assistência (art. $4^{\circ}$, “caput”; art. $7^{\circ}$; art. $9^{\circ}$ ), quando na verdade parece querer referir-se à simples gratuidade (e a distinção entre assistência jurídica; assistência judiciária e gratuidade foi assaz citada anteriormente).

Adverte-se, por isto, que os aspectos procedimentais que serão abordados referemse, a rigor, à isenção das custas, despesas e honorários, isto é, à gratuidade. Isto não quer dizer que não haja procedimento para a concessão, deferimento ou indeferimento, assim como revogação, dos benefícios da assistência jurídica ou mesmo a judiciária. Porém estes são eventos extraprocessuais, concentrados em expedientes administrativos, junto às Defensorias Públicas ou entes conveniados, responsáveis pela realização de triagens nas formas consideradas pertinentes pelo administrador público.

Mesmo na hipótese em que o juiz procede à indicação e nomeação de advogado dativo (art. $5^{\circ}, \S 3^{\circ}$, da Lei $n^{\circ} 1.060 / 50$ ) "o faz como autoridade judicial que é, e não como decorrência de uma atividade jurisdicional ... A decisão de caráter processual que se coloca diante do Juiz, está relacionada com a concessão, ou não, da justiça gratuita"600 .

A atividade administrativa relacionada à assistência jurídica está sujeita ao controle jurisdicional nos mesmos termos em que quaisquer outros atos ou procedimentos administrativos.

Assim, quando a lei se refere, por exemplo, à revogação dos benefícios da assistência (art. $7^{\circ}$, "caput"), não quer significar que a decisão que a procede extinga a representação processual por patrono dativo (já que a atividade de assistência judiciária

\footnotetext{
${ }^{600}$ MARCACINI, Augusto Tavares Rosa. Assistência jurídica, assistência judiciária e justiça gratuita, cit., p. 93. Segue o mesmo autor: "Assim, se utilizarmos rigor terminológico, só há procedimento para a concessão de justiça gratuita, pois apenas esta é resolvida no processo. A concessão do serviço de Assistência Jurídica pelo órgão prestador é ato de natureza administrativa, não jurisdicional” (cit., p. 93).
} 
consiste principalmente na indicação de advogado), mas sim que revogada está a isenção provisória das custas, despesas e honorários.

Não poderia mesmo se pensar que pudesse o magistrado substituir-se à Defensoria Pública ou órgão equivalente extinguindo a indicação do patrono, até porque esta indicação, como dito, é atividade administrativa extraprocessual (embora se refira ao processo, não o integra, ao contrário da isenção das custas, despesas e honorários). É evidente, entretanto, que neste caso incumbirá ao juiz oficiar ao órgão responsável pela indicação do patrono, e a revogação da gratuidade consistirá em fortíssimo indício a motivar a revogação da indicação. Nada impede que nesta hipótese o "ex-assistido" constitua o mesmo patrono, agora a título particular, para prosseguir em sua defesa (poderá, por exemplo, ter-lhe conquistado a confiança).

Da mesma forma, e logicamente ao reverso, eventual revogação administrativa da indicação (ou seria mais técnico dizer anulação da indicação, por incongruência entre os pressupostos de fato que a ensejaram), extinguindo-se a representação processual da parte assistida, não implicará automática cessação da gratuidade. Apenas que deverá a parte providenciar a regularização de sua representação na forma do art. 13 do Código de Processo Civil. Não se esqueça que pode a parte representada por advogado constituído limitar seu pleito à gratuidade, como, aliás, é bastante corrente na praxe forense.

Nesta hipótese, contudo, é recomendável que o magistrado se acerque dos motivos que levaram o serviço de assistência à revogação da indicação, a fỉm de saber se daí decorrem elementos aptos a justificar desconfiança quanto à veracidade da declaração de pobreza (art. $4^{\circ}$, “caput”), podendo, se o caso, exigir elementos probatórios adicionais da parte, podendo até mesmo revogar de ofício a isenção (art. $8^{\circ}$ ).

O pressuposto para a concessão da assistência jurídica é aquele referido pelo inciso LXXIV do art. $5^{\circ}$ da Constituição da República: comprovação da insuficiência de recursos. Como oportunamente se explorará melhor, isto não implica a revogação do art. $4^{\text {o }, ~ " c a p u t ", ~}$ da Lei $\mathrm{n}^{\mathrm{o}} 1.060 / 50$, que se contenta com a afirmação de pobreza em termos legais, pelo interessado, presumida verdadeira de acordo com o $\S 1^{\circ}$, até porque presunção é também meio de prova.

Parece claro que o referido "caput" do art. $4^{\circ}$ se destina a regular a feição processual do benefício, já que fala em "parte" e em "petição inicial", do que se poderia deduzir que não rege esta regra o pressuposto para a concessão da assistência jurídica ou 
judiciária que, como dito, ocorre em sede extraprocessual, na seara administrativa (daí a atecnia da redação do dispositivo).

Nada impede, entretanto, que este dispositivo seja utilizado analogicamente, ou apenas como parâmetro, para a atuação administrativa dos serviços de assistência jurídica. Apesar disto, nada há de inconstitucional ou ilegal se a entidade prestadora, à declaração de pobreza, acresce a exigência de outras informações, que realize um pequeno questionário acerca da condição sócio-econômica da parte, enfim, que proceda a expedientes a fim aferir a real necessidade do suporte público.

Certo é, entretanto, que para a concessão da gratuidade fronteiras do processo adentro o pressuposto é aquele do art. $4^{\circ}$, “caput" e $\S 1^{\circ}$ (afirmação de pobreza), com a exceção que será oportunamente apontada (possibilidade de o juiz exigir, em casos justificados, corroboração por outras provas).

\section{Requerimento e concessão do benefício}

A primeira informação relevante acerca deste ponto diz respeito à impossibilidade de concessão do benefício da gratuidade de ofício pelo juiz ${ }^{601}$. De fato, o tratamento benéfico indiscutivelmente está situado na esfera de disponibilidade da parte, plenamente abarcado pelo princípio dispositivo, carreando-se à parte sobretudo o ônus da alegação ${ }^{602}$, e que no caso se materializa na afirmação referida pelo art. $4^{\circ}$, "caput", da Lei no 1.060/50.

\footnotetext{
${ }^{601}$ Previa a possibilidade de concessão de ofício a antiga redação do $\S 7^{\circ}$ do art. 789 da Consolidação das Leis do Trabalho, dada pelo Decreto-lei no 8.737/1946: "É facultado aos presidentes dos tribunais do trabalho conceder ex-ofício o benefício da Justiça gratuita, inclusive quanto a traslados e instrumentos, àqueles que perceberem salário igual ou inferior ao dobro do mínimo legal ou provarem o seu estado de miserabilidade".

${ }^{602}$ YARSHELL, Flavio Luiz. A assistência judiciária sob o ângulo do requerido. Revista do Advogado, São Paulo, n. 59, p. 82, jun. 2000. Há, contudo, decisões em sentido contrário oriundas do C.Superior Tribunal Justiça, como a seguir transcritas: "Processual civil. Simples afirmação da necessidade da justiça gratuita. Possibilidade de deferimento do beneficio. Art. $4^{\circ}$, da Lei $\mathrm{n}^{\circ}$ 1.060/50. 1- A simples afirmação da necessidade da justiça gratuita e suficiente para o deferimento do beneficio, visto que o art. $4^{\circ}$, da Lei $n^{\circ}$ 1.060/50 foi recepcionado pela atual Constituição Federal. Precedentes da Corte. 2- Ainda que assim não fosse, e dever do estado prestar assistência judiciária integral e gratuita, razão pela qual, nos termos da jurisprudência do STJ, permite-se a sua concessão ex officio, o que só vem reforçar a tese dos recorrentes. 3- Recurso Especial conhecido por ambas as alineas e provido, para deferir o beneficio da justiça gratuita" (STJ, REsp no 104.400/SP, Rel. Fernando Gonçalves, j 17.11.1997). Ainda: "Processual civil - Assistência judiciária - Parte impossibilitada de contratar advogado - Defensor designado pelo juiz independente de requerimento da parte - A norma jurídica precisa ser interpretada teleologicamente, buscando sempre, porque, aí esta sua finalidade, realizar solução de interesse social. Se assim não for, a atividade judiciária será ociosa, inútil, mera homenagem à tradição. Os modernos princípios de acesso ao Judiciário abonam o aresto recorrido, relator o Juiz Herondes de Andrade, do E. Tribunal de Alçada do Estado de Minas Gerais. A Constituição da República estatui ser a assistência jurídica obrigação do Estado, aos necessitados (art. $5^{\circ}$, LXXIV). O instituto tem sua história. No primeiro momento, o postulante precisa comprovar o estado de
} 
A própria forma de comprovação eleita pela Lei denuncia a necessidade de requerimento expresso da parte, pois que como poderia o magistrado deferir a benesse sem a afirmação da pobreza "em termos jurídicos"?

Não se pode também esquecer que a concessão do benefício traz repercussões importantes sobre a esfera jurídica do adversário e do Estado, o que ainda mais justifica aguarde o juiz a devida provocação do interessado.

A praxe adotada no dia-a-dia do foro é a anexação à inicial, juntamente com a procuração outorgada ao patrono e todos os demais documentos que a instruem, de uma dita "declaração de pobreza" firmada pela própria parte, enquanto que no corpo da inicial o patrono limita-se a requerer os benefícios da gratuidade.

A verdade, contudo, é que a letra da lei não exige esta cisão, contentando-se com a afirmação na própria inicial, ou seja, no bojo e no corpo desta, acerca da falta de condições de arcar com os custos do processo, e é esta afirmação que se presume verdadeira. Inclusive basta a assinatura do advogado, normalmente aposta à inicial, para que a afirmação tenha valia, desnecessária também a outorga de poderes especiais ${ }^{603}$.

Há casos não muito comuns em que é acostada à inicial a referida "declaração de pobreza" firmada pela parte, porém na inicial não se requer formalmente a gratuidade. Mesmo nestes casos o juiz deve apreciar o pleito. É que este se considera feito com a afirmação da pobreza pela parte interessada, tenha sido veiculada na própria inicial, ou na “declaração de pobreza".

Uma importante decorrência da aplicação do princípio dispositivo ao caso, conforme já apontado, é que o juiz não poderia deferir à parte a isenção total, quando esta se limita a pedir a parcial (art. 13 da Lei $\mathrm{n}^{\mathrm{o}}$ 1.060/50), assim como não poderia deferir isenção, total ou parcial, quando o pedido da parte restringe-se ao diferimento do

pobreza em seguida, é, como hoje, suficiente afirmar a necessidade. O juiz de outro lado, agente do Estado, exerce papel saliente e obrigatório para a prestação jurisdicional não ser mera forma, singela sucessão de atos. Como ocorreu nestes autos evidenciou sensibilidade para realizar justiça material. Esta, por seu turno, reclama que a parte tenha acesso ao debate, requeira, impugne, recorra. O magistrado precisa ficar atento para isso não ser acessível aos privilegiados de fortuna, ou que, pelo menos, possam contratar advogado. Só assim, garantir-se-á a igualdade de tratamento às partes" (STJ, REsp nº 109.796/MG, Rel. Luiz Vicente Cernicchiaro, j.24.02.1997).

${ }^{603} \mathrm{Na}$ jurisprudência, exigindo poderes especiais: “ASSISTÊNCIA JUDICIÁRIA - REQUISITO DECLARAÇÃO DE POBREZA SUBSCRITA PELO INTERESSADO OU SEU PROCURADOR NECESSIDADE. O benefício da justiça gratuita pode ser pleiteado a qualquer tempo, mediante declaração de pobreza assinada pelo interessado, podendo ser ela substituída por sua assinatura na petição inicial onde afirme tal condição, ou, ainda, outorgue poderes especiais a seu advogado para fazê-la" (2 $2^{\circ} \mathrm{TAcSP}, \mathrm{Al} \mathrm{n}$ 735.609-00/7 - 5 Câm. - Rel. Juiz Oscar Feltrin - j. 3.4.2002). Há outros julgados neste sentido, os quais são alicerçados no art. $1^{\circ}$ da Lei $n^{\circ} 7.115 / 83$. 
pagamento (como, p.ex., autorizado em casos especificados na Lei paulista $\mathrm{n}^{\circ} 11.608 / 03$ ). Ao proceder assim, estaria o juiz a obrar ultra petita, em afronta aos limites impostos pelos tão citados arts. 128 e 460 do Código de Processo Civil, tornando, em princípio, nula sua decisão.

Uma questão que surgiu após a edição da atual Constituição da República diz respeito à possível revogação (não-recepção) do art. $4^{\circ}$, “caput” e $\S 1^{\circ}$, da Lei no 1.060/50, em face do inciso LXXIV do art. $5^{\circ}$ da Lei Maior, já que neste se fala em assistência jurídica integral e gratuita aos que comprovem insuficiência de recursos, e aquele contentase com a afirmação de pobreza que se presume verdadeira (portanto, aparentemente, dispensando a tal comprovação).

Há, entretanto, três bons argumentos que sepultam esta idéia. O primeiro deles, até simplório, atenta para o fato de que a Constituição não especificou o meio pelo qual o interessado comprovaria a insuficiência de recursos. Seria admissível, como até já dito anteriormente, atividade infranconstitucional trazendo detalhamentos.

Ora, não deveria haver espanto algum na eleição do meio "presunção" para comprovação da insuficiência de recursos, visto que se trata de um dos meios de prova arrolados pelo diploma civil, conforme se vê do art. 212, IV, do Código Civil. Tal, aliás, já constava do antigo Código Civil de 1916 (art. 136, V).

E nem se haveria de afirmar inconstitucionalidade por outro motivo: a Constituição não limitou o meio de prova da insuficiência de recursos, de modo que não poderia o legislador fazê-lo (limitando-o à presunção). É que a Lei no 1.060/50 não estabeleceu limite, pois não afirmou que a afirmação de pobreza seria exclusivo meio de prova. Tratase do primeiro meio (e diga-se, o mais simples para o beneficiário) de que se valerá o interessado. Contudo, surgindo dúvida acerca de seu estado de miserabilidade, seja a partir de impugnação do adversário, seja mesmo em razão de atividade de ofício pelo juiz, o interessado poderá se valer de quaisquer meios de prova (CPC, art. 332) para comprovar a insuficiência de recursos que alega.

O segundo argumento lembra a distinção igualmente já explicitada, acerca dos conceitos de assistência jurídica e gratuidade, apontando para o fato de que a Constituição da República exige a comprovação da insuficiência de recursos para fins de deferir aquela, que constitui serviço público qualificado, porém para a mera isenção de custas e despesas 
processuais, que é o quanto regulado pelo art. $4^{\circ}$ da Lei $n^{\circ} 1.060 / 50$, basta a afirmação de pobreza.

Esta a posição de Rizzatto Nunes, que conclui pela compatibilidade entre a Lei $\mathrm{n}^{\circ}$ 1.060/50 e a Constituição da República:

\begin{abstract}
"o que o legislador constituinte disciplinou foi uma determinação para que o Estado garanta assistência jurídica integral e gratuita a quem necessitar. É para esse tipo de serviço essencial que o cidadão deve comprovar insuficiência de recursos - e não para requerer a mera isenção de taxas, custas e despesas processuais" ${ }^{\prime 604}$.
\end{abstract}

Um terceiro e último argumento: a garantia da assistência jurídica integral e gratuita está incluída entre os direitos e garantias fundamentais da Constituição, e constitui característica de declarações de direitos assim postas a oferta de um mínimo, que a lei não pode suplantar ${ }^{605}$. Destarte, se a lei amplia estes direitos e garantias fundamentais, potencializando sua eficácia, facilitando sua implementação ou alargando seus limites, não há afronta ao espírito da Lei Maior ${ }^{606}$.

\footnotetext{
${ }^{604}$ RIZZATTO NUNES, Luiz Antônio. A assistência judiciária e a assistência jurídica: uma confusão a ser solvida, cit., p. 85. No mesmo sentido Araken de Assis (Benefício da gratuidade, cit., p. 175-176).

${ }^{605}$ DINAMARCO, Cândido Rangel. Instituições de direito processual civil, cit., v. 2, p. 697. Cândido Alfredo Silva Leal Junior observa mais ou menos os mesmos argumentos, e igualmente conclui pela compatibilidade da regra inserta no art. $4^{\circ}$ da Lei $\mathrm{n}^{\circ} 1.060 / 50 \mathrm{com}$ o inciso LXXIV do art. $5^{\circ}$ da Constituição. Em artigo dedicado ao tema, o autor releva dois possíveis ângulos de interpretação da norma. Primeiro, o "espírito da lei", com o que recorre à interpretação finalística e sistemática. Pondera aí que o sentido tanto da Lei $\mathrm{n}^{\mathrm{o}} 1.060 / 50$ como do próprio texto constitucional (a cujos antecedentes históricos recorre, lembrando as discussões e textos propostos na Constituinte), foi de prestigiar a tendência ampliativa de acesso à justiça, sendo instrumento de desembaraço e facilitação. Deste modo, interpretar a questão da comprovação de forma a torná-la óbice burocratizante seria inadmissível. A Constituição, por isto, não proibiu o legislador ordinário de ir além e outorgar o benefício mesmo sem prova da carência. Numa segunda possibilidade, a interpretação literal, o autor anota que não seria função própria ao Constituinte descer a minúcias de destrinchar o meio de comprovação da insuficiência de recursos, o que é função do legislador infraconstitucional. Em dizer o legislador que o meio de prova adequado é este ou aquele não afrontou a Lei Maior: "Eis aí a forma pela qual se produz a prova, trazendo-se ao conhecimento do juiz (caput) o meio de prova suficiente para que seja concedida a gratuidade jurídica: a simples afirmação da condição pelo interessado ( $\$ 1^{\circ}$ )" (LEAL JR, Cândido Alfredo Silva. A comprovação da insuficiência de recursos para concessão da assistência jurídica gratuita. Revista de Processo, São Paulo, v. 16, n. 62, p. 274, abr./jun. 1991).

${ }^{606} \mathrm{Na}$ jurisprudência, encontramos neste sentido: "PROCESSUAL CIVIL. ASSISTÊNCIA JUDICIÁRIA GRATUITA. COMPROVAÇÃO DA HIPOSSUFICIÊNCIA. DESNECESSIDADE. LEI N N $1.060 / 50$, ARTS. $4^{\circ} \mathrm{E} 7^{\circ}$. 1. A Constituição Federal recepcionou o instituto da assistência judiciária gratuita, formulada mediante simples declaração de pobreza, sem necessidade da respectiva comprovação. Ressalva de que a parte contrária poderá requerer a sua revogação, se provar a inexistência da hipossuficiência alegada. 2. Recurso conhecido e provido" (STJ, REsp no 200.390/SP, Rel. Edson Vidigal, j. 24.10.00). Ainda: "Assistência judiciária. Beneficio postulado na inicial, que se fez acompanhar por declaração firmada pela autora. Inexigibilidade de outras providências. Não revogação do art. $4^{\circ}$ da lei $1.060 / 50$ pelo disposto no inciso LXXIV do art. $5^{\circ}$ da Constituição. Precedentes. Recurso conhecido e provido. - Em principio, a simples declaração firmada pela parte que requer o beneficio da assistência judiciária, dizendose 'pobre nos termos da lei', desprovida de recursos para arcar com as despesas do processo e com o
} 
Há um entendimento de Arthur Mendes Lobo, buscando compatibilizar uma “suposta" contrariedade entre o art. 5\%, LXXIV, da Constituição e o art. $4^{\circ}$, "caput" e $\S 1^{\circ}$ da Lei $n^{\circ}$ 1.060/50 (o que já temos refutado) defendendo que a concessão baseada na mera afirmação de pobreza se daria em sede de cognição sumária, com natureza de medida liminar e destinada exclusivamente em assegurar o acesso à Justiça. Após o trânsito em julgado da sentença, e sendo condenado o beneficiário provisório da gratuidade, aí então deveria comprovar a insuficiência de recursos ${ }^{607}$.

Referido posicionamento parte do pressuposto de que a mera afirmação de pobreza vertida em inicial e a presunção que a acompanha não sejam meio de prova da insuficiência de recursos, o que temos refutado nos parágrafos anteriores. De toda forma fica registrada a posição dissonante supra transcrita.

Uma superficial leitura dos parágrafos do art. $4^{\text {o }}$ da Lei $\mathrm{n}^{\mathrm{o}}$ 1.060/50 causará certamente perplexidade, pois que a contradição salta aos olhos. $\mathrm{O} \S 1^{\circ}$ alude à presunção de veracidade da afirmação de pobreza, enquanto que o $\S 2^{\circ}$ trata da impugnação e seu processamento. Já o $\S 3^{\circ}$ refere que o juiz, à vista da carteira de trabalho e previdência social do interessado, poderia dispensar a juntada dos atestados exigidos pelos $\S \S 1^{\mathrm{o}}$ e $2^{\circ}$. Ora, primeiro que os parágrafos em questão não se referem a atestados; segundo que se estipula que a afirmação de pobreza seria, nesta oportunidade processual, suficiente para a concessão da isenção, sem necessidade de acréscimo de outros documentos.

Reclama-se uma avaliação histórica da regra, que é realizada de forma percuciente por Marcacini ${ }^{608}$. No regime do Código de Processo Civil de 1939 a parte que pretendesse o benefício de gratuidade mencionaria, na petição, o rendimento ou vencimentos que percebe e os seus encargos pessoais e de família, estabelecendo-se que quem prestasse falsa declaração ficaria sujeito às sanções previstas na lei penal (art. 72, “caput” e p.único). Outrossim, o pedido deveria vir instruído com atestado de pobreza expedido pelo serviço

pagamento de honorários de advogado, e, na medida em que dotada de presunção iuris tantum de veracidade, suficiente a concessão do beneficio legal” (STJ, REsp no 38.124/RS, Rel. Sálvio de Figueiredo Teixeira, j. 20.10.93). E mais: "A concessão dos benefícios da assistência judiciária gratuita não se condiciona à prova do estado de pobreza do requerente, mas tão-somente à mera afirmação desse estado, sendo irrelevante o fato de o pedido haver sido formulado na petição inicial ou no curso do processo" (STJ, REsp no 469.594/RS, Rel. Nancy Andrighi, j. 22.05.03).

${ }^{607}$ LOBO, Arthur Mendes. Duração razoável do processo x abuso na assistência judiciária gratuita: a interpretação das isenções conforme a Constituição à luz da proporcionalidade. Repertório de Jurisprudência IOB, n. 17, p. 526, $1^{\text {a }}$ quinz. set. 2007.

${ }^{608}$ MARCACINI, Augusto Tavares Rosa. Assistência jurídica, assistência judiciária e justiça gratuita, cit., p. 94-99. 
de assistência social ou pela autoridade policial do distrito ou circunscrição onde residisse o interessado (art. 74).

A Lei $n^{\circ}$ 1.060/50 manteve, na sua original configuração, regime idêntico. Segundo o "caput" do art. $4^{\circ}$ o interessado deveria mencionar na petição "o rendimento ou vencimento que percebe e os encargos próprios e os da família", a petição da mesma forma deveria ser instruída com "atestado de que conste ser o requerente necessitado, não podendo pagar as despesas do processo. Este documento será expedido, isento de selos e emolumentos, pela autoridade policial ou pelo prefeito municipal” $\left(\S 1^{\circ}\right.$, podendo o Prefeito nas Capitais de Estado e Distrito Federal delegar tal atividade a servidor designado, conforme $\S 2^{\circ}$ ).

Em 1968 a chamada Lei de Alimentos (Lei $n^{\circ}$ 5.478) antecipou o regime que hoje vige em geral, exclusivamente no âmbito das ações por ela reguladas, estatuindo que a parte poderia gozar as benesses da isenção "por simples afirmativa dessas condições perante o juiz, sob pena de pagamento até o décuplo das custas judiciais", inclusive atribuindo-se à tal afirmação a presunção de veracidade $\left(\operatorname{art.} 1^{\circ}, \S \S 2^{\circ}\right.$ e $3^{\circ}$ ).

Paralelamente, na esfera trabalhista, tivemos em 1970 a edição da Lei $n^{\circ}$ 5.584, que teve, em primeiro lugar, o efeito de sindicalizar a assistência judiciária no que concerne à Justiça do Trabalho. Além disto, o art. $14, \S 1^{\circ}$, do referido diploma estabeleceu que faria jus à assistência quem percebesse salário igual ou inferior ao dobro do mínimo legal, assegurado ao trabalhador de maior salário igual benefício se comprovado que sua situação econômica não lhe permitia demandar sem prejuízo do sustento próprio e da família.

As duas alterações que se seguiram no regime geral da Lei $\mathrm{n}^{\circ}$ 1.060/50 buscaram atender à tendência desburocratizante, combinando elementos da experiência haurida na esfera trabalhista.

Primeiro a Lei $n^{\circ} 6.654 / 79$ acrescentou um $\S 3^{\circ}$ ao art. $4^{\circ}$ onde estatuiu que a apresentação da carteira de trabalho e previdência social na qual o juiz verificasse a necessidade da parte substituiria os atestados que até então eram referidos pelos $\S \S 1^{\circ}$ e $2^{\circ}$.

Meses depois, a Lei $n^{\circ}$ 6.707/79 também alterou a redação do $\S 1^{\circ}$, estabelecendo que o atestado de pobreza seria "dispensado à vista de contrato de trabalho comprobatório de que o mesmo percebe salário igual ou inferior ao dobro do mínimo legal regional”.

A vigência simultânea dos $\S \S 1^{\circ}$ e $3^{\circ}$ gerou certas dúvidas interpretativas, já que num caso se estipulava a dispensa do atestado para os requerentes que percebessem valor 
igual ou inferior ao dobro do salário mínimo, isto é, por critério objetivo; e noutro esta dispensa estaria vinculada à discricionariedade do magistrado à luz do que constasse da carteira de trabalho e previdência social.

A solução conciliatória apresentada Marcacini é a correta: na verdade não havia incompatibilidade entre as regras: se o interessado percebesse valor igual ou inferior ao teto de dois salários mínimos, estaria dispensado de apresentar o tal atestado de pobreza; se percebesse mais que dois salários mínimos, poderia ainda fazer jus ao benefício, provando sua pobreza, aí sim, pelo atestado, porém, "mesmo assim o Juiz poderia, a seu prudente arbítrio, dispensar o atestado de pobreza ante a exibição da CTPS" $"$ 609.

Em 1983 sobreveio a Lei $n^{\circ} 7.115 / 83$, que substituiu o famigerado atestado de pobreza por uma declaração firmada pelo interessado, que seria presumida verdadeira ${ }^{610}$. A propósito, é bem provável que advenha deste diploma legislativo a praxe atualmente difundida nas trincheiras forenses de se apresentar, anexa à inicial, a famigerada “declaração de pobreza” firmada pelo interessado, quando a mera afirmação na petição inicial seria suficiente.

E foi justamente a previsão da simples afirmação a culminância desta evolução legislativa acerca do assunto. Em 1986 a Lei $n^{\circ}$ 7.510, incorporando o regime já previsto desde 1968 para as ações reguladas pela Lei n 5.478 (Alimentos), previu que a parte gozaria da benesse legal "mediante simples afirmação, na própria petição inicial, de que não está em condições de pagar as custas do processo e os honorários de advogado, sem prejuízo próprio ou de sua família" (art. $4^{\circ}$, “caput”), alterando igualmente o $\S 1^{\circ}$, que estabeleceu a presunção de veracidade desta afirmação, e o $\S 2^{\circ}$, que regulamentou a impugnação do direito à assistência, prevendo a ausência de suspensividade em relação à ação principal e pertinência de sua autuação em apartado.

Apenas que por lapso legislativo, permaneceu o restolho do antigo regime: o $\S 3^{\circ}$, ao prever a apresentação da carteira de trabalho e previdência. É óbvio que perdeu inteiramente sua eficácia, restando, a rigor, revogado tacitamente pelo novo regime estabelecido pelo "caput" do art. $4^{\circ}$ e pelo $\S 1^{\circ}\left(\mathrm{LICC}, \operatorname{art} .2^{\circ}, \S 1^{\circ}\right)$.

\footnotetext{
${ }^{609}$ MARCACINI, Augusto Tavares Rosa. Assistência jurídica, assistência judiciária e justiça gratuita, cit., p. 97. ${ }^{610}$ Art. $1^{\text {o: }}$ "A declaração destinada a fazer prova de vida, residência, pobreza, dependência econômica, homonímia ou bons antecedentes, quando firmada pelo próprio interesse ou por procurador bastante, e sob as penas da Lei, presume-se verdadeira”.
} 
Dúvidas têm surgido acerca da exigência probatória para o caso do pedido formulado no curso do processo. A propósito, convém lembrar que o art. $6^{\circ}$ regula a hipótese nos seguintes termos: "O pedido, quando formulado no curso da ação, não a suspenderá, podendo o juiz, em face das provas, conceder ou denegar de plano o benefício de assistência” (destaque nosso).

O problema interpretativo aqui tem sido a alusão à análise de provas pelo juiz, o que poderia induzir a crença de que no caso do pedido formulado no curso do processo, à parte requerente incumbiria produzir prova concreta acerca de sua condição, não valendo aí a mera afirmação a que alude o art. $4^{\text {o }}$ "“caput”, da Lei no $1.060 / 50^{611}$.

O que se percebe, contudo, é que ao passo em que o pedido inicial sofreu marcante processo evolutivo, desde a originária regulamentação legal, conforme já exposto anteriormente a partir das alterações que retalharam o art. $4^{\circ}$, o art. $6^{\circ}$ não foi alvo da correspondente evolução. A boa técnica legislativa recomendava que as alterações procedidas ao longo do tempo o fossem de forma paralela para ambos os casos: pedido inicial ou superveniente ao curso do processo.

Nenhuma justificativa há para discriminar-se a exigência probatória da parte em razão do momento em que formula seu pleito de gratuidade. O máximo que se poderia dizer, como o faz Araken de Assis, é que no caso do pedido amparado no art. $6^{\circ}$, isto é, formulado no curso do processo, faculta-se ao requerente a produção de provas além da simples afirmação ${ }^{612}$. Esta prova pode interessar-lhe, especialmente, por exemplo, se é o caso de justificar a não formulação do pedido inicialmente (isto é, um caso de alteração de fortuna ocorrida no curso do processo) ou mesmo a fim de prevenir a possível impugnação do adversário.

Fato é, contudo, que a faculdade desta produção de provas não decorre da circunstância do pedido ter sido formulado no curso da liça. Se quiser fazê-lo aquele que o formula na inicial (ou na resposta) também não haverá impedimento algum, pois que está provendo um plus ao pressuposto legal mínimo.

É importante gizar que a parte que requer o benefício no curso do processo deve esclarecer o juízo acerca da modificação de sua condição econômica. Não se está a afirmar que terá de comprovar por meios diversos que apenas a declaração de pobreza, idéia que

\footnotetext{
${ }^{611}$ Esta a posição de Evandro Fernandes de Pontes (PONTES, Evandro Fernandes de. A assistência judiciária na mira do modelo garantista do processo, cit., p. 63).

${ }^{612}$ ASSIS, Araken de. Benefício da gratuidade, cit., p. 178.
} 
de resto já foi rechaçada no final do item anterior. Ou seja, sua afirmação de pobreza gozará a mesma presunção de veracidade que aquela da parte que apresenta seu pedido na primeira oportunidade que fala nos autos.

Porém neste caso sua afirmação de pobreza terá uma nota distinta que será a informação ao juízo acerca da mudança de seu quadro econômico. E isto se justifica porque a parte vinha, até então, arcando regularmente com todo o custo do processo, o que denota capacidade financeira para tanto. Logo, a declaração que sobressai no curso do processo de certa forma destoa da conduta da parte até então.

Não se pense que o requerimento do benefício no curso do processo apenas pode ter por amparo a mudança na situação econômica da parte. Haverá situações em que intercorrências imprevistas ao curso do próprio processo poderão causar à parte a impossibilidade de exercer na plenitude seu direito de acesso à justiça sem recurso à benesse legal, sem que tenha havido propriamente em relação à parte qualquer alteração da sua condição econômica.

Para ficarmos num exemplo já antes aventado: imagine-se a parte que ajuíza ação de usucapião, programando-se para efetuar certo montante de despesas inerentes ao curso do processo (citações e intimações obrigatórias, e até mesmo certa reserva para arcar com eventual necessidade de uma singela perícia). Pode ocorrer que no desenrolar do debate judicial, por exemplo, a partir de questões suscitadas em contestação de um dos réus, surja a necessidade de uma perícia mais elaborada, um levantamento topográfico, compensação ambiental, enfim, procedimentos de alto custo que escapam à possibilidade da parte, suplantando a reserva que já fora feita.

Veja-se que nesta hipótese a parte não experimentou propriamente em sua condição econômica alteração alguma. A surpresa adveio no curso do processo e em razão do rumo tomado na instrução deste.

Nesta hipótese não há óbice algum a que a parte pleiteie o benefício, pois o que deve prevalecer é o direito constitucional de acesso à justiça de forma plena, isto é, ao exercício não apenas do direito de ação, mas de todas as posições ativas que o evolver da relação processual propicia. 


\section{Oportunidades processuais para requerimento}

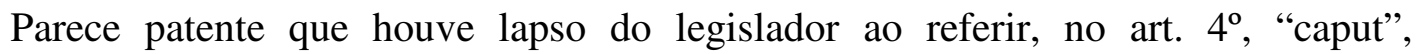
unicamente ao pedido formulado em "petição inicial", simplesmente porque não apenas ao autor o benefício é facultado. Tanto a réu(s) como a terceiros intervenientes podem ser concedidos os benefícios da gratuidade desde que preenchido o pressuposto constitucional/legal.

O réu que desejar apresentar o pleito desde o início do processo (leia-se início para ele, réu) o fará na resposta, expressão que é usada propositalmente: poderá o réu formular o pedido seja na própria contestação, seja nas exceções rituais ou mesmo na reconvenção (CPC, art. 297). Não há motivo para afirmar-se que o pedido formulado, por exemplo, no incidente formado a partir de uma exceção ritual, abranja apenas o tal procedimento anexo ao principal.

Importa que assim como a reconvenção, as exceções rituais valem-se da mesma base procedimental da ação principal, formando-se quanto a estas procedimentos incidentais que não são dotados de existência autônoma em relação ao processo principal, por outras palavras, não se forma relação processual autônoma. Logo, seja formulado em reconvenção, seja nas exceções rituais, ou mesmo em impugnação ao valor da causa, a gratuidade deferida tem o efeito amplo de atingir todo o procedimento ao qual se referem estes incidentes. A forma contrária é também válida: o pedido formulado e deferido no bojo do processo principal atinge igualmente os incidentes que venham a se anexar no curso do embate.

Veja-se que temos adotado o princípio de que o que vale nesta seara não é propriamente o caráter autônomo das pretensões (é indiscutível, por exemplo, que a reconvenção veicula ação diversa da principal), mas sim a formação ou não de relação processual autônoma e independente da principal. Onde não houver tal formação, o pedido formulado em um incidente abrange toda a relação processual, e o formulado na relação processual principal, abarca os incidentes. Isto se diz porque a gratuidade defere-se para o processo, que se materializa no procedimento, e não em favor da pretensão.

Tendo em mente este princípio, fica fácil a solução de problemas relacionados aos possíveis incidentes processuais ou pretensões simultâneas. A ação declaratória incidental, por exemplo, representa nova pretensão encravada na mesma relação processual, mera ampliação do objeto do mesmo processo, daí porque valem as mesmas assertivas feitas 
anteriormente quanto aos demais incidentes: a gratuidade se lhe abrange (aliás, quando ofertada pelo réu até ostenta natureza reconvencional) ${ }^{613}$.

Seguindo o mesmo raciocínio, a gratuidade deferida num determinado processo não abrange outro, ainda que veicule pretensão idêntica, conexa ou contingente. Repita-se: a benesse é concedida em atenção ao processo, não à pretensão nele posta.

Por isto também o benefício concedido na execução não abrange os embargos do devedor, nem vice-versa. É que "o oferecimento dos embargos dá ensejo à formação de

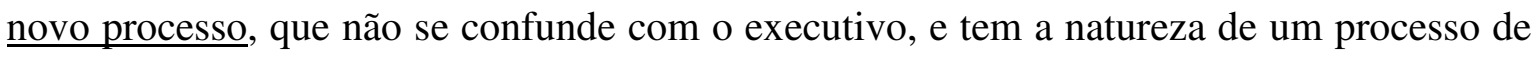
cognição" ${ }^{\text {614 }}$ (destaque nosso).

Indaga-se se poderia a parte formular o pedido após a extinção do processo, ou por exemplo, da fase cognitiva. A primeira resposta há de ser necessariamente negativa, o que se compreende a partir de uma simplória exegese gramatical do art. $6^{\circ}$ da Lei $n^{\circ} 1.060 / 50$ : com a extinção não há mais processo "em curso". O principal problema neste caso é o da parte que, agonizando derrota na ação, busca ver-se livre dos encargos sucumbenciais a que foi condenada. Este artifício não é de ser admitido. Na verdade a questão aqui mais se liga aos efeitos temporais da decisão concessiva (que como adiante veremos, não podem, a rigor, ser retroativos, de modo que concedida a benesse após a condenação sucumbencial, esta não restará elidida), mas as palavras de Araken de Assis acerca do assunto são lapidares, e merecem transcrição: "a necessidade não é causa legal de remissão das obrigações contraídas em virtude do processo, e sim de isenção das despesas processuais futuras",615.

É óbvio que o benefício pode ser concedido na fase de cumprimento de sentença ou no processo de execução, porém jamais abarcará a verba sucumbencial fixada na fase de conhecimento, que constitui parte do crédito exeqüendo, tendo neste caso seus efeitos limitados às custas, despesas e honorários correspondentes ao feito executivo ou á fase executiva ${ }^{616}$.

\footnotetext{
${ }^{613}$ Barbosa Moreira a respeito leciona: "Daí em diante, assim, a questão subordinada como a subordinante passam a integrar, em conjunto, o objeto do processo, e o pronunciamento judicial sobre ambas se revestirá, todo ele, da autoridade da coisa julgada (art. 470)" (O novo processo civil brasileiro. 22. ed. Rio de Janeiro: Forense, 2002. p. 92).

${ }^{614}$ BARBOSA MOREIRA, José Carlos. O novo processo civil brasileiro, cit., p. 288.

${ }^{615}$ ASSIS, Araken de. Benefício da gratuidade, cit., p. 179.

616، A parte sucumbente em ação de cobrança, com sentença transitada em julgado, contudo, somente pode pleitear o benefício nos autos da execução ou dos embargos do devedor - ações autônomas - no que se refere ao novo processo. Não pode seu deferimento retroagir para alcançar a verba honorária fixada na sentença exeqüenda" (STJ, REsp n ${ }^{\circ}$ 410.227/PR, Rel. Castro Filho, j. 03.09.02).
} 
Não há óbice também para que o pedido se formule já na fase recursal ${ }^{617}$.

O terceiro formulará seu pedido na peça por meio da qual intervier no processo, ou em manifestações posteriores acaso não seja o caso de requerimento originário.

Afora a questão da comprovação do estado de pobreza, já tratado, há um outro problema interpretativo acerca do art. $6^{\circ}$ da Lei $\mathrm{n}^{\circ} 1.060 / 50$, que trata do pedido de gratuidade formulado no curso da ação. Isto decorre do emprego dúbio da expressão "neste caso", aludindo à hipótese de autuação em separado do incidente acerca da concessão ou não da gratuidade.

Uma primeira leitura não permite saber se o "caso" a que se alude seria o simples requerimento formulado no curso da ação, ou se se trataria da hipótese de denegação do pedido, caso em que a autuação em apartado possibilitaria a subida dos autos do incidente à instância recursal para apreciação da apelação (sem a autuação em apartado não haveria possibilidade de subida dos autos em sede de apelação, se é que este é o recurso próprio, como se tratará adiante).

A doutrina não é uníssona acerca da correta interpretação da expressão "neste caso", a declarar se se refere ao pedido formulado no curso da ação, que sempre será autuado em apartado, seja o caso de deferimento, seja de indeferimento, ou se apenas haverá autuação em separado se houver a denegação, como se poderia cogitar em razão da dubiedade da redação do dispositivo ${ }^{618}$.

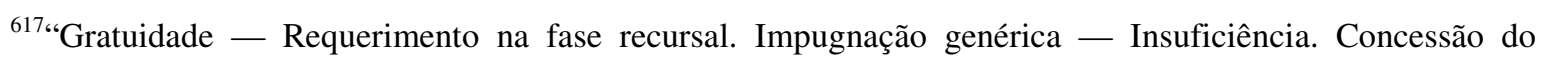
benefício, ressalvada sua irretroatividade" (TJSP, Ap nº 1.108.737-0/6, Rel. Cláudio Lima Bueno de Camargo, j. 18.03.08).

${ }^{618}$ Entendem que autuação em separado deve ocorrer sempre que o pedido for ulterior Fredie Didier Jr e Rafael Oliveira (Benefício da justiça gratuita, cit., p. 42); André Bonelli (Aspectos processuais da Lei de Assistência Judiciária. In: FARIAS, Cristiano Chaves de; DIDIER JR, Fredie (Coords.). Procedimentos especiais cíveis: legislação extravagante. São Paulo: Saraiva, 2003. p. 1.545) e R.L.L.DEMO (Assistência judiciária gratuita, cit., p. 352). Maurício Vidigal entende que a autuação em separado a que alude a regra refere-se ao caso de denegação do benefício: "Pela interpretação literal, mesmo indeferido o pedido no cabeçalho da própria petição, ela deve ser autuada em apartado, cabendo então apelação como recurso próprio" (Lei da Assistência Judiciária interpretada, cit., p. 52, destaque nosso). Marcacini, de sua banda, entende em qualquer caso inaplicável a norma do art. $6^{\circ}$, ou seja, seja o requerimento formulado na primeira oportunidade na qual falar a parte nos autos, seja formulado posteriormente, seja ele deferido ou denegado, não se autua em separado: “Com a simplificação feita pelas leis posteriores, não vemos porque o pedido de justiça gratuita formulado no curso do processo deva ter formalidades diversas daquelas exigidas initio litis. O procedimento previsto no art. $6^{\circ}$, portanto, não deve ser aplicado ao caso. Ao mencionar que o juiz concederá ou denegará o benefício em face das provas, o dispositivo se mostra defasado, por descuido do legislador em não adaptá-lo às novas exigências para a concessão do benefício da gratuidade. Mesmo no curso do processo, basta a mera declaração feita na própria petição em que se solicita o benefício, não sendo de autuá-la em separado" (Assistência jurídica, assistência judiciária e justiça gratuita, cit., p. 99). $\mathrm{Na}$ jurisprudência encontramos exigência de autuação apartada sempre que formulado o pedido no curso da lide, inclusive com diversa exigência probatória: "Não tendo a agravante - empresa comercial - feito prova 
O recurso ao antecedente histórico imediato desta regra, a saber, o art. 73 do Código de Processo Civil de 1939 revela a correta interpretação da regra, atribuindo razão à primeira corrente, no sentido de que a autuação em separado sempre tem lugar quando o pedido é formulado no curso da marcha processual: "O pedido formulado no curso da lide não a suspenderá, podendo o juiz, à vista das circunstâncias, conceder, de plano, a isenção. A petição, neste caso, será autuada em apartado, apensando-se os respectivos autos aos da causa principal, depois de resolvido o incidente". A melhor alocação das expressões torna induvidosa a regra.

Note-se, entretanto, que a inobservância desta regra procedimental de autuação apartada não implica qualquer espécie de nulidade, mas mera informalidade. Poderá gerar, conforme uma certa corrente que será oportunamente analisada, diversidade quanto ao recurso cabível (se processada nos próprios autos, cabível agravo de instrumento; se em apartado, apelação). Porém não se cogitará nulidade procedimental porque o pedido, inadvertidamente, acabou processado nos próprios autos em que já estava em curso o processo principal. Cuida-se aí de mera irregularidade.

\section{Decisão acerca do requerimento: fundamentação e efeito}

Segundo afirma o art. $5^{\circ}$ da Lei $n^{\circ} 1.060 / 50$, “o juiz, se não tiver fundadas razões para indeferir o pedido, deverá julgá-lo de plano, motivando ou não o deferimento, dentro do prazo de 72 horas".

$\mathrm{O}$ primeiro ponto que deve nesta seara ser ressaltado diz respeito à necessidade de expressa decisão acerca do pedido. Isto porque, conforme bem alerta Marcacini, o art. $4^{\circ}$, "caput", dá uma falsa impressão de que a parte gozará do benefício mediante a simples afirmação, isto é, que não se depende de aquiescência judicial, numa espécie de "autodeferimento", o que é equivocado. Cuida-se de questão processual, que deve ser solvida pelo juiz, não havendo que se falar em concessão tácita ou implícita.

\footnotetext{
da sua incapacidade financeira para assumir os ônus decorrentes do ingresso em juízo, além do que apenas requereu a concessão dos benefícios da justiça gratuita depois da distribuição da ação, descabido o deferimento do pedido formulado no curso da demanda, suportado apenas na declaração de sua insuficiência de recursos para custear as despesas do processo e, ante a necessidade do processamento do pertinente incidente em autos em apenso, para a instauração do contraditório amplo, porquanto a presunção 'juris tantum' que antes militava a favor da parte requerente do benefício, cede lugar à necessária comprovação da modificação de sua situação financeira aponto de justificar o deferimento do benefício pretendido, cujo principal escopo é garantir o acesso à Justiça daquele comprovadamente hipossuficiente" (TJSP, AI n ${ }^{\circ}$ 1.019.459-00/1, Rel. Amorim Cantuária, j. 25.04.06).
} 
O mesmo autor, entretanto, embora afirmando que a expressa concessão seja a regra, chega a defender: "O silêncio do juiz, neste caso, significaria que, mediante um juízo de valor, a gratuidade foi concedida; pois, do contrário, teria expressamente denegado o benefício" "619. No sentido contrário, Araken de Assis leciona: "A eventual omissão do órgão judiciário, ignorando o requerimento do interessado, não traduz acolhimento, ou seja, a concessão automática do benefício, nem transforma seu ato omisso em decisão agravável",620.

A razão parece estar com a segunda posição. Não há como, a esta altura do desenvolvimento das garantias constitucionais do processo, especialmente a expressa diretriz contida no art. 93, IX, da Constituição (se toda decisão do Poder Judiciário há de ser fundamentada, que dirá expressa?), defender-se a possibilidade de que uma omissão judicial se traduza em juízo decisório. Ainda mais porque a decisão concessiva do benefício representa gravame para o adversário, para o próprio Estado e para serventuários extrajudiciais intervenientes no processo ${ }^{621}$.

Assim que se o juiz se omite diante do requerimento, isto não implica deferimento ou indeferimento do benefício, mas nada além de sua não-concessão. A isenção de custas, despesas e honorários constitui circunstância especial no regime jurídico geral da parte litigante, isto é, nota diferenciadora no seu modo de litigar, daí porque dizer-se que depende de regular concessão judicial. Na ausência de tal decisão temos que a tal nota diferenciadora não incide, isto é, remanesce a parte sujeita ao regime geral dos litigantes, segundo o qual cabe às partes prover as despesas dos atos que realizam ou requerem no processo (CPC, art. 19).

Ao interessado neste caso incumbirá opor embargos de declaração à decisão que, por exemplo, deferiu a citação sem apreciar o requerimento de gratuidade (ou, no caso de requerimento formulado no curso da ação, embargar a decisão judicial seguinte ao requerimento, que não o apreciou), ou meramente reiterar o pedido. Porém, quedando-se inerte a parte e remanescendo a omissão judicial, deverá arcar com as custas processuais.

Outro ponto assaz referido pela doutrina diz respeito à necessidade de motivação do deferimento, já que a letra do art. $5^{\circ}$ "caput" da Lei $\mathrm{n}^{\circ}$ 1.060/50 a dispensa. Diz-se que esta

\footnotetext{
${ }^{619}$ MARCACINI, Augusto Tavares Rosa. Assistência jurídica, assistência judiciária e justiça gratuita, cit., p. 102. ${ }^{620}$ ASSIS, Araken de. Benefício da gratuidade, cit., p. 182.

${ }^{621}$ Também defendendo a necessidade de decisão sempre expressa: DEMO, Roberto Luis Luchi. Assistência judiciária gratuita, cit., p. 358.
} 
dispensa não conta com recepção constitucional (art. 93, IX, da CR) ${ }^{622}$. Em sentido contrário, entretanto, afirma-se igualmente que a dispensa de motivação nestas hipóteses não fere o dispositivo constitucional retro citado, apenas significando que o magistrado não encontra razões para indeferi-lo, e que "somente viria retardar o andamento já moroso dos processos se, em decisões semelhantes, fosse exigida a exposição dos fundamentos do deferimento"623.

A rigor motivação seria exigível. A questão é que dada a configuração legal deste deferimento inicial, de plano, feito unicamente à luz da declaração de pobreza, realmente não haveria muito que se dizer, senão as fórmulas sem expressão de conteúdo como "à luz da declaração juntada, defiro...”; "presentes os requisitos legais, defiro..."; etc. Exigir uma tal sorte de "motivação" sob pena de nulidade parece ter um quê de formalismo pouco proveitoso. Mas uma coisa é certa, o deferimento deve ser expresso ${ }^{624}$.

O já citado art. 50, "caput", fala ainda que o pedido deve ser julgado "de plano". Entende-se por esta expressão que inexistindo elementos aptos a inspirar no juiz dúvidas acerca da veracidade da declaração de pobreza, o deferimento é imperioso, sem maiores dilações probatórias. Isto é, é um juízo sumário $^{625}$ ou imediato, sem determinação de diligências $^{626}$.

Segundo leciona José Roberto de Castro, tanto o deferimento como o indeferimento podem ocorrer mediante "julgamento de plano", e que ambas as sortes de decisão deverão conter motivação adequada ${ }^{627}$. O que normalmente se aconselha ao juiz é que, vislumbrando que apesar da afirmação de pobreza subsistem elementos a ampararem a

\footnotetext{
${ }^{622}$ DEMO, Roberto Luis Luchi. Assistência judiciária gratuita, cit., p. 358. No mesmo sentido: ASSIS, Araken de. Benefício da gratuidade, cit., p. 181. Marcacini tem posição híbrida: embora afirme a necessidade de motivação, que será concisa, observa que sua falta também não implica nulidade (Assistência jurídica, assistência judiciária e justiça gratuita, cit., p. 102-103).

${ }^{623}$ VIDIGAL, Mauricio. Lei da Assistência Judiciária interpretada, cit., p. 43.

${ }^{624} \mathrm{Na}$ jurisprudência encontramos o seguinte pronunciamento: "Monitória - Processo julgado extinto, por motivo de perda do interesse processual do autor, em vista de transação extrajudicial com a parte contrária Gratuidade processual requerida pelo autor e não apreciada expressamente pelo juiz - Indícios de que a benesse foi deferida implicitamente - Anulação do processo incompatível com a gratuidade processual Recurso desprovido, com observação" (1º TAcSP, Ap nº 1.084.516-4, Rel. Cerqueira Leite, j. 13.08.03). É interessante deixar consignado que da leitura do voto condutor do referido julgamento, extrai-se o entendimento de que a rigor a decisão deveria ser expressa. Apenas que na hipótese o juiz de primeiro grau havia, ao rejeitar embargos de declaração versando a falta de decisão acerca da gratuidade, expressamente declarado que era à parte contrária que incumbia impugnar o benefício, daí porque a Segunda Instância entendeu que teria, excepcionalmente, ocorrido uma decisão implícita de deferimento.

${ }^{625}$ ASSIS, Araken de. Benefício da gratuidade, cit., p. 181.

${ }^{626}$ VIDIGAL, Mauricio. Lei da Assistência Judiciária interpretada, cit., p. 42.

${ }^{627}$ CASTRO, José Roberto de. Manual de assistência judiciária: teoria, prática e jurisprudência, cit., p. 109.
} 
rejeição do pedido de gratuidade, que intime a parte para que complemente a prova ou preste esclarecimentos pertinentes $^{628}$.

Certo é que o juiz não é obrigado a tanto, e não haveria de se falar em nulidade se o magistrado, à luz dos elementos já constantes dos autos formasse seu convencimento negativamente quanto ao estado de pobreza legal, e de plano indeferisse o pedido. $\mathrm{O}$ contraditório não restaria maculado, pois à parte prejudicada se permitirá oportuno recurso com a decisão negativa.

Ao interpor a cláusula "se não tiver fundadas razões para indeferir", quis o legislador expressar que "só pode ser denegado de ofício se houver prova inequívoca de que o postulante não se ajusta ao perfil de beneficiário" "629. Lembre-se, entretanto, que a decisão que à luz da simples declaração defere o benefício é precária, dotada da cláusula rebus sic stantibus ${ }^{630}$.

Defende Artêmio Zanon que feito o pedido de assistência, por qualquer das modalidades, deveria ter vista do processado o Ministério Público para manifestar-se a respeito $^{631}$. À luz, contudo, das balizas para tal intervenção, hoje postas no art. 82 do Código de Processo Civil, não parece haja algum propósito que o justifique, pois o interesse diretamente discutido será patrimonial e disponível.

Há, é certo, subjacentes interesses maiores, públicos, como a isonomia das partes no processo, o correto exercício da jurisdição, assegurar o acesso à justiça, etc.. Argumenta-se, entretanto, que tais interesses, na verdade, subjazem a qualquer processo judicial, e assim a intervenção do Ministério Público seria geral e obrigatória em todo e qualquer feito, o que não se sustenta em recôndito algum da doutrina.

Assim é que a intervenção ministerial para manifestação acerca da gratuidade/assistência requerida dar-se-á nos casos enumerados no art. 82 do Código de Processo Civil.

\footnotetext{
628،"não há dúvida de que, sponte sua, o juiz, antes do não-deferimento (de plano), pode fazer com que aos autos sejam carreados os elementos complementares de que padece o pedido. Porém, o julgamento de plano a que se refere a lei há de se entender apenas a decisão que defere. O deferimento imprescinde de maior fundamentação, permissa venia" (ZANON, Artêmio. Assistência Judiciária gratuita: comentários à Lei da Assistência Judiciária (Lei no 1.060, de 5-2-1950), cit., p. 53).

${ }^{629}$ MARCACINI, Augusto Tavares Rosa. Assistência jurídica, assistência judiciária e justiça gratuita, cit., p. 103.

${ }^{630}$ DEMO, Roberto Luis Luchi. Assistência judiciária gratuita, cit., p. 359.

${ }^{631}$ ZANON, Artêmio. Assistência Judiciária gratuita: comentários à Lei da Assistência Judiciária (Lei $\mathrm{n}^{\circ}$ 1.060, de 5-2-1950), cit., p. 53.
} 
Outro ponto espinhoso diz respeito aos efeitos temporais da decisão concessiva da gratuidade. Se fôssemos levar a detalhamento rigoroso a questão, seríamos obrigados a afirmar que sempre haverá uma carga de retroatividade na decisão que concede a gratuidade, pois que no mínimo ela serve para isentar a parte das obrigações pecuniárias relacionadas ao processo constituídas após o pedido, e este sempre será anterior à decisão. Por outras palavras: a decisão sempre retroagirá ao menos até a data da realização do pedido em juízo.

Esta assertiva poderia parecer irrelevante, mas não é. Já tratamos alhures da questão da interpretação da omissão judicial acerca do pedido. Imagine-se, entretanto, que não haja propriamente omissão, mas mero atraso ou retardamento na análise da questão pelo juiz, e que durante este lapso de retardamento, e tendo o processo seu curso regular, obrigações pecuniárias se constituam. A pergunta é: se o juiz, oportunamente percebe o lapso, e então defere o benefício, como ficam estas obrigações?

Ao contrário do caso em que omissão judicial completa acerca do pedido ocorre, neste caso o juiz reconhece formalmente o estado de pobreza, e é inevitável ter que sua decisão tem natureza declaratória, retroagindo para reconhecer tal estado no momento da afirmação vertida nos autos, de modo que as obrigações constituídas no interregno entre o pedido e a decisão judicial serão abarcadas pela isenção.

Por óbvio que se entre o pedido e a decisão há fugaz espaço temporal, ou irrisória movimentação processual, sem eclosão de obrigações pecuniárias, irrelevante será tal retroatividade.

Assim é bom deixar claro que quando se debate a presença ou não de efeito retroativo (ex tunc) no deferimento da gratuidade, pensa-se na possibilidade (ou não) de abrangência de obrigações constituídas antes do pedido formulado formalmente pela parte $^{632}$.

Na doutrina, pois, não há maiores hesitações em reconhecer-se que a gratuidade não opera retroativamente, nos termos em que entendida esta expressão no parágrafo anterior, isto é, não abarca obrigações constituídas antes do pedido ${ }^{633}$.

\footnotetext{
${ }^{632}$ Neste sentido: MARCACINI, Augusto Tavares Rosa. Assistência jurídica, assistência judiciária e justiça gratuita, cit., p. 105.

${ }^{633}$ Lecionam a respeito Fredie Didier e Rafael Oliveira: "Se o requerente, mesmo necessitado, não pleiteou o benefício no primeiro momento em que poderia fazê-lo, não há qualquer óbice a que deduza o seu pedido ulteriormente. Entretanto, as despesas que fez, aquelas cujo fato gerador já ocorreu ou, ainda, aquelas já adiantadas pela outra parte não lhe serão devolvidas ou dispensadas. Isto porque o deferimento do benefício
} 
Convém, entretanto, apontar uma nuance interessante na posição de Marcacini, para quem embora a decisão não tenha efeitos retroativos a período anterior ao pedido, abrange obrigações constituídas antes de tal marco (pedido) desde que ainda não pagas pela parte:

\begin{abstract}
"Mesmo que a custa ou despesa seja relativa a ato anterior ao pedido, mas que não tenha sido paga até então, fica compreendida na isenção. Isto porque, desde que formulado o pedido de gratuidade, não tem a parte condições de fazer qualquer pagamento, senão com prejuízo de seu sustento. $\mathrm{O}$ fato de $\mathrm{o}$ ato ser anterior ao benefício não torna a situação diferente, nem faz com que o sustento atual do carente deixe de ser prejudicado. A concessão não irá, porém, retroagir para atingir pagamentos já feitos pelo beneficiário" ${ }^{634}$.
\end{abstract}

A irretroatividade para o autor em questão significa apenas a impossibilidade de repetição dos pagamentos já efetuados antes do pedido. Alerte-se apenas para o fato de que as despesas efetuadas pelo adversário do requerente antes da formulação do pedido de gratuidade igualmente não estarão abarcadas pela isenção, isto é, o adversário, sagrando-se vencedor, fará jus ao ressarcimento daquelas despesas feitas antes da concessão da benesse.

Acresça-se ainda que em relação ao réu bem como ao terceiro interveniente, a nota de retroatividade intrínseca à decisão concessiva da gratuidade a que já aludimos é mais pronunciada. Isto porque tais personagens necessariamente intervém após considerável

tem efeito ex nunc, constituindo situação jurídica nova, que não abrange as despesas processuais anteriores ao pedido" (Benefício da justiça gratuita, cit., p. 44). Esta também a posição de Araken de Assis (Benefício da gratuidade, cit., p. 179) e de Roberto Luis Luchi Demo, que, contudo, afirma o caráter constitutivo e não declaratório da decisão concessiva (Assistência judiciária gratuita, cit., p. 358). Parece, como já dito no corpo do texto, que a decisão é declaratória, ocorre, contudo, a limitação de seu caráter retroativo (como, aliás, é inerente a decisões desta espécie) ao pedido. Isto não quer dizer que a decisão seja constitutiva, o que implicaria a impossibilidade de abrangência das obrigações constituídas desde a formulação do pedido até sua prolação. Flávio Yarshell leciona: "não há dúvida de que a parte pode pleitear o benefício $a$ qualquer tempo. Mas, precisamente por isso, somente poderá o interessado desfrutar do benefício a partir do momento em que, requerendo, seja ele deferido. Isso ocorre porque, como visto, é ônus do interessado afirmar a necessidade da providência e requerê-la expressamente. Portanto, antes disso, não há que se cogitar da vigência do benefício" (A assistência judiciária sob o ângulo do requerido, cit., p. 86). Igualmente a jurisprudência é neste sentido: "É correta a afirmativa de que o benefício da assistência judiciária pode ser concedido a qualquer tempo, inclusive em sede de execução, no entanto, seus efeitos deverão atingir tão-somente os atos que daquele momento em diante se aperfeiçoarem, sendo vedada a retroatividade de sua eficácia para fins de liberação do beneficiado de encargos surgidos em processo cognitivo anterior" (STJ, REsp n 478.352/PA, Rel. Vicente Leal, j. 11.02.03). Ainda: “ASSISTÊNCIA JUDICIÁRIA - GRATUIDADE DA JUSTIÇA - EFEITOS - É impossível retroagir a concessão da gratuidade da Justiça - Beneficio que abrange as despesas processuais verificadas a partir da sua concessão - MOMENTO PROCESSUAL - Pedido de gratuidade da Justiça que pode ser deduzido em qualquer grau de jurisdição - Necessidade, todavia, de se comprovar a alteração da condição financeira do postulante, quando o pedido é formulado no curso do processo - Pessoa Jurídica - Admissibilidade - Pedido, contudo, sujeita à comprovação do alegada - Inexistência de prova acerca da necessidade do beneficio. - Recurso de Agravo de Instrumento não provido" (TJSP, AI n 7.043.024-1, Rel. Amado de Faria, j. 8.03.06).

${ }^{634}$ MARCACINI, Augusto Tavares Rosa. Assistência jurídica, assistência judiciária e justiça gratuita, cit., p. 105. 
transcurso processual. Assim é que na primeira oportunidade que teria o réu de se manifestar no processo, já teria ocorrido, por exemplo, o desembolso da taxa judiciária e despesa de condução de oficial de justiça pelo autor. Não há que se defender que o réu que pede a gratuidade logo na primeira oportunidade que fala nos autos seja obrigado a arcar com tais custas se vencido, porque ocorridas antes de formulado o pedido.

O que importa aqui é que o pedido tenha sido feito pela parte na primeira oportunidade que teve para falar nos autos, caso em que a retroatividade é medida de justiça $^{635}$.

Uma última indagação neste subitem: caberia recurso da decisão que de plano defere o benefício? Em entrelinhas, Artêmio Zanon dá a entender que sim, e mais, que seria o recurso previsto pelo art. 17 da Lei $n^{\circ} 1.060 / 50$, ou seja, a apelação ${ }^{636}$. Marcacini, de sua parte, observa que esta concessão à vista da simples afirmação de pobreza se faz sem oitiva da parte contrária, de modo que "quaisquer argumentos que tenha a parte contrária para elidir esta presunção devem ser trazidos primeiramente à apreciação do juiz da causa, mediante a impugnação" ${ }^{637}$, lembrando que o recurso diretamente interposto, na espécie, suprimiria um grau de jurisdição. Propõe então a analogia com o juízo positivo acerca da petição inicial, deferindo a citação, decisão que se entende não agravável porque a parte terá, na contestação, a oportunidade de expor os motivos pelos quais entendia que a inicial era de ser indeferida.

Mais consistente é deveras a segunda posição. Já foi afiançado que a decisão que concede de plano a gratuidade é dotada de caráter precário, com base em juízo de cognição sumária, passível de revogação a qualquer tempo. Daí a razão pela qual prevê a lei instrumento processual próprio para buscar-se a reforma desta decisão ainda em primeira instância, a saber, a impugnação a que alude o art. $7^{\circ}$ da Lei $n^{\circ} 1.060 / 50$, ou mesmo a revogação de ofício pelo juiz (art. $8^{\circ}$ ).

\footnotetext{
${ }^{635}$ Rafael Oliveira e Fredie Didier Jr bem justificam assim a posição: “A distinção de tratamento se justifica pelos momentos processais em que o réu e terceiro interveniente ingressam na demanda. Entender o contrário seria permitir que esses sujeitos processuais nunca pudessem gozar do benefício em sua plenitude, vez que teriam que suportar as despesas anteriores ao respectivo ingresso" (Benefício da justiça gratuita cit., p. 45).

${ }^{636}$ Eis o excerto: "A tramitação dos autos de assistência judiciária, ocorrendo deferimento e não havendo recurso (art. 17), é a apontada, no que aplicável, nos parágrafos do artigo em exame" (ZANON, Artêmio. Assistência Judiciária gratuita: comentários à Lei da Assistência Judiciária (Lei nº 1.060, de 5-2-1950), cit., p. 53, a referência é ao art. $5^{\circ}$ da Lei no $1.060 / 50$ ).

${ }^{637}$ MARCACINI, Augusto Tavares Rosa. Assistência jurídica, assistência judiciária e justiça gratuita, cit., p. 112.
} 
Nem é propriamente a questão da dita supressão de instância que obstaria o recurso (porque há hipóteses em que ocorre a dita supressão sem que se cogite aí ilegalidade ou inconstitucionalidade, como por exemplo medidas de originária competência das instâncias ordinariamente recursais), mas sim a falta de interesse recursal, por inexistência de necessidade da tutela, ainda. Isto é, a opção pela via recursal neste caso afigura-se prematura $^{638}$.

Deixemos para discutir a natureza da decisão acerca da gratuidade quando tratarmos do recurso cabível, tema que merecerá item próprio.

\section{Impugnação ao benefício. Revogação "ex officio"}

A impugnação vem regulamentada no art. $7^{\circ}$ da Lei $n^{\circ} 1.060 / 50$, nos seguintes termos: “A parte contrária poderá, em qualquer fase da lide, requerer a revogação dos benefícios de assistência, desde que prove a inexistência ou o desaparecimento dos requisitos essenciais à sua concessão". Ajunta o parágrafo único que "Tal requerimento não suspenderá o curso da ação e se processará pela forma estabelecida no final do artigo $6^{\circ}$ desta Lei".

A primeira nota que logo sobressai no dispositivo é a distribuição do ônus da prova, que no caso observa correspondência com a presunção de veracidade da afirmação de pobreza feita pelo requerente na forma do art. $4^{\circ}, \S 1^{\circ}$, do diploma. Ou seja, se a tal afirmação é dotada de presunção relativa de veracidade, conseqüência inarredável é que à parte contrária incumbirá a prova da inexistência ou desaparecimento do pressuposto da miserabilidade em termos legais.

Não há um regramento preciso acerca do procedimento a ser seguido neste incidente de impugnação, apenas a referência ao art. $6^{\circ}$ que igualmente é lacônico, estabelecendo nada mais que a necessidade da autuação em separado e apensamento assim que resolvida a questão: “(...) será autuada em separado, apensando-se os respectivos autos aos da causa principal, depois de resolvido o incidente". Por "resolução do incidente" entenda-se a solução por decisão firme, isto é, passada em julgado.

É intuitivo que por respeito ao contraditório deve-se facultar ao beneficiário impugnado manifestar-se em resposta à impugnação. O prazo será o assinado pelo juiz ou,

\footnotetext{
${ }^{638}$ Em sentido contrário, dando pelo cabimento do Agravo de Instrumento: STJ, REsp n ${ }^{\circ} 745.595 / \mathrm{SP}$, Rel. Nancy Andrighi, $3^{\circ}$ Turma, j. 18.04.2006.
} 
na falta, o supletivo a que alude o art. 185 do Código de Processo Civil ${ }^{639}$. O direito à prova também é amplo, de ambas as partes, impugnante e impugnado, valendo a respeito toda a amplidão permitida pelo art. 332 do Código de Processo Civil: “Todos os meios legais, bem como os moralmente legítimos, ainda que não especificados neste Código, são hábeis para provar a verdade dos fatos, em que se funda a ação ou a defesa".

A propósito, é comum em incidentes como este que haja requerimentos de expedição de ofícios visando a obtenção de informações acobertadas por sigilo (p.ex. Receita Federal a fim de obter-se a última declaração de imposto de renda do impugnado; instituições financeiras para aferir a existência e montante de movimentação de recursos por parte do impugnado; existência de veículos ou imóveis em seu nome; ofícios a empregadoras para informe de rendas; etc.).

Por vezes tais pleitos são indeferidos com o argumento de que incumbe à parte diligenciar a prova de suas alegações, ao que se contra-argumenta que no mais das vezes tais informes somente podem ser obtidos mediante a intercessão judicial, justamente porque protegidos por sigilo, como já apontado.

O dilema comporta solução parcimoniosa. De um lado não se pode permitir que a parte que oferta impugnação absolutamente genérica, veiculando mera desconfiança de que o adversário não faça jus ao benefício, pretenda por esta via instrutória realizar verdadeira investigação ou devassa para aferir a real condição financeira do oponente. Isto é, aquele que oferta a impugnação deve já contar com elementos mais ou menos concretos com os quais afirma a falsidade da "declaração" de pobreza, de modo que as expedições de ofícios pleiteadas representem mera complementação ou confirmação daquilo que já se sabe ou ao menos se acredita verdadeiro. Nesta hipótese de fato o indeferimento sem maiores critérios pelo juízo implica cerceamento de defesa, por impossibilitar à parte (que não tem por si acesso a estas informações) o respeito de seu direito à prova (que, diga-se em passagem, é constitucional) ${ }^{640}$.

\footnotetext{
${ }^{639}$ MARCACINI, Augusto Tavares Rosa. Assistência jurídica, assistência judiciária e justiça gratuita, cit., p. 100. Segundo Fredie Didier Jr e Rafael Oliveira, o prazo para manifestação do impugnado seria o de 48 horas, por analogia ao constante do art. $8^{\circ}$ da Lei $\mathrm{n}^{\circ} 1.060 / 50$, salvo se a impugnação vier instruída com documentos, caso em que se dilata o prazo para os cinco dias referidos pelo art. 398 do CPC (Benefício da justiça gratuita cit., p. 51).

${ }^{640}$ Uma coisa é a parte impugnar afirmando que o beneficiário adversário é proprietário, p.ex., de um veículo de luxo, de alto custo, e para tanto requerer a expedição de ofício aos órgãos de trânsito para que informem quais veículos há registrados em seu nome. Outra bem diversa é impugnar genericamente a gratuidade requerida e pedindo a expedição de ofícios a órgãos de trânsito para aferir se o impugnado é proprietário de veículo. Esta a advertência igualmente de Flávio Luiz Yarshell (A assistência judiciária sob o ângulo do requerido, cit., p. 85).
} 
O incidente de impugnação não é dotado de efeito suspensivo, e como já dito, será apresentado em separado, autuado em apenso aos autos principais (art. $4^{\circ}, \S 2^{\circ}$, da Lei ${ }^{\circ}$ 1.060/50). Repele a jurisprudência, por isto, sua apresentação no bojo da própria contestação, impondo-se a oferta de peça própria, até para possibilitar a formação dos autos do incidente onde toda dilação probatória necessária terá lugar, inclusive, se o caso, prova oral $^{641}$.

Sempre que possível a regra formal supra mencionada deve ser observada, contudo, não se pode também prestigiar o culto à forma pelo simples objetivo de vê-la atendida. As principais razões que amparam a dita autuação em apartado da impugnação à gratuidade são evitar tumulto no feito principal, em razão do desenvolvimento de discussão paralela, possibilitando ainda que nos autos apartados se desenvolva dilação probatória própria, sem confusão com a dilação correspondente à ação principal.

Ora, se mesmo tendo sido apresentada a impugnação no corpo da contestação, a prova produzida acerca do assunto é inteiramente documental, sem necessidade de maior dilação, e se a parte adversa, em réplica, manifestou-se sobre a tal impugnação, apresentando também a prova que lhe apeteça, não se vislumbra prejuízo algum a que o juiz decida desde logo a questão (provavelmente no bojo da decisão saneadora).

Não teria muito sentido obrigar as partes a simplesmente repetirem as peças e documentos em autos apartados quando a questão já admite solução imediata, sem causar tumulto ao debate principal da causa. Não houve prejuízo ao contraditório e respeitou-se o devido processo legal no aspecto do amplo direito à prova conferido aos litigantes. A solução flexibilizadora proposta constitui emanação dos princípios da economia processual e instrumentalidade das formas, atualmente tão difundidos.

A impugnação, conforme o dispositivo legal, pode ser apresentada "em qualquer fase da lide". Não há preclusão temporal, portanto. No caso de impugnação fundada no desaparecimento da condição de necessitado é prudente tal flexibilidade, pois que pode a modificação da condição ocorrer a qualquer tempo.

Já no caso da inexistência do pressuposto a justificativa prende-se ao fato de que o interessado pode não conhecer desde o início a condição econômica do adversário, "vindo

\footnotetext{
${ }^{641}$ Neste sentido: "Impugnação ofertada pelo réu no corpo da sua contestação, argüida em preliminar - Não cabimento - A impugnação à assistência judiciária deve ser feita em peça própria, que será autuada em autos apartados, e não no próprio corpo da contestação - Exegese do art. $4^{\circ}, \S 2^{\circ}$ da Lei $n^{\circ} 1.060 / 50-$ Preliminar afastada" (TJSP, Ação Rescisória n 1.094.786-0/7, Rel. Carlos Nunes, j. 21.08.07).
} 
a descobrir posteriormente fatos que demonstram existência de situação econômica avantajada, possa impugnar fundamentadamente a concessão do benefício" ${ }^{\text {642 }}$.

Preclusão consumativa ${ }^{643}$ há: "feita a impugnação e rejeitada pelo Juiz, deve o impugnante, se quiser rever a decisão, oferecer o recurso cabível. Não recorrida a decisão, opera-se a preclusão" ${ }^{644}$. É certo que com base em fato superveniente nova impugnação poderá ser ofertada, a qualquer tempo.

Difícil imaginar uma hipótese de preclusão dita lógica à impugnação (uma suposta conduta da parte que seja incompatível com a vontade de impugnar, para ficarmos, por analogia, nos lindes do texto legal assaz citado a título exemplificativo acerca do assunto, CPC, art. 503, p.único). Poder-se-ia dizer que a parte que mesmo tomando conhecimento da ausência do pressuposto legal da miserabilidade pelo adversário continua a arcar com as despesas processuais, e deixa de suscitar a questão na primeira oportunidade que falar nos autos após tal ciência, mesmo sabendo que em razão da gratuidade concedida ao adversário não terá expectativa de reembolso, teria renunciado à possibilidade de impugnação. É, contudo, discutível tal assertiva, porque a letra da lei faculta a impugnação a qualquer tempo, sem restrição em razão da parte ter-se omitido mesmo após ter tomado conhecimento da real situação econômica do adversário ${ }^{645}$.

De acordo com o p.único do art. 63 do Regimento Interno do Supremo Tribunal Federal: "Prevalecerá no Tribunal a assistência judiciária já concedida em outra instância". Disposição idêntica é contida no art. $115, \S 2^{\circ}$, do Regimento Interno do Superior Tribunal de Justiça. Segundo aponta Maurício Vidigal há duas interpretações viáveis: primeiro a de que seria desnecessária renovação na instância recursal extraordinária da gratuidade já concedida em grau inferior, o que seria redundante à luz do constante no art. $9^{\circ}$ da Lei $n^{\circ}$

\footnotetext{
${ }^{642}$ MARCACINI, Augusto Tavares Rosa. Assistência jurídica, assistência judiciária e justiça gratuita, cit., p. 101.

${ }^{643}$ Por alheias ao assunto, abstemo-nos de considerações críticas acerca da classificação das preclusões, notadamente a caracterização de uma tal "perda da faculdade" em razão de seu exercício (que seria a tal preclusão consumativa), idéia que parece conter uma contradição em seus próprios termos (como se poderia pensar na "perda" de uma faculdade que foi plenamente exercida, e por isto, exaurida).

${ }^{644}$ MARCACINI, Augusto Tavares Rosa. Assistência jurídica, assistência judiciária e justiça gratuita, cit., p. 101.

${ }^{645}$ Esta a posição de Rafael Oliveira e Fredie Didier Jr: "Conquanto a lei não o diga expressamente, a impugnação do benefício pela parte contrária está sujeita à preclusão. Por isso, deverá a parte manejar a sua impugnação no primeiro momento em que tiver de falar nos autos, após tomar conhecimento da inexistência ou do desaparecimento da condição de necessitado do beneficiário. Não há, destarte, prazo certo para que o faça, mas há um momento: a primeira vez que vier aos autos após o conhecimento da ausência de miserabilidade. E assim deve ser em respeito ao sistema de preclusões imposto pelo CPC (aplicação, in casu, do art. 245), tendente a garantir às partes a necessária segurança jurídica. Do contrário, ter-se-ia que admitir à parte impugnante guardar uma 'carta na manga', de que pudesse lançar mão a qualquer momento, até mesmo na instância máxima do STF, o que não se coaduna com a premissa do devido processo legal" (Benefício da justiça gratuita cit., p. 50).
} 
1.060/50. A segunda, que ao ver do autor em questão seria a única razoável, "é a vedação de pedido de revogação do benefício na instância extraordinária e especial"646 , o que é até bastante lógico já que, conforme o mesmo autor lembra, estas instâncias apenas examinam questões de direito, e a decisão em pauta é eminentemente fática.

Ainda a ensinança de Maurício Vidigal observa que estando a causa já a processarse em grau recursal ordinário, a impugnação será processada na forma da habilitação incidente, conforme disposição do art. 1.059 do Código de Processo Civil. Valendo-se por analogia do disposto no p.único do art. 800 do mesmo diploma, lembra-se ainda que a impugnação pode ser processada em primeira instância mesmo após a prolação de sentença, porém desde que ainda não ofertado recurso. Acaso já interposto, então o processamento dar-se-á na instância recursal competente para apreciar a irresignação relativa à causa principal ${ }^{647}$.

Há uma distinção proposta entre a impugnação do direito à assistência (art. $4^{\circ}, \S$ $2^{\circ}$, da Lei $\mathrm{n}^{\circ}$ 1.060/50), fundado que seria na inexistência dos requisitos essenciais à concessão e o pedido de revogação (art. $7^{\circ}$, "caput” e p.único) amparado na alteração das condições do beneficiário, com o desaparecimento dos pressupostos ${ }^{648}$.

Poder-se-ia pensar que a distinção não tenha maiores relevâncias, o que é errôneo. O reconhecimento de que o pressuposto legal da pobreza nunca existiu implica necessariamente a afirmação de que a parte nunca fez jus ao benefício, e que deve arcar com todas as custas e despesas, desde o início de sua atuação processual.

De outra banda, reconhecer-se que os pressupostos desapareceram significa dizer que a parte fazia jus ao benefício, porém em dado instante deixou de fazê-lo, e justo é que a partir deste instante é que deva arcar com as custas e despesas processuais ${ }^{649}$.

\footnotetext{
${ }^{646}$ VIDIGAL, Mauricio. Lei da Assistência Judiciária interpretada, cit., p. 58.

${ }^{647}$ VIDIGAL, Mauricio. Lei da Assistência Judiciária interpretada, cit., p. 59.

${ }^{648}$ Veja-se o seguinte excerto da obra de André Bonelli: "Se, todavia, o autor ou réu vierem a postular a concessão no curso da demanda (art. $6^{\circ}$ ), ou se qualquer um deles impugnar o pedido do outro (art. $4^{\circ}, \S$ $2^{\circ}$ ), ou mesmo requerer a revogação do benefício já concedido, motivado na alteração das condições do beneficiado (art. $7^{\circ}$, p.único), todos esses requerimentos devem ser processados em autos apartados, apensos aos principais" (Aspectos processuais da Lei de Assistência Judiciária, cit., p. 1.545).

${ }^{649}$ Em sentido contrário: “(...) a revogação do benefício não opera retroativamente. Seja se comprovada a inexistência ou desaparecimento superveniente (à concessão do benefício) dos requisitos essenciais à sua concessão, porque desconstitui uma situação jurídica anterior (ainda que constituída ilegitimamente, na hipótese de inexistência), tem efeito ex nunc e não pode retirar a validade dos atos processuais praticados sem o recolhimento das custas processuais" (DEMO, Roberto Luis Luchi. Assistência judiciária gratuita, cit., p. 358). Veja-se que em alguns casos seria mesmo impossível invalidar o ato processual porque definitivamente consumado. É o caso da prova pericial que, uma vez produzida, passa a integrar o acervo probatório e pertencer ao processo. Nesta hipótese, em ocorrendo a revogação da gratuidade com a fixação
} 
Fala-se da dificuldade probatória que recai sobre o impugnante, pois que teria de provar o que se convencionou chamar de "fato negativo", isto é, que o adversário não é legalmente necessitado. A prova, então, consistiria em "fatos que se contraponham ao fato que se pretende negar. Portanto, é preciso que o órgão julgador admita, com certa largueza, a iniciativa probatória do requerido" ${ }^{\circ 50}$.

A rigor, entretanto, pode esta assertiva ser apresentada em fórmula positiva: caberá ao impugnante não comprovar a falta de caracterização da condição de necessitado, mas a presença de condições econômicas suficientes por parte do beneficiário. Reconhece-se, entretanto, que "o impugnante deparar-se-á com imensas dificuldades ao alegar a inexistência dos requisitos, para administrar provas hábeis ... Atenuam-se os obstáculos, parcialmente, na hipótese de desaparecimento da condição de necessitado, pois mudança de fortuna deixa rastros visíveis"

$\mathrm{O}$ art. $7^{\circ}$, "caput", já citado menciona que a legitimidade para a impugnação recai sobre a "parte contrária". Segundo compreende Maurício Vidigal, a expressão abarca qualquer interessado que participe do processo, incluindo o Ministério Público na qualidade de fiscal da lei ${ }^{652}$. Entende ainda o mesmo autor que mesmo o litisconsorte do beneficiado pode ter interesse na revogação, porque pode ser o caso dos dois dividirem custas ou despesas.

Não parece, com toda vênia, ser exato tal entendimento. É certo que havendo litisconsortes, dividirão proporcionalmente custas, despesas processuais e honorários (cf. art. 23 do Código de Processo Civil).

Por outro lado, não há porque conferir-se à gratuidade o efeito de fazer recair sobre um litisconsorte (ou sobre os demais, não beneficiados) todo o encargo, inclusive a parte que seria cabível ao beneficiado. Não custa recordar que é ao Estado que incumbe a

do termo inicial da cessação em data anterior à produção de tal prova, poderá o perito judicial buscar da parte outrora beneficiária o pagamento de seus honorários. Se estes já tiverem sido pagos pelo Estado, então este é que poderá ressarcir-se junto à parte que teve revogado o benefício. Em outras hipóteses é possível exigir-se o imediato recolhimento do valor sob pena de extinção do processo, como é o caso da taxa judiciária.

${ }^{650}$ YARSHELL, Flavio Luiz. A assistência judiciária sob o ângulo do requerido, cit., p. 85.

${ }^{651}$ ASSIS, Araken de. Benefício da gratuidade, cit., p. 184.

${ }^{652}$ VIDIGAL, Mauricio. Lei da Assistência Judiciária interpretada, cit., p. 57. Segundo entende José Amir do Amaral, "o Ministério Público, nas causas em que não for parte por substituição, somente poderá atuar, salvo melhor juízo, como custos legis, em hipóteses de indeferimento do benefício, buscando, assim, assegurar a efetiva garantia constitucional. Deferido o pedido, faltar-lhe-ia interesse a lhe animar" (AMARAL, José Amir do. Da legitimidade do Estado e dos servidores da Justiça para impugnar a gratuidade de justiça deferida a parte. Ajuris: revista da Associação dos Juízes do Rio Grande do Sul, Porto Alegre, v. 21, n. 62, p. 206, nov. 1994). 
assistência jurídica integral e gratuita, e não aos litisconsortes. Todavia, também não seria razoável defender que nenhum dos litisconsortes teria, então, de arcar com as custas, despesas processuais e honorários, em razão da gratuidade conferida a um deles.

Justo é, por isto, que o beneficiário da gratuidade fique isento de sua cota-parte nas custas, despesas processuais e honorários, que será custeada pelo Estado, e que aos demais litisconsortes caiba apenas arcar com a cota que lhes seria cabível independentemente da gratuidade $^{653}$. Na verdade esta solução é decorrência direta do caráter individual do benefício, apregoado pelo art. 10 da Lei $\mathrm{n}^{\circ}$ 1.060/50.

Haverá, é certo, situações de difícil solução. No Estado de São Paulo, por exemplo, os honorários periciais nos casos em que cabe a beneficiários de gratuidade arcar com o encargo são fixados de acordo com tabela própria (via de regra bem inferiores aos normalmente estimados pelos peritos nos casos em que gratuidade não há).

Já nos casos em que aquele sobre quem recai o encargo não é beneficiário, os honorários são estimados pelo perito (e como dito, há uma defasagem entre os valores da tabela e aqueles normalmente apontados pelo vistor, de acordo com pisos salariais).

Indaga-se então: se um dos litisconsortes é beneficiário da gratuidade, situação em que caberá ao Estado arcar com sua cota nos honorários periciais, com base em qual critério serão fixados os honorários: com base na tabela própria em razão de $u m$ dos litisconsortes ser beneficiário da gratuidade; ou com base no quantum estimado pelo perito, em razão de os demais litisconsortes não contarem com a benesse?

Uma solução mista é possível: os litisconsortes arcam com a cota que lhes seria atribuível com base no valor estimado pelo perito, e o Estado arca com a cota que seria atribuível ao beneficiário com base no valor constante da tabela ${ }^{654}$.

Há ainda um certo entendimento de que aos serventuários do juízo também socorreria o direito a "demonstrarem suas inconformidades com a concessão da assistência

\footnotetext{
${ }^{653}$ É esta também a solução proposta por Fredie Didier Jr e Rafael Oliveira (Benefício da justiça gratuita cit., p. 23).

${ }^{654}$ Imagine-se o seguinte exemplo: o perito nomeado pelo juízo estima honorários em $\mathrm{R} \$ 1.000,00$ para um estudo de engenharia, num caso em que são dois os litisconsortes sobre os quais recai o ônus financeiro da prova; um deles beneficiário da gratuidade. Os honorários previstos na tabela própria para o caso de gratuidade são de R\$ 500,00. Compõe-se honorária mista: o Estado arca com os R\$250,00 que seriam cabíveis ao beneficiário, se fosse fixado valor com base na tabela; o litisconsorte não-beneficiário arca com $\mathrm{R}$ \$ 500,00, valor que lhe seria cabível se os honorários fossem fixados sem incidência da gratuidade. A verba honorária totaliza neste caso $\mathrm{R} \$ 750,00$ (na verdade, um meio termo entre as duas verbas possíveis).
} 
judiciária"655. Tal legitimidade, contudo, estaria restrita aos serventuários que atuem sob regime de custas para retribuição de seu trabalho, pois que os que estejam sob regime de vencimentos não teriam interesse na impugnação.

Outrossim, também ao Estado-Administração caberia "não só a faculdade, mas o poder-dever de buscar retirar o benefício deferido pelo Estado-Juiz, posto que inarredável o legítimo interesse na quaestio juris" ${ }^{\prime 656}$. Se por algum motivo deixar o Estado de valer-se da impugnação, e tendo transitado em julgado a decisão definitiva no processo em que a parte indevidamente fruiu das benesses da gratuidade, nada impede que recorra a procedimentos próprios, tanto administrativos (lançamento ex officio e notificação do contribuinte) como judiciais (ação de ressarcimento de dano). Por estas vias o Estado pode buscar o ressarcimento não apenas da taxa judiciária, mas também das verbas que pagou a terceiros em razão de sua (do Estado) incumbência quanto à assistência jurídica (p.ex. indenizações pagas a testemunhas; honorários pagos a peritos; etc.) ${ }^{657}$.

Acresça-se que os terceiros intervenientes igualmente detêm legitimidade e interesse para ofertarem impugnação. São os casos do denunciado à lide (que pode oferecêla tanto em face do denunciante, contra quem litiga secundariamente, como em face do adversário, em relação a quem goza, juntamente com o denunciante, da posição de adversário), do opoente, do chamado ao processo e do assistente. O mesmo vale no caso de nomeação à autoria, em que na verdade há sucessão de partes, e o nomeado assume, para todos os efeitos, a condição de sujeito processual.

A decisão que revoga os benefícios da gratuidade, seja por inexistência seja por desaparecimento do pressuposto legal da miserabilidade, representa indício de improbidade no processo, merecendo sanção por litigância de má-fée 658 .

\footnotetext{
${ }^{65}$ AMARAL, José Amir do. Da legitimidade do Estado e dos servidores da Justiça para impugnar a gratuidade de justicadeferida a parte, cit., p. 202.

${ }^{656}$ AMARAL, José Amir do. Da legitimidade do Estado e dos servidores da Justiça para impugnar a gratuidade de justicadeferida a parte, cit., p. 205.

${ }^{657}$ AMARAL, José Amir do. Da legitimidade do Estado e dos servidores da Justiça para impugnar a gratuidade de justicadeferida a parte, cit., p. 206.

${ }^{658}$ YARSHELL, Flavio Luiz. A assistência judiciária sob o ângulo do requerido, cit., p. 85. Há posição no sentido de que a aplicação na espécie de pena por litigância de má-fé "não se justifica porque, para a hipótese de assistência judiciária concedida e não merecida, há sanção específica" (TJSP, Ap. civ. ${ }^{\circ}$ 535.843-4/8-00, Rel. José Araldo da Costa Teles, j. 07.05.08). O julgado refere-se à pena de pagamento de até o décuplo das custas judiciais, nos termos do $\S 1^{\circ}$ do art. $4^{\circ}$ da Lei $n^{\circ} 1.060 / 50$, para quem afirmar falsamente a condição de pobreza. A rigor, entretanto, mesmo a pena em questão não deixa de representar uma sanção por litigância de má-fé, porém uma pena específica pra um caso específico: falsa declaração de pobreza. Ou seja, seja por incidência das penas genéricas previstas no art. 18 do CPC, seja aplicando-se a pena específica prevista pelo dispositivo retro citado da Lei $\mathrm{n}^{\circ}$ 1.060/50, em qualquer caso há litigância de má-fé.
} 
Na hipótese de inexistência do pressuposto legal temos que a afirmação de pobreza era, desde o início, falsa. No caso de desaparecimento admite-se que a afirmação era inicialmente verdadeira, porém deixou de sê-lo no curso do processo. A lealdade processual impunha que o necessitado que deixou de sê-lo informasse ao juízo acerca de sua nova e vantajosa condição, possibilitando a revogação do benefício a partir de então.

Em qualquer caso presume-se que houve litigância ímproba, cabendo ao beneficiário elidir tal presunção. Observe-se apenas que no caso de desaparecimento da condição de necessitado não caberia responsabilizar a parte por falsa afirmação de pobreza, pois a "declaração", como dito, era inicialmente legítima. Deixou de sê-lo no curso da lide. Embora isto caracterize litigância de má-fé omissiva (pela falta de alerta ao juízo), não chega a representar falsidade documental ${ }^{659}$.

Por fim, cumpre lembrar que também por atuação ex officio do juiz o benefício da gratuidade pode ser revogado, desde que presente algum dos pressupostos referidos no já citado art. $7^{\circ}$, quais sejam, inexistência ou desaparecimento dos requisitos essenciais à concessão. Neste caso ao juiz incumbe, antes de decretar a revogação, ouvir o interessado em 48 horas improrrogáveis (cf. art. $8^{\circ}$ ).

A letra do art. $8^{\circ}$ retro referido refere que juiz "poderá" proceder à revogação, dando a equivocada impressão de que se cuida de faculdade judicial, sujeita a alguma nota de discricionariedade. Assim, contudo, não é. “Assim como há o interesse público em conceder o benefício a quem dele necessite, a fim de garantir o acesso de todos a Justiça, também há interesse público em não admitir que quem não seja pobre se utilize indevidamente do privilégio" 660 .

Mais do que isto, é poder-dever do juiz assegurar a igualdade das partes no processo, velar pela paridade de armas na disputa, se não fosse por disposição legal expressa à qual vinculado (CPC, art. 125, I), seria como conseqüência inarredável do fato de se erigir num dos principais agentes políticos encarregados da concretização das normas

\footnotetext{
659،'É típica, a princípio, a conduta da pessoa que assina declaração de 'pobreza' para obter os benefícios da assistência judiciária gratuita e, todavia, apresenta evidentes condições de arcar com as despesas e custas do processo judicial. Não se vislumbra, assim, qualquer constrangimento ilegal na decisão do Juízo Cível, que determinou a remessa de cópia de declaração de pobreza firmada nos autos de ação monitória ao Ministério Público, para a análise de possível cometimento do crime de falsidade ideológica. 3- Recurso desprovido" (STJ, RHC n ${ }^{\circ}$ 21.628/SP, Rel. Min. Laurita Vaz, 5 ${ }^{\text {a }}$ Turma, DJe 09/03/2009). Em sentido contrário: "FALSIDADE IDEOLÓGICA. DECLARAÇÃO DE POBREZA PARA FINS DE GRATUIDADE JUDICIÁRIA. Declaração passível de averiguação ulterior não constitui documento para fins penais. HC deferido para trancar a ação penal" (STF, HC no 85.976/MT, Rel. Ellen Gracie, j. 13.12.05).

${ }^{660}$ TJSP, AI n ${ }^{\circ}$ 7.277.397-8, Rel. Álvaro Torres Jr, j. 8\%09/08.
} 
constitucionais que constituem pilares do Estado Democrático, como o é o princípio da igualdade.

Por isto afirma-se que é dever do magistrado proceder à revogação do benefício ex officio acaso constate a inexistência ou desaparecimento da miserabilidade em termos legais.

Aliás, é bom de ver que a autorização legal para que proceda o juiz de ofício à revogação da benesse mitiga muito a importância que se poderia dar à possibilidade ou não de incidir preclusão sobre a impugnação facultada à parte contrária, ponto abordado alhures. Ou seja, mesmo se entendêssemos preclusa a oportunidade para impugnação pela parte que deixou transcorrer inerte a primeira oportunidade em que falou nos autos após tomar ciência da inexistência ou desaparecimento da condição de pobreza (uma espécie de preclusão lógica referida anteriormente), seríamos obrigados a admitir que a tal parte interessada poderia simplesmente alertar ao juiz acerca da ausência do pressuposto da pobreza, e este procederia de ofício à revogação.

A preclusão consumativa que impede a parte de apresentar nova impugnação fundada nos mesmos fatos já objeto de anterior incidente decidido definitivamente, conforme também já apontado anteriormente, igualmente impede a atuação de ofício do juízo.

Não adentraremos aqui o agudo debate acerca da caracterização de preclusões para o juiz. Fiquemos no porto seguro de afirmar que para o magistrado há fenômeno processual assemelhado ao que para as partes se convenciona chamar preclusão, e que igualmente o impede de estorvar a marcha processual. Falamos do famigerado art. 471: "Nenhum juiz decidirá novamente as questões já decididas, relativas à mesma lide, salvo: ... I - se, tratando-se de relação jurídica continuativa, sobreveio modificação no estado de fato ou de direito; caso em que poderá a parte pedir a revisão do que foi estatuído na sentença e II - nos demais casos prescritos em lei”.

Assim é que tendo havido impugnação pela parte adversa ao beneficiário e definitivamente decidida (evidente, com rechaço), não poderia o juízo, mesmo atuando de ofício, proceder à revogação do benefício com fundamento nos mesmos fatos, os quais já foram objeto de cognição judicial.

É claro que fundado em fato superveniente, poderia o juízo proceder a tal revogação de ofício, ou mesmo mediante provocação da parte que, também neste caso, poderia aforar nova impugnação. Aí sim incide a exceção contida no inciso I do art. 471, do CPC, já transcrito. 
É importante deixar vincado que o art. 471 do Código de Processo Civil não impede novo pronunciamento apenas no caso de já ter havido prévia impugnação já decidida definitivamente, mas obsta novo pronunciamento judicial sobre questão já decidida sem que haja fato superveniente que o justifique. Transitando para a nossa seara: não pode o juízo proceder à revogação de ofício após inicial deferimento do benefício sem que nenhum elemento se tenha acrescido aos autos no que concerne à capacidade financeira da parte requerente. Por outras palavras, não é lícito ao juízo simplesmente mudar de idéia acerca do que antes já apreciou para deferir a benesse ${ }^{661}$.

Uma nota de precisão terminológica deve ser feita a esta altura. Julgados que tratam da questão da revogação de ofício do benefício da gratuidade comumente referem à necessidade de prova da alteração da condição financeira do litigante, para então concluir que não pode o juiz proceder à revogação de ofício sem que haja modificação no estado inicial que amparou o deferimento ${ }^{662}$. Não é bem assim, contudo. A alteração da fortuna é apenas requisito para a revogação, seja de ofício seja provocada, no caso de desaparecimento do pressuposto legal da pobreza. No caso de inexistência do tal pressuposto, entende-se que o beneficiário nunca fez jus ao amparo legal, não há falar aqui em modificação alguma, que não é pressuposto para a revogação do benefício. A modificação que se espera neste caso não é na condição econômica da parte, mas na feição do acervo probatório, que inicialmente nada revelava que motivasse desconfiança acerca da afirmação de pobreza, e que agora a revela falsa ${ }^{663}$.

Note-se que a revogação de ofício pode ocorrer a qualquer tempo e grau ordinário de jurisdição. Ocorrida na instância recursal, deve-se facultar ao interessado suprir o preparo, não sendo de se revogar o benefício e concomitantemente declarar deserto o

\footnotetext{
661“Não se revoga de ofício a justiça gratuita, antes concedida, por simples reapreciação dos dados já existentes nos autos ao ser, anteriormente, deferido o benefício, sem que se faça qualquer referência concreta probante da possibilidade financeira da beneficiária - Agravo provido" (2० $\mathrm{TAcSP}, \mathrm{AI} \mathrm{n}^{\circ}$ 681.56500/7, Rel. Juiz Lino Machado, j. 14.3.2001).

${ }^{662}$ A título exemplificativo cite-se: "Justiça gratuita - Revogação do benefício de ofício - Art. $8^{\circ}$ da Lei 1.060/50 - Revogação que deve ocorrer em conformidade com o citado artigo, ou seja, desde que comprovada a inexistência ou o desaparecimento dos requisitos que nortearam a concessão do benefício Decisão combatida que não mencionou eventual alteração da situação financeira da agravante - Caso em que nada indica que houve o desaparecimento dos requisitos essenciais à concessão da gratuidade Agravado que nem sequer apresentou impugnação à assistência judiciária" (TJSP, AI n ${ }^{\circ}$ 991.09.046218-2, Rel. José Marcos Marrone, j. 25.11.09).

663،Mesmo não alteradas as condições econômico-financeiras do beneficiário, a vinda para os autos de novas provas a respeito delas pode ser motivo da revogação" (VIDIGAL, Mauricio. Lei da Assistência Judiciária interpretada, cit., p. 62). Fredie Didier Jr e Rafael Oliveira igualmente ponderam no mesmo sentido: "Mas a revogação aqui [isto é, de ofício] somente poderá ter por fundamento fato superveniente (p.ex., ciência de alteração do patrimônio financeiro durante o curso da demanda) ou fato antigo de cuja existência apenas recentemente teve ciência o magistrado" (Benefício da justiça gratuita cit., p. 51).
} 
recurso ${ }^{664}$. É discutível a possibilidade de revogação de ofício em instâncias recursais extraordinárias, considerando que nesta sede apenas questões de direito são debatidas, e a verificação da ausência ou desaparecimento do pressuposto legal da pobreza é matéria eminentemente fática.

Segundo o citado art. $8^{\circ}$ da Lei $\mathrm{n}^{\circ} 1.060 / 50$, a parte interessada, ou seja, o beneficiário, deverá ser ouvido antes de proceder o juízo à revogação de ofício, oitiva esta que se faculta em 48 horas improrrogáveis.

Tal providência é imperiosa, e obviamente decorrente da incidência do princípio do contraditório, implicando sua falta nulidade da decisão ${ }^{665}$. É conveniente que o juiz, ao proferir o despacho que abre à parte oportunidade para manifestação, aponte ainda que perfunctoriamente qual (ou quais) ponto (s) lhe inspira dúvidas acerca da veracidade da afirmação de pobreza. Caso contrário tal despacho representará quimera, formalidade inútil, visto que na prática não se permitirá à parte influir no espírito duvidoso do julgador mediante a produção de contra-prova.

Um último ponto é digno de estudo neste item. Na seara que estamos tratando a iniciativa probatória do juízo é marcante. De fato, ao magistrado cabe, de ofício, condicionar a concessão da gratuidade à produção de provas pelo requerente, acaso desconfie por motivos justificáveis da veracidade da afirmação de pobreza. Tal exigência pode ser feita à luz do simples requerimento inicial da parte, após a impugnação do adversário ou mesmo vislumbrando o juiz a possibilidade de revogação ex officio do benefício anteriormente concedido ${ }^{666}{ }_{-}^{667}$.

\footnotetext{
${ }^{664 ، " V e r i f i c a d a ~ a ~ i n e x i s t e ̂ n c i a ~ o u ~ o ~ d e s a p a r e c i m e n t o ~ d o s ~ r e q u i s i t o s ~ e s s e n c i a i s ~ a ~ c o n c e s s a ̃ o ~ d a ~ a s s i s t e ̂ n c i a ~}$ judiciária gratuita, admite-se a sua revogação, ex offício, pelo juiz, mas desde que ouvida a parte interessada, possibilitando-se a regularização do preparo" (STJ, REsp n ${ }^{\circ}$ 811.482/SP, Rel. Jorge Scartezzini, j. 16.03.06). Segundo Maurício Vidigal é ao relator que incumbirá, como juiz preparador, decidir a questão, seja de ofício, seja no caso de impugnação vertida no grau recursal, salvo se o regimento interno contiver disposição contrária.

${ }^{665}$ VIDIGAL, Mauricio. Lei da Assistência Judiciária interpretada, cit., p. 61.

666،Duvidando o Juiz da afirmativa do interessado, há necessidade de prova, e, indubitavelmente, o órgão judiciário poderá produzi-las ex officio” (ASSIS, Araken de. Benefício da gratuidade, cit., p. 182). Na jurisprudência encontramos: "1. A presunção contida no art. $4^{\circ}$ da Lei 1.060/50, quanto à declaração de pobreza, dispensa o requerente de comprovação. 2. Possibilidade de exigir-se prova quando assim o entender o magistrado, ou quando houver impugnação da parte contrária. 3. O juiz pode, de ofício, exigir comprovação, se não se satisfez com a mera afirmação. 4. Recurso especial provido" (STJ, REsp $n^{\circ}$ 465.966/RS, Rel. Eliana Calmon, j. 09.12.03).

${ }^{667}$ Em sentido contrário, com interpretação bastante restrita da atuação judicial nesta seara, Clito Fornaciari Junior defende que ao juiz seria vedado ingressar em investigações acerca da pertinência da presunção de veracidade da declaração de pobreza: “'O juiz apreciará livremente a prova', prevê o art. 131 do texto processual, porém não a realiza. Quem aprecia não pode produzir para que não perca a isenção, dando maior valor à sua realização. A presunção, portanto, permite reverter o quadro, se evidenciar-se a
} 


\section{Recurso cabível e respectivo regime jurídico}

Eis aqui, sem dúvida, um dos pontos mais espinhosos na disciplina do assunto, pois que objeto de antigas e ainda mal resolvidas disputas doutrinárias e jurisprudenciais, as quais em larga medida têm contribuído para insegurança dos operadores do Direito e partes.

Por concessão à clareza da exposição, o primeiro ponto a merecer abordagem diz respeito à fixação da natureza jurídica da decisão acerca da gratuidade, seja ela proferida nos próprios autos principais, seja a proferida nos incidentes apartados possivelmente formados. Aliás, é evidente que tal natureza não varia de acordo com a sede em que tenha sido proferida (autos principais ou incidente apartado).

O principal problema aqui decorre da infeliz redação do art. 17 da Lei $\mathrm{n}^{\circ}$ 1.060/50: “Caberá apelação das decisões proferidas em consequiência da aplicação desta Lei; a apelação será recebida somente no efeito devolutivo, quando a sentença conceder o pedido". A redação em questão foi conferida pela Lei nº 6.014 de 27 de dezembro de 1973. Dizia a redação original: "Caberá recurso de agravo de instrumento das decisões proferidas em consequiência de aplicação desta Lei, salvo quando a decisão fôr denegatória da assistência, caso em que o agravo será de petição".

Disse-se infeliz a redação, pois que o Código de Processo Civil havia adotado, antes da reforma introduzida pela Lei $\mathrm{n}^{\mathrm{o}} 11.232 / 05$, um critério bastante objetivo e seguro acerca da distinção dos atos judiciais em sentenças, decisões interlocutórias e despachos de mero expediente. E de acordo com este critério não poderia haver dúvida que os pronunciamentos proferidos com base na Lei $n^{\circ} 1.060 / 50$ revestiam-se da natureza de decisões interlocutórias.

De feito, dizia o $\S 1^{\circ}$ do art. 162 do Código de Processo Civil, com originária redação: "Sentença é o ato pelo qual o juiz põe termo ao processo, decidindo ou não o mérito da causa". O $\S 2^{\circ}$ (inalterado pela reforma): "Decisão interlocutória é o ato pelo qual o juiz, no curso do processo, resolve questão incidente" e o $\S 3^{\circ}$, por exclusão, definia: "São despachos todos os demais atos do juiz praticados no processo, de ofício ou a requerimento da parte, a cujo respeito a lei não estabelece outra forma”. 
Ora, não poderia haver dúvidas de que as definições judiciais acerca da assistência judiciária ou da mera gratuidade situavam-se entre as questões incidentais ao processo, e caracterizando-se como decisões interlocutórias.

No sistema recursal originário do Código de Processo Civil o confronto apelação/agravo estava jungido à distinção sentença/decisão interlocutória, pois que da sentença cabia apelação (CPC, art. 513); das decisões interlocutórias agravo de instrumento (CPC, art. 522, "caput”, com redação original) e os despachos de expediente consideravam-se irrecorríveis (CPC, art. 504).

Pois em contravenção a esta estrutura procedimental, o art. 17 retro citado, com redação da Lei $n^{\circ}$ 6.014/73, definiu como "sentença" a decisão acerca das questões versadas pela Lei $\mathrm{n}^{\mathrm{o}} 1.060 / 50$, e mais, fixou a apelação como o recurso cabível (talvez pensando haver coerência). Ironicamente, como anota Marcacini, a Lei no 6.014/73 tinha o objetivo de adequar o referido art. 17 ao sistema recursal implantado pelo Código de Processo Civil de 1973, pois que a redação original (que como citada alhures aludia ao "agravo de instrumento" e ao "agravo de petição") era consentânea ao Código de Processo Civil de $1939^{668}$.

Não se haveria de dar prevalência ao nomen juris dado atecnicamente pelo legislador em detrimento da substância do ato judicial. Desimporta, por isto, que a lei diga que é "sentença" tal ato judicial, quando seu conteúdo e efeitos sobre a relação processual denunciam tratar-se de decisão interlocutória. Deveras, solucionar a questão atinente à assistência judiciária ou gratuidade significa solver questão lateral ao mérito da causa.

Com razão, por isto, a doutrina que já avisava que a "sentença" referida pelo art. 17 retro citado cuidava-se de decisão interlocutória ${ }^{669}$.

Esta assertiva não foi alterada pela modificação introduzida pela Lei ${ }^{\circ}$ 11.232/05 no conceito de sentença. Passou a ser redigido nestes termos do CPC, art. 162, $\S 1^{\text {o. }}$ "Sentença é o ato do juiz que implica alguma das situações previstas nos arts. 267 e 269 desta Lei”. Parece evidente que a decisão oriunda das disposições da Lei $n^{\circ}$ 1.060/50 não implica resolução do mérito (art. 269) nem extingue sem resolução do mérito o processo (art. 267). É certo que, por exemplo, eventual revogação da gratuidade por inexistência do

\footnotetext{
${ }^{668}$ MARCACINI, Augusto Tavares Rosa. Assistência jurídica, assistência judiciária e justiça gratuita, cit., p. 106. ${ }^{669}$ Neste sentido: A MARCACINI, Augusto Tavares Rosa. Assistência jurídica, assistência judiciária e justiça gratuita, cit., p. 104; ASSIS, Araken de. Benefício da gratuidade, cit., p. 185-186 e DEMO, Roberto Luis Luchi. Assistência judiciária gratuita, cit., p. 350.
} 
pressuposto da pobreza estabelecerá a exigência de recolhimento das custas iniciais pelo autor, pena de extinção do feito por falta de pressuposto processual, porém a decisão revocatória neste caso não implica automaticamente tal extinção, pois que à parte será facultado suprir o recolhimento, e não ocorrendo tal suprimento, aí sim nova decisão, esta com natureza sentencial, extinguirá o processo sem a resolução do mérito.

Quer-se dizer, assim, que o novo conceito de sentença veiculado pela Lei $\mathrm{n}^{\circ}$ 11.232/05 em nada alterou o entendimento anterior de que, a despeito da redação do art. 17 da Lei $\mathrm{n}^{\mathrm{o}} 1.060 / 50$, o ato judicial que decide as questões suscitadas com base na Lei $\mathrm{n}^{\mathrm{o}}$ 1.060/50 cuida-se de decisão interlocutória.

A questão então que se segue é óbvia: fixada como interlocutória a decisão supra citada, seja proferida no bojo dos autos principais, seja a proferida no incidente formado à parte, o recurso cabível é o agravo (em consonância com a estrutura recursal do Código de Processo Civil, mas em contrariedade à letra do art. 17) ou a apelação (em consonância com a letra do art. 17 porém contrariando o arquétipo do Código de Processo Civil)?

É na resposta a esta questão que doutrina e jurisprudência se engalfinham. Marcacini, por exemplo, afirma veementemente tratar-se a apelação da via recursal inadequada, ponderando dois argumentos: i) a apelação contra uma decisão interlocutória está em desacordo com o sistema recursal consagrado pelo Código de Processo Civil de 1973 e ii) o processamento de tal apelação no caso da decisão ter sido proferida nos próprios autos principais causa embaraço procedimental, pois que não teria sentido remeter os autos à superior instância causando a paralisação do feito. Por isto defende ser em qualquer caso cabível o recurso de agravo ${ }^{670}$.

Também defendem o cabimento de agravo em qualquer hipótese Fredie Didier Jr e Rafael Oliveira, os quais inclusive ponderam que a aplicação do art. 17 da Lei $\mathrm{n}^{\circ}$ 1.060/50 levaria a situações absurdas, especialmente em razão da incompatibilidade entre a necessidade de subida dos autos para processamento da apelação e o curso da ação principal, "a menos que se cogite de uma apelação por instrumento, modalidade recursal inexistente" 671 .

\footnotetext{
${ }^{670}$ MARCACINI, Augusto Tavares Rosa. Assistência jurídica, assistência judiciária e justiça gratuita, cit., p. 109.

${ }^{671}$ DIDIER JR, Fredie; OLIVEIRA, Rafael. Benefício da justiça gratuita cit., p. 54. A formação de um "instrumento de apelação" tem sido cogitada a partir da reforma trazida ao art. 162 , § $1^{\circ}$, do Código de Processo Civil, pela Lei $n^{\circ} 11.232 / 05$. Imagine-se o caso do pleito reconvencional indeferido de plano por reconhecimento de prescrição ou decadência. Cuidava-se, antes da reforma em questão, de decisão interlocutória, pois que não extinguia o processo no qual encravada a pretensão reconvencional.
} 
Luiz Guilherme Pennachi Dellore, em artigo dedicado ao tema, advoga o cabimento do agravo seja o caso de decisão acerca da gratuidade proferida nos próprios autos da causa principal, seja no caso de decisão em apartado, concluindo então que o art. 17 da Lei $\mathrm{n}^{\circ} 1.060 / 50$ resta letra morta em nosso sistema, inaplicável em qualquer hipótese ${ }^{672}$.

Roberto Luis Luchi Demo defende que em se cuidando de decisão proferida nos próprios autos da ação principal, é o agravo o recurso cabível; porém proferida a decisão em autos apartados, é a apelação a via adequada, afirmando referido autor cuidar-se esta da posição majoritária do C. Superior Tribunal de Justiça ${ }^{673}$.

É igualmente esta a posição de Araken de Assis, segundo quem a regra do art. 17 "é inatendível pelo mais contrito positivista"674. Assim, julgado de plano o pedido, ou internamente ao processo, o recurso próprio seria o agravo, pena de atravancamento do andamento processual; autuado em separado o pedido de concessão ou a impugnação, “conquanto incidentes do processo, a resolução do $1^{\circ}$ grau desafiará apelação. Impróprio que seja semelhante recurso, considerando a tipologia dos atos no estatuto em vigor... sua tramitação em autos apartados em nada prejudica o prosseguimento do processo" ${ }^{\text {675. }}$.

Maurício Vidigal, em posicionamento semelhante, leciona: “A melhor orientação é a de que o recurso será de apelação, sempre que a decisão for proferida em procedimento

Presentemente, tal decisão, conquanto não extinga o processo, implica a situação prevista no art. 269, IV, do CPC, logo, segundo o conceito do $\S 1^{\circ}$ do art. 162 do CPC, tratar-se-ia de sentença. Seria esta, então, passível de apelação? Como ficaria o processamento da causa principal face à interposição deste recurso? Seria cabível uma "apelação por instrumento" nesta hipótese? Todas estas questões estão na ordem do dia em tema do que se logrou denominar "sentenças parciais".

${ }^{672}$ DELLORE, Luiz Guilherme Pennachi. Do recurso cabível das decisões referentes à gratuidade da justiça (Lei 1.060/50). In: NERY JR, Nelson; WAMBIER, Teresa Arruda Alvim (Coord.). Aspectos polêmicos e atuais dos recursos cíveis e assuntos afins. São Paulo: Ed. Revista dos Tribunais, 2006. v. 9, p. 328-332.

${ }^{673}$ DEMO, Roberto Luis Luchi. Assistência judiciária gratuita, cit., p. 350. A título exemplificativo, citamos a respeito os seguintes julgados da lavra do C. Superior Tribunal de Justiça: “A decisão que aprecia o incidente de impugnação ao deferimento da gratuidade judiciária, processado em autos apartados, desafia recurso de apelação, e não de agravo de instrumento. Nessa hipótese, não se aplica o princípio da fungibilidade recursal, por se configurar erro grosseiro. Precedentes. Agravo não provido" (STJ, AgRg no Ag n $n^{\circ}$ 579.729/SP, Rel. Nancy Andrighi, j. 14.06.04); "Havendo impugnação ao deferimento da assistência judiciária, processada em autos apartados, contra a sentença que a acolhe cabe o recurso de apelação. Não há, portanto, plausibilidade para admitir-se, no caso, a fungibilidade recursal"'(STJ, REsp no 256.281/AM, Rel. Carlos Alberto Menezes Direito, j.22.05.01); "PROCESSUAL CIVIL. ASSISTÊNCIA JUDICIÁRIA GRATUITA. INDEFERIMENTO. RECURSO CABÍVEL. APELAÇÃO. ARTIGO 17 DA LEI 1.060/50. 1. Da decisão que indefere pedido de assistência judiciária gratuita, por via de incidente próprio, cabível é o recurso de apelação, e não o de agravo de instrumento. 2. Inteligência do artigo 17 da Lei 1.060/50. 3. Recurso conhecido e improvido" (STJ, REsp n ${ }^{\circ}$ 152.465/RS, Rel. Hamilton Carvalhido, j. 23.05.00).

${ }^{674}$ ASSIS, Araken de. Benefício da gratuidade, cit., p. 186.

${ }^{675}$ ASSIS, Araken de. Benefício da gratuidade, cit., p. 186. 
preparatório ou em apartado, e agravo quando lançada nos próprios autos" ${ }^{\text {,676 }}$. É esta também a posição de Nelson Nery Jr e Rosa Maria de Andrade Nery ${ }^{677}$.

José Roberto de Castro, de sua banda, defende irrestritamente o cabimento da apelação, argumentando que as decisões relativas à Lei $\mathrm{n}^{\circ}$ 1.060/50, analisadas no sentido formal, isto é, à luz do art. 458 do Código de Processo Civil, realmente não seriam sentenças, porém defende que tais atos judiciais sejam considerados em sentido material, “e em termos materiais, a decisão no processo de assistência judiciária põe termo ao processo" ${ }^{\text {678 }}$, e assim sendo, consistem em sentenças que desafiam apelação, conforme a sistemática em vigor.

Alhures já tivemos oportunidade de defender a natureza de decisão interlocutória do pronunciamento judicial acerca da gratuidade/assistência judiciária, não sendo o caso aqui de meramente repetir os argumentos.

Parece possível defender o cabimento da apelação, como o faz José Roberto de Castro, sem a necessidade de distorcer a natureza da decisão judicial impugnada, afirmando um fenômeno que definitivamente inexiste, qual seja, a formação de um processo de assistência judiciária que seja extinto pela dita "sentença" (até porque a extinção do processo nem mais é o marco que serve à definição da natureza do ato judicial). Um argumento, a bem ver, põe pá de cal em assertiva desta estirpe: "caso se tratasse de uma relação processual autônoma [o incidente apartado de gratuidade], tal decisão deveria ser coberta pelos efeitos da coisa julgada material"679, o que implicaria irremediavelmente que a gratuidade deferida no caso devesse ser observada em quaisquer demandas, ao menos enquanto inalterada a situação de fato.

Repita-se: o que se forma é um incidente processual, ocasionalmente processado em apartado, como, de resto, ocorre em outras situações, v.g. as exceções rituais e a impugnação ao valor da causa. A questão decidida, entretanto, não deixa de ser marginal ao mérito. Se se quer defender nesta hipótese o cabimento da apelação, que se faça de forma coerente, compreendendo tratar-se de uma anomalia do sistema (cabimento

\footnotetext{
${ }^{676}$ VIDIGAL, Mauricio. Lei da Assistência Judiciária interpretada, cit., p. 89.

677، 'O LAJ 17 prevê o recurso de apelação para a hipótese do benefício ser postulado em procedimento à parte. Se o pedido é feito no meio de outro processo, o deferimento ou indeferimento da postulação se dá por decisão interlocutória, que desafia o recurso de agravo de instrumento" (cit., p. 1.465).

${ }^{678}$ CASTRO, José Roberto de. Manual de assistência judiciária: teoria, prática e jurisprudência, cit., p. 155.

${ }^{679}$ DELLORE, Luiz Guilherme Pennachi. Do recurso cabível das decisões referentes à gratuidade da justiça (Lei 1.060/50), cit., p. 332.
} 
excepcional, em razão de expressa estipulação legal, de uma apelação contra decisão interlocutória).

Também defende o cabimento da apelação Luiz Paulo da Silva Araújo Filho, em artigo assaz citado acerca do assunto ${ }^{680}$. O autor em questão argumenta ser da tradição do ordenamento jurídico brasileiro a preocupação com os efeitos com que recebido o recurso que impugna a decisão acerca do benefício da gratuidade, especialmente no caso de indeferimento ou revogação, prestigiando-se sempre o acesso à justiça por meio da não sujeição à parte aos ônus econômicos do processo até que a questão esteja definitivamente decidida inclusive em instância recursal.

Lembrando que o agravo não é dotado, ao menos por regra, de efeito suspensivo, aponta a possibilidade de que no caso de indeferimento ou revogação a parte se veja compelida a arcar desde logo com as despesas processuais, vendo-se então numa conjuntura que denominou desastrosa, de "ter de pagar para ver declarado o seu direito de não pagar, em virtude de sua hipossuficiência" ${ }^{681}$.

Reconhece o autor, ainda, a existência de descompasso entre o sistema preconizado pelo já referido art. 17 e aquele desenhado pelo Código de Processo Civil, porém lembra que não seria a primeira vez em que uma lei especial contrariaria o Código de Processo a fim de aproveitar determinadas características de via recursal que lhe seja mais adequada, resgatando a própria redação originária do art. 17 em comparação com o Código de Processo Civil de 1939, já que este previa o agravo de petição como o recurso adequado contra as "decisões que impliquem a terminação do processo principal, sem lhe resolverem o mérito", e aquele dispositivo previa o agravo de petição para impugnação à decisão indeferitória da gratuidade, que evidentemente não implicava "terminação do processo sem solução do mérito". Admite então o tal descompasso, ponderando ser plenamente explicável face à necessidade de aproveitarem-se os efeitos conferidos pelo Código de Processo à apelação.

Um outro possível fundamento para defender-se o cabimento da apelação é o princípio da especialidade, segundo o qual entende-se que a disciplina do art. 17 da Lei $\mathrm{n}^{\circ}$ 1.060/50, sendo especial sobre o regramento geral contido no Código de Processo Civil,

\footnotetext{
${ }^{680}$ ARAÚJO FILHO, Luiz Paulo da Silva. Decisão que aprecia questão do direito a assistência judiciária recurso cabível. Revista de Processo, São Paulo, v. 14, n. 53, p. 231, jan./mar. 1989.

${ }^{681}$ ARAÚJO FILHO, Luiz Paulo da Silva. Decisão que aprecia questão do direito a assistência judiciária recurso cabível, cit., p. 233.
} 
sobre ele deve prevalecer, mesmo que lhe seja anterior ${ }^{682}$, valendo a respeito o disposto no art. $2^{\circ}, \S 2^{\circ}$, da Lei de Introdução ao Código Civil ${ }^{683}$.

Dellore alinha outros dois argumentos contrários ao cabimento de apelação em qualquer situação referente à Lei $n^{\circ} 1.060 / 50^{684}$. O primeiro baseia-se no elevado ônus que se poderia carrear ao adversário do beneficiário em razão da necessidade de recolher o preparo da apelação. Vendo-se vencido no incidente de impugnação, o adversário do beneficiário seria instado a interpor apelação. Como o incidente em questão não ostenta "valor da causa" próprio, seria de se proceder à fixação do preparo com base no valor da causa, e quando o beneficiário for o autor da ação, seria ele quem estabeleceria o valor da causa, e indiretamente, o valor do preparo. Inflando artificialmente o valor da causa teria o autor um poderoso instrumento para desestimular e dificultar a interposição recursal pelo adversário.

No caso do recurso de agravo o preparo, nos Estados em que exigido, é prefixado em valor certo, arrostando o perigo apontado no parágrafo anterior ${ }^{685}$.

A crítica é válida, porém não é inerente às questões de gratuidade: em qualquer caso em que o adverso tenha de interpor apelação terá este mesmo inconveniente, salvo no caso de sentença condenatória em que, ao menos no Estado de São Paulo, o preparo é fixado sobre o valor da condenação.

O segundo argumento de Dellore prende-se à observação de que a decisão do juiz que revoga ou indefere a gratuidade terá sua eficácia automaticamente suspensa com a interposição da apelação, já que tal recurso é, salvo expressa ressalva legal, dotado do efeito suspensivo (CPC, art. 520, “caput”, lembrando-se que apenas a decisão concessiva da gratuidade desafia apelação a ser recebida sem o efeito suspensivo, a teor do art. 17, in fine, da Lei $n^{\circ}$ 1.060/50). Logo, “desprestigia a decisão do juiz proferida após a cognição

\footnotetext{
${ }^{682}$ Falamos que o art. 17 com redação dada pela Lei $n^{\circ}$ 6.014/73 é anterior ao regramento do Código de Processo Civil (embora este também remonte a 1973, inclusive a data anterior à Lei ${ }^{\circ}$ 6.014/73) pois que leis posteriores à Lei $\mathrm{n}^{\circ}$ 6.014/73 alteraram o regime jurídico do recurso de agravo.

${ }^{683} \mathrm{Na}$ jurisprudência, neste sentido: "Impugnação à gratuidade processual. Incidente processado em apartado. Recurso cabível. Nos termos do art. 17 da Lei 1.060/50, sujeita-se ao recurso de apelação a decisão acerca de impugnação à gratuidade processual processada em apartado. Disciplina recursal especial relativamente a do CPC e por isso sobre ela prevalente. Fungibilidade recursal inadmitida na espécie, por ausência de dúvida objetiva na doutrina e na jurisprudência acerca do tema. Agravo de instrumento não conhecido" (TJSP, AI n ${ }^{\circ} 737.857 / 6$, Rel. Arantes Theodoro, j. 09.05.02).

${ }^{684}$ DELLORE, Luiz Guilherme Pennachi. Do recurso cabível das decisões referentes à gratuidade da justiça (Lei 1.060/50), cit., p. 335-336.

${ }^{685} \mathrm{O} \S 5^{\circ}$ do art. $4^{\circ}$ da Lei Estadual paulista ${ }^{\circ} 11.608 / 03$ dispõe: "A petição do agravo de instrumento deverá ser instruída com o comprovante do pagamento da taxa judiciária correspondente a 10 (dez) UFESPs e do porte de retorno, fixado na forma do parágrafo anterior, nos termos do $\S 1^{\circ}$ do artigo 525 do Código de Processo Civil".
} 
realizada no bojo da impugnação, em prol da decisão inicial, tomada sem qualquer dilação probatória, fundada apenas na singela afirmação da parte autora"686.

Mais uma vez ousamos observar: a crítica pode até ser procedente, porém é imprópria, porque não se prende necessariamente à questão da gratuidade. Cuida-se, a bem ver, de um problema que atinge qualquer caso em que o recurso seja dotado do efeito suspensivo, o que, aliás, é a regra geral no caso de apelação. Logo, poderíamos dizer que a regra geral implicaria "desprestígio" à decisão de primeira instância, porém não estaríamos tratando especificamente de um argumento relacionado ao regramento do procedimento recursal em questões atinentes à aplicação da Lei no 1.060/50.

Veja-se que haverá um caso excepcional em que o recurso cabível deveras será a apelação. Referimo-nos à hipótese em que, por motivos peculiares ao andamento de determinado processo, a questão da gratuidade seja decidida na própria sentença que julga o feito.

Imagine-se, então, que encerrada a instrução, a parte que até então não gozava o benefício, vem a requerê-lo nas alegações finais, e o juízo decida a questão em ato único, isto é, conjuntamente com mérito (ou proferindo sentença terminativa, porém apreciando a questão).

Pode também ocorrer que o incidente de impugnação, tramitando paralelamente ao feito principal, chegue juntamente com este na fase decisória. A boa técnica manda que o magistrado decida separadamente a causa principal e o incidente que tramita em apartado acerca da gratuidade. Entretanto, se proferir o juízo decisão única, nenhuma nulidade haverá, mera irregularidade procedimental.

Nestes casos será cabível o recurso de apelação, não em razão da incidência do disposto no art. 17 da Lei $\mathrm{n}^{\circ} 1.060 / 50$, mas face ao princípio da unirrecorribilidade das decisões, de modo que esta hipótese ora aventada é alheia ao debate acerca da eficácia do art. 17 em questão.

Marcacini empreende uma análise histórica da gênese da regra do art. 17 e do intento do legislador com a edição da Lei $n^{\circ}$ 6.014/73. Segundo observa argutamente o autor citado, o diploma em questão teve mais em vista os efeitos do recurso, e não sua forma ou adequação procedimental. Isto porque sempre houve por parte do legislador a

\footnotetext{
${ }^{686}$ DELLORE, Luiz Guilherme Pennachi. Do recurso cabível das decisões referentes à gratuidade da justiça (Lei 1.060/50), cit., p. 336.
} 
preocupação de afastar do recurso interposto contra o deferimento do benefício o efeito suspensivo, a fim de viabilizar ao requerente que seguisse usufruindo da benesse até a decisão da superior instância. De outro lado o recurso contra o indeferimento ou revogação sempre foi dotado de tal efeito, a fim de impedir que tal decisão pudesse desde logo obstruir o acesso da parte à isenção. A idéia da Lei $n^{0}$ 6.014/73 foi justamente de tentar manter esta mesma linha ${ }^{687}$.

Sob a égide do Código de Processo Civil de 1939 o recurso cabível contra a decisão que denegasse ou revogasse a gratuidade era o agravo de instrumento, conforme art. 842, V. Não havia recurso previsto para o caso de deferimento do benefício ${ }^{688}$. Embora o agravo de instrumento não fosse (como ainda não é) dotado de efeito suspensivo, previa-se excepcionalmente que neste caso o recurso suspenderia apenas a obrigação do pagamento das custas (art. 843, $\S 1^{\circ}$ ).

A redação original do art. 17 da Lei $\mathrm{n}^{\circ}$ 1.060/50 observou o mesmo parâmetro, prevendo o recurso de agravo de instrumento como o cabível, "salvo quando a decisão for denegatória da assistência, caso em que o agravo será de petição”. A novidade foi a previsão da recorribilidade da decisão concessiva do benefício, a saber, o agravo de instrumento. Como este não era dotado de efeito suspensivo, a concessão operava-se desde logo; de outro lado, contra a decisão denegatória (ou revocatória) o recurso pertinente era o agravo de petição, este sim dotado de efeito suspensivo, o que impedia que a decisão contrária ao requerente dos benefícios produzisse desde logo seu efeito gravoso.

Com a supressão do agravo de petição pelo novo sistema recursal trazido pelo Código de Processo Civil de 1973, o legislador procurou adaptar o art. 17 da Lei $\mathrm{n}^{\circ}$ 1.060/50, observando então aquele mesmo regime jurídico no que concerne à modulação dos efeitos recursais a fim de evitar que em caso de denegação ou revogação do benefício, a parte tivesse desde logo de recolher custas e despesas, aguardando-se sempre a palavra final da instância recursal acerca do assunto.

\footnotetext{
${ }^{687}$ MARCACINI, Augusto Tavares Rosa. Assistência jurídica, assistência judiciária e justiça gratuita, cit., p. 106-107. Por isto ao defender o cabimento de agravo em qualquer hipótese em que se decida acerca da gratuidade, o autor em questão aponta que ao agravo deverá ser acrescido o atributo suspensivo no caso de a decisão hostilizada ser de denegação ou revogação do benefício, a fim de respeitar o intento do art. 17 da Lei $\mathrm{n}^{\circ} 1.060 / 50$.

${ }^{688}$ Então, apenas as interlocutórias enumeradas em lei comportavam o agravo de instrumento, daí porque a decisão concessiva era irrecorrível. Observa Araken de Assis que justamente a vedação da via recursal à parte contrária é que motivou a criação do incidente de impugnação, então amparado no art. 77 do Código de Processo Civil de 1939 (Benefício da gratuidade, cit., p. 186).
} 
E tal adaptação deu-se com a eleição da apelação como a via adequada, seja para impugnação da decisão concessiva, seja para insurgência contra a denegatória. Tal recurso é, salvo expressa disposição em contrário, dotado de efeito suspensivo (CPC, art. 520, “caput”), de modo que no caso de denegação ou revogação do benefício, a suspensão dos efeitos da decisão negativa convinha para permitir que a parte continuasse a usufruir da isenção até decisão final; já no caso de decisão concessiva, o tal efeito suspensivo impediria sua eficácia imediata com a presta isenção, daí porque retirou-se-lhe tal atributo, como se vê da segunda parte do art. 17.

O problema foi que ao mirar apenas a questão dos efeitos recursais, o legislador descurou da incongruência em prever apelação para o caso de uma evidente decisão interlocutória a qual, para piorar, ainda chamou "sentença".

Analisando a questão rigorosamente sob aspecto técnico, a regra do art. 17 é de todo inaplicável, sendo de defender-se realmente o cabimento de agravo em qualquer hipótese na qual a decisão verse questões incidentais relacionadas à Lei $\mathrm{n}^{\circ}$ 1.060/50, salvo quando por peculiaridades no andamento do processo, tal decisão acabe proferida no bojo da própria sentença.

Todavia, deveras a posição que grassa especialmente em jurisprudência é a que prestigia a interpretação salvacionista. E não vai aí sacrilégio muito grande. Sabe-se bem o princípio de hermenêutica jurídica segundo o qual, havendo diversas interpretações possíveis, não se deve eleger aquela que esvazie completamente de utilidade o dispositivo interpretado. Assim é que o art. 17 teria sua aplicação restrita aos casos em que a questão atinente à gratuidade seja decidida no incidente apartado (requerimento no curso da lide ou impugnação), numa excepcional hipótese em que decisão interlocutória desafia apelação.

Um ponto de interesse é saber se o agravo a ser interposto necessariamente observará a forma de instrumento ou poderá permanecer retido nos autos. Esta questão assume especial relevo após a edição da Lei nº 11.187/2005.

Como sabido antes da edição do diploma em questão interpor o agravo pela forma de instrumento ou retida constituía-se em opção da parte recorrente. O novo regime jurídico contudo tornou regra geral a observância da forma retida, enumerando taxativamente o cabimento da formação de instrumento para os casos em que "se tratar de decisão suscetível de causar à parte lesão grave e de difícil reparação, bem como nos casos de inadmissão da apelação e nos relativos aos efeitos em que a apelação é recebida, quando 
será admitida a sua interposição por instrumento" (CPC, art. 522, "caput", do Código de Processo Civil).

A primeira idéia que exsurge até sem maiores necessidades de digressão refere-se à hipótese de indeferimento da gratuidade requerida ou sua revogação. Parece evidente o risco de grave dano a que fica sujeita a parte, até tornando sem propósito a retenção do recurso nos autos. É que retido o recurso o processo seguirá seu trâmite normal e a parte terá de arcar com todas as despesas daí advindas, até que em sede preliminar de eventual apelação veja provido seu agravo deferindo-lhe a gratuidade quando então já terá suportado a quase totalidade das despesas processuais ${ }^{689}$.

De outro lado, interpondo o agravo na forma retida e abstendo-se de recolher as custas, a parte se sujeitará à extinção do processo, no caso de ser o autor, ou, mesmo na hipótese de ser réu, a consequiências gravosas (p.ex. preclusão de prova pericial por falta de recolhimento de honorários; preclusão de prova oral por falta de recolhimento da condução do oficial de justiça para intimação de testemunha; etc. $)^{690}$.

Parece, pois, inviável sustentar posição diversa nos casos em que haja indeferimento ou revogação da gratuidade, senão que poderá a parte interessada valer-se do agravo na forma de instrumento.

Observe-se que o fato de a decisão de indeferimento ou revogação ter sido proferida nos autos principais ou no incidente em apartado é indiferente para fins de fixação da forma da interposição.

Como visto alhures, as divergências situam-se na questão do cabimento do recurso de agravo ou de apelação no caso de autuação em apartado. Para aqueles que entendem cabível o agravo no caso de decisão proferida no apenso incidental, é irrelevante esta circunstância para fixar como devida a forma de instrumento ou retida.

\footnotetext{
${ }^{689}$ Aliás, entende Luiz Guilherme Pennachi Dellore que se "em virtude do indeferimento da gratuidade a parte recolher as custas iniciais, é de se concluir que, em verdade, inexistia a impossibilidade para o pagamento. E o mesmo ocorre em relação ao recolhimento das custas de eventual apelação. Se assim é, acaso interposto agravo retido, faltará interesse de agir (necessidade) ao agravante, razão pela qual, em preliminar de apelação, o recurso não deverá ser conhecido" (Do recurso cabível das decisões referentes à gratuidade da justiça (Lei 1.060/50), cit., p. 341).

${ }^{690}$ Também neste sentido o escólio de Fredie Didier Jr e Rafael Oliveira: "se a decisão interlocutória hostilizada indefere ou revoga o benefício, não faz sentido exigir-se do requerente que aguarde até o julgamento da sua (eventual) apelação para que, já ao fim do processo, veja analisado seu pedido de dispensa das despesas do processo - ate porque, muito provavelmente, para chegar até ali, o requerente já teve que antecipar todos os custos" (Benefício da justiça gratuita cit., p. 55).
} 
Já no caso de concessão da gratuidade ou de rechaço à impugnação, com manutenção do benefício, a primeira impressão que se tem é a de que inexista para o adversário risco algum a ensejar a interposição de agravo pela via de instrumento ${ }^{691}$. Em linha de princípio, o adversário teria de todo modo de aguardar a solução final da lide para saber se faria jus ao reembolso de despesas (porque declarado vencedor). Esta primeira idéia é, entretanto, equivocada.

Imagine-se, a título exemplificativo, que o réu oferte impugnação à gratuidade concedida ao autor, incidente este julgado improcedente. Interposto agravo, este permanece retido nos autos, sob uma suposta ausência de risco de prejuízo irreparável. Suponha-se então que a ação seja julgada improcedente. Em linha de princípio, havendo interposição de apelação pelo autor, ao réu que outrora ofertara a impugnação caberá, nas contra-razões, reiterar o agravo retido. E se o autor adversário não interpuser a apelação? O réu-impugnante que se sagrou vencedor na ação principal, porém fora derrotado no incidente, não terá interesse recursal para apelar de sentença que lhe foi favorável, de modo que seu agravo retido nunca chegará a ser conhecido pela instância superior. Dificilmente se poderia sustentar que o réu nesta hipótese teria interesse recursal para apelar apenas para possibilitar a subida de seu agravo retido.

O mesmo vale quando pensamos na impugnação ofertada pelo autor à gratuidade concedida ao réu, e que seja julgada improcedente com a interposição pelo autorimpugnante de agravo retido. Pense-se que a ação seja julgada procedente e o réu não oferte apelação. Não teria o autor interesse recursal para apelar, impedindo também o conhecimento no grau recursal do agravo retido.

Poderíamos, então, formular uma regra geral no seguinte sentido: mesmo no caso de concessão ou manutenção da gratuidade, o adversário terá interesse para interpor agravo por instrumento pois há risco de dano irreparável, a saber, o caso de sagrar-se vencedor na lide principal e seu adversário (que fora vencedor no incidente) deixar de interpor o recurso próprio, caso em que não haverá interesse recursal do impugnante para interpor o recurso principal que veicularia em seu bojo a reiteração do agravo retido.

Luiz Guilherme Pennachi Dellore sugere que mesmo no caso em que haja recurso por parte do assistido que amargou derrota na ação principal, com a possibilidade de

\footnotetext{
${ }^{691}$ Lembre-se apenas que, como anteriormente já abordado, há divergência acerca do cabimento de recurso em face da decisão que de plano concede os benefícios da gratuidade, diante da oferta ao adversário da impugnação a que alude o art. $7^{\circ}$ da Lei $n^{\circ} 1.060 / 50$, antes da opção pela via recursal.
} 
reiteração do agravo retido nas contra-razões da apelação pelo impugnante, haveria risco de tumulto processual:

"Diante da interposição de apelação por parte do autor, o réu-impugnante insiste no agravo retido interposto - para que seja possível desde logo executar os honorários. O agravo retido, julgado antes da apelação, é provido, para afastar a gratuidade.

Instado a recolher as custas processuais (iniciais e de preparo) pelo tribunal, o autor-agravado permanece inerte. Qual será a conseqüência? Extinção do processo sem julgamento do mérito - possibilitando, inclusive, nova propositura da demanda"692.

Não nos parece, entretanto, que a solução alvitrada seja própria. No caso em questão bastaria que se julgasse deserta a apelação, e que com relação às custas iniciais, houvesse extração de cópias para inscrição na dívida ativa, ensejando a cobrança pelo Estado pelas vias próprias. Evitar-se-ia assim a extinção sem resolução do mérito em prejuízo do agravanteimpugnante que já obteve em primeiro grau sentença favorável, a qual, inclusive, transitará em julgado com o não conhecimento da apelação em razão da falta do preparo.

De todo modo, mesmo que no caso específico referido no parágrafo anterior não haja o risco de grave dano para o impugnante, temos que possibilidade daquela outra situação já exemplificada, isto é, em que o impugnado derrotado na ação não interponha recurso, justifica que se admita o agravo na forma de instrumento também nos casos de concessão ou manutenção da gratuidade ${ }^{693}$.

A longa exposição feita até aqui com recurso a diversas lições doutrinárias de respeito, indicando as latentes divergências que pairam a respeito do sistema recursal aplicável às decisões acerca da gratuidade, denotariam um fecundo campo para aplicação do famigerado princípio da fungibilidade recursal. É com perplexidade, entretanto, que verificamos o contrário: há alguma resistência à sua aplicação no caso, tanto em doutrina como em jurisprudência ${ }^{694}$.

\footnotetext{
${ }^{692}$ DELLORE, Luiz Guilherme Pennachi. Do recurso cabível das decisões referentes à gratuidade da justiça (Lei 1.060/50), cit., p. 342.

${ }^{693}$ Fredie Didier Jr e Rafael Oliveira igualmente defendem sempre cabível o agravo por instrumento, mesmo no caso de decisão que conceda ou mantenha a gratuidade, justificando que "há inclusive interesse do próprio Estado em que a questão seja logo apreciada, a fim de que se evite, por exemplo, o desembolso de custas em favor de pessoa que não deveria ser beneficiada com a dispensa prevista em lei" (DIDIER JR, Fredie; OLIVEIRA, Rafael. Benefício da justiça gratuita cit., p. 55-56).

${ }^{694 ، “ A}$ decisão que aprecia o incidente de impugnação ao deferimento da gratuidade judiciária, processado em autos apartados, desafia recurso de apelação, e não de agravo de instrumento. Nessa hipótese, não se aplica o princípio da fungibilidade recursal, por se configurar erro grosseiro" (STJ, AgRg no Ag nº 579.729/SP, Rel. Nancy Andrighi, j. 14.06.04).
} 
Não é o caso de descermos a minúcias acerca das nuances que envolvem o princípio processual em questão, mas sabe-se que são padrões comumente referidos a dúvida objetiva acerca do cabimento de determinada espécie recursal; a inexistência de erro grosseiro da parte recorrente, e ainda, a observância do menor prazo entre aqueles correspondentes aos recursos "concorrentes".

Ora, não pode haver receio diante das tão díspares manifestações doutrinárias e jurisprudenciais acerca do assunto, de que haja efetiva e real dúvida objetiva, o que afasta a caracterização de erro crasso na interposição de um ou outro recurso (apelação ou agravo de instrumento). A observância do menor prazo possível (que no caso seria o decêndio previsto para o agravo) é requisito que se deve aferir no caso concreto.

Não se justifica, portanto, negar neste caso a aplicação do sobredito princípio, parecendo mesmo tratar-se até de exemplo acadêmico acerca do tema ${ }^{695}$.

Há uma observação crítica de Marcacini ${ }^{696}$ que merece referência, e diz respeito à comum alusão a que no caso de denegação do benefício da gratuidade, é de se deferir efeito suspensivo ao recurso interposto (seja a apelação, que neste caso já é dotada ope legis deste atributo, seja o caso de agravo, ao qual neste caso se deveria dar tal efeito por força do princípio constitucional de acesso à justiça), o que evitaria que a parte tivesse de recolher preparo para debater acerca de seu direito de não ter de arcar com as despesas, o que inclusive violaria seu direito de acesso à justiça acaso real a situação de pobreza.

Veja-se que na hipótese de decisão que nega o benefício, a concessão de efeito suspensivo ao agravo interposto, ou mesmo o reconhecimento de que a apelação seja dotada de tal efeito, teria no máximo o condão de evitar que ela produza seu efeito denegatório desde logo. Contudo, negar efeito à decisão que negou o benefício não deveria representar concessão, isto é, efeito positivo.

\footnotetext{
${ }^{695}$ Defendendo sua aplicação: Fredie Didier Jr e Rafael Oliveira (Benefício da justiça gratuita cit., p. 55); Luiz Guilherme Pennachi Dellore (Do recurso cabível das decisões referentes à gratuidade da justiça (Lei 1.060/50), cit., p. 344, embora em outro trecho do texto chegue a defender o descabimento da aplicação do princípio em questão no caso de apelação interposta de decisão proferida no bojo dos autos principais); Maurício Vidigal (Lei da Assistência Judiciária interpretada, cit., p. 93); Augusto Marcacini (Assistência jurídica, assistência judiciária e justiça gratuita, cit., p. 110); Araken de Assis (Benefício da gratuidade, cit., p. 187). Contra a aplicação do princípio da fungibilidade: Roberto Luis Luchi Demo (Assistência judiciária gratuita, cit., p. 360), inclusive invocando o seguinte precedente: STJ, REsp nº 154.764/MG, Rel. Adhemar Maciel, j. 20.10.98. É de ver que o julgado retro mencionado refere-se genericamente aos requisitos para a aplicação do princípio da fungibilidade recursal, porém não trata especificamente da aplicação de tal princípio ao caso do art. 17 da Lei $\mathrm{n}^{\circ}$ 1.060/50 em confronto com o sistema recursal do Código de Processo Civil.

${ }^{696}$ MARCACINI, Augusto Tavares Rosa. Assistência jurídica, assistência judiciária e justiça gratuita, cit., p. 110.
} 
Por isto é que a "não-exigência do recolhimento de custas, até o julgamento definitivo da questão, se dá muito mais em cumprimento das garantias constitucionais do que em decorrência dos efeitos que tenha o recurso" ${ }^{\text {,697. }}$.

Então é que no caso de denegação do benefício requerido, tecnicamente adequado seria que a parte que interponha o agravo de instrumento obtenha não propriamente o efeito suspensivo (repita-se: suspender a decisão que nega não equivale a conceder o que antes não fora requerido ou deferido), mas sim a antecipação dos efeitos da tutela recursal, com o deferimento da isenção seja para o processamento do próprio recurso, seja para a continuidade do trâmite da causa na instância inferior, até que a superior instância dê a definitiva solução da questão. É a providência prevista no art. 527, III, $2^{\circ}$ parte, do Código de Processo Civil, que nos meios forenses se logrou denominar efeito ativo.

A lacuna se verifica para o caso em que houve simples indeferimento do benefício (e não revogação) com interposição de apelação, pois que embora dotada de efeito suspensivo, não é dotada do efeito ativo, o que tornaria impossível manter-se isenção que não fora anteriormente deferida. Neste caso a incidência da isenção até julgamento de tal apelo deve decorrer das garantias constitucionais referidas por Marcacini.

Já no caso de agravo ou apelação interpostos contra a decisão revocatória, isto é, que desdiz anterior decisão concessiva do benefício, a situação é diferente. Nesta conjuntura é próprio falar-se em efeito suspensivo (seja do agravo, seja da própria apelação), pois que outorgado tal efeito ao recurso a decisão revocatória remanesce com sua eficácia sustada, prevalecendo a anterior concessão, até que haja definitiva solução da pendenga. Ou seja, o pretenso beneficiário seguirá sem o ônus de arcar com as despesas processuais.

Uma última informação convém seja registrada. O projeto de Código de Processo Civil em vias de aprovação tratou em um único artigo acerca da gratuidade (art. 99). O $\S 2^{\circ}$ do dispositivo em questão espanca todas as dúvidas acerca do recurso cabível nos casos de decisão acerca da gratuidade: "Das decisões relativas à gratuidade de justiça, caberá agravo de instrumento, salvo quando a decisão se der na sentença”" (destaques nossos).

Igualmente, o art. 969, adotando o critério de enumeração das decisões que desafiam agravo de instrumento, tratou de prever no inciso $\mathrm{V}$ das decisões interlocutórias que versarem sobre a gratuidade de justiça.

${ }^{697}$ MARCACINI, Augusto Tavares Rosa. Assistência jurídica, assistência judiciária e justiça gratuita, cit., p. 110. 


\section{Assistência jurídica em recurso repetitivo}

A Lei ${ }^{\circ}$ 11.418/06 instituiu nos arts. 543-A e 543-B do Código de Processo Civil novo pressuposto de admissibilidade (repercussão geral) e forma de julgamento por amostragem (acerca deste pressuposto), aplicáveis ao Recurso Extraordinário.

A Lei $n^{\circ} 11.672$ de maio de 2008 estendeu o segundo incidente também para o Recurso Especial, no âmbito do Superior Tribunal de Justiça. Acrescendo o art. 543-C e parágrafos ao Código de Processo Civil, previu-se que em caso de multiplicidade de recursos com fundamento em idêntica questão de direito, caberá ao presidente do Tribunal a quo selecionar para acesso à Instância Superior um ou mais recursos representativos da controvérsia, suspendendo então o trâmite dos demais Recursos Especiais até que se pronuncie o Superior Tribunal de Justiça sobre a questão.

Esta medida, se não adotada pelo presidente do Tribunal a quo, poderá ser promovida de ofício pelo próprio Relator do Recurso Especial no Superior Tribunal de Justiça, determinando-se a suspensão nos Tribunais da Segunda Instância, dos recursos repetitivos.

Não é o caso aqui de destrinchar a matéria, valendo apenas consignar a nota elogiosa à providência racionalizadora.

O que nos é afeto, no caso, é salientar a relevância desta providência para o âmbito das questões debatidas acerca da assistência jurídica, especialmente a modalidade gratuidade judiciária.

Uma superficial pesquisa jurisprudencial indicará a enorme profusão de recursos em torno da aplicação da Lei ${ }^{\circ} 1.060 / 50$ e as controvérsias que ela suscita, especialmente em Segunda Instância. A própria quantidade enorme de julgados citados neste trabalho é prova desta circunstância. Assusta também a diversidade de sentidos das manifestações jurisprudenciais, bem como a repetitividade dos temas.

Numa breve meditação seríamos capazes de destacar diversos assuntos: i) extensão da benesse às pessoas jurídicas; ii) parâmetros para concessão do benefício de acordo com a natureza e finalidade dos entes morais; iii) verbas abarcadas pela isenção, com diversos padrões de confronto; iv) suficiência da declaração de pobreza (ou seja, forma de comprovação do estado de miserabilidade); v) iniciativa probatória do juiz no ponto. 
Todos estes são temas recorrentes na instância recursal extraordinária, e que bem se comportariam na aplicação do regramento do julgamento por amostragem, que já estaria em ocasião de ser providenciado.

Conforta saber que ao menos uma destas questões já logrou ascender na forma preconizada pelo citado art. 543-C do Código de Processo Civil. O Recurso Especial $\mathrm{n}^{\circ}$ 1.120.642 oriundo de São Paulo, de relatoria da Min. Denise Arruda, é representativo da questão referente à concessão do benefício da assistência judiciária gratuita (na verdade quer-se dizer gratuidade) à pessoa jurídica sem fins lucrativos. O reconhecimento da representatividade do Recurso em questão deu-se em novembro de 2009, e consta o inconformismo na ordem de inclusão para julgamento pela Corte Especial sob o $n^{\circ} 354$. O acórdão hostilizado, prolatado pelo Eg Tribunal de Justiça do Estado de São Paulo, indeferiu no caso a concessão do benefício à pessoa jurídica sem fins lucrativos.

É oportuno observar que há no seio do próprio C.Superior Tribunal de Justiça, divergência entre seus componentes acerca das expectativas acerca do mecanismo, com duas posições. A primeira defende que a discussão em torno do recurso representativo da controvérsia deveria apenas ratificar as conclusões já obtidas em precedentes anteriores, uma espécie de chancela. Já uma segunda corrente defende a possibilidade de que o Tribunal, nesta ocasião, tenha a chance de ir além dos precedentes anteriores, avaliando eventual legislação superveniente acerca do assunto, e mesmo amadurecendo as idéias acerca do assunto, uma oportunidade para evolução e atualização da jurisprudência. É esta a posição da Ministra Fátima Nancy Andrighi ${ }^{698}$.

Seria, então, de todo proveitoso que outros recursos representativos das demais questões, como aquelas já citadas exemplificativamente, fossem submetidos a julgamento

\footnotetext{
${ }^{698}$ ANDRIGHI, Fátima Nancy. Recursos repetitivos. Revista de Processo, São Paulo, v. 35, n. 185, p. 265, jul. 2010. No artigo em questão, originado de uma conferência, a Ministra revela diversos postulados formulados pelo C. Superior Tribunal de Justiça a partir de dificuldades práticas encontradas no dia-a-dia para a operacionalização do mecanismo de julgamento em questão. Resumimos a seguir algumas: a) encontrou-se dificuldade, inicialmente, porque num recurso repetitivo que veiculasse diversas teses objeto de multiplicidade de controvérsias, constatava-se muitas vezes que em relação a alguns destes pontos os recursos não superavam o juízo de admissibilidade. Entendeu-se, então, que além da questão idêntica ter sido debatida no acórdão impugnado e nas razões de recurso especial, todos os requisitos de admissibilidade deveriam ser preenchidos. Tornou-se, então, praxe afetar-se um único tema dentro de um recurso especial, ou ainda, afetar-se tantos recursos quantos forem necessários de acordo com as teses envolvidas; b) no caso do Recurso Especial representativo selecionado pelo Tribunal de $2^{o}$ grau não preencher os pressupostos de admissibilidade (de acordo com a idéias de duplo juízo, no Tribunal $a$ quo e no ad quem), caberá ao Ministro Relator simplesmente indeferir a instauração do incidente, negando seguimento ao especial selecionado pela Instância a quo; c) a coletivização do debate retira do recurso seu caráter exclusivamente individual, de modo que não se há de admitir, após a instauração do incidente, desistência por parte do recorrente, pena de permitir-se a indevida manipulação da atividade jurisdicional. Estas são algumas questões acerca do incidente. Não há aqui espaço nem propósito para aprofundá-lo.
} 
de acordo com o novo e alvissareiro regime, especialmente para que se propiciasse, de acordo com a segunda posição supra descrita, novas e mais profundas meditações acerca de diversos padrões e argumentos acerca destas questões. Embora a legislação sobre o assunto seja vetusta, e diversos dos debates já corriqueiros, a evolução das aspirações sociais e do contexto sócio-político-econômico reclama constantes reavaliações daquilo que se tem como solidificado.

\section{Regime jurídico do assistido}

Tratemos nesta oportunidade das regras peculiares que regem a atuação processual do assistido, segundo prescrição do $\S 5^{\circ}$ do art. $5^{\circ}$ da Lei $n^{\circ}$ 1.060/50: "Nos Estados onde a Assistência Judiciária seja organizada e por eles mantida, o Defensor Público, ou quem exerça cargo equivalente, será intimado pessoalmente de todos os atos do processo, em ambas as Instâncias, contando-se-lhes em dobro todos os prazos". O dispositivo foi incluído pela Lei $\mathrm{n}^{\circ} 7.871 / 89$.

Não há porque haver dúvidas maiores acerca da constitucionalidade da regra, de acordo com foros de isonomia em sentido material, e bem assim de acordo com aquela famigerada idéia de que se deve tratar desigualmente os desiguais em consonância com a desigualdade que apresentam, o que até já foi tratado com maiores detalhes alhures.

O principal problema interpretativo nesta sede diz respeito à extensão que se dá, e a que se pretende dar, à expressão "cargo equivalente" contida na regra. Sendo mais preciso: o ponto nodal aqui, de longa e antiga discussão na doutrina e jurisprudência diz respeito à aplicabilidade dos benefícios processuais em questão ao advogado dativo, isto é, aos casos em que não haja serviço organizado e mantido pelo Estado (isto é, Defensoria Pública), e em que patrono não integrante de carreira pública seja indicado para patrocinar a causa do necessitado.

As manifestações doutrinárias são as mais divergentes. Antônio Carlos de Araújo Cintra, em parecer lavrado em favor do Departamento Jurídico do glorioso Centro Acadêmico XI de Agosto (Faculdade de Direito da Universidade de São Paulo) põe-se favorável à extensão.

Segundo o professor titular do Largo de São Francisco o Departamento Jurídico em questão (que constitui o que em outras escolas se denomina escritório-escola; escritóriosmodelo; etc.) embora não se confunda com serviço público em sentido estrito, dele se 
aproxima por seus objetivos e finalidades, autêntica delegação da Defensoria Pública, inclusive recebendo recursos desta, para quem atua como verdadeira longa manus, "com suas vestes de Defensoria Pública, fazendo jus a prerrogativas a esta reconhecidas na defesa dos necessitados em juízo" ${ }^{\text {,99 }}$.

Segue o mesmo autor lembrando que as prerrogativas em questão não foram estabelecidas em favor do Defensor Público, mas sim do atendido pelo serviço de assistência, e mediatamente, ao interesse público da boa distribuição da justiça. Assim, a menção a "cargo equivalente" destina-se a evitar violação da isonomia, de modo que "o defensor do necessitado atendido pela Procuradoria teria melhores condições de prestar a assistência jurídica devida do que o defensor do necessitado encaminhado pela mesma Procuradoria",700.

Ainda André Bonelli assim se manifesta: “A equivalência ente defensor público e quem exerça outro cargo, a que a lei se refere, é a correspectividade de sentido, função, objeto e finalidade das atividades desenvolvidas por ambos", e adiante conclui que o legislador "quis estender a todos aqueles que, destinatários da assistência gratuita, atuassem no processo representados por advogados vinculados a entidades criadas para a prestação filantrópica" ${ }^{, 701}$.

Marcacini igualmente tem posição favorável à interpretação extensiva do benefício. Segundo argumenta há duas ordens de razões a justificar benefícios processuais em geral, como aqueles conferidos à Fazenda Pública e ao Ministério Público: uma de ordem prática,

${ }^{699}$ CINTRA, Antônio Carlos de Araújo. Assistência judiciária. Revista dos Tribunais, São Paulo, v. 87, n. 758, p. 65, dez. 1998. Na jurisprudência, dando amparo a esta tese: "PROCESSO CIVIL. PRAZO EM DOBRO. DEFENSOR PÚBLICO. ART. 5,$\S 5^{\circ}$, LEI 1060/50. 1. São contados em dobro os prazos processuais nas causas sob o patrocínio do defensor público ou daquele que exerça cargo equivalente, inclusive o advogado vinculado à assistência judiciária. 2. Exegese do art. $5^{\circ}, \S 5^{\circ}$ da Lei n 1060/50. 3. Recurso conhecido em parte e, nesta extensão, provido" (STJ, REsp n ${ }^{\circ}$ 164.633/PA, Rel. Fernando Gonçalves, j. 20.10.98). Ainda: “AGRAVO DE INSTRUMENTO - COBRANÇA - PRAZO EM DOBRO E INTIMAÇÃO PESSOAL - ADVOGADO EXERCENDO A DEFENSORIA PÚBLICA, EM RAZÃO DE CONVÊNIO CELEBRADO ENTRE OAB E PGE - ADMISSIBILIDADE. "Da exegese do texto legal, artigo 5o, $\S \mathrm{S}^{\circ}$, da Lei 1.060/50, com a redação conferida pela Lei 7.871/89, conjuntamente com os termos do convênio celebrado entre a OAB e a PGE, da qual o patrono da parte é integrante, deriva que o advogado, no caso revestido das condições de defensor público, faz Jus às prerrogativas estabelecidas no dispositivo legal em tela. RECURSO PROVIDO" ( $2^{\circ}$ TACivSP, AI n 765.536-0/6, Rel. Henrique Nelson Calandra, j. 12.11.02).

${ }^{700}$ CINTRA, Antônio Carlos de Araújo. Assistência judiciária, cit., p. 67.

${ }^{701}$ BONELLI, André. Aspectos processuais da Lei de Assistência Judiciária, cit., p. 1.555. Adiante o mesmo autor ainda enfatiza: "Possibilitar prazo dobrado para esta camada da população é conceder a igualdade processual, a possibilidade real de idêntica participação no processo (contraditório e ampla defesa) entre aqueles que podem contratar advogados exclusivos e os que têm de contentar-se com os congestionados e precários serviços de assistência gratuita. Se não for assim, não há isonomia processual; não há garantia de acesso à justiça e não existe a assistência jurídica integral. Esses são direitos sociais conquistados pela nação e garantidos na Constituição da República, que exigem consequiências práticas, efetivas e reais” (cit., p. 1.555). 
considerando a dificuldade de atuação destes órgãos, e outra de ordem valorativa, considerando os interesses tutelados por tais órgãos (defesa do patrimônio público e dos interesses sociais indisponíveis).

Estes dois fundamentos igualmente amparam os benefícios concedidos aos Defensores Públicos, e com base neles o autor defende que a expressão cargo deve ser lida como função, e por isto as benesses se estendem a todos os órgãos prestadores de assistência, e não apenas ao órgão oficial, pois que as dificuldades de atendimento que justificam a concessão do prazo em dobro para o órgão oficial são as mesmas enfrentadas pelos causídicos particulares que suprem as lacunas do Poder Público ${ }^{702}$.

Em sentido contrário, entretanto, Maurício Vidigal argumenta que a intenção do legislador era estender os mesmos privilégios processuais concedidos à Fazenda Pública e ao Ministério Público, para contornar as falhas e carências do serviço público, concluindo que "a outorga não teve em mira as necessidades das partes carentes, mas as deficiências referidas. Se outro fosse seu objetivo, o prazo dobrado teria sido previsto para todos os beneficiados pela justiça gratuita" ${ }^{, 703}$.

Nega, assim, que o fundamento seja o princípio da isonomia, pois se fosse, nada justificaria sua não extensão aos beneficiários da gratuidade defendidos por advogados de sua própria escolha. É a consideração da diversidade da situação do serviço público, "que a ninguém pode negar atendimento, e dos particulares que podem restringir sua assistência" $^{\text {704. }}$.

\footnotetext{
${ }^{702}$ MARCACINI, Augusto Tavares Rosa. Assistência jurídica, assistência judiciária e justiça gratuita, cit., p. 77. Há um antigo julgado, citado por José Roberto de Castro, dilatando o termo inicial do prazo para contestação no caso do réu ser beneficiário da assistência: "O estado de miserabilidade equipara-se à força maior e assim o prazo pra contestar principia no momento em que o advogado recebe da Ordem a nomeação para funcionar na causa" (TJDF, Ap. no 40.186, Rel. Osni Dutra Pereira, DJ 18.09.58). Mais recentemente, também manifestou-se neste sentido o Eg.TJSP: "EMBARGOS À EXECUÇÃO - Defensor nomeado pela $\mathrm{OAB}$ - Início do prazo para oposição de embargos à execução com a intimação do defensor de suas funções - Obstáculo judicial - Embargos à execução opostos tempestivamente - Recurso provido para considerar tempestivos os embargos à execução e, com autorização do art. 515, § $3^{\circ}$, do Código de Processo Civil, julgar improcedentes os embargos opostos" (TJSP, Ap. ${ }^{\circ}$ 7.073.266-8, Rel. Silveira Paulilo, j. 22.08.07).

${ }^{703}$ VIDIGAL, Mauricio. Lei da Assistência Judiciária interpretada, cit., p. 45.

${ }^{704}$ VIDIGAL, Mauricio. Lei da Assistência Judiciária interpretada, cit., p. 46. É neste sentido também a posição de Roberto Luis Luchi Demo: "A figura do defensor dativo ou nomeado ad hoc não se confunde com a do Defensor Público. Não tem, por isso, prazo em dobro para recorrer, nem direito à intimação pessoal" (Assistência judiciária gratuita, cit., p. 343).
} 
Também Araken de Assis manifesta-se contrariamente à extensão dos benefícios aos advogados particulares que atuem como dativos ${ }^{705}$.

A jurisprudência tem observado a interpretação restritiva no que concerne ao alcance do mencionado $\S 5^{\circ}$ do art. $5^{\circ}$ da Lei $n^{\circ} 1.060 / 50$, especialmente com o fundamento de que o termo "cargo" é dotado de sentido técnico próprio, relacionado ao Direito Administrativo, não se lhe estendendo a função desempenhada por advogados dativos, mesmo que suprindo deficiências do Poder Público ${ }^{706}$.

Como se nota, portanto, a negativa de extensão das benesses processuais aos advogados dativos tem sido baseada primordialmente na interpretação gramatical da norma do $\S 5^{\circ}$ do art. $5^{\circ}$ já citado. Compreende-se, então, que o termo cargo empregado pela lei é dotado de sentido técnico preciso e inconfundível, a saber, a unidade orgânico-funcional componente da estrutura administrativa do Estado, criada por lei, com atribuições e remuneração vinculadas ao princípio da legalidade estrita.

O advogado dativo, segundo esta corrente, conquanto desempenhe função equivalente àquela cometida ao Estado, a rigor, não ocupa cargo público algum.

\footnotetext{
705“O emprego da palavra cargo, cuja acepção técnica, no Direito Administrativo, é inconcussa, desautoriza sua extensão aos advogados indicados pela Ordem dos Advogados (art. $5^{\circ}, \S 2^{\circ}$ ), designados pelo órgão judiciário $\left(\operatorname{art.} 5^{\circ}, \S 3^{\circ}\right)$ ou aos que, indicados pelo beneficiário, aceitam o encargo $\left(\operatorname{art} .5^{\circ}, \S^{\circ}\right)$. Faltou à lei a audácia do passo adiante, generalizando o quantitativo ampliado" (Benefício da gratuidade, cit., p. 189).

${ }^{706}$ A título exemplificativo, cito os seguintes julgados: "Defensor dativo. Inaplicabilidade das prerrogativas processuais da Lei n. ${ }^{\circ} 1.060 / 50$, art. $5^{\circ}, \S 5^{\circ}$, com a redação que lhe deu a Lei n. ${ }^{\circ} 7.871 / 89$, c/c a Lei Complementar n. ${ }^{\circ}$ 80/94, art. 44, I; art. 89, I, e art. 128,I: intimação pessoal e prazo em dobro, que se estendem, apenas, aos Defensores Públicos e aos agentes estatais, que, no âmbito de uma estrutura de assistência judiciária organizada e mantida pelo Poder Público, desempenhem os encargos institucionais a que se refere o art. 134 da Constituição Federal" (STF, AI nº 153.928 AgR-ED-ED-EDv-AgR/RJ, Rel. Néri da Silveira, j. 22.11.01); "PROCESSUAL CIVIL. ADVOGADO DATIVO: PRAZO EM DOBRO: IMPOSSIBILIDADE. Lei 1.060/50, redação da Lei 7.871/89, art. $5^{\circ}$, § $5^{\circ}$. I. - Não se aplica ao advogado dativo a norma inscrita no art. $5^{\circ}, \S 5^{\circ}$, da Lei $1.060 / 50$, redação da Lei 7.871/89, dado que as prerrogativas processuais da intimação pessoal e do prazo em dobro somente concernem aos Defensores Públicos (LC 80/94, art. 44, I, art. 89, I e art. 128, I). II. - Precedentes do STF: Pet 932-SP, Min. Celso de Mello; Ag 166.716-RS, Min. Moreira Alves; Ag 166.754-RS, Min. Sepúlveda Pertence; Ag 167.023-RS, Min. Celso de Mello; Ag 167.086-RS, Min. Marco Aurélio. III. - Agravo não provido" (STF, CR no 7.870 AgRAgR/EU - Estados Unidos da América, Rel. Marco Aurélio, j. 07.03.01); "O prazo em dobro é concedido apenas ao Defensor Público da Assistência Judiciária, não se estendendo à parte, beneficiária da justiça gratuita, mas representada por advogado que não pertence aos quadro da Defensoria do Estado, sendo irrelevante a existência de convênio com a Ordem dos Advogados do Brasil" (STJ, AgRg no Ag n⿳亠丷厂 765.142/SP, Rel. Carlos Alberto Menezes Direito, j. 10.10.06); "I - O defensor dativo não exerce cargo equivalente ao de defensor público, mas sim de advogado nomeado para patrocinar uma determinada causa. II - A intimação pessoal do defensor dativo só passou a ser necessária após o advento da Lei no 9.271/1996, que deu a redação do $\S 4^{\circ}$ do art. 370, CPP. III - O $\S 5^{\circ}$ do art. $5^{\circ}$ da Lei $n^{\circ} 1.060 / 50$, por sua vez, teve sua redação determinada pela Lei $\mathrm{n}^{\circ} 7.871 / 89$, e refere-se especificamente ao Defensor Público ou a quem exerça cargo equivalente. IV - A norma de Direito Processual Penal, em princípio, tem aplicação imediata e não retroage. Princípio do tempus regit actum" (STJ, HC nº 32.874/SP, Rel. Felix Fischer, j. 17.08.04).
} 
Conquanto seja uma das formas de legítima hermenêutica de textos legais, sabe-se bem que a interpretação gramatical é, de todas as vias interpretativas possíveis, a mais pobre, pois que rente ao texto da lei, sujeita-se às imprecisões de palavras dúbias utilizadas sem sentido unívoco, às más colocações pronominais, má técnica de redação legislativa, etc., tudo em prol da insegurança jurídica. Por isto é que freqüentemente vê-se doutrina e jurisprudência batendo-se com afirmações do naipe "o legislador disse menos do que devia ter dito" ou "o legislador disse mais do que devia".

Recorrermos aos foros de teleologia da regra, à acomodação sistemática do sentido sugerido pela interpretação gramatical, e mesmo a resquícios históricos da formação de determinado regime jurídico, dá mais segurança.

Por isto força-se a busca pelos fins visados pelo legislador com a previsão de benefícios processuais à parte carente. Não falamos aqui do sentido imediato de atendimento da isonomia material, cuja obviedade dispensa maiores comentários e até já foi referida anteriormente. Mas sim de compreender qual seja o fator de discrímen a justificar o tratamento diferenciado.

Parece não restar dúvidas, então, de que o que moveu o legislador no caso foi o sobejamente maior volume de serviço ao qual submetidos os órgãos públicos prestadores de assistência jurídica, bem como a considerável diversidade das causas que lhes são apresentadas. Atender a esta monstruosa e extremamente variada demanda não é opção do Defensor Público (ou do Procurador do Estado que atue junto à Assistência Judiciária, no caso de São Paulo), mas sim seu dever funcional, isto é, é atribuição legal que integra o feixe de utilidades que lhe incumbe prestar aos destinatários do serviço.

É óbvio que constitui dever do advogado, igualmente previsto lei, prestar a assistência jurídica quando nomeado em virtude da impossibilidade da Defensoria Pública, constando do rol de infrações disciplinares a afronta a este comando (EOAB, art. 34, XII). Depreende-se igualmente este dever do art. 14 da Lei $\mathrm{n}^{\circ}$ 1.060/50.

Não há dúvidas também de que a atividade desempenhada pelo profissional advogado constitui munus público, e nem poderia ser diferente uma vez que a advocacia é considerada função essencial ao desempenho da atividade jurisdicional pelo Estado, e o advogado é tido como indispensável à administração da justiça (cf. art. 133 da Constituição da República; art. $2^{\circ}$, “caput” e $\S 2^{\circ}$, in fine, do EOAB). 
Por outro lado há de ter alguma relevância a afirmação legal de que, apesar de prestar serviço público e exercer função social, o advogado desempenha ministério privado (art. $2^{\circ}, \S 1^{\circ}$, do EOAB).

Quer isto dizer que por mais que a regulamentação legal da profissão seja no caso dos advogados marcante, predominando aquele caráter de munus, ainda resta um quê de iniciativa privada, uma margem de liberdade ao patrono para que administre e direcione sua banca. As restrições impostas pelo Estado não vão ao ponto de suprimir completamente aquilo que se convenciona chamar de iniciativa privada, que por resquício ainda vigora na advocacia.

Assim é que ao advogado ainda se permite gerenciar sua atividade, permitindo-selhe faculdades que aos Defensores Públicos (ou aos ocupantes de cargos públicos que prestem assistência) não se deferem. Certamente que pode o advogado, vendo-se diante de avalanche de serviço com a qual não possa lidar, afastar-se de causas, substabelecendo a colegas ou mesmo renunciando a mandatos (CPC, art. 45). Mesmo que eventual regime firmado com a Defensoria Pública impeça tal providência (o que não parece ocorrer), pode o advogado que se vê assoberbado cancelar temporariamente sua inscrição junto ao serviço de assistência judiciária, cuidando de administrar os casos que acompanha antes de assumir novas demandas, pondo assim ordem a seu ministério privado.

Mais que isto, é facultado também ao causídico prestar assistência em área de atuação de sua predileção, com as quais tenha maior afinidade e em relação às quais, naturalmente, tenha mais facilidade, tornando o trabalho muito mais fluído e menos penoso.

Com isto quer-se chamar a atenção para a idéia de que, mesmo que sujeito a diversos regramentos legais, o advogado ainda presta assistência judiciária sob o signo da voluntariedade. Note-se que voluntariedade não se confunde com gratuidade. Isto é: o advogado dativo será justamente remunerado pelo Estado por sua atividade, porém sua atuação a suprir as lacunas da Defensoria Pública ainda se faz nos termos de sua disposição para tanto, seja em quantidade (volume de serviço assumido) seja em qualidade (tipos de causas patrocinadas).

Ora, é justamente neste ponto que reside a justificativa para que o Defensor Público ou o advogado integrante de carreira pública seja tratado com mais condescendência pela lei processual, a impossibilidade de exercer sua atividade com as características deste 
ministério privado, não se lhe dando recusar causas para adequar o volume de serviço à sua própria capacidade de vazão, nem selecioná-las para adequar o serviço à sua predileção pessoal. Vale, para tais figuras, o conselho do sábio bíblico: “Tudo quanto te vier à mão para fazer, faze-o conforme as tuas forças" ${ }^{\text {,707. }}$.

E se esta característica não está presente na atividade do advogado dativo, muito embora sob regime de assistência jurídica, nada há que possa justificar a extensão das benesses legais.

A conclusão, pois, não poderia ser outra: a interpretação restritiva do $\S 5^{\circ}$ do art. $5^{\circ}$ da Lei $\mathrm{n}^{\mathrm{o}} 1.060 / 50$, sobre coadunar-se com o sentido gramatical do texto, alinha-se com os fins sociais visados pela lei.

Vale observar, contudo, que em sede processual penal impõe-se a intimação pessoal do defensor dativo, seja integrante de carreira pública, seja o próprio advogado nomeado para prestar assistência jurídica. Porém isto não decorre de alguma interpretação peculiar da regra do $\S 5^{\circ}$ do art. $5^{\circ}$ da Lei $n^{\circ} 1.060 / 50$, mas sim de específica disposição do Código de Processo Penal, a saber, o $\S 4^{\circ}$ do art. 370: "A intimação do Ministério Público e do defensor nomeado será pessoal" (grifamos).

Aliás, quisesse o legislador resolver de vez a pendenga, e bastaria tivesse destinado as benesses do dito $\S 5^{\circ}$ aos defensores dativos, expressão que abrange todos quantos litigam em favor dos economicamente desfavorecidos sob a indicação, seja do órgão público próprio, da Ordem dos Advogados do Brasil ou do próprio juiz, nos termos dos demais parágrafos do art. $5^{\circ}$, os quais já foram analisados, não estando tal expressão restrita, portanto, aos integrantes de carreiras públicas.

Duas outras regras benéficas merecem alusão. A primeira diz respeito à dispensa do advogado dativo do ônus da impugnação especificada, a teor do p.único do art. 302 do Código de Processo Civil ${ }^{708}$.

A segunda diz respeito à possibilidade de que ao advogado do assistido seja outorgado mandato em audiência, lançando-se por termo na ata desta a outorga. Outrossim, o mandato não será exigido quando a parte for representada em juízo por advogado

\footnotetext{
${ }^{707}$ Eclesiastes, capítulo 9, versículo 10, primeira parte.

708، Prestação de serviços - Telefone celular - Ação de cobrança - Procedência - Dívida não questionada Recurso interposto com objetivo de obter arbitramento dos honorários do advogado dativo nomeado nos termos do convênio entre a $\mathrm{OAB}$ e a Procuradoria Geral do Estado - Regra do ônus da impugnação especificada que não se aplica ao advogado dativo - Recurso provido" (TJSP, Ap. no 923.534-0/3, Rel. César Lacerda, j. 28.11.06).
} 
integrante de entidade de direito público incumbido na forma da lei, de prestação de assistência judiciária gratuita (art. 16, “caput” e p.único, da Lei n 1.060/50). Ressalva-se a exigência de mandato para a prática dos atos previstos no art. 38 do Código de Processo Civil, bem como para "requerimento de abertura de inquérito por crime de ação privada, a proposição de ação penal privada ou o oferecimento de representação por crime de ação pública condicionada".

Marcacini observa que a dispensa do mandato no caso de entidade de direito público prestadora do serviço decorre do fato de que em relação a ela há ato formal de posse, investindo o indivíduo no cargo correspondente, de modo que todo advogado legalmente investido em tal cargo estará habilitado a proceder à defesa ${ }^{709}$. A rigor, nestes casos a defesa do carente não é patrocinada por este ou aquele advogado, mas pelo cargo.

Há crítica à exigência do mandato, mesmo que outorgado em audiência, no caso de parte assistida por advogado indicado pelo serviço de assistência (não membro de entidade de direito público). Argumenta-se que mesmo nesta hipótese o advogado não é de escolha do necessitado, e que a outorga de mandato seria absolutamente inútil, sendo por isto de dispensá-la ${ }^{710}$.

Note-se ainda que o "caput" do art. 16 alude ao advogado do assistido, o que implicaria a conclusão de aplicabilidade unicamente aos casos em que a parte vem a juízo representada por advogado indicado pelo serviço de assistência. Entende-se, entretanto, pela incidência extensiva da referida regra, no sentido de aplicá-la também ao advogado escolhido pela parte, lembrando seu intento simplificador ${ }^{711}$.

Algumas observações adicionais são ainda pertinentes. Veja-se que a divergência retratada alhures acerca da extensão dos benefícios dos prazos em dobro e intimação pessoal, refere-se unicamente ao advogado dativo, que embora não integrante de carreiras públicas encarregadas da assistência, seja indicado para atender ao necessitado. Não cogita mesmo a doutrina extensiva de estender estes benefícios aos casos de simples gratuidade ${ }^{712}$.

\footnotetext{
${ }^{709}$ MARCACINI, Augusto Tavares Rosa. Assistência jurídica, assistência judiciária e justiça gratuita, cit., p. 80.

${ }^{710}$ VIDIGAL, Mauricio. Lei da Assistência Judiciária interpretada, cit., p. 86. O autor refere ainda corrente jurisprudencial segundo a qual considera-se haver mandato tácito quando o advogado comparece à audiência assistindo uma parte, mas não exibe o instrumento.

${ }^{711}$ VIDIGAL, Mauricio. Lei da Assistência Judiciária interpretada, cit., p. 87.

712“'A contagem, em dobro, dos prazos processuais é privilégio restrito do defensor público e do integrante do serviço estatal de assistência judiciária. Não cabe tal prerrogativa ao advogado particular de beneficiário da justiça gratuita. Embargos de declaração rejeitados" (STJ, EDcl no AgRg no Ag 694.590/SP, Rel. Nilson Naves, j. 28.03.06).
} 
De fato, já vimos que assistência judiciária não se confunde com gratuidade, e no caso desta o patrocínio da causa pode ser feito normalmente por advogado da confiança da parte, e por ela inclusive contratado. Por outras palavras, os benefícios não são atrelados, e as regras processuais mais benéficas, mesmo que adotada a corrente ampliativa, não se estendem aos beneficiários unicamente de gratuidade.

Não há necessidade de deferimento judicial a respeito da contagem do prazo em dobro. Basta que a parte compareça a juízo assistida por Defensor Público ou advogado integrante de carreira pública encarregada de assistência, e automaticamente os prazos estarão dobrados ${ }^{713}$.

Outrossim, defende Marcacini que as intimações destinadas à parte defendida por órgão prestador de assistência judiciária devem ser invariavelmente pessoais, "toda vez que o ato determinado envolva alguma atividade desta" ${ }^{, 714}$, sem que se possa praticar o ato de cientificação na pessoa do patrono.

O mesmo autor, ainda, defende a inaplicabilidade da regra do art. 316 do Código de Processo Civil à parte defendida por Defensor Público ou mesmo advogado indicado por serviço de assistência. O dispositivo em questão, sabe-se bem, faz bastar a procuração geral para o foro, de forma excepcional, para receber citação (na verdade a intimação acerca da reconvenção ofertada pelo adversário), o que normalmente exige poderes especiais.

Defende-se, então, que se cuida, na verdade, de ato citatório, e que a considerarmos que o Defensor ou advogado indicado sequer procuração ostenta, não se deveria admitir seja "intimado" (leia-se: citado) em nome da parte, impondo-se o respeito ao contraditório real e efetivo, bem como ao devido processo legal ${ }^{715}$.

Em anterior nota de rodapé deste texto referimos um certo entendimento jurisprudencial (na verdade apontados foram dois julgados, um antiqüíssimo, da década de cinqüenta do século anterior, e outra mais recente), segundo a qual o prazo para que o defensor dativo apresente defesa em nome do assistido iniciar-se-ia com sua intimação pessoal acerca da nomeação.

\footnotetext{
${ }^{713}$ MARCACINI, Augusto Tavares Rosa. Assistência jurídica, assistência judiciária e justiça gratuita, cit., p. 78. ${ }^{714}$ MARCACINI, Augusto Tavares Rosa. Assistência jurídica, assistência judiciária e justiça gratuita, cit., p. 80.

${ }^{715} \mathrm{Na}$ jurisprudência, em sentido contrário: “Cumprimento de sentença - Impugnação à reconvenção - Falta de intimação pessoal da reconvinda e da advogada dativa para manifestar-se quanto a reconvenção Intimação pela imprensa - Possibilidade - Agravo não provido" (TJSP, AI n 990.09.343739-2, Rel. Luiz Eurico, j. 03.05.10).
} 
Vale nesta oportunidade anotar um certo posicionamento de Defensorias Públicas, amparadas no art. 128, I, da Lei Complementar nº 80/94 (conforme redação dada pela Lei Complementar $\left.n^{\circ} 132 / 2009\right)$ segundo o qual o prazo de contestação para o assistido atendido pelo órgão iniciar-se-ia com a abertura de vista dos autos ao Defensor Público, desprezando-se a regra do art. 241 do Código de Processo Civil ${ }^{716}$.

A jurisprudência não tem sido complacente com tal idéia, prestigiando a regra do art. 241 do Código de Processo Civil, lembrando: i) que a regra do art. 128, I, da Lei Complementar $n^{\circ}$ 80/94 refere-se exclusivamente às intimações; ii) o ato citatório é personalíssimo, e o réu nunca é citado na pessoa de seu patrono, mesmo quando patrocinada a causa por advogado particular, contando-se o prazo na forma do art. 241 do Código de Processo Civil e iii) admitir a tese da Defensoria seria contemplar uma espécie de interrupção do prazo para contestação, que por completo carece de respaldo legal ${ }^{717}$.

\footnotetext{
${ }^{716}$ Estipula o art. 128, I, da Lei Complementar em questão, como prerrogativa das Defensorias Públicas dos Estados: "receber, inclusive quando necessário, mediante entrega dos autos com vista, intimação pessoal em qualquer processo e grau de jurisdição ou instância administrativa, contando-se-lhes em dobro todos os prazos".

${ }^{717}$ Estes foram os argumentos acolhidos pelo C.Superior Tribunal de Justiça e expressos no julgamento do REsp n ${ }^{\circ}$ 660.900/MS, Rel. Mauro Campbell Marques, j. 19.11.09.
} 


\section{CONDENAÇÃO DO BENEFICIÁRIO VENCIDO}

Impõe-se tratar-se nesta oportunidade de antiga divergência jurisprudencial e doutrinária, acerca do cabimento da condenação do beneficiário da gratuidade/assistência judiciária nas verbas sucumbenciais, à luz do que dispõe o art. 12 da Lei $\mathrm{n}^{\mathrm{o}}$ 1.060/50: “A parte beneficiada pela isenção do pagamento das custas ficará obrigada a pagá-las, desde que possa fazê-lo, sem prejuízo do sustento próprio ou da família, se dentro de cinco anos, a contar da sentença final, o assistido não puder satisfazer tal pagamento, a obrigação ficará prescrita".

A questão é saber se para efetivar-se o pagamento pelo ex-beneficiário (que perdeu a condição de pobreza) dos ônus sucumbenciais deverá ter havido a condenação, apenas que com a suspensão da exigibilidade da verba, sob a condição do desaparecimento das condições que motivaram a concessão do benefício.

Augusto Marcacini refere três correntes jurisprudenciais que se formaram acerca deste tema: uma isentando totalmente o beneficiário, sequer impondo-lhe condenação; outra entendendo que condenação deve haver, condicionada a cobrança à perda da condição de beneficiário; e por fim, a terceira, impondo a condenação sem qualquer restrição. $\mathrm{O}$ autor empreende uma avaliação analítica de todas as três correntes, concluindo pelo maior acerto da intermediária (condenação condicionada à perda da condição de

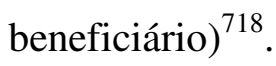

A primeira destas correntes argumentava com o texto da Constituição da República de 1988, o já citado art. 5 , LXXIV, que pura e simplesmente isenta a parte que comprove o estado de miserabilidade jurídica, não abrindo espaço a que se efetue qualquer cobrança em prazo algum, mesmo que perdida a condição de miserabilidade, e neste sentido, o citado art. 12 sequer teria sido recepcionado pela então novel ordem constitucional $^{719}$.

Não vemos, contudo, no texto do citado art. 12 qualquer menoscabo ao comando constitucional dito vilipendiado. A norma constitucional assegura a assistência jurídica

\footnotetext{
${ }^{718}$ MARCACINI, Augusto Tavares Rosa. Assistência jurídica, assistência judiciária e justiça gratuita, cit., p. 52 e ss. É esta também a posição de Araken de Assis (Benefício da gratuidade, cit., p. 193). Em sentido contrário posiciona-se José Roberto de Castro: "Para nós, desnecessária e imprópria a condenação nas custas, porquanto, de acordo com o art. 12 da Lei 1.060, já existe a obrigação de se pagar as custas, dispensando-se, assim, a condenação" (CASTRO, José Roberto de. Manual de assistência judiciária: teoria, prática e jurisprudência, cit., p. 134).

${ }^{719}$ VIDIGAL, Mauricio. Lei da Assistência Judiciária interpretada, cit., p. 74.
} 
integral e gratuita ao juridicamente pobre, e não é preciso grande esforço argumentativo para aferir que é esta condição mais delicada que enseja o tratamento mais benéfico. Ora, desaparecido o fator de discrímen, esvai-se também a justificativa para o tratamento díspare, que passa a constituir odioso privilégio. É também saudável estabelecer-se um prazo para que tal alteração possa ensejar a cobrança a ser encetada contra o outrora beneficiário, em prestígio à segurança jurídica. Não haveria motivos para tornar imprescritível a obrigação em questão ${ }^{720}$.

O Supremo Tribunal Federal reconheceu a compatibilidade do art. 12 da Lei $\mathrm{n}^{\circ}$ 1.060/50 com o texto do art. 5º, LXXIV, da Constituição da República, inclusive proclamando o cabimento da condenação do vencido, ainda que beneficiário da gratuidade $^{721}$.

Põe-se, assim, que a gratuidade (concedida em conjunto com a assistência judiciária ou isoladamente) constitui-se em paliativo dilatório, isto é, uma dilatação do momento de pagar com prazo limitado ${ }^{722}$, evitando-se que a parte deixe de demandar por, naquele momento específico em que possível o ajuizamento, achar-se financeiramente desfavorecida.

É bom observar que a menção do art. 12 exclusivamente às "custas" não significa dizer que com relação à verba honorária devida ao patrono do adversário (ou seja, sucumbencial) estará o beneficiário definitivamente isento.

Lembramos mais uma vez que a regra em comento foi cunhada sob um regime em que a condenação ao pagamento de honorários ao advogado do adversário era excepcional $^{723}$, ou seja, o beneficiário vencido normalmente apenas teria de arcar com as verbas inseridas no conceito de custas processuais (a condenação ao pagamento de honorários ocorria naquelas hipóteses já referidas, como por exemplo, a chamada “absolvição da instância”). Daí estar plenamente justificada a omissão legislativa.

\footnotetext{
${ }^{720}$ Há divergências sobre a caracterização do prazo qüinqüenal como prescricional, o que será abordado oportunamente. Vale também lembrar que sob a égide do CPC/1939 não havia prazo extintivo da possibilidade de cobrança do beneficiário que perde a condição de necessitado. Dizia o art. 78: “A parte isenta do pagamento das custas ficará obrigada a pagá-las, em qualquer tempo, desde que possa fazê-lo sem prejuízo do sustento próprio ou da família”.

${ }^{721}$ “O beneficiário da justiça gratuita, que sucumbe é condenado ao pagamento das custas, que, entretanto, só lhe serão exigidas, se até cinco anos contados da decisão final, puder satisfazê-las sem prejuízo do sustento próprio ou da família: incidência do art. 12 da L. 1.060/50, que não e incompatível com o art. 5, LXXIV, da Constituição" (STF, RE no 184.841/DF, Rel. Sepúlveda Pertence, j. 21.03.95).

${ }^{722}$ ZANON, Artêmio. Assistência Judiciária gratuita: comentários à Lei da Assistência Judiciária (Lei $\mathrm{n}^{\circ}$ 1.060, de 5-2-1950), cit., p. 99.

${ }^{723}$ MARCACINI, Augusto Tavares Rosa. Assistência jurídica, assistência judiciária e justiça gratuita, cit., p. 55.
} 
Tal omissão não impede a que recorramos à integração ao regime atual de sucumbência, numa interpretação legal que se afine com o princípio da isonomia, mesmo que para fazer acrescentar ao texto legal algo que ali não se contenha.

Presentemente o ônus sucumbencial compreende tanto as custas e despesas processuais, como os honorários do patrono adversário (CPC, art. 20, “caput”; o art. 22 da Lei $\mathrm{n}^{\circ}$ 8.906/94 alude aos honorários convencionados e aos de sucumbência de forma distinta. Alude-se também aos fixados por arbitramento judicial, que são os previstos para os casos em que não haja acordo ou estipulação entre cliente/patrono, conforme se vê do $\S$ $2^{\circ}$ do mesmo art. 22).

A tônica aqui é que a perda da condição de necessitado implique para o "exbeneficiário" a inserção no regime jurídico comum, isto é, previsto para qualquer litigante, pois que, como já mencionado, não há razão que justifique a manutenção de tratamento diverso. Parece evidente, portanto, que não haveria forma de isentar o beneficiário que adquire saudáveis condições financeiras do pagamento dos honorários de sucumbência, sem afrontar a idéia de isonomia, visto que qualquer outro litigante nestas mesmas condições (ou seja de "regularidade" econômica) seria chamado a tal encargo se derrotado saísse da liça.

Controverte-se acerca da natureza do prazo qüinqüenal previsto no citado art. 12 . O problema aqui é que as noções basilares que informam o instituto da prescrição não se acham presentes, o que causa uma falta de sintonia entre o texto legal, que fala em obrigação prescrita, e o que sedimentada doutrina reputa como tal.

Em geral, sabe-se bem que a prescrição extintiva pressupõe a possibilidade de exercício de uma pretensão (ou seja, uma pretensão exigível), e a inércia do titular pelo período de tempo previsto pela lei em caráter geral ou específico, contando com causas interruptivas, suspensivas ou impeditivas conforme previsões igualmente gerais ou específicas.

A perplexidade surge quando notamos que no caso das obrigações oriundas do ônus de sucumbência não estamos diante de pretensão exigível pelo credor (vencedor no processo em que litigou contra o beneficiário). Isto é, enquanto não verificada a alteração da condição financeira do beneficiário, o credor nada tem a fazer, pois que a obrigação remanesce com sua exigibilidade suspensa. Seria um disparate falar em inércia daquele que está legalmente manietado, impedido de agir na defesa de seu eventual direito. 
É por isto que a doutrina reluta em reconhecer o caráter prescricional do prazo em questão, havendo quem o afirme decadencial ${ }^{724}$. Esta posição, entretanto, não é menos problemática, pois que conforme tradicionalíssima doutrina, um dos pontos de contato entre a decadência e a prescrição é justamente o basearem-se, tanto uma como outra, na inércia do titular ${ }^{725}$.

Ora, repita-se o que já foi dito: não há a mínina congruência em se falar em inércia se o direito não é exigível. Por outras palavras: somente se pode acusar de inerte aquele que tenha a possibilidade jurídica de exercitar o direito que perece por esta via extintiva.

Por isto é que a posição intermediária sustentada por Marcacini é a única juridicamente adequada para a espécie:

"Ao que tudo indica, o prazo de cinco anos integra a condição. Em outras palavras, quis o legislador dizer que o beneficiário vencido ficará obrigado a pagar se perder a condição de beneficiário, e se a perder nos cinco anos seguintes ao trânsito em julgado da sentença. Assim como quem diz 'dou-lhe um automóvel se se casar neste ano', o prazo integra a condição. Não é prazo prescricional, nem decadencial",726.

Assim é que o prazo "não se suspende ou interrompe por ato do credor conservativo do direito: passados cinco anos do trânsito em julgado, a obrigação fica extinta sem jamais ter sido exigível"727.

Ficará a cargo dos credores verificar a ocorrência da condição referida pelo já citado art. 12 da Lei ${ }^{\circ}$ 1.060/50, incumbindo-lhes igualmente a prova de sua ocorrência, e da conseqüente erupção de exigibilidade da condenação sucumbencial. Não se deve esquecer que sendo o caso de sentença que decida relação jurídica sujeita a condição, o credor não poderá executar o tal título sem provar que se realizou a condição $(\mathrm{CPC}$, art. $572)^{728}$.

\footnotetext{
${ }^{724}$ DEMO, Roberto Luis Luchi. Assistência judiciária gratuita, cit., p. 330. Fala-se em direito potestativo do Estado em executar o beneficiário vencido. Araken de Assis, embora negando-lhe o caráter prescricional, define-o como um prazo de espera (Benefício da gratuidade, cit., p. 195), o que, na realidade, pouco esclarece. José Roberto de Castro não questiona o caráter prescricional do prazo (CASTRO, José Roberto de. Manual de assistência judiciária: teoria, prática e jurisprudência, cit., p. 133-134).

${ }^{725}$ CÂMARA LEAL, Antônio Luís. Da prescrição e da decadência. 2. ed. Rio de Janeiro: Forense, 1959. p. 393.

${ }^{726}$ MARCACINI, Augusto Tavares Rosa. Assistência jurídica, assistência judiciária e justiça gratuita, cit., p. 59.

${ }^{727}$ VIDIGAL, Mauricio. Lei da Assistência Judiciária interpretada, cit., p. 76.

${ }^{728 ، " E m ~ t e m a ~ d e ~ e x e c u c ̧ a ̃ o ~ d o s ~ o ̂ n u s ~ d a ~ s u c u m b e ̂ n c i a, ~ s e n d o ~ o ~ e x e c u t a d o ~ b e n e f i c i a ́ r i o ~ d a ~ j u s t i c ̧ a ~ g r a t u i t a, ~}$ incumbe ao exeqüente a demonstração de que aquele teria condições de suportar o pagamento, estando a viabilidade da execução condicionada a essa prova" (STJ, Emb. Dev. na AR nº 431/RS, Rel. Sálvio de Figueiredo Teixeira, j. 25.10.00).
} 
A prova da ocorrência da condição deverá instruir a inicial da execução, conforme a prescrição do art. 614, III, do Código de Processo Civil (que na verdade será requerimento de cumprimento de sentença, na forma dos arts. 475-J e ss.). Poderá ocorrer de tal prova ser pré-constituída, de modo que independa de qualquer procedimento prévio destinado à sua colheita (imagine-se o exemplo de que o credor tenha, em mãos, cópias de declarações de imposto de renda recentes do antigo beneficiário, e que indicam a elevação substancial de seus ganhos e incremento de patrimônio. O exemplo não é verossímil, mas pode ocorrer, basta lembrar que um dos credores será o Estado, e que se o beneficiário foi servidor deste, normalmente deve apresentar anualmente sua declaração de bens/rendimentos ao Poder Público "empregador”).

No mais das vezes, entretanto, o credor terá alguma desconfiança da mudança da condição financeira do devedor em razão de elementos indiciários (p.ex. vê-lo circulando em veículo regalado), e então necessitará de um procedimento judicial, ainda que sumário, mas que lhe possibilite a colheita de elementos a demonstrar se sua desconfiança era justificada ou não.

Há algumas propostas procedimentais para efetivar-se tal prova. Marcacini refere o procedimento comum, ordinário ou sumário ${ }^{729}$. Imagina-se que tal processo, de natureza cognitiva, teria por objeto declarar a exigibilidade do título judicial que condenou o beneficiário ao pagamento das custas e honorários.

O mesmo autor ainda cogita o procedimento de justificação, referido pelo art. 861 do Código de Processo Civil, porém com a ressalva de que no caso o tal procedimento limita-se à colheita da prova, sem que se formule juízo valorativo acerca de sua pertinência e suficiência para a prova do fato justificado ${ }^{730}$. Neste caso, discussões mais aprofundadas acerca da verificação da condição seriam relegadas para eventual impugnação ao cumprimento de sentença, que no caso seria fundada no inciso II do art. 475-L (inexigibilidade do título, ao menos no que concerne ao argumento que se refira à nãoocorrência de mudança da situação financeira).

Considerando as modificações introduzidas pela Lei $\mathrm{n}^{\circ} 11.232 / 05$, a prova assim obtida certamente instruiria o requerimento do credor a que alude o art. 475-J do Código de Processo Civil.

\footnotetext{
${ }^{729}$ MARCACINI, Augusto Tavares Rosa. Assistência jurídica, assistência judiciária e justiça gratuita, cit., p. 61. ${ }^{730}$ MARCACINI, Augusto Tavares Rosa. Assistência jurídica, assistência judiciária e justiça gratuita, cit., p. 61.
} 
Araken de Assis sugere a aplicação do incidente previsto pelo art. $7^{\circ}$, "caput", da própria Lei $\mathrm{n}^{\circ} 1.060 / 50$, cabendo neste caso ao credor pleitear a revogação do benefício outrora concedido, comprovando o desaparecimento das condições que ensejaram a concessão $^{731}$.

O procedimento em questão é singelo e rápido, contando com a manifestação do impugnado em cinco dias, produção da prova necessária, e decisão da qual caberia apelação (art. 17 da Lei $n^{\circ}$ 1.060/50). A competência seria do mesmo juízo que proferiu a condenação sucumbencial.

Esta solução não padece dos inconvenientes das outras duas referidas. Primeiro, o procedimento comum, sujeito a todos os incidentes e entraves que lhe são típicos, obrigando o credor a percorrer novamente toda a via crucis já antes palmilhada por ocasião do processo do qual adveio a condenação em sucumbência. O segundo (justificação), pela ausência de manifestação judicial de conteúdo valorativo acerca da prova produzida, isto é, sem o efetivo reconhecimento da ocorrência ou não da condição, o que é na realidade o essencial motivo que traz o credor novamente a juízo.

${ }^{731}$ ASSIS, Araken de. Benefício da gratuidade, cit., p. 194. 


\section{PROJETO DE CÓDIGO DE PROCESSO CIVIL}

De público conhecimento na comunidade jurídica o trâmite, já em vias de aprovação, de Projeto de Novo Código de Processo Civil, elaborado por qualificada comissão de juristas, composta especificamente para este tema. Já no corpo do texto algumas alusões foram feitas às novas disposições, porém decidiu-se por formar capítulo autônomo.

Pertinente trazer aqui breves notícias acerca das disposições concernentes à assistência jurídica contidas no projeto em questão. Deliberadamente optamos pelo viés crítico e sugestivo, à simples exposição do que contém o projeto, inclusive com algumas alusões a propostas de emendas formuladas, e às quais tivemos acesso.

Regulamentação propriamente dita houve apenas da gratuidade, com alusões pontuais à "assistência judiciária" e "assistência jurídica". Mesmo assim, o regime de isenção provisória foi tratado de forma comedida, unicamente pelo art. 99, composto pela cabeça e dois parágrafos.

Consta proposta de Emenda $n^{\circ} 11$, de autoria do Senador Romero Jucá, que sugere nova redação para o art. 85, desdobrando-o em dez parágrafos, com a disciplina detalhada da concessão de gratuidade de justiça. Afastar-se-ia, assim, a mera remissão do projeto à lei especial que deva tratar do assunto, além de propor a revogação da Lei $n^{\circ} 1.060$, de $5^{\circ}$ de fevereiro de 1950.

É óbvio que enquanto não houver aprovação de nova lei especial, as remissões do Código à lei especial que trate da gratuidade devem ser entendidas como referentes à Lei $\mathrm{n}^{\circ}$ 1.060/50. Aliás, é bom notar que aprovado como está o Projeto, remanesce em vigor a Lei $\mathrm{n}^{\mathrm{o}} 1.060 / 50$, porque o novel diploma não trata inteiramente das questões respeitantes à gratuidade.

O art. 99, "caput", já foi anteriormente transcrito, dispensando-se repetição ${ }^{732}$. As duas principais virtudes são logo perceptíveis pela primeira leitura do texto legal comparado ao art. $2^{\circ}$, "caput", da Lei n ${ }^{\circ}$ 1.060/50: i) expressa alusão às pessoas jurídicas e ii) ampliação do benefício com relação aos estrangeiros.

\footnotetext{
732،“A pessoa natural ou jurídica, brasileira ou estrangeira, com insuficiência de recursos para pagar as custas e as despesas processuais e os honorários de advogado gozará dos benefícios da gratuidade de justiça, na forma da lei".
} 
Quanto à primeira observação feita, é de ser elogiada a iniciativa, que, porém, não deixa de ser acanhada. Já foi referido no texto o entendimento predominante no sentido da extensão da gratuidade às pessoas jurídicas. Viu-se bem que as principais celeumas causadoras de insegurança jurídica na atualidade não versam propriamente este ponto, mas sim nos pressupostos que podem (ou devem) ser exigidos para que os entes morais sejam albergados pelo benefício.

Perdeu-se, então, a oportunidade de esclarecer-se se as pessoas jurídicas são sujeitas ao mesmo regime comprobatório da miserabilidade que as pessoas naturais, ou se haverá alguma distinção, principalmente à vista da natureza e finalidade de tais entes.

Conforme dito, a segunda novidade foi a previsão da extensão da gratuidade a estrangeiros independentemente de manterem, no país, sua residência, circunstância exigida pela antiga Lei $\mathrm{n}^{\circ}$ 1.060/50. A rigor houve mera adequação ao regime constitucional da assistência jurídica, já prevista como direito fundamental e, portanto, extensível aos estrangeiros ainda que simplesmente em trânsito, conforme opinião anteriormente manifestada.

Outrossim, o $\S 1^{\circ}$ do referido art. 99 veio plasmar em direito positivo o que já era de doutrina e jurisprudência sólidos: "O juiz poderá determinar de ofício a comprovação da insuficiência de que trata o caput, se houver nos autos elementos que evidenciem a falta dos requisitos legais da gratuidade de justiça”.

Por fim, o $\S 2^{\circ}$ do dito art. 99 resolveu a antiga celeuma relativa ao recurso cabível das decisões acerca da gratuidade, assunto já abordado à saciedade anteriormente. Previuse, então, o cabimento do agravo de instrumento, salvo quando a decisão acerca da questão se der na sentença (cf. também art. 969, V).

Perdeu sentido a discussão acerca do cabimento do agravo retido, recurso extinto pelo sistema projetado.

Curiosa a proposta de emenda ao projeto apresentada pelo Senador Adelmir Santana, versando o acréscimo de parágrafo ao art. 85, vedando o benefício da gratuidade da justiça nas ações cujo objeto contrarie jurisprudência dominante do respectivo tribunal estadual, do Superior Tribunal de Justiça ou do Supremo Tribunal Federal. O objetivo, segundo se diz, é vedar abusos por parte de quem pleiteia o benefício.

A proposta é de constitucionalidade bastante duvidosa. Estabelece-se um discrímen fundado unicamente na capacidade econômica da parte, simplificando: aquele que tenha 
condições de custear o litígio, adquire também o direito de ver sua tese jurídica, mesmo que minoritária, apreciada pelo Estado-juiz; aquele que não ostenta a mesma saúde financeira, é obrigado a conformar-se.

Uma coisa é submeter pretensões em desacordo com jurisprudência dominante a um julgamento mais célere e simplificado, como hoje se prevê, por exemplo, no art. 557 do Código de Processo Civil, no que não vai mal algum, até porque tal previsão aplica-se seja para negar seguimento, seja para dar provimento ao recurso (este último caso quando a decisão impugnada estiver em confronto com jurisprudência dominante de Tribunal Superior).

Outra bem distinta é impedir que tal pretensão chegue a ser apreciada erigindo o fator econômico como barreira.

Isto não vai em confronto com o que foi defendido alhures, no sentido de que deve haver uma análise da plausibilidade jurídica da pretensão trazida pelo assistido, análise esta a ser feita pelo defensor indicado.

Não se pode dizer que toda pretensão que contrarie jurisprudência dominante seja destituída de fundamento jurídico razoável pelo só fato de contrariar aquele entendimento solidificado. Haverá casos em que a pretensão será juridicamente disparatada, e além disto, contrariará jurisprudência dominante. Nestes casos incumbirá ao defensor, dando as razões ao assistido, evitar o ajuizamento da ação. Não porque seja contrária à jurisprudência dominante, mas por carecer de amparo jurídico. Em outras hipóteses, a tese, embora minoritária, será dotada de fundamento jurídico não desprezível. Nestes casos deve-se assegurar ao interessado o direito de levar sua pretensão à apreciação do Estado-juiz independentemente de sua condição econômica.

Não se pode levar o mito da "jurisprudência dominante" a extremos tão radicais, a ponto de dificultar o próprio acesso à justiça. Os que militam no foro já por algum tempo tiveram a oportunidade de assistir aos altos e baixos dos entendimentos jurisprudenciais, $\mathrm{o}$ suceder e retroceder de teses antagônicas como majoritárias ou minoritárias. A própria evolução do corpo social leva a isto, que é absolutamente saudável.

Outro ponto que merece ser lembrado diz respeito à tão debatida prova pericial no caso da parte requerente, a quem caberia arcar com o custo, ser beneficiária da gratuidade. O projeto adota solução que parece adequada no que concerne ao momento de reembolso do perito. 
Há na doutrina vozes que indicam a necessidade de que o perito aguarde o fim do processo, para ver-se remunerado pelo vencido, ou pelo Estado se o vencido for o beneficiário da gratuidade (cf. a respeito o item 23), o que sempre nos pareceu problemático em extremo. O projeto, pois, previu no $\S 5^{\circ}$ do art. 97 a seguinte disposição: "Se, ao final, o beneficiário da gratuidade de justiça for vencedor, o Poder Público promoverá a execução para reaver do vencido os valores adiantados para pagamento da perícia”.

Daí depreende-se facilmente que sendo o custo financeiro da prova pericial ônus do beneficiário, caberá ao Estado remunerar imediatamente o perito judicial, sub-rogando-se na posição do beneficiário (credor do reembolso em caso de vitória). A solução é extremamente saudável porque deixa de transferir ao perito o ônus do tempo de tramitação do processo, período pelo qual, se adotado aquele entendimento retro citado, aguardaria para ver-se remunerado.

Importante ainda ressaltar a previsão, como preliminar de contestação, da "indevida concessão do benefício da gratuidade de justiça” (art. 327, XIII). Certamente discutir-se-á a revogação do incidente de impugnação à gratuidade, previsto pelo art. $7^{\circ}$ da Lei $n^{\circ} 1.060 / 50$.

O art. 921, § $1^{\circ}$, expressamente isentou da caução para propositura de ação rescisória os beneficiários da gratuidade.

Outro ponto que merece referência foi o tratamento dado à questão da extensão de benefícios como o prazo dobrado e a intimação pessoal, a advogados que atuem na assistência, porém em regime privado, isto é, não integrantes de carreiras públicas. A este propósito, estipulou o $\S 4^{\circ}$ do art. 161 que tais benefícios se estendem "aos escritórios de prática jurídica das faculdades de direito reconhecidas na forma da lei e às entidades que prestam assistência jurídica gratuita em razão de convênios firmados com a Ordem dos Advogados do Brasil”.

Embora em anterior item ( $\mathrm{n}^{\circ}$ 36) tenhamos acompanhado a jurisprudência majoritária em arrostar tais benesses do advogado dativo, parece difícil a manutenção de tal posição em face da estipulação vertida no projeto, acaso aprovada. É que ao contrário do $\S 5^{\circ}$ do art. $5^{\circ}$ da Lei $n^{\circ} 1.060 / 50$, que alude expressamente a quem exerça "cargo" equivalente (o que nem foi invocado por nós como fundamento para a posição defendida), a regra projetada de forma expressa estende os benefícios a profissionais que 
desempenham o serviço de assistência porém em regime privado, como é o caso dos escritórios vinculados a Faculdades de Direito, e entidades conveniadas à Ordem dos Advogados do Brasil.

Não parece haver muito sentido em permitir-se que profissionais vinculados a determinada entidade filantrópica conveniada à Ordem dos Advogados do Brasil, gozem o benefício, e os profissionais indicados pela própria Ordem dos Advogados em razão de convênio com a Defensoria Pública, sejam alijados. Aí o maltrato à isonomia seria inevitável. 
TERCEIRA PARTE CONCLUSÃO 


\section{CONCLUSÕES}

Com as considerações que trouxemos buscamos realizar um apanhado geral da doutrina e jurisprudência acerca dos limites objetivos e subjetivos da gratuidade, bem como aspectos procedimentais acerca do instituto, tema central do processo civil contemporâneo. Ainda procuramos contribuir com humildes anotações críticas, ou mesmo dúvidas que surgiram no curso da elaboração do trabalho, e que certamente comportarão até melhor desenvolvimento por estudiosos mais gabaritados.

O norte foi sempre aquele anunciado ao início do trabalho: lembrar da imperiosa necessidade de que também para o necessitado exista o processo justo constitucional. E atender esta necessidade incumbe aos juristas, que devem criativamente imaginar as alternativas processuais que atendam a seu reclamo, trazendo respostas ${ }^{733}$.

Sem o cuidado necessário na abordagem do tema, aquele modelo de acesso à Justiça facilmente se esvai, e para citar ainda Morello, cuja obra nesta particular assunto é fecunda, "pues ella (la Justicia) se ofrece como las puertas abiertas del Hotel Ritz, que únicaamente pueden trasponer los afortunados en condiciones de pagar su elevadísimo costo" ${ }^{, 734}$.

\footnotetext{
${ }^{733}$ MORELLO, Augusto Mario. La justicia, de frente a la realidad, cit., p. 30-31.

${ }^{734}$ MORELLO, Augusto Mario. La justicia, de frente a la realidad, cit., p. 30. Algumas páginas adiante, o autor traz magnífica sintetização da idéia de processo justo: "Concentración, inmediación, flexibilización de los princípios, colaboración y transparência en los sujetos bajo la orientación firme o inteligente de un juez dotado de deberes de ejercicio activo, y registración suficiente, seguro en la aplicación de las reglas de la sana crítica y en la motivación de los actos sentenciales, han de sobrevenir, si se arropan en una mentalidad distinta bajo el idôneo control de los abogados de parte y un contradictorio limpio y cabal. Que atienda a los resultados valiosos de lo hecho en y durante la sustanciación del litígio. Con ello el proceso constitucional justo en el ámbito civil se aproximará (en esta fase histórica) a la pauta guía preambular de afianzar la justicia" (cit., p. 39, destaques originais). Demanda-se, segundo segue seu escólio, um retorno à personalização do processo, isto é, à consideração central da pessoa como sujeito do processo, preferindose sempre que possível a atenção ao homem que está envolvido no conflito, os problemas em que se vê absorto, transitando do formalismo estéril à garantia de efetividade da defesa. Humanizar o processo é personalizá-lo, conseqüência na verdade do reconhecimento de que um direito autenticamente instrumental deve estar em permanente adaptação. Ainda para um estudo amplo do art. 111 da Constituição Italiana, que veicula a garantia do giusto processo, à luz do art. $6^{\circ}$ da Convenção Européia dos Direitos do Homem e da jurisprudência da Corte de Estrasburgo, com elementos também de Direito Comparado: TARZIA, Giuseppe, L'art. 111 Cost. e le garanzie europee del processo civile. Revista de Processo, São Paulo, v. 26, n. 103, p. 156, jul./set. 2001.
} 


\section{Conclusões gerais}

Arrolamos a seguir o que pensamos ser os principais pontos defendidos nos restritos limites do trabalho proposto.

1. A fase instrumentalista, embora tendo fundamental papel da correção dos excessos do autonomismo, vai dando sinais de exaustão, reclamando uma nova consciência, que é justamente arraigada na idéia da efetividade processual.

2. Cerne da efetividade é o reconhecimento do direito fundamental à tutela jurisdicional efetiva.

3. A democracia liberal emerge das expectativas econômicas e políticas postas pela burguesia, sob uma tríade de valores: igualdade fundamental de todos os homens; visão antropocêntrica do universo e dessacralização do poder. Desvincula-se o econômico do político.

3.1 São emblemas de um processo de feições liberais: princípio da inércia jurisdicional; princípio da congruência ou correlação; princípio dispositivo e legitimação ordinária.

4. A democracia liberal conduz ao surgimento da questão econômica, eis que as forças do mercado não operaram corretivamente como se esperava, ensejando o intervencionismo estatal. Estas as bases da democracia social. Mesmo o modelo de Welfare State malogrou, levando à formação de uma intocável casta de burocratas e de um Estado que oprime.

5. À superação do modelo de Estado liberal não correspondeu a superação do desenho de processo liberal. A consequiência é o descompasso entre as expectativas e necessidade sociais e o instrumento estatal posto à disposição.

6. Marchamos hoje para um terceiro tempo: a democracia representativa, que tem como características a participação nas decisões; o controle da execução em todas as circunstâncias e acesso às informações. Ultrapassa-se o sistema representativo parlamentar: A pergunta da ciência processual do nosso tempo é de se saber qual o modelo processual que se coaduna com este contexto.

6.1 Pensa-se em processo como instrumento de participação política do cidadão; controle dos poderes político e econômico, além de instrumento de criação e aplicação do Direito. 
6.2 O Estado pós-social preconiza o Judiciário como órgão da sociedade civil que, a par da garantia dos direitos fundamentais, é veículo de crítica popular às disposições ilegítimas: é um contra-poder da própria sociedade.

6.3 Aplicar o Direito tende a configurar-se como resíduo da atividade judiciária, agora também combinada com a escolha de valores e a aplicação de modelos de justiça, no enfrentamento de conflitos multipolares, tendo à mão um arcabouço de normas organizadas em rede, oriundas também de centros periféricos de emanação jurígena.

7. Dois são os temas fundamentais da ciência processual na sociedade contemporânea: acesso à justiça e efetividade processual.

7.1 O movimento de acesso à justiça constitui solução de compromisso, revolução cultural, isto é, do pensamento jurídico, representando uma reação contra o dogmatismo puro, e mudança de perspectiva na análise do Direito, que passa a ser visto sob a ótica de seu consumidor.

7.2 Fatores endógenos e exógenos obstaculizam o acesso à ordem jurídica justa.

7.3 Acesso à ordem jurídica justa pressupõe técnica processual minimamente apta a satisfazer os escopos aos quais se propõe. Daí o liame entre acesso à justiça e efetividade processual.

$7.4 \mathrm{O}$ direito fundamental de acesso à ordem jurídica justa compreende como uma de suas emanações o direito a um processo efetivo.

8. O acesso formal à justiça, consentâneo com o ideário liberal clássico, não atende aos reclamos de efetivação de direitos substantivos a uma atuação estatal positiva, típicos ao Welfare State.

9. A idéia de acesso à justiça constitui ponto central na moderna processualística.

10. A questão econômica erige-se como importante elemento estratificador do acesso à justiça.

11. Assomam em importância na análise da questão econômica e seus efeitos na busca pela tutela processual, analisar o impacto das custas judiciais e honorários de advogado. 
12. Entre os sistemas americano (que não impõe ao vencido ressarcir ao vencedor os honorários despendidos) e o sucumbencial (que o impõe), o brasileiro está a meio termo, podendo se dizer híbrido.

13. Muitas vezes, a perspectiva de que o custo do processo seja superior ao montante da controvérsia, ou mesmo que tal custo consuma todo o conteúdo do pedido, torna a demanda uma futilidade.

14. Outra coisa é saber por quanto tempo logrará a parte permanecer sem a disponibilidade do recurso econômico investido para ingresso em juízo, e aqui a correlação é precisamente entre a duração razoável do processo e a questão econômica.

15. Também interligada à questão econômica, está o problema da falta de aptidão para o reconhecimento de um direito. Aliás, a incerteza quanto aos direitos é não apenas elemento alijador de acesso à justiça, como ensejador de um acesso despropositado.

16. No Brasil os direitos individuais e especialmente o direito de acesso à justiça não foram incorporados na consciência do cidadão.

17. Ao cidadão reconhece-se o direito à informação, como acesso geral ao conhecimento que lhe permita situar-se a respeito de seus direitos e obrigações. De outro lado este direito implica o dever de informação cometido ao Estado. Reconhece-se este acesso como um prius sem o qual todos os demais direitos têm sua satisfação comprometida.

18. Proposta corrente, a eliminação geral das custas constitui ponto de divergência. De um lado afirma-se o estímulo ao demandismo. Além de não haver dados empíricos que comprovem essa afirmação, parte ela da idéia de que o aumento do número de demandas é resultado indesejável, o que não é necessariamente correto.

19. O princípio da igualdade, partindo do pressuposto de uma possível hierarquização substancial de princípios constitucionais, assume posição de proeminência. É simultaneamente uma norma definidora de um direito, um princípio e uma garantia.

20. A insuficiência da concepção formal de igualdade e a necessidade de recurso ao seu aspecto material representam o reconhecimento de que a lei é uma abstração, ao passo que as relações sociais são reais. Daí a possibilidade de surgimento (que freqüentemente ocorre) de descompasso na aplicação da regra em cotejo com a idéia de igualdade. 
21. Considerando que tanto a igualdade material como o acesso à justiça, entendido este em sentido substancial como acesso à ordem jurídica justa, a um processo justo e équo, são valores constitucionalmente exaltados, legitimam-se políticas públicas e posturas judiciais que, desigualando, igualem.

22. O princípio da igualdade processual é derivação da matriz constitucional, aplicando-se-lhe todas as idéias já lançadas à guisa daquele, especialmente a contraposição entre os sentidos material e formal.

23. Tratamento igualitário em sentido substancial é noção nuclear ao conceito de devido processo legal e reflexo da imparcialidade do juiz, nele deita raízes também o contraditório.

24. É fora de dúvida que o fator econômico reflete sobre a relação jurídica processual como elemento de desestabilização das partes, tanto no que concerne ao ingresso em juízo, como no que respeita ao desempenho dos ônus processuais necessários para levar a uma perspectiva de vitória.

25. Apontam-se como elementos causadores da defasagem dos pobres e incultos na perseguição de seus direitos, a parcialidade dos próprios juristas e o inchaço no aparato judiciário. Ademais, numa sociedade marcada pela perseguição implacável do lucro, a prestação de serviço gratuita normalmente é fator de aprofundamento do desequilíbrio, eis que feito de forma vagarosa e qualitativamente inferior.

26. Incumbe ao juiz, na direção do processo, conferir às partes tratamento substancialmente igualitário. Cuida-se de poder-dever. Há de ser superado o velho mito consistente na má interpretação do princípio da imparcialidade, identificando-o com passividade judicial e indiferença com o resultado do processo.

27. Subjaz em todo processo judicial o interesse público e indisponível pela correção no exercício da jurisdição, que é distinto do interesse material debatido no processo que pode, este sim, observar regime de disponibilidade.

28. Valer-se da iniciativa probatória é uma das mais fecundas formas de contribuir o juiz para a real equalização das partes no processo, notadamente sob o prisma econômico.

29. Indisponível ou não o direito deve o juiz participar ativamente da instrução, pois somente assim garantirá um contraditório equilibrado. Deste modo a postura ativa do 
magistrado não é de ficar restrita apenas às demandas que versem relação de consumo (em relação às quais há expressa permissão legal para inversão do onus probandi).

30. O lema do processo civil moderno em matéria de iniciativa probatória não é o da contraposição entre o juiz e as partes, e muito menos de opressão destas por aquele, mas sim o da colaboração entre um e outras.

31. Necessária a redefinição do papel do juiz no processo contemporâneo. Parcialidade positiva é uma das palavras de ordem no contexto de ensejar o adequado balanceamento na atividade das partes.

32. Importa saber acerca da possibilidade de proceder o magistrado à inversão do ônus, inclusive financeiro, da prova, constatando uma realidade de patente desequilíbrio econômico da parte.

32.1 Nota-se certa resistência da jurisprudência em admitir procedimento deste jaez, mesmo nas hipóteses de relação de consumo, onde há expressa permissão legal, o que é altamente incoerente.

32.2 Nossa indagação é mais ousada. Volta-se a perquirir as situações excluídas do regime da Lei $\mathrm{n}^{\circ}$ 8.078/90: seria nestes casos legítimo proceder-se à inversão do ônus financeiro constatadas as circunstâncias referidas no item 23 ?

33. Uma regra matriz acerca da distribuição do ônus da prova se apresenta como um mal necessário, porque permite que o juiz se pronuncie sobre o mérito da causa em qualquer conjuntura. Por isto, as regra de distribuição são ditas como normas mais de decisão que de direito probatório propriamente dito.

34. A distribuição como estatuída pelo art. 333 do Código de Processo Civil é prévia, abstrata e estática, sem atenção às peculiaridades do caso concreto.

34.1 Esta forma de distribuição pode acarretar iniqüidade à luz das peculiaridades da situação concreta, representando neste caso violação oculta à garantia de acesso útil à justiça.

35. A doutrina reconhece no $\mathrm{CDC}$, art. $6^{\circ}$, VIII, uma concessão expressa e positivada no direito brasileiro a uma forma de dinamização do ônus probatório.

36. Do p.único, II, do art. 333, do Código de Processo Civil se depreende um postulado geral de que a repartição do ônus probatório nunca deve tornar impossível ou excessivamente difícil a uma parte o exercício do direito. 
37. Em resumo a distribuição dinâmica do ônus da prova compreende incumbir o encargo probatório a quem, pelas circunstâncias particulares do caso concreto, e sem que interesse se desempenha o papel processual de autor ou réu, se encontre em melhores condições de produzir a prova respectiva.

37.1 A doutrina em questão comporta aplicação excepcional e subsidiária.

37.2 A doutrina em questão representa a flexibilização da teoria tradicional em homenagem ao princípio da efetividade da tutela jurisdicional.

38. A doutrina das cargas dinâmicas tem pelo menos quatro ordens de fundamentação: i) princípio da igualdade; ii) respeito aos deveres de lealdade e colaboração das partes; iii) princípio do acesso à justiça; iv) processo concebido como instrumento ético destinado à concretização de valores que a sociedade, ao constitucionalizá-los, firma ter na mais alta conta.

39. A teoria da dinamização do ônus da prova deve ser aplicada em conexão com as garantias constitucionais do processo, das quais, inclusive, ela é expressão. Por isto, o contraditório e a ampla defesa, por exemplo, hão de ser sempre preservados, de modo que, ao aplicar tais idéias, o juiz deve, além de fundamentar sua decisão, garantir às partes a produção de provas que, em razão da dinamização, passaram a ser de seu encargo. A dinamização não pode causar surpresa.

40. A distribuição dinâmica do ônus da prova é compatível com o sistema brasileiro, e inclusive já tem sido prestigiada em jurisprudência de peso. O processo civil brasileiro está impregnado de princípios que se ajustam perfeitamente à doutrina em questão.

41. A aplicação da dinamização viria também a calhar no caso de inviabilização da prova por ato culposo do adverso processual, em afronta ao dever de cooperação.

42. Com a doutrina da distribuição dinâmica não se confunde a do senso comum. Segundo esta a existência de determinadas circunstâncias provadas nos autos autorizariam o julgador a, conforme as máximas da experiência, considerar demonstrada outra, sem a necessidade de realizar perícia, e a despeito da natureza técnica da matéria.

42.1 A teoria remete ao campo da valoração probatória, e não implica inversão ou nova atribuição do ônus probatório. 
43. A doutrina da carga dinâmica é expressamente acolhida no Anteprojeto de Código de Processo Coletivo brasileiro, e no projeto de Código de Processo Civil em trâmite no Congresso Nacional.

44. O conceito já vergastado de devido processo legal tem experimentado uma evolução especialmente na última década, rumo a um moderno garantismo que induz novas exigências. Tais exigências são sintetizadas na idéia de processo justo e équo.

44.1 A idéia de acesso à justiça em sentido substancial constitui o núcleo do conceito de processo justo e équo.

44.2 O modelo de devido processo legal desenhado na Constituição brasileira é considerado na vanguarda da idéia de processo justo e équo. Os reflexos deste novo modelo constitucional surgem mais tanto maior seja a abertura da ciência processual a um objetivo comum de política judiciária, a saber, o contínuo melhoramento da efetividade processual, emergindo como instrumento de progresso evolutivo do ordenamento jurídico.

44.3 Fala-se então de um novo e moderno jusnaturalismo processual.

44.4 Esta evolução de que temos tratado corresponde à superação da noção de procedural due process of law, rumo ao devido processo legal substancial.

45. Um sistema de assistência jurídica ao menos favorecido eficaz e adequado à realidade constitui viga mestra, alicerce, de qualquer modelo que se pretenda alinhado com um desenho de processo justo e équo.

46. É obrigação do Estado não apenas propiciar o acesso à Justiça, mas também meios para que, dentro do processo, sejam superadas as desigualdades de fato.

47. Embora seja este o campo mais fecundo da sua atuação, não há necessária correlação entre carência econômica e assistência judiciária.

48. Assistência judiciária designa a prestação de serviço restrita ao processo judicial, desde o ingresso em juízo e durante seu desenrolar. Assistência jurídica contém conceito mais largo, abrangendo atividades extra e pré-processuais.

49. Pende no ordenamento pátrio lacuna quanto aos serviços de assistência préprocessual e extra-processual, visto que a Lei $\mathrm{n}^{\circ} 1.060 / 50$ refere-se apenas aos atos do processo. No Estado de São Paulo o convênio firmado entre Defensoria Pública e Ordem dos Advogados do Brasil também é omisso a respeito. 
50. Há também omissão na tabela que prevê os honorários pagos pelo Estado aos advogados que atuem junto à assistência quanto à remuneração para o caso de atuação préprocessual. O suprimento desta omissão seria importante estímulo para a instalação de setores de conciliação pré-processuais.

51. A Constituição prevê a assistência jurídica, o que denota a extensão da garantia a todos os recônditos da vida do cidadão onde problemas jurídicos possam surgir, e sabe-se bem que questões desta natureza não exsurgem apenas nos processo judiciais, porém notadamente também na necessidade de assessoria para a prática de atos jurídicos, bem como a assistência voltada a processos administrativos.

52. Mesmo com todos os esforços de advogados e defensores o serviço prestado está bem aquém da demanda.

53. Em sede constitucional a assistência jurídica é prevista pelo inciso LXXIV do art. $5^{\circ}$, entre os direitos e garantias fundamentais. Conseqüência disto é sua inclusão entre as cláusulas pétreas.

53.1 A norma que prevê a assistência jurídica integral e gratuidade é dotada de eficácia plena. Atividade legislativa ordinária nesta sede seria admissível, porém não indispensável para a plena operatividade do comando constitucional.

53.2 A Lei $\mathrm{n}^{\circ} 1.060 / 50$, sendo anterior ao texto constitucional, abrange apenas parte da noção de assistência jurídica integral e gratuita.

53.3 A assistência jurídica integral e gratuita é prestação positiva a cargo do Poder Público que se insere no contexto do Estado Social de Direito, em que a preocupação é proporcionar melhorias substanciais à sociedade civil.

53.4 É possível a utilização de instrumentos judiciais para a efetivação da garantia de acesso à justiça, contudo é impossível escapar à tautologia: para garantia do acesso à justiça por vias judiciais, é preciso que haja acesso à justiça.

54. A Constituição brasileira reflete a fase madura da constitucionalização das garantias fundamentais do processo.

54.1 Uma das maiores dificuldades que se tem verificado ao redor do mundo é justamente a adaptação das previsões normativas infraconstitucionais e da praxe quotidiana ao modelo constitucional do processo civil. 
54.2 Incumbe ao juiz dispor-se a, em cada processo que individualmente transita por suas mãos, reproduzir em nível microscópico a realidade macroscopicamente prevista nas normas superiores de regência do Estado.

55. O modelo de assistência jurídica instituído no Reino Unido a partir de 1949 (Legal Aid and Advice Act) é um dos expoentes da ideologia do Welfare State.

55.1 Atualmente, e sob a égide do Access to Justice Act de 1999, a assistência está a cargo da Legal Service Commission, vinculada ao Lord Chancellor.

55.2 São duas as grandes vertentes de atuação da LSC: Community Legal Service (CLS) e Criminal Defence Service (CDS).

55.3 A qualificação de um requerente como apto a obter o benefício depende do Funding Code, conjunto de regras que norteia a concessão da assistência em termos de condições subjetivas do pretendente.

56. A partir da segunda metade do século passsado instituiu-se nos Estados Unidos da América o Legal Service Program, vinculado ao Office of Economic Opportunity, no contexto de uma política geral de combate à pobreza.

56.1 Em 1974 houve a criação da Legal Service Corporation (LSC), despolitizando a assistência, com atividade limitada à esfera civil.

56.2 Há uma preocupação em impedir que a assistência legal se imiscua na seara da atividade política (militância partidária ou adoção de ideologias vinculadas a correntes políticas), já em razão dos traumas sucedidos ao anterior Legal Service Program.

57. Os modelos instituídos no Reino Unido e nos Estados Unidos da América representam o sinal da evolução da assistência, passando do munus honorífico de caráter caritativo à atividade custeada pelo Estado. Estes dois modelos são os dois grandes pólos em termos de mio de organização de assistência: advocacia convencionada (judicare system, modelo adotado no Reino Unido) e advocacia pública (salaried staff attorney, modelo adotado nos Estados Unidos). A tendência, contudo, é a hibridização dos sistemas, adotando-se regimes mistos.

58. No regime vigente na Alemanha são basicamente dois os requisitos para o gozo da benesse legal de apoio judiciário: perspectiva de êxito da causa e carência econômica, o primeiro chamado pressuposto intrínseco, o segundo, extrínseco.

59. Na Itália também a probabilidade de êxito da demanda é elemento considerado. 
60. Em ambos os países (Alemanha e Itália) prevê-se um procedimento preliminar em que a causa já é debatida, porque intervém também o adverso, porém o objeto a ser decidido restringe-se à assistência legal.

61. Na Alemanha prevê-se, além da contribuição parcial do beneficiário em situação intermédia, o parcelamento das despesas processuais.

61.1 Tendência que merece destaque no cenário tedesco é ainda a crescente cobertura por seguros privados dos riscos patrimoniais de processos judiciais.

62. A Itália mantém, para perplexidade de muitos, o vetusto e ineficaz sistema de dever honorífico seja para advogados que atuem na defesa dos carentes, seja para os demais figurantes no processo, como peritos judiciais.

62.1 Em Itália o pedido é apresentado a uma Comissão, e também conta com a manifestação do adversário num contraditório preliminar. O pedido inicial é marcadamente formal.

62.2 Aponta-se que o necessitado acaba sofrendo com um inferior nível qualitativo dos serviços que lhe são prestados, já que apenas advogados jovens e inexperientes, ou mesmo fracassados, atendem a este dever honorífico.

62.3 Não se prevê na Itália consulta extrajudicial ou admissão parcial à assistência.

63. A França foi o primeiro país a organizar em legislação um sistema de apoio judiciário, com o Code de l'Assistance Judiciaire de 1851. Após 1851 foram três as principais reformas procedidas, em 1972, 1991 e 1998.

64. O sistema inaugurado em 1991 prevê a assistência legal em duas vertentes: i) apoio jurisdicional; ii) apoio no acesso ao direito. Esta última mediante consulta preventiva de litígios, com a prestação de informação e aconselhamento sobre direitos e deveres, assessorando a prática de atos jurídicos, além da assistência perante comissões de caráter não-jurisdicional.

64.1 A lei de 1998 prestigia a solução alternativa das disputas, prevenindo o recurso à via jurisdicional.

65. No que concerne ao apoio extrajudicial os principais órgãos na França que atendem aos cidadãos são os CDAD's (Conseils Departamentaux d'Accès au Droit); MJD's (Maisons de Justice et du Droit) e PAD'S (Points d'Accès au Droit). Merece 
também destaque a atuação do Médiateur de la Republique, traduzido como Provedor de Justiça, que exerce juntamente com seus delegados a atividade de mediador administrativo.

66. Na Argentina a assistência legal é exercida por meio do Defensor Del Pueblo de La Nación e do Ministerio Público de La Defensa.

67. O rol do art. $3^{\circ}$ da Lei $\mathrm{n}^{\circ}$ 1.060/50 ostenta caráter exemplificativo, o que atende postulado de acesso irrestrito à justiça. Este caráter, contudo, não pode se prestar a tornar o beneficiário parte indevidamente privilegiada no processo.

67.1 As multas processuais sancionatórias, embora contadas como custas, não estão abrangidas pelo regime de gratuidade.

67.2 A isenção que é justificada é aquela que atinja as despesas decorrentes naturalmente do regular exercício do direito de ação ou de defesa.

67.3 O benefício da gratuidade não abarca as multas coercitivas, porém esta técnica de efetivação do comando judicial muito provavelmente terá pouco poder persuasivo em face do obrigado pobre em termos jurídicos.

68. A isenção da taxa judiciária que se define como espécie do gênero "taxa de serviço", compreende não apenas o serviço jurisdicional prestado em primeiro grau, mas também aquele ofertado em instância recursal (preparo), assim como o porte de remessa e retorno, embora este não se enquadre na idéia de "taxa".

69. Sob o manto dos emolumentos e custas estão as isenções de despesas com condução de oficial de justiça, extração de cópias, autenticação destas, etc.

69.1 A gratuidade se estende aos atos extrajudiciais que sejam desdobramento necessário e imediato do direito subjetivo reconhecido no processo no qual a benesse tenha sido concedida. Abrangidas estão também as despesas com atos da serventia extrajudicial necessários à instrução do processo.

69.2 A isenção abrange as separações/divórcios, inventários/partilhas, extrajudiciais.

70. As publicações que estão abarcadas pela gratuidade serão as indispensáveis, isto é, as que consubstanciem citações e intimações via edital.

70.1 A parte beneficiária da gratuidade é isenta da publicação em jornal particular. 
71. No caso de indenizações às testemunhas, o regime do art. 419, p.único, do Código de Processo Civil, prevalece sobre o art. $3^{\circ}$, IV, da Lei ${ }^{\circ}$ 1.060/50.

71.1 No caso da testemunha ter experimentado despesas para comparecer em juízo, aplica-se analogicamente o art. 419, p.único, do Código de Processo Civil, oficiando o juiz ao Estado para que se opere em favor da testemunha o ressarcimento devido.

71.2 No caso de testemunha que não trabalhe sob regime remuneratório de salário, porém com ganhos diários, a ela incumbirá demonstrar o quantum deixou de auferir durante o afastamento exigido para depor, e requerer em juízo o reembolso, na forma do mesmo art. 419 do Código de Processo Civil. O juiz prudentemente arbitrará a indenização devida, que no caso de recair sobre a parte beneficiária da gratuidade, ficará a cargo do Estado.

71.3 A testemunha não pode ser obrigada a aguardar o fim do processo para ressarcir-se das despesas que teve com o comparecimento.

72. Os arts. $3^{\circ}$, V e 11 da Lei $n^{\circ} 1.060 / 50$ devem ser interpretados em consonância com o sistema sucumbencial vigente quando de sua edição. Se comparados com o atual regime, parecem altamente incongruentes.

72.1 No sistema originariamente previsto pelo Código de 1939 a condenação em honorários sucumbenciais era excepcional. Uma das exceções era justamente o caso do vencedor ser beneficiário da gratuidade, daí porque a necessidade de expressa menção pelo art. 11. Daí também a possibilidade do vencido reaver do vencedor tais verbas acaso este perdesse a condição de necessitado (já que o que justificava a condenação do vencido era a condição de necessitado do vencedor).

72.2 A regra do art. $3^{\circ}, \mathrm{V}$, da Lei $\mathrm{n}^{\circ}$ 1.060/50 abrange tanto os honorários do próprio patrono como os do adversário, neste caso em razão da sucumbência.

$72.3 \mathrm{O}$ art. 11 , “caput” e $\S 2^{\circ}$, perderam eficácia, porque previstos para um regime assentado sob premissas diversas. $\mathrm{O} \S 1^{\circ}$ não subsiste porque implica situação de iníqua desequiparação com relação ao advogado que não atue sob regime de gratuidade.

72.4 Ao Estado incumbe arcar com o custo integral decorrente da prova pericial: honorários e despesas indiretas. A regulamentação desta questão pelos órgãos públicos tem, na prática, inviabilizado tanto o direito à prova da parte que litiga sob regime de gratuidade, como o direito à remuneração assegurado ao perito. 
73. No caso de exames de código genético a isenção abrange não apenas a remuneração dos laboratórios, como as despesas inerentes à prova, como o transporte ao local do exame.

74. Considerando-se a constitucionalização do direito à assistência jurídica integral e gratuita, elevado à categoria de direito fundamental (CR, art. 5 LXXIV), seu alcance subjetivo passou a ser aquele que informa todos os demais direitos que neste patamar se inserem.

74.1 Aos estrangeiros em trânsito também se estendem os benefícios inerentes à assistência jurídica integral e gratuita.

75. Pobre em termos jurídicos não é necessariamente o miserável ou indigente, não se postula estado de mendicância.

75.1 Situação econômica não diz respeito à situação patrimonial, ou seja, o que se avalia é a liquidez financeira, a posse de recursos, para ser mais claro, dinheiro.

$75.2 \mathrm{O}$ conceito de família abarcado pelo art. $2^{\circ}$ da Lei $\mathrm{n}^{\circ} 1.060 / 50$ é o mais amplo possível, abrange agregados, familiares ou não, que dependam economicamente do requerente. Não se exige também residência sob mesmo teto.

76. Em princípio não se pode vincular a natureza do direito material ou a grandeza econômica do bem da vida à condição econômica da parte. Em casos limítrofes, entretanto, tais elementos acabam revelando-se poderosos instrumentos para aferir a verdade.

77. Distinguem-se as noções de necessitado jurídico e econômico. No caso do necessitado jurídico entende-se que a parte necessite de assistência técnico-jurídica de um advogado, sem nenhuma consideração à sua condição econômica.

78. Apesar dos indícios de que o intento originário do legislador fosse restringir a assistência à pessoa física, fato é que as tendências ampliativas, que inclusive culminaram com o atual art. $5^{\circ}$, LXXIV, da Constituição da República, implicaram a extensão dos benefícios às pessoas jurídicas.

78.1 Não há fator de discrímen que justifique uma diferença de tratamento em desfavor da pessoa jurídica, no sentido de impedir ou restringir seu acesso à justiça em razão de precária condição financeira. 
78.2 Pode-se facilmente aludir-se ao "sustento próprio" das pessoas jurídicas, referindo-se às obrigações próprias relacionadas a seu giro empresarial, o que corresponde no que respeita às pessoas naturais, com aquilo que despende para sua própria subsistência.

78.3 Imiscuir na avaliação acerca do cabimento do benefício a finalidade da pessoa jurídica que o requer parece destoar dos limites traçados pela Constituição e pela legislação infraconstitucional para o instituto.

78.4 A declaração de insuficiência econômica apresentada pelo representante legal da pessoa jurídica goza a mesma credibilidade que aquela apresentada pela pessoa natural, pois não há fator de discrímen que justifique uma tal distinção, quando todos os demais compostos do regime jurídico da assistência judiciária e gratuidade são aplicados de forma indistinta em relação à pessoa jurídica.

78.5 Como as idéias de "necessitado" e "prejuízo próprio" são diversas no que concerne à pessoa jurídica, requer-se do órgão judicial maior perspicácia na avaliação da condição econômica desta a partir dos elementos constantes dos autos, ou mesmo da realidade conhecida.

78.6 A assistência jurídica é extensível aos entes que, embora não dotados de personalidade jurídica, o são de personalidade judiciária, isto é, gozam capacidade de estar em juízo.

79. A assistência judiciária é incumbência precípua da União e dos Estados, embora não em caráter de exclusividade. A gratuidade fica a cargo do ente situado na esfera de atuação da atividade jurisdicional que for acionada.

79.1 As demais atividades relacionadas à assistência jurídica, como a consultoria extrajudicial, são cometidas a todas as pessoas políticas conforme a dicção constitucional, o que abarca igualmente os Municípios.

79.2 No Brasil prevalece um quadro peculiar de prestação da assistência: a forma mista ou combinada (advogados particulares remunerados pelo Estado, atuando em conjunto com advogados servidores públicos), não por opção legislativa, mas por incompetência do Estado.

79.3 A sociedade civil poderá vir em apoio ao Estado na atuação da assistência jurídica. 
80. Sugere-se que a Defensoria Pública, a par de sua atuação concreta voltada à assistência jurídica, igualmente atue como órgão gestor, fiscalizador e arregimentador das entidades privadas e especialmente de advogados particulares que atuem em auxílio do Poder Público.

81. O novo perfil institucional do Ministério Público, advindo da ordem constitucional de 1988, tornou incompatível com a instituição a prestação de assistência jurídica ao necessitado, o que lhe era imposto pela Lei Complementar no 40/81.

81.1 Apesar desta constatação, há resquícios normativos da realidade que imperava antes de 1988, como se vê do art. 68 do Código de Processo Penal, dispositivo que o C.Supremo Tribunal Federal entendeu vigente enquanto não instituída a Defensoria Pública.

81.2 O desempenho desta atividade pelo Ministério Público se faz excepcionalmente e de forma atípica, não se justificando sua atuação sequer para suprir deficiências da Defensoria Pública ou de órgão com esta conveniado.

82. A ordem de preferência dos $\S \S 1^{\circ}$ a $4^{\circ}$ do art. $5^{\circ}$ da Lei $n^{\circ} 1.060 / 50$ continua em vigor, e a nomeação pelo juiz não implica achaque ao art. $5^{\circ}$ da Lei no ${ }^{\circ}$.906/94.

82.1 Apesar da letra do $\S 4^{\circ}$ do art. $5^{\circ}$ da Lei $n^{\circ} 1.060 / 50$ em questão e da afirmação corrente em doutrina de que se deve assegurar ao assistido o direito de indicar advogado que lhe tenha conquistado a fidúcia, a verdade é que apenas se viabiliza tal escolha nos casos em que a parte limita sua pretensão à gratuidade (comparece em juízo com advogado já constituído, e pede apenas a gratuidade).

82.2 A doutrina inclina-se por negar a possibilidade de substabelecimento no caso de patrono indicado pelo serviço de assistência, pela OAB ou nomeado pelo juiz, entendendo que a defensoria dativa é munus intransferível, sequer havendo no caso outorga de mandato.

82.3 Desde que haja justificativa plausível e razoável, pode a parte recusar a indicação de patrono para defender-lhe os interesses, sujeitando-se a recusa à apreciação do órgão responsável pela nomeação.

82.4 Se se permitisse ao órgão que procede à triagem fazê-la não apenas tendo por objeto a condição econômica da parte, mas especialmente a viabilidade jurídica de sua 
pretensão muitas demandas absolutamente infundadas estariam alijadas do acesso irresponsável a juízo.

83. A atividade administrativa relacionada à assistência jurídica está sujeita ao controle jurisdicional nos mesmos termos em que quaisquer outros atos ou procedimentos administrativos.

84. Apenas as questões relacionadas à gratuidade são diretamente resolvidas no processo; aquelas referentes à assistência judiciária ou assistência jurídica são extraprocessuais, de caráter administrativo.

85. O benefício da gratuidade não pode ser concedido de ofício pelo juiz. Da mesma forma não pode o juiz deferir a isenção total quando a parte se limita a pedir a parcial, nem deferir a isenção total ou parcial quando a parte requere apenas o diferimento do pagamento (quando permitido, como ocorre no Estado de São Paulo).

86. Há três bons argumentos que militam em favor da recepção do art. 4", "caput" e $\S 1^{\circ}$, da Lei no $1.060 / 50$ pela atual Constituição da República:

86.1 A Constituição não especificou o meio de comprovação da insuficiência de recursos, podendo eleger o legislador infraconstitucional a presunção, nos termos do art. 212, IV, do Código Civil de 2002 (correspondente ao antigo art. 136, V).

86.2 A Constituição exige comprovação para concessão da assistência jurídica, serviço público qualificado, porém para a simples isenção de custas e despesas processuais, que é o quanto regulado pelo art. $4^{\circ}$ em questão, basta a afirmação de pobreza.

86.3 A lei operou a potencialização do mínimo assegurado pela Constituição da República a respeito da assistência jurídica, facilitando a prova da insuficiência de recursos. Por isto não há afronta ao espírito da Constituição.

87. Apenas por meio de uma avaliação histórica das sucessivas alterações aos parágrafos do art. $4^{\circ}$ da Lei $n^{\circ} 1.060 / 50$ se pode entender a permanência, ali, do atual $\S 3^{\circ}$. Esta regra, entretanto, está tacitamente revogada.

88. À parte que requer o benefício no curso do processo não se exige requisito probatório diferenciado em relação àquela que o faz na primeira oportunidade em que fala nos autos.

88.1 Neste caso, entretanto, sua afirmação de pobreza terá uma nota distinta que será a informação ao juízo acerca da mudança de seu quadro econômico. 
88.2 Note-se que a necessidade do benefício no curso do processo pode advir não apenas de mudanças na condição econômica da parte, porém dos rumos assumidos pelo debate judicial travado.

89. Seja formulado o pedido em reconvenção, seja nas exceções rituais, ou mesmo em impugnação ao valor da causa, a gratuidade deferida tem o efeito amplo de atingir todo o procedimento ao qual se referem estes incidentes. O pedido formulado e deferido no bojo do processo principal atinge igualmente os incidentes que venham a se anexar ao curso do embate.

89.1 O critério que rege a questão aqui é a formação ou não de nova relação processual. Onde não houver tal formação o pedido formulado em um incidente abrange toda a relação processual e vice-versa. Daí porque a gratuidade conferida num processo não abrange outro, ainda que veicule pretensão idêntica, conexa ou contingente.

89.2 A gratuidade concedida na fase de cumprimento de sentença ou no processo executivo não abrange a verba sucumbencial que integra o crédito exeqüendo, mas apenas as custas, despesas e honorários referentes ao feito executivo ou à fase de cumprimento de sentença.

90. A gratuidade merece apreciação judicial expressa, não se havendo que falar em concessão tácita. A omissão judicial impede que a parte goze do regime jurídico especial a que sujeitos os que litigam sob o signo da gratuidade.

90.1 A rigor é exigível motivação da decisão que aprecia a questão da gratuidade. Esta exigência, contudo, é bastante mitigada à luz da configuração legal simplória deste deferimento inicial.

90.2 Tanto o deferimento quanto o indeferimento do benefício podem ocorrer mediante julgamento "de plano". Apenas que se aconselha ao juiz que, em havendo simples dúvida quanto ao estado de pobreza alegado, intime a parte para que preste esclarecimentos ou complemente provas. Porém se já houver elementos para a formação de convicção do magistrado, poderá proceder este ao imediato julgamento.

90.3 A decisão que à luz de simples declaração defere o benefício é precária, dotada da cláusula rebus sic stantibus. 
91. Sempre haverá na decisão concessiva da gratuidade um grau mínimo de retroatividade, de modo a abranger as obrigações constituídas entre o pedido e a decisão. A questão controversa que se põe diz respeito à retroação a períodos anteriores ao pedido.

91.1 O adversário do assistido, sagrando-se vencedor, fará jus ao ressarcimento daquelas despesas feitas antes da concessão da benesse.

91.2 Com relação ao réu ou a terceiros que intervêm no processo já após considerável marcha processual, importa que o pedido seja feito na primeira oportunidade que falar nos autos, caso em que mesmo despesas ocorridas antes poderão ser abarcadas.

91.3 A decisão que de plano concede o benefício não é recorrível, porque a lei prevê instrumento processual próprio para buscar-se a reforma desta decisão ainda em primeira instância (impugnação). Assim, a opção pela via recursal seria prematura.

92. No caso de impugnação deve-se facultar ao impugnado manifestação em resposta, no prazo assinado pelo juiz ou no legal supletivo (CPC, art. 185).

92.1 O direito à prova é também amplo, para ambas as partes (impugnante e impugnado), valendo a respeito o art. 332 do Código de Processo Civil.

92.2 As expedições de ofícios buscando informações sigilosas apenas hão de ser deferidas quando a impugnação veicular elementos mais ou menos concretos acerca da dita falsidade da declaração de pobreza, e não quando se pretenda devassa fundada em mera desconfiança.

92.3 A impugnação deve ser apresentada em peça autônoma. Porém se vier no bojo da contestação, e desde que não haja prejuízo para o contraditório ou tumulto processual, nada impede decisão nos autos principais.

92.4 Não há preclusão temporal para a impugnação. Há, contudo, preclusão consumativa, bem como lógica.

92.5 A impugnação pode ser processada em primeira instância mesmo após a prolação de sentença, desde que ainda não ofertado recurso. Neste caso, contudo, a instância recursal apreciará a impugnação, conforme analógica aplicação do art. 800, p.único, do Código de Processo Civil.

92.6 No caso de acolhimento da impugnação os termos iniciais da exigibilidade do benefício variam de acordo com o caso de inexistência dos pressupostos (parte nunca fez jus à benesse) ou o desaparecimento (parte fez jus até o tal desaparecimento). 
93. No caso de litisconsórcio, o beneficiário ficará isento de sua cota-parte nas custas, despesas processuais e honorários, o que será custeado pelo Estado. Aos demais litisconsortes caberá apenas arcar com a cota-parte que lhes seria cabível, independentemente da gratuidade. Esta solução decorre do caráter individual do benefício (art. 10).

93.1 Há entendimento segundo o qual serventuários remunerados segundo regime de custas, bem como o Estado-Administração, tenham legitimidade para impugnar a gratuidade ou requerer a revogação. Também têm legitimidade os terceiros intervenientes.

94. A decisão que revoga os benefícios da gratuidade representa indício de improbidade no processo, merecendo sanção por litigância de má-fé.

95. É dever do magistrado proceder à revogação do benefício de ofício, acaso constate a inexistência ou o desaparecimento da miserabilidade em termos legais.

95.1 A preclusão consumativa que impede a parte de apresentar nova impugnação fundada nos mesmos fatos já objeto de anterior incidente decidido definitivamente, igualmente impede a atuação de ofício do juízo, por força do art. 471 do Código de Processo Civil.

95.2 A falta de oportunização à parte para que se manifeste antes que se opere a revogação na forma do art. $8^{\circ}$ da Lei $n^{\circ} 1.060 / 50$, implica nulidade. É conveniente também que o juiz, ao facultar esta manifestação, indique qual ponto do acervo probatório lhe inspira dúvida.

96. Apesar do nomen juris atecnicamente dado pelo legislador (art. 17 da Lei $\mathrm{n}^{\circ}$ 1.060/50), a "sentença" referida pela Lei é, na verdade, decisão interlocutória.

96.1 O novo conceito de sentença veiculado pela Lei $n^{\circ} 11.232 / 05$ em nada altera o entendimento anterior de que o ato judicial referido pelo art. 17 da Lei $n^{\circ}$ 1.060/50 cuida-se de decisão interlocutória.

96.2 A natureza da decisão em questão não é alterada pelo fato de ser ela proferida nos autos principais ou em apartado.

96.3 Há uma prestigiosa corrente jurisprudencial que afirma ser cabível o recurso de agravo, sempre que a decisão for proferida no bojo dos autos principais; e apelação quando o for nos autos incidentais (apartados). 
96.4 Se por motivos peculiares ao andamento do processo a questão da gratuidade acabar decidida na sentença, então o recurso cabível será o de apelação, mesmo que a tal decisão tenha sido proferida nos autos principais (princípio da unirrecorribilidade).

96.5 É o agravo por instrumento a via adequada para a impugnação, tanto da decisão concessiva ou de manutenção da gratuidade, quanto da indeferitória.

97. Diante das díspares manifestações doutrinárias e jurisprudenciais acerca do assunto, não pode haver receio em se reconhecer que haja real e efetiva dúvida objetiva, o que afasta a caracterização de erro grosseiro na interposição de um ou outro recurso (apelação ou agravo de instrumento). A observância do menor prazo possível é requisito que se deve aferir no caso concreto.

98. No que respeita ao regime jurídico do assistido, a principal divergência é a correta interpretação do art. $5^{\circ}, \S 5^{\circ}$, da Lei $n^{\circ} 1.060 / 50$, precisamente no que concerne à expressão "cargo equivalente".

98.1 Na jurisprudência tem prevalecido o entendimento restritivo à extensão dos benefícios do $\S 5^{\circ}$ do art. $5^{\circ}$ da Lei $n^{\circ} 1.060 / 50$ aos advogados dativos. O principal argumento é o gramatical: "cargo" tem sentido técnico específico em Direito Administrativo, e o advogado dativo, conquanto desempenhe função equivalente, a rigor não ocupa cargo público algum.

98.2 Entende-se que à raiz dos benefícios processuais conferidos ao serviço público de assistência está o reconhecimento de que atender a uma monstruosa e extremamente variada demanda é seu dever funcional. Apesar de toda regulamentação legal da profissão do advogado, desempenha ele ministério privado, isto é, ainda lhe resta um quê de iniciativa privada, uma margem de liberdade para que administre e direcione sua banca.

98.3 Esta liberdade de gerência conferida ao advogado dativo é que justifica que se não lhe estendam as benesses do $\S 5^{\circ}$ do art. $5^{\circ}$ da Lei ${ }^{\circ} 1.060 / 50$.

98.4 Conclui-se, então, que a interpretação restritiva da regra sob comentário, sobre coadunar-se com o sentido gramatical do texto, alinha-se com os fins sociais visados pela lei.

98.5 Outros dois benefícios processuais concedidos aos assistidos são a dispensa do ônus da impugnação especificada (CPC, art. 302, p.único) e a possibilidade de outorga de 
mandato em audiência, e a própria dispensa deste nos casos de representação por advogado vinculado a órgão público prestador de assistência (art. 16).

98.6 As regras processuais mais benéficas, mesmo que adotada a corrente ampliativa, não se estendem aos beneficiários unicamente da gratuidade.

98.7 Seja no caso de assistido defendido por advogado dativo, seja defendido por Defensor Público, o prazo da contestação conta-se na forma do art. 241 do Código de Processo Civil.

99. A regra do art. 12 da Lei $n^{\circ} 1.060 / 50$ é plenamente compatível com o texto constitucional, porque desaparecida a condição de necessitado, o fator de discrímen que justificava o tratamento benéfico igualmente desapareceu.

99.1 Apesar da omissão do art. 12 da Lei $n^{o}$ 1.060/50 que tem raízes históricas, entende-se que a verba honorária acha-se incluída nas "custas" processuais mencionadas pelo dispositivo.

99.2 O prazo qüinqüenal não é prescricional ou decadencial. É simplesmente um prazo que integra a condição. Cuida-se de relação jurídica sujeita a condição, e o credor não poderá executar o tal título sem prova que se realizou o evento futuro e incerto (CPC, art. 572).

99.3 Incumbe ao credor a prova da mudança da condição econômica do beneficiário antes isento, podendo valer-se tanto do processo de conhecimento (ordinário ou sumário); procedimento de justificação (CPC, art. 861) e processamento de pedido de revogação na forma do art. $7^{\circ}$ da Lei $n^{\circ} 1.060 / 50$. 


\section{REFERÊNCIAS BIBLIOGRÁFICAS}

AMARAL, José Amir do. Da legitimidade do Estado e dos servidores da Justiça para impugnar a gratuidade de justiça deferida a parte. Ajuris: revista da Associação dos Juízes do Rio Grande do Sul, Porto Alegre, v. 21, n. 62, p. 202-207, nov. 1994.

ANDRIGHI, Fátima Nancy. Recursos repetitivos. Revista de Processo, São Paulo, v. 35, n. 185, p. 265-281, jul. 2010.

ARAÚJO CINTRA, Antonio Carlos de; GRINOVER, Ada Pellegrini; DINAMARCO, Cândido Rangel. Teoria geral do processo. 15. ed. São Paulo: Malheiros Ed., 1999. 358 p.

ARAÚJO FILHO, Luiz Paulo da Silva. Decisão que aprecia questão do direito a assistência judiciária - recurso cabível. Revista de Processo, São Paulo, v. 14, n. 53, p. 231-235, jan./mar. 1989.

ASSIS, Araken de. Benefício da gratuidade. Ajuris: revista da Associação dos Juízes do Rio Grande do Sul, Porto Alegre, v. 25, n. 73, p. 162-200, jul. 1998.

BARBOSA MOREIRA, José Carlos. O direito a assistência jurídica - evolução no ordenamento brasileiro de nosso tempo. Revista de Processo, São Paulo, v. 17, n. 67, p. 124-134, jul./set. 1992.

A função social do processo civil moderno e o papel do juiz e das partes na direção e na instrução do processo. Revista de Processo, São Paulo, ano 10, n. 37, p. 140$150,1985$.

La igualdad de las partes en el proceso civil. Revista de Processo, São Paulo, v. 11, n. 44, p. 176-185, out./dez. 1986.

Notas sobre o problema da efetividade do processo. In: GRINOVER, Ada Pellegrini et. al. (Coords.). Estudos de direito processual em homenagem a José Frederico Marques no seu $70^{\circ}$ aniversário. São Paulo: Saraiva, 1982. p. 203-220.

O novo processo civil brasileiro. 22. ed. Rio de Janeiro: Forense, 2002. 345 p.

BARROS JR, Carlos Schmidt. de. Justiça gratuita. Revista Forense, Rio de Janeiro, n. 101, p. 50-55, jan. 1945.

BEDAQUE, José Roberto dos Santos. Arts. 20 e 125. In: MARCATO, Antônio Carlos (Org.). Código de Processo Civil interpretado. 3. ed. São Paulo: Atlas, 2008.

Direito e processo. 5. ed. São Paulo: Malheiros Ed., 2009. 191 p.

Efetividade do processo e técnica processual. 2. ed. São Paulo: Malheiros Ed., 2007. $605 \mathrm{p}$.

Poderes instrutórios do juiz. 4. ed. São Paulo: Ed. Revista dos Tribunais, 2009.

$181 \mathrm{p}$. 
BERIZONCE, Roberto Omar. La organización de la asistencia jurídica (un estúdio sintético de la legislación comparada). Revista de Processo, São Paulo, ano 14, n. 54, abr./jun. 1989.

BOBBIO, Norberto. A era dos direitos. Trad. port. C.N.Coutinho. Rio de Janeiro: Campus, 1992. Título original: L'età dei diritti.

BONELLI, André. Aspectos processuais da Lei de Assistência Judiciária. In: FARIAS, Cristiano Chaves de; DIDIER JR, Fredie (Coords.). Procedimentos especiais cíveis: legislação extravagante. São Paulo: Saraiva, 2003. 1584 p.

BORGES, José Souto Maior. Significação do princípio da isonomia na Constituição de 1988. Revista Trimestral de Direito Público, São Paulo, v. 15, 1996.

BRAUNER, Daniela Jacques. Acesso à justiça no MERCOSUL. Revista Brasileira de Direito Constitucional, São Paulo, v. 15, jan./jun. 2010. Disponível em: $<$ http://www.esdc.com.br/RBDC/RBDC-15/RBDC-15-067-

Daniela_Jacques_Brauner_(Acesso_a_Justica_no_Mercosul).pdf $>$.

BUENO, Cássio Scarpinella. Art. 461. In: MARCATO, Antônio Carlos (Org.). Código de Processo Civil interpretado. 3. ed. São Paulo: Atlas, 2008.

CABRAL, Marcelo Malizia. Concretização do direito humano de acesso à justiça: imperativo ético do Estado Democrático de Direito. In: COLETÂNEA de Trabalhos de Conclusão de Curso apresentados ao Programa de Capacitação em Poder Judiciário - FGV Direito Rio. Porto Alegre: Tribunal de Justiça do Estado do Rio Grande do Sul, 2009. p. 13-87.

CALAMANDREI, Piero. Opere giuridiche. Napoli: Morano Editore, 1965. v. 1. 711p.

Proceso y democracia. Trad. espanhola Hector Fix Zamudio. Buenos Aires: Ediciones Jurídicas Europa-America, 1960. Título original: Processo e democrazia.

CALMON DE PASSOS, José Joaquim. Democracia, participação e processo. In: GRINOVER, Ada Pellegrini et al. (Coord.). Participação e processo. São Paulo: Ed. Revista dos Tribunais, 1988. p. 83-97.

CÂMARA LEAL, Antônio Luís. Da prescrição e da decadência. 2. ed. Rio de Janeiro: Forense, 1959. $428 \mathrm{p}$.

CAMPILONGO, Celso Fernandes. Os desafios do Judiciário: um enquadramento teórico. In: FARIA, José Eduardo (Org). Direitos humanos, direitos sociais e justiça. 1. ed. 3. tir. São Paulo: Malheiros Ed., 2002. p. 30-51.

CANOTILHO, J. J. Gomes. [Entrevista]. Diálogos \& Debates, Escola Paulista da Magistratura, ano 8, n. 3, mar. 2008.

CAPPELLETTI, Mauro. Constitucionalismo moderno e o papel do Poder Judiciário na sociedade contemporânea. Revista de Processo, Sao Paulo, v. 15, n. 60, p. 110-117, out./dez. 1990. 
CAPPELLETTI, Mauro. Dimensioni della giustizia nella società contemporanee. Bologna: Il Mulino, 1994. 206 p.

. La justicia de los pobres. Trad. esp. de Santiago Sentis Mellendo, Tomás A. Banzhaf. In: . Proceso, ideologias, sociedad. Buenos Aires: EJEA, 1974. 638 p.

. El proceso como fenomeno social de masa. Trad. esp. de Santiago Sentis Mellendo, Tomás A. Banzhaf. In: Proceso, ideologias, sociedad. Buenos Aires: EJEA, 1974. 638 p.

; GARTH, Bryant. Acesso à justiça. Trad. port. de Northfleet, Ellen Gracie. Porto Alegre: Sérgio Antônio Fabris Editor, 2002. 168 p. Título original: Access to justice.

CARPES, Arthur Thompsen. A distribuição dinâmica do ônus da prova no formalismovalorativo. Revista da AJURIS, Porto Alegre, v.3 3, n. 104, p. 9-18, dez. 2006.

CARPI, Federico. A proposito di giusto processo. Rivista Trimestrale di Diritto $e$ Procedura Civile, Milano, ano LXI, n. 1, p. 293-296, 2007.

CARVALHO, André de; RIBEIRO, Marcus Vinicius. Direitos humanos, inclusão jurídica e o papel da assistência jurídica no Brasil do século XXI. Revista Forense, Rio de Janeiro, ano 106, v. 409, p. 27-61, maio/jun. 2010.

CARVALHO, Leandro Coelho. As atribuições da Defensoria Pública sob a ótica do acesso à ordem jurídica justa. Revista de Processo, São Paulo, v. 33, n. 156, p. 204-224, fev. 2008.

CASTRO, José Roberto de. Manual de assistência judiciária: teoria, prática e jurisprudência. 1. ed. Rio de Janeiro: Aide Ed., 1987. 251 p.

CINTRA, Antônio Carlos de Araújo. Assistência judiciária. Revista dos Tribunais, São Paulo, v. 87, n. 758, p. 65-67, dez. 1998.

; GRINOVER, Ada Pellegrini; DINAMARCO, Cândido Rangel. Teoria geral do processo. 15. ed. São Paulo: Malheiros Ed., 1999. 358 p.

COMOGLIO, Luigi Paolo. Garanzie costituzionali e "giusto processo" (modelli a confronto). Revista de Processo, São Paulo, v. 23, n. 90, p. 95-150, abr./jun. 1998.

CORDOPATRI, Francesco. La responsabilità processuale: profili storico-dommatici. Roma, La Sapienza Editrice, 1991. 188 p.

COSTA MACHADO, Antonio Cláudio. Código de Processo Civil interpretado. 7. ed. São Paulo: Manole, 2008. 1670 p.

DALL'AGNOL JUNIOR, Antonio Janyr. Distribuição dinâmica dos ônus probatórios. Revista dos Tribunais, São Paulo, v. 90, n. 788, p. 92-107, jun. 2001. 
DELLORE, Luiz Guilherme Pennachi. Do recurso cabível das decisões referentes à gratuidade da justiça (Lei 1.060/50). In: NERY JR, Nelson; WAMBIER, Teresa Arruda Alvim (Coord.). Aspectos polêmicos e atuais dos recursos cíveis e assuntos afins. São Paulo: Ed. Revista dos Tribunais, 2006. v. 9, 672 p.

DEMO, Roberto Luis Luchi. Assistência judiciária gratuita. Revista da AJURIS, Porto Alegre, v. 27, n. 83, p. 330-370, set. 2001.

DENTI, Vittorio. L'evoluzione del legal aid nel mondo contemporaneo. In: STUDI in onore di Enrico Tullio Liebman. Milano: Giuffrè, 1979. v. 2, p.1159-1182.

Riflessioni sula crisi della giustizia civile. Sociologia del Diritto, Milano, v. 13, p. 59-79, 1986.

DIDIER JR, Fredie. Notas sobre a garantia constitucional do acesso à justiça: o princípio do direito de ação ou da inafastabilidade do Poder Judiciário. Revista de Processo, São Paulo, v. 27, n. 108, p. 23-31, out./dez. 2002.

2008. 69 p.

OLIVEIRA, Rafael. Benefício da justiça gratuita. 3. ed. Salvador, Jus Podivm,

DINAMARCO, Cândido Rangel. A instrumentalidade do processo. 7. ed. São Paulo: Malheiros Ed., 1999. 341 p.

$724 \mathrm{p}$.

. Instituições de direito processual civil. 6. ed. São Paulo: Malheiros Ed., 2009. 4 v.

FARIA, José Eduardo. O Judiciário e seus dilemas. Revista do Advogado, São Paulo, n. 56, p. 64-67, set. 1999.

FAZZALARI, Elio. La imparzialità del giudice. Rivista di Diritto Processuale, Milano, n. 2, p. 193-203, 1972.

FORNACIARI JR, Clito. Provas para a concessão de justiça gratuita. Tribuna do Direito, São Paulo, n. 191, mar. 2011.

GIANNAKOS, Ângelo Maraninchi. Assistência judiciária no direito brasileiro. Porto Alegre, Livr. do Advogado, 2008. 137 p.

GODINHO, Robson Renault. Prova e acesso à justiça: apontamentos sobre a distribuição do ônus da prova. In: CARVALHO, Fabiano; BARIONI, Rodrigo (Coord.). Aspectos processuais do Código de Defesa do Consumidor. São Paulo: Ed. Revista dos Tribunais, 2008.

GRAU, Eros Roberto. $O$ direito posto e o direito pressuposto. 7. ed. São Paulo: Malheiros Ed., 2008. 366p.

GRECO FILHO, Vicente. Direito processual civil brasileiro. 15. ed. São Paulo: Saraiva, 2000. 260 p. 
GRINOVER, Ada Pellegrini. Assistência judiciária e acesso à justiça. Revista da Procuradoria Geral do Estado, São Paulo, n. 22, p. 17-26, jan./dez. 1984.

A crise do Poder Judiciário. Revista de Direito Público, São Paulo, v. 24, n. 98, p.18-26, abr./jun. 1991.

GUERRA FILHO, Willis Santiago. Judiciário e conflitos sociais (na perspectiva da pósmodernidade). Revista de Processo, Sao Paulo, v. 18, n. 70, p. 135-142, abr./jun. 1993.

HABSCHEID, Walther J. As bases do direito processual civil. Tradução de Arruda Alvim. Revista de Processo, São Paulo, ano 3, n. 11/12, 1978.

INCLUSION EUROPE. CONSEILS DEPARTEMENTAUX D'ACCES AU DROIT (CDAD). Disponível em: <http://www.inclusion-europe.org/FFOR/FR/FR_CDAD.pdf>. Acesso em: 04 maio 2011.

KNIJNIK, Danilo. As (perigosíssimas) doutrinas do "ônus dinâmico da prova" e da "situação de senso comum" como instrumentos para assegurar o acesso à justiça e superar a "probatio diabolica". In: FUX, L.; NERY JR., N.; WAMBIER, T. A. A. (Coord.). Processo e constituição: estudos em homenagem ao professor José Carlos Barbosa Moreira. São Paulo: Ed. Revista dos Tribunais, 2006. 1085 p.

LEAL JR, Cândido Alfredo Silva. A comprovação da insuficiência de recursos para concessão da assistência jurídica gratuita. Revista de Processo, São Paulo, v. 16, n. 62, p. 268-277, abr./jun. 1991.

LEGAL AID. Disponível em: <http://www.lawcentres.org.uk/uploads/Legal_Aid.pdf>. Acesso em: mar. 2011.

LE MÉDIATEUR DE LA RÉPUBLIQUE. Disponível em: <http://www.mediateurrepublique.fr/fr-citoyen-03-01-01>. Acesso em: 06 maio 2011.

LENZ, Luís Alberto Thompson Flores. Da concessão da assistência judiciária gratuita às pessoas jurídicas e aos entes beneficentes. Revista dos Tribunais, São Paulo, v. 80, n. 674, p. 63-69, dez. 1991.

LEWIS, Anthony. Gideon's trumpet. New York: Vintage Books, 1989. 277 p.

LIEBMAN, Enrico Tullio. Manual de direito processual civil. Tradução de Cândido Rangel Dinamarco. 3. ed. São Paulo: Malheiros Ed., 2005. v. 1. Título original: Manuale de diritto processuale civile.

Problemi del processo civile. Napoli: Morano Ed., 1962. 521 p.

LIMA, Rogério Medeiros Garcia de. Serventias extrajudiciais e justiça gratuita. Revista de Processo, Sao Paulo, v. 21, n. 83, p. 234-237, jul./set. 1996.

LOBO, Arthur Mendes. Duração razoável do processo x abuso na assistência judiciária gratuita: a interpretação das isenções conforme a Constituição à luz da proporcionalidade. Repertório de Jurisprudência IOB, n. 17, 1ª quinz. set. 2007. 
LOPES, Maurício Antônio Ribeiro. Garantia de acesso à justiça: assistência judiciária e seu perfil constitucional. In: CRUZ E TUCCI, José Rogério et. al. Garantias constitucionais do processo civil: homenagem aos 10 anos da Constituição Federal de 1988. São Paulo: Ed. Revista dos Tribunais, 1999. 262 p.

LSC - LEGAL SERVICE CORPORATION. Disponível em: $<$ www.lsc.gov/about:lsc.php>.

LUCON, Paulo Henrique dos Santos. Devido processo legal substancial e efetividade do processo. In: MARTINS, Ives Gandra da Silva; JOBIM, Eduardo (Coords.). O processo na Constituição. São Paulo: Quartier Latin do Brasil, 2008. 926 p.

Garantia do tratamento paritário das partes. In: CRUZ E TUCCI, José Rogério et al. (Coord.). Garantias constitucionais do processo civil: homenagem aos 10 anos da Constituição Federal de 1988. São Paulo: Ed. Revista dos Tribunais, 1999. 262 p.

MARCACINI, Augusto Tavares Rosa. Assistência Jurídica, assistência judiciária e justiça gratuita. Rio de Janeiro: Forense, 1996. 146 p.

MARCATO, Antônio Carlos (Org.). Código de Processo Civil interpretado. 3. ed. São Paulo: Atlas, 2008. 3018 p.

MARINONI, Luiz Guilherme. O custo e o tempo do processo civil brasileiro. Revista Forense, Rio de Janeiro, v. 100, n.375, p. 81-102, set./out. 2004.

Técnica processual e tutela dos direitos. 2. ed. São Paulo: Ed. Revista dos Tribunais, 2008. 511 p.

MELLO, Celso Antônio Bandeira. O conteúdo jurídico do princípio da igualdade. 3. ed. São Paulo: Malheiros Ed., 1997. 48 p.

MENGER, Anton. El derecho civil y los pobres. Trad. esp. Adolfo Posada, Granada: Editorial Comares, 1998. 277 p.

MINISTÈRE DE LA JUSTICE. Tribunal de Grande Instance de Bordeaux. Disponível em: <http://www.maisondejustice.fr>. Acesso em: 05 maio 2011.

MIRANDA, Gilson Delgado. Art. 511. In: MARCATO, Antônio Carlos (Org.). Código de Processo Civil interpretado. 3. ed. São Paulo: Atlas, 2008.

MONTERO AROCA, Juan. El derecho procesal en el siglo XX. Valencia: Tirant lo Blanch, 2000. 142 p.

MORAES, Alexandre de. Direito constitucional. 13. ed. São Paulo: Atlas, 2003. 836 p.

Direito constitucional. 25. ed. São Paulo: Atlas, 2010.

MORAES, Humberto Peña de. Assistência judiciária pública e os mecanismos de acesso à justiça, no Estado democrático. In: GRINOVER, Ada Pellegrini et al. (Coord.). Participação e processo. São Paulo: Ed. Revista dos Tribunais, 1988. 
MORELLO, Augusto Mario. El conocimento de los derechos como presupuesto de la participación (el derecho a la información y la realidad social). In: GRINOVER, Ada Pellegrini et al. (Coord.). Participação e processo. São Paulo: Ed. Revista dos Tribunais, 1988. p. 166-179.

2002. 200 p.

La justicia, de frente a la realidad. Buenos Aires: Rubinzal-Culzoni Editores,

MUSCARI, Marco Aurélio Botto. Justiça no Brasil: barata para os litigantes de má-fé, mas não para os bons cidadãos. Revista de Processo, São Paulo, v. 35, n. 181, p. 305-312, mar. 2010.

NALINI, José Renato. O juiz e o acesso à justiça. 2. ed. São Paulo: Ed. Revista dos Tribunais, 2000. 183 p.

NEGRÃO, Theotonio; GOUVÊA, José Roberto. Código de Processo Civil e legislação processual em vigor. 33. ed. São Paulo: Saraiva, 2002. 2105 p.

NERY JUNIOR, Nelson. Princípios do processo na Constituição Federal. 9. ed. São Paulo: Ed. Revista dos Tribunais, 2009. 415 p.

; NERY, Rosa Maria Andrade. Código de Processo Civil comentado e legislação extravagante. 7. ed. São Paulo: Ed. Revista dos Tribunais, 2003.

PEYRANO, Jorge Walter. La doctrina de las cargas probatorias dinámicas y la máquina de impedir en materia jurídica. In: PEYRANO, Jorge Walter (Dir.); WHITE, Inês Lépori (Coord.). Cargas probatorias dinámicas. Buenos Aires: Rubinzal-Culzoni, 2008. 638 p.

La regla de la carga de la prueba enfocada como norma de clausula del sistema. Revista de Processo, São Paulo, v.35, n.185, p. 107-116, jul. 2010.

; CHIAPPINI, Julio O. Lineamientos de las cargas probatorias "dinámicas". In: PEYRANO, Jorge Walter (Dir.); WHITE, Inês Lépori (Coord.). Cargas probatorias dinámicas. Buenos Aires, Rubinzal-Culzoni, 2008. 638 p.

PINHEIRO, Eduardo Bezerra de Medeiros. Breves observações acerca da Lei $n^{\circ}$ 1.060/50. Revista dos Tribunais, Sao Paulo, v. 85, n. 733, p. 94-108, nov. 1996.

PINTO, Robson Flores. A garantia constitucional da assistência jurídica estatal aos hipossuficientes. Cadernos de Direito Constitucional e Ciência Política, São Paulo, v. 1, n. 3, p. 101-119, abr./jun. 1993.

PONTES, Evandro Fernandes de. A assistência judiciária na mira do modelo garantista do processo. In: GARCIA LA GUARDIA, Jorge Mario et. al. Acesso à justiça e cidadania. São Paulo: Konrad Adenauer, 2000. 118 p.

PRIETO ALVAREZ, Anselmo. O Estado social democrático de direito no Brasil e a assistência jurídica integral e gratuita. Revista dos Tribunais, São Paulo, v. 95, n. 848, p. 36-59, jun. 2006. 
PRUDENTE, Antônio Souza. Custas processuais e acesso à justiça. Cadernos de Direito Constitucional e Ciência Política, São Paulo, v. 6, n. 22, p. 292-310, jan./mar. 1998.

RAMOS, Glauco Gumerato. Assistência jurídica integral ao necessitado. Revista dos Tribunais, São Paulo, v. 88, n. 765, p. 48-58, jul. 1999.

RIBEIRO, Paulo de Tarso Ramos. Direito e processo: razão burocrática e acesso à justiça. São Paulo: Max Limonad, 2002. 214p.

RIZZATTO NUNES, Luiz Antônio. A assistência judiciária e a assistência jurídica: uma confusão a ser solvida. Revista do Instituto dos Advogados, São Paulo, v. 7, n. 14, p. 85-90, jul./dez. 2004.

Curso de direito do consumidor. 3. ed. São Paulo: Saraiva, 2008. 844p.

ROCHA, Cármen Lucia Antunes. Direito constitucional à jurisdição. In: TEIXEIRA, Sálvio de Figueiredo Teixeira (Coord). As garantias do cidadão na justiça. São Paulo: Saraiva, 1993. $391 \mathrm{p}$.

ROSAS, Roberto. Processo civil e justiça social. Revista dos Tribunais, São Paulo, ano 71, v. 564, out. 1982.

SACCHIS, Bianca Rocha; CEZNE, Andréa Nárriman. A inconstitucionalidade da cobrança das custas processuais sobre o valor da causa perante a natureza jurídica tributária. In: TELLINI, Denise Estrela; JOBIM, Geraldo Cordeiro; JOBIM, Marco Félix (Orgs.). Tempestividade e efetividade processual: novos rumos do processo civil brasileiro: estudos em homenagem à professora Elaine Harzheim Macedo. 1. ed. Caxias do Sul: Plenum, 2010. $671 \mathrm{p}$.

SADEK, Maria Tereza Aina. Acesso à justiça: visão da sociedade. Justitia, São Paulo, n. 65, n. 198, p. 271-279, jun. 2008.

SILVA, José Afonso da. Acesso à justiça e cidadania. Revista de Direito Administrativo, Rio de Janeiro, n. 216, p. 9-23, abr./jun. 1999.

$878 \mathrm{p}$.

Curso de direito constitucional positivo. 20. ed. São Paulo: Malheiros Ed., 2001.

SILVA, Marco Antônio Marques da. A efetividade do acesso à justiça. Revista do Instituto dos Advogados de São Paulo, São Paulo, v. 9, n. 17, p. 125-144, jan./jun. 2006.

SILVA, Ovídio A. Baptista da. Democracia moderna e processo civil. In: GRINOVER, Ada Pellegrini et al. (Coord.). Participação e processo. São Paulo: Ed. Revista dos Tribunais, 1988. p. 98-113.

SOUSA SANTOS, Boaventura de (Dir. Científico). O acesso ao direito e à justiça: um direito fundamental em questão. Coordenadores: João Pedroso, Catarina Trincão; João Paulo Dias. DHNet. Disponível em: <www.dhnet.org.br/dados/lex/a_pdf/01_boaventura_acesso_jud_pt.pdf $>$. Acesso em: 29 mar. 2011. 
SOUZA, Artur César. A parcialidade positiva do juiz. São Paulo: Ed. Revista dos Tribunais, 2008. 269 p.

SOUZA, Silvana Cristina Bonifácio. Assistência jurídica integral e gratuita. São Paulo: Ed. Método, 2003. 158 p.

TABOSA, F. Art. 333. In: MARCATO, Antônio Carlos (Org.). Código de Processo Civil interpretado. 3. ed. São Paulo: Atlas, 2008.

TARTUCE, Fernanda. Assistência judiciária, gratuidade e a Lei 11.441/2007. In: MATHIAS COLTRO, Antônio Carlos; DELGADO, Mario Luiz (Coord.). Separação, divórcio, partilhas e inventários: questionamentos sobre a Lei ${ }^{\circ} 11.441 / 2007$. São Paulo: Método, 2007. 352 p.

TARUFFO, Michele, Le garanzie fondamentali della giustizia civile nel mondo globalizzato. RTDC: revista trimestral de direito civil, Rio de Janeiro, v. 5, n. 17, p. 115130, jan./mar. 2004.

TARZIA, Giuseppe, L'art. 111 Cost. e le garanzie europee del processo civile. Revista de Processo, São Paulo, v. 26, n. 103, p. 156-174, jul./set. 2001.

THEODORO JR, Humberto. Estrutura e função no campo do direito processual: visão estática e visão dinâmica do fenômeno jurídico. In: THEODORO JR, Humberto; LAUAR, Maira Terra (Coords.). Tutelas diferenciadas como meio de incrementar a efetividade da prestação jurisdicional. Rio de Janeiro: GZ, 2010.p. 3-24.

TREVISAN, Oswaldo, A assistência judiciária: fundamentos constitucionais. Revista $d a$ Procuradoria Geral do Estado, São Paulo, n. 22, p. 175-184, jan./dez. 1984.

TROCKER, Nicolo. Processo civile e Costituzione: problemi di diritto tedesco e italiano. Milano: Giuffrè, 1974. 768 p.

VIDIGAL, Mauricio. Lei da Assistência Judiciária interpretada. São Paulo: Juarez de Oliveira, 2000. 100 p.

VIGLIAR, José Marcelo Menezes, Assistência jurídica integral e gratuita. Tutela constitucional e concessão do benefício. Justitia, São Paulo, v. 57, n. 171, p. 60-72, jul./set. 1995.

WATANABE, Kazuo. Acesso à justiça e sociedade moderna. In: GRINOVER, Ada Pellegrini et al. (Coord.). Participação e processo. São Paulo: Ed. Revista dos Tribunais, 1988. p.128-135.

Assistência judiciária como instrumento de acesso à ordem jurídica justa. Revista da Procuradoria Geral do Estado, São Paulo, n. 22, jan./dez. 1984.

. Da cognição no processo civil. São Paulo: Ed. Revista dos Tribunais, 1987. 135 p.

YARSHELL, Flavio Luiz. A assistência judiciária sob o ângulo do requerido. Revista do Advogado, São Paulo, n. 59, p. 82-88, jun. 2000. 
YARSHELL, Flavio Luiz. Antecipação da prova sem o requisito da urgência e direito autônomo à prova. São Paulo: Malheiros Ed., 2009. 478 p.

ZANON, Artêmio. Assistência Judiciária gratuita: comentários à Lei da Assistência Judiciária (Lei no 1.060, de 5-2-1950). São Paulo: Saraiva, 1985. 150 p. 